DOE/CH/CRE-6-1999

\title{
LIFE-CYCLE COST AND RISK ANALYSIS OF ALTERNATIVE CONFIGURATIONS FOR SHIPPING LOW-LEVEL RADIOACTIVE WASTE TO THE NEVADA TEST SITE
}

December 1999

Prepared for the Center for Risk Excellence U.S. Department of Energy, Chicago Operations Office

In Consultation with the U.S. Department of Energy's Nevada Operations Office, National Transportation Program, Low-Level Waste/Mixed Low-Level Waste Center for Excellence, Center for Acquisition and Business Excellence

Pacific Northwest National Laboratory Richland, Washington

Operated for the U.S. Department of Energy

Under Contract DE AC06 76 RLO 1830 
This Page Intentionally Left Blank 


\section{DISCLAIMER}

This report was prepared as an account of work sponsored by an agency of the United States Government. Neither the United States Government nor any agency thereof, nor any of their employees, make any warranty, express or implied, or assumes any legal liability or responsibility for the accuracy, completeness, or usefuiness of any information, apparatus, product, or process disclosed, or represents that its use would not infringe privately owned rights. Reference herein to any specific commercial product, process, or service by trade name, trademark, manufacturer, or otherwise does not necessarily constitute or imply its endorsement, recommendation, or favoring by the United States Government or any agency thereof. The views and opinions of authors expressed herein do not necessarily state or reflect those of the United States Government or any agency thereof. 


\section{DISCLAIMER}

Portions of this document may be illegible in electronic image products. Images are produced from the best available original document. 


\title{
Pacific Northwest National Laboratory
}

Operated by Battelle for the

U.S. Department of Energy

December 15, 1999

\author{
Dr. Al Young \\ Center for Risk Excellence \\ U.S. Department of Energy \\ Chicago Operations Office \\ 9800 South Cass Ave. \\ Argonne, IL 60439 \\ Dear Dr. Young \\ SUBJECT: TRANSMTTTAL OF LIFE-CYCLE COST AND RISK ANALYSIS OF \\ ALTERNATIVE CONFIGURATIONS FOR SHIPPING LOW-LEVEL \\ RADIOACTIVE WASTE TO THE NEVADA TEST SITE
}

Enclosed please find the Final Report; Life-Gole Cost And Risk Anabysis Of Altermative Configurations For Shipping Low-Level Radioactive Waste To The Nevada Test Site. As you know, the report reflects the contributions of a multi-laboratory team who began work over year ago under the direction of $\mathrm{Mr}$. Peter Siebach of your staff. The technical assessments and document preparation were performed by myself, Dr. Bruce Biwer of Argonne National Laboratory, and Mr. Steve Ross of BattelleAlbuquerque.

In addition to the multi-laboratory team that performed the analysis and prepared the attached report, a number of others contributed guidance, technical and administrative support, and comments on draft manuscripts, including

- Mr. E. Frank DiSanza, DOE-Nevada Operations Office

- Mr. Steven Hamp, DOE-Albuquerque, National Transportation Program

- Mr. Ken Small, DOE-Nevada, Center of Excellence for Low-Level and Mixed Low-Level Waste

- Mr. Bruce Church, Desert Research Institute

- Mr. Michael Giblin, DOE-Nevada Operations Office

- Ms. Kathleen Grassmeier, DOE-Nevada Operations Office

- Ms. Ruth Weiner, Sandia National Laboratory

- Mr. Ed Parsons, Federal Energy Technology Center.

- Mr. Bill Andrews, Pacific Northwest National Laboratory

On behalf of myself and the team, I would like to thank you personally for the opportunity to develop this report and work closely with Mr. Siebach, the DOE-Nevada staff, and their

902 Battelle Boulevard • P.O. Box 999 - Richland, WA 99352

Telephone (509) 372-4239 — Email phil.daling@pnl.gov — Fax (509) 372-4995 


\section{Dr. Al Young}

December 15, 1999

Page 2

stakeholders. We believe the report will provide a valuable resource to support transportation planning in Nevada and at potential LLW generator sites. We look forward to continuing to work closely with the Center for Risk Excellence.

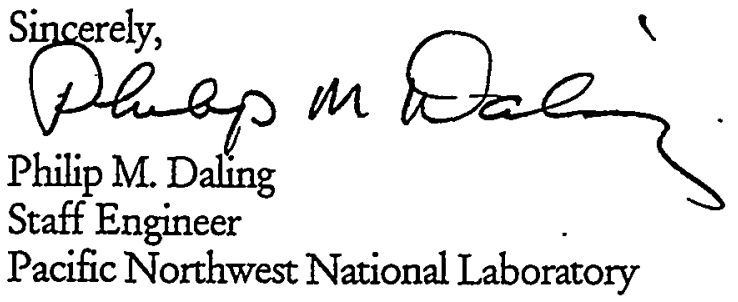

Encl:

cc (w/o encl.): P. Siebach, EPG

M. Williams, AI

A. Kapoor, AL

S. Hamp, AL

G. Duggan, ID

K. Grassmeier, NV

M. Giblin, NV

K. Small, NV

E. Parsons, FETC

C. Crawford, FETC

M. Letourneau, EM-20

T. Mustin, EM-20

J. Rhoderick, EM-20

H. Belencan, EM-20

N. Akgunduz, Fernald

W. Dixon. Yucca Mountain Project Office

J. Booth, Yucca Mountain Project Office

B. Biwer, ANL

R. Weiner, SNL/NM

W. Andrews, PNNL

P. Daling, PNNL

S. Ross, PNNL

F. Dilger, Clark County

D. Bechtel, Clark County

G. Swartz, State of Nevada

E. Dixon, UNLV

J. Williams

L. Bradshaw, Nye County

B. Church, DRI

J. Sharp 


\section{EXECUTIVE SUMMARY}

The Nevada Test Site (NTS) is a major receiver of low-level radioactive waste (LLW) for disposal. Currently, all LLW received at NTS is shipped by truck. The trucks use highway routes to NTS that pass through the Las Vegas Valley and over Hoover Dam, which is a concern of local stakeholder groups in the State of Nevada. Rail service offers the opportunity to reduce transportation risks and costs, according to the Waste Management Programmatic Environmental Impact Statement (WM-PEIS). However, NTS and some DOE LLW generator sites are not served with direct rail service so intermodal transport is under consideration. Intermodal transport involves transport via two modes, in this case truck and rail, from the generator sites to NTS. LLW shipping containers would be transferred between trucks and railcars at intermodal transfer points near the LLW generator sites, NTS, or both. An Environmental Assessment (EA) for Intermodal Transportation of Low-Level Radioactive Waste to the Nevada Test Site (referred to as the NTS Intermodal EA) has been prepared to determine whether there are environmental impacts to alterations to the current truck routing or use of intermodal facilities within the State of Nevada. However, an analysis of the potential impacts outside the State of Nevada are not addressed in the NTS Intermodal EA. This study examines the rest of the transportation network between LLW generator sites and the NTS and evaluates the costs, risks, and feasibility of integrating intermodal shipments into the LLW transportation system.

This study evaluates alternative transportation system configurations for NTS approved and potential generators based on complex-wide LLW load information. Technical judgments relative to the availability of DOE LLW generators to ship from their sites by rail were developed. Public and worker risk and life-cycle cost components are quantified. The study identifies and evaluates alternative scenarios that increase the use of rail (intermodal where needed) to transport LLW from generator sites to NTS.

Two LLW disposal options and four transportation system configurations are considered in this study. These options are consistent with the LLW options being considered in the development of the WM-PEIS Record of Decision (ROD). The first LLW disposal option is a "high waste volume" case in which NTS is the primary disposal site for DOE LLW that will be shipped offsite (most of the LLW will be disposed onsite at four other DOE generator sites). The second disposal option is one in which the LLW to be disposed offsite will be about equally split between NTS and the Hanford Site in the State of Washington. This option is referred to here as the "low waste volume" case. The four shipping configurations evaluated here are:

- $100 \%$ truck transport using existing routes (base case),

- $100 \%$ truck transport using routes that avoid Las Vegas and Hoover Dam,

- intermodal transport from large generator sites using a candidate intermodal transfer facility in Barstow, California, and

- intermodal transport using a candidate intermodal transfer facility in Caliente, Nevada.

There are a total of $23 \mathrm{LLW}$ generator sites that are projected to ship waste to NTS for disposal. Of these 23 sites, the physical capabilities of nine generator sites representing over $93 \%$ of the LLW volume to be shipped to NTS for disposal were examined. The other 14 sites are smaller-volume generators that were assumed to ship waste to NTS by truck. It was determined that, of these nine large-volume generators, five currently have direct rail access and four would require truck transport to an offsite railhead. For these four sites, intermodal transport would be used at both the origin and destination in order to use rail service. The other five generator sites could load LLW directly on to railcars onsite and ship by rail to the intermodal transfer facility near NTS. 


\begin{abstract}
"Life-cycle"
This study estimates "life-cycle" costs and risks of transporting LLW to NTS. This means that the risk and cost estimates developed here are accumulated or summed over an assumed 70-yr operating period for the $L L W$ generators and NTS $L L W$ disposal facilities. This involves projecting out to 70 years the $L L W$ volume estimates from each generator and assumes waste treatment, transportation, and disposal technologies remain constant over this time frame. Obviously, technologies will change over this time frame, resulting in more efficient $L L W$ management practices. Other technological changes over the next 70 years could also affect the results and conclusions presented here, such as development of safer vehicles, new materials, and development and construction of safer highway and rail systems. It is also assumed that regulatory requirements are for all practical purposes constant over this time frame, or at least that regulatory change does not result in substantial changes in costs, efficiencies, or operational risks. Finally, decisions over the next 70 years could affect the results in this' study, such as decision to dispose $L L W$ onsite.
\end{abstract}

It should be noted that not all of the LLW generators considered here are approved generators for disposal at NTS. Those sites not currently on the approved generator list will need to undergo the approval process prior to their first shipment. The rail capability assessment addressed rail and intermodal physical capabilities and does not consider local opposition or political issues.

Furthermore, although the DOE LLW generator sites in the "truck" category were assumed in this study to ship only by truck, they are also capable of shipping by rail, either via direct rail service or intermodal service. However, since these sites are small-quantity generators, the top nine LLW generators will effectively demonstrate the trends in impacts for switching over to rail transport.

The cost and risk analyses in this report were performed using existing DOE methods and data to the extent possible. The HIGHWAY and INTERLINE computer codes were used to develop route-specific information for shipments between DOE LLW generators and NTS, including shipping distances and population density data. The RADTRAN 4 computer code was used to calculate the risks to the public and workers from routine (incident-free) transport and accidents during shipments of LLW to NTS. Commonly used fatality rates for general freight service (fatality risk per mile traveled) were used to calculate the nonradiological risks of accidents (physical risks) and routine vehicular emissions.

Transportation cost information was extracted from a number of sources, including the WM-PEIS, to calculate the life-cycle costs of the various shipping configurations and waste loading cases examined in this study. The life-cycle cost estimates presented in this study include carrier charges, procurement and replacement costs for reusable LLW shipping containers, and first-order estimates of intermodal transfer costs. Not included are potential costs for improving rural highways in Nevada, upgrading emergency response capabilities along the routes, and capital costs for intermodal transfer facilities. The intent of these calculations is to identify the tradeoffs that exist between the various "risk" measures quantified in this study relative to increasing the use of rail to transport LLW to NTS as well as avoiding the Las Vegas Valley and Hoover Dam.

Table ES-1 summarizes the quantitative results of this study. The table includes total shipping distances, five health and safety risk measures, and total life-cycle costs for the four shipping configurations investigated. The key observations made about the results are:

- The life-cycle costs for the intermodal configurations are significantly lower than the all-truck configurations. The increased costs for intermodal transfers and the truck segment from the intermodal facility to NTS are more than offset by the lower costs for rail shipping from LLW generators to the intermodal facility, relative to the all-truck configurations. 
Table ES-1. Summary of Transportation Impacts for the High Waste Volume Case ${ }^{(a)}$

\begin{tabular}{|l|c|c|c|c|}
\hline \multirow{2}{*}{ Impact Measure } & \multicolumn{3}{|c|}{ 70-yr Life-Cycle Cost and Risk Estimates } \\
\cline { 2 - 5 } & $\begin{array}{c}\text { 1A (Intermodal } \\
\text { at Barstow, } \\
\mathrm{CA})^{(\mathrm{b})}\end{array}$ & $\begin{array}{c}1 \mathrm{~B} \text { (Intermodal } \\
\text { at Caliente, } \\
\mathrm{NV})^{(\mathrm{b})}\end{array}$ & $\begin{array}{c}2 \text { (100\% truck on } \\
\text { routes that avoid } \\
\text { Las Vegas) }\end{array}$ & $\begin{array}{c}3 \text { (100\% truck on } \\
\text { routes that travel } \\
\text { through Las Vegas) }\end{array}$ \\
\hline $\begin{array}{l}\text { Cost (\$millions) } \\
\text { Shipping Distance } \\
\text { (million mi) }\end{array}$ & 130 & 140 & 230 & 210 \\
\hline $\begin{array}{l}\text { Radiological } \\
\text { Routine-Workers } \\
\text { (Fatalities) }\end{array}$ & 0.095 & 0.11 & 0.29 & 45 \\
\hline $\begin{array}{l}\text { Radiological } \\
\text { Routine-Public } \\
\text { (Fatalities) }\end{array}$ & 0.087 & 0.098 & 0.42 & 0.27 \\
\hline $\begin{array}{l}\text { Radiological } \\
\text { Accident Risks } \\
\text { (Fatalities) }\end{array}$ & $8.0 \mathrm{E}-06$ & $1.2 \mathrm{E}-05$ & $1.9 \mathrm{E}-05$ & $1.9 \mathrm{E}-05$ \\
\hline $\begin{array}{l}\text { Nonradiological } \\
\text { Accident Risks } \\
\text { (Fatalities) }\end{array}$ & 1.2 & 1.3 & 1.8 & 1.5 \\
\hline $\begin{array}{l}\text { Nonradiological } \\
\text { Routine Emissions } \\
\text { (Fatalities) }\end{array}$ & 0.13 & 0.16 & 0.21 & 0.28 \\
\hline
\end{tabular}

Note: Results are given in abbreviated scientific notation; e.g., $8.0 \mathrm{E}-06=8.0 \times 10^{-6}=0.0000080$.

(a) Includes costs and risks of truck and rail transport plus intermodal transfer operations, where applicable.

(b) For intermodal configurations, the top nine LLW generators by volume are assumed to ship by rail. Smaller-quantity LLW generators are assumed to ship by truck on routes that avoid Las Vegas.

- The life-cycle cost for the all-truck option that avoids Las Vegas is slightly higher than the cost for the all-truck option that travels through Las Vegas. This is due to the longer shipping distances that will become necessary to avoid Las Vegas. This cost difference is on the order of $10 \%$ of the total life-cycle costs, which is smaller than the uncertainties in the cost estimates.

- Total life-cycle costs were lower for the intermodal configuration in which the Barstow facility is assumed than for the configuration in which Caliente is the intermodal transfer point. This is a small cost difference that is within the uncertainties of the cost estimates. A lower life-cycle cost, however, is real because total shipping distance calculated for the Barstow configuration is shorter than that for Caliente.

- Radiological incident-free (or routine) risks were shown to be highest in the all-truck options and lowest in the intermodal options.
Risk Value Clarification

Risk values greater than 1.0 represent the number of fatalities projected to occur over the 70-yr life cycle of the $L L W$ transportation and disposal operations. They may be rounded to the nearest whole number. Risk values less than 1.0 (i.e., fractional fatality) may be restated as the probability that at least one fatality occurs over the 70-yr life cycle by taking the inverse of the fractional fatality. In other words, if the risk estimate is 0.1 fatalities, there is a 1 in 10 chance (i.e., 1.0 divided by 0.1) of at least one fatality occurring in the 70-yr period. 
- Nonradiological accident risks are higher than the other risk measures examined in this study. The nonradiological accident risks are higher in the all-truck options than in the intermodal options.

- Of the four main shipping configurations analyzed in this study, the intermodal configurations represent the lowest health and safety risks. Overall, the intermodal configuration in which intermodal transfers are performed at Barstow, CA, has the lowest risk, the Caliente intermodal configuration is second lowest, the all-truck option on routes that travel through Las Vegas is the third lowest, and the highest-risk option is the all-truck configuration that travels on routes that avoid Las Vegas.

- It can be seen by comparing the two alltruck options (Configurations 2 and 3 in Table ES-1) that routing around Las Vegas results in higher radiological routine risks than using routes that travel through Las Vegas. This is consistent with the trend in total shipping distance. Based on this observation, the increase in shipping distance associated with routing around Las Vegas more than offsets the potential radiological risk reductions associated with shifting the routes to less densely populated areas of Nevada. Thus, the radiological routine dose risks are lower if the routes through Las Vegas and Hoover Dam are used.

- Similar to the radiological routine risk trends, the increase in shipping distance required to route around Las Vegas has a greater influence on the nonradiological accident risk rankings than the more favorable accident rates on interstate and primary state highways in Nevada. Longer shipping distances are required to avoid Las Vegas and Hoover Dam. This increases the nonradiological risks, which are approximately linear with respect to shipping distance. (Note: they are not exactly a linear function because the type of highway and type of population zone influence the accident rates.) The more direct routes through Las Vegas are on well-maintained interstate and primary highways that have generally lower accident rates than the rural highways required to avoid Las Vegas. However, on a DOE complex basis, it was shown that the nonradiological accident and routine radiological dose risks are lower if the LLW truck shipments use the more direct routes.

\section{Types of Health and Safety Risk}

Several different types of health and safety risk are quantified in this study. Brief descriptions of these risk types are as follows:

- Incident-free radiological risk is the risk associated with LLW shipments that reach their destination without experiencing an accident or loss of radioactive cargo. The risk in this case arises from the low levels of radiation that penetrate through the walls of the $L L W$ shipping containers exposing persons nearby to an external radiation dose. Federal regulations specify the maximum external radiation dose rate permitted to penetrate through the walls of the LLW shipping containers.

- Radiological accident risk refers to potential releases of radioactive material that could be caused by a traffic accident that results in failure of the LLW packaging system. This type of risk is calculated by multiplying the frequency of an represented by the radiation dose from inhalation, ingestion, and external exposure to the radioactive material that escapes from the shipping container. of physical injury or death from vehicular accidents involving the LLW shipments. An example would be motorist in a vehicle that collides with an $L L W$ shipment. These risks are independent of the $L L W$ cargo being transported.

- Nonradiological incident-free risks are the risks associated with human exposure to vehicular emissions. These risks are independent of the $L L W$ cargo being transported. accident by its consequences. Consequences are

- Nonradiological accident risks represent the risks 
- A number of comparisons of the risk estimates developed in this study for transporting LLW to NTS were made to risks commonly encountered in everyday life. It was demonstrated through these comparisons that the LLW transportation risks are small in relation to other, more commonly encountered risks, including natural background radiation doses. Furthermore, the analytical models and data used to calculate the transportation risks were shown to be conservative (i.e., tend to overpredict the risks), providing further indication that the risks of transporting LLW to NTS are small. Examples of important conservative elements of the risk analysis are summarized in Section 5.3. 
This Page Intentionally Left Blank 


\section{ACKNOWLEDGMENTS}

The authors would like to express their appreciation to several individuals for their assistance in preparing and improving this report. We wish to thank Mr. Peter Siebach, DOE Center for Risk Excellence, for his valuable assistance and support throughout this project. We also wish to thank Mr. E. Frank Di Sanza, Mr. Michael Giblin, and Ms. Kathleen Grassmeier of DOE's Nevada Operations Office for their guidance and encouragement of this study. In addition, we wish to express our appreciation to Mr. Steve Hamp of DOE's National Transportation Program for his guidance and thoughtful reviews of draft versions of this report. Other reviewers that provided valuable comments and suggestions instrumental in improving this report include Mr. Robert Rea and Mr. Thomas Enyeart (SAIC-Las Vegas), Ms. Ruth Weiner (Sandia National Laboratory), Mr. James Williams (Nye County, Nevada), Mr. Russell DiBartolo (Clark County, Nevada), and Ms. Ginger Swartz (Nye County, Nevada). Finally, we wish to express our appreciation to Mr. Gary Smith, MACTEC, for providing the waste volumes used in this study, Mr. Mark John, Idaho National Engineering and Environmental Laboratory, for his transportation logistics support, and Mr. Ronald Pope, Oak Ridge National Laboratory, for providing the historical transportation cost information from the ETAS database. 
This Page Intentionally Left Blank 


\section{GLOSSARY}

$\begin{array}{ll}\text { ANL-E } & \text { Argonne National Laboratory - East } \\ \text { ANL-W } & \text { Argonne National Laboratory - West } \\ \text { BCL } & \text { Battelle Columbus Laboratory } \\ \text { BNL } & \text { Brookhaven National Laboratory } \\ \text { CEQ } & \text { Council for Environmental Quality } \\ \text { CFR } & \text { U.S. Code of Federal Regulations } \\ \text { CPQT } & \text { Consolidated PBS Quantity Tables (database) } \\ \text { CRE } & \text { Center for Risk Excellence (DOE) } \\ \text { DOE } & \text { U.S. Department of Energy } \\ \text { DOT } & \text { U.S. Department of Transportation } \\ \text { ETEC } & \text { Energy Technology Engineering Center } \\ \text { FEMP } & \text { Fernald Environmental Management Project } \\ \text { GE Val } & \text { General Electric Vallecitos Nuclear Center } \\ \text { GJPO } & \text { Grand Junction Projects Office } \\ \text { HRCQ } & \text { Highway-Route Controlled Quantity (of radioactive materials) } \\ \text { INEEL } & \text { Idaho National Engineering and Environmental Laboratory } \\ \text { ITRI } & \text { Inhalation Toxicology Research Institute } \\ \text { LANL } & \text { Los Alamos National Laboratory } \\ \text { LBNL } & \text { Lawrence Berkley National Laboratory } \\ \text { LCF } & \text { Latent Cancer Fatality } \\ \text { LLNL } & \text { Lawrence Livermore National Laboratory } \\ \text { LLW } & \text { Low-Level Waste } \\ \text { NEPA } & \text { National Environmental Policy Act } \\ \text { NRC } & \text { U.S. Nuclear Regulatory Commission } \\ \text { NTP } & \text { National Transportation Program (DOE) } \\ \text { NTS } & \text { Nevada Test Site } \\ \text { ORR } & \text { Oak Ridge Reservation } \\ \text { PGDP } & \text { Paducah Gaseous Diffusion Plant } \\ \text { PNNL } & \text { Pacific Northwest National Laboratory } \\ \text { PORT } & \text { Portsmouth Gaseous Diffusion Plant } \\ \text { PPPL } & \text { Princeton Plasma Physics Laboratory } \\ \text { RFETS } & \text { Rocky Flats Environmental Technology Site } \\ \text { SNL } & \text { Sandia National Laboratory } \\ \text { SPRU } & \text { Separations Process Research Unit } \\ \text { SRS } & \text { Savannah River Site } \\ & \end{array}$

\begin{tabular}{|c|c|c|c|}
\hline - & \multicolumn{3}{|c|}{ Units Conversions } \\
\hline 1 mile (mi.) & $=$ & \multicolumn{2}{|c|}{$1.609 \mathrm{~km}$} \\
\hline 1 Sievert (Sv) & $=$ & \multicolumn{2}{|l|}{$100 \mathrm{rem}$} \\
\hline 1 Curie (Ci) & $=$ & \multicolumn{2}{|c|}{ 3.7E+10 Becquerels $(\mathrm{Bq})$} \\
\hline $1 \mathrm{lb}$ & $=$ & \multicolumn{2}{|c|}{$0.454 \mathrm{~kg}$} \\
\hline $1 \mathrm{ft}$ & $=$ & \multicolumn{2}{|l|}{$0.3048 \mathrm{~m}$} \\
\hline $1 \mathrm{ft}^{3}$ & $=$ & \multicolumn{2}{|l|}{$0.028 \mathrm{~m}^{3}$} \\
\hline \multicolumn{4}{|c|}{ Scientific Notation } \\
\hline $9.4 \mathrm{E}-02$ & $=$ & $9.4 \times 10^{-2}$ & $=0.094$ \\
\hline
\end{tabular}


This Page Intentionally Left Blank 


\section{CONTENTS}

EXECUTIVE SUMMARY

ACKNOWLEDGMENTS

GLOSSARY

1.0 INTRODUCTION .

2.0 LLW TRANSPORTATION DISPOSAL OPERATIONS

AND SHIPPING DATA

2.1 DESCRIPTION OF ALTERNATIVE SHIPPING CONFIGURATIONS

2.2 WASTE VOLUME AND SHIPPING DATA

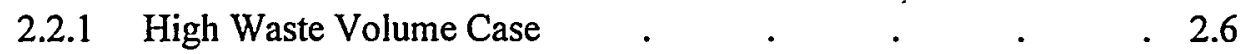

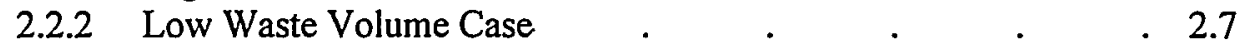

3.0 CAPABILITIES OF LLW GENERATORS TO SHIP BY RAIL. 3.1

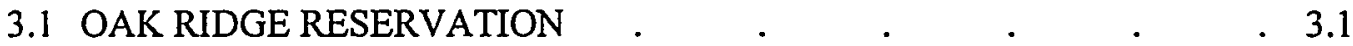

3.2 LOS ALAMOS NATIONAL LABORATORY $\quad$ • $\quad$. $\quad$ • $\quad 3.3$

3.3 FERNALD ENVIRONMENTAL RESTORATION

MANAGEMENT CORP. . $\quad . \quad$. $\quad . \quad$. $\quad . \quad . \quad .3 .3$

3.4 ROCKY FLATS ENVIRONMENTAL TECHNOLOGY SITE . $\quad 3.3$

3.5 EG\&G MOUND APPLIED TECHNOLOGIES, INC. ․ . . $\quad$. 3.3

3.6 LAWRENCE LIVERMORE NATIONAL LABORATORY . . $\quad$ • $\quad 3.3$

3.7 BROOKHAVEN NATIONAL LABORATORY . $\quad . \quad$. $\quad$. 3.3

3.8 IDAHO NATIONAL ENGINEERING AND ENVIRONMENTAL

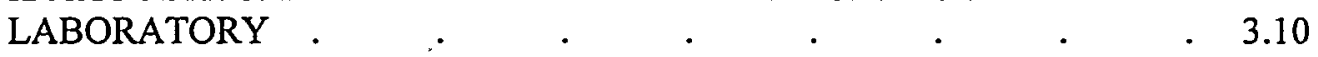

3.9 ARGONNE NATIONAL LABORATORY - EAST. $\quad$. $\quad$. $\quad 3.10$

3.10 SUMMARY OF RAIL ACCESS INFORMATION . . . . $\quad$. 3.10

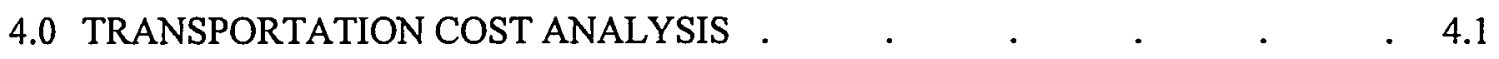

4.1 TRUCK AND RAIL CARRIER CHARGES $\quad$. $\quad$. $\quad$. $\quad$. 4.1

4.1.1 Transportation Cost Data From The

4.1.2 Transportation Cost Data From The WM-PEIS . $\quad$. $\quad$. 4.3

4.1.3 DOE Historical Shipment Cost Data . . . . $\quad$. 4.4

4.1.4 Rationale for Selection of Carrier Costs Used in this Study $\quad$. 4.5

4.2 SHIPPING CONTAINER PROCUREMENT COSTS $\quad . \quad$. $\quad . \quad 4.8$

4.3 INTERMODAL TRANSFER COSTS $\quad . \quad$. $\quad . \quad$. $\quad . \quad 4.9$

4.4 RESULTS OF TRANSPORTATION COST ANALYSIS . $\quad . \quad$. $\quad 4.9$

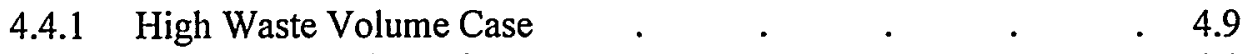

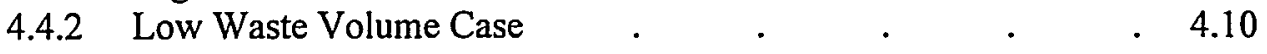




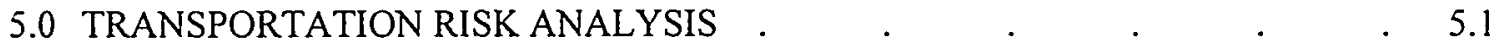

5.1 METHODOLOGY DESCRIPTION . . . . . . 5.5

5.1.1 In-Transit Radiological Impact Methodology _ . . . . 5.6

5.1.2 Radiological Exposures to Workers at Intermodal

5.1.3 Physical (Nonradiological) Routine Risks _ . . . . 5.13

5.1.4 Physical (Nonradiological) Accident Risks In-Transit . $\quad 5.14$

5.1.5 Physical (Nonradiological) Accident Risks to Workers

5.2 COMPARISON OF INPUT PARAMETERS WITH

OTHER STUDIES . $\quad . \quad$. $\quad$. $\quad$. $\quad$. $\quad$. $\quad . \quad 5.14$

5.2.1 Shipment Volumes and Configurations . $\quad . \quad$. $\quad . \quad 5.17$

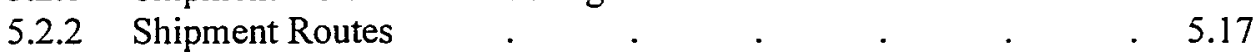

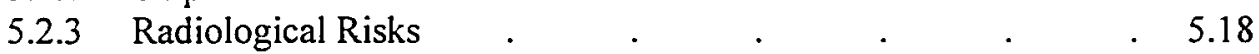

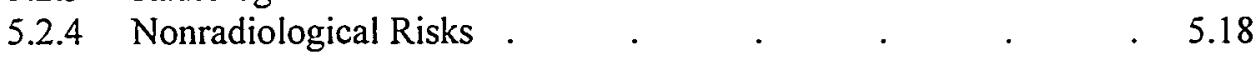

5.3 RESULTS OF TRANSPORTATION IMPACT ANALYSES $\quad$ • $\quad 5.19$

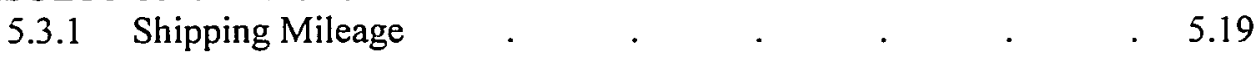

5.3.2 Transportation Risks by Generator Site _ . . . . 5.21

5.3.3 Transportation Risks by State . $\quad . \quad$. $\quad . \quad$. 5.34

6.0 MOTOR CARRIER CONSIDERATIONS IN ROUTING NON HIGHWAY

ROUTE CONTROLLED CLASS 7 NUCLEAR MATERIALS $\quad . \quad$. $\quad$. 6.1

6.1 ROUTING CONSIDERATIONS IN DOE'S TRANSPORTATION

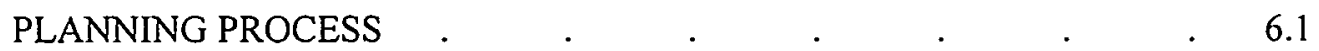

6.2 MOTOR CARRIER REQUIREMENTS $\quad . \quad$. $\quad . \quad$. $\quad . \quad$. 6.5

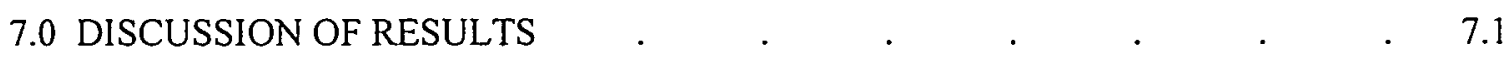

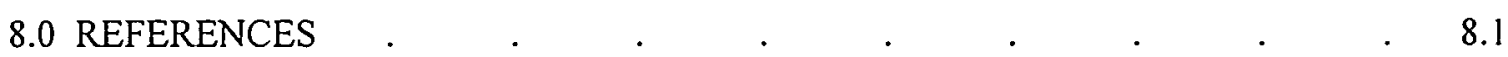

APPENDIX A ROUTE DESCRIPTIONS ․ . . . . . . . . A.1

APPENDIX B SELECTED DETAILED RESULTS OF TRANSPORTATION RISK ANALYSES - RESULTS SORTED FIRST BY STATE AND THEN BY SITE . B.1

APPENDIX C SELECTED DETAILED RESULTS OF TRANSPORTATION RISK ANALYSES - RESULTS SORTED BY SITE AND THEN BY STATE . - C. C.1 


\section{TABLES}

ES-1 Summary of Transportation Impacts and Rankings $\quad . \quad \ldots \quad \ldots \quad$. $\quad . \quad$. vii

2.1 Life-Cycle LLW Volumes to be Transported to the NTS Under the High

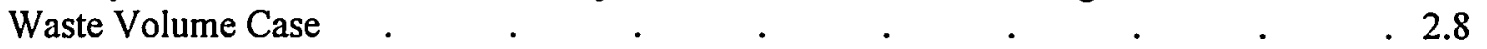

2.2 Numbers of Truck and Rail Shipments of LLW Destined for NTS Disposal

Facilities - High Waste Volume Case (70-yr life-cycle) . $\quad . \quad$. $\quad . \quad$. 2.11

2.3 LLW Volumes and Number of LLW Shipments to NTS - Low Waste Volume Case _ . 2.12

4.1 Truck and Intermodal Transportation Costs for LLW Shipments to NTS . 4.2

4.2 Transportation Costs Derived from the WM-PEIS for NTS LLW Generators 4.4

4.3 Cost Data for Consignments From FY 1997 and FY $1998 \quad$. $\quad$. $\quad$. $\quad$. 4.6

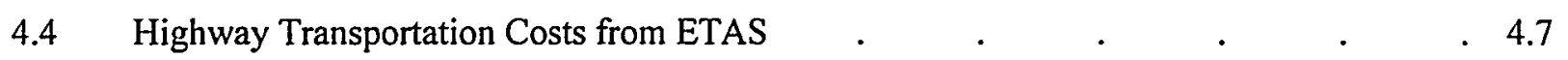

4.5 Life-Cycle Shipping Costs (\$M) for Each Alternative - High Waste Volume . 4.10

4.6 Life-Cycle Shipping Costs (\$M) for Each Alternative - Low Waste Volume 4.11

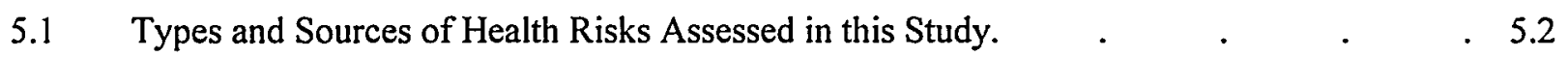

5.2 RADTRAN 4 Parameters Used in the Analysis of Incident-Free Radiological Exposures . 5.8

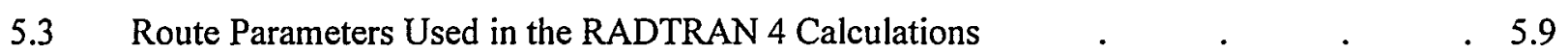

5.4 RADTRAN 4 Input Parameters Used in the Radiological Accident Analysis 5.12

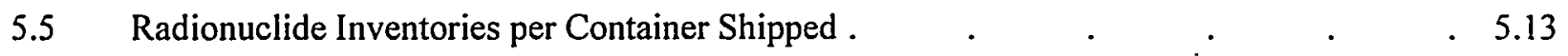

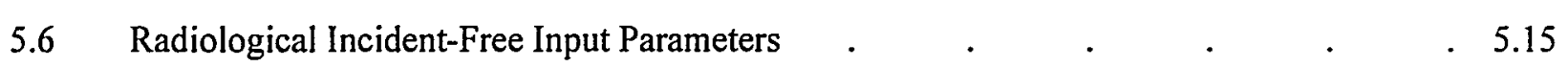

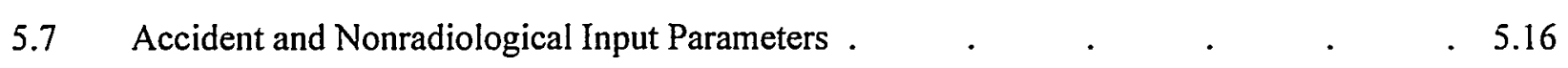

$\begin{array}{lll}5.8 & \text { Results of Transportation Impact Analysis for Configuration 1A (Rail/Intermodal } \\ & \text { Through Barstow, Trucks Avoid Las Vegas, High Waste Volume) } & 5.22\end{array}$

$\begin{array}{llll}5.9 & \text { Results of Transportation Impact Analysis for Configuration 1A (Rail/Intermodal } \\ \text { Through Barstow, Trucks Avoid Las Vegas, Low Waste Volume) . . . } & 5.23\end{array}$

$\begin{array}{lll}5.10 & \text { Results of Transportation Impact Analysis for Configuration 1B (Rail/Intermodal } \\ \text { Through Caliente, Trucks Avoid Las Vegas, High Waste Volume) } & \text {. } & 5.24\end{array}$

5.11 Results of Transportation Impact Analysis for Configuration 1B (Rail/Intermodal
Through Caliente, Trucks Avoid Las Vegas, Low Waste Volume) . . $\quad 5.25$ 
5.12 Results of Transportation Impact Analysis for Configuration 1B (Rail/Intermodal

Through Caliente, Trucks Through Las Vegas, High Waste Volume) 5.26

5.13 Results of Transportation Impact Analysis for Configuration 2 (100\% Truck,

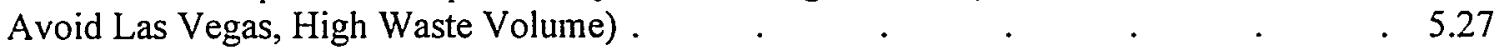

5.14 Results of Transportation Impact Analysis for Configuration 2 (100\% Truck,

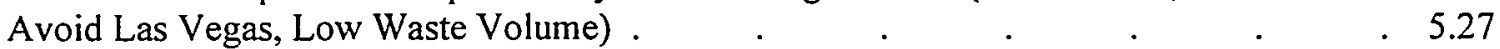

5.15 Results of Transportation Impact Analysis for Configuration 3 (100\% Truck,

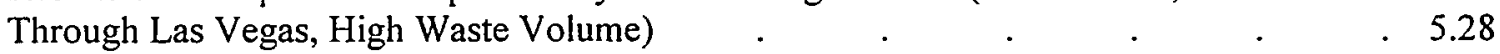

5.16 Results of Transportation Impact Analysis for Configuration 2 (100\% Truck,

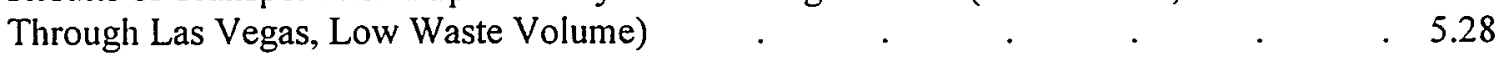

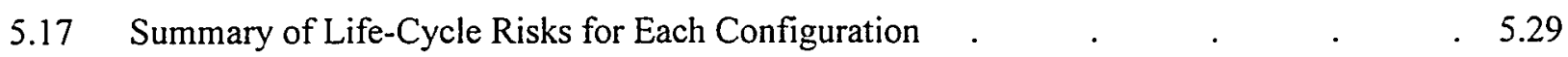

5.18 Detailed Truck and Rail Incident-Free Doses for Major LLW Generators _ 5.33

5.19 Total Risk by State: Configuration 1A (Intermodal at Barstow) - High Waste Volume,

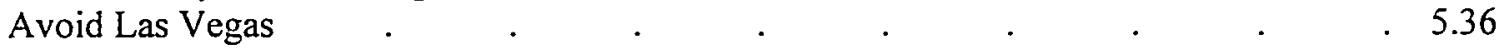

5.20 Total Risk by State: Configuration 1B (Intermodal at Caliente) - High Waste Volume,

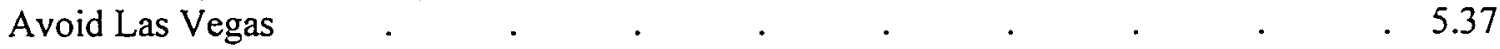

5.21 Total Risk by State: Configuration $2(100 \%$ Truck, Avoid Las Vegas) ～. 5.38

5.22 Total Risk by State: Configuration 3 (100\% Truck, Through Las Vegas). . . . . 5.39 


\section{FIGURES}

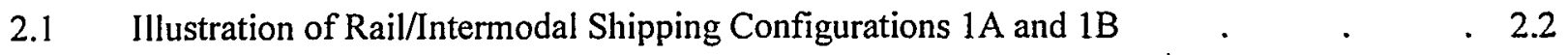

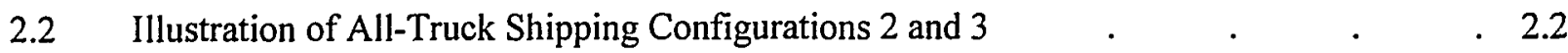

2.3 Intermodal Routes and Highway Routes that Avoid Las Vegas Enroute to NTS . $\quad$. 2.3

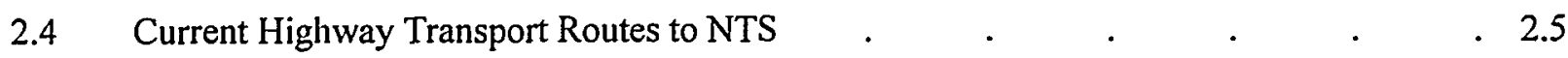

2.5 Life-Cycle Disposal Volumes for the High Waste Volume Case . $\quad$. . . . 2.7

2.6 Near-Term Annual LLW Flow to NTS for the High Waste Volume Case . $\quad$ 2.9

2.7 Life-Cycle LLW Flow to the NTS for the High Waste Volume Case $\quad$. $\quad$. $\quad$. 2.10

2.8 Life-Cycle LLW Disposal Volumes for the Low Waste Volume Case $\quad$ - 2.12

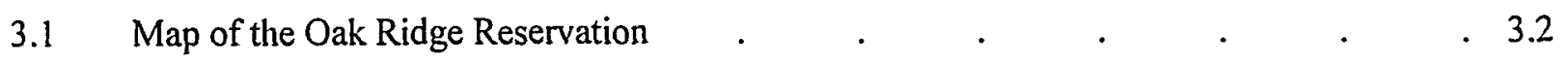

3.2 Map of the Los Alamos National Laboratory Transportation Routes $\quad$ - $\quad$ • $\quad$. 3.4

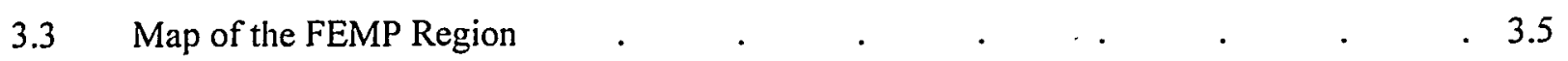

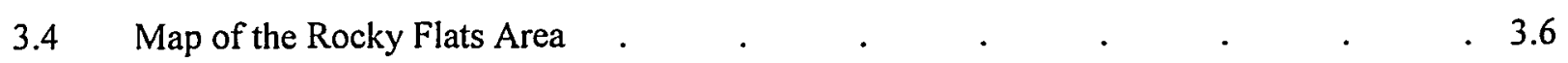

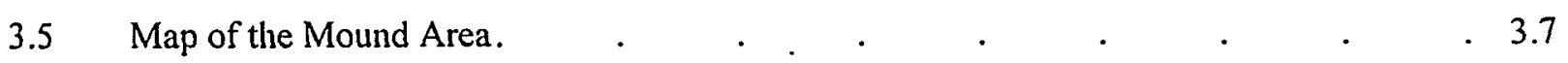

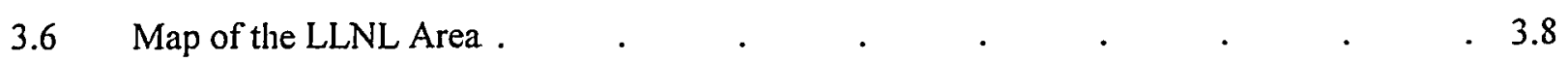

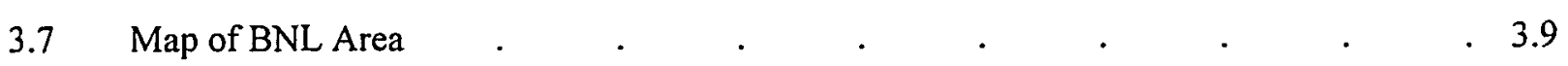

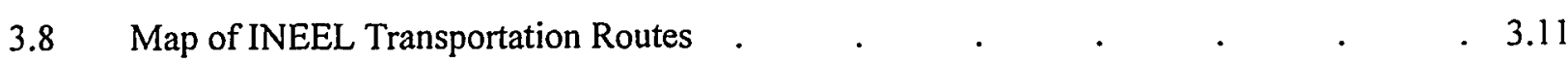

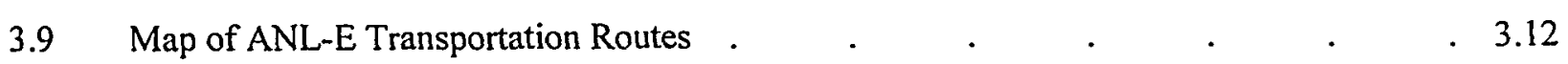

4.1 Plot of Truck and Rail Transportation Costs as a Function of Shipping Distance _ _ . 4.3

4.2 Comparison of Transportation Cost Data from Three Sources $\quad . \quad$. $\quad$. $\quad ~ \cdot 4.7$

5.1 Truck and Rail Shipping Mileage Totals for all Configurations - High Waste
Volume Option.
. . . . . . . . . . .

5.2 Truck and Rail Shipping Mileage Totals for all Configurations - Low Waste
Volume Option.

5.3 Plot of Total Transportation Risks for the High Waste Loading Option _ . 5.30

\begin{tabular}{l}
5.4 Components of Incident-Free Radiological Public Risks for Each LLW Shipping \\
Configuration . \\
\hline
\end{tabular} 


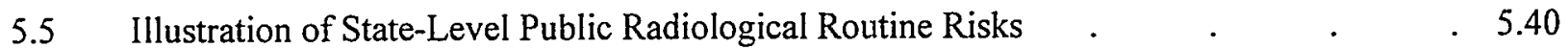

5.6 Illustration of State-Level Nonradiological Accident Risks _ . . . . . . 5.40 


\subsection{INTRODUCTION}

Regionalized options for disposal of low-level radioactive waste (LLW) are the preferred alternatives identified in the Final Waste Management Programmatic Environmental Impact Statement for Managing, Treatment, Storage, and Disposal of Radioactive and Hazardous Waste (WM PEIS; DOE 1997). The regional disposal alternatives consolidate LLW disposal operations at a few DOE sites. A total of six LLW disposal options are currently being considered, each of which combines onsite disposal at certain sites with disposal of offsite-generated LLW at one or more regional facilities. One of the facilities under consideration for disposal of onsite- and offsite-generated LLW is the Nevada Test Site (NTS).

Two modal options were considered in the analysis of LLW transportation impacts in the PEIS: $100 \%$ truck and $100 \%$ rail. It was recognized that all sites are capable of shipping by truck but less than half of the sites have onsite rail capabilities. The $100 \%$ rail option was assumed in the PEIS for calculational purposes. In general, it was determined that the $100 \%$ rail option would result in lower health and safety impacts than the $100 \%$ truck option. It is unlikely that DOE sites that generate small volumes of LLW would consider constructing direct rail service to their LLW facilities because of the costs involved. Therefore, a more likely scenario will involve a mix of truck and rail service. In addition, NTS lacks direct rail access to its LLW disposal facilities.

Intermodal service to the NTS is being studied as part of DOE's ongoing efforts to responsibly manage its risks. The draft Intermodal Transportation of Low-Level Radioactive Waste to the Nevada Test SiteDraft Environmental Assessment (DOE 1998a), referred to here as the NTS Intermodal EA, was issued for review in 1998. Intermodal transport is done in three general steps. Intermodal shipments consist of a combination of truck and rail service. For generator sites that currently have direct rail access, the LLW would be loaded onto railcars and transported by general freight rail service from the generator sites to an intermodal transfer facility near NTS. Dedicated train service in which the LLW containers are the only cargo aboard the train was not evaluated in this study. At the intermodal facility, the rail shipping container would be offloaded from the railcar and placed on a truck. Trucks would transport the LLW cargo to disposal areas on NTS. For LLW generators without rail access, intermodal transfers would occur at the origin and destination of the shipments. The LLW would first be loaded onto trucks at the generator sites and moved to a nearby railhead or intermodal transfer facility where the LLW containers would be loaded onto railcars. For this type of service, truck trailers carrying LLW may be transported on rail flatcars to simplify the loading and unloading processes. The rest of the shipment would proceed as described above for sites with direct rail access. Using these concepts, increasing the use of rail to transport LLW from generator and treatment sites to NTS for disposal is technically feasible for all DOE LLW generator sites.

The purpose of the report is to develop a credible basis for DOE-Nevada, authorized (and prospective) LLW shipping sites, stakeholders, and carriers to manage, understand, and discuss risks and costs associated with transportation of LLW to NTS. The report will:

- Investigate alternative transportation system configurations including truck and intermodal (mix of truck and rail) options.

- Assess life-cycle (70 year) human health risks and costs.

- Assess DOE systems-wide (generator site to NTS) human health risks and costs

- Dovetail with truck and intermodal alternatives identified in the NTS Intermodal EA. 
- Address both cargo (i.e., radiological) and vehicle (i.e., non-radiological) related risk.

- Document cost trends among alternatives based on historical DOE transportation costs. Both capital and operating costs will be considered.

- Enable site-specific and national comparisons of cost vs. risk tradeoffs among truck and intermodal alternatives.

- Enable comparison of risk impacts by state for all alternatives

- Flag areas where more precise assessment could uncover opportunities for enhanced transportation safety and efficiency.

- Demonstrate to any DOE site that may receive waste or materials from other sites the framework and process for a thorough transportation risk assessment. It will apply concepts identified in the Resource Handbook on DOE Transportation Risk Assessment (Chen et al. 1999).

Limitations to the report include:

- The disposal configurations identified in this report should not be construed as policy. Policy will be determined when the DOE issues a Record of Decision (ROD) for LLW based on the WM-PEIS. The report is based on a today's understanding of waste loads (i.e., volumes and characteristics) and prospective generating sites (being considered in the WM PEIS ROD process) that could ship to NTS. The configurations were not crafted or altered by the authors of this report. It is recognized that waste volume loads and sites approved for disposal at NTS have been dynamic and are expected to remain dynamic until (and to a lesser extent after) the WM PEIS ROD is issued.

- This report does not attempt to anticipate new LLW transportation options that may result from Yucca Mountain high-level waste (HLW) decisions. However, data contained in this report may be useful to DOE management responsible for and stakeholders interested in cumulative transportation impacts associated with Yucca Mountain and HLW decisions.

- Assumptions concerning highway and rail routes are made that are representative (but not entirely reflective) of actual routes chosen by carriers. Assumptions are also made concerning locations of intermodal facilities near generator sites. They were made for purposes of assessment and are in no way binding on sites or carriers. Variations in routes and intermodal sites are expected; however, they are not expected to significantly impact the comparisons among alternatives.

- While the NTS Intermodal EA contains three potential intermodal sites, this report considers only two. For the purposes of this assessment, the Yermo, California, alternative is considered sufficiently reflective of the Barstow, California, alternative so the Yermo alternative was not analyzed.

- All LLW generating sites are assumed to ship waste to NTS via uniform volume "Sea-Land" containers. Additionally, all containers were assumed to be completely filled (if sufficient waste exists) to $75 \%$ by volume of the maximum cargo capacity of each shipping container. In reality, many different containers of varying capacity meet Department of Transportation requirements and could be used. Likewise, the fill rate of the assumed Sea-Land container could be constrained by weight and packaging (so the entire volume of the container may not be filled). If other assumptions concerning container volume or fill rate are made, impacts from this report can be scaled to the new 
volume. For example, if containers are assumed to be only $50 \%$ filled by volume, vehicle-related impacts could be multiplied by 1.5 (i.e., $75 \%$ divided by 50\%). More shipments would be needed to transport the same volume of LLW, leading to higher transportation costs, higher nonradiological impacts, etc. Additional shipping containers may also be needed.

- Additional modeling assumptions have been made and are identified later in this report. Consistent assumptions tend to influence the magnitude of the impacts reported, rather than trends in impacts among alternatives. Therefore, more confidence should be placed in the trends among impacts than magnitude of impacts.

- Only state-specific accident statistics were used. Route-specific road segment accident statistics were insufficient to base an analysis upon.

- The report focuses on transportation -- it does not consider disposal cost. It also does not consider how transfer of hazard (i.e., LLW) from generator sites to NTS translates to transfer of mortgage (e.g., risk or cost).

Several interrelated tasks were performed to fulfill the purposes of this study. These tasks are listed below and brief descriptions are provided.

- Rail/Intermodal Capability Assessment: The capabilities of various DOE LLW generator sites to ship LLW to the NTS via rail or truck/rail intermodal service was investigated via telephone contacts with site representatives. Additional information was obtained from various published sources. This information was used to demonstrate whether it is feasible for waste generators to ship by rail and was also used in the evaluation of the costs and risks of rail/intermodal shipping configurations.

- Transportation Cost Analysis: This task calculated life-cycle (70 yr) transportation costs for various options for shipping LLW to NTS. Basic cost data were extracted from several sources and used to estimate the total life-cycle costs of transporting LLW to NTS.

- Transportation Risk Analysis: Life-cycle transportation risks were calculated using existing DOE methodologies, including the RADTRAN 4, HIGHWAY, and INTERLINE computer codes. These methods were used to calculate routine radiological doses to the public and workers involved in the transport of LLW to NTS, radiological accident risks, nonradiological accident risks, and risks from exposure to vehicle emissions. The cost and risk information was then integrated to identify tradeoffs among the shipping configuration options evaluated in this study.

- DOE and Motor Carrier Routing Evaluations: Information from a number of sources was collected and summarized to describe the evaluations performed by DOE and motor carriers relative to the transportation of LLW.

The results of the risk and cost analyses of each alternative LLW transportation configuration were combined with the evaluation of major stakeholder issues and the routing/risk analysis comparisons to develop insights that could help DOE to effectively manage LLW transportation system risks. 
This Page Intentionally Left Blank 


\subsection{LLW WASTE DISPOSAL OPTIONS AND SHIPPING DATA}

This chapter provides supporting data for estimating the risks and costs associated with the increased use of rail to ship LLW to NTS disposal areas. Information in this chapter includes descriptions of the alternative shipping configurations examined in this study and site-by-site LLW generator waste loads.

\subsection{DESCRIPTION OF ALTERNATIVE SHIPPING CONFIGURATIONS}

Four alternative LLW transportation system configurations were constructed to examine the impacts on costs and risks of increasing the percentage of rail shipments to NTS. Two LLW volume projections to be shipped to NTS were also evaluated. The waste loads were taken from ongoing supplement analyses being conducted in support of the WM-PEIS Record of Decision (ROD) for LLW. In the first case, referred to here as the "high waste volume" case, all LLW shipped offsite is disposed at NTS. Four other sites dispose of their own LLW onsite, including Hanford, INEEL, Los Alamos, and SRS. This option maximizes the volume of LLW shipped to NTS. In the second case, referred to as the "low waste volume" case, both Hanford and NTS are used for offsite disposal of LLW, and INEEL, LANL, and SRS dispose of their LLW onsite (LANL also ships about $20 \%$ of its LLW to NTS). The volume of offsite waste shipped to NTS and Hanford is about equal. This option was selected for use in this study as it provides DOE with flexibility by maintaining two regional LLW disposal sites.

The four alternative transportation system configurations examined in this study were constructed to illustrate the potential differences in risks, costs, and operational efficiencies for increased use of rail service to NTS. The configuration options are labeled similarly to the alternatives analyzed in the NTS Intermodal EA. The four configurations are illustrated in Figures 2.1 and 2.2 and are described below.

\section{Configuration 1A - Intermodal Service Via Barstow, California}

This configuration is one of two analyzed in this study that avoids the Las Vegas Valley and Hoover Dam areas to the extent possible by encouraging the use of rail shipments to NTS (see Figure 2.3). Existing rail lines would be used to transport the wastes from LLW generator sites to Barstow, CA. At Barstow, the waste containers, which may be truck trailers loaded onto rail flatcars, would be transferred from railcars to trucks, and transported to NTS via I-15, CA 127, NV 373, and US 95. The intermodal facility at Barstow would be used to transfer the loaded shipping containers onto trucks for transit to NTS disposal areas. Generator sites without rail service currently would need to use trucks to ship to an intermodal transfer facility near their site to use this intermodal option. This configuration was constructed to examine the costs and risks of increasing the use of rail service for LLW shipments to NTS. It would involve establishing intermodal transfer capabilities ${ }^{1}$ at generator sites currently without rail service as well as intermodal transfer capabilities at Barstow, CA. This alternative explores the costs and benefits of long-distance rail shipments for LLW and avoidance of truck shipments through the Las Vegas Valley and Hoover Dam areas to the extent practicable. Small quantity generator sites, where it would not be cost-effective to invest in direct or intermodal rail service, were assumed to ship via highway routes that avoid Las Vegas and Hoover Dam.

\footnotetext{
${ }^{\prime}$ DOE and its contractors are not anticipated to invest in new facilities or equipment to establish intermodal service. This is assumed to be a business decision on the part of the private sector.
} 


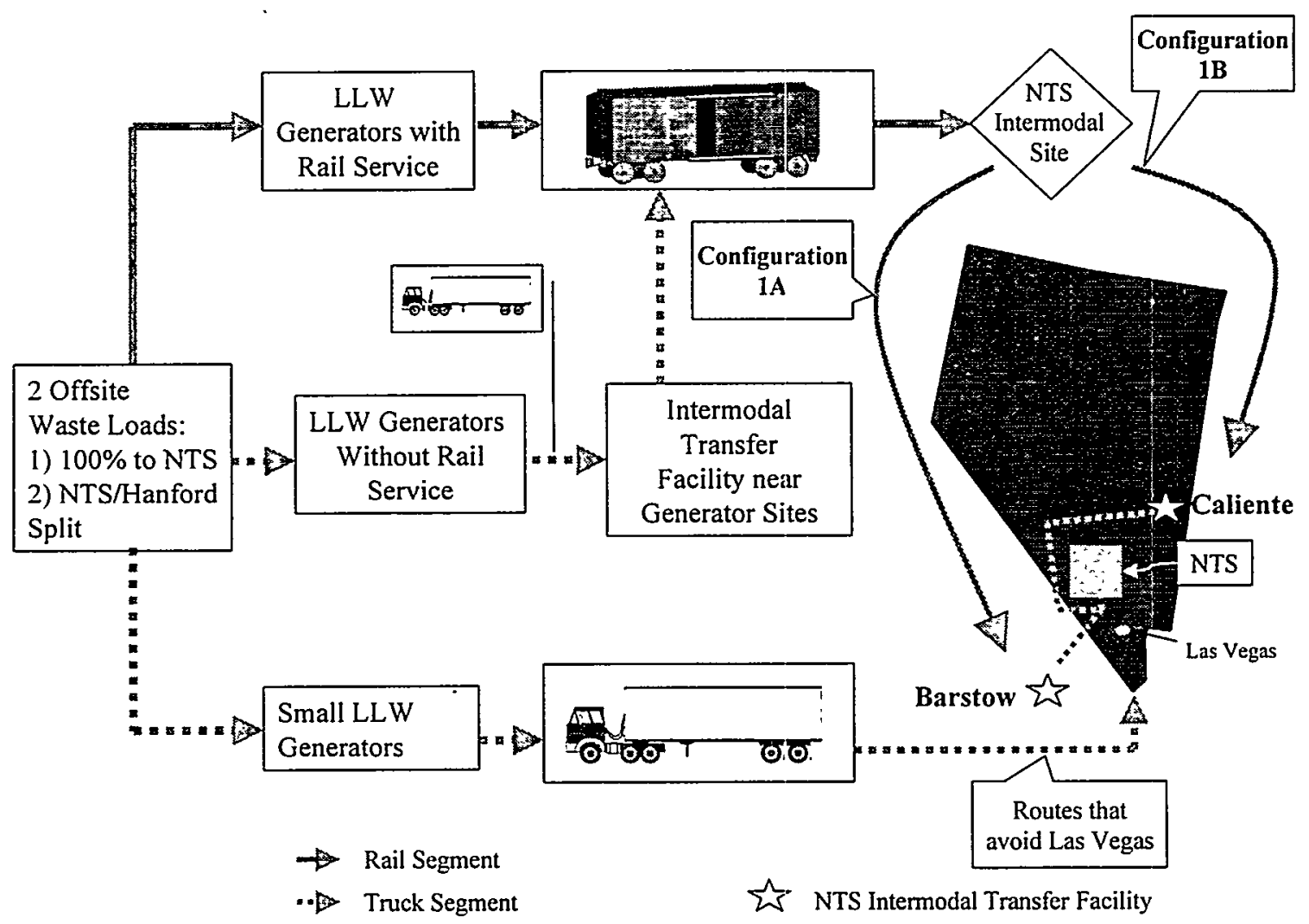

Figure 2.1. Illustration of Rail/Intermodal Shipping Configurations $1 \mathrm{~A}$ and $1 \mathrm{~B}$

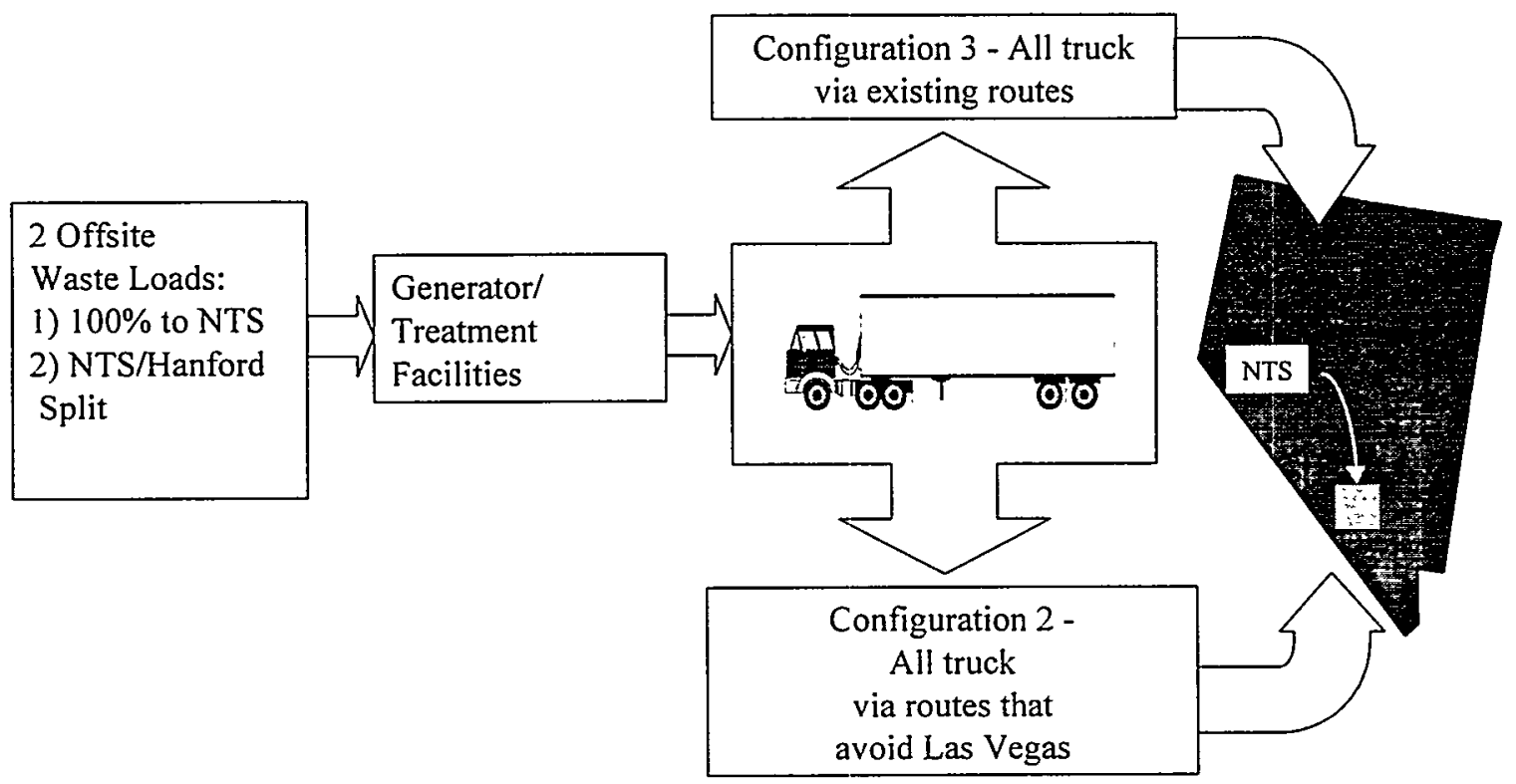

Figure 2.2. Illustration of All-Truck Shipping Configurations 2 and 3 


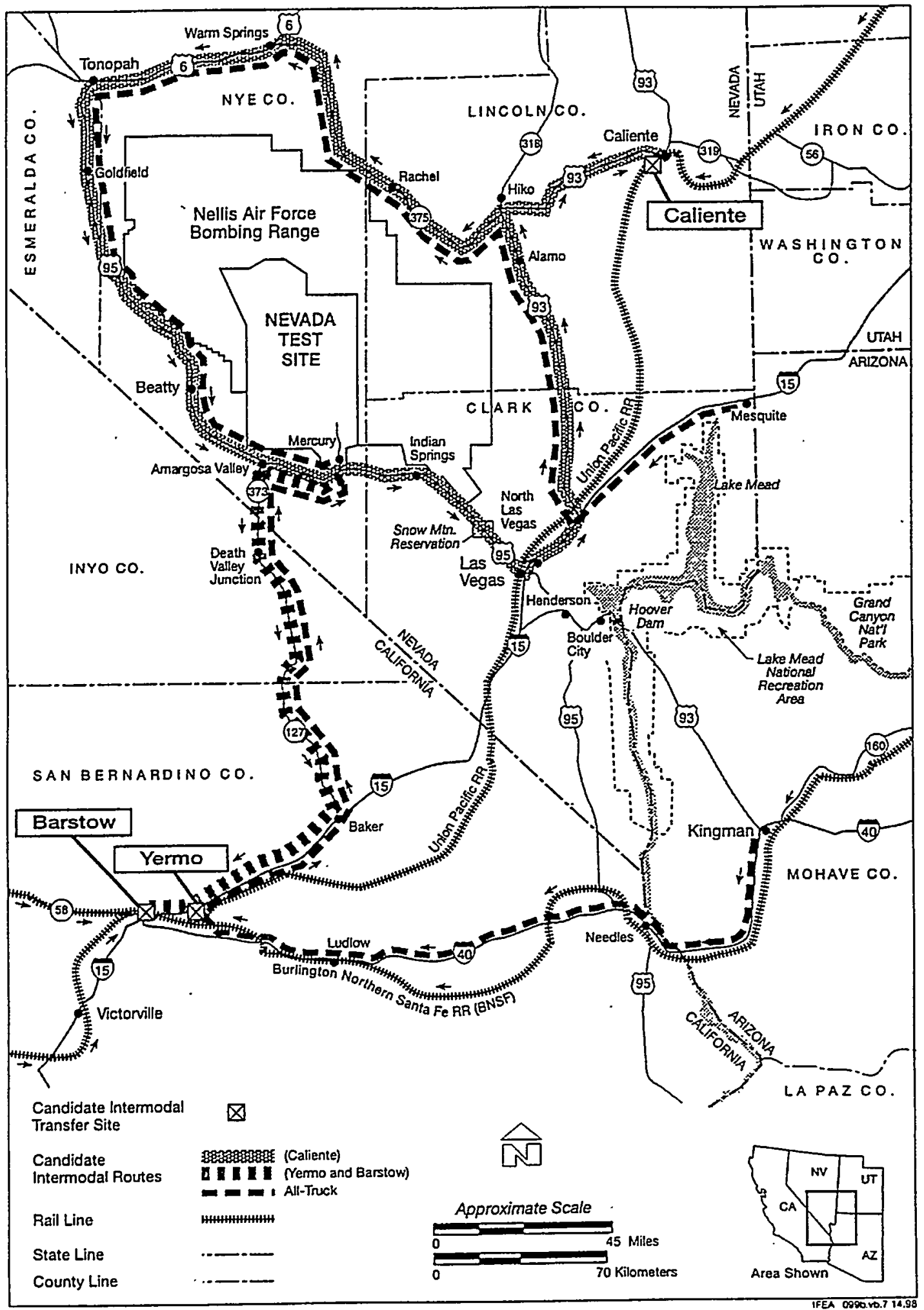

Figure 2.3. Intermodal Routes and Highway Routes that Avoid Las Vegas Enroute to NTS 


\section{Configuration 1B - Intermodal Service Via Caliente, Nevada}

This configuration is similar to Configuration 1A in that it avoids the Las Vegas Valley and Hoover Dam areas to the extent possible by encouraging the use of rail shipments to NTS. Existing rail lines would be used to transport the wastes from LLW generator sites to Caliente, Nevada. At Caliente, the waste containers would be removed from railcars, loaded onto trucks, and transported to NTS via US 93, NV 375 , US 6, and US 95. An intermodal facility at Caliente would be used to transfer the loaded shipping containers onto trucks for transit to NTS disposal areas. The facility would also be used to load empty containers onto railcars for further use. A different route (i.e., via US 95, I-15, and US 93 that traverses the Las Vegas Valley) could be followed for empty return shipments to reduce the distance and transit time and allow the opportunity to use maintenance and service facilities in Las Vegas. As with Configuration 1A, generator sites without rail service currently would need to invest in direct rail access or intermodal transfer capabilities to use the intermodal option at NTS. This configuration would involve establishing intermodal transfer capabilities at generator sites currently without rail service, would take advantage of lower risks for rail shipments, and would avoid truck shipments through the Las Vegas Valley and Hoover Dam areas. Small quantity generator sites, where it would not be cost-effective to invest in direct or intermodal rail service, would ship via highway routes that avoid Las Vegas and Hoover Dam. No distinction is made here between the Caliente In-town and South sites for the potential intermodal transfers that were considered in the NTS Intermodal EA.

\section{Configuration 2 - 100\% Truck Via Routes that Avoid Las Vegas}

This configuration combines NTS Intermodal EA Alternatives 2A and 2B. In this configuration, all LLW shipments to NTS would be by truck over more circuitous routes that avoid the Las Vegas Valley and Hoover Dam (see Figure 2.3). Truck shipments that currently use the US 93 route that enters Nevada from the southeast would deviate at Kingman, Arizona, continuing on Interstate 40 (1-40) until it intersects with Interstate 15 in Barstow, California. At Barstow, the truck would take: I-15 northeast to Baker, California; California 127 north; and then Nevada 373 and US 95 to NTS. Shipments that currently enter Nevada from the east on I-15 would deviate from the current routes at the intersection with US 93. The shipments would take US 93 north to the intersection of Nevada 375, follow Nevada 375 northwest to US 6, travel west to US 95 at Tonopah, NV, and then take US 95 south to NTS. This configuration was constructed to compare the impacts of alternative highway routes to NTS. It would not involve the costs to upgrade NTS and LLW generator sites to rail or intermodal service, and would involve longer transit times and highway distances. However, this would avoid the highly populated Las Vegas Valley and recreation facilities at Hoover Dam.

\section{Configuration 3 - 100\% Truck Via Existing Routes}

This configuration represents the No-Action Alternative in the NTS Intermodal EA. It assumes LLW transportation to NTS would continue via legal-weight truck across Hoover Dam and through metropolitan Las Vegas (see Figure 2.4). The highway routes would enter Nevada on Interstate 15 (I15) or U.S. Highway 93 (US 93) and travel through Las Vegas and on to NTS. The US 93 route, which is used by more than $80 \%$ of the shipments, also travels over Hoover Dam. The remaining $20 \%$ of the shipments enter Nevada from the east or west on I-15. This configuration provides a basis for comparing the risk and cost impacts of alternative highway and rail configurations that avoid the

Planned Las Vegas Beltway A beltway is currently being constructed around the urban center of Las Vegas. The initial beltway facility is planned to be completed by 2003. It is unknown if use of the beltway by LLW shipments would alleviate the concerns of Las Vegas residents about shipping radioactive material through the city on I-15 and US 95. The beltway also gives rise to two potentially more-optimum intermodal transfer facilities, one southwest and one northeast of the city center. Further analyses are necessary to evaluate these potential intermodal alternatives. 


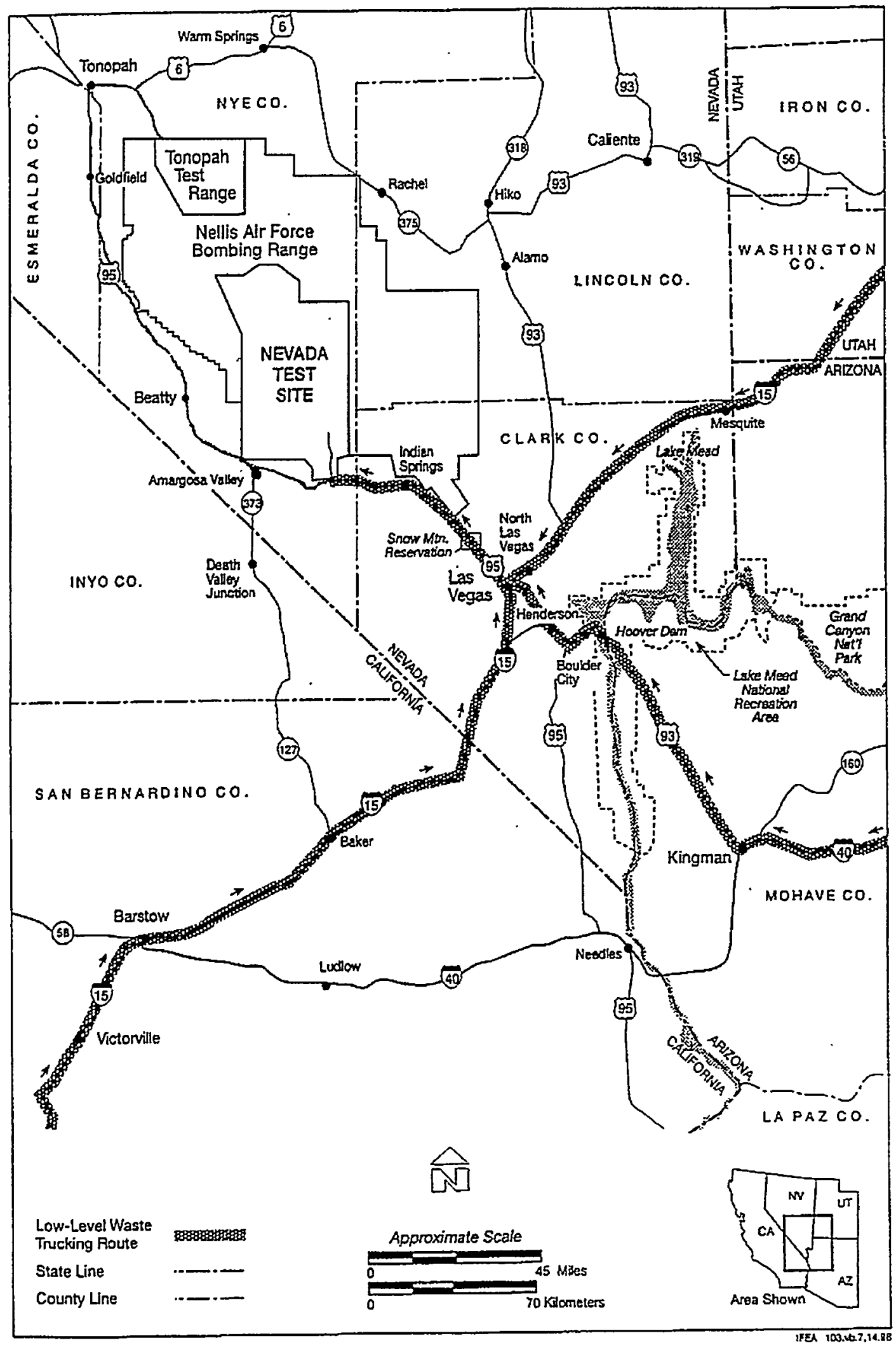

Figure 2.4. Current Highway Transport Routes to NTS 
Las Vegas Valley. Changes in costs and risks estimates for the other configurations will be measured against this alternative

\subsection{WASTE VOLUMES AND SHIPPING DATA}

Two NTS disposal cases were examined in this study: 1) high waste volume case, and 2) low waste volume case. Waste volumes and shipping data were obtained from the Consolidated PBS Quantity Tables (CPQT) database, which is being used in the supplement analyses being conducted to support the WM-PEIS ROD. The CPQT data is an improved and evolved version of the database used in preparation of Accelerating Cleanup - Paths to Closure (DOE 1998b). The data used here is a snapshot of the CPQT data provided in late FY 1998. The CPQT data was characterized as becoming more stable as it has evolved and the data provided by the sites has become more and more consistent from year to year. The CPQT database is being placed under formal change control and this will improve its future stability.

\subsubsection{High Waste Volume Case}

In the high waste volume case, NTS is the primary disposal site for offsite LLW. A small quantity of offsite LLW is also disposed at Hanford but the bulk is disposed at NTS. Figure 2.5, generated using waste volume data from the CPQT database, illustrates the life-cycle LLW volumes to be disposed onsite (i.e., disposed at the generator site) and at offsite LLW disposal facilities. The waste volumes include those projected to be generated from Waste Management (WM) and Environmental Restoration (ER) activities at DOE sites. Note that there are five other LLW disposal sites, including Hanford, INEEL, LANL, SRS, and a commercial disposal site. The four DOE sites will continue to dispose of LLW onsite. The LANL and INEEL will continue onsite disposal until the projected capacity is reached and then will ship the remaining LLW to NTS for disposal. The commercial disposal site will dispose of certain LLW streams from ANL-E, LLNL, LBL, and SRS and certain ER LLW streams from BNL, ETEC, LANL, LBNL, and Pantex.

As shown in Figure 2.5, NTS is projected to receive about $740,000 \mathrm{~m}^{3}\left(26\right.$ million $\left.\mathrm{ft}^{3}\right)$ of LLW over the 70 -yr life-cycle from offsite generators. This is the upper bound LLW volume to be shipped to NTS considered in this study. This does not include about $215,000 \mathrm{~m}^{3}$ of LLW projected to be generated onsite at NTS, predominantly from ER activities.

Table 2.1 provides the waste loads to be transported to NTS from each generator site under the high waste volume case. As with the data in Figure 2.5, the site-by-site waste volume data were extracted from the September version of the CPQT database. The data provides the current projected life-cycle LLW volumes from both DOE-EM Waste Management operations as well as waste volumes projected to result from Environmental Restoration activities at DOE sites. The data was provided by the LLW generator site. It should be noted that waste volume projections over a 70-yr period have substantial uncertainties. However, the uncertainty in the waste volume projections does not affect the comparisons between shipping configurations as the uncertainties apply equally to all alternatives.

As shown in Table 2.1, over $93 \%$ of the total LLW volume destined for disposal at NTS under the high waste volume case is generated at nine sites (shaded area of Table 2.1). These nine sites are the most likely candidates for intermodal transport and, if significant cost and risk reductions are anticipated to result from increased use of rail service, the bulk of the savings will be derived from these sites. The other sites shown in Table 2.1 represent relatively small quantities of LLW and thus less significant cost and risk reductions from increased use of rail service. It was assumed that these sites would continue to ship by truck. 


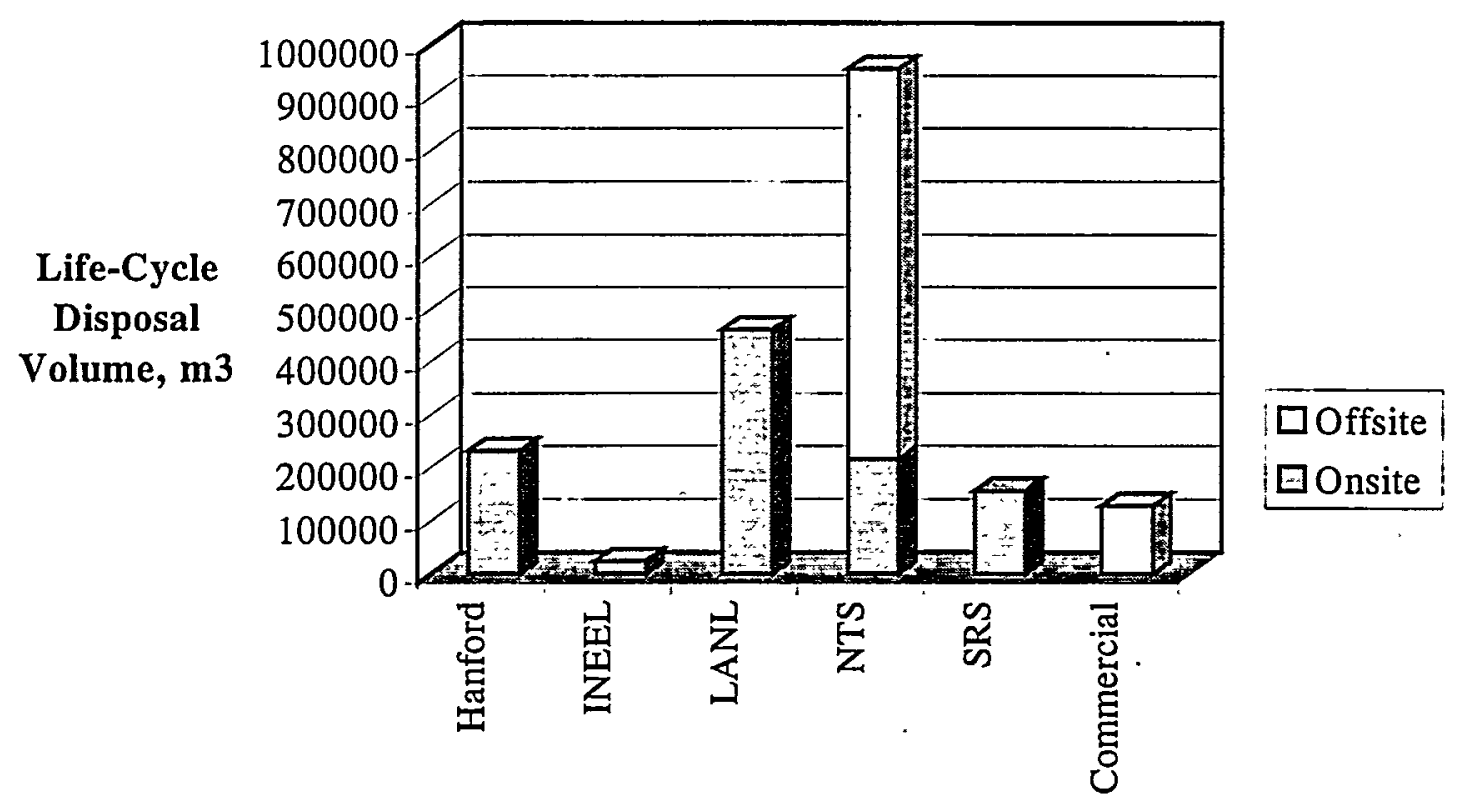

Candidate Disposal Site

Figure 2.5. Life-Cycle LLW Disposal Volumes for the High Waste Volume Case

Staff of the DOE National Transportation Program (NTP) were requested to perform a detailed sort of the CPQT data to determine if the annual waste flows to NTS were within the analyzed boundaries of the NTS Site-wide EIS. Figures 2.6 and 2.7 present annual waste flows to NTS for the near-term (through 2010) and life-cycle (through 2070), respectively. As shown in Figure 2.6 (near-term), the largest annual flow occurs in the year 2001 and amounts to just over $40,000 \mathrm{~m}^{3}\left(1,410,000 \mathrm{ft}^{3}\right)$ of LLW per year. This is well below the upper bound LLW annual receipt rate analyzed in the NTS Site-Wide EIS, Expanded Use Alternative.

The numbers of shipments from the various waste generators to the NTS for the high waste volume case are shown in Table 2.2. The numbers of shipments were calculated by dividing the total inventory projected to be shipped by an assumed LLW shipment capacity. Each LLW shipment was assumed to consist of packaged LLW (e.g., 55-gal drums or standard boxes) within an external steel box shipping container, similar to the 20-ft Sea-Land container assumed in the NTS Intermodal EA. One container would be transported per truck shipment and three per rail shipment. It was assumed that each container would be loaded to $75 \%$ of its maximum cargo capacity or approximately $26.7 \mathrm{~m}^{3}\left(940 \mathrm{ft}^{3}\right)$ per truck shipment and $80 \mathrm{~m}^{3}\left(2800 \mathrm{ft}^{3}\right)$ per rail shipment. The shipment capacities were not adjusted to account for packaging efficiencies or weight limitations. Since this assumption was applied to all shipping configurations, it does not affect the trends in cost or risk impacts between the all-truck and rail/intermodal options.

\subsubsection{Low Waste Volume Case}

In this case, NTS and Hanford are the sites for disposal of LLW generated elsewhere. The volumes of waste shipped to NTS are about the same as the waste volume shipped to Hanford from offsite LLW generators (exclusive of large volumes of contaminated soil and debris that will be generated by 
Table 2.1. Life-Cycle LLW Volumes to be Transported to NTS under the High Waste Volume Case ${ }^{(a)}$

\begin{tabular}{|c|c|c|c|c|c|}
\hline \multirow{2}{*}{$\begin{array}{c}\text { LLW } \\
\text { Generator } \\
\text { Site }^{(\mathbf{b})}\end{array}$} & \multicolumn{3}{|c|}{ Life-Cycle Waste Volume, $\mathrm{m}^{3}$} & \multirow{2}{*}{$\begin{array}{c}\text { Percentage } \\
\text { of } \\
\text { Total }\end{array}$} & \multirow[b]{2}{*}{$\begin{array}{l}\text { Cumulative } \\
\text { Percentage }\end{array}$} \\
\hline & $\begin{array}{c}\text { Waste } \\
\text { Management }\end{array}$ & $\begin{array}{l}\text { Environmental } \\
\text { Restoration }\end{array}$ & TOTAL & & \\
\hline ORR & 242,160 & 20,267 & 262,427 & $35.52 \%$ & $35.52 \%$ \\
\hline LANL & 102,022 & 0 & 102,022 & $13.81 \%$ & $49.33 \%$ \\
\hline Fernald & 0 & 83,591 & 83,591 & $11.31 \%$ & $60.64 \%$ \\
\hline RFETS & 20,215 & 44,817 & 65,032 & $8.80 \%$ & $69.44 \%$ \\
\hline Mound & & 64,177 & 64,177 & $8.69 \%$ & $78.13 \%$ \\
\hline LLNL & 37,216 & .0 & 37,216 & $5.04 \%$ & $83.17 \%$ \\
\hline$\overline{B N L}$ & 17,213 & 18,421 & 35,634 & $4.82 \%$ & $87.99 \%$ \\
\hline INEEL & 24,860 & 0 & 24,860 & $3.36 \%$ & $91.35 \%$ \\
\hline$\overline{\text { ANL-E }}$ & 13,217 & 778 & 13,995 & $1.89 \%$ & $93.25 \%$ \\
\hline WVDP & 11,297 & 0 & 11,297 & $1.53 \%$ & $94.78 \%$ \\
\hline$\overline{\mathrm{BCL}}$ & 0 & 9,192 & 9,192 & $1.24 \%$ & $96.02 \%$ \\
\hline SPRU & 0 & 8,220 & 8,220 & $1.11 \%$ & $97.13 \%$ \\
\hline Sandia & 3,684 & 1,387 & 5,071 & $0.69 \%$ & $97.82 \%$ \\
\hline PGDP & 4,379 & 0 & 4,379 & $0.59 \%$ & $98.41 \%$ \\
\hline ETEC & 0 & 3,401 & 3,401 & $0.46 \%$ & $98.87 \%$ \\
\hline ITRI & 2,313 & 0 & 2,313 & $0.31 \%$ & $99.19 \%$ \\
\hline PORT & 2,031 & 0 & 2,031 & $0.27 \%$ & $99.46 \%$ \\
\hline PPPL & 1,960 & $\overline{0}$ & 1,960 & $0.27 \%$ & $99.73 \%$ \\
\hline Pantex & 1,403 & 0 & 1,403 & $0.19 \%$ & $99.92 \%$ \\
\hline$\overline{\mathrm{LBL}}$ & 434 & $\overline{0}$ & 434 & $0.06 \%$ & $\overline{99.97 \%}$ \\
\hline Ames. & 118 & 0 & 118 & $0.02 \%$ & $99.99 \%$ \\
\hline$\overline{\mathrm{GJPO}}$ & 0 & 55 & 55 & $0.01 \%$ & $100.00 \%$ \\
\hline GE Val & 0 & 21 & 21 & $0.00 \%$ & $100.00 \%$ \\
\hline TOTAL & $\sim 480,000$ & $\sim 250,000$ & $\sim 740,000$ & NA & NA \\
\hline
\end{tabular}

NOTE: Table contains excess significant figures that were retained for calculation purposes.

(a) Shaded region of table indicates most likely candidate LLW generator sites for rail/intermodal service. Waste volumes do not include LLW generated and disposed onsite at NTS.

(b) See glossary for definitions of acronyms used in this table.

ER activities at Hanford and disposed onsite). Some LLW generators that ship to NTS in the high waste volume case will dispose of their waste at Hanford rather than NTS. Another key difference between this case and the high waste volume case is that some of the sites will dispose of certain categories of LLW onsite rather than shipping it to an offsite disposal facility.

Figure 2.8 illustrates the LLW volumes to be disposed onsite (i.e., at the LLW generator sites) and at offsite disposal facilities over the next 70 years. As with the high waste volume case, this data was developed using the August 1998 version of the CPQT database. Table 2.3 presents a summary of the LLW projected to be shipped to NTS for disposal from offsite LLW generators. Note that the offsite waste volume disposed at NTS is about one-third of the waste volume disposed at NTS in the high waste volume case. Several of the LLW generators that ship to NTS in the high waste volume case ship their waste to NTS in this case but some ship elsewhere. 


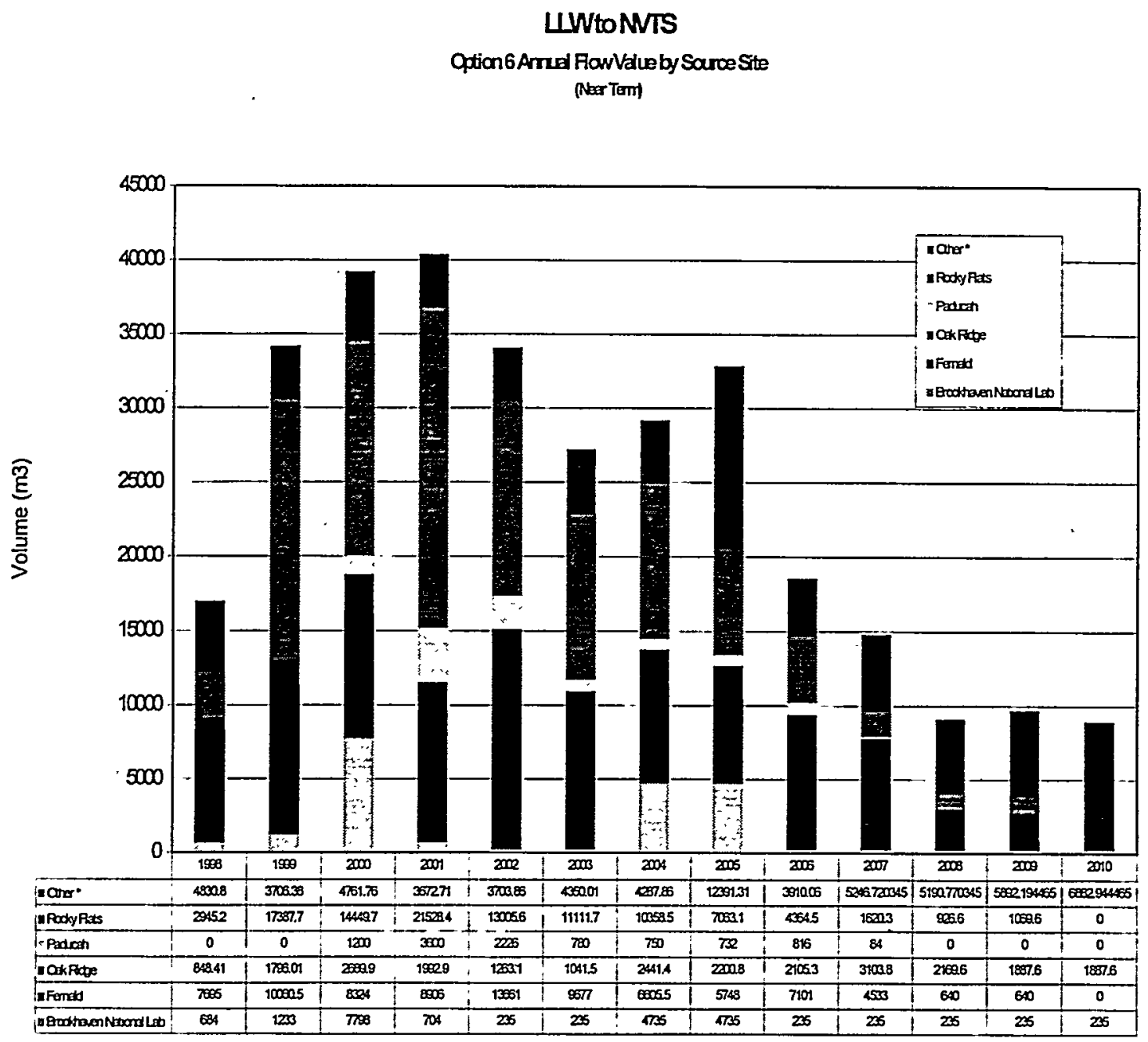

Figure 2.6. Near-Term Annual LLW Flow to NTS for the High Waste Volume Case (numbers contain excess significant figures) 
- LW TONTS

Option 6 Amual FowValue by Source Site

(Lifecyde)

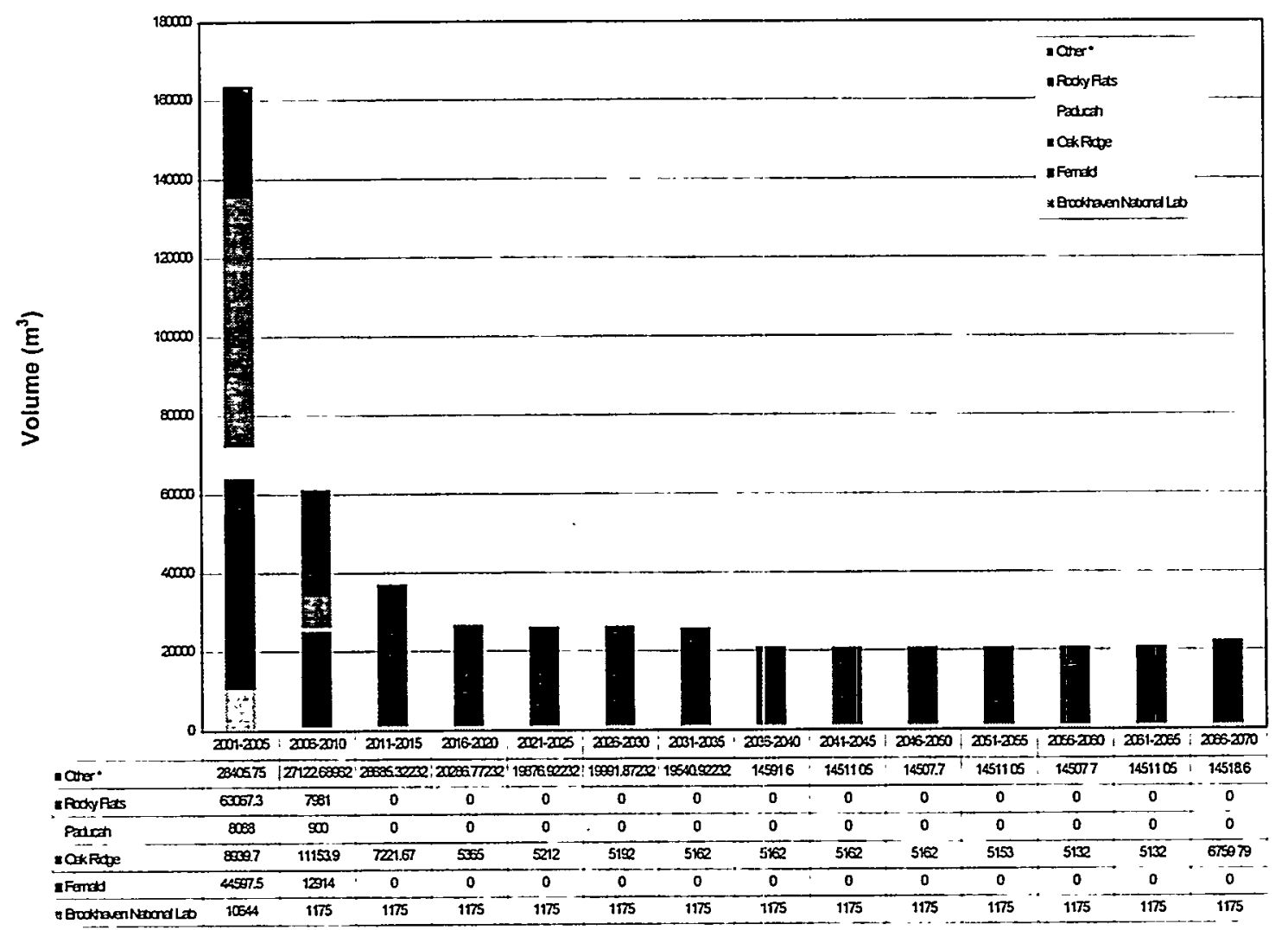

Figure 2.7. Life-Cycle LLW Flow to NTS for the High Waste Volume Case (numbers contain excess significant figures) 
Table 2.2. Numbers of Truck and Rail Shipments of LLW Destined for NTS Disposal Facilities - High Waste Volume Case (70-yr life-cycle) ${ }^{(a)}$

\begin{tabular}{|l|c|c|c|c|}
\hline \multirow{2}{*}{ LLW Generator } & \multicolumn{2}{|c|}{$\begin{array}{c}\text { Configurations 1A and 1B } \\
\text { (Rail/Intermodal) }\end{array}$} & \multicolumn{2}{c|}{$\begin{array}{c}\text { Configurations 2 and 3 } \\
\text { (All Truck) }\end{array}$} \\
\cline { 2 - 5 } & Truck or Rail & $\begin{array}{c}\text { Number of } \\
\text { Shipments }\end{array}$ & Truck or Rail & $\begin{array}{c}\text { Number of } \\
\text { Shipments }\end{array}$ \\
\hline ORR & Rail & 3,283 & Truck & 9,848 \\
\hline LANL & Rail & 1,277 & Truck & 3,829 \\
\hline Fernald & Rail & 1,046 & Truck & 3,137 \\
\hline RFETS & Rail & 814 & Truck & 2,441 \\
\hline Mound & Rail & 803 & Truck & 2,409 \\
\hline LLNL & Rail & 466 & Truck & 1,397 \\
\hline BNL & Rail & 446 & Truck & 1,338 \\
\hline INEEL & Rail & 311 & Truck & 933 \\
\hline ANL-E & Rail & 176 & Truck & 526 \\
\hline WVDP & Truck & 424 & Truck & 424 \\
\hline BCL & Truck & 345 & Truck & 345 \\
\hline SPRU & Truck & 309 & Truck & 309 \\
\hline Sandia-NM & Truck & 191 & Truck & 191 \\
\hline PGDP & Truck & 165 & Truck & 165 \\
\hline ETEC & Truck & 128 & Truck & 128 \\
\hline ITRI & Truck & 87 & Truck & 87 \\
\hline PORT & Truck & 77 & Truck & 77 \\
\hline PPPL & Truck & 74 & Truck & 74 \\
\hline Pantex & Truck & 53 & Truck & 53 \\
\hline LBL & Truck & 17 & Truck & 17 \\
\hline Ames & Truck & 5 & Truck & 5 \\
\hline GJPO & Truck & 3 & Truck & 3 \\
\hline GE Val & Truck & 1 & Truck & 1 \\
\hline
\end{tabular}

(a) The table provides the number of long-haul shipments and does not provide information on the number of truck shipments between LLW generators and intermodal transfer facilities nor the number of truck shipments between Nevada intermodal facilities and NTS. 


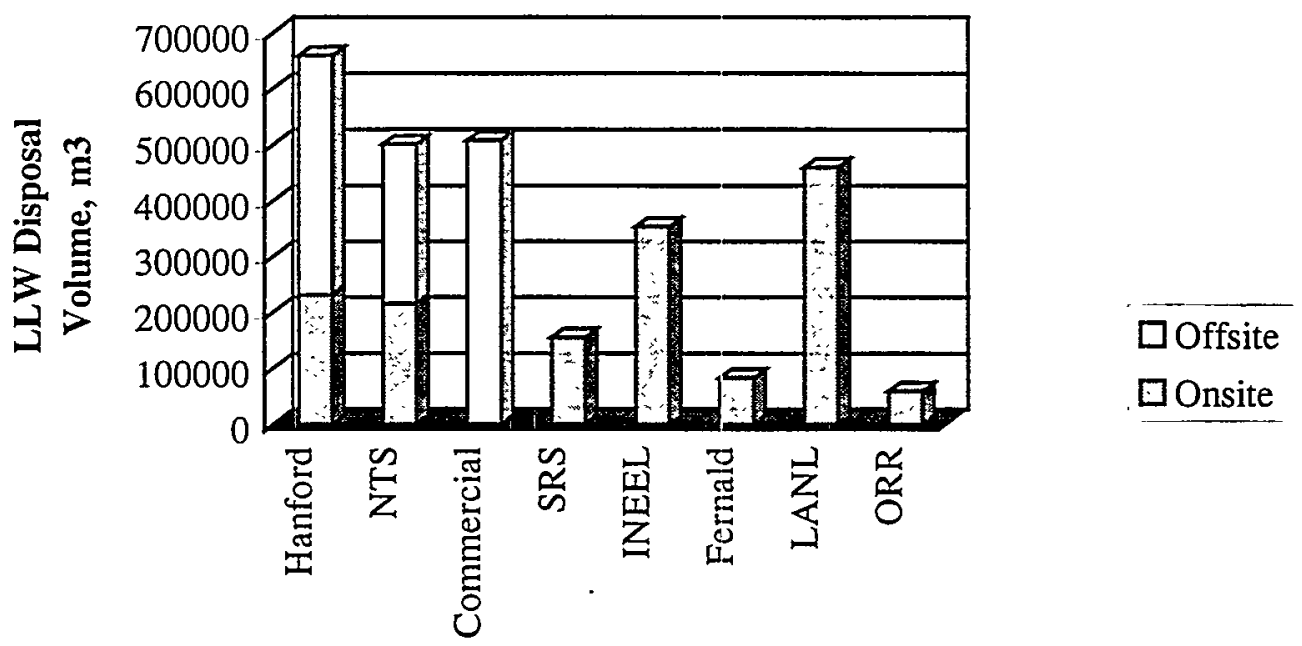

LLW Disposal Site

Figure 2.8. Life-Cycle LLW Disposal Volumes for the Low Waste Volume Case

Table 2.3. LLW Volume and Number of LLW Shipments ${ }^{(a)}$ to NTS - Low Waste Volume Case ${ }^{(b)}$

\begin{tabular}{|c|c|c|c|c|c|}
\hline \multirow[b]{2}{*}{ LLW Generator } & \multirow{2}{*}{$\begin{array}{c}\text { Waste } \\
\text { Volume, } \\
\mathrm{m}^{3}\end{array}$} & \multicolumn{2}{|c|}{ Configuration $1 \mathrm{~A}$ and $1 \mathrm{~B}$} & \multicolumn{2}{|c|}{ Configuration 2 and 3} \\
\hline & & $\begin{array}{c}\text { Truck or } \\
\text { Rail }\end{array}$ & $\begin{array}{l}\text { Number of } \\
\text { Shipments }\end{array}$ & Truck or Rail & $\begin{array}{l}\text { Number of } \\
\text { Shipments }\end{array}$ \\
\hline LANL & 101,022 & Rail & 1,264 & Truck & 3,791 \\
\hline Fernald & 83,591 & Rail & 1,045 & Truck & 3,131 \\
\hline RFETS & 65,032 & Rail & 814 & Truck & 2,441 \\
\hline Mound & 64,177 & Rail & 803 & Truck & 2,409 \\
\hline LLNL & 37,216 & Rail & 466 & Truck & 1,397 \\
\hline Sandia & 5,071 & Truck & 191 & Truck & 191 \\
\hline PGDP & 4,379 & Truck & 165 & Truck & 165 \\
\hline ETEC & 2,760 & Truck & 104 & Truck & 104 \\
\hline ITRI & 2,313 & Truck & 87 & Truck & 87 \\
\hline PORT & 2,031 & Truck & 77 & Truck & 77 \\
\hline Pantex & 1,403 & Truck & $\overline{53}$ & Truck & 53 \\
\hline TOTAL & $\sim 369,000$ & & & & \\
\hline
\end{tabular}

(a) The table provides the number of long-haul shipments and does not provide information on the number of truck shipments between LLW generators and intermodal transfer facilities nor the number of truck shipments between Nevada intermodal facilities and NTS.

(b) Shaded region of table indicates most likely candidate LLW generator sites for rail/intermodal service. Waste volumes do not include LLW generated and disposed onsite at NTS. 


\subsection{CAPABILITIES OF LLW GENERATORS TO SHIP BY RAIL TO NTS}

Rail/intermodal access data for the LLW generators was collected via telephone contacts with the cognizant DOE Traffic Managers and is described in this chapter for nine sites. It is anticipated that not all sites will be candidates for rail/intermodal service. Some sites generate only small volumes of LLW and it would not be cost-effective to undertake projects to change over to rail or intermodal service. In addition, rail carriers are most interested in moving large volumes and would have high unit costs for small quantity generator sites. Thus, a cutoff was established below which changes to rail/intermodal capability were not investigated. The cutoff was established based on selecting the LLW generators that will ship over $90 \%$ of the LLW volume to be transported to NTS. These sites are the Oak Ridge Reservation (ORR), Los Alamos National Laboratory (LANL), Fernald, Rocky Flats Environmental Technology Site (RFETS), Mound, Lawrence Livermore National Laboratory (LLNL), Brookhaven National Laboratory (BNL), Idaho National Engineering and Environmental Laboratory (INEEL), and Argonne National Laboratory - East (ANL-E). For the small quantity LLW generator sites, a separate investigation will be conducted to explore the possibility they could ship LLW by truck to the nearest large quantity generator site and there it would be transferred onto railcars for shipment to NTS. The results of this assessment will be provided in the final report.

An informal phone survey of the traffic managers for these nine sites revealed that four of the nine sites surveyed do not have the capability to directly ship LLW offsite by rail (LANL, RFETS, ANL-E, and LLNL). The cost to upgrade three of the four sites without the capability to directly ship LLW by rail ranges from $\$ 500,000$ to $\$ 10,000,000$ based on a rule-of-thumb construction cost of $\$ 1,000,000$ per rail mile. However, there is much uncertainty relative to the feasibility of obtaining access to construct a rail spur. The fourth site (Los Alamos National Laboratory) would require hauling the LLW approximately 40 miles by truck to the nearest rail access. Consequently, intermodal shipping was assumed for these sites.

The following sections summarize the results of the telephone surveys for each of the nine sites surveyed including the rail line serving the site and the site crane capacity.

\subsection{OAK RIDGE RESERVATION}

See Figure 3.1 for a map of the Oak Ridge Reservation (ORR).

\section{K-25 Site}

The K-25 site has the capability to ship LLW offsite by rail. Norfolk-Southern Railway Co. through Blair, TN, serves the K-25 facility. The facility performs internal switching within the plant area, taking delivery of cars from Southern Railway at the north end of the plant at an interchange yard located approximately 5 miles south of Blair. The facility's maximum crane capacity is 75 tons.

\section{Y-12 Plant}

The Y-12 Plant has the capability to ship LLW offsite by rail. The Y-12 Plant trackage connects at Oak Ridge, TN (DuPont Siding) with the CSX Railroad Company for this area. The Y-12 plant performs onsite internal switching arrangements. Trackage is available to receive 20 rail cars at one time. The facility crane capacity is 75 tons. 


\section{DOE-OAK RIDGE INSTALLATIONS}

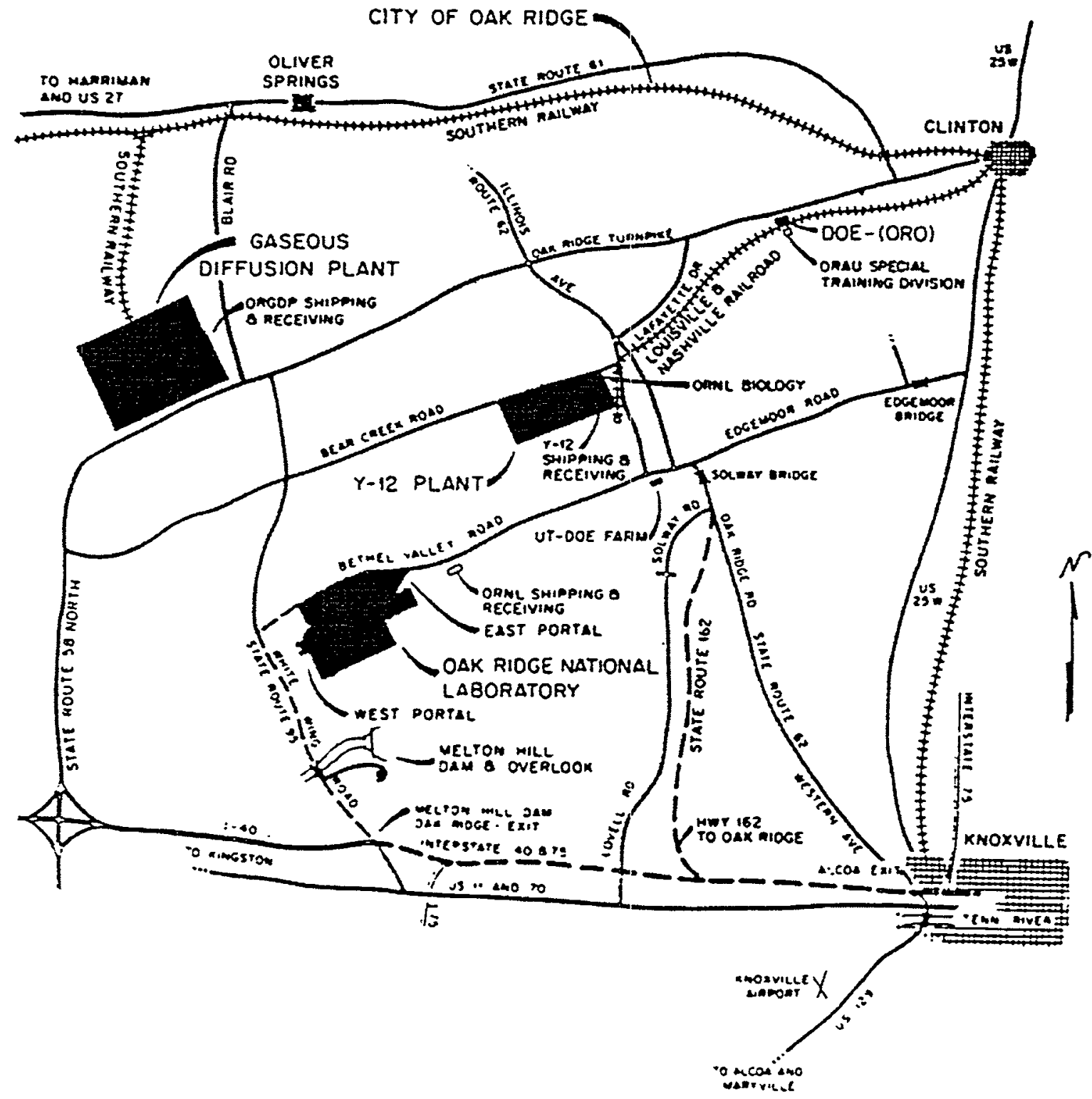

Figure 3.1. Map of Oak Ridge Reservation 


\subsection{LOS ALAMOS NATIONAL LABORATORY}

There is no rail service to Los Alamos, NM. The nearest rail siding with unloading facilities is Lamy, NM, approximately 40 miles to the east. Rail and intermodal service is also available in Albuquerque, NM, approximately 100 miles to the south. The BNSF Railroad serves both. Facility crane capacity is 10 tons. A map of LANL is shown in Figure 3.2.

\subsection{FERNALD ENVIRONMENTAL RESTORATION MANAGEMENT CORPORATION (FERMCO)}

The Fernald site has the ability to ship LLW offsite by rail. The Fernald site trackage connects at Shandon, Ohio, with the CSX System. The Fernald site performs internal switching and trackage is available to receive 30 rail cars. The mobile crane capacity is 33 tons. A map of Fernald is shown in Figure 3.3.

\subsection{ROCKY FLATS ENVIRONMENTAL TECHNOLOGY SITE}

The Rocky Flats site does not currently have the capability to ship LLW offsite by rail. The installation of approximately 0.5 miles of rail track would be required to enable the shipment of LLW offsite by rail. The Union Pacific (UP) is the only line serving Rocky Flats, that also performs internal switching. There is a paved area for off-loading with a crane with a capacity of 25 tons. Intermodal service is available in Denver, approximately 20 miles from RFETS. A map of Rocky Flats is shown in Figure 3.4.

\subsection{EG\&G MOUND APPLIED TECHNOLOGIES, INC̣.}

The Mound facility has the ability to ship LLW waste offsite by rail. Trackage connects at Miamisburg, $\mathrm{OH}$, with Conrail, which performs internal switching. The facility crane capacity is 35 tons. A map of the Mound Site is shown in Figure 3.5.

\subsection{LAWRENCE LIVERMORE NATIONAL LABORATORY}

No rail sidings are available at the Lawrence Livermore National Laboratory. In Livermore, CA, the Public Team Tracks of Union Pacific Railroad are available. They are approximately four miles from the facility. Site 300 uses the Public Team Tracks of Union Pacific Railroad, in Tracy, CA, approximately 13 miles from Site 300 . Facility Riggers with a 20-ton crane and other lifting equipment (fork-lifts, cherrypickers) are available. A map of LLNL is shown in Figure 3.6.

\subsection{BROOKHAVEN NATIONAL LABORATORY}

The capability to ship LLW directly offsite by rail exists at Brookhaven. The Brookhaven site trackage connects at Yaphank with the Long Island Railroad. Trackage is available to receive 20 rail cars at one time. Side and end ramps are available. The facility crane capacity is 65 tons. A map of BNL is shown in Figure 3.7. 


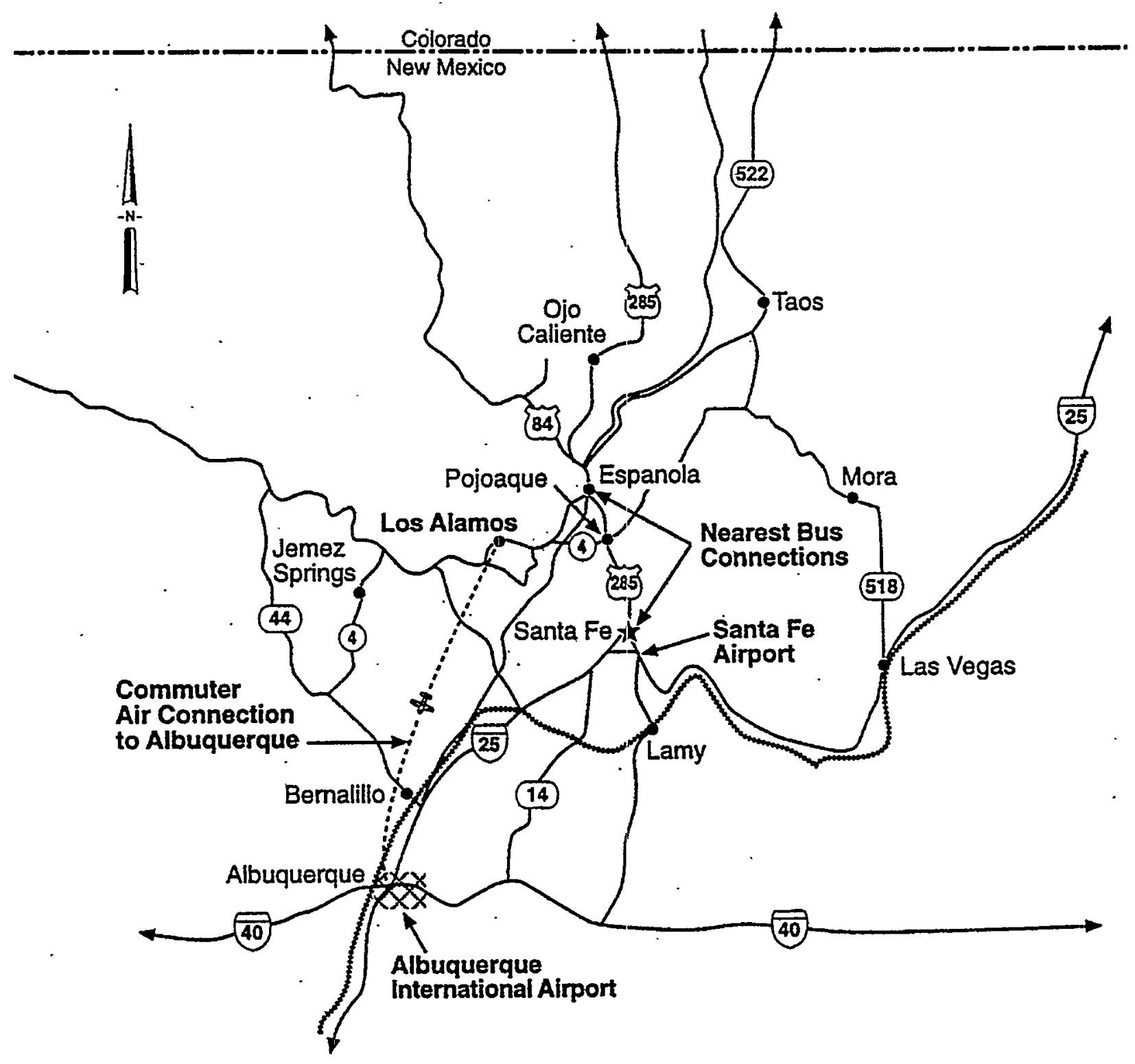

Figure 3.2. Map of Los Alamos National Laboratory Transportation Routes 


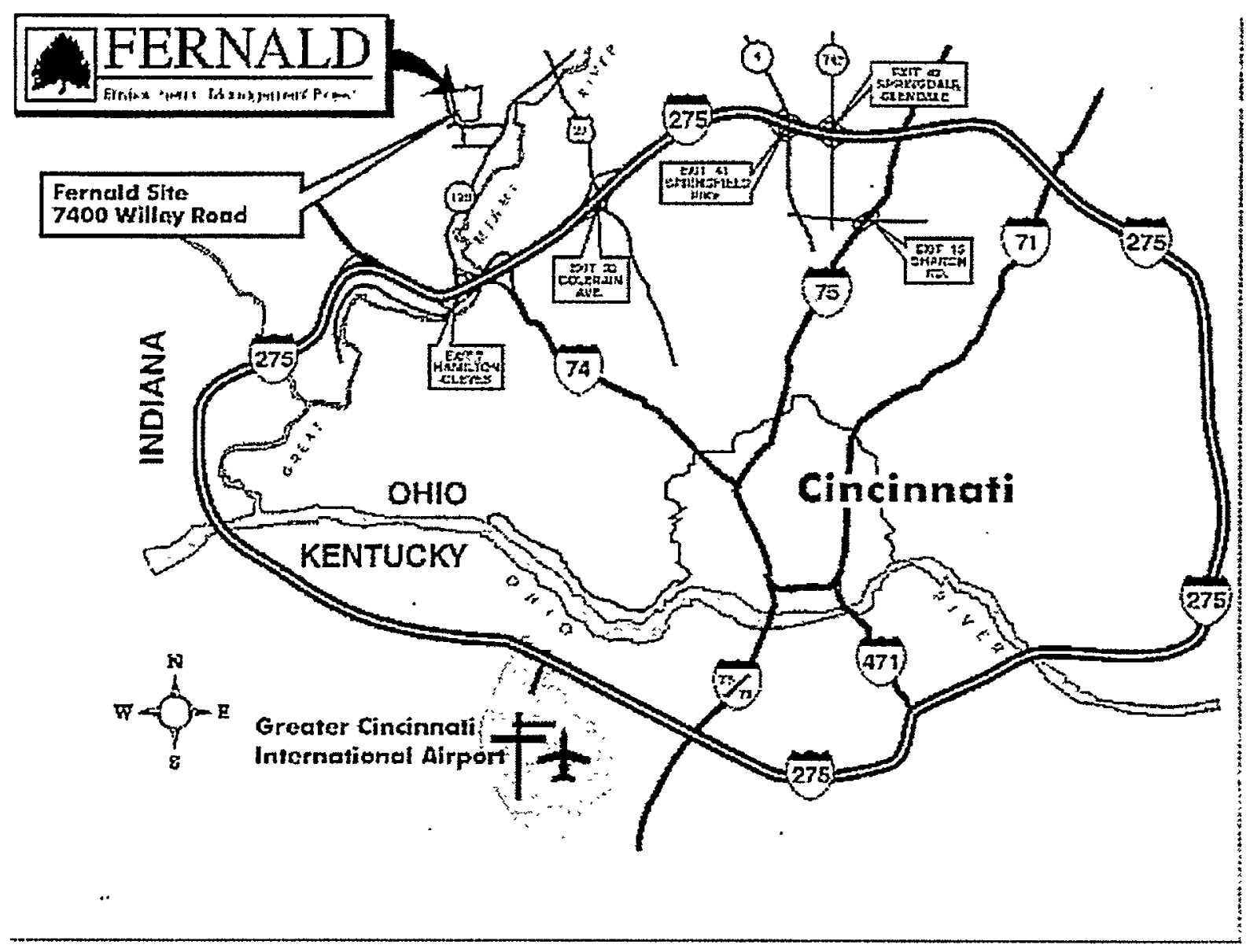

Figure 3.3. Map of FEMP Region 


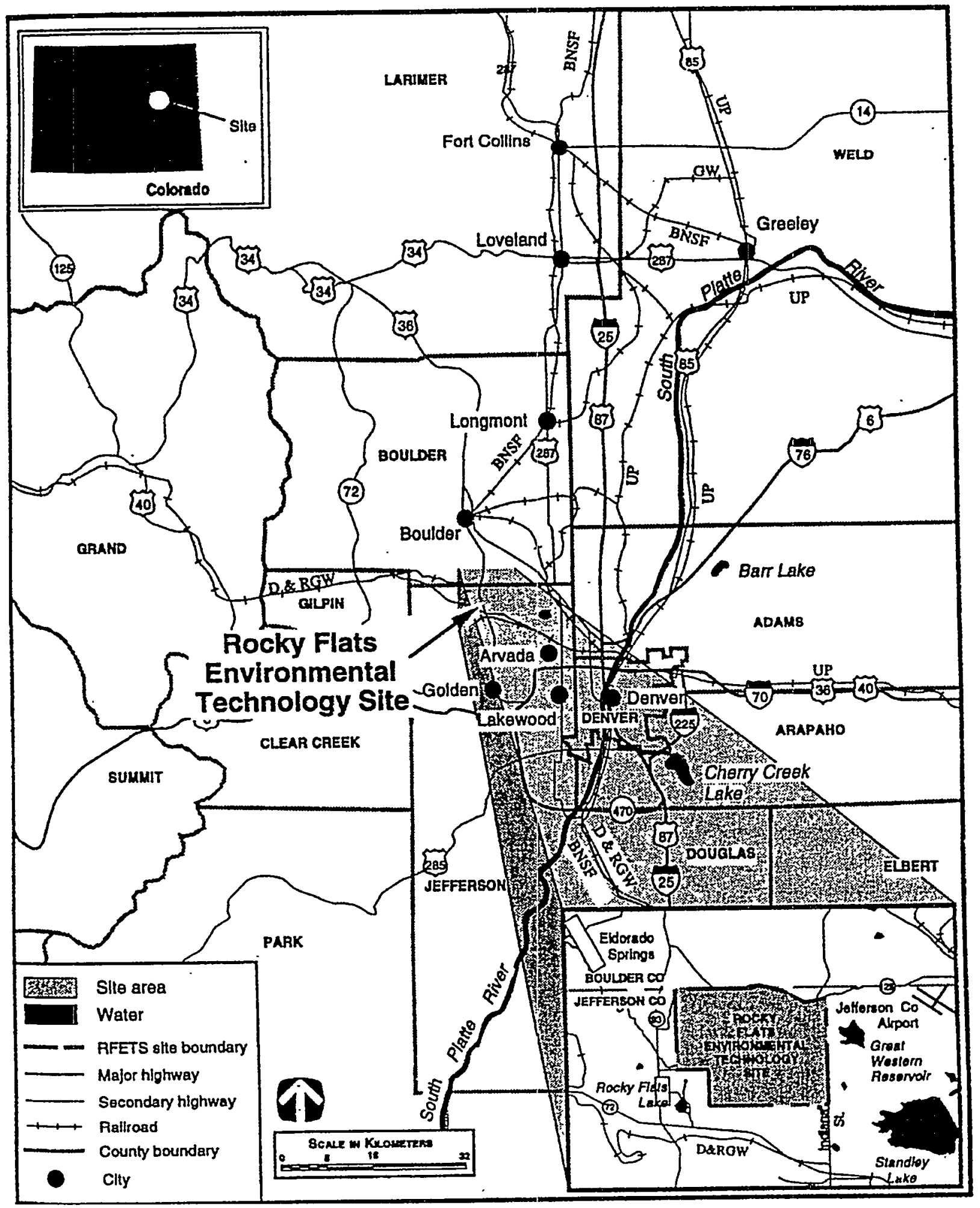

Figure 3.4 Map of Rocky Flats Area 


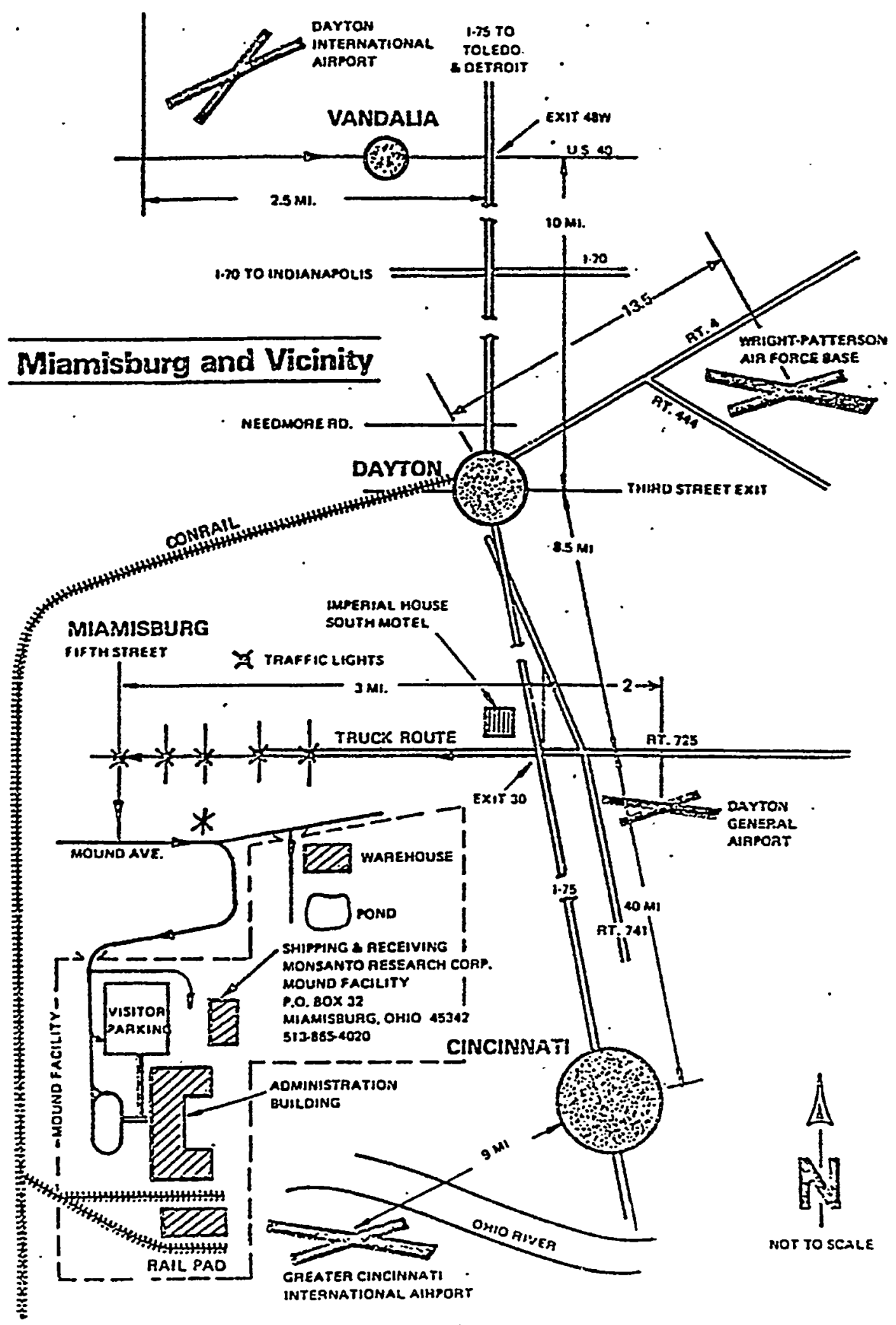

Figure 3.5. Map of Mound Area 


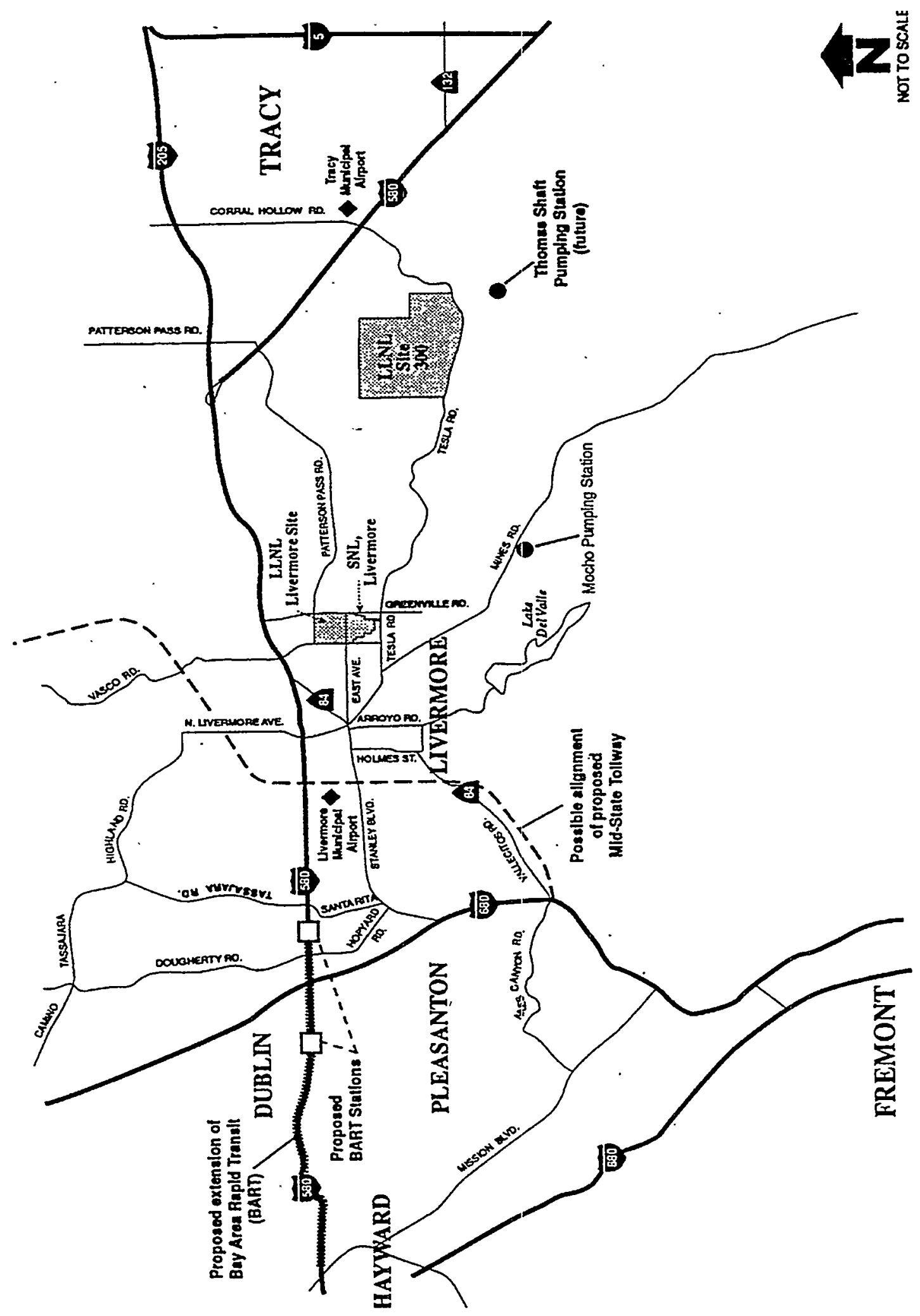

Figure 3.6. Map of LLNL Area 


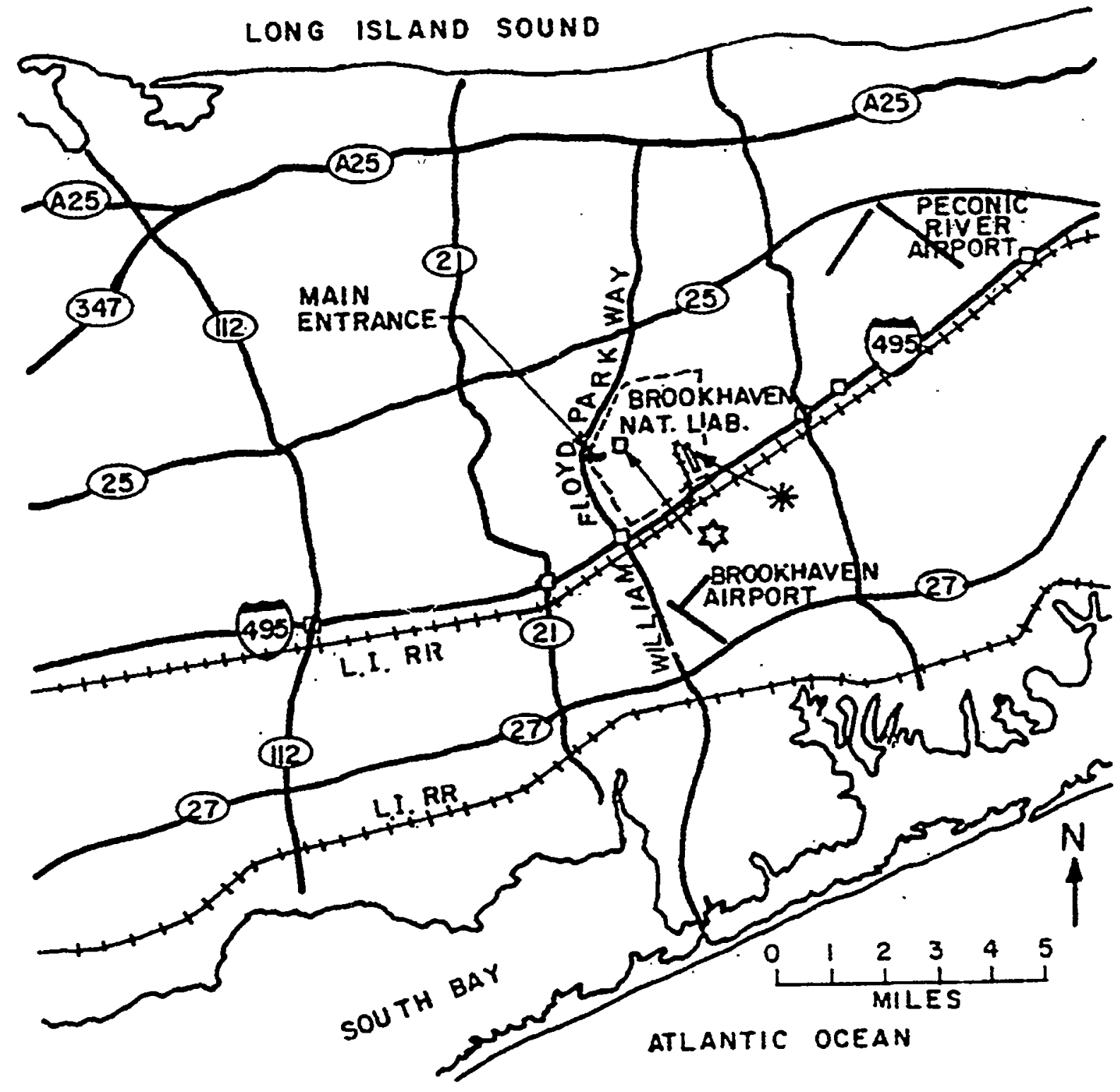

BROOKHAVEN NATIONAL LABORATORY

Figure 3.7. Map of BNL Area 


\subsection{DAHO NATIONAL ENGINEERING AND ENVIRONMENTAL LABORATORY}

INEEL has the capability to directly ship LLW by rail. INEEL site trackage connects with the Union Pacific Railroad at the Scoville, ID siding, approximately 3 miles from the Central Facility Area (CFA). The contractor or government performs internal switching. End ramp unloading is available in addition to routine flat and boxcars. The facility has a stationary gantry crane with a capacity of 160 tons and a mobile hydraulic crane with a capacity of 75 tons. A map of INEEL is shown in Figure 3.8.

\subsection{ARGONNE NATIONAL LABORATORY - EAST}

ANL-E does not currently have direct rail service although a rail spur does connect to the site. The opinion of those contacted indicated that intermodal service is more likely to be used in the future than direct rail service. The site is located approximately 10 miles from a railyard where trucks could deliver LLW to a rail shipper. Truck shipping facilities are provided with a 50-ton crane. A map of ANL-E is provided in Figure 3.9.

\subsection{SUMMARY OF RAIL ACCESS INFORMATION}

The following sites of the top nine LLW generators have direct rail service available for LLW shipments to NTS:

- Oak Ridge

- Fernald

- Mound

- INEEL

- Brookhaven

Of the top nine LLW generators, the following sites would require intermodal transfers near the origin facilities to ship LLW by rail. The distance from the generator sites to the nearest rail access point is also provided.

- Los Alamos: 40 miles to Lamy, NM, or about 100 miles to Albuquerque, NM

- Rocky Flats: Install about 0.5 miles of track to link to existing rail line

- LLNL: 13 miles to Tracy, CA

- ANL-E: approximately 10 miles to nearest railyard 

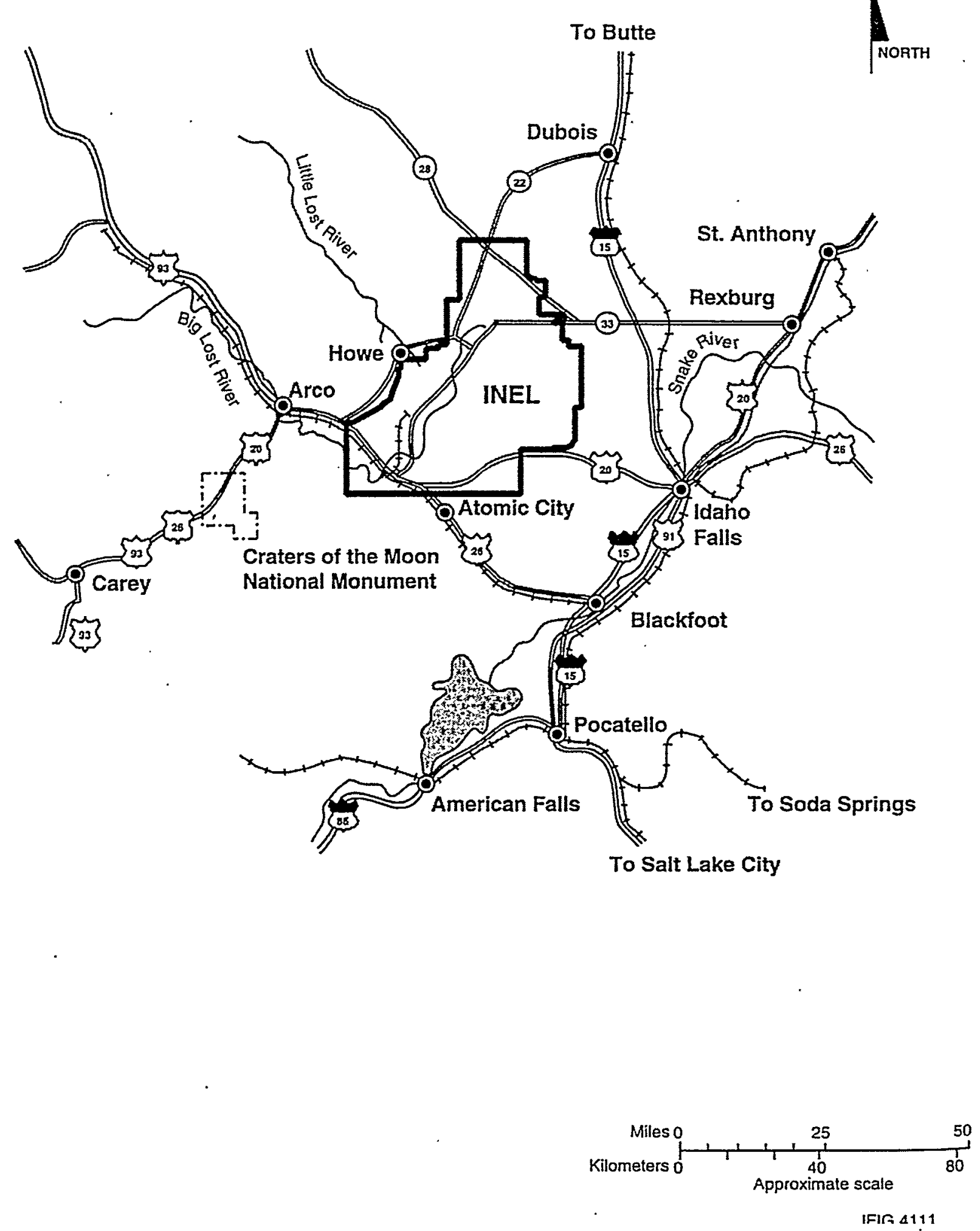

Figure 3.8. Map of INEEL Transportation Routes 


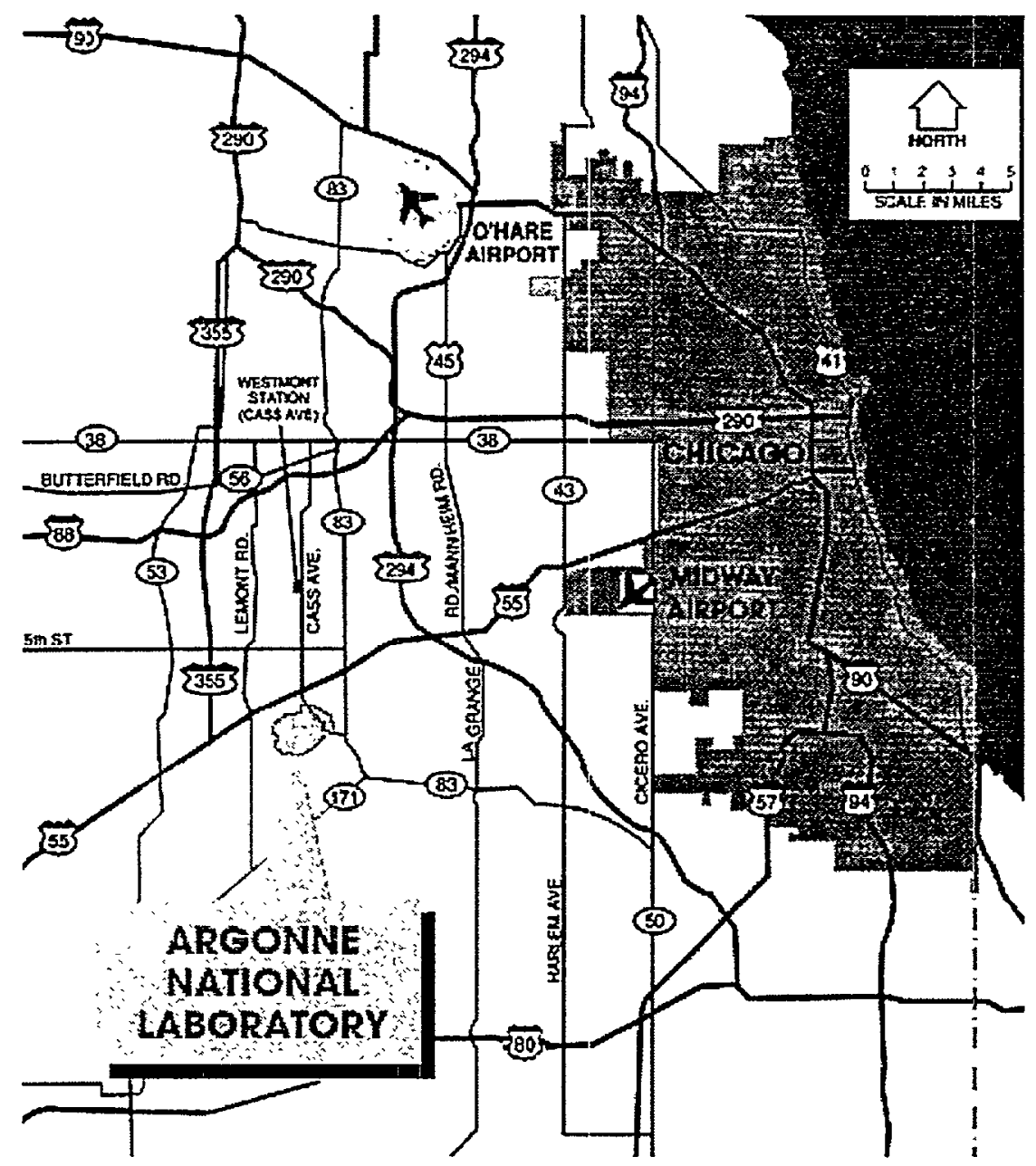

Figure 3.9. Map of ANL-E Transportation Routes 


\subsection{TRANSPORTATION COST ANALYSIS}

This chapter presents basic unit transportation cost data that will be used in the cost analysis of the truck and intermodal shipping configurations. Cost data from published sources and historical cost data on DOE shipments are extracted and summarized in this chapter, along with recommendations on their use and applicability.

For this assessment, it was assumed that the costs to upgrade or modify potential intermodal transfer facilities to accept and handle LLW shipments would be borne by private industry. This is consistent with the NTS Intermodal EA. Since the shipments are speculative, based on generator LLW volume projections, negotiations between DOE and private industry have not yet occurred. However, based on the potential business represented by DOE's LLW shipments, it does not seem unreasonable that private industry would invest in such a business venture.

\subsection{TRUCK AND RAIL CARRIER CHARGES}

This section presents and compares truck and rail carrier cost information from three recent sources, including the NTS Intermodal EA,WM-PEIS, and historical data from and DOE's Enterprise Transportation Analysis System (ETAS) database. This data is summarized in Sections 4.1.1, 4.1.2, and 4.1.3, respectively. The rationale for selection of the basic carrier cost information used in the cost estimates in this study is presented in Section 4.1.3.

\subsubsection{Transportation Cost Data from the NTS Intermodal EA}

The NTS Intermodal EA provided transportation cost information that was obtained from carriers and LLW generators. The data includes truck and intermodal transportation costs for shipments of $20-\mathrm{ft}$ containers from $11 \mathrm{LLW}$ generators to NTS. This data is summarized in Table 4.1.

There are some important caveats that accompany the cost data. The data was obtained from commercial carrier companies and LLW generators so it represents reasonable estimates of true costs. However, actual costs will not be known until contracts are negotiated with carriers. The estimated costs are for transportation of LLW in 20-ft cargo containers; transportation in smaller or larger shipping containers would have different unit costs. One container would be shipped in each truck shipment and rail shipments could handle three containers per railcar. Shipment capacities are approximately $26.65 \mathrm{~m}^{3}$ $\left(940 \mathrm{ft}^{3}\right)$ of LLW per truck shipment and $79.95 \mathrm{~m}^{3}\left(2820 \mathrm{ft}^{3}\right)$ of LLW per rail shipment. One final caveat is that the cost estimates are based on reasonable throughput rates. Unit costs for high throughput rates may be lower than those presented and higher for low throughput rates. The uncertainty associated with this variable introduces uncertainty in the cost estimates because actual rates cannot be determined until contracts are negotiated.

The cost estimates included in the table are costs to be paid to carriers for over-the-road or rail transport only and do not include purchase or lease costs for the 20 - $\mathrm{ft}$ cargo containers. Costs for demurrage of the carriers vehicles and driver detention while awaiting completion of loading and unloading activities were considered in the cost. In the NTS Intermodal EA, it was assumed that the freight containers would be disposable. Therefore, the costs for empty return shipments were not estimated. 
Table 4.1. Truck and Intermodal Transportation Costs for LLW Shipments to NTS (DOE-NVO 1998)

\begin{tabular}{|l|r|r|r|r|r|r|}
\hline \multicolumn{1}{|c|}{ Origin } & $\begin{array}{c}\text { Shipping } \\
\text { Dist. Using } \\
\text { Existing } \\
\text { Routes (mi.) }\end{array}$ & $\begin{array}{c}\text { Truck } \\
\text { Cost (\$) } \\
\text { per 20-ft } \\
\text { Container }\end{array}$ & $\begin{array}{c}\text { Distance to } \\
\text { Avoid Las } \\
\text { Vegas } \\
\text { Valley (mi.) }\end{array}$ & $\begin{array}{c}\text { Shipping } \\
\text { Distance to } \\
\text { Avoid Las } \\
\text { Vegas } \\
\text { Valley (mi.) }\end{array}$ & $\begin{array}{c}\text { Adjusted } \\
\text { Truck Cost } \\
(\$) \text { per 20-ft } \\
\text { Container }\end{array}$ & $\begin{array}{c}\text { Rail Cost per 20-ft } \\
\text { Container }\end{array}$ \\
\hline Aberdeen, MD & 2542 & 5084 & 294 & 2896 & 5672 & 4200 \\
\hline Canoga Park, CA & 383 & 1210 & 10 & 393 & 1242 & \\
\hline Fernald, OH & 2012 & 4124 & 294 & 2306 & 4727 & 3200 \\
\hline Ashtabula, OH (RMI) & 2207 & 4414 & 294 & 2501 & 5002 & $4200^{(\text {(b) }}$ \\
\hline Miamisburg, OH & 2044 & 4088 & 294 & 2338 & 4676 & 3350 \\
\hline San Diego, CA & 400 & 1104 & 10 & 410 & 1132 & \\
\hline Kansas City, MO & 1419 & 2838 & 294 & 1713 & 3426 & 2800 \\
\hline Livermore, CA & 593 & 1601 & 10 & 603 & 1624 & \\
\hline Amarillo, TX & 930 & 2000 & 234 & 1164 & 2386 & $2200^{(\mathrm{c})}$ \\
\hline Golden, CO & 809 & 1780 & 294 & 1103 & 2261 & 2100 \\
\hline Albuquerque, NM & 645 & 1710 & 234 & 879 & 2224 & \\
\hline
\end{tabular}

(a) Costs are for one-way transport of 20 -ft containers shipped via the Caliente, NV, intermodal transfer facility, except where indicated otherwise.

(b) Includes cost of returning reusable containers to origin facility.

(c) Assumes shipment via the Barstow, CA, intermodal facility. Costs for shipping via the Barstow facility for shipments from Golden, $\mathrm{CO}$, and Kansas City, MO, are slightly higher than the costs for using the Caliente, NV, intermodal transfer facility.

The data is presented in Table 4.1 for shipments from $11 \mathrm{LLW}$ generator sites. The system configuration described in Chapter 2 includes 23 potential LLW generator sites. To extend the data to include these additional 12 generators, the cost data in Table 4.1 was plotted and a line through the data points was developed using linear-regression techniques. The trend line was also extrapolated to longer shipping distances than those given in Table 4.1. This plot is shown in Figure 4.1. Note that the trend lines for truck and intermodal shipment costs cross at a one-way shipping distance of about 1000 miles. Truck shipping costs are lower for shipping distances less than about 1000 miles and rail is more cost-effective for shipping distances greater than 1000 miles.

Note that the rail cost estimate for shipments from Ashtabula, OH (RMI) to NTS includes the costs of returning the empty container to the origin facility. The other rail cost estimates are for one-way shipment of the loaded container only. Thus, it is necessary to adjust the cost estimates in Table 4.1 to include the costs of the empty return shipment. This was done by multiplying the costs for the other generators by a factor that represents the ratio of the round-trip costs from Ashtabula, $\mathrm{OH}$, to the one-way costs for shipments from Fernald, $\mathrm{OH}$. Based on this adjustment, the round-trip rail costs are estimated to increase by about $30 \%$ to account for the empty return shipments. 


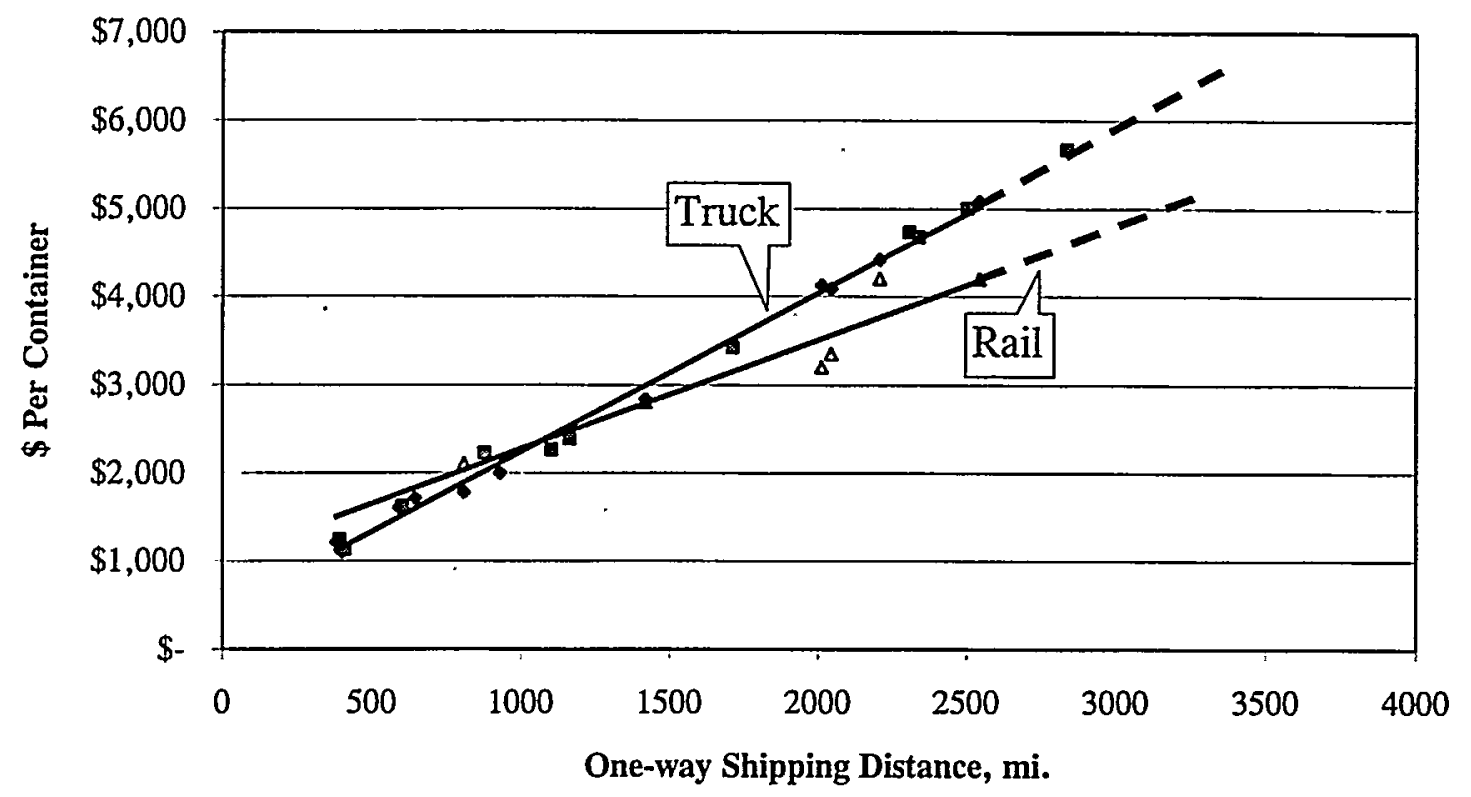

Figure 4.1. Plot of Truck and Rail Transportation Costs as a Function of Shipping Distance

\subsubsection{Transportation Cost Data from the WM-PEIS}

Transportation costs for various waste types were estimated in the WM-PEIS. Feizollahi, Shropshire, and Burton (1995) developed the supporting transportation cost data that was used in the WM-PEIS. The costs are for general freight rail service. No cost estimates were provided for dedicated train shipments (i.e., rail shipments in which LLW would be the only cargo aboard the train). Even though dedicated trains may offer some potential advantages (e.g., higher average speed, reduced stop time, reduced worker exposure), dedicated train shipments were not assumed in this analysis because there is little recent cost information for shipping hazardous cargo via dedicated train.

Feizollahi, Shropshire, and Burton (1995) followed a similar process to that used in the NTS Intermodal $E A$ for developing the cost estimates; i.e., by obtaining estimates from various carriers and transportation hardware providers. A methodology was developed in which transportation costs are the sum of fixed and variable components. For LLW, the fixed component of the costs was $\$ 880$ per shipment. The variable costs, referred to as the cost per loaded mile (CPLM), are as follows:

- Less than 30 miles:

$\$ 5.94 / \mathrm{mile}$

- 30 - 200 miles: $\quad \$ 4.98 /$ mile

- More than 200 miles: $\$ 4.00 /$ mile

To estimate the costs for a single shipment of LLW, one needs to multiply the shipping distance between the generator site and NTS by the appropriate CPLM and then add the fixed cost component. This has been done in Table 4.2 for the same generator sites that were shown in Table 4.1. This has also been done for rail shipment costs using a fixed cost of $\$ 750 /$ container and the following variable costs: 
Table 4.2. Transportation Costs Derived from WM-PEIS for NTS LLW Generators

\begin{tabular}{|l|r|c|c|r|r|c|}
\hline & \multicolumn{3}{|c|}{ Truck, per container } & \multicolumn{3}{c|}{ Rail, per container } \\
\cline { 2 - 7 } & $\begin{array}{c}\text { Distance, } \\
\text { mi. }^{\text {(a) }}\end{array}$ & $\begin{array}{c}\text { Cost per } \\
\text { Shipment }\end{array}$ & $\begin{array}{c}\text { Unit Cost, } \\
\text { per mile }\end{array}$ & $\begin{array}{c}\text { Distance, } \\
\text { mi. }^{\text {(b) }}\end{array}$ & $\begin{array}{c}\text { Cost per } \\
\text { Shipment }\end{array}$ & $\begin{array}{c}\text { Unit Cost, } \\
\text { per mile }\end{array}$ \\
\hline Aberdeen, MD & 2542 & $\$ 11,048.00$ & $\$ 4.35$ & 2542 & $\$ 4,817.20$ & $\$ 1.90$ \\
\hline Canoga Park, CA & 383 & $\$ 2,412.00$ & $\$ 6.30$ & 383 & $\$ 1,638.56$ & $\$ 4.28$ \\
\hline Fernald, OH & 2012 & $\$ 8,928.00$ & $\$ 4.44$ & 2391 & $\$ 4,575.60$ & $\$ 1.91$ \\
\hline Ashtabula, OH (RMI) & 2207 & $\$ 9,708.00$ & $\$ 4.40$ & 2391 & $\$ 4,575.60$ & $\$ 1.91$ \\
\hline Miamisburg, OH & 2044 & $\$ 9,056.00$ & $\$ 4.43$ & 2386 & $\$ 4,567.60$ & $\$ 1.91$ \\
\hline San Diego, CA & 400 & $\$ 2,480.00$ & $\$ 6.20$ & 400 & $\$ 1,678.00$ & $\$ 4.20$ \\
\hline Kansas City, MO & 1419 & $\$ 6,556.00$ & $\$ 4.62$ & 1670 & $\$ 3,939.70$ & $\$ 2.36$ \\
\hline Livermore, CA & 593 & $\$ 3,252.00$ & $\$ 5.48$ & 1370 & $\$ 3,928.40$ & $\$ 2.87$ \\
\hline Amarillo, TX & 930 & $\$ 4,600.00$ & $\$ 4.95$ & 1376 & $\$ 3,942.32$ & $\$ 2.87$ \\
\hline Golden, CO & 809 & $\$ 4,116.00$ & $\$ 5.09$ & 987 & $\$ 3,039.84$ & $\$ 3.08$ \\
\hline Albuquerque, NM & 645 & $\$ 3,460.00$ & $\$ 5.36$ & 1065 & $\$ 3,220.80$ & $\$ 3.02$ \\
\hline
\end{tabular}

(a) Truck shipping distances were taken from the NTS Intermodal EA.

(b) Rail shipping distances were taken from the WM-PEIS where available and were assumed the same as truck shipping distances given in the NTS Intermodal EA where not available.

- 500 to 1,000 miles:

$\$ 2.32 / \mathrm{mile}$

- 1,000 to 2,000 miles: $\quad \$ 1.91 /$ mile

- More than 2,000 miles: $\$ 1.60 /$ mile

\subsubsection{DOE Historical Shipment Cost Data}

A third source of transportation cost data is described in this section. The following information was provided to the authors of this report by staff representing DOE's National Transportation Program (NTP).

The Enterprise Transportation Analysis System (ETAS) is being designed to provide the DOE NTP with data about all DOE hazardous materials shipments and with analytical tools that can be used to project future shipping trends and costs for DOE.

ETAS is evolving from an earlier system called the Shipment Mobility Accountability Collection (SMAC) system. SMAC was originally developed to provide a database of all DOE shipping activities. SMAC has been used to gather data about DOE shipping activities since the late 1980 s. For years, members of the SMAC staff have manually developed reports about DOE shipping activities using this data. Reports have been produced to satisfy two circumstances (a) standard data reports to DOE HQ, DOE operations offices, and DOE contractors, and (b) special data reports developed upon user requests.

ETAS development began from the solid foundation provided by evolving from the SMAC system. This base provides much of the necessary infrastructure, database, interface to data sources, etc. that is required for a system like ETAS to function. The two primary goals for ETAS are to provide users with easier access to the DOE hazardous shipment data and to provide tools that will allow users to easily project shipping costs and activity. For more information on ETAS, readers are encouraged to contact the DOE NTP. 
ETAS staff searched the ETAS database for fiscal years 1997 and 1998 for cost information on LLW shipments. The search resulted in almost 1000 shipments over the 2-yr period, about half of which included relevant transportation cost data. The ETAS database also provided information on each shipment's mode of transport (motor carrier, rail, or private motor carrier), cargo weight, origin, destination, carrier, and date of shipment. ETAS staff then implemented the TRAGIS system to determine the most likely routes and projected one-way shipping distances. The distances determined using TRAGIS are not significantly different than those determined using HIGHWAY and INTERLINE in Chapter 5. The cost, distance, and cargo weight data was then manipulated to calculate the unit cost for each shipment (\$/ton-mile) or shipping campaign. The unit cost data is summarized in Table 4.3.

The transportation cost data for the truck shipments listed in Table 4.3 was averaged to obtain a unit cost of about $\$ 0.37 /$ ton-mi. (based on the mean cost column). This average unit cost was applied to the shipping distances for the origin-destination pairs in the NTS Intermodal EA to calculate the cost per shipment from each LLW generator. A total cargo weight of 40,000 lbs (20 tons) was assumed in the calculations. The results are shown in Table 4.4.

The truck transportation costs from all three sources of cost information were compared to each other. Rail costs are not included in this comparison because the rail cost data from ETAS was insufficient (i.e., only one data point) to support calculation of the relationship between costs and shipping distance. Note that the truck costs from ETAS are consistently higher than those from the WM-PEIS and NTS Intermodal $E A$. The differences are related to the different bases (e.g., container capacities, disposable vs. reusable shipping containers) between the studies and the ages of the data.

\subsubsection{Rational for Selection of Carrier Costs Used in This Study}

The truck and rail cost data in Tables $4.1,4.2$, and 4.4 was plotted as a function of one-way shipping distance in Figure 4.2. As can be seen, the unit cost (\$/container-mile) estimates derived using the ETAS data are significantly higher than those derived using the WM-PEIS, which in turn are significantly higher than those given in the NTS Intermodal EA. Truck transportation costs derived from the WM-PEIS are about a factor of two higher than those given in the NTS Intermodal EA. Rail costs are about 10 to $40 \%$ higher in the WM-PEIS than the NTS Intermodal EA. Part of the difference comes from different packaging assumptions. The WM-PEIS rates are based on truck shipment in 48- $\mathrm{ft}$ long truck trailers carrying up to $44,000 \mathrm{lb}$ of LLW per shipment whereas 20 - $\mathrm{ft}$ containers were used in the NTS Intermodal $E A$. Three 20 -ft containers were assumed in the NTS Intermodal EA to be transported by rail and two 40 $\mathrm{ft}$ containers were assumed to be transported per railcar in the WM-PEIS. The differences in weight between the NTS Intermodal EA and WM-PEIS shipment configurations explain at least part of the difference. Another potential difference is the fixed costs given in the WM-PEIS. The fixed costs generally represent the costs for demurrage of vehicles and detention of drivers during loading and unloading activities. In addition, the WM-PEIS fixed cost components are stated to include the costs of procuring and maintaining the shipping containers, tractors, and railroad cars used to perform the shipments. The final difference is related to whether or not the costs for empty return shipments are included in the cost estimates. In the NTS Intermodal EA, shipping containers were assumed to be disposed along with the LLW, so there are no costs associated with empty return shipments. Reuse of the shipping containers was assumed in the WM-PEIS, so the costs of empty return shipments are included in Table 4.2. 
Table 4.3. Cost Data for Consignments from FY 1997 and FY 1998

\begin{tabular}{|c|c|c|c|c|c|c|c|c|c|c|}
\hline \multirow{4}{*}{ Origin } & \multirow{4}{*}{ Destination } & \multirow{4}{*}{$\begin{array}{c}\text { Modea } \\
\text { |Number of } \\
\text { Shipments| }\end{array}$} & \multirow{4}{*}{$\begin{array}{c}\text { Route } \\
\text { distance } \\
\text { (mi) }\end{array}$} & \multicolumn{7}{|c|}{ Transportation Cost } \\
\hline & & & & \multirow{3}{*}{$\begin{array}{c}\begin{array}{c}\text { Actual Cost } \\
\text { from ETAS }\end{array} \\
\text { (\$) } \\
\text { Range }\end{array}$} & \multicolumn{6}{|c|}{ Projected Cost Rate using TRAGIS } \\
\hline & & & & & \multicolumn{3}{|c|}{ (\$/ton-mi) } & \multicolumn{3}{|c|}{$(\$ / \mathrm{mi})$} \\
\hline & & & & & Min & Mean & Max & $\operatorname{Min}$ & Mean & Max \\
\hline ANL & Janford, WA & $\mathrm{M}[23]$ & 1981 & $1855-4226$ & 0.10 & 0.39 & 0.68 & 1.04 & 1.61 & 2.23 \\
\hline Bettis Atomic. ID & $\begin{array}{l}\text { Puget Sound } \\
\text { Naval Shipyard }\end{array}$ & $M[1]$ & 773 & 2362 & 7.64 & 7.64 & 7.64 & 3.06 & 3.06 & 3.06 \\
\hline Bettis Atomic, PA & SRS & $\mathrm{M}$ & $608 /[25]$ & $2371-3159$ & 0.18 & 0.24 & $0.30^{\mathrm{d}}$ & 3.97 & 4.59 & 5.20 \\
\hline BMI. OH & Envirocare & $M[8]$ & 1794 & $3348^{c}$ & 0.08 & 0.11 & 0.14 & 1.87 & 1.87 & 1.87 \\
\hline BMI, OH & Hanford, WA & $\mathrm{M}[1]$ & 2318 & 4044 & 0.31 & 0.31 & 0.31 & 1.74 & 1.74 & 1.74 \\
\hline B\&W Ohio & Envirocare & $M[6]$ & 1739 & $2389-2400$ & 0.08 & 0.13 & 0.17 & 1.37 & 1.375 & 1.38 \\
\hline B\&W Ohio & NTS & M [33] & 2036 & $2400-3200$ & 0.07 & 0.13 & 0.19 & 1.18 & 1.38 & 1.57 \\
\hline $\begin{array}{l}\text { DynCorp } \\
\text { of Colorado }\end{array}$ & NTS & $M[37]$ & 814 & $1562-3363$ & 0.10 & 2.51 & 4.92 & 1.92 & 3.03 & 4.13 \\
\hline $\begin{array}{l}\text { Fermi Nat Acc.. } \\
\text { IL }\end{array}$ & Hanford, WA & $M$ & $1960 /[2]$ & $3775-3885$ & 0.09 & 0.09 & 0.09 & 1.93 & 1.96 & 1.98 \\
\hline $\begin{array}{l}\text { FluorDaniel, } \\
\text { Fernald }\end{array}$ & Envirocare & $M$ & $1718 /[2]$ & 1718 & 0.16 & 0.17 & 0.18 & 2.80 & 2.80 & 2.80 \\
\hline $\begin{array}{l}\text { FluorDanici. } \\
\text { Fernald }\end{array}$ & NTS & $\bar{M}[11], E[2]$ & 2013 & $2013-2875$ & 0.07 & .085 & 0.10 & 1.39 & 1.72 & 2.05 \\
\hline $\begin{array}{l}\text { Princeton, Plasma } \\
\text { Pliy, NJ }\end{array}$ & Hanford, WA & $M[2]$ & 2774 & 2774 & 0.19 & 0.25 & 0.31 & 2.11 & 2.11 & 2.11 \\
\hline $\begin{array}{l}\text { RMI Titanium, } \\
\mathrm{OH}\end{array}$ & NTS & $M[4]$ & 2268 & 2268 & 0.08 & 0.095 & 0.11 & 1.39 & 1.39 & 1.39 \\
\hline West Valley, NY & Envirocare & $M[3]$ & 1995 & 1995 & 0.26 & 0.29 & 0.31 & 3.51 & 3.51 & 3.51 \\
\hline B\&W Ohio & Envirocare & $\mathrm{R}[308]$ & 1998 & $6375-6566$ & 0.03 & 0.035 & $0.04^{c}$ & 3.19 & 3.24 & 3.29 \\
\hline
\end{tabular}

a $M=$ motor, $E=$ private motor, $R=$ rail.

b Costs in ETAS are assembled from individual sites using ATMS, clectronic transfers, manual inputs of freiglt bills, or waste manifests.

c One cost shown was $\$ 348$. while all others were $\$ 3348$. It is suspected that this is a data entry error. Data for that shipment not included here.

d One consignment showed only 423 pounds, which results in very high cost per ton-mile value of $\$ 19.45$. Data for that shipment not included here.

e One consignment has an anomalous data entry for cost. Data for this consignment (number 225) not included here. In addition, one consignment was for a partial railcar load of only 6566 pounds, which led to an single, exceptionally high cost per ton-mile value of $\$ 1.00$. Data for that shipment not included here. 
Table 4.4. Highway Transportation Costs from ETAS

\begin{tabular}{|l|r|r|}
\hline \multicolumn{1}{|c|}{ LLW Generator } & $\begin{array}{c}\text { Shipping } \\
\text { Distance, mi }\end{array}$ & $\begin{array}{c}\text { Costs, \$/shipment } \\
\text { (20-ton cargo } \\
\text { capacity) }\end{array}$ \\
\hline Aberdeen, MD & 2,542 & 18,811 \\
\hline Canoga Park, CA & 383 & 2,834 \\
\hline Fernald, OH & 2,012 & 14,889 \\
\hline Ashtabula, OH (RMI) & 2,207 & 16,332 \\
\hline Miamisburg, OH & 2,044 & 15,126 \\
\hline San Diego, CA & 400 & 2,960 \\
\hline Kansas City, MO & 1,419 & 10,501 \\
\hline Livermore, CA & 593 & 4,388 \\
\hline Amarillo, TX & 930 & $6,8 \dot{2}$ \\
\hline Golden, CO & 809 & 5,987 \\
\hline Albuquerque, NM & 645 & 4,773 \\
\hline
\end{tabular}

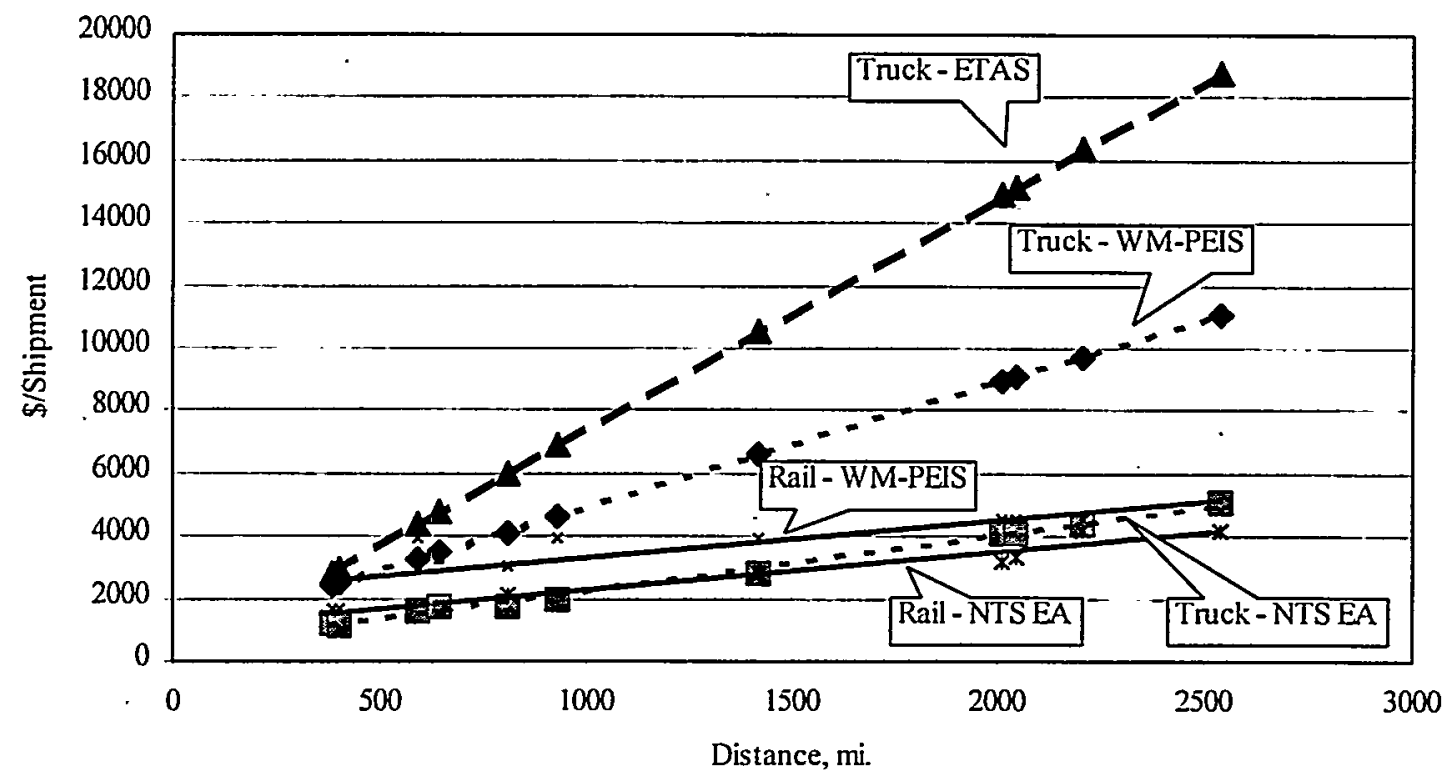

Figure 4.2. Comparison of Transportation Cost Data from Three Sources

The cost data from the WM-PEIS will be used in this study for the following reasons. First, the $W M-P E I S$ data is internally consistent and provides a consistent basis for comparison of truck, rail, and intermodal alternatives. The cost data in the NTS Intermodal EA was not used because it is based on a fundamentally different assumption than is used here; i.e., the assumption that the shipping containers will be disposed of along with the LLW. The historical data from ETAS was not used directly, although it also is internally consistent. It is also more recent and may reflect actual current costs. However, the cost data for rail shipping was insufficient to develop unit 
costs as a function of distance. Thus, there was no comparable data set to compare truck, rail, and intermodal shipping costs. Since the basic purpose of this study is to illustrate trends that develop among alternative shipping configurations, the WM-PEIS cost data is believed to be sufficient.

\subsection{SHIPPING CONTAINER PROCUREMENT COSTS}

The total life-cycle shipping costs for the alternatives examined here include the costs for procurement of the required number of shipping containers to allow each site to ship its LLW to NTS. It was assumed here that shipping containers will be reused whereas the NTS Intermodal $E A$ assumed the shipping containers would be disposed along with each shipment of LLW. Reusable shipping containers were assumed here because it is the current practice for most LLW shipments. There does not appear to be a need to include an outer packaging to meet long-term LLW disposal performance requirements, as all LLW was assumed to be prepackaged in metal drums and boxes prior to being loading into shipping containers. It is recognized that some LLW types and forms will be shipped in different packaging systems due to differing shielding, long-term performance, and other requirements. However, until detailed characterization of the LLW has been performed, the volumes, types, and origins of LLW streams that will require a different packaging concept are difficult to accurately project.

The required number of shipping containers at each LLW generator site was calculated by first determining the approximate transit time to travel between the generator facility and destination. The shipping distances presented in Chapter 5 were divided by the average intransit speeds for truck (assumed here to be $40 \mathrm{mi} / \mathrm{hr}$ over the entire trip) and rail shipments (assumed to be $10 \mathrm{mi} / \mathrm{hr}$ ) to determine the round-trip travel time. Total trip time also includes the handling time (also referred to as turnaround time) at the origin and destination facilities, assumed to be 24 hours of clock time at each end. This includes the time it takes to unload the shipping containers as well as any required decontamination, monitoring, inspection, and maintenance. For intermodal shipments, an additional 8 hours of clock time was added at the shipment origin to ship the LLW by truck from the generator facility to the railhead. In addition, 24 hours of clock time was added at the intermodal facility to transfer the containers from the rail cars to truck and an additional 6 hours was added to ship the LLW by truck from the intermodal facility to NTS. Total round-trip transit times were calculated for each LLW generator by combining these estimates where appropriate.

The number of shipping containers required to transport the prescribed volume of LLW to NTS each year was calculated by dividing the number of container-hrs/yr required by the average availability of each shipping container. A total availability of $2000 \mathrm{hrs} / \mathrm{yr}$ per container was used in this calculation. The container-hrs per year required is the product of the average number of shipments per year from each generator (total life-cycle waste volume divided by 70 years) and the round-trip transit time calculated above. Then, it was assumed that the shipping containers would be replaced every 10 years so a total of seven procurement cycles will be included in the life-cycle cost estimates (i.e., initial procurement plus six replacement cycles). Thus, the total number of containers required over the 70 -year life cycle is the number of shipping containers required annually multiplied by seven total procurement cycles. The total life-cycle container cost is the product of the number of containers required over the 70-year life-cycle and the unit cost of a shipping container. According to Feizollahi, Shropshire, and Burton (1995), the cost of a Sea-Land type container is about $\$ 3,500$. 


\subsection{INTERMODAL TRANSFER COSTS}

The costs for intermodal transfers of LLW shipping containers were difficult to obtain, primarily because there is little recent experience with this type of shipment. As a result, firstorder cost estimates were developed here to include in the total life-cycle costs for Configurations $1 \mathrm{~A}$ and $1 \mathrm{~B}$.

Intermodal transfer operations were broken down into trucking and handling activities to develop the cost estimates. The trucking portions of the intermodal transfers were costed using the basic carrier charges presented in Sections 4.1 to 4.3. The transfer portion was costed using the following assumptions:

- Heavy-lift equipment costs were estimated at $\$ 500$ per transfer. This includes the costs at the railhead nearest to the LLW generator to lease a heavy-lift forklift or crane to lift the shipping containers off a truck trailer and set, it down on a railcar. The reverse operation occurs at the intermodal transfer facility near NTS, and the costs are assumed to be the same.

- The costs for salaries, benefits, etc. for equipment operators at the intermodal facilities were also included. It was assumed that a total of 5 man-hours is required for each transfer, including heavy-equipment operators, railyard personnel, riggers, and any necessary support staff. The transfer operation is relatively simple, so this estimate is believed to be reasonable. Personnel costs were estimated assuming a unit cost of $\$ 50.00$ per hour.

The unit transfer costs were then estimated to be $\$ 850 /$ transfer. To account for uncertainties, the unit transfer cost was rounded to $\$ 1,000 /$ transfer.

\subsection{RESULTS OF TRANSPORTATION COST ANALYSIS}

The results of applying the unit transportation costs to the DOE complex LLW transportation configurations are presented in this section. The basic carrier costs used here are those presented in Section 4.2 from the WM-PEIS.

\subsubsection{High Waste Volume Case}

Table 4.5 presents the total life-cycle shipping cost results for the high waste volume case 
Table 4.5. Total Life-Cycle Shipping Costs (\$M) for Each Alternative - High Waste Volume

\begin{tabular}{|c|c|c|c|c|c|c|}
\hline \multirow[t]{2}{*}{ Alternative } & \multirow{2}{*}{$\begin{array}{l}\text { Highway } \\
\text { Carrier }\end{array}$} & \multirow{2}{*}{$\begin{array}{c}\text { Rail } \\
\text { Carrier }\end{array}$} & \multicolumn{2}{|c|}{ Intermodal Transfers } & \multirow{2}{*}{$\begin{array}{c}\text { Container } \\
\text { Costs }\end{array}$} & \multirow[t]{2}{*}{ Total } \\
\hline & & & Carrier & Transfer & & \\
\hline $1 \mathrm{~A}$ & 17 & 37 & 48 & 26 & 1.2 & 130 \\
\hline $1 \mathrm{~B}$ & 17 & 36 & 62 & 26 & 1.2 & 140 \\
\hline 2 & 230 & 0 & 0 & 0 & 1.1 & 230 \\
\hline 3 & 210 & 0 & 0 & 0 & 1.0 & 210 \\
\hline
\end{tabular}

considered in this study. The total shipping costs for the all-truck configurations include highway carrier costs and the costs for procurement of the required number of shipping containers. For the intermodal shipping configurations, the costs include those for direct truck shipments from smallquantity LLW generators as well as rail carrier costs and intermodal transfer costs at the origin and destination of the rail shipments.

As shown in Table 4.5, the costs for the intermodal alternatives (1A and 1B) are significantly lower than for the all-truck shipping configurations ( 2 and 3 ). The costs for the intermodal transfers are more than offset by the generally lower costs for rail shipping, resulting in lower overall costs for the intermodal alternatives. In comparing the all-truck options, the option of shipping through Las Vegas was slightly lower than the option of shipping around Las Vegas, although the small difference is within the uncertainties of the costs estimates. This difference is real, however, given the generally longer shipping distances that result from avoiding Las Vegas, but the magnitude of the difference shown in the table is uncertain. Similarly, of the two intermodal configurations (1A and 1B), lower life-cycle costs were estimated for the intermodal configuration in which the Barstow facility is assumed. The main difference is in the costs to transport LLW from the intermodal facility to NTS. Barstow is closer to NTS than Caliente, resulting in lower costs to transport LLW by truck from Barstow. This difference more than offsets the smaller rail carrier costs for the Caliente option. Caliente is a shorter shipment than Barstow for the LLW transported from LLW generators in the eastern and southern United States.

The table illustrates that the costs for procurement and replacement of shipping containers are insignificant relative to the shipping and transfer costs. Therefore, although more shipping containers are required to complete the required shipments in the intermodal alternatives, the increased costs are much smaller than the other cost elements. Shipping container requirements are higher in the intermodal alternatives than the all-truck alternatives because rail shipments travel at slower average speeds and thus have substantially longer transit times than truck shipments.

\subsubsection{Low Waste Volume Case}

The total life-cycle shipping costs for the low waste volume case are shown in Table 4.6. Note that the total costs shown in Table 4.6 are about one-third of the costs for the high waste volume case, similar to the ratio of waste volumes.

The general cost trends in Table 4.6 are similar to those in Table 4.5, including:

- The life-cycle costs for the intermodal configurations are significantly lower than the alltruck configurations. 
Table 4.6. Total Life-Cycle Shipping Costs (\$M) for Each Alternative - Low Waste Volume

\begin{tabular}{|c|c|c|c|c|c|c|}
\hline \multirow[t]{2}{*}{ Alternative } & \multirow{2}{*}{$\begin{array}{l}\text { Highway } \\
\text { Carrier }\end{array}$} & \multirow{2}{*}{$\begin{array}{c}\text { Rail } \\
\text { Carrier }\end{array}$} & \multicolumn{2}{|c|}{ Intermodal Transfers } & \multirow{2}{*}{$\begin{array}{c}\text { Container } \\
\text { Costs }\end{array}$} & \multirow[t]{2}{*}{ Total } \\
\hline & & & Carrier & Transfer & & \\
\hline IA & 3.5 & 15 & 19 & 10 & 0.54 & 48 \\
\hline $1 \mathrm{~B}$ & 3.5 & 15 & 24 & 10 & 0.56 & 53 \\
\hline 2 & 95 & 0 & 0 & 0 & 0.47 & 95 \\
\hline 3 & 82 & 0 & 0 & 0 & 0.47 & 83 \\
\hline
\end{tabular}

- The life-cycle costs for the all-truck option that avoids Las Vegas are slightly higher than the costs for the all-truck option that travels through Las Vegas.

- Lower life-cycle costs were estimated for the intermodal configuration in which the Barstow facility is assumed than for the configuration in which Caliente is the intermodal transfer point. 
This Page Intentionally Left Blank 


\subsection{TRANSPORTATION RISK ANALYSIS}

The objective of this chapter is to present estimates of the radiological and physical (i.e., nonradiological) risks ${ }^{1}$ for the different transportation system configurations and waste loads investigated in this study. The scope of the transportation risk assessment includes radiological routine and accident risks as well as the physical hazards (i.e., fatalities) projected to occur from traffic accidents involving the LLW shipments that are independent of the cargo being transported. Health effects from routine vehicular emissions are also quantified. Radiological and physical risks to workers at intermodal transfer facilities are also estimated in this chapter. The total life cycle (70-year) radiological and nonradiological risks as well as state-by-state risks are presented for each alternative. Table 5.1 summarizes the types of risks assessed in this study and their associated pathways and sources.

"Risk" is a difficult term to define to everyone's satisfaction. The dictionary defines risk as "the possibility of loss or injury." However, risk may also mean the possible occurrence of a "desired" event, such as winning the Lottery. In these contexts, the engineering definition of risk was derived; i.e., risk is the product of the likelihood of an event and its consequences. This is the definition of risk used in this report.

Two categories of radiological risk are evaluated in this study, incident-free (or routine) risk and accident risk. These two types of risk are calculated using different methods. The vast majority of LLW shipments to NTS are expected to reach their destination without experiencing an accident or incident or releasing any LLW cargo. The "incident-free" risks from these normal, routine shipments arise from the low levels of radiation that are emitted externally from the shipping container. Although Federal regulations in 10 CFR 71 and 49 CFR 173 impose constraints on radioactive material shipments, some radiation penetrates the shipping container and exposes nearby persons to low levels of radiation. The Federal regulations also impose maximum allowable limits on external radiation; e.g., radiation levels must be less than or equal to $10 \mathrm{mrem} / \mathrm{hr}$ at $2 \mathrm{~m}$ from the edge of the transport vehicle. Actual radiation levels emitted from most LLW shipments to NTS will usually be a fraction (a few percent) of the regulatory maximum levels and are often low enough to be undetectable. However, a fraction of the shipments will emit dose rates near or at regulatory limits. Regulations also limit the maximum allowable dose rate in occupied areas of the transport vehicle, such as the truck cab.

The general equation for calculating external (including incident-free) radiological dose to an individual is to combine two terms, the dose rate (or radiation field strength) and the length of time a person is exposed as follows:

$$
\text { Individual Radiation Dose }(\text { mrem })=\text { Dose Rate }(\mathrm{mrem} / \mathrm{hr}) \times \text { Exposure Duration }(\mathrm{hr})
$$

The dose rate is a function of the source strength, amount of shielding between the source and receptor, and the distance from the source. Because radiation dose rates decrease with distance from the source, the farther away a person is from the shipping container, the lower the dose rate. Shielding, such as the steel walls of the waste packages (e.g., 55-gal. drums) and shipping containers, also reduces the radiation dose rate.

The transportation risk analysis methodology used here calculates incident-free doses to populations exposed to the passing shipments of LLW by recognizing that the external dose rate from the package is the source of radiation, and treating this external dose rate mathematically like the radiation source. Therefore, the dose and risk from incident-free transportation depend only on the external dose rate, and

' In this report, the terms "risk" and "impact" may be used interchangeably. 
Table 5.1. Types and Sources of Health Risks Assessed in this Study

\begin{tabular}{|c|c|c|c|c|}
\hline Endpoint & $\begin{array}{l}\text { Exposure } \\
\text { Period }\end{array}$ & Receptor & Pathway & Source \\
\hline \multirow[t]{3}{*}{$\begin{array}{l}\text { Latent cancer } \\
\text { fatalities from } \\
\text { radiological } \\
\text { sources }\end{array}$} & \multirow[t]{3}{*}{$\begin{array}{l}\text { 70-yr LLW } \\
\text { disposal life- } \\
\text { cycle }\end{array}$} & Public & $\begin{array}{l}\text { Direct Radiation } \\
\text { exposures from routine } \\
\text { transport } \\
\text { Inhalation and direct } \\
\text { radiation exposures } \\
\text { from accidents during } \\
\text { transport }\end{array}$ & $\begin{array}{l}\text { Cargo (radioactive } \\
\text { material in LLW) }\end{array}$ \\
\hline & & $\begin{array}{l}\text { Intermodal } \\
\text { facility } \\
\text { workers }\end{array}$ & $\begin{array}{l}\text { Direct radiation } \\
\text { exposures from routine } \\
\text { handling operations }\end{array}$ & $\begin{array}{l}\text { Cargo (external } \\
\text { radiation field emitted } \\
\text { from LLW shipping } \\
\text { containers) }\end{array}$ \\
\hline & & $\begin{array}{l}\text { Truck/rail } \\
\text { crewmembers }\end{array}$ & $\begin{array}{l}\text { Direct radiation } \\
\text { exposures from routine } \\
\text { transport }\end{array}$ & $\begin{array}{l}\text { Cargo (external } \\
\text { radiation field emitted } \\
\text { from LLW shipping } \\
\text { containers) }\end{array}$ \\
\hline $\begin{array}{l}\text { Latent fatali- } \\
\text { ties from } \\
\text { non-radiation } \\
\text { sources }\end{array}$ & $\begin{array}{l}\text { 70-yr LLW } \\
\text { disposal life- } \\
\text { cycle }\end{array}$ & Public & $\begin{array}{l}\text { Inhalation of } \\
\text { carcinogenic chemicals }\end{array}$ & $\begin{array}{l}\text { Routine vehicle } \\
\text { emissions (diesel fuel } \\
\text { combustion products, } \\
\text { fugitive dust, tire } \\
\text { particles) }\end{array}$ \\
\hline \multirow{2}{*}{$\begin{array}{l}\text { Trauma } \\
\text { (physical) } \\
\text { fatalities }\end{array}$} & \multirow{2}{*}{$\begin{array}{l}\text { 70-yr LLW } \\
\text { disposal life- } \\
\text { cycle }\end{array}$} & Public & Physical hazards & $\begin{array}{l}\text { Traffic accidents in } \\
\text { transit }\end{array}$ \\
\hline & & $\begin{array}{l}\text { Intermodal } \\
\text { facility } \\
\text { workers }\end{array}$ & Physical hazards & $\begin{array}{l}\text { Industrial accidents } \\
\text { during handling } \\
\text { operations }\end{array}$ \\
\hline
\end{tabular}

not on the nature of the radioactive material being transported. The general formula for calculating population doses (sometimes referred to as "collective doses") is:

Population Dose $($ person $-m r e m)=$ Dose Rate $(m r e m / h r) \times$ Exposure Duration $(h r) \times$ No. Exposed Persons

Mathematical models are used to calculate and track the dose rate at various distances from the shipping container, the number and locations of persons in the affected population group (e.g., bystanders at truck stops, persons residing near the highway or rail line), and the length of time they are exposed. The calculated population doses, in units of person-rem, are then multiplied by a risk factor that estimates the number of latent cancer fatalities (LCFs) that are projected to occur in the exposed population. A detailed discussion of these models may be found in Neuhauser and Kanipe (1995).

In terms of the definition of risk; i.e., probability times consequence, the probability that there will be some amount of incident-free radiological risk is essentially 1.0. This is because the probability that the LLW shipment reaches its destination without incident is essentially 1.0 , as opposed to accidents in which the probability is orders of magnitude less than 1.0 (on the order of 1 serious accident per hundred million miles traveled). The consequence term is the projected dose in the exposed population. Since the probability term is 1.0 , incident-free LCF risk is taken to be the consequence (dose) multiplied by an LCF risk factor. 


\section{Radiation Terms}

Dose refers to the amount of energy deposited in body tissue due to radiation exposure. Various technical terms, such as dose equivalent, effective dose equivalent and collective dose, are used to evaluate the amount of radiation an exposed person receives. All are expressed in units of rem (or Sievert in the Standard International unit system). The dose equivalent takes into account the difference in tissue damage caused by different types of radiation (e.g., alpha, gamma, and neutron). The effective dose equivalent (EDE) takes into account the different absorption by, and damage to, different tissues (e.g., thyroid, lung). The committed or total effective dose equivalent (CEDE or TEDE) is the EDE for the 50-yr period after the radioactive material is ingested or inhaled.

Collective or population dose is the sum of the total effective dose equivalent values for all individuals in a specified population. Collective dose is expressed in units of person-rem (or person-Sievert).

External dose or exposure is the portion of the dose equivalent received from radiation sources outside the body (e.g., "external sources" such as the LLW shipping container).

Internal dose or exposure is the portion of the dose equivalent received from radioactive material taken into the body via inhalation, ingestion, or absorption through the skin. There are no internal doses unless radioactive material is released into the environment, such as following a severe transportation accident that results in failure of the LLW packages and shipping container.

Rem is a unit used in radiation protection to measure the amount of damage to human tissue from a dose of radiation. Millirem (mrem) is one-thousandth of a rem. An average American receives 0.360 rem (360 mrem) of radiation each year from natural and man-made sources (National Research Council 1990).

Accident risks are calculated using different mathematical models than those used to calculate incidentfree risks. The risk in this case results from potential exposures to radioactive material that could be released from the LLW shipping container if it is subjected to severe enough accident conditions to cause a breach or opening in the packaging system (shipping container plus internal waste containers) that confine the cargo. This is a different concept than incident-free risks, in which no cargo is released from the shipping container.

In terms of the risk of transportation accidents, risk is the product of the likelihood (or frequency) of an accident during transport and the consequences of that accident. In other words, if the frequency of an accident is estimated to be once per hundred years $\left(10^{-2}\right.$ per yr) and its consequence is ten fatalities, the risk of this accident is $10^{-2}$ per yr times 10 fatalities $10^{-1}$ fatalities per yr. Since there is a spectrum of possible accidents that could occur, ranging from minor fender-benders with no or only minor consequences to severe accidents that could result in serious injuries and deaths, accident scenarios causing similar damage are grouped together using binning techniques to simplify the mathematics. These groups or bins are called "accident severity categories" and the grouping used in this analysis is presented in Section 5.1.1.2. Total risk is the sum of the risks of each severity category. Risk is then calculated as the frequency of each severity category times the consequences of an accident in that category, and then summed over all the accident severity categories.

Two mathematical terms are combined to estimate the likelihood of a transportation accident. These are the overall mode-specific accident rate (e.g., the rate of accidents experienced by heavy-combination trucks, such as those used for LLW shipments to NTS, or the rate experienced by rail shipments), and the 
conditional probability that an accident will produce conditions encompassed by each severity category. For example, if 9 out of 10 accidents are minor and do not threaten the cargo, the conditional probability of a severity category that results in no release from the packaging is 0.9. Similar conditional probabilities are developed for each severity category.

The second general term in the risk equation is the consequence of a release of radioactive material. Accident consequences are a function of the amount of radioactive material released as a result of a given accident. The conditions the shipping containers and waste packages are exposed to in an accident, as well as the container and material responses to these conditions, determine the amount of material released. Radionuclide-specific "release fractions" are developed to describe the quantity of each radionuclide released to the environment. The release fractions are multiplied by the initial inventory of radioactive materials in the shipment to determine the amount of radioactive material that escapes from the damaged shipping container. Release fractions may be developed for gaseous (e.g., tritium and krypton), semi-volatile (e.g., cesium), and particulate radionuclides (e.g., plutonium). One would expect a higher release fraction for a gas than for a semi-volatile material and higher release fraction for semi-volatiles than for particles. In other words, an accident of a given severity may release $100 \%$ of the gaseous radionuclides, $50 \%$ of the semi-volatile radionuclides, and $1 \%$ of the particulates. A more severe accident may release $100 \%$ of the gases, semi-volatiles, and particulates. In this manner, the severity categories and release fractions are related to each other. The release fractions are also modified by the fraction of the released material that is of dispersable-sized particles and the fraction that is of respirable size. The dispersible fraction determines the quantity of the released material that is small enough to be dispersed in the air after release (large particles are too heavy to be dispersed). The respirable fraction determines the quantity of released materials that is small enough to be inhaled into the lungs (large particles are filtered by the human respiratory system and do not reach the lungs). These quantities are then input to the atmospheric dispersion, pathway, and internal/external dose models to calculate the consequences of the release.

The models developed to calculate the consequences of radioactive material releases assume the released material is dispersed into the environment, which models the dilution of the released "plume" of radioactive material as the distance from the release point increases. The released plume travels in the direction the prevailing wind takes it and spreads out vertically and horizontally after it escapes from the shipping container. The concentration of radioactive material in the plume decreases with distance from the source due to this spreading effect. Radioactive material may also be deposited on the ground or in water bodies as particles fall out of the plume.

The next process in calculating consequences from a release of radioactive material is to model the potential human exposure pathways for the released material. In most cases, the most important exposure pathway is inhalation of radioactive material by people who might be within the passing plume.

Inhalation leads to an "internal" dose: the dose to the individual is from radioactive material that is taken internally into the body. Ingestion is a second internal dose pathway. The ingestion dose results from persons consuming food products and drinking water that may contain released material. A third internal exposure pathway is resuspension. In this pathway, persons can inhale radioactive material that has been deposited on the ground and then becomes airborne again (resuspended). Two additional external exposure pathways - radiation from airborne material ("cloudshine") and from material deposited on the ground ("groundshine") - can also result in an external radiation dose. The contributions of groundshine and cloudshine to the total dose are usually very small. 
The accident consequence model tracks the concentration of radioactive material in the plume and on the ground as a function of the distance from the release point. The population model is then superimposed on the population density map of the route to estimate the number of persons in the plume, the atmospheric and ground concentrations of radioactive material they would be exposed to at those locations, and the amount of time they would be exposed. This information is combined with radionuclide-specific dose conversion factors that determine the radiological doses to persons exposed to the released material. For example, for inhalation doses, the model determines the concentration of radioactive materials in the plume at various distances from the accident in $\mathrm{Ci} \mathrm{per} \mathrm{m}^{3}$ of air. An average breathing rate is then used to determine the amount of each radionuclide inhaled. A detailed description of these calculations is contained in Neuhauser and Kanipe (1995). The dose conversion factors (in units of rem per $\mathrm{Ci}$ inhaled) are then applied to calculate the dose that would result from inhalation of that quantity. Ingestion is a more complicated pathway to evaluate but the concept is the same; i.e., dose conversion factors (in units of rem per $\mathrm{Ci}$ ingested) specific for ingestion are used to calculate the dose from ingestion of contaminated food and water. For external exposure pathways, the dose conversion factors relate the gamma radiation emissions from radioactive material in the airborne cloud to the dose. Accident risks are then calculated by combining the accident frequency and consequence terms for each severity category and then summing over the severity categories.

Calculation of both incident-free and transportation accident risks is usually done on a per-shipment basis, which may then be summed over the number of shipments per year and number of years per shipping campaign to calculate the total incident-free and accident risks of a shipping campaign. For example, a single shipment of LLW may be modeled, resulting in an incident-free and accident dose risk, both of which are expressed in units of person-rem/shipment. The term "dose risk" is used for accident models (rather than just "dose" as the units imply) because the probabilities are involved in the calculations. The per-shipment dose and risk estimates are multiplied by the number of shipments in an average year to result in average annual risk estimates (person-rem/yr). Or, they may be multiplied by the total number of shipments over an entire shipping campaign to calculate the total life-cycle dose and dose risk in personrem. The population doses and dose risks (person-rem) may be multiplied by an appropriate risk factor (LCF per person-rem) to predict the number of LCFs in the exposed population. Even though the units of accident risk and incident-free risk may be the same, it is suggested that they not be added together . because of the differences in the bases and calculation methods (i.e., probabilistic basis for accident risks versus pure consequence-based incident-free risks).

Existing DOE transportation risk analysis computer models are used in this study to develop the necessary input data (i.e., the HIGHWAY and INTERLINE routing codes) and calculate life-cycle transportation risks (i.e., RADTRAN). The methods and data used in the risk analysis are generally consistent with the NTS Intermodal EA and the WM-PEIS. In some areas, there are differences in the data used to quantify LLW transportation risks. However, these differences may affect the magnitude of the calculated risks but should not affect the comparisons among alternatives.

\subsection{METHODOLOGY DESCRIPTION}

This section presents a brief overview of the methods used to calculate transportation impacts. The RADTRAN 4 computer code (Neuhauser and Kanipe 1992) was used to calculate the routine (or incidentfree) radiological doses and accident risks of the in-transit segments between LLW generator sites and NTS. The HIGHWAY (Johnson et al. 1993a) and INTERLINE (Johnson et al. 1993b) computer codes were implemented to develop the routing data (e.g., shipping distances and population distributions along the routes) that is used by the RADTRAN 4 code. Published unit risk factors (risk per unit distance traveled) are used to estimate the physical impacts of accidents during the in-transit segments. A unit risk 
factor approach is also used to estimate the impacts of nonradiological routine (i.e., chemical pollutant) emissions. Hand calculations were employed to estimate the routine radiological doses and physical accident risks to workers at the intermodal transfer facilities. A unit factor approach (impacts per unit handled) was used to quantify these impacts.

\subsubsection{In-Transit Radiological Impact Methodology}

The radiological incident-free doses and accident risks associated with truck and rail transport of LLW to NTS were calculated using the RADTRAN 4 computer code (Neuhauser and Kanipe 1992). The following sections present descriptions of RADTRAN 4 and the HIGHWAY (Johnson et al. 1993a) and INTERLINE (Johnson et al. 1993b) routing models. For additional information, readers are referred to the computer codes' user's manuals.

RADTRAN 4 is used to estimate radiological risks to populations. The code was developed in the 1970s and has been extensively reviewed, updated, and used for transportation risk assessments. Population risks are the primary means of comparing the LLW transportation system configurations and waste load options investigated in this study.

The RADTRAN 4 computer code is organized into eight sets of models listed below:

- Material model

- Transportation model

- Population distribution models

- Material models: isotopic compositions and properties

- Accident severity and package behavior models

- Meteorological dispersion model

- Health effects model

- Economic model.

The code uses these models to calculate the potential population doses from normal (routine or incidentfree) transportation and to calculate the risk to the population from user-defined accident scenarios. The economic model is not used in this study.

\subsubsection{Population Exposures from Routine (Incident-Free) Transport}

The RADTRAN 4 incident-free models calculate external radiation doses to people on or near the transportation routes from exposure to the low-levels of radiation emitted from the loaded shipping containers. RADTRAN 4 calculates incident-free doses to the following population groups:

- Persons along the route (referred to as "off-link population"). RADTRAN 4 calculates population doses to persons living or working within $0.8 \mathrm{~km}(0.5) \mathrm{mi}$ on each side of a transportation route. The population densities developed by the routing codes are distributed in this model within this $0.8-\mathrm{km}$-wide band.

\section{Risks Not Quantified in this Study}

This study does not quantify the risks to workers of LLW package handling at NTS or long-term risks to the public and workers of $L L W$ disposal at NTS. These risks are independent of the four shipping configurations constructed for this analysts (Configurations IA. IB. 2. and 3). All LLI' shipments are received at NTS by truck. Consequently, handling risks are identical for all four shipping configurations. Long-lerm disposal risks are also independent of the shipping configurations used to transport the $L L W$ to the disposal site. 
- Persons sharing the route ("on-link population"). Population doses to persons in vehicles sharing the transportation route, both traveling in the same and opposite directions, are calculated by RADTRAN 4.

- Persons at stops. RADTRAN 4 calculates population doses to persons who may be exposed to a shipment while it is at a stop. For truck shipments, stops may be made for refueling, vehicle inspections, food, or rest. For rail shipments, stops may be made for classification or train makeup purposes.

- Crew members. RADTRAN 4 calculates incident-free doses to truck and rail crew members.

The total public doses from incident-free transportation are the sum of the doses to the off-link population, on-link population, and persons at stops.

Incident-free doses calculated by RADTRAN 4 are generally based on extrapolating the dose rate emitted from the package as a function of distance from a point source. The public and worker doses are dependent upon parameters such as population density, shipping distance, exposure distance, exposure duration, stop times, traffic density, and the Transportation Index (TI) of the package or packages. The TI is defined as the highest package dose rate in millirem per hour at a distance of $1 \mathrm{~m}$ from the external surface of the package. The values used for this parameter and others are presented in Table 5.2. Dose consequences are also dependent on the longest dimension of the package, as indicated in the material model description, which determines whether the package is modeled as a point source or line source for close-proximity exposures. The package size and other important parameters used in the RADTRAN 4 analysis of incident-free transport of LLW to NTS are also presented in the table.

RADTRAN 4 calculations are performed for each origin-destination pair (i.e., LLW generator and NTS). For each pair, HIGHWAY or INTERLINE is implemented to develop route characteristics, including distances traveled in rural, suburban, and urban population zones and their corresponding population

\section{General Equations for Calculating Risks}

The following are generalized equations for calculating transportation risks.

\section{Incident-Free Radiological Doses}

Population Dose $($ person $-m r e m)=$ Dose Rate $(m r e m / h r) \times$ Exposure Duration $(h r) \times$ No. Exposed Persons Population "doses" are then multiplied by ICRP "dose to risk" conversion factor.

$$
\begin{aligned}
& \text { Radiological Accident Risks } \\
& \text { Risk }=\sum_{\text {Surciat }} \text { Frequency }_{\text {Sercit }} \times \text { Consequence }_{\text {Sirc } \text { ot }}
\end{aligned}
$$

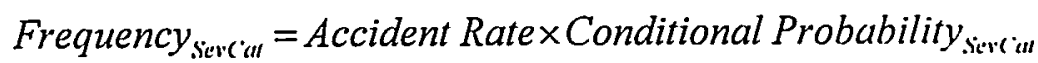

$$
\begin{aligned}
& \text { Consequence }_{\text {Sercut }}=\text { External Dose }_{\text {Serc cut }}+\text { Inhalation Dose }_{\text {Surcut }}+\text { Ingestion Dose }_{\text {sirc ut }}
\end{aligned}
$$

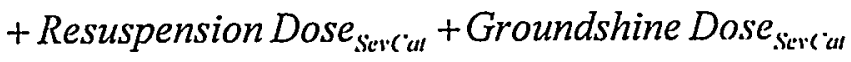

$$
\begin{aligned}
& \text { Nonradiological Accident Risks } \\
& \text { Risk }=\text { Fatality Rate per } \mathrm{km} \times \text { Total Distance Traveled } \\
& \text { Nonradiological Risks Due to Routine Vehicular Emissions } \\
& \text { Risk = Emission Risk Per km inUrban Region } \times \text { Total Distance Traveled in Urban Regions }
\end{aligned}
$$


Table 5.2. RADTRAN 4 Input Parameters Used in the Analysis of Incident-Free Radiological Exposures

\begin{tabular}{|c|c|c|}
\hline \multirow[t]{2}{*}{ Input Parameter } & \multicolumn{2}{|c|}{ Parameter Value } \\
\hline & Truck & Rail \\
\hline \multicolumn{3}{|c|}{ Package Data } \\
\hline Transport Index (mrem $/ \mathrm{h}$ at $1 \mathrm{~m})$ & 1 & 1 \\
\hline Package Size $(m)^{\mathrm{a}}$ & 6.1 & 18.3 \\
\hline \multicolumn{3}{|c|}{ Shipment/Route Data } \\
\hline No. of crew & 2 & 5 \\
\hline Distance from source to crew $(\mathrm{m})$ & 4.3 & 152 \\
\hline Average vehicular speed $(\mathrm{km} / \mathrm{h})$ & & \\
\hline Rural & 88 & 64 \\
\hline Suburban & 40 & 40 \\
\hline Urban & 24 & 24 \\
\hline Stop time $(\mathrm{h} / \mathrm{km}) \quad \therefore \mathrm{s}$ & $0.011^{\mathrm{b}}$ & 0.033 \\
\hline No. of people exposed while stopped & $25^{\mathrm{c}}$ & 100 \\
\hline No. of people per vehicle sharing route & 2 & 3 \\
\hline $\begin{array}{l}\text { Population densities (persons } / \mathrm{km}^{2} \text { ) } \\
\text { Rural } \\
\text { Suburban } \\
\text { Urban }\end{array}$ & Route-specific & Route-specific \\
\hline One-way traffic count (vehicles/h) & & \\
\hline Rural & 470 & 1 \\
\hline Suburban & 780 & 5 \\
\hline Urban & 2,800 & 5 \\
\hline
\end{tabular}

(a) Package size for truck crew exposures is $3 \mathrm{~m}$.

(b) Set to zero for intermodal truck shipments from Barstow and Caliente to NTS.

(c) Set to 2 for truck shipments from LLW generators to intermodal transfer facilities and from intermodal facilities to NTS.

densities. For intermodal shipments from the major generators, up to three shipment segments are analyzed: 1) a truck segment from the LLW generator to an intermodal transfer facility; 2) a rail segment from the intermodal facility near the generator site to an intermodal facility near NTS, and 3) a truck segment from the intermodal facility to NTS. The total incident-free doses for an intermodal shipment are the sum of the doses calculated for the three segments. For LLW generators with rail service, the total incident-free doses include only a rail segment and the final truck segment. Only a single segment is needed to model truck shipments. The HIGHWAY routing model is manipulated until it provides the data for the exact route desired (i.e., through or around Las Vegas and Hoover Dam; see Figures 2.3 and 2.4). The shipping distances and population densities used in this analysis are presented in Table 5.3. The actual routes assumed to be taken by the shipments are presented in Appendix A. An example RADTRAN 4 output file is presented in Appendix B. 
Table 5.3. Route Parameters Used in the RADTRAN 4 Calculations

\section{Configuration 1A - Rail Shipments to Barstow and Truck Shipments from Barstow to NTS}

\begin{tabular}{|c|c|c|c|c|c|c|c|}
\hline \multirow{2}{*}{$\begin{array}{l}\text { LLW } \\
\text { Shipper }\end{array}$} & \multirow{2}{*}{$\begin{array}{l}\text { One-way } \\
\text { Distance, } \\
\text { km }\end{array}$} & \multicolumn{3}{|c|}{ Travel Fraction, $\%$} & \multicolumn{3}{|c|}{ Population Density, persons $/ \mathrm{km}^{2}$} \\
\hline & & Rural & Suburban & Urban & Rural & Suburban & Urban' \\
\hline ORR & 3759 & 88.8 & 10.4 & 0.9 & 6.1 & 339.4 & 2170.0 \\
\hline LANL & 1231 & 95.6 & 4 & 0.4 & 2.8 & 272.2 & 2098.3 \\
\hline Fernald & 3763 & 90.1 & 8.7 & 1.2 & 5.3 & 352.7 & 2261.1 \\
\hline RFETS & 2045 & 91.8 & 6.7 & 1.5 & 3.3 & 417.7 & 2205.1 \\
\hline Mound & 3947 & 87.4 & 10.9 & 1.7 & 6 & 362.3 & 2237.9 \\
\hline LLNL & 645 & 73.3 & 19.7 & 7.0 & 9.1 & 353.0 & 2273.1 \\
\hline BNL & 4953 & 75.7 & 19.4 & 4.8 & 6.9 & 375.7 & 2573 \\
\hline INEEL & 2051 & 83.7 & 12.2 & 4.1 & 5.7 & 337.6 & 2373.6 \\
\hline ANL-E & 3268 & 93.1 & 6.2 & 0.7 & 4.5 & 329.6 & 2155.7 \\
\hline \multicolumn{8}{|c|}{ Route Data for Truck Shipment from Barstow to NTS } \\
\hline NTS & 320 & 99.5 & 0.1 & 0.4 & 1.8 & 759.6 & 2615.8 \\
\hline
\end{tabular}

Configuration 1B - Rail Shipments to Caliente andTruck Shipments from Caliente to NTS

\begin{tabular}{|c|c|c|c|c|c|c|c|}
\hline \multirow{2}{*}{$\begin{array}{c}\text { LLW } \\
\text { Shipper }\end{array}$} & \multirow{2}{*}{$\begin{array}{c}\text { One-way } \\
\text { Distance, } \\
\text { km }\end{array}$} & \multicolumn{3}{|c|}{ Travel Fraction, \% } & \multicolumn{3}{|c|}{ Population Density, persons $/ \mathrm{km}^{2}$} \\
\hline & & Rural & Suburban & Urban & Rural & Suburban & Urban \\
\hline ORR & 3683 & 90.9 & 7.5 & 1.6 & 6.6 & 394.7 & 2178.7 \\
\hline LANL & 2066 & 91.6 & 7.2 & 1.2 & 3.1 & 410.7 & 2202.8 \\
\hline Fernald & 3483 & 89.4 & 9.0 & 1.7 & 5.4 & 394.2 & 2269.3 \\
\hline RFETS & 1249 & 95.4 & 4.4 & 0.3 & 2.6 & 330.7 & 2191.3 \\
\hline Mound & 3614 & 82.9 & 13.3 & 3.8 & 6.2 & 410.2 & 2546.3 \\
\hline LLNL & 1747 & 89.8 & 7.1 & 3.1 & 2.9 & 399.0 & 2446.5 \\
\hline $\mathrm{BNL}$ & 4578 & 72.5 & 21.7 & 5.7 & 7.4 & 388.4 & 2566.8 \\
\hline INEEL & 885 & 90.8 & 7.4 & 1.7 & 4 & 401.3 & 2022.2 \\
\hline ANL-E & 2953 & 91.6 & 7.2 & 1.2 & 4.5 & 372.0 & 2164.6 \\
\hline \multicolumn{8}{|c|}{ Route Data for Truck Shipment from Caliente to NTS } \\
\hline NTS & 484 & 99.8 & 0.2 & 0 & 1.2 & 89.8 & 0 \\
\hline
\end{tabular}




\section{Configuration 2 - Truck Shipments That Avoid Las Vegas}

\begin{tabular}{|l|c|c|c|c|c|c|c|}
\hline \multirow{2}{*}{$\begin{array}{c}\text { LLW } \\
\text { Shipper }\end{array}$} & $\begin{array}{c}\text { One-way } \\
\text { Distance, } \\
\mathrm{km}\end{array}$ & \multicolumn{3}{|c|}{ Travel Fraction, \% } & \multicolumn{2}{c|}{ Population Density, persons/km ${ }^{2}$} \\
\cline { 3 - 8 } & Rural & Suburban & Urban & Rural & Suburban & Urban \\
\hline ORR & 3641 & 89.9 & 8.9 & 1.2 & 5.9 & 328.5 & 2139.9 \\
\hline LANL & 1569 & 94.7 & 4.7 & 0.5 & 3.4 & 395.4 & 2174.8 \\
\hline Fernald & 3627 & 88.7 & 9.9 & 1.4 & 6.2 & 327.6 & 2372.4 \\
\hline RFETS & 1799 & 95.2 & 4.5 & 0.3 & 2.1 & 309.9 & 1878.3 \\
\hline Mound & 3664 & 88.0 & 10.2 & 1.8 & 6.3 & 355.0 & 2336.7 \\
\hline LLNL & 916 & 96.5 & 2.7 & 0.8 & 4.1 & 246.1 & 2156.6 \\
\hline BNL & 4761 & 84.4 & 13.5 & 2.1 & 6.9 & 326.5 & 2494.9 \\
\hline INEEL & 1427 & 97.0 & 2.7 & 0.3 & 2.2 & 335.5 & 1820.7 \\
\hline ANL-E & 3382 & 92.9 & 6.5 & 0.6 & 3.8 & 306.4 & 2176.9 \\
\hline WVDP & 4240 & 86.7 & 11.9 & 1.4 & 5.9 & 309.8 & 2229.1 \\
\hline BCL & 3752 & 87.8 & 10.5 & 1.7 & 6.4 & 343.0 & 2347.0 \\
\hline SPRU & 4681 & 83.5 & 14.9 & 1.5 & 6.9 & 298.3 & 2227.5 \\
\hline Sandia & 1430 & 94.9 & 4.2 & 0.9 & 2.9 & 424.4 & 2128.4 \\
\hline PGDP & 3228 & 91.2 & 7.7 & 1.1 & 5.1 & 348.3 & 2145.3 \\
\hline ETEC & 550 & 76.4 & 9.2 & 14.4 & 2.2 & 553.2 & 3031.4 \\
\hline ITRI & 1430 & 94.9 & 4.2 & 0.9 & 2.9 & 424.4 & 2128.4 \\
\hline PORT & 3802 & 88.3 & 10.0 & 1.7 & 6.3 & 349.7 & 2286.2 \\
\hline PPPL & 4553 & 81.8 & 16.0 & 2.2 & 7.9 & 314.1 & 2335.3 \\
\hline Pantex & 1900 & 94.7 & 4.2 & 1.1 & 3.0 & 443.2 & 2166.5 \\
\hline LBNL & 981 & 92.5 & 4.7 & 2.8 & 4.3 & 382.2 & 2845.3 \\
\hline Ames & 2922 & 93.8 & 5.5 & 0.7 & 3.3 & 304.1 & 2121.3 \\
\hline GJPO & 1400 & 97.7 & 2.2 & 0.2 & 1.5 & 343.9 & 1764.7 \\
\hline GE Val & 930 & 95.6 & 3.1 & 1.3 & 4.2 & 292.9 & 2117.5 \\
\hline
\end{tabular}

Configuration 3 - Truck Shipments Through Las Vegas

\begin{tabular}{|l|c|c|c|c|c|c|c|}
\hline \multirow{2}{*}{$\begin{array}{c}\text { LLW } \\
\text { Shipper }\end{array}$} & $\begin{array}{c}\text { One-way } \\
\text { Distance, } \\
\mathrm{km}\end{array}$ & \multicolumn{3}{|c|}{ Travel Fraction, \% } & \multicolumn{2}{c|}{ Population Density, persons/km ${ }^{2}$} \\
\cline { 3 - 8 } & & Rural & Suburban & Urban & Rural & Suburban & Urban \\
\hline ORR & 3252 & 87.8 & 10.5 & 1.8 & 6.5 & 343.9 & 2213.6 \\
\hline LANL & 1179 & 90.6 & 7.5 & 1.9 & 4.1 & 443.2 & 2341.5 \\
\hline Fernald & 3237 & 86.4 & 11.6 & 2.0 & 6.9 & 341.6 & 2387.9 \\
\hline RFETS & 1318 & 91.5 & 7.6 & 0.8 & 2.5 & 391.1 & 2103.3 \\
\hline Mound & 3274 & 85.8 & 11.9 & 2.4 & 7.0 & 367.4 & 2355.8 \\
\hline LLNL & 948 & 94.3 & 4.6 & 1.1 & 4.3 & 335.7 & 2240.1 \\
\hline BNL & 4280 & 82.1 & 15.5 & 2.4 & 7.8 & 338.4 & 2486.1 \\
\hline INEEL & 1141 & 84.1 & 13.3 & 2.6 & 4.0 & 486.7 & 2101.6 \\
\hline ANL-E & 2901 & 90.9 & 8.2 & 0.9 & 4.3 & 341.1 & 2209.3 \\
\hline WVDP & 3759 & 84.3 & 14.0 & 1.7 & 6.7 & 325.3 & 2237.6 \\
\hline BCL & 3363 & 85.5 & 12.1 & 2.3 & 7.2 & 355.3 & 2364.1 \\
\hline SPRU & 4199 & 81.0 & 17.1 & 1.8 & 7.8 & 309.9 & 2234.6 \\
\hline Sandia & 1041 & 90.3 & 7.1 & 2.6 & 3.5 & 476.0 & 2291.1 \\
\hline PGDP & 2838 & 89.0 & 9.3 & 1.7 & 5.7 & 367.1 & 2230.1 \\
\hline
\end{tabular}




\begin{tabular}{|l|c|c|c|c|c|c|c|}
\hline \multirow{2}{*}{$\begin{array}{c}\text { LLW } \\
\text { Shipper }\end{array}$} & $\begin{array}{c}\text { One-way } \\
\text { Distance, } \\
\mathrm{km}\end{array}$ & \multicolumn{4}{|c|}{ Travel Fraction, \% } & \multicolumn{2}{c|}{ Population Density, persons $/ \mathrm{km}^{2}$} \\
\cline { 3 - 8 } & & Rural & Suburban & Urban & Rural & Suburban & Urban \\
\hline ETEC & 582 & 73.9 & 11.9 & 14.1 & 2.6 & 525.2 & 3009.5 \\
\hline ITRI & 1041 & 90.3 & 7.1 & 2.6 & 3.5 & 476.0 & 2291.1 \\
\hline PORT & 3413 & 86.1 & 11.5 & 2.3 & 6.9 & 362.2 & 2313.5 \\
\hline PPPL & 4166 & 79.4 & 17.8 & 2.8 & 8.7 & 321.5 & 2348.3 \\
\hline Pantex & 1511 & 91.5 & 6.2 & 2.3 & 3.4 & 481.0 & 2276.6 \\
\hline LBNL & 1014 & 90.5 & 6.5 & 3.0 & 4.5 & 402.5 & 2805.2 \\
\hline Ames & 2441 & 91.6 & 7.4 & 1.0 & 3.9 & 350.2 & 2166.7 \\
\hline GJPO & 919 & 93.7 & 5.4 & 0.8 & 1.8 & 495.0 & 2163.9 \\
\hline GE Val & 962 & 93.4 & 5.0 & 1.5 & 4.4 & 355.8 & 2184.6 \\
\hline
\end{tabular}

\subsubsection{Radiological Accident Risks}

Accident risk assessment is performed by RADTRAN 4 by combining the frequencies and consequences of accidents to produce a "risk" value (see Section 5.0). RADTRAN 4 considers a spectrum of potential transportation accidents, ranging from those with high frequencies and low consequences (e.g., "fender benders") to those with low frequencies and high consequences (accidents in which the shipping container is exposed to severe mechanical and thermal conditions).

Accident analysis in RADTRAN 4 is performed using accident severity and package release models. The user can define up to 20 severity categories for three population densities (urban, suburban, and rural). In general, higher-numbered accident severity categories result in more severe potential damage to the container and are less probable than lower-numbered severity categories. Severity categories are related to scenarios, including fire, puncture, crush, and immersion environments created in vehicular accidents. For this study, the eight severity categories defined in NUREG-0170 (NRC 1977) were adopted. Severity Category I represents minor accidents in which the packaging system (drum or box within a Sea-Land container) retains confinement of the LLW cargo (i.e., no release). Higher severity categories represent more severe accident conditions with correspondingly higher releases (and higher consequences) and lower frequencies. In the highest severity categories, the release fractions are set to 1.0 (i.e., $100 \%$ of the radioactive material is released from the packaging system).

The frequency of each specific accident scenario is calculated by multiplying together the overall rate of all accidents and the probability that the specific accident scenario occurs. In RADTRAN 4, each severity category has a conditional probability assigned to it; i.e., the probability given an accident that it will be of the specified severity. The accident scenarios are further defined by allowing the user to input release fractions and aerosol and respirable fractions for each severity category. These fractions are also a function of the physical-chemical properties of the materials being transported.

The input parameters used in this analysis are shown in Table 5.4. The radiological inventories per shipment of LLW, taken from the NTS Intermodal EA, are shown in Table 5.5. These inventories were developed in the NTS Intermodal EA based on waste characterization data from the NTS Site-wide EIS and are representative of the actual LLW shipped to NTS in the past. Radionuclide inventories are generator-specific and are anticipated to change over time. Radionuclide decay will reduce the inventories of short-lived radionuclides. The inventories will also change, some increasing and some decreasing, when generators revise waste management practices or complete waste management and environmental restoration projects and begin new ones. At any rate, since these inventories were used 
Table 5.4. RADTRAN 4 Input Parameters for Radiological Accident Analysis ${ }^{(a)}$

\begin{tabular}{|c|c|c|c|c|c|c|}
\hline \multirow[t]{2}{*}{ Parameter } & \multicolumn{3}{|c|}{ Truck } & \multicolumn{3}{|c|}{ Rail } \\
\hline & Rural & Suburban & Urban & Rural & Suburban & Urban \\
\hline Accident Rate & \multicolumn{3}{|c|}{ State-specific (Saricks and Tompkins 1999) } & \multicolumn{3}{|c|}{ State-specific (Saricks and Tompkins 1999) } \\
\hline \multicolumn{7}{|c|}{ Fractional Occurrence by Severity Category (conditional probability given an accident occurs) } \\
\hline I & \multicolumn{3}{|c|}{0.55} & \multicolumn{3}{|c|}{0.50} \\
\hline II & \multicolumn{3}{|c|}{0.36} & \multicolumn{3}{|c|}{0.30} \\
\hline III & \multicolumn{3}{|c|}{0.07} & \multicolumn{3}{|c|}{0.18} \\
\hline IV & \multicolumn{3}{|c|}{0.016} & \multicolumn{3}{|c|}{0.018} \\
\hline $\mathrm{V}$ & \multicolumn{3}{|c|}{0.0028} & \multicolumn{3}{|c|}{0.0018} \\
\hline VI & \multicolumn{3}{|c|}{0.0011} & \multicolumn{3}{|c|}{$1.3 \mathrm{E}-04$} \\
\hline VII & \multicolumn{3}{|c|}{$8.5 \mathrm{E}-05$} & \multicolumn{3}{|c|}{$6.0 \mathrm{E}-05$} \\
\hline VIII & \multicolumn{3}{|c|}{$1.5 \mathrm{E}-05$} & \multicolumn{3}{|c|}{$1.0 \mathrm{E}-05$} \\
\hline \multicolumn{7}{|c|}{$\begin{array}{l}\text { Fractional Occurrence by Population Zone (conditional probability given an accident occurs of the specified severity } \\
\text { category) }\end{array}$} \\
\hline I & 0.10 & 0.10 & 0.80 & 0.10 & 0.10 & 0.80 \\
\hline II & 0.10 & 0.10 & 0.80 & 0.10 & 0.10 & 0.80 \\
\hline III & 0.30 & 0.40 & 0.30 & 0.30 & 0.40 & 0.30 \\
\hline IV & 0.30 & 0.40 & 0.30 & 0.30 & 0.40 & 0.30 \\
\hline V & 0.50 & 0.30 & 0.30 & 0.50 & 0.30 & 0.30 \\
\hline VI & 0.70 & 0.20 & 0.10 & 0.70 & 0.20 & 0.10 \\
\hline VII & 0.80 & 0.10 & 0.10 & 0.80 & 0.10 & 0.10 \\
\hline VIII & 0.90 & 0.05 & 0.05 & 0.90 & 0.05 & 0.05 \\
\hline \multicolumn{7}{|c|}{ Release Fraction (fraction released from shipping container by severity category) } \\
\hline $\mathrm{I}$ & \multicolumn{3}{|c|}{0} & \multirow{2}{*}{\multicolumn{3}{|c|}{$\begin{array}{c}0 \\
0.01\end{array}$}} \\
\hline II & \multicolumn{3}{|c|}{0.01} & & & \\
\hline III & \multicolumn{3}{|c|}{0.1} & \multicolumn{3}{|c|}{0.1} \\
\hline IV & & 1 & & \multicolumn{3}{|c|}{1} \\
\hline V & & 1 & & & 1 & \\
\hline VI & & 1 & & & 1 & \\
\hline VII & & 1 & & & 1 & \\
\hline VIII & & 1 & & & 1 & \\
\hline Aerosol Fraction ${ }^{(0)}$ & & 0.006 & & & 0.0 & \\
\hline $\begin{array}{l}\text { Respirable } \\
\text { Fraction }\end{array}$ & & 0.01 & & & 0.0 & \\
\hline
\end{tabular}

(a) Data taken from NUREG-0170 (NRC 1977) except where indicated otherwise.

(b) Source: NTS Intermodal EA.

consistently across the alternative shipping configurations, this parameter will not affect the comparisons of radiological accident risk among the alternatives.

For accidents that result in a release of radioactive material, RADTRAN 4 assumes the material is dispersed into the environment according to standard Gaussian diffusion models. The code allows the user to choose two different methods for modeling the atmospheric transport of radionuclides after a potential accident. The user can either input Pasquill atmospheric-stability category data or averaged time-integrated concentrations. In this analysis, the dispersion of radionuclides after a potential accident is modeled assuming Pasquill Stability Class D and wind speed of $4 \mathrm{~m} / \mathrm{sec}$ (i.e., neutral conditions).

As was described in Section 5.0, RADTRAN 4 calculates the population dose from the released radioactive material for four exposure pathways. These are: 
Table 5.5. Radionuclide Inventories per Container Shipped

( 1 container per truck and 3 per railcar)

\begin{tabular}{|l|c||l|c||c|c|}
\hline $\begin{array}{c}\text { Radio- } \\
\text { nuclide }\end{array}$ & $\begin{array}{c}\text { Inventory, } \\
\text { Ci per container }\end{array}$ & $\begin{array}{c}\text { Radio- } \\
\text { nuclide }\end{array}$ & $\begin{array}{c}\text { Inventory, } \\
\text { Ci per container }\end{array}$ & $\begin{array}{c}\text { Radio- } \\
\text { nuclide }\end{array}$ & $\begin{array}{c}\text { Inventory, } \\
\text { Ci per container }\end{array}$ \\
\hline $\mathrm{Ba}-137 \mathrm{~m}$ & $2.86 \mathrm{E}-04$ & $\mathrm{Mn}-54$ & $5.54 \mathrm{E}-03$ & Tc-99 & $1.23 \mathrm{E}-04$ \\
\hline $\mathrm{Bi}-212$ & $1.19 \mathrm{E}-06$ & $\mathrm{~Pa}-234 \mathrm{~m}$ & $2.95 \mathrm{E}-06$ & Th-228 & $1.59 \mathrm{E}-09$ \\
\hline $\mathrm{C}-14$ & $1.48 \mathrm{E}-04$ & $\mathrm{~Pb}-212$ & $9.95 \mathrm{E}-07$ & Th-231 & $2.87 \mathrm{E}-05$ \\
\hline $\mathrm{Co}-58$ & $5.12 \mathrm{E}-03$ & $\mathrm{Po}-212$ & $2.57 \mathrm{E}-08$ & Th-232 & $2.41 \mathrm{E}-08$ \\
\hline $\mathrm{Co}-60$ & $5.17 \mathrm{E}-03$ & $\mathrm{Po}-216$ & $3.98 \mathrm{E}-10$ & Th-234 & $1.47 \mathrm{E}-02$ \\
\hline $\mathrm{Cs}-134$ & $5.73 \mathrm{E}-03$ & Ra-224 & $9.95 \mathrm{E}-08$ & U-235 & $1.14 \mathrm{E}-04$ \\
\hline $\mathrm{Cs}-137$ & $7.53 \mathrm{E}-03$ & Ra-228 & $5.95 \mathrm{E}-08$ & $\mathrm{U}-238$ & $1.50 \mathrm{E}-01$ \\
\hline $\mathrm{H}-3$ & $1.00 \mathrm{E}-03$ & $\mathrm{Sr}-90$ & $1.39 \mathrm{E}-04$ & $\mathrm{Y}-90$ & $3.47 \mathrm{E}-03$ \\
\hline
\end{tabular}

Note: Results are given in abbreviated scientific notation. For example, $5.54 \mathrm{E}-03=5.54 \times 10^{-3}$ $=0.00554$.

- External exposure to the passing cloud of radioactive material (cloudshine)

- External exposure to contaminated soil deposited on the ground by the passing plume (groundshine)

- Internal exposure from inhalation of airborne radioactive contaminants (inhalation and resuspension),

- Internal exposure from ingestion of contaminated food (ingestion).

Standard radionuclide uptake and dosimetry models are incorporated in RADTRAN 4. Dose conversion factors were taken from DOE (1988a and 1988b). The computer code combines the accident consequences and frequencies of each severity category, sums over the severity categories, and then integrates over all the shipments. Accident risk impacts are provided in the form of a population dose (person-rem over the entire shipping campaign), which is then converted to health risk using health effects conversion factors. The conversion factors were taken from the International Commission on Radiological Protection (ICRP) Publication 60 (ICRP 1991) and amount to 4.0E-04 latent cancer fatalities (LCF) per person-rem for workers and 5.0E-04 LCF/person-rem for the general public.

\subsubsection{Radiological Exposures to Workers at Intermodal Transfer Facilities}

Workers at intermodal transfer facilities will be exposed to the external radiation fields surrounding the LLW shipping containers. Hand calculations were performed to quantify these doses. The handcalculations combine a population dose estimate per unit handled (person-rem per container) for transferring LLW containers from trucks to railcars and vice versa and the total number of handling cycles. The population dose per unit handled was based on the NTS Intermodal EA where an estimate of about 1.7E-04 person-rem per container was developed. This was calculated using a TI value of 0.5 $\mathrm{mrem} / \mathrm{hr}$. Since the TI used in this analysis is $1.0 \mathrm{mrem} / \mathrm{hr}$ (see Table 5.2), the unit collective dose used in the NTS Intermodal EA was doubled to 3.4E-04 person-rem per container handled $(0.00034$ person-rem or 0.34 person-millirem per container) for this analysis. This unit dose factor is multiplied by the total number of container handlings at intermodal facilities, including intermodal transfers that occur near the LLW generator and near NTS. The resulting population dose was next converted to LCFs using the risk factor for workers given above. For this assessment, shipping container transfer operations are assumed to be the same at all intermodal transfer facilities.

\subsubsection{Physical (Nonradiological) Routine Risks}

Nonradiological routine impacts consist of fatalities from pollutants emitted from the vehicles. This category of impacts is not related to the radiological characteristics of the cargo. Hand calculations were 
performed using unit risk factors (fatalities per $\mathrm{km}$ of travel) to derive estimates of the nonradiological impacts. The nonradiological impacts were calculated by multiplying the unit risk factors by the total shipping distances for all of the shipments in each shipping option. Nonradiological unit risk factors for incident-free transport were taken from Rao et al. (1982) and amount to 1.0E-07 latent cancers per km traveled in urban areas for truck shipments and 1.3E-07 latent cancers/railcar-km for rail shipments.

\subsubsection{Physical (Nonradiological) Accident Risks in Transit}

This section describes the analyses performed to assess nonradiological impacts of vehicular accidents involving the LLW shipments to NTS.

The nonradiological impacts associated with the transportation of LLW are assumed to be comparable to the impacts associated with general transportation activities in the United States. To calculate nonradiological impacts or fatalities, fatality rates for the specific transport modes (i.e., fatalities per $\mathrm{km}$ or fatalities per mi.) are multiplied by the shipment distance. Fatality rates and shipping distances (provided by INTERLINE and HIGHWAY) are developed for three population density regions (rural, suburban, and urban) to account for differences in risk that arise during transport in highly populated areas relative to suburban and rural areas. The fatalities are due to vehicular impacts with solid objects, rollovers, or collisions and are not related to the radioactive nature of the cargo being transported. The fatality rates used in the analysis were developed using state-specific accident data (Saricks and Tompkins 1999). A single combined fatality rate was used to encompass either truck or rail crew members and the public.

\subsubsection{Physical (Nonradiological) Accident Risks to Workers at Intermodal Transfer Facilities}

Workers at intermodal transfer facilities will be exposed to the general physical hazards associated with material handling that are not related to the radioactive nature of the cargo. A unit risk factor approach is used here to estimate these impacts. The unit risk factor was derived from Bureau of Labor Statistics (BLS) accident data representative of material handling industries. Fatality rate data from 1996 was reviewed to identify industry classifications that are representative of intermodal transfer activities. Three were identified, including "trucking and warehousing," "material-moving equipment operator," and "laborers except construction." Of these three industry categories, the highest fatality rate was for "trucking and warehousing," operations, which amounted to 20.8 fatalities per 100,000 workers in 1996. This was rounded down to 20 fatalities/100,000 workers to account for the lower fatality rate operations (e.g., laborers that perform hands-on operations as opposed to equipment operators). This was converted to a fatality rate per person-hr (using 2000 person-hr/yr) to calculate a fatality rate of $1 \mathrm{E}-07$ fatalities per person-hr for intermodal transfer operations. The unit risk factor for intermodal transfer operations was estimated by multiplying this fatality rate by the per-container exposure durations given in the NTS Intermodal $E A$ that amounted to about 0.5 person-hr per container. The unit risk factor was calculated to be $5 \mathrm{E}-08$ fatalities per container handled. The total life-cycle risk of intermodal transfer operations was calculated by multiplying this fatality rate by the total number of containers processed at intermodal transfer facilities near the LLW generator sites and near NTS.

\subsection{COMPARISONS OF INPUT PARAMETERS WITH OTHER STUDIES}

This section compares the assumptions and parameters used in the determination of transportation risks in this study with other recent LLW transportation risk assessments. A summary and comparison of input data with the other risk assessments (NTS Intermodal EA [DOE 1998], NTS Site-Wide EIS [DOE 1996], and WM-PEIS [DOE 1997]) are given in Tables 5.6 and 5.7. 
Table 5.6. Radiological Incident-Free Input Parameters

\begin{tabular}{|c|c|c|c|c|c|c|c|c|}
\hline & \multicolumn{2}{|c|}{ This Studly } & \multicolumn{2}{|c|}{ NTS Intermodal EA } & \multicolumn{2}{|c|}{ NTS Site-wide IIS $^{(a)}$} & \multicolumn{2}{|c|}{ WM PEIS } \\
\hline & Truck & Rail & Truck & Rail & Truck & Rail & Truck & Rail \\
\hline \multicolumn{9}{|l|}{ Package Data } \\
\hline Transport Index (mrem/h at $1 \mathrm{~m})$ & 1 & 1 & 0.5 & $N A^{(0)}$ & 0.05 & NA & 1 & 1 \\
\hline Package Size $(\mathrm{m})^{(\mathrm{c})}$ & 6.1 & 18.3 & 6.1 & NA & 6.4 & NA & 12 & 16 \\
\hline \multicolumn{9}{|l|}{ Shipment/Route Data } \\
\hline No. of crew & 2 & 5 & 2 & NA & 2 & NA & 2 & 5 \\
\hline Distance from source to crew $(\mathrm{m})$ & 4.3 & 152 & 4.3 & NA & 3 & NA & 3 & 152 \\
\hline $\begin{array}{l}\text { Average vehicular speed }(\mathrm{km} / \mathrm{h}) \\
\text { Rural } \\
\text { Suburban } \\
\text { Urban }\end{array}$ & $\begin{array}{l}88 \\
40 \\
24\end{array}$ & $\begin{array}{l}64 \\
40 \\
24\end{array}$ & $\begin{array}{l}88 \\
40 \\
24\end{array}$ & NA & $\begin{array}{l}88 \\
40 \\
24\end{array}$ & NA & $\begin{array}{l}88 \\
40 \\
24\end{array}$ & $\begin{array}{l}64 \\
40 \\
24\end{array}$ \\
\hline Stop time $(\mathrm{l} / \mathrm{km})$ & $0.011^{(d)}$ & 0.033 & $0^{(c)}$ & NA & NA & NA & 0.011 & 0.033 \\
\hline No. of people exposed while stopped & $25^{(1)}$ & 100 & $2^{(\mathrm{g})}$ & NA & 25 & NA & 25 & 100 \\
\hline No. people per vehicle sharing route & 2 & 3 & 2 & NA & 2 & NA & 2 & 3 \\
\hline $\begin{array}{l}\text { Population densities (persons } / \mathrm{km}^{2} \text { ) } \\
\text { Rural } \\
\text { Suburban } \\
\text { Urban }\end{array}$ & $\begin{array}{l}\text { Route- } \\
\text { specific }\end{array}$ & $\begin{array}{l}\text { Route- } \\
\text { specific }\end{array}$ & $\begin{array}{c}6 \\
719 \\
3,861\end{array}$ & NA & $\begin{array}{l}\text { Route- } \\
\text { specific }\end{array}$ & NA & $\begin{array}{c}6 \\
719 \\
3,861\end{array}$ & $\begin{array}{c}6 \\
719 \\
3,861\end{array}$ \\
\hline $\begin{array}{l}\text { One-way traffic count (vehicles/h) } \\
\text { Rural } \\
\text { Suburban } \\
\text { Urban }\end{array}$ & $\begin{array}{c}470 \\
780 \\
2,800\end{array}$ & $\begin{array}{l}1 \\
5 \\
5\end{array}$ & $\begin{array}{c}470 \\
780^{\circ} \\
2,800\end{array}$ & NA & $\begin{array}{l}\text { Route- } \\
\text { specific }\end{array}$ & NA & $\begin{array}{c}470 \\
780 \\
2,800\end{array}$ & $\begin{array}{l}1 \\
5 \\
5\end{array}$ \\
\hline
\end{tabular}

"Note that the NTS Site-wide EIS did not use RADTRAN. Thus, direct comparison of parameters with the other studies may not necessarily be valid.

NA - Not Applicable.

¿ Package size for crew exposure is $3 \mathrm{~m}$ except for the NTS Site-wide EIS.

${ }^{d}$ Set to zero for intermodal shipments from Barstow and Caliente.

${ }^{\mathrm{c}}$ Based on trip duration less than $8 \mathrm{~h}$.

' Set to 2 for intermodal shipments.

${ }^{g}$ One stop assumed for vehicle inspection when crossing the NV state line. 
Table 5.7. Accident and Nonradiological Input Parameters

\begin{tabular}{|c|c|c|c|c|}
\hline Parameter & This Study & NTS Intermodal EA & NTS Site-wide EIS & WM PEIS \\
\hline $\begin{array}{l}\text { Total Inventory and } \\
\text { Shipments }\end{array}$ & $\begin{array}{l}738,848 \mathrm{~m}^{3} \text { for high case, } \\
\text { approximately } 27,725 \\
\text { truck shipments }\end{array}$ & $\begin{array}{l}\text { Assumed same number of } \\
\text { truck shipments as NTS } \\
\text { Site-wide EIS, } 25,084 \text { (10- } \\
\text { yr Period) or } 9,457 \text { railcars } \\
\text { using truck to railcar ratio } \\
\text { from WMPEIS }\end{array}$ & $\begin{array}{l}1 \text { million } \mathrm{m}^{3} \text {, includes } \\
\text { Hanford, SRS, and NTS } \\
36,672 \text { truck shipments } \\
\text { (10 yr. period) }\end{array}$ & $\begin{array}{l}\text { LLW Centralized } 2 \text { Altern. } \\
1.5 \text { million } \mathrm{m}^{3} \text {, includes } \\
\text { Hanford, SRS, and NTS } \\
257,000 \text { truck shipments } \\
\text { (stored }+20 \mathrm{yr} \text {. generation } \\
\text { period) }\end{array}$ \\
\hline \multicolumn{5}{|l|}{ Accident Parameters } \\
\hline Radionuclide Inventory & $\begin{array}{l}1 \text { container profile, } \\
\text { profile from EA to be used }\end{array}$ & $\begin{array}{l}1 \text { container profile, See } \\
\text { Table } 5.5 \text { of this report. }\end{array}$ & $\begin{array}{l}\text { I profile derived from site- } \\
\text { specific data }\end{array}$ & Site-specific \\
\hline Accident Rates & $\begin{array}{l}\text { Saricks \& Tompkins } \\
\text { (1999) }\end{array}$ & Route-specific & Nevada-specific & Saricks \& Kvitek (1994) \\
\hline Conditional Probabilities & NUREG-0170 & NUREG-0170 & NUREG-0170 & NUREG-0170 \\
\hline $\begin{array}{l}\text { Release/ Aerosol/ } \\
\text { Respirable Fractions }\end{array}$ & $\begin{array}{l}\text { NUREG-0170/ } \\
\text { DOE Release Fraction } \\
\text { Handbook (DOE 1994) }\end{array}$ & $\begin{array}{l}\text { NUREG-0170/ } \\
\text { DOE Release Fraction } \\
\text { Handbook (DOE 1994) }\end{array}$ & $\begin{array}{l}\text { Modified NUREG-0170/ } \\
\text { DOE Release Fraction } \\
\text { Handbook(DOE 1994) } \\
\end{array}$ & $\begin{array}{l}\text { NUREG-0170/ } \\
\text { RADTRAN suggestions }\end{array}$ \\
\hline \multicolumn{5}{|l|}{ Nonradiological Input } \\
\hline Emission Fatalities & $\begin{array}{l}\text { Latent fatalities from } \\
\text { diesel exhaust and fugitive } \\
\text { dust emissions, Rao et al. } \\
\text { (1982) }\end{array}$ & $\begin{array}{l}\text { Latent cancer fatalities } \\
\text { from diesel exhaust, } \\
\text { derived from EPA's Motor } \\
\text { Vehicle-Related Air Toxics } \\
\text { Study (1993) }\end{array}$ & $\begin{array}{l}\text { Latent fatalities from Rao } \\
\text { et al. (1982) and latent } \\
\text { cancer fatalities derived } \\
\text { from EPA (1993) }\end{array}$ & $\begin{array}{l}\text { Latent fatalities from } \\
\text { diesel exhaust and fugitive } \\
\text { dust emissions, Rao et al. } \\
\text { (1982) }\end{array}$ \\
\hline Accident Fatalities & $\begin{array}{l}\text { Saricks \& Tompkins } \\
(1999)\end{array}$ & Nevada-specific & Nevada-specific & Saricks \& Kvitek (1994) \\
\hline
\end{tabular}


The intent of this section is to place the input assumptions and parameters in perspective with other studies, so the reader is aware of the most significant differences among the various studies that analyzed the risk of LLW transportation. For the most part, the differences affect only the magnitudes of the calculated risk values. The differences do not affect the comparisons between alternative shipping configurations, which are the predominant interests in this study, but would affect the absolute magnitudes of the calculated risks. As an illustration, assume that the radiation dose rate (the input parameter is the Transport Index or TI) is approximately $10 \mathrm{mrem} / \mathrm{hr}$ rather than 1.0 . The calculated radiological incident-free doses are approximately linear with respect to the TI. As a result, the calculated impacts would be 10 times higher for the case where the TI was set to 10 than it would be for a TI of 1.0. However, as long as the TI value used is consistently applied to all alternatives, the differences between alternatives would still be valid.

Finally, it should be noted that the LLW volume projections assumed in this study include a number of LLW generators that are currently not on the NTS disposal facility's approved generator list. For the purposes of this study, it was assumed that all potential DOE LLW generators are capable of obtaining approval to dispose of their LLW at NTS.

\subsubsection{Shipment Volumes and Configurations}

Truck shipments are assumed to consist of one $20-\mathrm{ft}$ container (cargo capacity $=26.65 \mathrm{~m}^{3}$ of LLW per shipment). Rail shipments are considered to be one railcar with three $20-\mathrm{ft}$ containers $\left(79.95 \mathrm{~m}^{3} /\right.$ shipment). Risks are estimated for two waste load projections, high and low cases, covering a 70-year period. Both cases consider Waste Management (WM) and Environmental Restoration (ER) wastes. For the high case, with NTS as the primary offsite LLW disposal site, current projections of waste to be disposed of at NTS are about $740,000 \mathrm{~m}^{3}$ from 23 sites. On an average or levelized annual basis, this is equivalent to receiving about $10,600 \mathrm{~m}^{3}\left(370,000 \mathrm{ft}^{3}\right)$ of $L L W$ per year for 70 years. This is well below the annual LLW volumes projected to be disposed at NTS in the NTS Site-wide EIS.

The WM-PEIS Centralized 2 Alternative, where all LLW is disposed of at NTS, had approximately 257,000 truck shipments (approximately 1.5 million $\mathrm{m}^{3}$ ) of waste being disposed at NTS. This figure includes shipments from sites such as Hanford and SRS. Current inventories in storage plus a 20-year generation period were assumed. Only WM waste was considered in the $W M-P E I S$.

The major differences between the WM-PEIS and the other studies in the number of shipments are the 20yr generation period, changing waste volume estimates, and the assumption of shipments being weight limited. Waste characterization estimates for LLW in the WM-PEIS included both volume and weight estimates. Shipments were found in many cases to be weight limited (legal weight truck shipments must be $80,000 \mathrm{lb}$ or less, truck and cargo combined). Thus, the $W M-P E I S$ used a 44,000 -lb truck weight limit (120,000-lb railcar limit) for the LLW cargo. The NTS Site-wide EIS assumed 12 4-ft x 4-ft x 7-ft boxes per LLW truck shipment (approximately $38 \mathrm{~m}^{3}$ or less). This study and the NTS Intermodal EA assume a standard $20-\mathrm{ft}$ shipping container (approximately $26.7 \mathrm{~m}^{3}$ ) for all LLW shipments.

\subsubsection{Shipment Routes}

Different alternatives were analyzed for each of the two waste load options. The alternatives analyzed in this study match those analyzed in the NTS Intermodal EA. For the configurations with rail/intermodal shipping in this study, only the 9 sites with the largest volumes of waste ( $>93 \%$ of the total) would ship by rail (ORR, LANL, Fernald, RFETS, Mound, LLNL, BNL, INEEL, and ANL-E). The remaining sites. were assumed to always ship by truck because their waste volumes are less likely to justify use of the larger railcar shipment volumes. This is a departure from the NTS Intermodal EA where all sites were assumed to ship by rail in the rail/intermodal configurations. 
Shipment routes were determined in this study using the HIGHWAY (Johnson et al. 1993a) and INTERLINE codes (Johnson et al. 1993b) for truck and rail shipments, respectively. The NTS Intermodal $E A$ does not evaluate national transportation risk, but it states that over $80 \%$ of the LLW shipments that enter Nevada currently do so via US 93 at Hoover Dam in legal-weight trucks. This percentage is based on the past volumes shipped by approved generator sites. Using the sites and waste volumes identified for this study, approximately $73 \%$ of the shipments in the high waste volume case would be routed over Hoover Dam using the representative truck routes determined with HIGHWAY.

\subsubsection{Radiological Risks}

\section{Incident-Free Transportation}

Collective population incident-free risks were estimated in this study using RADTRAN and the general input parameters shown in Table 5.6. The values for these parameters, with the exception of the transport index, stop parameters, and population densities, were the same as those values used in the NTS Intermodal $E A$. Stop parameters more appropriate for national transportation scenarios, as found in the WM PEIS, were used. Route-specific population densities were used in this study. No credit for shielding of the exposed collective populations (crew and general public) was taken. The NTS Site-wide $E I S$ used attenuation factors ranging from 0.0001 to 0.01 .

\section{Transportation Accident Risks}

References for the various accident input parameters can be found in Table 5.7. State-specific accident rates from Saricks and Tompkins (1999), an update of Saricks and Kvitek (1994) that is commonly used in other studies, were used here (see Section 5.2.4). The accident rates used in this study for travel in Nevada are the primary (non-interstate) highway accident rates in the State of Nevada (Saricks and Tompkins 1999). As used in all previous studies, the accident category scheme and associated conditional accident probabilities suggested in NUREG-0170 (NRC 1977) were input into RADTRAN for calculating collective population risks. As in the NTS Intermodal EA, accident release fractions were taken from NUREG-0170, and the associated aerosolized and respirable fractions were based on recommendations in the DOE handbook on release and respirable fractions (DOE 1994). The radionuclide inventory per shipping container available for release was taken from the NTS Intermodal $E A$.

\subsubsection{Nonradiological Risks}

Accident fatalities were assessed using the fatality rates in Saricks and Tompkins (1999).

The most recent truck and rail accident and fatality rate statistics (Saricks and Tompkins 1999) were used in this report. These rates update the values in an earlier report (Saricks and Kvitek 1994) that were used in the WM PEIS. As discussed in Saricks and Tompkins (1999), the truck accident statistics are similar for the two reports although they are not directly comparable. Accident reporting criteria for highway accidents, and therefore the statistical basis, had changed between the years investigated by the first study (1986-1988) and the years investigated by the second study (1994-1996). Reporting criteria for rail incidents/accidents remained consistent between the two studies.

The use of the new truck fatality rates results in a reduction of approximately a factor of one-half in the vehicle-related accident impacts for alternatives on a national scale. This reduction is attributed in part to the availability of more effective safety equipment and the completion of the U.S. interstate system

(Saricks and Tompkins 1999). On the other hand, the national average rail fatality rate increased by more 
than a factor of 3, from 2.35E-08 to 7.82E-08 fatalities/railcar-km (Saricks and Kvitek [1994] and Saricks and Tompkins [1999], respectively). These fatality rates include all fatalities occurring at gradecrossings, along rights-of-way, and in railyards. However, the WM PEIS used a rail fatality rate as stated in Saricks and Kvitek (1994) that was consistent with the truck fatality rate which excludes most fatalities occurring in rail yards. Such an approach is misleading because these fatalities occur primarily during marshalling of the train versus loading of the cars, that is, a necessary function for shipment by general rail that does not have a truck counterpart. Such a rate is not given in Saricks and Tompkins (1999). Thus, the new applicable national average rail fatality rate, $7.82 \mathrm{E}-08$ fatalities/railcar-km, is approximately 100 times larger than the $6.5 \mathrm{E}-10$ fatalities/railcar-km used in the WM PEIS. This increase in rates does not have as a pronounced effect on the rail fatality impacts estimated in this study because state-specific fatality rates were used (Saricks and Tompkins 1999). The use of state-specific fatality rates lowers the impacts because the high national average is driven by a number of eastern states, most of which are not involved in the rail routes analyzed. State-specific rail accident fatality rates were not available in Saricks and Kvitek (1994). In summary, for vehicle-related accident fatalities, the truck rates used in this report are approximately a factor of one-half lower, and the rail rates are approximately a factor of 30 higher than the rates used in the WMPEIS.

Fatalities from vehicle emissions were assessed in this study using the latent fatality risk factors in Rao et al. (1982). These risks factors are for latent cancer fatalities in urban areas resulting from emissions of diesel exhaust, fugitive dust, and tire and brake particulates. The emission risk factor in the NTS Intermodal $E A$ is only for latent cancer fatality from just diesel exhaust. As a result, such estimates for a given shipment will be at least 100 to 1,000 times lower than when using Rao et al.'s factor, which is only valid for urban zones but accounts for all emissions and health effects. The NTS Site-wide EIS used both sets of emission risk factors.

\subsection{RESULTS OF TRANSPORTATION IMPACT ANALYSES}

This section presents the results of the transportation risk analyses of the shipping configurations and waste load options examined in this study. Detailed results are presented in Appendices B and C.

\subsubsection{Shipping Mileage}

Figure 5.1 is a comparison of the truck, rail, and total mileage traveled by LLW shipments destined for NTS for the high waste loading option. In Configuration $1 \mathrm{~A}$ (intermodal transfer at Barstow), the total distance traveled is about 40 million $\mathrm{km}(25$ million $\mathrm{mi}$ ) if the direct truck shipments from small generator sites travel through Las Vegas and about 41 million $\mathrm{km}$ (26 million mi) if the direct truck shipments travel on routes that avoid Las Vegas. For Configuration 1B (intermodal at Caliente), the total distances traveled are about 45 million $\mathrm{km}$ ( 28 million $\mathrm{mi})$ and 44 million $\mathrm{km}$ ( 27 million mi), for direct truck routes that travel around or through Las Vegas, respectively. Rail shipping distances shown in the figure were calculated on a per-railcar basis. In Configuration 2, truck carriers are encouraged to operate on routes that avoid Hoover Dam and the Las Vegas Valley. In this configuration, the total distance traveled by loaded LLW shipments was calculated to be about 84 million $\mathrm{km} \mathrm{(52} \mathrm{million} \mathrm{mi).} \mathrm{In} \mathrm{Configuration} 3$, in which past carrier routing options were assumed, the total highway distance traveled is about 73 million km (45 million mi.).

In the two all-truck configurations, the one in which the Las Vegas and Hoover Dam areas are avoided represents about $15 \%$ more miles traveled on a DOE complex-wide basis than the configuration in which travel over Hoover Dam and through the Las Vegas Valley is assumed. If intermodal transfers at Barstow are assumed, the total distances traveled are reduced to about $56 \%$ of the total distance traveled assuming present all-truck shipping practices. The total mileage is reduced to about $60 \%$ of the all-truck 


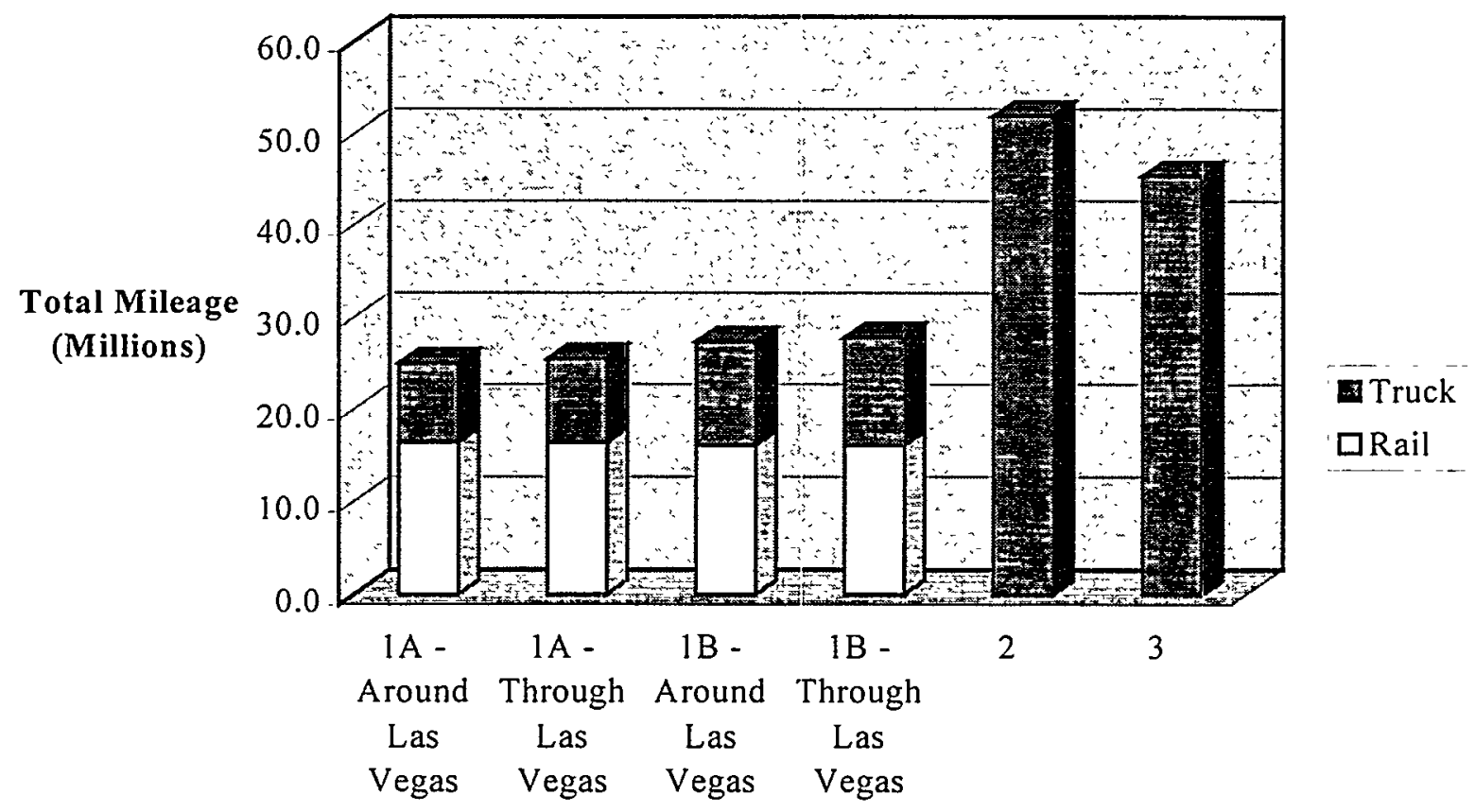

Figure 5.1. Truck and Rail Shipping Mileage Totals for all Configurations High Waste Volume Option

(Configuration 3) shipping distances if intermodal transfers occur at Caliente. The overall difference between Options 1A and 1B is less than 10\% in favor of the Barstow intermodal option. The shorter rail shipping distances between LLW generators and Caliente are more than offset by the substantially longer truck shipping distance between Caliente and NTS (about $300 \mathrm{mi}$ from Caliente to NTS versus about 200 mi from Barstow).

Figure 5.2 presents the same information for the low waste loading option. There is about a factor of 3 difference in shipping mileage between the high and low waste loading cases. The percentage differences between the various configurations are consistent with the percentage differences presented above for the high waste loading option. The differences between the configurations are approximately the same because about $94 \%$ of the LLW is transported by rail under both waste loading options.

Average Daily Traffic Volumes

Average daily traffic volumes were calculated based on a 70-y life-cycle and assuining $L L W$ is received at NTS 365 days/yr. The average daily traffic volumes for the all-truck configurations (2 and 3) amount to slightly over I vehicle per day. Assuming less-efficient packaging systems are used for some shipments, it is estimated that as many as 2 to 3 truck shipments of LLW may be received at NTS per day. Assuming the peak annual receipt rate is twice the average annual rate, as many as 6 shipments of $L L W$ may be received per day in peak years and substantially less than that in off-peak years. This is an extremely small truck traffic increment above current truck traffic volumes on Nevada's major highways, including Interstate 15 and US 95 through Las Vegas. It is a larger increase, but still a small fraction of the average daily traffic volume on highway routes that avoid Las Vegas, such as US 6, CA 127, and NV 375 (see the NTS Intermodal EA for average daily traffic volume data). 


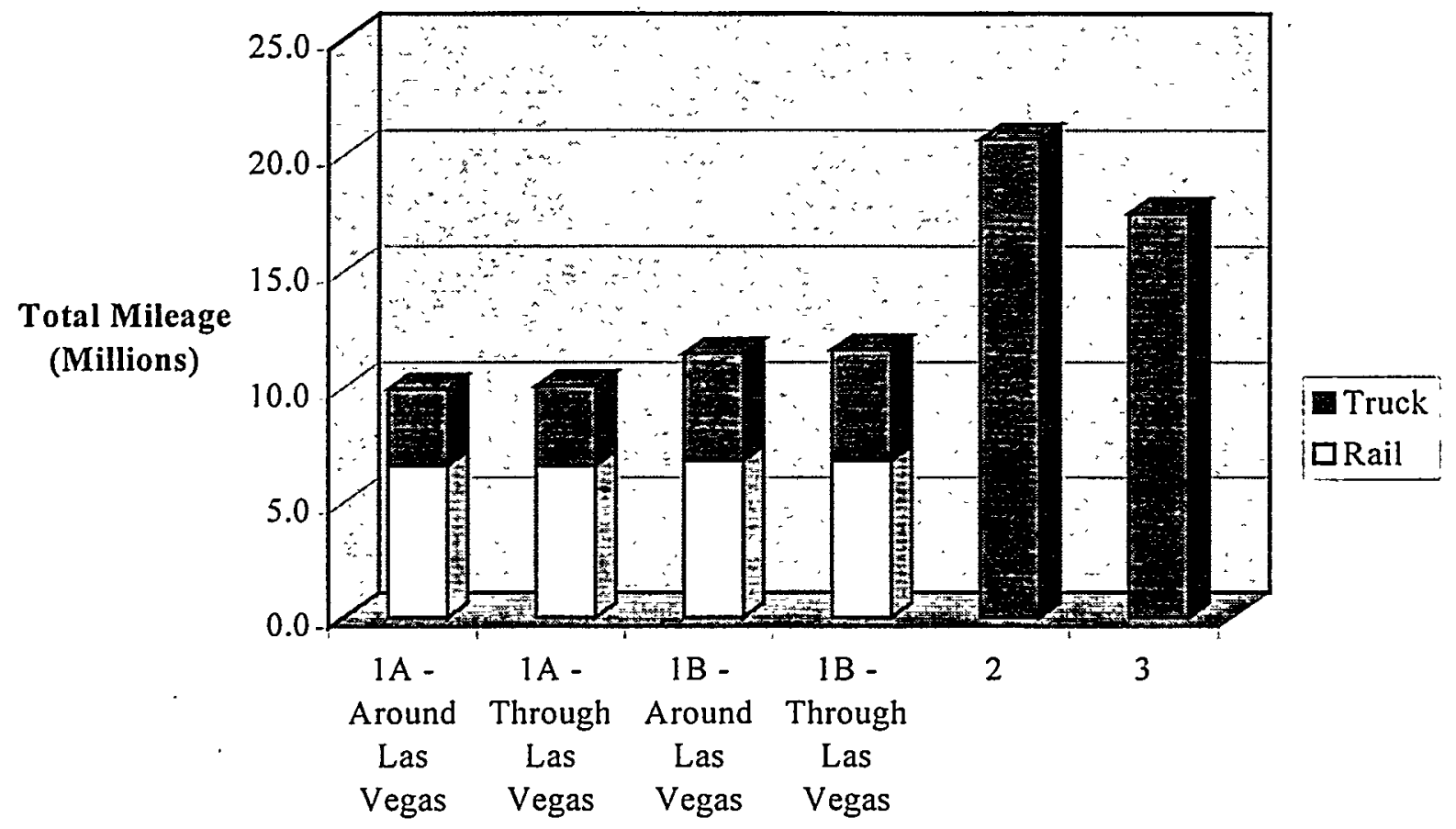

Figure 5.2. Truck and Rail Shipping Mileage Totals for all Configurations Low Waste Volume Option

\subsubsection{Transportation Risks by LLW Generator Site}

Tables 5.8 through 5.17 illustrate the differences in human health risk projections that result from the various shipping configurations examined in this study. Table 5.8 presents the human health risk results for Configuration 1A (intermodal at Barstow) for the high waste loading option, and Table 5.9 presents the same information for the low waste loading option. The results for Configuration 1B (intermodal at Caliente) are presented in Tables 5.10 and 5.11 for the high and low waste loading options, respectively. For all four of these tables, it was assumed that the direct truck shipments from small-quantity LLW generators would be routed around Las Vegas. Table 5.12 presents the results for Configuration 1B assuming the direct truck shipments travel through Las Vegas. The effect on transportation risks of assuming that the direct truck shipments travel through Las Vegas as they do presently is demonstrated by comparing Table 5.10 with Table 5.12. Table 5.13 presents the health risks of Configuration 2 in which all of the LLW in the high waste loading option is transported by truck on routes that avoid Las Vegas. The same information is presented in Table 5.14 for the low waste loading option. Tables 5.15 and 5.16 present the results for Configuration 3, all truck shipments through Las Vegas, for the high and low waste loading options, respectively.

The total life-cycle transportation risk assessment results for both waste-loading cases are presented in Table 5.17. The life-cycle risks for the high waste loading option are shown in Figure 5.3. As shown in the figure, nonradiological accident risks are the highest of the five risk measures examined in this study (note that radiological accident risks are not shown in Figure 5.3 due to their small values relative to the other risks shown in the figure). The life-cycle risks are highest in the all-truck options and lowest for the intermodal options. 
Table 5.8. Results of Transportation Impact Analysis for Configuration 1A (Rail/Intermodal Through Barstow, Trucks Avoid Las Vegas, High Waste Volume) ${ }^{(\text {a) }}$

\begin{tabular}{|c|c|c|c|c|c|}
\hline \multirow{3}{*}{\begin{tabular}{|l} 
LLW \\
Generator
\end{tabular}} & \multicolumn{3}{|c|}{ Radiological Impacts, Fatalities } & \multirow{2}{*}{\multicolumn{2}{|c|}{ Nonradiological Fatalities }} \\
\hline & \multicolumn{2}{|c|}{ Incident-Free Exposures } & \multirow{2}{*}{$\begin{array}{l}\text { Accident } \\
\text { Risk }\end{array}$} & & \\
\hline & Crew & Public & & Accidents & Emissions \\
\hline \multicolumn{6}{|c|}{ Rail to Barstow } \\
\hline ORR & $2.3 \mathrm{E}-02$ & $2.3 E-02$ & $1.9 \mathrm{E}-07$ & $4.4 \mathrm{E}-01$ & $2.8 \mathrm{E}-02$ \\
\hline LANL & $5.2 \mathrm{E}-03$ & $3.5 \mathrm{E}-03$ & $3.9 \mathrm{E}-08$ & $4.9 \mathrm{E}-02$ & $1.5 \mathrm{E}-03$ \\
\hline Fernald & $7.3 \mathrm{E}-03$ & $7.8 \mathrm{E}-03$ & $1.2 \mathrm{E}-06$ & $1.3 \mathrm{E}-01$ & $1.2 \mathrm{E}-02$ \\
\hline RFETS & $4.1 E-03$ & $4.5 \mathrm{E}-03$ & $7.9 \mathrm{E}-08$ & $4.3 \mathrm{E}-02$ & $6.6 \mathrm{E}-03$ \\
\hline Mound & $5.8 \mathrm{E}-03$ & $7.1 \mathrm{E}-03$ & $9.4 \mathrm{E}-07$ & $1.1 \mathrm{E}-01$ & $1.4 \mathrm{E}-02$ \\
\hline LLNL & $1.6 \mathrm{E}-03$ & $2.2 \mathrm{E}-03$ & $6.1 \mathrm{E}-08$ & $2.1 \mathrm{E}-02$ & $5.5 \mathrm{E}-03$ \\
\hline BNL & $3.7 \mathrm{E}-03$ & $9.1 \mathrm{E}-03$ & $1.2 \mathrm{E}-06$ & $1.1 \mathrm{E}-01$ & $2.8 \mathrm{E}-02$ \\
\hline INEEL & $1.6 \mathrm{E}-03$ & $2.4 \mathrm{E}-03$ & $7.2 \mathrm{E}-08$ & $2.7 \mathrm{E}-02$ & $6.8 \mathrm{E}-03$ \\
\hline ANL-E & $1.1 \mathrm{E}-03$ & $9.6 \mathrm{E}-04$ & $1.9 \mathrm{E}-07$ & $1.8 \mathrm{E}-02$ & $1.0 \mathrm{E}-03$ \\
\hline Subtotal & 5.3E-02 & 6.0E-02 & 4.9E-06 & $9.5 \mathrm{E}-01$ & $1.0 \mathrm{E}-01$ \\
\hline \multicolumn{6}{|c|}{ Truck from Barstow to NTS } \\
\hline Subtotal & $2.6 \mathrm{E}-02$ & $3.6 \mathrm{E}-03$ & $4.9 \mathrm{E}-07$ & $1.5 \mathrm{E}-01$ & $5.8 \mathrm{E}-03$ \\
\hline \multicolumn{6}{|c|}{ Direct Truck } \\
\hline WVDP & $6.5 \mathrm{E}-03$ & $9.3 \mathrm{E}-03$ & $9.2 \mathrm{E}-07$ & $4.1 \mathrm{E}-02$ & $5.0 \mathrm{E}-03$ \\
\hline $\mathrm{BCL}$ & $4.7 \mathrm{E}-03$ & $6.7 \mathrm{E}-03$ & $4.8 \mathrm{E}-07$ & $2.7 \mathrm{E}-02$ & $4.5 \mathrm{E}-03$ \\
\hline SPRU & $5.4 \mathrm{E}-03$ & $7.5 \mathrm{E}-03$ & $7.3 \mathrm{E}-07$ & $3.5 \mathrm{E}-02$ & $4.4 \mathrm{E}-03$ \\
\hline Sandia-NM & $9.0 \mathrm{E}-04$ & $1.4 \mathrm{E}-03$ & $1.2 \mathrm{E}-08$ & $5.1 E-03$ & $5.0 \mathrm{E}-04$ \\
\hline PGDP & $1.8 \mathrm{E}-03$ & $2.7 \mathrm{E}-03$ & $1.2 \mathrm{E}-07$ & $1.2 \mathrm{E}-02$ & $1.2 \mathrm{E}-03$ \\
\hline ETEC & $3.2 \mathrm{E}-04$ & $5.2 \mathrm{E}-04$ & $9.2 \mathrm{E}-09$ & $1.2 \mathrm{E}-03$ & $2.0 \mathrm{E}-03$ \\
\hline ITRI & $4.1 \mathrm{E}-04$ & $6.2 \mathrm{E}-04$ & $5.6 \mathrm{E}-09$ & $2.3 \mathrm{E}-03$ & $2.3 \mathrm{E}-04$ \\
\hline PORT & 1.1E-03 & $1.5 \mathrm{E}-03$ & $1.0 \mathrm{E}-07$ & $6.2 \mathrm{E}-03$ & $1.0 \mathrm{E}-03$ \\
\hline PPPL & $1.3 \mathrm{E}-03$ & $1.8 \mathrm{E}-03$ & $1.3 \mathrm{E}-07$ & $7.1 \mathrm{E}-03$ & $1.5 \mathrm{E}-03$ \\
\hline Pantex & $3.3 \mathrm{E}-04$ & $5.1 \mathrm{E}-04$ & $7.6 \mathrm{E}-09$ & $2.0 \mathrm{E}-03$ & $2.2 \mathrm{E}-04$ \\
\hline LBL & $5.8 \mathrm{E}-05$ & $8.9 \mathrm{E}-05$ & $1.5 \mathrm{E}-09$ & $2.6 \mathrm{E}-04$ & $9.4 \mathrm{E}-05$ \\
\hline Ames & $4.9 \mathrm{E}-05$ & $7.3 \mathrm{E}-05$ & $5.5 \mathrm{E}-09$ & $3.8 \mathrm{E}-04$ & $1.9 \mathrm{E}-05$ \\
\hline GJPO & $1.3 \mathrm{E}-05$ & $2.0 \mathrm{E}-05$ & $1.0 \mathrm{E}-10$ & $1.2 \mathrm{E}-04$ & $1.4 \mathrm{E}-06$ \\
\hline GE Val & $3.1 \mathrm{E}-06$ & $4.7 \mathrm{E}-06$ & $7.3 \mathrm{E}-11$ & $1.5 \mathrm{E}-05$ & $2.4 \mathrm{E}-06$ \\
\hline Subtotal & $2.3 \mathrm{E}-02$ & $3.3 \mathrm{E}-02$ & $2.5 \mathrm{E}-06$ & $1.4 \mathrm{E}-01$ & $2.1 \mathrm{E}-02$ \\
\hline \multicolumn{6}{|c|}{ Intermodal Transfer } \\
\hline Subtotal & $4.6 \mathrm{E}-03$ & Not Evaluated & Not Evaluated & $1.7 \mathrm{E}-03$ & Not Evaluated \\
\hline TOTAL & $1.1 \mathrm{E}-01$ & $9.7 \mathrm{E}-02$ & $8.0 \mathrm{E}-06$ & $1.2 \mathrm{E}+00$ & $1.3 \mathrm{E}-01$ \\
\hline
\end{tabular}

Note: $2.3 \mathrm{E}-02=2.3 \times 10^{-2}=0.023$

(a) Includes impacts of intermodal transfers in addition to in-transit impacts.

\section{Explanation of Risk Values}

The risk values shown in this and the following tables represent the integrated (or accumulated) risk to the affected population groups over 70 years. Risk values greater than 1.0 can be interpreted as that many fatalities over the 70-year life cycle (for example, 1.2 fatalities are projected to occur; this may be rounded to I). Risk values less than 1.0 may be restated as a probability of fatality over the 70-year life cycle. The probability of a fatality is the inverse of the risk value. In other words, if the risk estimate is 0.1 fatalities, then there is a 1 in 10 chance (i.e., 1.0 divided by 0.1 ) of at least one fatality occurring in the 70-year period. 
Table 5.9. Results of Transportation Impact Analysis for Configuration $1 \mathrm{~A}$ (Rail/Intermodal Through Barstow, Trucks Avoid Las Vegas, Low Waste Volume) ${ }^{(a)}$

\begin{tabular}{|c|c|c|c|c|c|}
\hline \multirow{3}{*}{$\begin{array}{l}\text { LLW } \\
\text { Generator }\end{array}$} & \multicolumn{3}{|c|}{ Radiological Impacts, Fatalities } & \multirow{2}{*}{\multicolumn{2}{|c|}{ Nonradiological Fatalities }} \\
\hline & \multicolumn{2}{|c|}{ Incident-Free Exposures } & \multirow{2}{*}{$\begin{array}{c}\text { Accident } \\
\text { Risk }\end{array}$} & & \\
\hline & Crew & Public & & Accidents & Emissions \\
\hline \multicolumn{6}{|c|}{ Rail to Barstow } \\
\hline LANL & $5.1 \mathrm{E}-03$ & $3.4 \mathrm{E}-03$ & $3.8 \mathrm{E}-08$ & $4.8 \mathrm{E}-02$ & $1.5 \mathrm{E}-03$ \\
\hline Fernald & $7.0 \mathrm{E}-03$ & $8.6 \mathrm{E}-03$ & $1.4 \mathrm{E}-06$ & $1.3 \mathrm{E}-01$ & $1.6 \mathrm{E}-02$ \\
\hline RFETS & $4.1 \mathrm{E}-03$ & $4.5 \mathrm{E}-03$ & $7.9 \mathrm{E}-08$ & $4.3 \mathrm{E}-02$ & $6.7 \mathrm{E}-03$ \\
\hline Mound & $5.8 \mathrm{E}-03$ & 7.1E-03 & $9.4 \mathrm{E}-07$ & $1.1 \mathrm{E}-01$ & $1.4 \mathrm{E}-02$ \\
\hline LLNL & $1.6 \mathrm{E}-03$ & $2.2 \mathrm{E}-03$ & $6.1 \mathrm{E}-08$ & $2.1 \mathrm{E}-02$ & $5.5 \mathrm{E}-03$ \\
\hline Subtotal & $2.4 \mathrm{E}-02$ & $2.6 \mathrm{E}-02$ & $2.5 \mathrm{E}-06$ & $3.5 \mathrm{E}-01$ & $4.3 \mathrm{E}-02$ \\
\hline \multicolumn{6}{|c|}{ Truck from Barstow to NTS } \\
\hline Subtotal & $1.3 \mathrm{E}-02$ & $1.8 \mathrm{E}-03$ & $2.5 \mathrm{E}-07$ & $7.8 \mathrm{E}-02$ & 3.0E-03 \\
\hline \multicolumn{6}{|c|}{ Direct Truck } \\
\hline Sandia-NM & $9.0 \mathrm{E}-04$ & $1.4 \mathrm{E}-03$ & $1.2 \mathrm{E}-08$ & $5.1 \mathrm{E}-03$ & $5.0 \mathrm{E}-04$ \\
\hline PGDP & $1.8 \mathrm{E}-03$ & $2.7 \mathrm{E}-03$ & $1.2 \mathrm{E}-07$ & $1.2 \mathrm{E}-02$ & $1.2 \mathrm{E}-03$ \\
\hline ETEC & $2.6 \mathrm{E}-04$ & $4.2 \mathrm{E}-04$ & $7.5 \mathrm{E}-09$ & $9.5 \mathrm{E}-04$ & $1.7 \mathrm{E}-03$ \\
\hline ITRI & $4.1 \mathrm{E}-04$ & $6.2 \mathrm{E}-04$ & $5.6 \mathrm{E}-09$ & $2.3 \mathrm{E}-03$ & $2.3 \mathrm{E}-04$ \\
\hline PORT & $1.1 \mathrm{E}-03$ & $1.5 \mathrm{E}-03$ & $1.0 \mathrm{E}-07$ & $6.2 \mathrm{E}-03$ & $1.0 \mathrm{E}-03$ \\
\hline Pantex & $3.3 \mathrm{E}-04$ & $5.1 \mathrm{E}-04$ & $7.6 \mathrm{E}-09$ & $2.0 \mathrm{E}-03$ & $2.2 \mathrm{E}-04$ \\
\hline Subtotal & $4.8 \mathrm{E}-03$ & $7.1 \mathrm{E}-03$ & $2.6 \mathrm{E}-07$ & $2.9 \mathrm{E}-02$ & $4.8 \mathrm{E}-03$ \\
\hline \multicolumn{6}{|c|}{ Intermodal Transfer } \\
\hline Subtotal & 3.0E-03 & Not Evaluated & Not Evaluated & $1.1 \mathrm{E}-03$ & Not Evaluated \\
\hline TOTAL & $4.4 \mathrm{E}-02$ & $3.5 \mathrm{E}-02$ & $3.0 \mathrm{E}-06$ & $4.6 \mathrm{E}-01$ & $5.1 \mathrm{E}-02$ \\
\hline
\end{tabular}

(a) Includes impacts of intermodal transfers in addition to in-transit impacts. 
Table 5.10. Results of Transportation Impact Analysis for Configuration 1B (Rail/Intermodal Through Caliente, Trucks Avoid Las Vegas, High Waste Volume) $)^{(a)}$

\begin{tabular}{|c|c|c|c|c|c|}
\hline \multirow{3}{*}{$\begin{array}{l}\text { LLW } \\
\text { Generator }\end{array}$} & \multicolumn{3}{|c|}{ Radiological Impacts, Fatalities } & \multirow{2}{*}{\multicolumn{2}{|c|}{ Nonradiological Fatalities }} \\
\hline & \multicolumn{2}{|c|}{ Incident-Free Exposures } & \multirow{2}{*}{$\begin{array}{c}\text { Accident } \\
\text { Risk }\end{array}$} & & \\
\hline & Crew & Public & & Accidents & Emissions \\
\hline \multicolumn{6}{|c|}{ Rail to Caliente } \\
\hline ORR & $2.3 \mathrm{E}-02$ & $2.7 \mathrm{E}-02$ & $4.2 \mathrm{E}-06$ & $3.3 \mathrm{E}-01$ & $4.9 \mathrm{E}-02$ \\
\hline LANL & $6.4 \mathrm{E}-03$ & $6.7 \mathrm{E}-03$ & $1.4 \mathrm{E}-07$ & $7.8 \mathrm{E}-02$ & $8.4 \mathrm{E}-03$ \\
\hline Fernald & $7.0 \mathrm{E}-03$ & $8.6 \mathrm{E}-03$ & $1.4 \mathrm{E}-06$ & $1.0 \mathrm{E}-01$ & $1.6 \mathrm{E}-02$ \\
\hline RFETS & $3.3 \mathrm{E}-03$ & $2.4 \mathrm{E}-03$ & $3.6 \mathrm{E}-08$ & $3.8 \mathrm{E}-02$ & $6.8 \mathrm{E}-04$ \\
\hline Mound & $5.5 \mathrm{E}-03$ & $1.1 \mathrm{E}-02$ & $1.6 \mathrm{E}-06$ & $8.4 \mathrm{E}-02$ & $2.9 \mathrm{E}-02$ \\
\hline LLNL & $2.2 \mathrm{E}-03$ & $2.9 \mathrm{E}-03$ & $5.3 \mathrm{E}-08$ & $2.7 \mathrm{E}-02$ & $6.5 \mathrm{E}-03$ \\
\hline BNL & $3.5 \mathrm{E}-03$ & $9.6 \mathrm{E}-03$ & $1.5 \mathrm{E}-06$ & $9.8 \mathrm{E}-02$ & $3.0 \mathrm{E}-02$ \\
\hline INEEL & $1.1 \mathrm{E}-03$ & $1.1 \mathrm{E}-03$ & $2.2 \mathrm{E}-08$ & $1.2 \mathrm{E}-02$ & $1.2 \mathrm{E}-03$ \\
\hline ANL-E & $1.1 \mathrm{E}-03$ & $1.1 \mathrm{E}-03$ & $3.1 \mathrm{E}-07$ & $1.6 \mathrm{E}-02$ & $1.6 \mathrm{E}-03$ \\
\hline Subtotal & $5.3 \mathrm{E}-02$ & $7.0 \mathrm{E}-02$ & 9.3E-06 & $7.8 \mathrm{E}-01$ & $1.4 \mathrm{E}-01$ \\
\hline \multicolumn{6}{|c|}{ Truck from Caliente to NTS } \\
\hline Subtotal & $3.9 \mathrm{E}-02$ & 4.7E-03 & 5.9E-08 & $4.1 \mathrm{E}-01$ & $0.0 \mathrm{E}+00$ \\
\hline \multicolumn{6}{|c|}{ Direct Truck } \\
\hline WVDP & $6.5 \mathrm{E}-03$ & $9.3 \mathrm{E}-03$ & $9.2 \mathrm{E}-07$ & $4.1 \mathrm{E}-02$ & $5.0 \mathrm{E}-03$ \\
\hline $\mathrm{BCL}$ & $4.7 \mathrm{E}-03$ & $6.7 \mathrm{E}-03$ & $4.8 \mathrm{E}-07$ & $2.7 \mathrm{E}-02$ & $4.5 \mathrm{E}-03$ \\
\hline SPRU & $5.4 \mathrm{E}-03$ & $7.5 \mathrm{E}-03$ & $7.3 \mathrm{E}-07$ & $3.5 \mathrm{E}-02$ & $4.4 \mathrm{E}-03$ \\
\hline Sandia-NM & $9.0 \mathrm{E}-04$ & $1.4 \mathrm{E}-03$ & $1.2 \mathrm{E}-08$ & $5.1 \mathrm{E}-03$ & $5.0 \mathrm{E}-04$ \\
\hline PGDP & $1.8 \mathrm{E}-03$ & $2.7 \mathrm{E}-03$ & $1.2 \mathrm{E}-07$ & $1.2 \mathrm{E}-02$ & $1.2 \mathrm{E}-03$ \\
\hline$\widehat{E T E C}$ & $3.2 \mathrm{E}-04$ & $5.2 \mathrm{E}-04$ & $9.2 \mathrm{E}-09$ & $1.2 \mathrm{E}-03$ & $2.0 \mathrm{E}-0 \overline{3}$ \\
\hline ITRI & $4.1 E-04$ & $6.2 \mathrm{E}-04$ & $5.6 \mathrm{E}-09$ & $2.3 \mathrm{E}-03$ & $2.3 \mathrm{E}-04$ \\
\hline PORT & $1.1 \mathrm{E}-03$ & $1.5 \mathrm{E}-03$ & $1.0 \mathrm{E}-07$ & $6.2 \mathrm{E}-03$ & $1.0 \mathrm{E}-03$ \\
\hline PPPL & $1.3 \mathrm{E}-03$ & $1.8 \mathrm{E}-03$ & $1.3 \mathrm{E}-07$ & $7.1 \mathrm{E}-03$ & $1.5 \mathrm{E}-03$ \\
\hline Pantex & $3.3 \mathrm{E}-04$ & $5.1 \mathrm{E}-04$ & $7.6 \mathrm{E}-09$ & $2.0 \mathrm{E}-03$ & $2.2 \mathrm{E}-04$ \\
\hline LBL & $5.8 \mathrm{E}-05$ & $8.9 \mathrm{E}-05$ & $1.5 \mathrm{E}-09$ & $2.6 \mathrm{E}-04$ & $9.4 \mathrm{E}-05$ \\
\hline Ames & $4.9 \mathrm{E}-05$ & $7.3 \mathrm{E}-05$ & $5.5 \mathrm{E}-09$ & $3.8 \mathrm{E}-04$ & $1.9 \mathrm{E}-05$ \\
\hline GJPO & $1.3 \mathrm{E}-05$ & $2.0 \mathrm{E}-05$ & $1.0 \mathrm{E}-10$ & $1.2 \mathrm{E}-04$ & $1.4 \mathrm{E}-06$ \\
\hline GE Val & $3.1 \mathrm{E}-06$ & $4.7 \mathrm{E}-06$ & $7.3 \mathrm{E}-11$ & $1.5 \mathrm{E}-05$ & $2.4 \mathrm{E}-06$ \\
\hline Subtotal & $2.3 \mathrm{E}-02$ & $3.3 \mathrm{E}-02$ & $2.5 \mathrm{E}-06$ & $1.4 \mathrm{E}-01$ & 2.1E-02 \\
\hline \multicolumn{6}{|c|}{ Intermodal Transfer } \\
\hline Subtotal & $4.6 \mathrm{E}-03$ & Not Evaluated & Not Evaluated & $1.7 \mathrm{E}-03$ & Not Evaluated \\
\hline TOTAL & $1.2 \mathrm{E}-01$ & $1.1 \mathrm{E}-01$ & $1.2 \mathrm{E}-05$ & $1.3 \mathrm{E}+00$ & $1.6 \mathrm{E}-01$ \\
\hline
\end{tabular}

(a) Includes impacts of intermodal transfers in addition to in-transit impacts. 
Table 5.11. Results of Transportation Impact Analysis for Configuration 1B (Rail/Intermodal Through Caliente, Trucks Avoid Las Vegas, Low Waste Volume) ${ }^{(\text {a) }}$

\begin{tabular}{|c|c|c|c|c|c|}
\hline \multirow{3}{*}{$\begin{array}{l}\text { LLW } \\
\text { Generator }\end{array}$} & \multicolumn{3}{|c|}{ Radiological Impacts, Fatalities } & \multirow{2}{*}{\multicolumn{2}{|c|}{ Nonradiological Fatalities }} \\
\hline & \multicolumn{2}{|c|}{ Incident-Free Exposures } & \multirow{2}{*}{$\begin{array}{l}\text { Accident } \\
\text { Risk }\end{array}$} & & \\
\hline & Crew & Public & & Accidents & Emissions \\
\hline \multicolumn{6}{|c|}{ Rail to Caliente } \\
\hline LANL & $6.3 \mathrm{E}-03$ & $6.7 \mathrm{E}-03$ & $1.3 \mathrm{E}-07$ & $7.7 \mathrm{E}-02$ & $8.4 \mathrm{E}-03$ \\
\hline Fernald & $7.0 \mathrm{E}-03$ & $8.6 \mathrm{E}-03$ & $1.4 \mathrm{E}-06$ & $1.0 \mathrm{E}-01$ & $1.6 \mathrm{E}-02$ \\
\hline RFETS & $3.3 \mathrm{E}-03$ & $2.5 \mathrm{E}-03$ & $3.6 \mathrm{E}-08$ & $3.8 \mathrm{E}-02$ & $6.9 \mathrm{E}-04$ \\
\hline Mound & $5.5 \mathrm{E}-03$ & $1.1 \mathrm{E}-02$ & $1.7 \mathrm{E}-06$ & $8.4 \mathrm{E}-02$ & $2.9 E-02$ \\
\hline LLNL & $2.2 \mathrm{E}-03$ & $2.9 \mathrm{E}-03$ & $5.3 \mathrm{E}-08$ & $2.7 \mathrm{E}-02$ & $6.5 \mathrm{E}-03$ \\
\hline Subtotal & $2.4 \mathrm{E}-02$ & 3.1E-02 & $3.3 \mathrm{E}-06$ & $3.3 \mathrm{E}-01$ & $6.0 \mathrm{E}-02$ \\
\hline \multicolumn{6}{|c|}{ Truck from Caliente to NTS } \\
\hline Subtotal & $2.0 \mathrm{E}-02$ & $2.4 \mathrm{E}-03$ & $3.0 \mathrm{E}-08$ & $7.8 \mathrm{E}-02$ & $3.0 \mathrm{E}-03$ \\
\hline \multicolumn{6}{|c|}{ Direct Truck } \\
\hline Sandia-NM & $9.0 \mathrm{E}-04$ & $1.4 \mathrm{E}-03$ & $1.2 \mathrm{E}-08$ & $5.1 \mathrm{E}-03$ & $5.0 \mathrm{E}-04$ \\
\hline PGDP & $1.8 \mathrm{E}-03$ & $2.7 \mathrm{E}-03$ & $1.2 \mathrm{E}-07$ & $1.2 \mathrm{E}-02$ & 1.2E-03 \\
\hline ETEC & $2.6 \mathrm{E}-04$ & $4.2 \mathrm{E}-04$ & $7.5 \mathrm{E}-09$ & $9.5 \mathrm{E}-04$ & $1.7 \mathrm{E}-03$ \\
\hline ITRI & $4.1 \mathrm{E}-04$ & $6.2 \mathrm{E}-04$ & $5.6 \mathrm{E}-09$ & $2.3 \mathrm{E}-03$ & $2.3 \mathrm{E}-04$ \\
\hline PORT & $1.1 \mathrm{E}-03$ & $1.5 \mathrm{E}-03$ & $1.0 \mathrm{E}-07$ & $6.2 \mathrm{E}-03$ & $1.0 \mathrm{E}-03$ \\
\hline$\overline{\text { Pantex }}$ & $3.3 \mathrm{E}-04$ & $5.1 \mathrm{E}-04$ & $7.6 \mathrm{E}-09$ & $2.0 \mathrm{E}-03$ & $2.2 \mathrm{E}-04$ \\
\hline Subtotal & $4.8 \mathrm{E}-03$ & $7.1 \mathrm{E}-03$ & $2.6 \mathrm{E}-07$ & 2.9E-02 & $4.8 \mathrm{E}-03$ \\
\hline \multicolumn{6}{|c|}{ Intermodal Transfer } \\
\hline Subtotal & 3.0E-03 & Not Evaluated & Not Evaluated & 1.1E-03 & Not Evaluated \\
\hline TOTAL & $5.2 \mathrm{E}-02$ & $4.1 \mathrm{E}-02$ & $3.6 \mathrm{E}-06$ & $4.4 \mathrm{E}-01$ & $6.8 \mathrm{E}-02$ \\
\hline
\end{tabular}

(a) Includes impacts of intermodal transfers in addition to in-transit impacts. 
Table 5.12. Results of Transportation Impact Analysis for Configuration 1B (Rail/Intermodal Through Caliente, Trucks Through Las Vegas, High Waste Volume) $)^{(a)}$

\begin{tabular}{|c|c|c|c|c|c|}
\hline \multirow{3}{*}{$\begin{array}{c}\text { LLW } \\
\text { Generator }\end{array}$} & \multicolumn{3}{|c|}{ Radiological Impacts, Fatalities } & \multirow{2}{*}{\multicolumn{2}{|c|}{ Nonradiological Fatalities }} \\
\hline & \multicolumn{2}{|c|}{ Incident-Free Exposures } & \multirow{2}{*}{$\begin{array}{c}\text { Accident } \\
\text { Risk }\end{array}$} & & \\
\hline & Crew & Public & & Accidents & Emissions \\
\hline \multicolumn{6}{|c|}{ Rail to Caliente } \\
\hline ORR & $2.3 \mathrm{E}-02$ & $2.7 \mathrm{E}-02$ & $4.2 \bar{E}-06$ & $3.3 \mathrm{E}-01$ & $4.9 \mathrm{E}-02$ \\
\hline LANL & $6.4 \mathrm{E}-03$ & $6.7 \mathrm{E}-03$ & $1.4 \mathrm{E}-07$ & $7.8 \mathrm{E}-02$ & $8.4 \mathrm{E}-03$ \\
\hline Fernald & $7.0 \mathrm{E}-03$ & $8.6 \mathrm{E}-03$ & $1.4 \overline{E-06}$ & $1.0 \mathrm{E}-01$ & $1.6 \mathrm{E}-02$ \\
\hline RFETS & $3.3 \mathrm{E}-03$ & $2.4 \mathrm{E}-03$ & $3.6 \mathrm{E}-08$ & $3.8 \mathrm{E}-02$ & $6.8 \mathrm{E}-04$ \\
\hline Mound & $5.5 \mathrm{E}-03$ & $1.1 \mathrm{E}-02$ & $1.6 \overline{E-06}$ & $8.4 \mathrm{E}-02$ & $2.9 \mathrm{E}-02$ \\
\hline LLNL & $2.2 \mathrm{E}-03$ & $2.9 \mathrm{E}-03$ & $5.3 \mathrm{E}-08$ & $2.7 \mathrm{E}-02$ & $6.5 \mathrm{E}-03$ \\
\hline BNL & $3.5 \mathrm{E}-03$ & $9.6 \mathrm{E}-03$ & $1.5 \mathrm{E}-06$ & $9.8 \mathrm{E}-02$ & $3.0 \mathrm{E}-02$ \\
\hline INEEL & $1.1 \mathrm{E}-03$ & $1.1 \mathrm{E}-03$ & $2.2 \mathrm{E}-08$ & $1.2 \mathrm{E}-02$ & $1.2 \mathrm{E}-03$ \\
\hline ANL-E & $1.1 \mathrm{E}-03$ & $1.1 \mathrm{E}-03$ & $3.1 E-07$ & $1.6 \mathrm{E}-02$ & $1.6 \mathrm{E}-03$ \\
\hline Subtotal & $5.3 \mathrm{E}-02$ & $7.0 \mathrm{E}-02$ & $9.3 \mathrm{E}-06$ & $7.8 \mathrm{E}-01$ & $1.4 \mathrm{E}-01$ \\
\hline \multicolumn{6}{|c|}{ Truck from Caliente to NTS } \\
\hline Subtotal & 3.9E-02 & $4.7 \mathrm{E}-03$ & $5.9 \mathrm{E}-08$ & $1.5 \mathrm{E}-01$ & $5.8 \mathrm{E}-03$ \\
\hline \multicolumn{6}{|l|}{ Direct Truck } \\
\hline WVDP & $6.0 \mathrm{E}-03$ & $8.3 \mathrm{E}-03$ & $9.2 \mathrm{E}-07$ & $1.6 \mathrm{E}-02$ & $2.8 \mathrm{E}-03$ \\
\hline$\overline{B C L}$ & $4.3 \mathrm{E}-03$ & $6.2 \mathrm{E}-03$ & $4.8 \mathrm{E}-07$ & $1.2 \mathrm{E}-02$ & $2.7 \mathrm{E}-03$ \\
\hline SPRU & $5.0 \mathrm{E}-03$ & $6.9 \mathrm{E}-03$ & $7.4 \mathrm{E}-07$ & $1.4 \mathrm{E}-02$ & $2.4 \mathrm{E}-03$ \\
\hline Sandia-NM & $7.1 \mathrm{E}-04$ & $1.1 \mathrm{E}-03$ & 9.0E-09 & $1.9 \mathrm{E}-03$ & $5.1 \mathrm{E}-04$ \\
\hline PGDP & $1.7 \mathrm{E}-03$ & $2.4 \mathrm{E}-03$ & $1.2 \mathrm{E}-07$ & $5.4 \mathrm{E}-03$ & $8.1 \mathrm{E}-04$ \\
\hline ETEC & $3.5 \mathrm{E}-04$ & $5.5 \mathrm{E}-04$ & $1.0 \mathrm{E}-08$ & $5.1 \mathrm{E}-04$ & $1.1 \mathrm{E}-03$ \\
\hline ITRI & $3.2 \mathrm{E}-04$ & $4.8 \mathrm{E}-04$ & $4.1 \mathrm{E}-09$ & $8.7 \mathrm{E}-04$ & $2.3 \mathrm{E}-04$ \\
\hline PORT & $9.7 \mathrm{E}-04$ & $1.4 \mathrm{E}-03$ & $1.0 \mathrm{E}-07$ & $2.8 \mathrm{E}-03$ & $6.2 \mathrm{E}-04$ \\
\hline PPPL & $1.2 \mathrm{E}-03$ & 1.7E-03 & $1.3 \mathrm{E}-07$ & $3.3 \mathrm{E}-03$ & $8.6 \mathrm{E}-04$ \\
\hline Pantex & $2.8 \mathrm{E}-04$ & $4.2 \mathrm{E}-04$ & $6.7 \mathrm{E}-09$ & $8.3 \mathrm{E}-04$ & $1.8 \mathrm{E}-04$ \\
\hline $\mathrm{LBL}$ & $4.5 \mathrm{E}-03$ & $6.7 \mathrm{E}-03$ & $1.1 E-07$ & $1.2 \mathrm{E}-04$ & $5.2 \mathrm{E}-05$ \\
\hline Ames & $4.2 \mathrm{E}-05$ & $6.2 \mathrm{E}-05$ & 5.6E-09 & $1.4 \mathrm{E}-04$ & $1.2 \mathrm{E}-05$ \\
\hline $\mathrm{GJPO}$ & $9.2 \mathrm{E}-06$ & $1.4 \mathrm{E}-05$ & $1.5 \mathrm{E}-10$ & $2.9 \mathrm{E}-05$ & $2.3 \mathrm{E}-06$ \\
\hline GE Val & $3.3 \mathrm{E}-06$ & $4.9 \mathrm{E}-06$ & $8.0 E-11$ & $6.7 \mathrm{E}-06$ & $1.5 \mathrm{E}-06$ \\
\hline Subtotal & $2.5 \mathrm{E}-02$ & $3.6 \mathrm{E}-02$ & $2.6 \mathrm{E}-06$ & 5.8E-02 & $1.2 \mathrm{E}-02$ \\
\hline \multicolumn{6}{|c|}{ Intermodal Transfer } \\
\hline Subtotal & $4.6 \mathrm{E}-03$ & Not Evaluated & Not Evaluated & $1.7 \mathrm{E}-03$ & Not Evaluated \\
\hline TOTAL & $1.2 \mathrm{E}-01$ & $1.1 \mathrm{E}-01$ & $1.2 \mathrm{E}-05$ & 9.9E-01 & $1.6 \mathrm{E}-01$ \\
\hline
\end{tabular}

(a) Includes impacts of intermodal transfers in addition to in-transit impacts. 
Table 5.13. Results of Transportation Impact Analysis for Configuration 2 (100\% Truck, Avoid Las Vegas, High Waste Volume)

\begin{tabular}{|c|c|c|c|c|c|}
\hline \multirow{3}{*}{$\begin{array}{l}\text { LLW } \\
\text { Generator }\end{array}$} & \multicolumn{3}{|c|}{ Radiological Impacts, Fatalities } & \multicolumn{2}{|c|}{ Nonradiological Fatalities } \\
\hline & \multicolumn{2}{|c|}{ Incident-Free Exposures } & \multirow{2}{*}{$\begin{array}{l}\text { Accident } \\
\text { Risk }\end{array}$} & & \\
\hline & Crew & Public & & Accidents & Emissions \\
\hline ORR & $1.3 \mathrm{E}-01$ & $1.8 \mathrm{E}-01$ & $4.1 \mathrm{E}-06$ & $7.3 \mathrm{E}-01$ & $8.5 \mathrm{E}-02$ \\
\hline LANL & $2.0 \mathrm{E}-02$ & $3.0 \mathrm{E}-02$ & $2.6 \mathrm{E}-07$ & $1.2 \mathrm{E}-01$ & $6.5 \mathrm{E}-03$ \\
\hline Fernald & $4.0 \mathrm{E}-02$ & $5.9 \mathrm{E}-02$ & $4.2 \mathrm{E}-06$ & $2.4 \mathrm{E}-01$ & $3.2 \mathrm{E}-02$ \\
\hline RFETS & $1.4 \mathrm{E}-02$ & $2.1 \mathrm{E}-02$ & $3.4 \mathrm{E}-07$ & $1.2 \mathrm{E}-01$ & $2.7 \mathrm{E}-03$ \\
\hline Mound & $3.2 \mathrm{E}-02$ & $4.6 \mathrm{E}-02$ & $3.3 \mathrm{E}-06$ & $1.9 \mathrm{E}-01$ & $3.1 \mathrm{E}-02$ \\
\hline LLNL & $4.2 \mathrm{E}-03$ & $6.3 \mathrm{E}-03$ & $9.7 \mathrm{E}-08$ & $2.0 \mathrm{E}-02$ & $2.1 \mathrm{E}-03$ \\
\hline $\mathrm{BNL}$ & $2.4 \mathrm{E}-02$ & $3.4 \mathrm{E}-02$ & $3 . \overline{\mathrm{E}-06}$ & $1.5 \mathrm{E}-01$ & $2.6 \mathrm{E}-02$ \\
\hline INEEL & $4.3 \mathrm{E}-03$ & $6.5 \mathrm{E}-03$ & $8.4 \mathrm{E}-08$ & $3.2 \mathrm{E}-02$ & $6.9 \mathrm{E}-04$ \\
\hline ANL-E & $6.0 \mathrm{E}-03$ & $8.8 \mathrm{E}-03$ & $8.8 \mathrm{E}-07$ & $4.4 \mathrm{E}-02$ & $2.1 \mathrm{E}-03$ \\
\hline WVDP & $6.5 \mathrm{E}-03$ & $9.3 \mathrm{E}-03$ & 9.2E-07 & $4.1 \mathrm{E}-02$ & $5.0 \mathrm{E}-03$ \\
\hline $\mathrm{BCL}$ & 4.7E-03 & $6.7 \mathrm{E}-03$ & $4.8 \mathrm{E}-07$ & $2.7 \mathrm{E}-02$ & $4.5 \mathrm{E}-03$ \\
\hline SPRU & $5.4 \mathrm{E}-03$ & $7.5 \mathrm{E}-03$ & 7.3E-07 & $3.4 \mathrm{E}-02$ & $4.4 \mathrm{E}-03$ \\
\hline Sandia-NM & $9.0 \mathrm{E}-04$ & $1.4 \mathrm{E}-03$ & $1.2 \mathrm{E}-08$ & $5.2 \mathrm{E}-03$ & $5.0 \mathrm{E}-04$ \\
\hline PGDP & $1.8 \mathrm{E}-03$ & $2.7 \mathrm{E}-03$ & $1.2 \mathrm{E}-07$ & $1.2 \mathrm{E}-02$ & $1.2 \mathrm{E}-03$ \\
\hline ETEC & $3.2 \mathrm{E}-04$ & $5.2 \mathrm{E}-04$ & $9.2 \mathrm{E}-09$ & $\cdot 1.2 \mathrm{E}-03$ & $2.0 \mathrm{E}-03$ \\
\hline ITRI & $4.1 \mathrm{E}-04$ & $6.2 \mathrm{E}-04$ & $5.6 \mathrm{E}-09$ & $2.3 \mathrm{E}-03$ & $2.3 \mathrm{E}-04$ \\
\hline PORT & $1.1 \mathrm{E}-03$ & $1.5 \mathrm{E}-03$ & $1.0 \mathrm{E}-07$ & $6.2 \mathrm{E}-03$ & $1.0 \mathrm{E}-03$ \\
\hline PPPL & $1.3 \mathrm{E}-03$ & $1.8 \mathrm{E}-03$ & $1.3 \mathrm{E}-07$ & $7.1 \mathrm{E}-03$ & $1.5 \mathrm{E}-03$ \\
\hline Pantex & $3.3 \mathrm{E}-04$ & $5.1 \mathrm{E}-04$ & $7.6 \mathrm{E}-09$ & $2.0 \mathrm{E}-03$ & $2.2 \mathrm{E}-04$ \\
\hline LBL & $5.8 \mathrm{E}-05$ & $8.9 \mathrm{E}-05$ & $1.5 \mathrm{E}-09$ & $2.6 \mathrm{E}-04$ & $9.4 \mathrm{E}-05$ \\
\hline Ames & $4.9 \mathrm{E}-05$ & $7.3 \mathrm{E}-05$ & $5.5 \mathrm{E}-09$ & $3.8 \mathrm{E}-04$ & $2.0 \mathrm{E}-05$ \\
\hline GJPO & $1.3 \mathrm{E}-05$ & $2.0 \mathrm{E}-05$ & $1.0 \mathrm{E}-10$ & $1.2 \mathrm{E}-04$ & $1.4 \mathrm{E}-06$ \\
\hline GE Val & $3.1 \mathrm{E}-06$ & $4.7 \mathrm{E}-06$ & $7.3 \mathrm{E}-11$ & $1.4 \mathrm{E}-05$ & $2.3 \mathrm{E}-06$ \\
\hline TOTAL & 2.9E-01 & 4.3E-01 & 1.9E-05 & $1.8 \mathrm{E}+00$ & 2.1E-01 \\
\hline
\end{tabular}

Table 5.14. Results of Transportation Impact Analysis for Configuration 2 (100\% Truck, Avoid Las Vegas, Low Waste Volume)

\begin{tabular}{|l|c|c|c|c|c|}
\hline \multirow{2}{*}{$\begin{array}{l}\text { LLW } \\
\text { Generator }\end{array}$} & \multicolumn{3}{|c|}{ Radiological Impacts, Fatalities } & \multicolumn{2}{c|}{ Nonradiological Fatalities } \\
\cline { 2 - 3 } & Incident-Free Exposures & \multirow{2}{*}{$\begin{array}{c}\text { Accident } \\
\text { Risk }\end{array}$} & & \\
\cline { 2 - 3 } & Crew & Public & Accidents & Emissions \\
\hline LANL & $2.0 \mathrm{E}-02$ & $2.9 \mathrm{E}-02$ & $2.6 \mathrm{E}-07$ & $1.1 \mathrm{E}-01$ & $6.5 \mathrm{E}-03$ \\
\hline Fernald & $4.0 \mathrm{E}-02$ & $5.9 \mathrm{E}-02$ & $4.2 \mathrm{E}-06$ & $2.4 \mathrm{E}-01$ & $3.2 \mathrm{E}-02$ \\
\hline RFETS & $1.4 \mathrm{E}-02$ & $2.1 \mathrm{E}-02$ & $3.4 \mathrm{E}-07$ & $1.2 \mathrm{E}-01$ & $2.7 \mathrm{E}-03$ \\
\hline iMound & $3.2 \mathrm{E}-02$ & $4.6 \mathrm{E}-02$ & $3.3 \mathrm{E}-06$ & $1.9 \mathrm{E}-01$ & $3.1 \mathrm{E}-02$ \\
\hline LLNL & $4.2 \mathrm{E}-03$ & $6.3 \mathrm{E}-03$ & $9.7 \mathrm{E}-08$ & $2.0 \mathrm{E}-02$ & $2.1 \mathrm{E}-03$ \\
\hline Sandia-NM & $9.0 \mathrm{E}-04$ & $1.4 \mathrm{E}-03$ & $1.2 \mathrm{E}-08$ & $5.1 \mathrm{E}-03$ & $5.0 \mathrm{E}-04$ \\
\hline PGDP & $1.8 \mathrm{E}-03$ & $2.7 \mathrm{E}-03$ & $1.2 \mathrm{E}-07$ & $1.2 \mathrm{E}-02$ & $1.2 \mathrm{E}-03$ \\
\hline ETEC & $2.6 \mathrm{E}-04$ & $4.2 \mathrm{E}-04$ & $7.5 \mathrm{E}-09$ & $9.5 \mathrm{E}-04$ & $1.7 \mathrm{E}-03$ \\
\hline ITRI & $4.1 \mathrm{E}-04$ & $6.2 \mathrm{E}-04$ & $5.6 \mathrm{E}-09$ & $2.3 \mathrm{E}-03$ & $2.3 \mathrm{E}-04$ \\
\hline ITORT & $1.1 \mathrm{E}-03$ & $1.5 \mathrm{E}-03$ & $1.0 \mathrm{E}-07$ & $6.2 \mathrm{E}-03$ & $1.0 \mathrm{E}-03$ \\
\hline Pantex & $3.3 \mathrm{E}-04$ & $5.1 \mathrm{E}-04$ & $7.6 \mathrm{E}-09$ & $2.0 \mathrm{E}-03$ & $2.2 \mathrm{E}-04$ \\
\hline TOTAL & $\mathbf{1 . 2 E}-01$ & $\mathbf{1 . 7 E - 0 1}$ & $\mathbf{8 . 5 E}-06$ & $7.1 \mathrm{E}-01$ & $\mathbf{7 . 9 E}-02$ \\
\hline
\end{tabular}


Table 5.15. Results of Transportation Risk Analysis for Configuration 3 (100\% Truck, Through Las Vegas, High Waste Volume)

\begin{tabular}{|c|c|c|c|c|c|}
\hline \multirow{3}{*}{$\begin{array}{l}\text { LLW } \\
\text { Generator }\end{array}$} & \multicolumn{3}{|c|}{ Radiological Risks, Fatalities } & \multicolumn{2}{|c|}{ Nonradiological Fatalities } \\
\hline & \multicolumn{2}{|c|}{ Incident-Free Exposures } & \multirow{2}{*}{$\begin{array}{l}\text { Accident } \\
\text { Risk }\end{array}$} & & \\
\hline & Crew & Public & & Accidents & Emissions \\
\hline ORR & $1.2 \mathrm{E}-01$ & $1.7 \mathrm{E}-01$ & $3.9 \mathrm{E}-06$ & $6.6 \mathrm{E}-01$ & $1.1 \mathrm{E}-01$ \\
\hline LANL & $1.6 \mathrm{E}-02$ & $2.3 \mathrm{E}-02$ & $1.9 \mathrm{E}-07$ & $8.9 \mathrm{E}-02$ & $1.7 \mathrm{E}-02$ \\
\hline Fernald & $3.7 \mathrm{E}-02$ & $5.3 \mathrm{E}-02$ & $4.2 \mathrm{E}-06$ & $2.2 \mathrm{E}-01$ & $4.0 \mathrm{E}-02$ \\
\hline RFETS & $1.1 \mathrm{E}-02$ & $1.6 \mathrm{E}-02$ & $3.8 \mathrm{E}-07$ & $6.9 \mathrm{E}-02$ & $5.3 \mathrm{E}-03$ \\
\hline Mound & $2.9 \mathrm{E}-02$ & $4.2 \mathrm{E}-02$ & $3.2 \mathrm{E}-06$ & $1.7 \mathrm{E}-0]$ & $3.8 \mathrm{E}-02$ \\
\hline LLNL & $4.4 \mathrm{E}-03$ & $6.7 \mathrm{E}-03$ & 1.1E-07 & $1.8 \mathrm{E}-02$ & $2.9 \mathrm{E}-03$ \\
\hline $\mathrm{BNL}$ & $2.2 \mathrm{E}-02$ & $3.1 \mathrm{E}-02$ & $3.3 \mathrm{E}-06$ & $1.2 \mathrm{E}-01$ & $2.8 \mathrm{E}-02$ \\
\hline INEEL & $4.0 \mathrm{E}-03$ & $5.7 \mathrm{E}-03$ & $1.5 \mathrm{E}-07$ & $2.0 \mathrm{E}-02$ & $5.5 \mathrm{E}-03$ \\
\hline ANL-E & $5.3 \mathrm{E}-03$ & 7.7E-03 & $8.9 \mathrm{E}-07$ & $3.3 \mathrm{E}-02$ & $2.7 \mathrm{E}-03$ \\
\hline WVDP & $6.0 \mathrm{E}-03$ & $8.3 \mathrm{E}-03$ & $9.2 \mathrm{E}-07$ & $3.2 \mathrm{E}-02$ & $5.5 \mathrm{E}-03$ \\
\hline$\overline{B C L}$ & $4.3 \mathrm{E}-03$ & $6.2 \mathrm{E}-03$ & $4.8 \mathrm{E}-07$ & $2.4 \mathrm{E}-02$ & $5.4 \mathrm{E}-03$ \\
\hline SPRU & $5.0 \mathrm{E}-03$ & $6.9 \mathrm{E}-03$ & $7.4 \mathrm{E}-07$ & $2.8 \mathrm{E}-02$ & $4.8 \mathrm{E}-03$ \\
\hline Sandia-NM & $7.1 \mathrm{E}-04$ & $1.1 \mathrm{E}-03$ & $9.0 \mathrm{E}-09$ & $3.8 \mathrm{E}-03$ & $1.0 \mathrm{E}-03$ \\
\hline PGDP & $1.7 \mathrm{E}-03$ & $2.4 \mathrm{E}-03$ & $1.2 \mathrm{E}-07$ & $1.1 \mathrm{E}-02$ & $1.6 \mathrm{E}-03$ \\
\hline ETEC & $3.5 \mathrm{E}-04$ & $5.5 \mathrm{E}-04$ & $1.0 \mathrm{E}-08$ & $1.0 \mathrm{E}-03$ & $2.1 \mathrm{E}-03$ \\
\hline ITRI & $3.2 \mathrm{E}-04$ & $\overline{4.8 \mathrm{E}-04}$ & $4.1 \mathrm{E}-09$ & $1.7 \mathrm{E}-03$ & $4.7 \mathrm{E}-04$ \\
\hline PORT & $9.7 \mathrm{E}-04$ & $1.4 \mathrm{E}-03$ & $1.0 \mathrm{E}-07$ & $5.7 E-03$ & $1.2 \mathrm{E}-03$ \\
\hline PPPL & $1.2 \mathrm{E}-03$ & $1.7 \mathrm{E}-03$ & $1.3 \mathrm{E}-07$ & $6.6 \mathrm{E}-03$ & $1.7 \mathrm{E}-03$ \\
\hline Pantex & $2.8 \mathrm{E}-04$ & $4.2 \mathrm{E}-04$ & 6.7E-09 & $1.7 \mathrm{E}-03$ & $3.7 \mathrm{E}-04$ \\
\hline$\overline{L B L}$ & $6.2 \mathrm{E}-05$ & $9.3 \mathrm{E}-05$ & $1.6 E-09$ & $2.4 \mathrm{E}-04$ & $1.0 \mathrm{E}-04$ \\
\hline Ames & $4.2 \mathrm{E}-05$ & $6.2 \mathrm{E}-05$ & $5.6 \mathrm{E}-09$ & $2.8 \mathrm{E}-04$ & $2.5 E-05$ \\
\hline GJPO & 9.2E-06 & $1.4 \mathrm{E}-05$ & $1.5 \mathrm{E}-10$ & $5.7 \mathrm{E}-05$ & $4.6 \mathrm{E}-06$ \\
\hline GE Val & $3.3 \mathrm{E}-06$ & $4.9 \mathrm{E}-06$ & $8.0 \mathrm{E}-11$ & $1.3 \mathrm{E}-05$ & $3.0 \mathrm{E}-06$ \\
\hline TOTAL & $2.7 \mathrm{E}-01$ & $3.9 \mathrm{E}-01$ & $1.9 \overline{\mathrm{E}-05}$ & $1.5 \mathrm{E}+00$ & $2.8 \mathrm{E}-01$ \\
\hline
\end{tabular}

Table 5.16. Results of Transportation Impact Analysis for Configuration 3 (100\% Truck, Through Las Vegas, Low Waste Volume)

\begin{tabular}{|c|c|c|c|c|c|}
\hline \multirow{3}{*}{$\begin{array}{l}\text { LLW } \\
\text { Generator }\end{array}$} & \multicolumn{3}{|c|}{ Radiological Impacts, fatalities } & \multirow{2}{*}{\multicolumn{2}{|c|}{ Nonradiological Fatalities }} \\
\hline & \multicolumn{2}{|c|}{ Incident-Free Exposures } & \multirow{2}{*}{$\begin{array}{l}\text { Accident } \\
\text { Risk }\end{array}$} & & \\
\hline & Crew & Public & & Accidents & Emissions \\
\hline LANL & $1.6 \mathrm{E}-02$ & $2.3 \mathrm{E}-02$ & 1.9E-07 & $8.8 \mathrm{E}-02$ & $1.7 \mathrm{E}-02$ \\
\hline Fernald & $3.7 \mathrm{E}-02$ & $5.3 \mathrm{E}-02$ & $4.2 \mathrm{E}-06$ & $1.1 \mathrm{E}-01$ & $2.0 \mathrm{E}-02$ \\
\hline RFETS & $1.1 \mathrm{E}-02$ & $1.6 \mathrm{E}-02$ & $3.8 \mathrm{E}-07$ & $6.9 \mathrm{E}-02$ & $5.3 \mathrm{E}-03$ \\
\hline Mound & $2.9 \mathrm{E}-02$ & $4.2 \mathrm{E}-02$ & $3.2 \mathrm{E}-06$ & $1.7 \mathrm{E}-01$ & $3.8 \mathrm{E}-02$ \\
\hline LLNL & $4.4 \mathrm{E}-03$ & $6.7 \mathrm{E}-03$ & $1.1 \mathrm{E}-07$ & $1.8 \mathrm{E}-02$ & 2.9E-03 \\
\hline Sandia-NM & $7.1 \mathrm{E}-04$ & $1.1 \mathrm{E}-03$ & $9.0 \mathrm{E}-09$ & $3.8 \mathrm{E}-03$ & $1.0 \mathrm{E}-03$ \\
\hline PGDP & $1.7 \mathrm{E}-03$ & $2.4 \mathrm{E}-03$ & $1.2 \mathrm{E}-07$ & $1.1 \mathrm{E}-02$ & $1.6 \mathrm{E}-03$ \\
\hline ETEC & $2.8 \mathrm{E}-04$ & $4.5 \mathrm{E}-04$ & $8.2 \mathrm{E}-09$ & $8.3 \mathrm{E}-04$ & $1.7 \mathrm{E}-03$ \\
\hline ITRI & $3.2 \mathrm{E}-04$ & $4.8 \mathrm{E}-04$ & $4.1 E-09$ & $1.7 \mathrm{E}-03$ & $4.7 \mathrm{E}-04$ \\
\hline PORT & $9.7 \mathrm{E}-04$ & $1.4 \mathrm{E}-03$ & $1.0 \mathrm{E}-07$ & $5.7 \mathrm{E}-03$ & $1.2 \mathrm{E}-03$ \\
\hline Pantex & $2.8 \mathrm{E}-04$ & $4.2 \mathrm{E}-04$ & $6.7 E-09$ & $1.7 \mathrm{E}-03$ & $3.7 \mathrm{E}-04$ \\
\hline TOTAL & $1.0 \mathrm{E}-01$ & $1.5 \mathrm{E}-01$ & $8.4 \mathrm{E}-06$ & $4.8 \mathrm{E}-01$ & 8.9E-02 \\
\hline
\end{tabular}


Table 5.17. Summary of Life-Cycle Risks for Each Configuration ${ }^{(a)}$

\begin{tabular}{|c|c|c|c|c|}
\hline Impact Measure & $\begin{array}{l}\text { IA (Intermodal at } \\
\text { Barstow, CA })^{(\mathbf{b})}\end{array}$ & $\begin{array}{c}\text { 1B (Intermodal } \\
\text { at Caliente, } \\
\mathrm{NV})^{(\mathrm{b})}\end{array}$ & $\begin{array}{l}2(100 \% \text { truck on } \\
\text { routes that avoid } \\
\text { Las Vegas })\end{array}$ & $\begin{array}{l}3(100 \% \text { truck on } \\
\text { routes that travel } \\
\text { through Las Vegas) }\end{array}$ \\
\hline \multicolumn{5}{|c|}{ High Waste Volume Case } \\
\hline $\begin{array}{l}\text { Shipping Distance } \\
\text { (mi.) }\end{array}$ & $2.6 \mathrm{E}+07$ & $2.8 \mathrm{E}+07$ & $5.2 \mathrm{E}+07$ & $4.5 \mathrm{E}+07$ \\
\hline $\begin{array}{l}\text { Radiological } \\
\text { Routine - Workers } \\
\text { (Fatalities) }\end{array}$ & $1.1 \mathrm{E}-01$ & $1.2 \mathrm{E}-01$ & $2.9 \mathrm{E}-01$ & 2.7E-01 \\
\hline $\begin{array}{l}\text { Radiological } \\
\text { Routine - Public } \\
\text { (Fatalities) }\end{array}$ & $9.7 \mathrm{E}-02$ & 1.1E-01 & $4.3 E-01$ & $3.9 \mathrm{E}-01$ \\
\hline $\begin{array}{l}\text { Radiological } \\
\text { Accident Risks } \\
\text { (Fatalities) }\end{array}$ & $8.0 \mathrm{E}-06$ & $1.2 \mathrm{E}-05$ & $1.9 \mathrm{E}-05$ & $1.9 E-05$ \\
\hline $\begin{array}{l}\text { Nonradiological } \\
\text { Accident Risks } \\
\text { (Fatalities) }\end{array}$ & $1.2 \mathrm{E}+00$ & $1.3 \mathrm{E}+00$ & $1.8 \mathrm{E}+00$ & $1.5 \mathrm{E}+00$ \\
\hline $\begin{array}{l}\text { Nonradiological } \\
\text { Routine Emissions } \\
\text { (Fatalities) }\end{array}$ & $1.3 \mathrm{E}-01$ & $1.6 \mathrm{E}-01$ & $2.1 \mathrm{E}-01$ & $2.8 \mathrm{E}-01$ \\
\hline \multicolumn{5}{|c|}{ Low Waste Volume Case } \\
\hline $\begin{array}{l}\text { Shipping Distance } \\
\text { (mi.) }\end{array}$ & $1.0 \mathrm{E}+07$ & $1.2 \mathrm{E}+07$ & $2.1 \mathrm{E}+07$ & $1.7 \mathrm{E}+07$ \\
\hline $\begin{array}{l}\text { Radiological } \\
\text { Routine - Workers } \\
\text { (Fatalities) }\end{array}$ & 3.7E-02 & 4.4E-02 & $1.2 \mathrm{E}-01$ & $1.0 \mathrm{E}-01$ \\
\hline $\begin{array}{l}\text { Radiological } \\
\text { Routine - Crew } \\
\text { (Fatalities) }\end{array}$ & $3.0 \mathrm{E}-02$ & $3.6 \mathrm{E}-02$ & $1.7 \mathrm{E}-01$ & $1.5 \mathrm{E}-01$ \\
\hline $\begin{array}{l}\text { Radiological } \\
\text { Accident Risks } \\
\text { (Fatalities) }\end{array}$ & $3.0 \mathrm{E}-06$ & $3.6 \mathrm{E}-06$ & 8.5E-06 & $8.4 \mathrm{E}-06$ \\
\hline $\begin{array}{l}\text { Nonradiological } \\
\text { Accident Risks } \\
\text { (Fatalities) }\end{array}$ & 4.6E-01 & 4.4E-01 & $7.1 \mathrm{E}-01$ & 4.8E-01 \\
\hline $\begin{array}{l}\text { Nonradiological } \\
\text { Routine Emissions } \\
\text { (Fatalities) }\end{array}$ & $5.1 \mathrm{E}-02$ & $6.8 \mathrm{E}-02$ & $7.9 \mathrm{E}-02$ & 8.9E-02 \\
\hline
\end{tabular}

(a) Includes risks from truck and rail transport of LLW as well as intermodal transfer operations.

(b) Transport from small LLW generator sites is by truck via routes that avoid Las Vegas. 


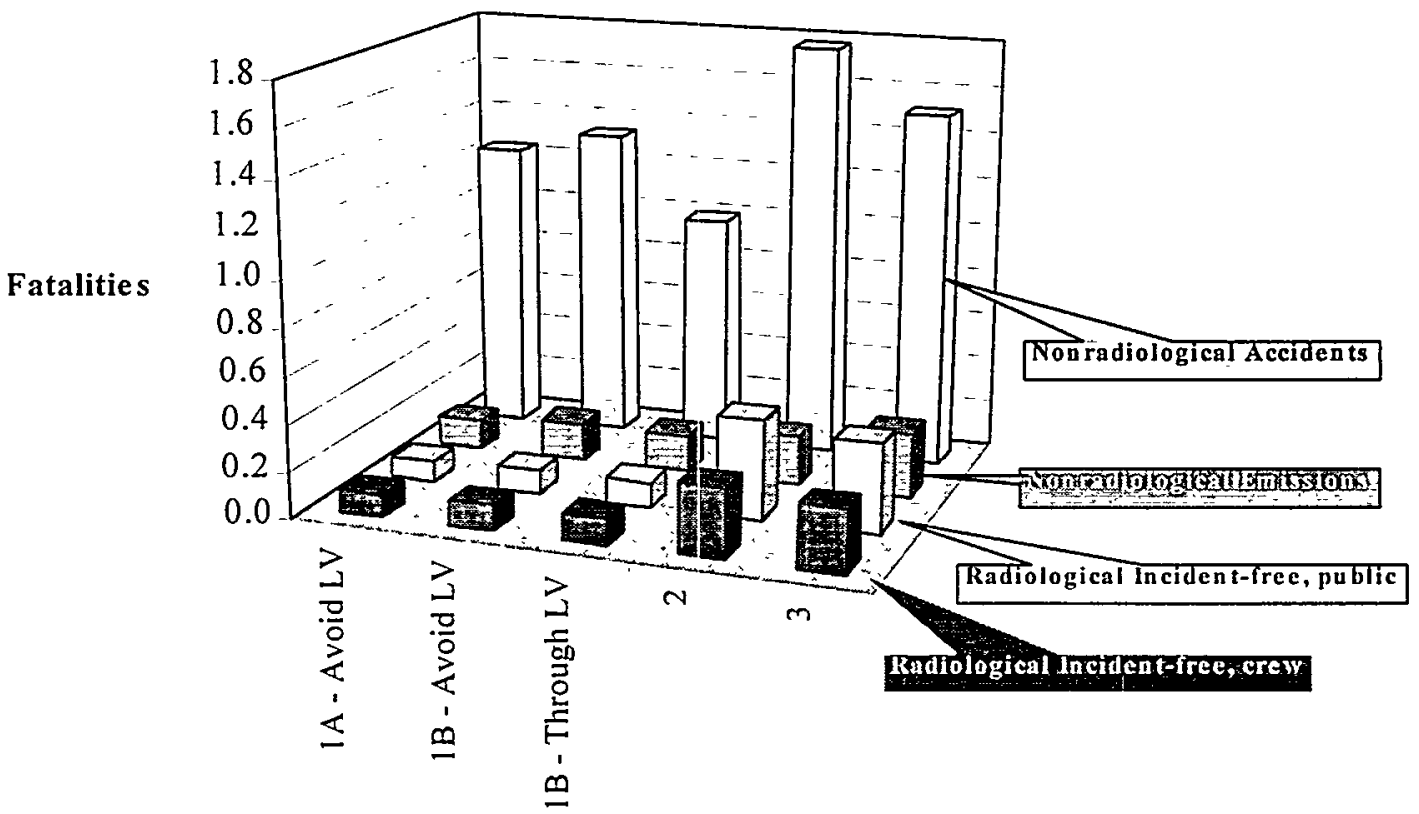

Figure 5.3. Plot of Total Transportation Risks for the High Waste Loading Option (Radiological Accident Risks Not Plotted)

The options in which routes avoid the Las Vegas Valley and Hoover Dam appear to result in higher public and worker risks than options that use routes through Las Vegas, in part because the total shipping distances are higher for the options that avoid Las Vegas. The option with the highest total shipping distance results in the highest nonradiological accident risks, which are approximately linear with shipping distance for any particular transport mode. Radiological routine risks, on the other hand, are affected by shipping distance as well as other parameters, specifically population density. One would think that the options that avoid Las Vegas would result in lower radiological routine risks because they divert the shipments away from densely populated areas of Nevada to rural highways. However, as the results in Table 5.17 indicate, on a DOE complex basis, the effects of the longer shipping distances associated with the options that avoid Las Vegas offset the reductions associated with diverting the shipments away from highly populated Las Vegas. Moreover, the Las Vegas

\section{Risk Perspective-Maximum Individual Doses}

The RADTRAN 4 results include an estimate of the maximum individual dose from incident-free transport. The estimate is based on a person that is located $30 \mathrm{~m}$ from the transport link exposed to a shipment passing by at $24 \mathrm{~km} / \mathrm{hr}(15 \mathrm{mph})$. The package dose rate in this example was conservatively set to $10 \mathrm{mrem} / \mathrm{hr}$ at $1 \mathrm{~m}$ from the package surface. Based on these assumptions. the maximum individual dose was calculated to be $5.6 \mathrm{E}$ 07 rem per shipment. Assuming this person is exposed 10 every truck shipment in the high waste volume configuration, the accumulated dose over 70 years (27,725 truck shipments) would be about 20 mrem. This is small relative to the annual radiation dose from natural and man-made sources of about $300 \mathrm{mrem} / \mathrm{yr}$ or 21,000 mrem over a 70-yr period. This is also a small fraction of the Nuclear Regulatory Commission's (NRC's) annual dose limit for members of the public 100 mrem/yr (see 10 CFR 20.1301). The dose to this maximum individual is equivalent to the dose from about 3 to 4 chest $X$-rays. Clearly, this maximum individual dose accumulated over 70 years represents an insignificant risk to this hypothetical individual. 


\section{Risk Perspective \\ Incident-free Population Dose}

The incident-free population risks from transporting $L L W$ to NTS can be compared to the risks of exposure to natural background radiation. Natural background doses were calculated using the population densities and shipping distances calculated by. HIGHWAY for the route from Boulder City, NV, to NTS (i.e., through Las Vegas). The calculation also used the RADTRAN 4 assumption that the exposed population includes all persons within $800 \mathrm{~m}$ on either side of a truck shipment. The total exposed population was assumed to be uniformly distributed in this $1.6-\mathrm{km}$-wide band over the entire length of the trip from Boulder City to NTS. Using these assumptions, the total exposed population would be about 81,000 people in this corridor. Using this value of the exposed population and assuming natural background dose rates are on the order of $360 \mathrm{mrem} / \mathrm{yr}$, the total population dose from natural background is about 29,000 person-rem/yr. This converts to about 15 Latent Cancer Fatalities (LCFs) per year. However, if the actual population of Nevada was used, the total population dose would be about 150,000 person-rem or, in terms of fatalities, about $75 \mathrm{LCF}$ ser year from natural background. The estimated incident-free dose risks from $L L W$ transport to NTS are all less than 1 cancer fatality (see Tables 5.19 to 5.22) in 70 years. This demonstrates that the incidentfree dose risks from transporting $L L W$ to NTS are a small fraction of the risks from background radiation. To further put this in perspective, there were about 3,000 deaths from all forms of cancer from all causes in Nevada in 1995 (National Center for Health Statistics 1997).
Valley, although densely populated, is only a small fraction of the any of the routes and thus does not greatly influence the total risk over the entire route.

The configurations that avoid Las Vegas divert shipments from well-maintained interstate and primary state highways to less well-maintained rural highways. The interstates and primary highways are also better designed and constructed to handle heavy truck traffic (roadbeds, shoulders, etc.) than rural highways. This is part of the reason why DOT highway routing guidelines direct carriers to use interstate highways in most instances. In addition, the routes that travel through Las Vegas are shorter and more direct than the routes that avoid Las Vegas. One would expect nonradiological fatalities to be lowest for alternatives that make the most extensive use of interstate highways and result in lower total shipping distances. This is borne out by the results presented in the previous tables.

Another observation is that the trend discussed above in which the risks are most favorable for options that travel

through Las Vegas is not applicable to nonradiological routine emissions. This is because the routes that avoid Las Vegas have higher proportions of the trips in rural and suburban areas than routes that travel through Las Vegas. The nonradiological routine risk factor is 0 in rural and suburban population zones (see Section 5.1.3). As a result, the effects of shifting LLW shipments to routes that avoid Las Vegas tend to result in lower nonradiological routine risks than shipping through Las Vegas. The decrease in travel through high population density regions more than offsets the risk increase that results from longer shipping distances as most of the mileage increase is in rural areas of Nevada where nonradiological routine emission risks are assumed to be 0 .

Figure 5.3 illustrates the comparison between shipping by truck around (Configuration 2 - see Tables 5.13 and 5.14) versus through Las Vegas (Configuration 3 - see Tables 5.15 and 5.16). It also illustrates the differences in the intermodal options when shipments from small LLW generator sites are routed around versus through Las Vegas (compare Tables 5.10 and 5.12). For both comparisons, the total lifecycle risks are higher for the options that avoid Las Vegas. The total risks in this figure include the intransit segments of the shipments as well as the nonradiological accident risks and radiological dose risks to workers at the intermodal transfer facilities. It should be noted that the intermodal transfer risks are small relative to the in-transit risks. The intermodal transfer risks amount to about $4 \%$ of the total worker radiological doses and less than $1 \%$ of the nonradiological fatality estimates for the intermodal configurations. 
The radiological doses to the truck crews and public in Figure 5.3 are about $10 \%$ lower for Configuration 3 relative to Configuration 2 whereas the nonradiological accident risks are about $15 \%$ lower for Configuration 2. Numerically, nonradiological accident risks are significantly higher than the radiological dose risks. This means that the absolute differences in the calculated risks are more significant for nonradiological accident risks than are the absolute differences in radiological dose risks, even though the percentage changes are about the same. For example, the absolute difference in nonradiological accident risks between Configurations 2 and 3 amounts to about 0.3 fatalities where the difference between public radiological risks amounts to about 0.05 fatalities.

The intermodal configurations examined in this study are projected to result in smaller radiological and nonradiological risks to workers (i.e., truck and rail crews) and to the public than the all-truck configurations. The main drivers for these differences are smaller total shipping distances (resulting from rail shipments having a higher capacity than truck shipments) and lower accident rates and unit risk factors for rail shipments than for truck shipments. The risks from intermodal transfer activities are small relative to the in-transit risks, so they can be ignored when making these comparisons.

Tables 5.8 through 5.17 report total public radiological risk for incident-free transportation. "Public risk" is the sum of off-link risk (the risk to people living and working within a half-mile of the route), on-link risk (the risk to occupants of vehicles sharing the route with the radioactive cargo), and stop risk (the risk to people at stops where the vehicle is stopped). The stop risk is always one to two orders of magnitude larger than off-link and on-link risks for truck transportation, so that the total public risks are usually just a reflection of the stop risk (see Table 5.18 and Figure 5.4). For intermodal transportation, which is primarily rail, the stop risk is the same order of magnitude as the off-link risk.

For truck transportation, the radiological risk to residents along the route (off-link risk) is about 1 to $4 \%$ of the total public risk, and is a slightly higher fraction for the routes through Las Vegas than for a route that avoids Las Vegas. For example, for the ORR-to-NTS route, the off-link risk is about $2.9 \%$ of the total public risk for the route through Las Vegas and about $2.2 \%$ of the total public risk for the route that avoids Las Vegas. For the RFETS-to-NTS route, off-link risks are about $1.8 \%$ of the total public risk for the route that travels through Las Vegas and about $0.8 \%$ of the total public risk on the route that avoids Las Vegas.

For rail transportation, the stop risks are smaller fraction of the incident-free public risks than for truck transportation, because there are far fewer people near the cargo at the stops. The off-link risks for rail transport are about half of the total public rail risk, compared to the 1 to $4 \%$ of the total for truck transport. This illustrates that increasing the use of rail causes the dominant incident-free public risks to shift from the population at truck stops to an approximate equal split between the population surrounding rail stops and the population within a half-mile of the rail lines.

In general, the life-cycle incident-free public risks from rail transportation are smaller than for truck transportation, as shown in the tables. However, the off-link doses, which are a concern to local stakeholder groups in Nevada and in corridor states, are actually lower on a DOE complex basis for truck shipments than for rail. Referring to Table 5.18, the total life-cycle off-link doses are 55 and 68 personrem for Intermodal Configurations $1 \mathrm{~A}$ and $1 \mathrm{~B}$, respectively. For Configurations 2 and 3 (100\% truck shipments), the off-link risks are 17 and 21 person-rem, respectively. Thus, there is about a factor of 3 to 4 difference in favor of truck shipments when only off-link doses or risks are considered. However, this difference is overwhelmed by the large difference in stop doses, which favor rail shipments. 
Table 5.18. Detailed Truck and Rail Incident-Free Doses for Major LLW Generators

\begin{tabular}{|c|c|c|c|c|c|}
\hline \multirow[b]{2}{*}{ LLW Generator } & \multirow{2}{*}{$\begin{array}{c}\text { Crew Dose } \\
\text { (person-rem) }\end{array}$} & \multicolumn{4}{|c|}{ Public Dose (person-rem) } \\
\hline & & Off-link & On-link & Stops & Total \\
\hline \multicolumn{6}{|c|}{ Configuration 1A: Intermodal at Barstow ${ }^{(a)}$} \\
\hline ORR & $7.1 \mathrm{E}+01$ & $1.9 \mathrm{E}+01$ & $3.5 \mathrm{E}+00$ & $1.9 \mathrm{E}+01$ & $4.1 E+01$ \\
\hline LANL & $1.8 \mathrm{E}+01$ & $9.1 \mathrm{E}-01$ & $1.1 \mathrm{E}+00$ & $3.3 E+00$ & $5.3 \mathrm{E}+00$ \\
\hline FEMP & $2.3 \mathrm{E}+01$ & $6.6 \mathrm{E}+00$ & $1.1 \mathrm{E}+00$ & $6.4 \mathrm{E}+00$ & $1.4 \mathrm{E}+01$ \\
\hline RFETS & $1.4 \mathrm{E}+01$ & $3.1 \mathrm{E}+00$ & $7.5 \mathrm{E}-01$ & $4.1 \mathrm{E}+00$ & $7.9 \mathrm{E}+00$ \\
\hline Mound & $1.8 \mathrm{E}+01$ & $7.1 \mathrm{E}+00$ & $9.1 \mathrm{E}-01$ & $5.2 \mathrm{E}+00$ & $1.3 E+01$ \\
\hline LLNL & $5.9 \mathrm{E}+00$ & $2.2 \mathrm{E}+00$ & $4.2 \mathrm{E}-01$ & $1.3 \mathrm{E}+00$ & $3.9 \bar{E}+00$ \\
\hline BNL & $1.1 \mathrm{E}+01$ & $1.3 \mathrm{E}+01$ & $6.9 \mathrm{E}-01$ & $3.5 \mathrm{E}+00$ & $1.8 \mathrm{E}+01$ \\
\hline INEEL & $5.2 \mathrm{E}+00$ & $2.8 \mathrm{E}+00$ & $3.2 \mathrm{E}-01$ & $1.3 \mathrm{E}+00$ & $4.4 \mathrm{E}+00$ \\
\hline ANL-E & $3.6 \mathrm{E}+00$ & $5.9 \mathrm{E}-01$ & $1.7 \mathrm{E}-01$ & $9.2 \mathrm{E}-01$ & $1.7 \mathrm{E}+00$ \\
\hline Subtotal & $1.7 \mathrm{E}+02$ & $5.5 \mathrm{E}+01$ & $9.0 \mathrm{E}+00$ & $4.5 \mathrm{E}+01$ & $1.1 \mathrm{E}+02$ \\
\hline Small Generators & $5.7 \mathrm{E}+01$ & $1.9 \mathrm{E}+00$ & $7.8 \mathrm{E}+00$ & $5.6 \mathrm{E}+01$ & $6.5 \mathrm{E}+01$ \\
\hline Grand Total & $2.3 \mathrm{E}+02$ & $5.7 \mathrm{E}+01$ & $1.7 \mathrm{E}+01$ & $1.0 \mathrm{E}+02$ & $1.7 \mathrm{E}+02$ \\
\hline \multicolumn{6}{|c|}{ Configuration 1B: Intermodal at Caliente ${ }^{(a)}$} \\
\hline ORR & $8.3 \mathrm{E}+01$ & $2.3 \mathrm{E}+01$ & $4.4 \mathrm{E}+00$ & $2.2 \mathrm{E}+01$ & $5.0 \mathrm{E}+01$ \\
\hline LANL & $2.6 \mathrm{E}+01$ & $4.3 \mathrm{E}+00$ & $1.6 \mathrm{E}+00$ & $6.4 \mathrm{E}+00$ & $1.2 \mathrm{E}+01$ \\
\hline FEMP & $2.6 \mathrm{E}+01$ & $7.8 \mathrm{E}+00$ & $1.4 \mathrm{E}+00$ & $6.8 \mathrm{E}+00$ & $1.6 \mathrm{E}+01$ \\
\hline RFETS & $1.5 \mathrm{E}+01$ & $5.6 \mathrm{E}-01$ & $9.2 \mathrm{E}-01$ & $2.6 \mathrm{E}+00$ & $4.1 \mathrm{E}+00$ \\
\hline Mound & $2.0 \mathrm{E}+01$ & $1.4 \mathrm{E}+01$ & $1.2 \mathrm{E}+00$ & $5.6 \mathrm{E}+00$ & $2.0 \mathrm{E}+01$ \\
\hline LLNL & $9.1 \mathrm{E}+00$ & $2.7 \mathrm{E}+00$ & $5.7 \mathrm{E}-01$ & $2.1 E+00$ & $5.3 \mathrm{E}+00$ \\
\hline$\overline{B N L}$ & $1.2 \mathrm{E}+01$ & $1: 4 \mathrm{E}+01$ & $8.3 \mathrm{E}-01$ & $3.5 \mathrm{E}+00$ & $1.9 \mathrm{E}+01$ \\
\hline INEEL & $5.3 E+00$ & $5.3 \mathrm{E}-01$ & $3.6 \mathrm{E}-01$ & $1.1 \mathrm{E}+00$ & $1.9 \mathrm{E}+00$ \\
\hline ANL-E & $4.1 \mathrm{E}+00$ & $8.0 \mathrm{E}-01$ & $2.2 \mathrm{E}-01$ & $9.8 \mathrm{E}-01$ & $2.0 \mathrm{E}+00$ \\
\hline Subtotal & $2.0 \mathrm{E}+02$ & $6.8 \mathrm{E}+01$ & $1.2 \mathrm{E}+01$ & $5.1 \mathrm{E}+01$ & $1.3 \mathrm{E}+02$ \\
\hline Small Generators & $5.7 \mathrm{E}+01$ & $1.9 \mathrm{E}+00$ & $7.8 \mathrm{E}+00$ & $5.6 \mathrm{E}+01$ & $6.5 \mathrm{E}+01$ \\
\hline Grand Total & $2.6 \mathrm{E}+02$ & $7.0 \mathrm{E}+01$ & $1.9 \mathrm{E}+01$ & $1.1 \mathrm{E}+02$ & $2.0 \mathrm{E}+02$ \\
\hline \multicolumn{6}{|c|}{ Configuration 2: Truck Shipments to NTS - Avoid Las Vegas (Truck Risks Only) } \\
\hline ORR & $3.1 \mathrm{E}+02$ & $7.8 \mathrm{E}+00$ & $4.0 \mathrm{E}+01$ & $3.2 \mathrm{E}+02$ & $3.6 \mathrm{E}+02$ \\
\hline LANL & $4.9 \mathrm{E}+01$ & $7.2 \mathrm{E}-01$ & $5.5 \mathrm{E}+00$ & $5.3 \mathrm{E}+01$ & $5.9 \mathrm{E}+01$ \\
\hline$\overline{\text { FEMP }}$ & $1.0 \mathrm{E}+02$ & $3.0 \mathrm{E}+00$ & $1.3 \mathrm{E}+01$ & $1.0 \mathrm{E}+02$ & $1.2 \mathrm{E}+02$ \\
\hline RFETS & $3.6 \mathrm{E}+01$ & $3.3 \mathrm{E}-01$ & $3.8 \mathrm{E}+00$ & $3.9 \mathrm{E}+01$ & $4.3 \mathrm{E}+01$ \\
\hline Mound & $7.9 \mathrm{E}+01$ & $2.7 \mathrm{E}+00$ & $1.1 \mathrm{E}+01$ & $7.8 \mathrm{E}+01$ & $9.2 \mathrm{E}+01$ \\
\hline LLNL & $1.0 \mathrm{E}+01$ & $1.3 \mathrm{E}-01$ & $1.2 \mathrm{E}+00$ & $1.1 \mathrm{E}+01$ & $1.3 \mathrm{E}+01$ \\
\hline $\mathrm{BNL}$ & $6.0 \mathrm{E}+01$ & $2.4 \mathrm{E}+00$ & $8.7 \mathrm{E}+00$ & $5.6 \mathrm{E}+01$ & $6.7 \mathrm{E}+01$ \\
\hline INEEL & $1.1 E+01$ & $7.5 \mathrm{E}-02$ & $1.1 \mathrm{E}+00$ & $1.2 \mathrm{E}+01$ & $1.3 \mathrm{E}+01$ \\
\hline ANL-E & $1.5 \mathrm{E}+01$ & $2.3 \mathrm{E}-01$ & $1.7 \mathrm{E}+00$ & $1.6 \mathrm{E}+01$ & $1.8 \mathrm{E}+01$ \\
\hline Subtotal & $6.8 \mathrm{E}+02$ & $1.7 \mathrm{E}+01$ & $8.6 \mathrm{E}+01$ & $6.8 \mathrm{E}+02$ & $7.8 \mathrm{E}+02$ \\
\hline Small Generators & $5.7 \mathrm{E}+01$ & $1.9 \mathrm{E}+00$ & $7.8 \mathrm{E}+00$ & $5.6 \mathrm{E}+01$ & $6.5 \mathrm{E}+01$ \\
\hline Grand Total & $7.3 \mathrm{E}+02$ & $1.9 \mathrm{E}+01$ & $9.4 \mathrm{E}+01$ & $7.4 \mathrm{E}+02$ & $8.5 \mathrm{E}+02$ \\
\hline \multicolumn{6}{|c|}{ Configuration 3: Truck Shipments to NTS - Through Las Vegas (Truck Risks Only) } \\
\hline ORR & $2.9 \mathrm{E}+02$ & $9.5 \mathrm{E}+00$ & $4.0 \mathrm{E}+01$ & $2.8 \mathrm{E}+02$ & $3.3 \mathrm{E}+02$ \\
\hline LANL & $4.0 \mathrm{E}+01$ & $1.4 \mathrm{E}+00$ & $5.6 \mathrm{E}+00$ & $4.0 \mathrm{E}+01$ & $4.7 \mathrm{E}+01$ \\
\hline FEMP & $9.3 \mathrm{E}+01$ & $3.5 \mathrm{E}+00$ & $1.3 \mathrm{E}+01$ & $9.0 \mathrm{E}+01$ & $1.1 \mathrm{E}+02$ \\
\hline RFETS & $2.8 \mathrm{E}+01$ & $5.7 \mathrm{E}-01$ & $3.3 E+00$ & $2.8 \mathrm{E}+01$ & $3.2 \mathrm{E}+01$ \\
\hline
\end{tabular}




\begin{tabular}{|l|c|c|c|c|c|}
\hline & Crew Dose & \multicolumn{5}{|c|}{ Public Dose (person-rem) } \\
\cline { 3 - 6 } LLW Generator & (person-rem) & Off-link & On-link & Stops & Total \\
\hline Mound & $7.3 \mathrm{E}+01$ & $3.1 \mathrm{E}+00$ & $1.1 \mathrm{E}+01$ & $7.0 \mathrm{E}+01$ & $8.4 \mathrm{E}+01$ \\
\hline LLNL & $1.1 \mathrm{E}+01$ & $2.2 \mathrm{E}-01$ & $1.4 \mathrm{E}+00$ & $1.2 \mathrm{E}+01$ & $1.3 \mathrm{E}+01$ \\
\hline BNL & $5.5 \mathrm{E}+01$ & $2.5 \mathrm{E}+00$ & $8.4 \mathrm{E}+00$ & $5.0 \mathrm{E}+01$ & $6.1 \mathrm{E}+01$ \\
\hline INEEL & $1.0 \mathrm{E}+01$ & $4.8 \mathrm{E}-01$ & $1.6 \mathrm{E}+00$ & $9.4 \mathrm{E}+00$ & $1.1 \mathrm{E}+01$ \\
\hline ANL-E & $1.3 \mathrm{E}+01$ & $2.8 \mathrm{E}-01$ & $1.6 \mathrm{E}+00$ & $1.3 \mathrm{E}+01$ & $1.5 \mathrm{E}+01$ \\
\hline \hline Subotal & $6.1 \mathrm{E}+02$ & $2.1 \mathrm{E}+01$ & $8.7 \mathrm{E}+01$ & $6.0 \mathrm{E}+02$ & $7.0 \mathrm{E}+02$ \\
\hline Small Generators & $5.2 \mathrm{E}+01$ & $2.1 \mathrm{E}+00$ & $7.7 \mathrm{E}+00$ & $4.9 \mathrm{E}+01$ & $5.9 \mathrm{E}+01$ \\
\hline Grand Total & $\mathbf{6 . 7 E}+\mathbf{0 2}$ & $\mathbf{2 . 4 E + 0 1}$ & $\mathbf{9 . 4 E + 0 1}$ & $\mathbf{6 . 4 E}+\mathbf{0 2}$ & $\mathbf{7 . 6 E}+\mathbf{0 2}$ \\
\hline
\end{tabular}

(a) These results include the in-transit doses for rail transport from LLW generators to the specified intermodal transfer facility, including stops for marshalling and inspection, in addition to the intransit doses for a truck shipment from the intermodal facility to NTS. Small generators were assumed to ship by truck via routes that avoid Las Vegas and Hoover Dam.

From a DOE-complex perspective, when only the off-link incident-free risk is considered, the risks on truck routes that travel through Las Vegas (Configuration 3) are about 1.3 times higher (i.e., 30\% higher) than the risks on truck routes that avoid Las Vegas (Configuration 2). This increase is within the uncertainty in the results and thus there is essentially no difference between the two truck routes on Complex-wide basis. For the major generators, the off-link risks were about 1.1 (BNL to NTS) to about 6 (INEEL to NTS) times higher for Configuration 3 than Configuration 2. For all but INEEL, the difference was less than a factor of 2. The large difference calculated for INEEL was due the fact that the route taken to avoid Las Vegas was determined by HIGHWAY to be $97 \%$ rural and the route taken through Las Vegas was determined to be only $84 \%$ rural (see Table 5.3). Even though the route that avoids Las Vegas is about $25 \%$ longer ( 887 versus $719 \mathrm{mi}$ ), the affected population (including persons on-link, off-link, and at stops) is about one-sixth of that along the route through Las Vegas. The rural travel fractions for the other major generators also follow this trend (i.e., generally higher rural travel fractions and longer shipping distances for Configuration 2), but are much less pronounced than the differences between the INEEL to NTS truck routes.

\subsubsection{Transportation Risks by State}

The risk estimates developed in this study were sorted by state to provide an understanding of the level of risks to be borne by each state along the transportation corridors between LLW generators and NTS. The state-by-state risk estimates for the high waste loading case are presented in Tables 5.19 to 5.22 for Configurations $1 \mathrm{~A}, 1 \mathrm{~B}, 2$, and 3 , respectively.

Figures 5.5 and 5.6 were plotted to illustrate the effect on state-level impacts of the various configurations. Since the shipments converge on the State of Nevada, the impacts of the shipping configurations are most likely to appear in Nevada and adjoining states Arizona. California, and Utah. Thus, Figures 5.5 and 5.6 focus on the impacts in these four states. Also, since public risks are often the most controversial, the figures focus on public routine radiological doses and public nonradiological accident risks.

Figures 5.5 and 5.6 illustrate trends in state-level risks. By comparing the all-truck configurations ( 2 and 3 ) in Figure 5.5, one can see that the public radiological risks for Configuration 2 (100\% truck on routes that avoid Las Vegas) are slightly lower than Configuration 3 in Nevada, Arizona, and Utah. These risks 


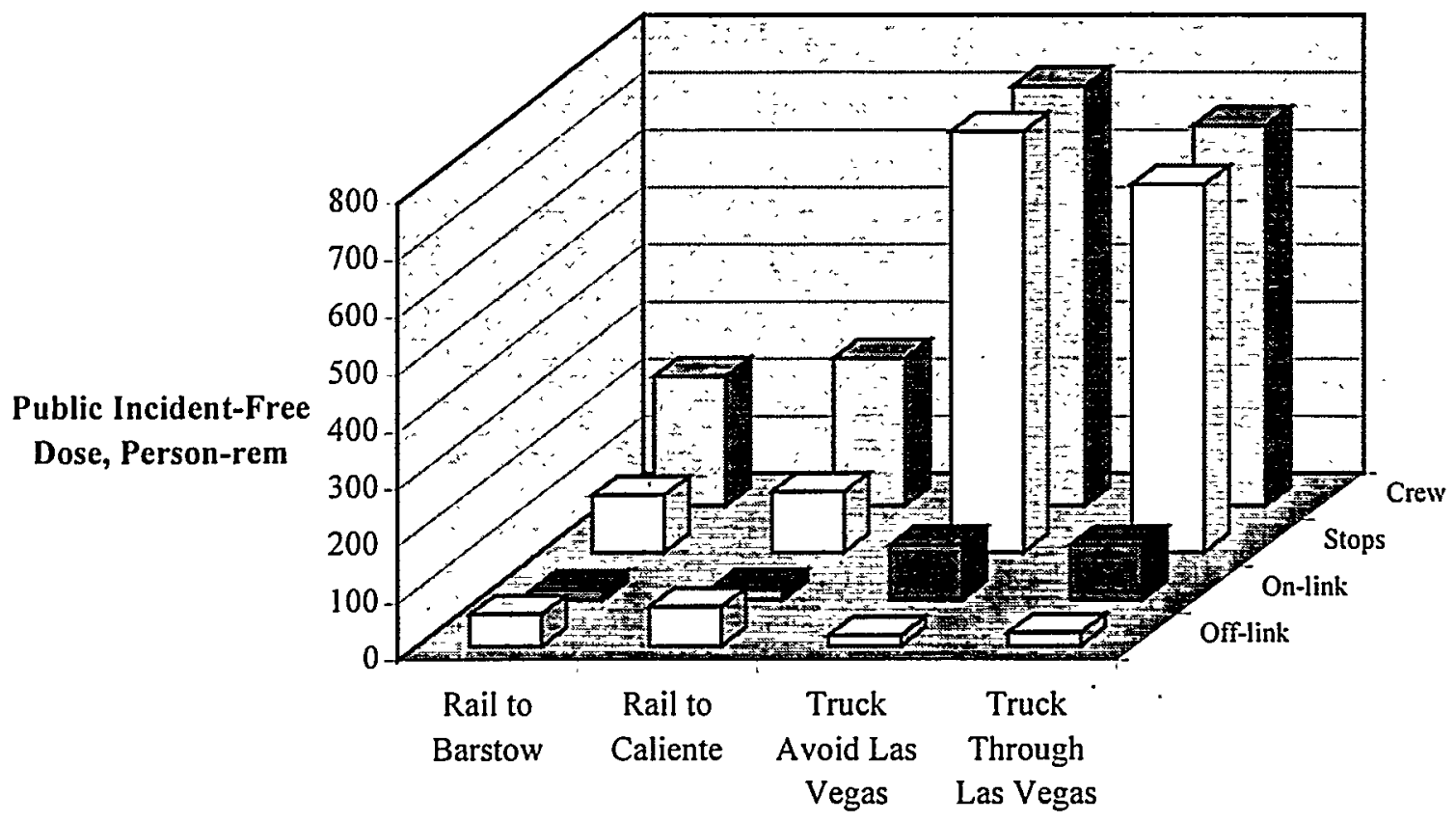

Figure 5.4. Components of Incident-Free Routine Radiological Public Risks For Each LLW Shipping Configuration

are significantly higher in California for Configuration 2 (avoid Las Vegas) than Configuration 3. The main reason for this is that many shipments that now enter the State of Nevada from the south (i.e., via Hoover Dam in Configuration 3), will be diverted to the west in Configuration 2 on Interstate 40 and enter Nevada on Highway 127 near Death Valley Junction (see Figure 2.3). This substantially increases the number of miles traveled in California relative to the current highway routing scheme. This illustrates one form of redistributing risks. However, this observation is valid only for the routing options that are evaluated here. Further analysis would be necessary to explore all potential highway routing alternatives for avoiding Las Vegas and Hoover Dam. In addition, even though the risks are significantly higher in California, the state-level risk estimates are small. The difference in California between Configurations 2 and 3 represents an incremental 100 person-rem, or a probability of about one chance in 20 of an excess latent cancer fatality, over 70 years. On an annual basis, the difference represents about 1 person-rem/ $1 \cdot r$ or less than one chance in 1000 per year of an excess latent cancer fatality.

In general, Figure 5.5 demonstrates that the rail/intermodal shipping configurations ( $1 \mathrm{~A}$ and $\mathrm{IB}$ ) result in lower routine radiological impacts to the public in all four states relative to the all-truck configurations 12 and 3). Also, note that Configuration 1A, where an intermodal transfer facility at Barstow is assumed. has higher public radiological risks in California and Arizona than Configuration IB (intermodal at Caliente) and lower risks in Utah and Nevada. This is primarily because a large fraction of the route used for the truck segments from the Barstow intermodal facility to NTS travels through California whereas the Caliente to NTS intermodal segment is entirely in Nevada. Also, direct truck shipments that use the southern route (Interstate 40) would also be diverted from entering Nevada at Hoover Dam, resulting in additional truck mileage in California. 
Table 5.19. Total Risk ${ }^{(a)}$ By State: Configuration 1 A (Intermodal at Barstow) High Waste Volume, Avoid Las Vegas

\begin{tabular}{|c|c|c|c|c|c|}
\hline \multirow[t]{3}{*}{ State } & \multicolumn{3}{|c|}{ Radiological Fatalities } & \multirow{2}{*}{\multicolumn{2}{|c|}{ Nonradiological Fatalities }} \\
\hline & \multicolumn{2}{|c|}{ Incident-Free Transport } & \multirow{2}{*}{$\begin{array}{l}\text { Accident } \\
\text { Risk }\end{array}$} & & \\
\hline & Crew & Public & & Accidents & Emissions \\
\hline $\mathrm{AL}$ & $9.9 \mathrm{E}-04$ & $1.5 \mathrm{E}-03$ & $5.4 \mathrm{E}-08$ & $3.6 \mathrm{E}-02$ & $2.3 \mathrm{E}-03$ \\
\hline $\mathrm{AZ}$ & $7.8 \mathrm{E}-03$ & $7.6 \mathrm{E}-03$ & $6.5 \mathrm{E}-08$ & $1.2 \mathrm{E}-01$ & $8.1 \mathrm{E}-03$ \\
\hline $\overrightarrow{\mathrm{AR}}$ & $8.6 \mathrm{E}-04$ & $8.4 \mathrm{E}-04$ & $1.2 \mathrm{E}-07$ & $4.0 \mathrm{E}-02$ & $8.2 \mathrm{E}-04$ \\
\hline $\mathrm{CA}$ & $3.8 \mathrm{E}-02$ & $2.4 \mathrm{E}-02$ & $8.3 \mathrm{E}-07$ & $3.0 \mathrm{E}-01$ & $2.0 \mathrm{E}-02$ \\
\hline $\mathrm{CO}$ & $3.8 \mathrm{E}-03$ & $4.5 \mathrm{E}-03$ & $1.8 \mathrm{E}-07$ & $1.9 \mathrm{E}-02$ & $6.0 \mathrm{E}-0 \overline{3}$ \\
\hline$\overline{G A}$ & $1.7 \mathrm{E}-05$ & $8.8 \mathrm{E}-06$ & $5.4 \mathrm{E}-10$ & $4.6 \mathrm{E}-04$ & $0.0 \mathrm{E}+00$ \\
\hline ID & $2.8 \mathrm{E}-04$ & $2.6 \mathrm{E}-04$ & $8.3 \mathrm{E}-09$ & $2.4 \mathrm{E}-03$ & $3.1 \mathrm{E}-04$ \\
\hline IL & $2.2 \mathrm{E}-03$ & $3.8 \mathrm{E}-03$ & $1.9 \mathrm{E}-06$ & $4.1 \mathrm{E}-02$ & $8.4 \mathrm{E}-03$ \\
\hline IN & $3.4 \mathrm{E}-03$ & $3.7 \mathrm{E}-03$ & $6.1 \mathrm{E}-07$ & $4.0 \mathrm{E}-02$ & $6.7 \mathrm{E}-03$ \\
\hline IA & $1.3 \mathrm{E}-03$ & $1.8 \mathrm{E}-03$ & $4.0 \mathrm{E}-08$ & $7.4 \mathrm{E}-03$ & $1.8 \mathrm{E}-04$ \\
\hline$\overline{\mathrm{KS}}$ & $2.3 \mathrm{E}-03$ & $1.8 \mathrm{E}-03$ & $4.0 \mathrm{E}-07$ & $2.2 \mathrm{E}-02$ & $5.1 \mathrm{E}-03$ \\
\hline KY & $8.7 \mathrm{E}-05$ & $1.2 \mathrm{E}-04$ & $5.8 \mathrm{E}-09$ & $5.2 \mathrm{E}-04$ & $1.8 \mathrm{E}-04$ \\
\hline MS & $2.0 \mathrm{E}-04$ & $1.9 \mathrm{E}-04$ & $4.5 \mathrm{E}-08$ & $1.4 \mathrm{E}-02$ & $0.0 \mathrm{E}+00$ \\
\hline $\mathrm{MO}$ & $5.2 \mathrm{E}-03$ & $5.3 \mathrm{E}-03$ & $4.5 \mathrm{E}-07$ & $6.5 \mathrm{E}-02$ & $7.9 \mathrm{E}-03$ \\
\hline $\mathrm{NE}$ & $2.4 \mathrm{E}-03$ & $2.2 \mathrm{E}-03$ & $4.9 \mathrm{E}-07$ & $1.2 \mathrm{E}-02$ & $1.4 \mathrm{E}-03$ \\
\hline NV & $8.8 \mathrm{E}-03$ & $4.0 \mathrm{E}-03$ & $1.1 \mathrm{E}-08$ & $8.6 \mathrm{E}-02$ & $7.0 \mathrm{E}-04$ \\
\hline $\mathrm{NJ}$ & $1.0 \mathrm{E}-05$ & $1.3 \mathrm{E}-05$ & $2.7 \mathrm{E}-09$ & $3.8 \mathrm{E}-05$ & $0.0 \mathrm{E}+00$ \\
\hline NM & $8.7 \mathrm{E}-03$ & $6.7 \mathrm{E}-03$ & $2.4 \mathrm{E}-08$ & $7.8 \mathrm{E}-02$ & $2.5 \mathrm{E}-03$ \\
\hline NY & $1.8 \mathrm{E}-03$ & $4.9 \mathrm{E}-03$ & $6.0 \mathrm{E}-07$ & $5.8 \mathrm{E}-02$ & $1.3 \mathrm{E}-02$ \\
\hline $\mathrm{OH}$ & $3.7 \mathrm{E}-03$ & $6.8 \mathrm{E}-03$ & $1.9 \mathrm{E}-07$ & $2.6 \mathrm{E}-02$ & $1.3 \mathrm{E}-02$ \\
\hline $\mathrm{OK}$ & $4.2 \mathrm{E}-03$ & $4.9 \mathrm{E}-03$ & $3.6 \mathrm{E}-07$ & $1.2 \mathrm{E}-01$ & $5.5 \mathrm{E}-03$ \\
\hline PA & $5.1 \mathrm{E}-04$ & $8.1 \mathrm{E}-04$ & $2.9 \mathrm{E}-08$ & $4.1 \mathrm{E}-03$ & $1.3 \mathrm{E}-03$ \\
\hline TN & $3.4 \mathrm{E}-03$ & $5.6 \mathrm{E}-03$ & $2.0 \mathrm{E}-07$ & $3.9 \mathrm{E}-02$ & $1.2 \mathrm{E}-02$ \\
\hline TX & $3.0 \mathrm{E}-03$ & $3.3 \mathrm{E}-03$ & $2.6 \mathrm{E}-07$ & $1.0 \mathrm{E}-01$ & $2.0 \mathrm{E}-03$ \\
\hline UT & $2.5 \mathrm{E}-03$ & $2.2 \mathrm{E}-03$ & $1.7 \mathrm{E}-09$ & $1.5 \mathrm{E}-02$ & $2.3 \mathrm{E}-06$ \\
\hline WV & $9.5 \mathrm{E}-06$ & $1.3 \mathrm{E}-05$ & $5.9 \mathrm{E}-11$ & $5.6 \mathrm{E}-05$ & $1.4 \mathrm{E}-06$ \\
\hline TOTAL & $1.1 \mathrm{E}-01$ & $9.7 \mathrm{E}-02$ & $8.0 \mathrm{E}-06$ & $1.2 \mathrm{E}+00$ & $1.3 \mathrm{E}-01$ \\
\hline
\end{tabular}

(a) Includes risk from in-transit segments and intermodal transfers. 
Table 5.20. Total Risk ${ }^{(\mathrm{a})}$ By State: Configuration $1 \mathrm{~B}$ (Intermodal at Caliente)High Waste Volume, Avoid Las Vegas

\begin{tabular}{|c|c|c|c|c|c|}
\hline \multirow[t]{3}{*}{ State } & \multicolumn{3}{|c|}{ Radiological Fatalities } & \multirow{2}{*}{\multicolumn{2}{|c|}{ Nonradiological Fatalities }} \\
\hline & \multicolumn{2}{|c|}{ Incident-Free Transport } & \multirow{2}{*}{$\begin{array}{l}\text { Accident } \\
\text { Risk }\end{array}$} & & \\
\hline & Crew & Public & & Accidents & Emissions' \\
\hline $\mathrm{AZ}$ & $2.5 \mathrm{E}-03$ & $3.5 \mathrm{E}-03$ & $1.3 \mathrm{E}-08$ & $1.2 \mathrm{E}-02$ & $5.4 \mathrm{E}-04$ \\
\hline$\overline{\mathrm{CA}}$ & $2.6 \mathrm{E}-03$ & $4.4 \mathrm{E}-03$ & $1.0 \mathrm{E}-07$ & $1.9 \mathrm{E}-02$ & $7.9 \mathrm{E}-03$ \\
\hline $\mathrm{CO}$ & $4.7 \mathrm{E}-03$ & $6.2 \mathrm{E}-03$ & $2.8 \mathrm{E}-07$ & $4.7 \mathrm{E}-02$ & $8.8 \mathrm{E}-03$ \\
\hline ID & $2.8 \mathrm{E}-04$ & $2.6 \mathrm{E}-04$ & $8.3 \mathrm{E}-09$ & $2.4 \mathrm{E}-03$ & $3.1 \mathrm{E}-04$ \\
\hline$\overline{\mathrm{IL}}$ & $3.1 \mathrm{E}-03$ & $8.9 \mathrm{E}-03$ & $3.4 \mathrm{E}-06$ & $7.9 \mathrm{E}-02$ & $2.9 \mathrm{E}-02$ \\
\hline$\overline{\mathrm{IN}}$ & $2.8 \mathrm{E}-03$ & $4.8 \mathrm{E}-03$ & $1.2 \mathrm{E}-06$ & $7.6 \mathrm{E}-02$ & $1.1 \mathrm{E}-02$ \\
\hline$\overline{I A}$ & $2.2 \mathrm{E}-03$ & $3.7 \mathrm{E}-03$ & $1.5 \mathrm{E}-06$ & $2.5 \mathrm{E}-02$ & $6.1 \mathrm{E}-03$ \\
\hline KS & $1.4 \mathrm{E}-03$ & $1.7 \mathrm{E}-03$ & 4.3E-07 & $2.4 \mathrm{E}-02$ & 2.2E-03 \\
\hline$\overline{\mathrm{KY}}$ & $1.3 \mathrm{E}-03$ & $2.6 \mathrm{E}-03$ & $1.3 \mathrm{E}-07$ & $3.2 \mathrm{E}-02$ & $8.8 \mathrm{E}-03$ \\
\hline$\overline{\mathrm{MO}}$ & $3.6 \mathrm{E}-03$ & $6.7 \mathrm{E}-03$ & $6.0 \mathrm{E}-07$ & $5.3 \mathrm{E}-02$ & $1.7 \mathrm{E}-02$ \\
\hline $\mathrm{NE}$ & $5.9 \mathrm{E}-03$ & $5.8 \mathrm{E}-03$ & $2.5 \mathrm{E}-06$ & $6.8 \mathrm{E}-02$ & $5.3 \mathrm{E}-03$ \\
\hline NJ & 4.7E-02 & $3.4 \mathrm{E}-02$ & $1.5 \mathrm{E}-09$ & $3.8 \bar{E}-05$ & $4.8 \mathrm{E}-05$ \\
\hline NV & $5.1 \mathrm{E}-02$ & $.1 .3 \mathrm{E}-05$ & $6.3 \mathrm{E}-08$ & $4.4 \mathrm{E}-01$ & $1.1 \mathrm{E}-03$ \\
\hline$\overline{\mathrm{NM}}$ & $3.7 \mathrm{E}-03$ & $3.7 \mathrm{E}-03$ & $1.6 \mathrm{E}-08$ & $1.9 \mathrm{E}-02$ & $2.6 \mathrm{E}-03$ \\
\hline NY & $1.8 \mathrm{E}-03$ & $4.9 \mathrm{E}-03$ & $6.8 \mathrm{E}-07$ & $5.8 \mathrm{E}-02$ & $1.3 \mathrm{E}-02$ \\
\hline$\overline{\mathrm{OH}}$ & $3.8 \mathrm{E}-03$ & $7.3 \mathrm{E}-03$ & $3.8 \mathrm{E}-07$ & $3.0 \mathrm{E}-02$ & $1.9 \mathrm{E}-02$ \\
\hline$\overline{\mathrm{OK}}$ & $1.8 \mathrm{E}-03$ & $1.8 \mathrm{E}-03$ & $9.3 \mathrm{E}-08$ & $1.0 \mathrm{E}-02$ & $1.3 \mathrm{E}-03$ \\
\hline PA & $5.1 \mathrm{E}-04$ & $8.1 \mathrm{E}-04$ & $6.0 \mathrm{E}-08$ & $4.1 \mathrm{E}-03$ & $1.5 \mathrm{E}-03$ \\
\hline$\overline{T N}$ & $2.8 \mathrm{E}-03$ & $2.0 \mathrm{E}-03$ & $3.8 \mathrm{E}-08$ & $1.5 \mathrm{E}-02$ & $1.4 \mathrm{E}-04$ \\
\hline $\mathrm{TX}$ & $6.7 \mathrm{E}-04$ & $1.0 \mathrm{E}-03$ & $8.5 \mathrm{E}-08$ & $5.1 \mathrm{E}-03$ & 6.0E-04 \\
\hline UT & 8.0E-03 & $1.0 \mathrm{E}-02$ & $3.2 \mathrm{E}-07$ & $3.0 \mathrm{E}-01$ & $2.3 \mathrm{E}-02$ \\
\hline WV & $9.5 \mathrm{E}-06$ & $1.3 \mathrm{E}-05$ & $3.3 \mathrm{E}-10$ & $5.6 \mathrm{E}-05$ & $5.5 \mathrm{E}-05$ \\
\hline WY & $4.6 \mathrm{E}-03$ & $3.3 \mathrm{E}-03$ & $5.1 \mathrm{E}-08$ & $1.9 \mathrm{E}-02$ & $3.7 \mathrm{E}-03$ \\
\hline TOTAL & $1.2 \mathrm{E}-01$ & 1:1E-01 & $1.2 \mathrm{E}-05$ & $1.3 \mathrm{E}+00$ & $1.6 \mathrm{E}-01$ \\
\hline
\end{tabular}

(a) Includes risk from in-transit segments and intermodal transfers. 
Table 5.21. Total Risk ${ }^{(a)}$ by State: Configuration 2 (100\% Truck Avoid Las Vegas)

\begin{tabular}{|c|c|c|c|c|c|}
\hline \multirow[t]{3}{*}{ State } & \multicolumn{3}{|c|}{ Radiological Fatalities } & \multicolumn{2}{|c|}{ Nonradiological Fatalities } \\
\hline & \multicolumn{2}{|c|}{ Incident-Free Transport } & \multirow{2}{*}{$\begin{array}{c}\text { Accident } \\
\text { Risk }\end{array}$} & & \\
\hline & Crew & Public & & Accidents & Emissions \\
\hline $\mathrm{AZ}$ & $4.0 \mathrm{E}-02$ & $6.0 \mathrm{E}-02$ & $2.7 \mathrm{E}-07$ & $2.3 \mathrm{E}-01$ & $1.1 \mathrm{E}-02$ \\
\hline$\overline{\mathrm{AK}}$ & $1.7 \mathrm{E}-02$ & $2.3 \mathrm{E}-02$ & $4.3 \mathrm{E}-07$ & $5.6 \mathrm{E}-02$ & $2.2 \mathrm{E}-03$ \\
\hline $\mathrm{CA}$ & $3.6 \mathrm{E}-02$ & $5.5 \mathrm{E}-02$ & $9.1 \mathrm{E}-07$ & $1.6 \mathrm{E}-01$ & $1.1 \mathrm{E}-02$ \\
\hline $\mathrm{CO}$ & $1.1 E-02$ & $1.5 \mathrm{E}-02$ & $7.3 \mathrm{E}-07$ & $6.8 \mathrm{E}-02$ & $3.8 \mathrm{E}-03$ \\
\hline ID & $1.4 \mathrm{E}-03$ & $2.1 \mathrm{E}-03$ & $6.9 \mathrm{E}-08$ & $3.2 \mathrm{E}-03$ & $5.4 \mathrm{E}-04$ \\
\hline $\mathrm{IL}$ & $8.4 \mathrm{E}-03$ & $1.2 \mathrm{E}-02$ & $3.5 \mathrm{E}-06$ & $3.7 \mathrm{E}-02$ & $6.1 \mathrm{E}-03$ \\
\hline$\overline{\mathrm{IN}}$ & $8.5 \mathrm{E}-03$ & $1.1 \mathrm{E}-02$ & $2.1 \mathrm{E}-06$ & $2.8 \mathrm{E}-02$ & $8.9 \mathrm{E}-03$ \\
\hline IA & $4.5 \mathrm{E}-03$ & $6.3 \mathrm{E}-03$ & $1.2 \mathrm{E}-06$ & $2.4 \mathrm{E}-02$ & $3.4 \mathrm{E}-04$ \\
\hline $\mathrm{KY}$ & $8.6 \mathrm{E}-05$ & $1.2 \mathrm{E}-04$ & $7.9 \mathrm{E}-09$ & $5.2 \mathrm{E}-04$ & $1.8 \mathrm{E}-04$ \\
\hline $\mathrm{MO}$ & $1.2 \mathrm{E}-02$ & $1.6 \mathrm{E}-02$ & $2.0 \mathrm{E}-06$ & $7.2 \mathrm{E}-02$ & $2.1 \mathrm{E}-02$ \\
\hline $\mathrm{NE}$ & $5.0 \mathrm{E}-03$ & $7.6 \mathrm{E}-03$ & $1.7 \mathrm{E}-06$ & $4.1 \mathrm{E}-02$ & $5.0 \mathrm{E}-03$ \\
\hline$\overline{N V}$ & $1.8 \mathrm{E}-02$ & $2.9 \mathrm{E}-02$ & $3.2 \mathrm{E}-08$ & $2.0 \mathrm{E}-01$ & $1.5 \mathrm{E}-04$ \\
\hline NJ & $9.6 \mathrm{E}-04$ & $1.3 \mathrm{E}-03$ & $1.3 \mathrm{E}-07$ & $3.6 \mathrm{E}-03$ & $5.9 \mathrm{E}-03$ \\
\hline NM & $3.9 \mathrm{E}-02$ & $5.8 \mathrm{E}-02$ & $2.9 \mathrm{E}-07$ & $2.7 \mathrm{E}-01$ & $4.4 \mathrm{E}-02$ \\
\hline NY & $2.2 \mathrm{E}-03$ & $2.8 \mathrm{E}-03$ & $2.7 \mathrm{E}-07$ & $1.3 \mathrm{E}-02$ & $1.1 \mathrm{E}-02$ \\
\hline $\mathrm{OH}$ & $5.5 \mathrm{E}-03$ & $6.7 \mathrm{E}-03$ & $4.5 \mathrm{E}-07$ & $8.9 \mathrm{E}-03$ & $8.5 \mathrm{E}-03$ \\
\hline $\mathrm{OK}$ & $3.2 \mathrm{E}-02$ & $4.5 \mathrm{E}-02$ & $2.1 \mathrm{E}-06$ & $2.3 \mathrm{E}-01$ & $1.8 \mathrm{E}-02$ \\
\hline OR & $5.6 \mathrm{E}-04$ & $8.7 \mathrm{E}-04$ & $5.6 \mathrm{E}-09$ & $4.1 \mathrm{E}-03$ & $0.0 \mathrm{E}+00$ \\
\hline PA & $2.9 \mathrm{E}-0 \overline{3}$ & $3.9 \mathrm{E}-03$ & $2.3 \mathrm{E}-0 \overline{7}$ & $2.1 \mathrm{E}-02$ & $1.0 \mathrm{E}-03$ \\
\hline TN & $2.4 \mathrm{E}-02$ & $3.3 \mathrm{E}-02$ & $5.9 \mathrm{E}-07$ & $1.2 \mathrm{E}-01$ & $3.5 \mathrm{E}-02$ \\
\hline TX & $1.6 \mathrm{E}-02$ & $2.3 \mathrm{E}-02$ & $2.0 \mathrm{E}-06$ & $1.2 \mathrm{E}-01$ & $1.4 \mathrm{E}-02$ \\
\hline UT & $9.6 \mathrm{E}-03$ & $1.4 \mathrm{E}-02$ & $9.9 \mathrm{E}-08$ & $7.0 \mathrm{E}-02$ & $2.3 \mathrm{E}-03$ \\
\hline WV & $9.5 \mathrm{E}-06$ & $1.3 \mathrm{E}-05$ & $3.3 \mathrm{E}-10$ & $5.6 \mathrm{E}-05$ & $5.5 \mathrm{E}-05$ \\
\hline TOTALS & $2.9 \mathrm{E}-01$ & $4.3 \mathrm{E}-01$ & $1.9 \mathrm{E}-05$ & $1.8 \mathrm{E}+00$ & $2.1 \mathrm{E}-01$ \\
\hline
\end{tabular}

(a) Includes risk from in-transit segments between LLW generators and NTS. There are no intermodal transfers or rail shipments in this configuration. 
Table 5.22. Total Risk ${ }^{(a)}$ by State: Configuration 3 (100\% Truck Through Las Vegas)

\begin{tabular}{|c|c|c|c|c|c|}
\hline \multirow[t]{3}{*}{ State } & \multicolumn{3}{|c|}{ Radiological Fatalities } & \multicolumn{2}{|c|}{ Nonradiological Fatalities } \\
\hline & \multicolumn{2}{|c|}{ Incident-Free Transport } & \multirow{2}{*}{$\begin{array}{c}\text { Accident } \\
\text { Risk } \\
\end{array}$} & & \\
\hline & Crew & Public & & Accidents & Emissions \\
\hline $\mathrm{AZ}$ & $4.1 \mathrm{E}-02$ & $6.2 \mathrm{E}-02$ & $2.8 \mathrm{E}-07$ & $2.4 \mathrm{E}-01$ & $1.1 \mathrm{E}-02$ \\
\hline$\overline{\mathrm{AK}}$ & $1.7 \mathrm{E}-02$ & $2.3 \mathrm{E}-02$ & $4.3 \mathrm{E}-07$ & $5.6 \mathrm{E}-02$ & $2.2 \mathrm{E}-03$ \\
\hline$\overline{\mathrm{CA}}$ & $3.9 \mathrm{E}-03$ & $5.9 \mathrm{E}-03$ & $1.0 \mathrm{E}-07$ & $1.6 \mathrm{E}-02$ & $4.2 \mathrm{E}-03$ \\
\hline $\mathrm{CO}$ & $1.1 \mathrm{E}-02$ & $1.5 \mathrm{E}-02$ & $7.3 \mathrm{E}-07$ & $6.8 \mathrm{E}-02$ & $3.8 \mathrm{E}-03$ \\
\hline ID & $6.7 \mathrm{E}-04$ & $9.8 \mathrm{E}-04$ & $3.3 \mathrm{E}-08$ & $1.5 \mathrm{E}-03$ & $1.8 \mathrm{E}-04$ \\
\hline IL & $8.4 \mathrm{E}-03$ & $1.2 \mathrm{E}-02$ & $3.5 \mathrm{E}-06$ & $3.7 \mathrm{E}-02$ & $6.1 \mathrm{E}-03$ \\
\hline IN & $8.5 \mathrm{E}-03$ & $1.1 \mathrm{E}-02$ & $2.1 \mathrm{E}-06$ & $2.8 \mathrm{E}-02$ & $8.9 \mathrm{E}-03$ \\
\hline$\overline{I A}$ & $4.5 \mathrm{E}-03$ & $6.3 \mathrm{E}-03$ & $1.2 \mathrm{E}-06$ & $2.4 \mathrm{E}-02$ & $3.4 \mathrm{E}-04$ \\
\hline$\overline{K Y}$ & $8.6 \mathrm{E}-05$ & $1.2 \mathrm{E}-04$ & $7.9 \mathrm{E}-09$ & $5.2 \mathrm{E}-04$ & $1.8 \mathrm{E}-04$ \\
\hline MO & $1.2 \mathrm{E}-02$ & $1.6 \mathrm{E}-02$ & $2.0 \mathrm{E}-06$ & $7.2 \mathrm{E}-02$ & $2.1 \mathrm{E}-02$ \\
\hline $\mathrm{NE}$ & $5.0 \mathrm{E}-03$ & $7.6 \mathrm{E}-03$ & $1.7 \mathrm{E}-06$ & $4.1 \mathrm{E}-02$ & $5.0 \mathrm{E}-03$ \\
\hline NV & $2.0 \mathrm{E}-02$ & $3.0 \mathrm{E}-02$ & $5.9 \mathrm{E}-07$ & $6.4 \mathrm{E}-02$ & $7.0 \mathrm{E}-02$ \\
\hline NJ & $9.6 \mathrm{E}-04$ & $1.3 \mathrm{E}-03$ & $1.3 \mathrm{E}-07$ & $3.6 \mathrm{E}-03$ & 5.9E-03 \\
\hline NM & $3.9 \mathrm{E}-02$ & $5.8 \mathrm{E}-02$ & $2.9 \mathrm{E}-07$ & 2.7E-01 & $4.4 \mathrm{E}-02$ \\
\hline NY & $2.2 \mathrm{E}-03$ & $2.8 \mathrm{E}-03$ & $2.7 \mathrm{E}-07$ & $1.3 \mathrm{E}-02$ & $1.1 \mathrm{E}-02$ \\
\hline $\mathrm{OH}$ & $5.5 \mathrm{E}-03$ & $6.7 \mathrm{E}-03$ & $4.5 \mathrm{E}-07$ & $8.9 \mathrm{E}-03$ & $8.5 \mathrm{E}-03$ \\
\hline$\overline{\mathrm{OK}}$ & $3.2 \mathrm{E}-02$ & $4.5 \mathrm{E}-02$ & $2.1 E-06$ & $2.3 \mathrm{E}-01$ & $1.8 \mathrm{E}-02$ \\
\hline PA & $2.9 \mathrm{E}-03$ & $3.9 \mathrm{E}-03$ & 2.3E-07 & $2.1 \mathrm{E}-02$ & $1.0 \mathrm{E}-03$ \\
\hline TN & $2.4 \mathrm{E}-02$ & $3.3 \mathrm{E}-02$ & $5.9 \mathrm{E}-07$ & $1.2 \mathrm{E}-01$ & $3.5 \mathrm{E}-02$ \\
\hline TX & $1.6 \mathrm{E}-02$ & $2.3 \mathrm{E}-02$ & $2.0 \mathrm{E}-06$ & $1.2 \mathrm{E}-01$ & $1.4 \mathrm{E}-02$ \\
\hline UT & $1.2 \mathrm{E}-02$ & $1.8 \mathrm{E}-02$ & $1.9 \mathrm{E}-07$ & $8.5 \mathrm{E}-02$ & $6.6 \mathrm{E}-03$ \\
\hline WV & $9.5 \mathrm{E}-06$ & $1.3 \mathrm{E}-05$ & $3.3 \mathrm{E}-10$ & $5.6 \mathrm{E}-05$ & $5.5 \mathrm{E}-05$ \\
\hline TOTALS & $2.7 \mathrm{E}-01$ & $3.9 \mathrm{E}-01$ & $1.9 \mathrm{E}-05$ & $1.5 \mathrm{E}+00$ & $2.8 \bar{E}-01$ \\
\hline
\end{tabular}

(a) Includes risk from in-transit segments between LLW generators and NTS. There are no intermodal transfers or rail shipments in this configuration. 


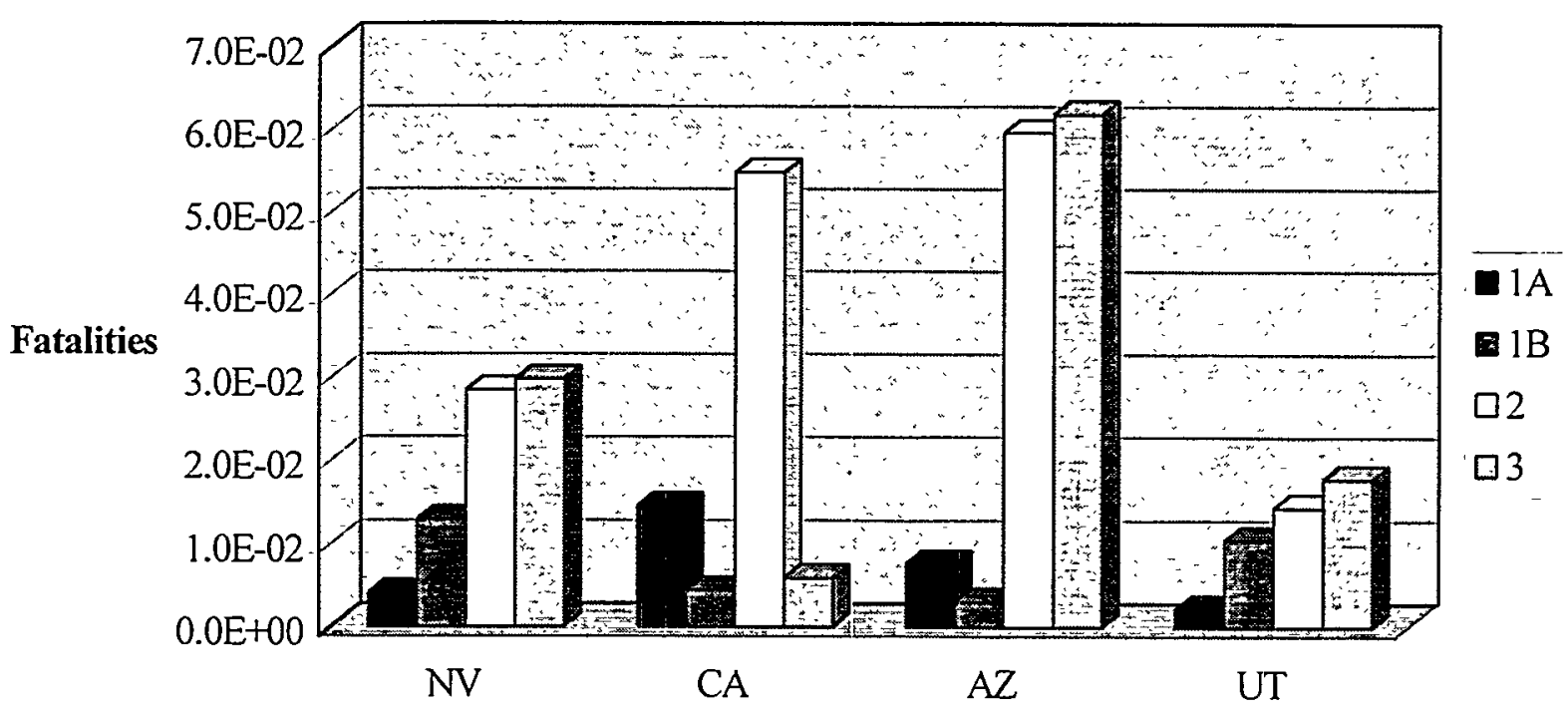

Figure 5.5. Illustration of State-Level Public Radiological Routine Risks

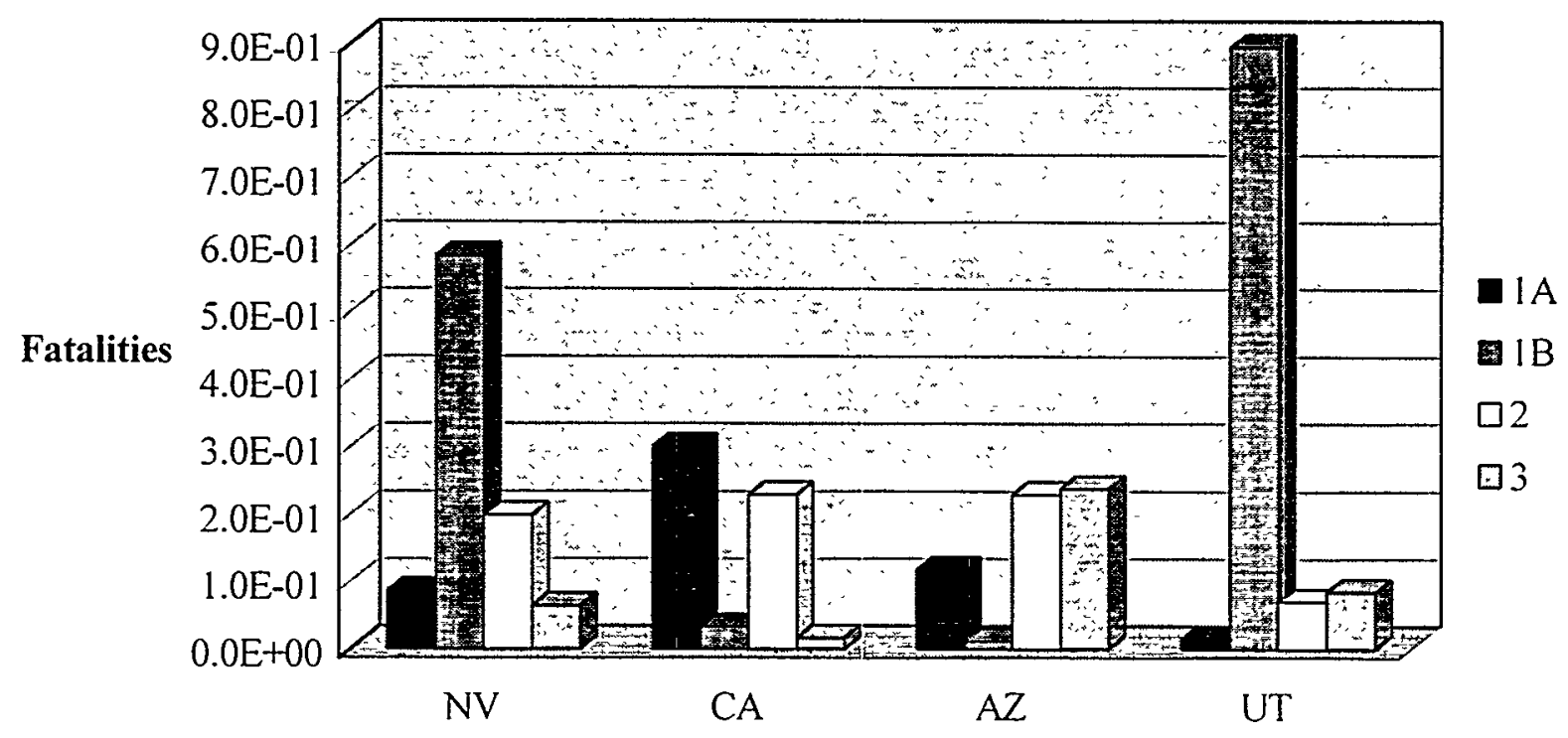

Figure 5.6. Illustration of State-Level Nonradiological Accident Risks 


Risk Perspective
Nonradiological (Pliysical) Accident
Risks
Several comparisons with actual motor
vehicle and truck transport accident risk
measures were developed to put the
nonradiological (physical) accident risk
projections in Tables 5.19 to 5.22 in
perspective. The State of Nevada will be
used as an example. The highest
projected nonradiological fatality estimate
from NTS LLW shipments by truck is for
Configuration 2, truck shipments that
avoid Las Vegas. The projection was 0.2
fatalities over 70 years, or an average of
about 0.003 deaths per year. This can be
compared to about 350 deaths per year
(1996 and 1997 data) from all motor-
vehicle traffic accidents in Nevada
(National Safety Council 1998 ). For
accidents involving heavy combination-
trucks, there were I0 to I2 deaths per year
(1995 and 1996 data) on interstate
highways, primary highways, and other
roads and highways in Nevada (Saricks
and Tompkins 1999 ). Based on these
comparisons, at the state-level, no
significant increases in nonradiological
accident risks are projected to result from
the truck traffic represented by LLW
shipments to NTS for any of the shipping
configuration alternatives.

Figure 5.6 illustrates the distribution of nonradiological accident risks in Nevada and its bordering states for each LLW shipping configuration. In comparing Configuration 2 to Configuration 3 , one can see that the nonradiological accident risks in Configuration 2 are higher in Nevada and California and slightly lower in Utah and Arizona relative to Configuration 3. This redistribution effect arises from the increased truck shipping distances in Nevada and California in Configuration 2 that are required to avoid Las Vegas and Hoover Dam. Nonradiological accident rates are also higher on the less-traveled rural highways in Nevada and California than they are on the interstate highway system and US 95 used in Configuration 3.

In Configuration 1A (Barstow intermodal facility), substantially higher nonradiological accident risks are projected in California and Arizona than in the all-truck configurations. The risks, however, are lower in Nevada and Utah relative to Configurations 2 and 3. The higher risks in California and Arizona result from the both the rail and direct truck shipment mileages increasing in these two states. This is because: 1) the destination for the rail shipments is the Barstow, CA, intermodal facility, 2) direct truck shipments using the southern route across the country are diverted from Hoover Dam and Las Vegas to the route that enters Nevada near Death Valley Junction, and 3) the intermodal truck segments travel over California highways to NTS (see Figure 2.3). The risks are lower in Nevada because truck shipments are diverted from US 93 and US 95 in Nevada to the highway routes in Arizona and California.

Configuration $1 \mathrm{~B}$ results in higher nonradiological accident risks in Nevada than all other configurations. The nonradiological accident risks in Nevada for Configuration 1B are higher than they would be if the present highway route through Las Vegas is used (Configuration 3). This is due to the increased truck shipping distances required to avoid Las Vegas and the relatively long highway segment in Nevada that would be used to move LLW from the Caliente intermodal facility to NTS. Nonradiological accident risks in Utah are also higher for Configuration IB than the others because of the rail shipments that travel through Utah on the way to Caliente, NV, that would otherwise enter the state from the south. The nonradiological accident risks in California and Arizona in Configuration 1B are lower than in Configuration $1 \mathrm{~A}$ because the rail shipments and subsequent intermodal truck shipments would not pass through these two states.

An additional observation about the state-level risk results is that the selection of the intermodal facility redistributes risks from one state to another at distances even farther than the states next to Nevada. It was observed that the risks in the State of Colorado are significantly higher when Caliente is the transfer point than they are when the intermodal transfer facility is located in Barstow. This is because shipments from southern and eastern LLW generators tend to stay farther north when they are destined for Caliente than they do when the shipments are destined for Barstow. Since there are few routing options for rail shipments and a limited set of routing options for highway shipments that avoid Las Vegas, many of the 
shipments had to be redirected northward rather than entering Nevada from the south. This resulted in increased travel through Colorado, as can be seen by comparing Tables 5.19 and 5.20.

This study demonstrates that the shipping configuration where an intermodal facility is located at Barstow, CA (Configuration 1A), is slightly favored over the intermodal facility at Caliente, NV, in terms of the total life-cycle radiological fatalities. The NTS Intermodal EA results indicate that Caliente is the preferred location for the intermodal facility. The most significant difference between these two studies is the assumption in the NTS Intermodal EA that the trucks receive a state inspection at the California/Nevada border. This assumption adds to the incident-free radiological risks of the Barstow intermodal configuration that is not included in the Caliente configuration, since the truck route from Caliente to NTS is entirely within Nevada. Given that there are over 27,000 shipments of LLW to NTS in the high waste volume case, this could be sufficient to drive the results in this study in favor of the Caliente intermodal configuration. There are also likely to be slight differences in highway and rail routes used in the two studies, particularly the selection of southern or northern interstate highways used to deliver the LLW to Nevada and the selection of rail routes.

Another inconsistency between the options favored in this study versus the NTS Intermodal EA is that the nonradiological accident risks in this study are lower in Configuration 3 (all truck through Las Vegas) than in Configuration 1A (intermodal at Barstow). The main difference in the two studies that leads to these conflicting results is the truck accident (fatality) rates used. The NTS Intermodal EA used accident rate data specific to the highway segments under analysis. This study used state-specific accident rates that are a level of detail less sophisticated than the route segment-specific data. Sections of the highway route between Barstow and NTS that avoid Las Vegas appear to have significantly higher fatality rates than the state-specific fatality rates used here. In any event, the difference in nonradiological accident risks between Configurations $\mathrm{IA}$ and 3 is less than the level of uncertainty in the results.

\section{Analytical Conservatisms}

The analytical methods and input parameters used to develop the risk analysis results tend to overpredict or develop conservative estimates of the actual risks of LLW transport. Some of the key sources of conservatism are described below:

- The RADTRAN 4 population distribution model used for incident-free risk calculations assumes a uniform population density out to $0.8 \mathrm{~km}(0.5)$ mi on both sides of the transport link (see Box on page 5.31).

- Shipment dose rates were selected to be high relative to the average dose rate emitted from DOE LLW shipments.

- Accidental releases were assumed to be dispersed in the atmosphere under neutral conditions with low wind speed. Such conditions are unlikely to coincide with an accident, yet no credit is taken for the low likelihood of these conditions.

- The conversion from radiation dose to latent cancer fatalities is conservative, although there is much controversy surrounding the theoretical basis for radiation-induced health effects.

- Stop frequency and duration (stop dose is a major component of incident-free truck doses and lesser component of rail doses) are high for long-distance truck shipments that use a two-person driving team.

- Average truck and rail speeds are very low relative to actual experience. This results in longer exposure times than would actually occur.

In general, the assumptions made in the analytical models and selection of conservative input data lead the authors to believe the predicted risks will be higher than the actual risks of transporting LLW to NTS. 


\subsection{HIGHWAY ROUTING CONSWERATIONS FOR DOE LLW SHIPMENTS TO NTS}

This chapter describes highway routing considerations applicable to DOE LLW shipments to NTS. Routing considerations addressed here include those considered in DOE's transportation planning process as well as highway routing requirements applicable to motor carriers. Note that there are no corresponding routing requirements for rail shipments of LLW or other radioactive materials. This chapter also provides some background information and insights on the highway routing requirements for LLW shipments versus requirements for Highway-Route Controlled Quantities (HRCQ) of radioactive materials, the most visible of which are commercial spent nuclear fuel (SNF) and high-level radioactive waste (HLW) shipments.

\subsection{ROUTING CONSDERATIONS IN DOE'S TRANSPORTATION PLANNING PROCESS}

Two routing-related components of DOE's planning process provide assurance that its transportation activities will be conducted in an environmentally protective manner. They include the environmental analysis required by the National Environmental Policy Act (NEPA) and motor carrier assessments conducted by the DOE's National Transportation Program. Although this report is not part of any NEPA study, traditionally, DOE has applied recommended NEPA analytical methods in most of its transportation planning. Along with motor carrier assessments, this approach has led to DOE's excellent overall record in the transportation of radioactive materials.

\subsubsection{National Environmental Policy Act}

The statutory basis requiring federal agencies to undertake risk assessment in decision making with regard to the transportation of radioactive materials is found in NEPA (see 42 CFR 4321). The cornerstone of NEPA is Section 102(2)(C), which requires that, to the fullest extent possible, all agencies of the Federal Government include in every recommendation or report on proposals for legislation and other major federal actions significantly affecting the environment, a detailed statement by the responsible official on (1) the environmental impact of the proposed action, (2) any adverse environmental effects which cannot be avoided should the proposal be implemented, (3) alternatives to the proposed action, (4) the relationship between the local short-term uses of man's environment and the maintenance and enhancement of the long-term productivity, and (5) any irreversible and irretrievable commitments of resources which would be involved in the proposed action should it be implemented. An agency is required to prepare an EIS whenever a proposed action qualifies as a "major federal action significantly affecting the quality of the human environment." ["Major," as used above in NEPA, reinforces but does not have a meaning independent of "significantly" (see 40 CFR 1508.18).]

The procedures that DOE uses to comply with Section 102(2) of NEPA and the Council on Environmental Quality (CEQ) regulations (40 CFR Parts 1500-1508) are provided in DOE Implementing Procedures (10 CFR 1021). Those procedures are intended to supplement and be used in conjunction with the CEQ regulations. DOE internal requirements and responsibilities for implementing NEPA, the CEQ regulations, and the DOE NEPA Implementing Procedures are established in DOE Order 451.1A. However, no specific federal requirements for conducting transportation risk assessments exist.

Guidance concerning the preparation of transportation risk assessments for DOE NEPA activities is contained in Recommendations for the Preparation of Environmental Assessments and Environmental Impact Statements, commonly called the "Green Book." The following is taken from the Green Book (DOE 1993): 


\section{Transportation Impacts}

When transport of waste or materials of a hazardous or radioactive nature is a necessary part of a proposed action or analyzed alternative, or, more generally, when transport is in any respect a major factor (e.g., transportation of construction materials for a proposed major dam), the environmental impacts of such transport should be analyzed, even when DOE is not responsible for the transportation. Transportation impacts include those from transport to a site, on-site, and from a site, when such activities are reasonably construed as part of the proposed action or analyzed alternative. If not otherwise analyzed, include any necessary loading or unloading activities in the transportation impact analysis.

As with the choice of alternatives, apply a sliding scale approach to the transportation analysis. The nature of the proposed action and analyzed alternative determines whether to describe the transportation impacts qualitatively or to analyze them quantitatively, and what types of potential transportation accidents to consider (see subsection 6.4).

Recommendations

- Analyze all transportation links that are reasonably foreseeable parts of the proposed action or analyzed alternative, such as overload transport, port transfer, and marine transport. If the action contains links that traverse the global commons (e.g., the oceans or outer space), then impacts from such transport should be included in the NEPA analysis; state that the global commons analysis is provided pursuant to Executive Order 12114.

- Do not rely on statements that transportation would be conducted in accordance with all applicable regulations or requirements of the U.S. Department of Energy, The Department of Transportation, the Environmental Protection Agency, the Nuclear Regulatory Commission, or State authorities.

- Evaluate both routine (i.e., incident-free) transport and accidents. (Accidents are discussed in subsection 6.4.) Give special emphasis to public or worker health impacts from exposure to chemicals or radiation.

- Be sure to use defensible estimation methods for assessing the radiological impacts of transportation (such as the most current version of RADTRAN).

- Estimate the annual and total impact of all DOE and non-DOE transportation associated with the use of specific routes (if known) over the term of the proposed action or analyzed alternative, including, for chemical and radiological exposure, the impact on a maximally exposed individual. The impacts of the proposed action related to transportation must be totaled over the duration of the project (e.g., 48 trips per year for 5 years). (Note: This total is not the cumulative impact of transportation impacts from the proposed action and other transportation activities over the same time period in the same area.) 
- In determining the cumulative impact from transportation activities, use available data to estimate, for example, the number of radioactive materials packages that were shipped over a given transportation system over a given period of time.

Although the Green Book guidance provides a.general overview of what a DOE NEPA transportation assessment should include, specific recommendations are not provided concerning specific end-points, methodologies, and input parameters.

More detailed guidance is provided in the Framework for Assessing the Effects of Radioactive Materials Transportation in Department of Energy Documents (DOE 1995a), subsequently referred to as the "Framework." The Framework discusses inclusion of packing and loading/unloading activities if the primary activity addressed by the EA or EIS is transportation. Such activities must be included if they are part of the proposed action. The analysis should consider the number of workers involved, protective equipment employed, and the sequence of events followed during packing or loading/unloading (i.e., time-motion studies), including movement of the material within the facility.

As recommended in the Framework, analysis of transportation activities should cover the shipment mode (e.g., truck or rail), the number of shipments, the number of crew members per shipment, origin and destination site (route definition), stops required along the route, and any necessary intermodal transfers. Incident-free transportation impacts to consider include radiological dose and resultant health effects to the general public and workers (crew and others at stops). Impacts to the public include persons alongside the route (pedestrians or persons living or working on the sides of the route), sharing the route (persons traveling on the same route), and at stops (e.g., rest areas or refueling areas). In addition, impacts to a maximally exposed individual (MEI) along the route (e.g., a person living next to the transport route) should be determined.

The Framework suggests that the focus on radiological effects from accident conditions should be the bounding accident (the most severe reasonably foreseeable accident). Such an accident could be trafficrelated, or due to acts of terrorism or sabotage. Results should be presented for the collectively exposed population and the MEI. Nonradiological effects, such as health effects due to vehicle emissions (e.g., fugitive dust and engine emissions) and hazards from vehicle accidents (e.g., fatalities), should also be addressed.

A draft guidance document, the EMNEPA Technical Guidance Handbook (DOE 1997a), was written to help streamline the DOE NEPA process and has been made available for comment. In the section on transportation assessment, the Framework is referenced and provides the basis for the transportation analysis. For impact assessment, HIGHWAY (Johnson et al. 1993a) and INTERLINE (Johnson et al. 1993b) are recommended as the routing models to use, and RADTRAN 4 (Neuhauser and Kanipe 1992) and RISKIND (Yuan et al. 1995) are recommended as the radiological models to use. Emphasis is also placed on analyzing the effects on traffic and roads (e.g., increased noise, traffic volume) in the immediate vicinity of the origin and destination sites. These latter effects need only be assessed if significant changes in traffic or traffic patterns result from the proposed action(s), and to the degree that they impact the environment.

Early in the history of NEPA document preparation, transportation impacts were addressed on an aggregate route basis using generic, national-average data (such as population distributions and accident rates). Today, a trend has developed toward more route-specific evaluations and the calculational tools used in NEPA documents have been improved to provide this capability. However, for LLW shipments, the routes analyzed in NEPA documents may not be the exact routes used by motor carriers. The carrier may select the exact route used by an LLW shipment after considering such items as trip duration, 
highway construction delays and hazards, inclement weather, availability of services, and traffic congestion. In fact, carriers may use different routes between two points based on current conditions and may even deviate from a planned route based on changes to these conditions. The point is that NEPA documents are somewhat "theoretical" with regard to transportation routing considerations. They attempt to develop bounding estimates of transportation impacts to allow decision-makers to compare alternatives. In this manner, the environmental impacts that form the basis for a Record of Decision are intended to be bounding, regardless of the actual route used by the shipments.

\subsubsection{Motor Carrier Evaluation Program (MCEP)}

DOE's National Transportation Program reports the following on its website:

The U.S. Department of Energy (DOE)'s Motor Carrier Evaluation Program (MCEP) provides $D O E$ and its contractors with a process to assure that only the most highly qualified motor carriers are utilized to transport DOE materials, including hazardous materials (particularly radioactive), hazardous substances, and hazardous and mixed wastes. The MCEP uses the United States Department of Transportation's (DOT) motor carrier safety fitness rating and SafetyNet reports as a basis. The MCEP outlines criteria and guides the transportation manager through an objective process of evaluating a carrier's overall management and operations (i.e., vehicle maintenance programs, drivers qualifications, safety programs, financial stability, emergency response, insurance coverage, freight damage claim procedures and other general data). During Fiscal Year 1994, DOE sites nationwide made 23,937 hazardous material shipments including 5,946 that were radioactive materials.

Since the inception of the MCEP in the spring of 1990, over sixty commercial motor carriers transporting various commodities for the DOE have voluntarily participated in the program. The $M C E P$ has provided DOE and its contractors with sufficient information to more effectively transport its hazardous commodities across the nation's highways in a safe and regulatory compliant manner. This program has helped DOE to maintain its excellent safety record in the transportation of all commodities, especially hazardous and radioactive materials, substances and wastes, during the 1990's.

The MCEP also responds to public concerns surrounding the transportation of hazardous materials, particularly radioactive materials and wastes, by the DOE and its contractors. Representatives of other Federal agencies, state and local governments, Indian tribes, the news media and the public in general have often expressed concern about the safety and capabilities of the motor carriers who transport hazardous materials for the DOE. Much of the concern regarding the qualifications for the motor carriers is centered around the question of the capability of the carrier to effectively transport hazardous materials including radioactive materials, such as spent fuel and low level waste.

As a prudent shipper of hazardous materials, the DOE believes it must take additional precautions to ensure that only the most qualified carriers are utilized for these types of commodities. The DOE views DOT safety requirements as the minimum standard for a motor carrier. The MCEP evaluates the carrier beyond this minimum standard. Through the MCEP the DOE extends its philosophy regarding safety, especially with regards to hazardous and radioactive materials, beyond the site boundaries to cover movement from origin to final destination.

The Motor Carrier Evaluation Program is currently developing a workshop to effectively train the local DOE and contractor traffic managers to perform evaluations of their regional and local 
carriers. The goal of DOE is to utilize only motor carriers that have been successfully evaluated through the TMD Motor Carrier Evaluation Program. DOE continues to refine the MCEP selection criteria and methodology needed to identify quality motor carriers.

The Motor Carrier Evaluation Program has proven itself as an effective "tool" to assist DOE Headquarters and the DOE Operations Offices in their goal of safe and cost effective transportation of hazardous materials over the nation's highways in support of its mission.

\subsection{MOTOR CARRIER REQUIREMENTS}

Title 49 of the Code of Federal Regulations (CFR) 397.101 states:

“... a carrier or any person operating a motor vehicle that contains a Class 7 (radioactive) material, as defined in 49 CFR 172.403, for which placarding is required under 49 CFR part 172 shall:

1. Ensure that the motor vehicle is operated on routes that minimize radiological risk.

2. Consider available information on accident rates, transit time, population density and activities, and the time of day and the day of the week during which transportation will occur to determine the level of radiological risk; ..."

While the Department of Transportation (DOT) has prepared Guidelines for Selecting Preferred Highway Routes for Highway Route Controlled Quantity (HRCQ) Shipments of Radioactive Materials, no such guidance exists for non-HRCQs. Telephone discussions with DOT Research and Special Programs Administration staff confirm that carriers are expected to use their professional judgment in considering "available information on accident rates, transit time, population density and activities, and the time of day and the day of the week during which transportation will occur to determine the level of radiological risk." However, no formal methods or level of rigor are prescribed by DOT, and enforcement of the requirement for non-HRCQ shipments is not a current DOT priority.

A discussion of the origin of the DOT regulations for HRCQ shipments of Class 7 radioactive material may shed light on risk requirements and the motor carrier's approach in addressing these requirements. It begins with understanding packaging. Properly designed, fabricated, and prepared packaging systems are the primary means of ensuring the safe transport of radioactive materials. Packaging systems provide containment of the radioactive materials (i.e., barrier to airborne and waterborne releases to the environment), shielding (barrier to penetrating radiation), and prevention of nuclear criticality. The second key element of transportation safety addressed in DOT regulations is vehicle safety. Vehicle safety includes such items as inspections of the condition of tractors and trailers, braking systems, shipping papers, and drivers. Another element of vehicle safety is shipment placarding. The third key element of transportation safety addressed in DOT regulations is highway routing.

The regulations allow radioactive materials to be shipped in different types of packaging systems, depending on the total radiological hazard of the material being shipped. Most DOE LLW shipments are well below the limits allowable for Type A packaging (for definition of Type A, see 49 CFR 173 Subpart I). The IAEA has determined that the consequences of accidental releases involving Type A quantities or less of radioactive material would be "acceptable, within the principles of radiological protection." Based on this determination, failure of a package containing DOE LLW waste would not produce a catastrophic health consequence. Conversely, severe transportation accidents. involving HRCQs of radioactive material, which are 3000 greater than the Type A packaging limits, could potentially result in serious consequences. For this reason, HRCQs of radioactive material must be shipped in accident-resistant Type B packaging systems (see 49 CFR 173, Subpart I) and special routing considerations are applicable. 
The U.S. DOT considered the overall hazards presented by shipments of Type A quantities of radioactive materials and decided not to impose the requirements for a formal routing evaluation and other restrictions that are applicable to shipments of HRCQs of radioactive material. To manage transportation of DOE LLW according to the requirements for shipping HRCQs of radioactive material would not be necessary or prudent based on the radiological hazard of the shipment. DOT HRCQ requirements do not apply to radioactive materials unless the Type $A$ limits are exceeded by a factor of 3000 . DOE LLW shipments typically contain a fraction of the Type A package limits and are thus approximately 4 orders of magnitude $\left(1 / 10,000^{\text {th }}\right)$ less hazardous than a typical HRCQ shipment. Management per DOT nonHRCQ requirements and NEPA guidelines (discussed in Section 6.1.1) should be assumed to be fully protective. 


\subsection{DISCUSSION OF RESULTS}

This chapter discusses the results of the technical analyses (rail or intermodal capabilities at generator sites, costs, risks, stakeholder issues, and carrier routing/risk evaluation process) and develops insights about the results, including the observed most favorable alternatives. Based on these insights, observations that could help DOE to safely and efficiently manage the risks of LLW transportation to NTS were developed. Discussions about the results from this study are presented in this chapter as a list of questions and answers.

\section{Is it feasible for DOE to encourage LLW generators to ship their waste to NTS by rail? ..}

Based on the survey of DOE Traffic Managers at major LLW generator sites performed in this study, it is technically feasible for all DOE LLW generators to ship by rail. Five of the nine major LLW generator sites surveyed indicated they had direct rail service to their sites. For the other four, it was determined to be feasible, although not necessarily cost-effective, to implement intermodal transportation at the LLW generator site in order to ship the waste to NTS by rail. The cost-effectiveness of intermodal transport at the generator sites is a function of the waste volume to be transported, shipping distance, the costs of necessary upgrades, and the actual rates negotiated with truck and rail carrier companies. However, at no site was it determined that rail service is not feasible, either directly or via an intermodal concept. Similarly, it is feasible for NTS, which is not provided with direct rail access, to receive waste shipped from generator sites by rail via an intermodal transport concept.

\section{Would DOE transportation system life-cycle costs favor the increased use of rail service to transport LLW to NTS?}

Seventy-year life-cycle transportation costs were developed in this study to examine the effects on costs of options that involve use of rail service to ship LLW to NTS. Cost elements included truck and rail carrier costs, intermodal transfer costs, and shipping container procurement costs. With regard to intermodal transportation options, the following general conclusions were derived from the life-cycle cost analysis presented in Chapter 4.

- The life-cycle costs for the intermodal configurations are significantly lower than the all-truck configurations. The increased costs for intermodal transfers and the truck segment from the intermodal facility to NTS is more than offset by the lower costs for rail shipping from LLW generators to the intermodal facility, relative to the all-truck configurations.

- Lower life-cycle costs were estimated for the intermodal configuration in which the Barstow facility is assumed than for the configuration in which Caliente is the intermodal transfer point. This is a small cost difference that is most likely within the uncertainties of the cost estimates. A lower lifecycle cost, however, is real because of the shorter distance between Barstow and NTS relative to the distance between Caliente and NTS. This leads to lower truck transport costs for the Barstow to NTS segment. Rail transport costs to the Barstow facility are higher than Caliente because of longer rail shipping distances to Barstow. However, the lower rail shipping costs to Caliente are more than offset by the higher truck shipping costs for the Caliente to NTS segment. Thus, the Barstow intermodal site is more cost-effective, although the overall differences are relatively small. 


\section{Would there be a significant risk rea'uction associated with the increased use of rail service to transport LLW to NTS?}

Five risk measures were calculated in Chapter 5 of this study of options for DOE's LLW transportation system to NTS. These included radiological routine doses to the public and workers, public radiological accident risks, public nonradiological (physical) accident risks, and public routine exposures to hazardous emissions. The results indicate that a tradeoff exists between routine radiological dose risks and nonradiological (physical) accident risks. Nonradiological accident risks are the highest of the five risk measures examined in this study. The nonradiological accident risks are lowest in the intermodal options and highest for the option in which all LLW is transported by truck via routes that travel through Las Vegas. Radiological routine doses, however, were shown to be highest in the all-truck options and lowest in the intermodal options. Several competing effects are illustrated here:

- The nonradiological (i.e., physical) accident risks calculated for the intermodal configurations are dominated by the rail shipment impacts.

- Traveling on routes that avoid Las Vegas, which is done in Configurations $1 \mathrm{~A}$ and $1 \mathrm{~B}$ (i.e., the intermodal configurations) as well as Configuration 2 (100\% by truck on routes that avoid Las Vegas), reduces radiological routine doses because the shipments would not travel through the densely populated Las Vegas Valley. The intermodal truck segments and direct truck shipments from LLW generators would be diverted to predominantly rural areas of Nevada (Caliente intermodal facility) and California (Barstow intermodal facility) versus traveling through Las Vegas and over Hoover Dam. Although this increases transit times and shipping distances, lower routine doses are calculated because there are fewer people along the rural highways in Nevada than in the Las Vegas Valley.

Therefore, a tradeoff exists between increasing the use of rail shipping to NTS (results in lower radiological dose risks to the public and truck crews, and health effects from routine emissions) and traveling through Las Vegas (results in lower nonradiological accident risks). Although there are no significant health risks for any of the shipping configurations studied here and nonradiological risks are higher than radiological risks, DOT still requires carriers to select routes that minimize radiological risk.

\section{From a DOE-complex perspective, would there be a significant risk reduction associated with transportation configuration alternatives that avoid the Las Vegas Valley and Hoover Dam?}

Similar to the answer given above, a tradeoff exists between nonradiological accident risks and routine radiological dose risks. The all-truck option that avoids Las Vegas was shown to have higher nonradiological accident risks than the all-truck option that travels through Las Vegas on historically used highways. The converse is true for radiological routine dose risks, which are highest for the all-truck configuration that travels through Las Vegas. Again, the sources of this tradeoff are the higher accident rates and longer shipping distances on the highway routes that avoid Las Vegas versus the larger populations exposed to low radiation dose rates emitted from the shipments that travel through Las Vegas. 


\section{From a DOE-complex perspective, would there be a cost penalty associated with transportation configuration alternatives that avoid the Las Vegas Valley and Hoover Dam?}

The life-cycle cost analysis results indicated that life-cycle costs for the all-truck option that avoids Las Vegas is slightly higher than the costs for the all-truck option that travels through Las Vegas. This is due to the longer shipping distances that will become necessary to avoid the routes through Las Vegas. It should be noted that this cost difference is on the order of $10 \%$ of the total life-cycle costs, which is smaller than the uncertainties in the cost estimates. However, since both all-truck configurations were costed using equivalent bases, some difference in cost is expected with the lowest-cost option being the option that travels through Las Vegas.

Overall, the three main observations about transportation costs are given below:

- The life-cycle costs for the intermodal configurations are significantly lower than the all-truck configurations.

- The life-cycle costs for the all-truck option that avoids Las Vegas are slightly higher than the costs for the all-truck option that travels through Las Vegas.

- Life-cycle costs were lower for the intermodal configuration in which the Barstow facility is assumed than for the configuration in which Caliente is the intermodal transfer point.

Based on these observations, transportation costs favor the intermodal options and there are slightly higher costs for using highway routes that avoid Las Vegas.

\section{Would routing/risk assessments performed by carriers to comply with. \\ Department of Transportation highway routing regulations reach the same conclusions as risk assessments performed in support of NEPA documents?}

Chapter 6 of this study compared and contrasted the routing evaluations performed by DOE in support of NEPA documentation and the DOT's routing requirements for LLW shipments as they are implemented by carriers (see 49 CFR 397.101). Basically, it was determined that DOE NEPA documents include transportation risk assessments, including route characterizations, where offsite transport is a part of the proposed action. However, DOE is not required to compare routes, so a "representative" route is typically selected and used as the basis for the impact calculations. This representative route is in no way binding on the carriers for LLW shipments. Carriers are responsible for selecting the actual routes they will use for LLW shipments. Because LLW shipments are far less hazardous than shipments of spent nuclear fuel and high-level waste (examples of highway route controlled quantity [HRCQ] shipments), no formal method exists for selecting highway routes for LLW shipments. Telephone discussions with DOT Research and Special Programs Administration staff confirm that carriers are expected to use their professional judgment in considering the non-HRCQ routing requirements to operate on routes that minimize radiological risk and consider available information on accident rates, transit time, population density and activities, and the time of day and the day of the week during which transportation will occur to determine the level of radiological risk (49 CFR 397.101). However, no formal methods or level of rigor are prescribed by DOT, and enforcement of the requirement for non-HRCQ shipments is not a current DOT priority. 
Which stakeholder issues generally encourage and which issues discourage increased use of rail scenarios? Are these conclusions consistent with the cost and risk analyses performed in this study?

The key stakeholder issue affecting LLW shipments in Nevada is the expressed desire by certain groups to avoid transporting LLW through the Las Vegas Valley and Hoover Dam areas. The possibility of an accident in a densely populated area, as well as the possible effects on tourism and property values, appear to be the drivers for this concern. This desire is not necessarily shared by all stakeholders, particularly those in the rural counties of Nevada, as their perception is that the risks are being transferred from the urban areas to less-represented rural areas. The rural counties point out the generally poor condition of the rural highways, potential lack of timely emergency response to an accident, and effects on property values as their main concerns. Both parties are concerned with the potential precedents that could be set by the LLW shipments for the future shipments of spent nuclear fuel and high-level waste to the proposed repository at Yucca Mountain and with the potential effects of radiation on residents of Nevada near the routes.

The results of the cost and risk evaluations in this study may be used to support either party's position on avoiding Las Vegas. The life-cycle costs generally favor the rail/intermodal shipping configurations (i.e., IA and (B). However, the all-truck configuration that avoids Las Vegas (Configuration 2) is more costly than the all-truck configuration that assumes travel through Las Vegas. The health risk assessment indicated that a tradeoff exists between nonradiological accident risk (higher for the configurations that avoid Las Vegas than the all-truck option that travels though Las Vegas) and radiological dose risk (highest in the configurations that travel though Las Vegas). The intermodal shipping configuration options and the all-truck option that avoids Las Vegas, however, transfer some risk from the highly populated Las Vegas Valley to the less populated rural counties. However, it should be noted that comparing the radiological and nonradiological risks on the same basis requires careful consideration. Nonradiological risks are based on statistically sound empirical data whereas radiological risks are projections that are driven in part by conservative assumptions and data. Although the consensus is that the radiological risk assessment methods used here are bounding and adequate for their intended purpose, empirical data needed to validate the radiation dose and health effects projections is lacking.

For the shipments from LLW generators that were projected to be shipped using rail or intermodal service, rail routes were selected that did not pass through Las Vegas. For example, the rail route from LANL to NTS was routed to the north through Pueblo, Colorado Springs, and eventually Denver, CO, before turning west, even though a more direct route to the west could be used. The more direct westerly route was considered and dismissed because it would travel through the Las Vegas Valley. The route distance in this case was 230 miles longer than the more direct route that would travel through Las Vegas. For the INEEL to Barstow rail shipments, the shipping distance increased by over 400 miles compared to the direct route that would travel through Las Vegas. The INEEL to NTS shipments had to be routed through Reno, NV, and Sacramento, Stockton, and Fresno, CA (although this route avoided the Salt Lake City area as well as Las Vegas). Consequently, from a DOE complex perspective, the Nevada stakeholder desire to avoid Las Vegas and Hoover Dam affects other states and locales as well as Nevada citizens. 


\section{What are the uncertainties that could influence the results of this analysis?}

Uncertainties are important factors to consider when developing conclusions based on the results of this evaluation. The shipping configurations and technical analyses were planned such that differences among alternatives could be observed. The intent was to treat each alternative on an equivalent basis so the differences would be highlighted and the reasons for the differences could be explored and verified. It could be said in some cases that the quantitative differences among alternatives are smaller than the uncertainties in the results, and thus the comparisons are not valid. However, by treating the alternatives on an equivalent basis, the differences that have arisen are "real," although they may be small.

Some of the major sources of uncertainty are described below:

- Waste volume estimates: The waste volume estimates used here are the best available. However, projections over a 70-year time frame are highly uncertain. Data such as these are constantly changing to reflect current technologies and regulatory requirements. As it is, DOE's waste volume data is becoming more and more stable, and should improve as time passes. However, at this time, the LLW generation projections for Environmental Restoration wastes are order-of-magnitude estimates, at best, particularly at the sites where large volumes are projected. This uncertainty has little effect on the comparisons among shipping configuration alternatives as the same waste volumes were used in the calculations for all the alternatives. It could affect the absolute magnitude of the results and the magnitude of the differences among alternatives but would have no effect on which alternative is most favorable.

- Shipping containers: To simplify the analysis, all LLW was assumed to be packaged in 55-gallon drums or boxes and then overpacked in a Seal-Land container for shipment to NTS. This is one source of uncertainty, as this concept is not yet certified for LLW transport. In reality, a number of different packaging systems will be used to transport LLW, including heavily-shielded shipping containers that are much less efficient. This would increase the number of shipments to NTS but would increase the number of shipments in each alternative by the same amount. However, it is not apparent that this uncertainty would affect the quantitative results of each alternative by the same amount. For example, if most of the less-efficient packaging systems are used at a large generator site, more rail shipments would be required in the intermodal alternatives, perhaps skewing the results of the comparisons with the all-truck alternatives. There is no reason to believe this would occur, although there are general differences in waste characteristics among sites (e.g., Fernald's LLW is generally contaminated with uranium whereas another site's LLW may be contaminated by fission products).

- Highway and rail routing evaluations: The best available highway and rail routing information was used to project the routes between LLW generators and NTS. However, as discussed in Chapter 6, actual routes cannot be determined until the time the shipment occurs and may even change after a shipment has departed from the generator's facility (e.g., for severe weather conditions, traffic obstructions, enroute repairs, etc.). The routing evaluations for all alternatives attempted to find the shortest and/or fastest route between the LLW generator and NTS. Shorter or faster routes than those used here may exist. Longer and slower routes than those used here may ultimately be used. Different routes would result in smaller (or larger) impacts. However, the route projections should affect each alternative equally so the comparisons among alternatives should not be affected. This uncertainty could affect the determination of the most favorable alternative. 


\section{What are the uncertainties that could influence the results of this analysis? (Continued)}

- Road conditions: The conditions of the highways on which the shipments are operated could affect accident rates and thus the comparisons among the alternatives. However, the best available data was used for both truck and rail accidents, including state-specific fatality rates and Nevada secondary highway fatality rates, so the differences are judged to be valid. Local conditions in some areas may be more hazardous than conditions in other areas. An analysis at a lower level of resolution (e.g., using mile-by-mile fatality rates versus state-level statistics) may yield a different result. Although mile-by-mile data could be obtained from each corridor state, it would be difficult and costly to perform a DOE complex-wide risk analysis on a mile-by-mile basis. Such an analysis may demonstrate that local risks are higher in some areas than others. Since the state-level statistics used here include the high accident rate areas in the data, DOE complex-wide (aggregate) risks should not be significantly different. Differences may appear in the state-level risk estimates shown in Section 5.3.3. As discussed in that section, differences in results were detected between this study and the NTS Intermodal EA that result from the use of higher accident rates on specific road segments than are reflected in the state-level statistics. However, the differences in risks illustrated in this study are within the level of uncertainty of the analysis, regardless of the data set used to calculate nonradiological accident risks.

- Transportation costs: The transportation costs are based on the best available data and are applied equally to all alternatives. However, actual costs are negotiated with carriers and so the cost estimates used here are uncertain, particularly when considering a 70-yr life-cycle. Even so, the comparisons among alternatives should be valid, even though the quantitative results of each alternative may be higher or lower. One aspect of the costs may affect the comparisons, and that is the relative difference between truck and rail carrier charges. However, reasonable attempts are made in the source documents for the transportation costs to obtain comparable data from both truck and rail carriers. Therefore, the relative differences in cost between truck and rail shipments are judged to provide an adequate basis for comparison.

- Transportation risk modeling: The uncertainties in the transportation risks models and input parameter values are, in general, larger than the differences among the alternatives. For example, the radiation dose rates used in the calculations may be high or low, depending on the radiological characteristics of the LLW being transported. Shipments may move at different speeds, depending on the local road conditions, traffic congestion, construction, etc. However, every attempt was made to evaluate each shipping configuration on an equivalent basis so the comparisons would be valid and differences between alternative would be real, although the absolute magnitudes of the risks may be higher or lower than those given in this report.

- Intermodal facility costs: The costs developed in this study for intermodal transfers are first-order approximations and highly uncertain. It was assumed that carriers would provide intermodal transfer service at or near the shipper's site and near NTS. No significant construction costs were included in the estimates. Should DOE or the carriers have to construct intermodal transfer facilities, the cost estimates for Configurations $1 \mathrm{~A}$ and $1 \mathrm{~B}$ would most likely increase. Other costs were difficult to characterize, such as the costs to provide radiation protection training, security, emergency response training, and other administrative costs that may be necessary to handle LLW shipments. These cost elements were included in the personnel cost estimates that form the basis for the intermodal transfer costs presented in Chapter 4, or at least in rounding of the basic cost estimates to a higher value to account for uncertainties. Consequently, the uncertainties in the intermodal facility cost and risk estimates could affect the observation that the intermodal shipping configurations (1A and $1 \mathrm{~B}$ ) have lower costs than the all-truck configurations ( 2 and 3 ). 


\subsection{REFERENCES}

Biwer, B. M., F. A. Monette, D. J. LePoire, and S. Y. Chen. 1994. "A Comprehensive Transportation Risk Assessment System Based on Isotopic Unit-Consequence Factors," in Waste Management '94 - Working Towards a Cleaner Environment, edited by R. G. Post and M. E. Wacks. Laser Options, Inc., Tucson, Arizona.

Chen, S.Y., Chairman, DOE Transportation Risk Assessment Working Group, 1999, Resource Handbook on DOE Transportation Risk Assessment, Argonne National Laboratory, Argonne, Illinois (Draft Report for Publication).

Feizollahi, F., D. Shropshore, and D. Burton, 1995, Waste Management Facilities Cost Information for the Transportation of Radioactive and Hazardous Materials, INEL/95-0300, Rev. 1., Idaho National Engineering Laboratory, Idaho Falls, Idaho.

Johnson, P.E., D.S. Joy, D.B. Clark, and J.M. Jacobi, 1993a, HIGHWAY 3.1, An Enhanced Transportation Routing Model: Program Description, Methodology, and Revised User's Manual, ORNL/TM-12124, Oak Ridge National Laboratory, Oak Ridge, Tennessee.

Johnson, P.E., D.S. Joy, D.B. Clark, and J.M. Jacobi, 1993b, INTERLINE 5.0, An Expanded Railroad Routing Model: Program Description, Methodology, and Revised User's Manual, ORNL/TM-12090, Oak Ridge National Laboratory, Oak Ridge, Tennessee.

National Center for Health Statistics, 1997, Monthly Vital Statistics Report, Volume 45, No. 11(S)2. Centers for Disease Control and Prevention, Atlanta, Georgia.

National Research Council, Committee on Biological Effects of Ionizing Radiation, 1990, Health Effects of Exposure to Low Levels of Ionizing Radiation (BEIR V). National Academy Press, Washington, D.C.

National Safety Council, 1998. Accident Facts ${ }^{\mathrm{TM}}$, 1998 Edition, Itasca, Illinois.

Neuhauser, K.S., and F.L. Kanipe, 1992, RADTRAN 4, Volume 3: User Guide, SAND89-2370, Sandia National Laboratories, Albuquerque, New Mexico.

Neuhauser, K.S., and F.L. Kanipe, 1995, RADTRAN 4, Volume 2: Technical Manual, SAND89-2370, Sandia National Laboratories, Albuquerque, New Mexico.

Rao, R.K., E.L. Wilmot, and R.E. Luna, 1982, Non-Radiological Impacts of Transporting Radioactive Material, SAND81-1703, TTC-0236, Sandia National Laboratories, Albuquerque, New Mexico.

Saricks, C.L., and T. Kvitek, 1994, Longitudinal Review of State-Level Accident Statistics for Carriers of Interstate Freight, ANL/ESD/TM-68, Argonne National Laboratory, Argonne, Illinois.

Saricks, C.L., and M.M. Tompkins, 1999, State-Level Accident Rates of Surface Freight Transportation: A Reexamination, ANL/ESD/TM-150, Argonne National Laboratory, Argonne, Illinois. 
U.S. Department of Energy, 1988a, External Dose-Rate Conversion Factors for Calculation of Dose to the Public. DOE/EH-0070. Washington, D.C.

U.S. Department of Energy, 1988b, Internal Dose Conversion Factors for Calculation of Dose to the Public. DOE/EH-0071. Washington, D.C.

U.S. Department of Energy, 1994. DOE Handbook: Airborne Release Fractions/Rates and Respirable Fractions for Nonreactor Nuclear Facilities. DOE-HDBK-3010-94. Washington, D.C.

U.S. Department of Energy. 1996, Final Environmental Impact Statement for the Nevada Test Site and Off-Site Locations in the State of Nevada, DOE/EIS-0243, Nevada Operations Office, Las Vegas, Nevada.

U.S. Department of Energy, 1997, Final Waste Management Programmatic Environmental Impact Statement for Managing Treatment, Storage, and Disposal of Radioactive and Hazardous Waste, DOE/EIS-0200-F, Office of Environmental Management, Washington, D.C.

U.S. Department of Energy, 1998a, Intermodal Transportation of Low-level Radioactive Waste to the Nevada Test Site, Preapproval Draft Environmental Assessment, Nevada Operations Office, Las Vegas, Nevada.

U.S. Department of Energy, 1998b, Accelerating Cleanup - Paths to Closure, DOE/EM-0362.

Office of Environmental Management, Washington, D.C.

U.S. Environmental Protection Agency, 1993, Motor Vehicle-Related Air Toxics Study, EPA 420R-93-005, Office of Mobile Sources, Ann Arbor, Michigan

U.S. Nuclear Regulatory Commission, 1977, Final Environmental Statement on the Transportation of Radioactive Material by Air and Other Modes, NUREG-0170, Washington, D.C. 
APPENDIX A

ROUTE DESCRIPTIONS 


$$
\text { 离. }
$$




\section{APPENDIX A ROUTE DESCRIPTIONS}

This appendix presents the route description information from the HIGHWAY and INTERLINE output files. It is organized as follows:

1. Truck Routes from LLW generators to NTS - Through Las Vegas

2. Truck Routes from LLW generators to NTS - Avoid Las Vegas

3. Truck Routes from intermodal facilities to NTS

4. Rail Routes from LLW generators to Barstow

5 . Rail Routes from LLW generators to Caliente

The format for the truck route information is as follows:

\begin{tabular}{|l|l|l|l|l|l|l|l|l|}
\hline $\begin{array}{l}\text { Segment } \\
\text { Length, } \\
\text { miles }\end{array}$ & $\begin{array}{l}\text { Highway } \\
\text { Designa- } \\
\text { tion }\end{array}$ & City & Intersection & State & $\begin{array}{l}\text { Cumula- } \\
\text { tive } \\
\text { distance, } \\
\text { miles }\end{array}$ & $\begin{array}{l}\text { Time to } \\
\text { travel } \\
\text { segment }\end{array}$ & Date & $\begin{array}{l}\text { Clock } \\
\text { time }\end{array}$ \\
\hline
\end{tabular}

The following is an example or a truck route output file to help the reader follow the tables in this appendix.

$\begin{array}{rcllllrrrrr}0.0 & & \text { AMES LAB } & & & \text { IA } & .0 & 0: 00 & 1 / 30 & \text { a } & 8: 47 \\ 3.0 & \text { LOCAL } & \text { AMES SW } & \text { U30 } & \text { LOCL } & \text { IA } & 3.0 & 0: 09 & 1 / 30 & \text { @ } & 8: 56 \\ 4.0 & \text { U30 } & \text { AMES E } & \text { I35 } & \text { XI11 } & \text { IA } & 7.0 & 0: 13 & 1 / 30 & \text { @ } & 9: 01 \\ 25.0 & \text { I35 } & \text { DES MOINES N I235 } & \text { I35 } & \text { IA } & 32.0 & 0: 36 & 1 / 30 & \text { a } & 9: 24\end{array}$

The format for the rail route information is as follows:

\begin{tabular}{|c|c|c|c|c|}
\hline Rail Carrier & $\begin{array}{l}\text { Rail "Node" } \\
\text { designator }\end{array}$ & City & State & $\begin{array}{l}\text { Cumulative } \\
\text { Distance }\end{array}$ \\
\hline IHB & 4170 & -LA GRANGE & IL & 1051. \\
\hline$-\quad-$ & -- & $\ldots-\cdots$ & - & - TRANSFER \\
\hline BNSF & 4170 & -LA GRANGE & IL & 1051 \\
\hline BNSF & 4190 & -AURORA & IL & 1076. \\
\hline
\end{tabular}


TRUCK ROUTES FROM LLW GENERATORS TO NTS - THROUGH LAS VEGAS

From: AMES LAB

to : MERCURY
IA Leaving : $1 / 30 / 99$ at $8: 47$ CST

NV Arriving: $1 / 31 / 99$ at $10: 40$ PST

Routing through:

\begin{tabular}{|c|c|c|c|c|c|c|c|c|c|}
\hline .0 & & AMES LAB & & & IA & .0 & $0: 00$ & $1 / 30$ & $8: 47$ \\
\hline 3.0 LOCAL & & AMES & SW U30 & LOCL & IA & 3.0 & $0: 09$ & $1 / 30 @$ & $8: 56$ \\
\hline $4.0 \cup 30$ & & AMES & E I35 & $x 1.11$ & IA & 7.0 & $0: 13$ & $1 / 30 @$ & 9:01 \\
\hline $25.0 \quad 135$ & & DES MOINES & I235 & I35 & IA & 32.0 & $0: 36$ & $1 / 30$ & $9: 24$ \\
\hline 14.0 I35 & I 80 & DES MOINES & I235 & I35 & IA & 46.0 & $0: 51$ & $1 / 30 \mathrm{C}$ & $9: 39$ \\
\hline $119.0 \quad 180$ & & COUNCIL BLUFFS & SE I29 & I80 & IA & 165.0 & $2: 41$ & $1 / 30$ & 8 \\
\hline $3.0 \mathrm{I} 29$ & I80 & COUNCIL BLUFFS & SW I29 & I80 & IA & 168.0 & $2: 44$ & $1 / 30$ & \\
\hline $354.0 \quad 180$ & & BIG SPRINGS & SW I76 & 180 & NE & 522.0 & $8: 44$ & $1 / 30$ & $16: 31$ \\
\hline $186.0 \quad 176$ & & ARVADA & S $\quad I 70$ & I76 & $\mathrm{CO}$ & 708.0 & $12: 08$ & $1 / 300$ & $19: 55$ \\
\hline $502.0 \quad I 70$ & & COVE FORT & I15 & I70 & UT & 1210.0 & $21: 53$ & $1 / 31$ & $5: 39$ \\
\hline 242.0 I15 & & LAS VEGAS & & & NV & 1452.0 & $26: 09$ & $1 / 310$ & 55 \\
\hline 1.0 U95 & & LAS VEGAS & U95 & U95B & NV & 1453.0 & $26: 10$ & $1 / 310$ & $8: 56$ \\
\hline $7.0 \mathrm{U95BU}$ & & LAS VEGAS & NW U95 & U95B & NV & 1460.0 & $26: 19$ & $1 / 31$ & 9:06 \\
\hline 51.0 U95 & & MERCURY & S U95 & LOCL & NV & 1511.0 & $27: 45$ & $1 / 31$ & \\
\hline $6.0 \mathrm{LOCAL}$ & & MERCURY & & & NV & 1517.0 & $27: 54$ & $1 / 31$ & 10. \\
\hline
\end{tabular}

From: ARGONNE NATL L to : MERCURY

IL Leaving : $1 / 30 / 99$ at $8: 34$ CST

NV Arriving: $1 / 31 / 99$ at $15: 43$ PST

Routing through:

\begin{tabular}{|c|c|c|c|c|c|c|c|c|c|c|}
\hline .0 & & ARGONNE NATL L & & & & IL & .0 & $0: 00$ & $1 / 30 \mathrm{C}$ & $8: 34$ \\
\hline $1.0 \mathrm{LOCAL}$ & & DARIEN & $S$ & I55 & $\times 273$ & IL & 1.0 & $0: 03$ & $1 / 30 \mathrm{C}$ & $8: 37$ \\
\hline 4.0 I55 & & LEMONT & NW & I355 & I55 & IL & 5.0 & $0: 07$ & $1 / 30$ & $8: 41$ \\
\hline $8.01355 \$$ & & DOWNERS GROVE & W & I355 & U34 & IL & 13.0 & $0: 16$ & $1 / 30$ & $8: 50$ \\
\hline $1.0 \cup 34$ & & LISLE & & U34 & S53 & IL & 14.0 & $0: 18$ & $1 / 30$ & $8: 5$ \\
\hline $1.0 \$ 53$ & & LISLE & $\mathrm{N}$ & I88 & S53 & IL & 15.0 & $0: 2$ & $1 / 30$ & \\
\hline 86.0 I88 \$ & TEWT\$ & ROCK FALLS & SE & I88 & $\times 44$ & IL & 101.0 & $1: 53$ & $1 / 30$ & $10: 27$ \\
\hline 44.0 I88 & & RAPIDS CITY & S & I80 & I88 & IL & 145.0 & $2: 41$ & $1 / 30$ & 11. \\
\hline 173.0 I 80 & & DES MOINES & $\mathrm{N}$ & I235 & I35 & IA & 318.0 & $5: 53$ & $1 / 30$ & \\
\hline 14.0 I35 & I80 & DES MOINES & W & I235 & I35 & IA & 332.0 & $6: 08$ & $1 / 30$ & 1 \\
\hline 119.0 I80 & & COUNCIL BLUFFS & SE & I29 & I80 & IA & 451.0 & $7: 58$ & $1 / 30$ & 16: \\
\hline 3.0129 & I80 & COUNCIL BLUFFS & SW & I 29 & I80 & IA & 454.0 & $8: 01$ & $1 / 30$ & $16:$ \\
\hline $354.0 \mathrm{I} 80$ & & BIG SPRINGS & SW & I76 & I80 & NE & 808.0 & $14: 30$ & $1 / 30$ & $22: 04$ \\
\hline $186.0 \quad 176$ & & ARVADA & S & 170 & I76 & $\mathrm{CO}$ & 994.0 & 17: & $1 / 31$ & \\
\hline $502.0 \quad I 70$ & & COVE FORT & $w$ & I15 & I70 & UT & 1496.0 & $27: 39$ & $1 / 31$ & 11: \\
\hline 242.0 I15 & & LAS VEGAS & & & & NV & 1738.0 & $31: 55$ & $1 / 31$ & $14: 28$ \\
\hline 1.0 U95 & & LAS VEGAS & W & U95 & U95B & NV & 1739.0 & 31: & $1 / 31$ & \\
\hline $7.0 \mathrm{l}$ & & LAS VEGAS & NW & U95 & U95B & NV & 1746.0 & $32: 06$ & $1 / 31$ & \\
\hline 51.0 U95 & & MERCURY & S & U95 & LOCL & NV & 1797.0 & 33:01 & $1 / 31$ & $15: 34$ \\
\hline $6.0 \mathrm{~L}$ & & MERCURY & & & & NV & 1803.0 & $33: 10$ & & \\
\hline
\end{tabular}


From: BROOKHAVEN LAB

to : MERCURY
NY Leaving : $1 / 30 / 99$ at $8: 32$ EST

NV Arriving: 2/01/99 at 10:10 PST

Routing through:

\begin{tabular}{|c|c|c|c|c|c|c|c|c|c|c|}
\hline .0 & & BROOKHAVEN LAB & & & & NY & .0 & $0: 00$ & $1 / 30$ & $8: 32$ \\
\hline $1.0 \mathrm{LOCAL}$ & & YAPHANK & NE & C46 & LOCL & NY & 1.0 & $0: 02$ & $1 / 30 @$ & $8: 34$ \\
\hline $2.0 \mathrm{C} 46$ & & UPTON & SW & I495 & $x 68$ & NY & 3.0 & $0: 04$ & $1 / 30$ & $8: 36$ \\
\hline $49.0 \quad I 495$ & & LITTLE NECK & S & I 495 & $\times 30$ & NY & 52.0 & $0: 58$ & $1 / 30$ @ & $9: 30$ \\
\hline 4.0 TCIP & & BAYSIDE & NW & I 295 & TCIP & NY & 56.0 & $1: 03$ & $1 / 30 @$ & $9: 34$ \\
\hline 3.0 I295\# & & LOCUST POINT & & I295 & I695 & NY & 59.0 & 1:06 & $1 / 30 @$ & $9: 38$ \\
\hline 1.01295 & & BRONX & SE & I678 & I95 & NY & 60.0 & 1:07 & $1 / 30 @$ & $9: 39$ \\
\hline 1.0195 & I278 & BRONX & $E$ & I278 & 195 & NY & 61.0 & $1: 09$ & $1 / 30 @$ & $9: 40$ \\
\hline 7.0195 & & G W BRIDGE & $E$ & 195 & $X 1 A$ & NY & 68.0 & $1: 20$ & 1/30@ & $9: 51$ \\
\hline $1.0195 \#$ & & FT LEE & NE & TPAL & 195 & NJ & 69.0 & $1: 26$ & $1 / 30 @$ & $9: 57$ \\
\hline 4.0195 & & BOGOTA & SE & 180 & I95 & NJ & 73.0 & $1: 30$ & $1 / 300$ & $10: 02$ \\
\hline $64.0 I 80$ & & PAHAQUARRY & $S$ & 180 & X1 & NJ & 137.0 & $2: 40$ & $1 / 30$ a & $11: 11$ \\
\hline 2.0 I80 \# & & E STROUDSBURG & $E$ & 180 & $\times 52$ & PA & 139.0 & $2: 43$ & $1 / 30 @$ & $1: 14$ \\
\hline 330.0 I80 & & NORTH JACKSON & NE & I76 & I80 & $\mathrm{OH}$ & 469.0 & $9: 43$ & 1/30@ & $18: 14$ \\
\hline $74.0 I 80 \$$ & & ELYRIA & NW & I80 & 190 & $\mathrm{OH}$ & 543.0 & $11: 04$ & $1 / 30$ a & $19: 35$ \\
\hline $281.0180 \$$ & $190 \$$ & PORTAGE & $W$ & I80 & I90 & IN & 824.0 & $16: 27$ & 1/31@ & $1: 58$ \\
\hline 1.0180 & & LAKE STATION & NE & I80 & I94 & IN & 825.0 & $16: 28$ & $1 / 31$ a & $1: 59$ \\
\hline $19.0 \quad I 80$ & I94 & LANSING & $W$ & I294 & I94 & IL & 844.0 & $16: 49$ & 1/31 @ & $2: 20$ \\
\hline $5.0 \mathrm{I} 294 \$$ & I80\$ & HOMEWOOD & $N W$ & I294 & 180 & IL & 849.0 & $16: 54$ & $1 / 31 @$ & $2: 25$ \\
\hline 326.0 I80 & & DES MOINES & $N$ & 1235 & I35 & IA & 1175.0 & $23: 22$ & $1 / 310$ & $8: 53$ \\
\hline $14.0 \mathrm{I} 35$ & I80 & DES MOINES & W & I235 & I35 & IA & 1189.0 & $23: 37$ & 1/31@ & $9: 08$ \\
\hline $119.0 \mathrm{I} 80$ & & COUNCIL BLUFFS & SE & I29 & 180 & $I A$ & 1308.0 & $25: 27$ & $1 / 31$ & $10: 58$ \\
\hline 3.0129 & I80 & COUNCIL BLUFFS & SW & I29 & I80 & IA & 1311.0 & $25: 30$ & $1 / 31$ & $11: 01$ \\
\hline $354.0 \quad I 80$ & & BIG SPRINGS & SW & I76 & I80 & NE & 1665.0 & $32: 00$ & 1/31@ & $16: 31$ \\
\hline 186.0176 & & ARVADA & S & 170 & 176 & $\mathrm{CO}$ & 1851.0 & $34: 54$ & $1 / 31 @$ & $19: 25$ \\
\hline $502.0 \quad 170$ & & COVE FORT & $W$ & I15 & 170 & UT & 2353.0 & $44: 39$ & $2 / 01$ & $5: 09$ \\
\hline $242.0 \mathrm{I} 15$ & & LAS VEGAS & & & & NV & 2595.0 & $48: 54$ & 2/01 @ & $8: 25$ \\
\hline 1.0 U95 & & LAS VEGAS & $W$ & U95 & U95B & NV & 2596.0 & $48: 56$ & 2/01 a & $8: 26$ \\
\hline 7.0 U95BU & & LAS VEGAS & NW & U95 & U95B & NV & 2603.0 & $49: 35$ & 2/01 a & $9: 05$ \\
\hline $51.0 \cup 95$ & & MERCURY & $S$ & U95 & LOCL & NV & 2654.0 & $50: 31$ & 2/01 a & $10: 01$ \\
\hline 6.0 LOCAL & & MERCURY & & & & NV & 2660.0 & $50: 40$ & 2/01@ & $10: 10$ \\
\hline
\end{tabular}

From: COLUMBUS to : MERCURY

NE I670 I71 OH Leaving: $1 / 30 / 99$ at $8: 36$ EST NV Arriving: $1 / 31 / 99$ at $21: 40$ PST

Routing through:

\begin{tabular}{|c|c|c|c|c|c|c|c|c|}
\hline .0 & & COLUMBUS & NE I670 & I71 & $\mathrm{OH}$ & 0 & $0: 00$ & 1/30 @ \\
\hline $4.0 \quad I 670$ & & COLUMBUS & W I 670 & I70 & $\mathrm{OH}$ & 4.0 & & $1 / 30$ a \\
\hline $169.0 \quad I 70$ & & INDIANAPOLIS & NE I65 & I70 & IN & 173.0 & $3: 03$ & $1 / 30 @ 11: 39$ \\
\hline $2.0 \mathrm{I} 65$ & I70 & INDIANAPOLIS & SE I65 & I70 & IN & 175.0 & $3: 0$ & $1 /$ \\
\hline 38.0 I70 & & TEUTOPOLIS & NW I57 & I70 & IL & 313.0 & $6: 01$ & $1 / 30$ \\
\hline 6.0 I57 & 170 & EFFINGHAM & SW I57 & I70 & IL & 319.0 & $6: 08$ & $15: 43$ \\
\hline $77.0 \quad 170$ & & EDWARDSVILLLE & SE I270 & I55 & IL & 396.0 & $7: 32$ & $17: 07$ \\
\hline
\end{tabular}




\begin{tabular}{|c|c|c|}
\hline $20.0 I 55$ & I70 & ST LOUIS \\
\hline 1.0155 & & ST LOUIS \\
\hline $290.0 \quad I 44$ & & JOPLIN \\
\hline $17.0 \mathrm{I} 44 \$$ & & MIAMI \\
\hline $72.0 I 44 \$$ & TWRT\$ & CATOOSA \\
\hline $200 \quad 144$ & & OAKHURST \\
\hline $86.0 I 44 \$$ & TTRT\$ & EDMOND \\
\hline $5.0 I 35$ & I 44 & OKLAHOMA CITY \\
\hline $10.0 \mathrm{I} 44$ & & OKLAHOMA CITY \\
\hline $1004.0 \quad 140$ & & KINGMAN \\
\hline 83.0 U93 & & ALUNITE \\
\hline $22.0 \cup 93$ & U95 & LAS VEGAS \\
\hline 1.0 U95 & & LAS VEGAS \\
\hline 7.0 U95BU & & LAS VEGAS \\
\hline 51.0 U95 & & MERCURY \\
\hline $6.0 \mathrm{LOCAL}$ & & MERCURY \\
\hline
\end{tabular}

\begin{tabular}{|c|c|c|c|c|c|c|}
\hline & I55 & I 64 & MO & 416.0 & $7: 54$ & $1 / 30$ @ $17: 29$ \\
\hline S & I 44 & I55 & MO & 417.0 & $7: 55$ & $1 / 30$ @ $17: 31$ \\
\hline SW & I44 & $X 1$ & MO & 707.0 & $12: 57$ & $1 / 30 @ 22: 32$ \\
\hline$E$ & I44 & X313 & OK & 724.0 & $13: 12$ & $1 / 30 @ 22: 47$ \\
\hline S & I 44 & $\times 241$ & OK & 796.0 & $14: 49$ & $1 / 31$ @ $0: 24$ \\
\hline$E$ & I44 & $\times 221$ & OK & 816.0 & $15: 09$ & $1 / 31$ \\
\hline SE & I35 & I 44 & OK & 902.0 & $16: 29$ & $1 / 31 @$ \\
\hline NE & I35 & I 44 & OK & 907.0 & $16: 34$ & $1 / 310$ \\
\hline W & I40 & I 44 & OK & 917.0 & $16: 45$ & 1/31@ \\
\hline \multirow[t]{3}{*}{ NW } & I 40 & $\times 48$ & $A Z$ & 1921.0 & $34: 17$ & $1 / 31 @ 18: 52$ \\
\hline & \multirow[t]{2}{*}{ U93 } & U95 & NV & 2004.0 & $36: 26$ & $1 / 31$ @ 20:01 \\
\hline & & & NV & 2026.0 & $36: 51$ & $1 / 31$ a $20: 25$ \\
\hline W & U95 & U95B & NV & 2027.0 & $36: 52$ & $1 / 31 @ 20: 26$ \\
\hline NW & U95 & U95B & NV & 2034.0 & $37: 01$ & $1 / 31$ @ $20: 36$ \\
\hline & U95 & LOCL & NV & 2085.0 & $37: 57$ & $1 / 31$ a $21: 31$ \\
\hline & & & NV & 2091.0 & $38: 06$ & $1 / 31 @ 21: 40$ \\
\hline
\end{tabular}

From: CANOGA PARK

to : MERCURY
S27 LOCL CA Leaving: 1/30/99 at 9:04 PST

NV Arriving: $1 / 30 / 99$ at $16: 15$ PST

Routing through:

\begin{tabular}{|c|c|c|c|c|c|c|c|c|c|}
\hline .0 & CANOGA PARK & & S27 & LOCL & CA & .0 & $0: 00$ & $1 / 30 @$ & $9: 04$ \\
\hline $3.0 \quad 527$ & WOODLAND HILLS & & U101 & S27 & $C A$ & 3.0 & $0: 04$ & $1 / 30$ & $9: 08$ \\
\hline 25.0 U101 & LOS ANGELES & & I10 & I5 & $\mathrm{CA}$ & 28.0 & $0: 31$ & $1 / 30 @$ & $9: 36$ \\
\hline $41.0 \quad \mathrm{I} 10$ & ONTARIO & $E$ & I10 & I15 & $C A$ & 69.0 & $1: 16$ & $1 / 30 a$ & $10: 20$ \\
\hline $228.0 \mathrm{I} 15$ & LAS VEGAS & & & & NV & 297.0 & $5: 56$ & $1 / 30$ & $15: 00$ \\
\hline 1.0 U95 & LAS VEGAS & $W$ & U95 & U95B & NV & 298.0 & $5: 57$ & $1 / 300$ & $15: 01$ \\
\hline 7.0 U95BU & LAS VEGAS & $\mathrm{NW}$ & U95 & U95B & NV & 305.0 & $6: 06$ & $1 / 30$ & $15: 10$ \\
\hline 51.0 บ95 & MERCURY & S & U95 & LOCL & NV & 356.0 & $7: 02$ & $1 / 30$ & $16: 06$ \\
\hline $6.0 \mathrm{LOCAL}$ & MERCURY & & & & NV & 362.0 & $7 \cdot 11$ & $1 / 30 @$ & $16: 15$ \\
\hline
\end{tabular}

From: FERNALD PLANT

to : MERCURY
$\mathrm{OH} \quad$ Leaving : $1 / 30 / 99$ at 8:23 EST

NV Arriving: $1 / 31 / 99$ at 20:03 PST

Routing through:

\begin{tabular}{|c|c|c|c|c|c|c|c|c|c|c|c|}
\hline .0 & & & FERNALD PLANT & & & & $\mathrm{OH}$ & .0 & $0: 00$ & 1/30@ & $8: 23$ \\
\hline 7.0 & S128 & & MIAMITOWN & $S$ & I74 & $x 7$ & $\mathrm{OH}$ & 7.0 & $0: 11$ & $1 / 30 @$ & $8: 34$ \\
\hline 2.0 & I 275 & 174 & HARRISON & SE & I275 & I74 & $\mathrm{OH}$ & 9.0 & $0: 13$ & $1 / 30 @$ & $8: 36$ \\
\hline 81.0 & 174 & & INDIANAPOLIS & SE & I465 & I74 & IN & 90.0 & $1: 34$ & $1 / 30 @$ & $9: 57$ \\
\hline 14.0 & I 465 & I74 & INDIANAPOLIS & SW & I 465 & I70 & IN & 104.0 & $1: 49$ & $1 / 30$ a & $10: 12$ \\
\hline 131.0 & 170 & & TEUTOPOLIS & $\mathrm{NW}$ & I57 & I70 & IL & 235.0 & $4: 06$ & 1/30@ & $13: 29$ \\
\hline 6.0 & I57 & I70 & EFFINGHAM & SW & I57 & 170 & IL & 241.0 & $4: 43$ & $1 / 30$ a & $14: 06$ \\
\hline 77.0 & 170 & & EDWARDSVILLE & SE & I 270 & I55 & IL & 318.0 & $6: 07$ & $1 / 30 @$ & $15: 30$ \\
\hline 20.0 & I55 & 170 & ST LOUIS & & I55 & I64 & MO & 338.0 & $6: 29$ & $1 / 30 @$ & $15: 52$ \\
\hline 1.0 & I55 & & ST LOUIS & $S$ & I44 & I55 & MO & 339.0 & $6: 30$ & 1/30@ & $15: 53$ \\
\hline 290.0 & I44 & & JOPLIN & SW & I44 & $\mathrm{X} 1$ & MO & 629.0 & $11: 32$ & $1 / 30 @$ & $20: 54$ \\
\hline 17.0 & I $44 \$$ & & MIAMI & $E$ & I44 & $x 313$ & OK & 646.0 & $11: 47$ & $1 / 30 @$ & $21: 10$ \\
\hline
\end{tabular}




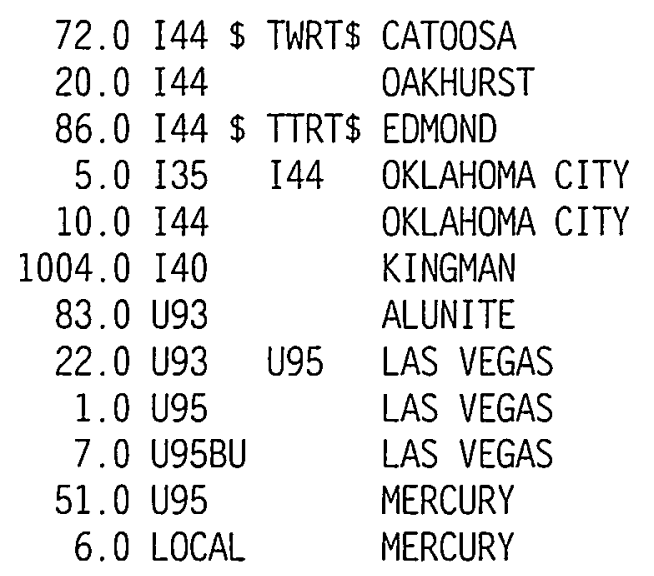

From: GE VALLECITOS

to : MERCURY

\begin{tabular}{|c|c|c|c|c|c|c|}
\hline S & I44 & $\times 241$ & OK & 718.0 & $12: 54$ & $1 / 30 @ 22: 16$ \\
\hline E & I44 & $\times 221$ & OK & 738.0 & $13: 44$ & $1 / 30 @ 23: 06$ \\
\hline SE & I35 & I44 & OK & 824.0 & $15: 04$ & $1 / 31 @ 0: 27$ \\
\hline$N E$ & I35 & I44 & OK & 829.0 & $15: 10$ & $1 / 31 @$ \\
\hline W & I40 & I44 & OK & 839.0 & $15: 20$ & 1/31@ \\
\hline \multirow[t]{3}{*}{ NW } & I40 & $\times 48$ & $A Z$ & 1843.0 & $32: 52$ & $1 / 31$ a $17: 14$ \\
\hline & U93 & U95 & NV & 1926.0 & $34: 31$ & $1 / 31$ @ $17: 53$ \\
\hline & & & NV & 1948.0 & $34: 56$ & $1 / 31$ @ $18: 18$ \\
\hline W & U95 & U95B & NV & 1949.0 & $34: 57$ & $1 / 31$ a $18: 19$ \\
\hline $\mathrm{NW}$ & U95 & U95B & NV & 1956.0 & $35: 06$ & $1 / 31$ @ $18: 28$ \\
\hline \multirow[t]{2}{*}{$S$} & U95 & LOCL & NV & 2007.0 & $36: 32$ & $1 / 31$ @ $19: 5$ \\
\hline & & & NV & 2013.0 & $36: 41$ & 1/31@ @20:0 \\
\hline
\end{tabular}

CA Leaving : $1 / 30 / 99$ at 9:05 PST

NV Arriving: $1 / 30 / 99$ at $21: 33$ PST

Routing through:

\begin{tabular}{|c|c|c|c|c|c|c|c|c|c|c|}
\hline .0 & & GE VALLECITOS & & & & $C A$ & .0 & $0: 00$ & $1 / 30$ & $9: 05$ \\
\hline $10.0 \mathrm{~S} 84$ & & LIVERMORE & NE & I580 & S84 & CA & 10.0 & $0: 14$ & $1 / 30$ & $9: 19$ \\
\hline $26.0 \quad$ I580 & & VERNALIS & $W$ & I5 & I580 & CA & 36.0 & $0: 42$ & $1 / 30$ & $9: 47$ \\
\hline 196.0 I5 & & STOCKDALE HWY & $W$ & I5 & LOCL & $\mathrm{CA}$ & 232.0 & $4: 46$ & $1 / 30$ & $13: 51$ \\
\hline $17.0 \mathrm{LOCAL}$ & & BAKERSFIELD & SW & S58 & S99 & $C A$ & 249.0 & $5: 15$ & $1 / 30$ & $14: 20$ \\
\hline $61.0 S 58$ & & MOJAVE & $N$ & S14 & S58 & $\mathrm{CA}$ & 310.0 & $6: 22$ & $1 / 30$ & $15: 27$ \\
\hline $1.0 \mathrm{S14}$ & S58 & MOJAVE & & S14 & S58 & $C A$ & 311.0 & $6: 23$ & $1 / 30$ & $15: 28$ \\
\hline $71.0 \mathrm{S58}$ & & BARSTOW & $E$ & $\mathrm{I} 15$ & S58 & $\mathrm{CA}$ & 382.0 & $7: 59$ & $1 / 30$ & $17: 04$ \\
\hline 151.0 I15 & & LAS VEGAS & & & & NV & 533.0 & $11: 13$ & $1 / 30$ & $20: 17$ \\
\hline 1.0 U95 & & LAS VEGAS & $W$ & U95 & U95B & NV & 534.0 & $11: 14$ & $1 / 30$ & $20: 19$ \\
\hline 7.0 U95BU & & LAS VEGAS & NW & U95 & U95B & NV & 541.0 & $11: 23$ & $1 / 30$ & $20: 28$ \\
\hline 51.0 U95 & & MERCURY & S & U95 & LOCL & NV & 592.0 & $12: 19$ & $1 / 30$ & a $21: 24$ \\
\hline $6.0 \mathrm{LOCAL}$ & & MERCURY & & & & NV & 598.0 & $12: 28$ & $1 / 30$ & $21: 33$ \\
\hline
\end{tabular}

From: GRAND JCT

to : MERCURY
U50 U6
Leaving : $1 / 30 / 99$ at $8: 48$ MST

Arriving: $1 / 30 / 99$ at $18: 10$ PST

Routing through:

\begin{tabular}{|c|c|c|}
\hline .0 & & GRAND JCT \\
\hline 6.0 U50 & U6 & GRAND JCT \\
\hline $258.0 \quad 170$ & & COVE FORT \\
\hline $242.0 \mathrm{I} 15$ & & LAS VEGAS \\
\hline 1.0 U95 & & LAS VEGAS \\
\hline 7.0 U95BU & & LAS VEGA \\
\hline 51.0 US & & MERCURY \\
\hline $6.0 \mathrm{~L}$ & & \\
\hline
\end{tabular}

U50 U6 CO

NW I70 X26 C0

W I15 I70 UT

W U95 U95B NV

NW U95 U95B NV

S U95 LOCL NV

$\begin{array}{rrrr}.0 & 0: 00 & 1 / 30 @ 0 \text { } & 8: 48 \\ 6.0 & 0: 07 & 1 / 30 \text { a } & 8: 55 \\ 264.0 & 4: 50 & 1 / 30 \text { a } 13: 39 \\ 506.0 & 9: 06 & 1 / 30 \text { a } 16: 54 \\ 507.0 & .9: 07 & 1 / 30 \text { a } 16: 55 \\ 514.0 & 9: 17 & 1 / 30 \text { a } 17: 05 \\ 565.0 & 10: 13 & 1 / 30 @ 18: 01 \\ 571.0 & 10: 22 & 1 / 30 \text { a } 18: 10\end{array}$


From: ID NATL ENG LAB U20 LOCL ID Leaving : 1/30/99 at 8:33 MST to : MERCURY NV Arriving: $1 / 30 / 99$ at 20:05 PST

Routing through:

\begin{tabular}{|c|c|c|c|c|c|c|c|c|c|}
\hline .0 & & ID NATL ENG LAE & & U20 & LOCL & & .0 & $0: 00$ & $1 / 30 @ 8: 33$ \\
\hline $4.0 \mathrm{U} 20$ & U26 & ATOMIC CITY & NW & U20 & U26 & ID & 4.0 & $0: 05$ & $1 / 30$ \\
\hline $36.0 \mathrm{U} 26$ & & BLACKFOOT & NW & I15 & $\times 92$ & ID & 40.0 & $0: 48$ & $1 / 30$ a \\
\hline $112.0 \mathrm{I} 15$ & & TREMONTON & W & I15 & I84 & UT & 152.0 & $2: 31$ & $1 / 30 @ 11: 04$ \\
\hline $39.0 \mathrm{I} 15$ & I84 & OGDEN & S & I15 & I84 & UT & 191.0 & $3: 09$ & $1 / 30 @ 11: 42$ \\
\hline $32.0 \quad \mathrm{I} 15$ & & SALT LAKE CITY & W & I15 & I80 & UT & 223.0 & $3: 43$ & 1/30 @ 12: \\
\hline $4.0 \quad 115$ & I80 & SALT LAKE CITY & $s$ & I15 & I 80 & UT & 227.0 & $3: 47$ & $1 / 30 @ 12: 20$ \\
\hline 417.0 I15 & & LAS VEGAS & & & & NV & 644.0 & $11: 17$ & $1 / 30 @ 18: 50$ \\
\hline 1.0 U95 & & LAS VEGAS & W & U95 & U95B & NV & 645.0 & $11: 18$ & $1 / 30$ a $18: 51$ \\
\hline 7.0 U95BU & & LAS VEGAS & $\mathrm{NW}$ & U95 & U95B & NV & 652.0 & $11: 28$ & $1 / 30 @ 19$ \\
\hline 51.0 U95 & & MERCURY & S & U95 & LOCL & NV & 703.0 & $12: 23$ & $1 / 30 @ 19$ \\
\hline $6.0 \mathrm{LOCAL}$ & & MERCURY & & & & NV & 709.0 & $12: 32$ & $1 / 30 @ 20: 05$ \\
\hline
\end{tabular}

From: SANDIA NATL LBS to : MERCURY
NM Leaving : $1 / 30 / 99$ at $8: 38$ MST

NV Arriving: $1 / 30 / 99$ at 19:23 PST

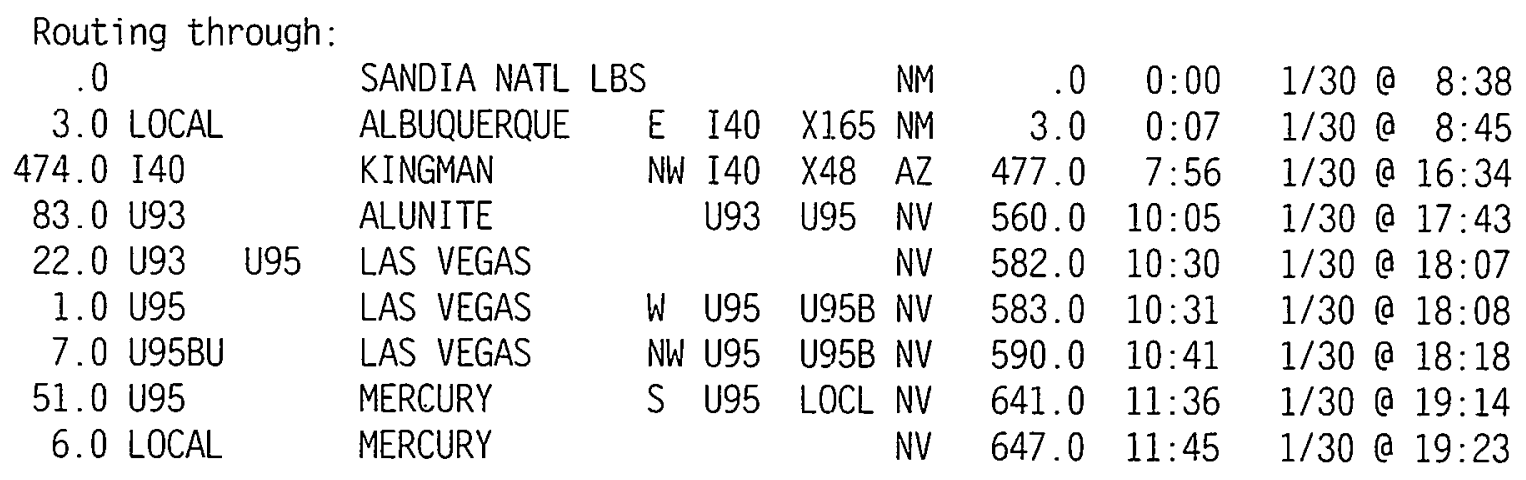

From: KAPL-KNOLLS

to : MERCURY
NY Leaving : $1 / 30 / 99$ at $8: 37$ EST

NV Arriving: $2 / 01 / 99$ at $8: 43$ PST

Routing through:

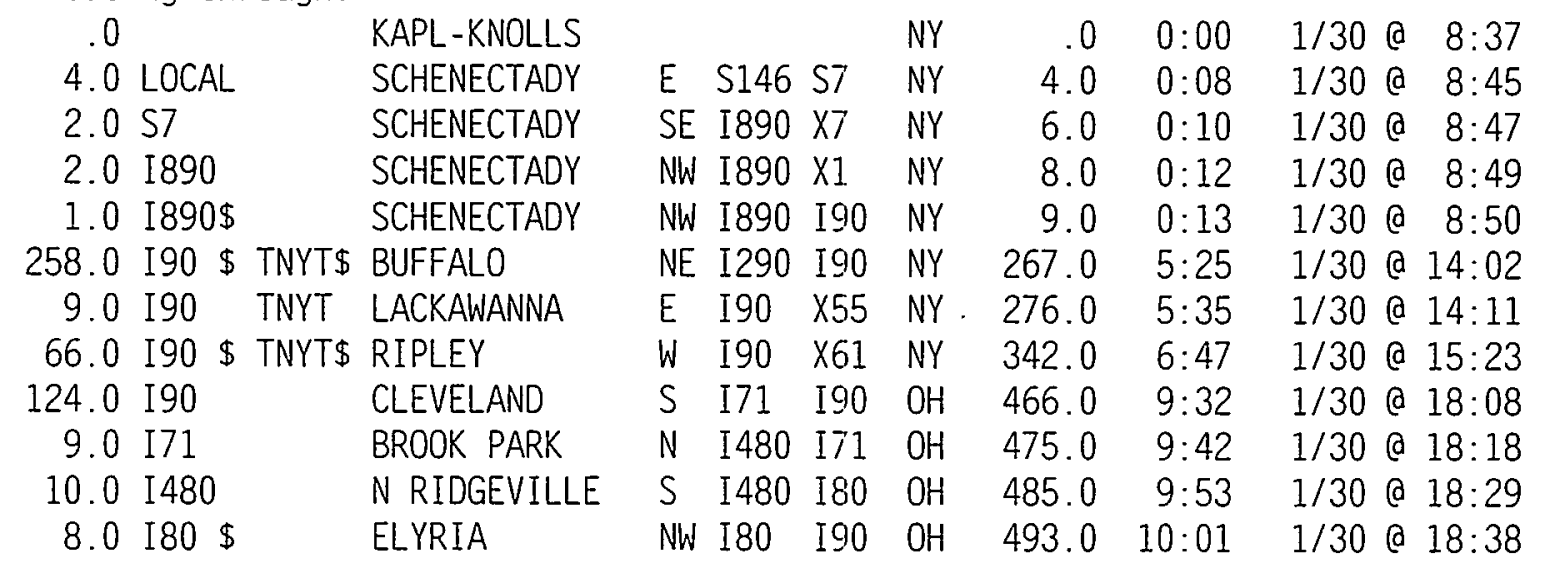




\begin{tabular}{|c|c|c|c|c|c|c|c|c|c|c|}
\hline 81.0180 & & $\$$ PORTAGE & W & I80 & I90 & IN & 774.0 & $15: 24$ & $1 / 31$ & $1: 01$ \\
\hline 1.0180 & & LAKE STATION & NE & I80 & I94 & IN & 775.0 & $15: 26$ & $1 / 31 @$ & $1: 02$ \\
\hline $19.0 \mathrm{I} 80$ & I94 & LANSING & $W$ & I294 & I94 & IL & 794.0 & $15: 46$ & $1 / 310$ & $1: 23$ \\
\hline $5.0 I 294 \$$ & $180 \$$ & HOMEWOOD & $\mathrm{NW}$ & I294 & I80 & IL & 799.0 & 2 & L/31@ & 1: \\
\hline 326.0180 & & DES MOINES & $\mathrm{N}$ & 1235 & 135 & IA & 1125.0 & & 131 & \\
\hline $14.0 \mathrm{I} 35$ & I80 & DES MOINES & $W$ & I235 & I35 & IA & 1139.0 & 5 & $1 / 31 @$ & $8: 1$ \\
\hline 119.0180 & & COUNCIL BLUFFS & SE & I29 & 80 & IA & & & & \\
\hline $3.0 \mathrm{I} 29$ & 180 & COUNCIL BLUFFS & SW & I 29 & 80 & IA & .0 & & 10 & \\
\hline $354.0 \quad I 80$ & & BIG SPRINGS & SW & I76 & 180 & NE & .0 & & @ & \\
\hline $186.0 \mathrm{I} 76$ & & ARVADA & $S$ & I70 & I76 & $\mathrm{CO}$ & 1801.0 & & & \\
\hline 502.0 & & COVE FORT & $W$ & I15 & I70 & UT & & & & \\
\hline 242.0 & & LAS VEGAS & & & & NV & 254 & & & \\
\hline 1.01 & & LAS VEGAS & $W$ & U95 & & NV & 2546.0 & & & \\
\hline 7.0 & & LAS VEGAS & NW & U95 & & NV & 2553.0 & & & 7: \\
\hline 51.0 U95 & & MERCURY & $S$ & U95 & LOCL & NV & 2604.0 & & & \\
\hline $6.0 \mathrm{LOCAL}$ & & MERCURY & & & & NV & 2610.0 & $49: 08$ & $2 / 0$ & \\
\hline
\end{tabular}

From: LOS ALAMOS

NM Leaving : $1 / 30 / 99$ at $8: 22$ MST

to : MERCURY

NV Arriving: $1 / 30 / 99$ at 21:07 PST

Routing through:

\begin{tabular}{|c|c|c|c|c|c|c|c|c|c|c|}
\hline .0 & & LOS ALAMOS & & & & NM & .0 & $0: 00$ & $1 / 30 @$ & $8: 22$ \\
\hline 6.0 LTRKR & & BANDELIER N M & $W$ & \$4 & LTRK & NM & 6.0 & $0: 10$ & $1 / 30 @$ & $8: 33$ \\
\hline $1.0 \mathrm{~S} 4$ & & BANDELIER N M & $N$ & S4 & S502 & NM & 7.0 & $0: 12$ & $1 / 30 @$ & $8: 34$ \\
\hline $12.0 \quad 5502$ & & POJOAQUE & & U285 & S502 & NM & 19.0 & $0: 27$ & $1 / 30 @$ & $8: 5$ \\
\hline 18.0 U285 & U84 & SANTA FE & & U285 & U84. & NM & 37.0 & $0: 47$ & $1 / 30 @$ & \\
\hline 2.0 U84 & & SANTA FE & $S$ & I25 & $\times 282$ & NM & 39.0 & $0: 50$ & $1 / 30$ a & $9: 1$ \\
\hline $56.0 \mathrm{I} 25$ & & ALBUQUERQUE & $E$ & I25 & I40 & NM & 95.0 & $1: 4$ & $1 / 30$ & \\
\hline $468.0 \mathrm{I} 40$ & & KINGMAN & $\mathrm{NW}$ & I40 & $\times 48$ & $A Z$ & 563.0 & $9: 56$ & $1 / 30$ & \\
\hline 83.0 U93 & & ALUNITE & & U93 & U95 & NV & 646.0 & $11: 35$ & $1 / 30$ & 18: \\
\hline 22.0 U93 & U95 & LAS VEGAS & & & & NV & 668.0 & $12: 00$ & $1 / 30$ & $19: 2$ \\
\hline 1.0 U95 & & LAS VEGAS & W & U95 & U95B & NV & 669.0 & $12: 01$ & $1 / 30$ & $19: 2$ \\
\hline 7.0 U95BU & & LAS VEGAS & NW & U95 & U95B & NV & 676.0 & $12: 10$ & $1 / 30$ & $19:$ \\
\hline $51.0 \mathrm{~L}$ & & MERCURY & $S$ & U95 & LOCL & NV & 727.0 & $13: 06$ & $1 / 30$ & \\
\hline $6.0 \mathrm{LOCAL}$ & & MERCURY & & & & NV & 733.0 & $13: 45$ & $1 / 30 @$ & $21: 07$ \\
\hline
\end{tabular}

From: L BERKELEY LAB

to : MERCURY

CA Leaving : 2/02/99 at 9:07 PST

NV Arriving: 2/02/99 at 22:10 PST

Routing through:

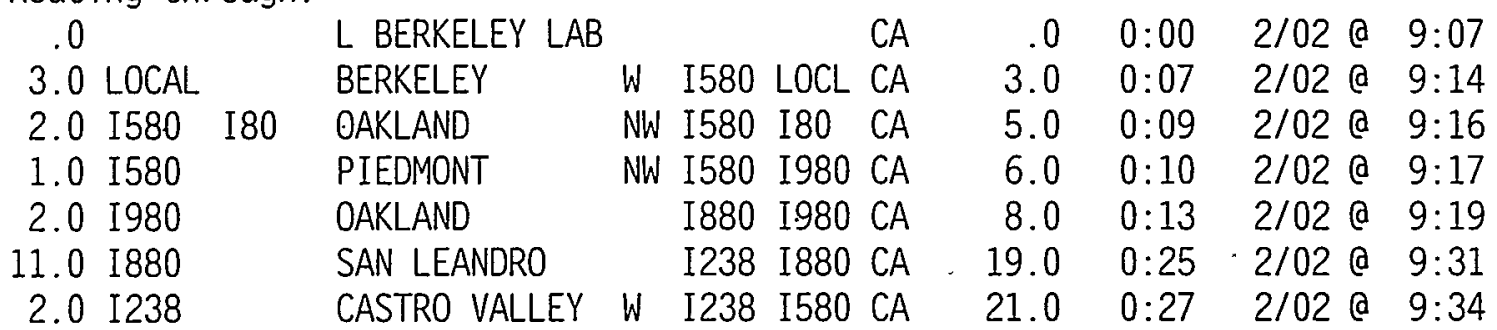




\begin{tabular}{|c|c|c|c|c|c|c|c|c|c|}
\hline $47.0 \quad I 580$ & & VERNALIS & W & 15 & $I 580$ & CA & 68.0 & $1: 18$ & $2 / 02 @ 10: 25$ \\
\hline 196.0 I5 & & STOCKDALE HWY & $W$ & I5 & LOCL & $C A$ & 264.0 & $5: 22$ & $2 / 02$ a $14: 29$ \\
\hline $17.0 \mathrm{LOCAL}$ & & BAKERSFIELD & SW & S58 & S99 & CA & 281.0 & $5: 51$ & $2 / 02 @ 14: 58$ \\
\hline $61.0 \$ 58$ & & MOJAVE & $N$ & S14 & $S 58$ & $\mathrm{CA}$ & 342.0 & $6: 58$ & $2 / 02$ @ $16: 04$ \\
\hline $1.0 \$ 14$ & S58 & MOJAVE & & S14 & $S 58$ & $C A$ & 343.0 & $6: 59$ & $2 / 02$ @ $16: 0$ \\
\hline $71.0 \quad 558$ & & BARSTOW & $E$ & I15 & S58 & CA & 414.0 & $8: 35$ & $2 / 02 @ 17$ \\
\hline 151.0 I15 & & LAS VEGAS & & & & NV & 565.0 & $11: 48$ & $2 / 02$ \\
\hline 10 U95 & & LAS VEGAS & W & U95 & U95B & NV & 566.0 & $11: 49$ & $2 / 0$ \\
\hline 7.0 U958U & & LAS VEGAS & $\mathrm{NW}$ & U95 & U95B & NV & 573.0 & $11: 59$ & \\
\hline 51.0 U95 & & MERCURY - & $S$ & U95 & $\mathrm{LOCL}$ & NV & 624.0 & $12: 55$ & \\
\hline $5.0 \mathrm{LOCAL}$ & & MERCURY & & & & NV & 630.0 & $13: 04$ & $2 / 0$ \\
\hline
\end{tabular}

From: L LIVERMORE LB to : MERCURY

CA Leaving : 1/30/99 at 9:03 PST

NV Arriving: $1 / 30 / 99$ at 21:20 PST

Routing through:

\begin{tabular}{|c|c|c|c|c|c|c|c|c|c|}
\hline .0 & & L LIVERMORE LB & & & & CA & 0 & $0: 00$ & $1 / 30 @$ \\
\hline $3.0 \mathrm{LOCAL}$ & & ALTAMONT & SW & I580 & LOCL & $C A$ & 3.0 & $0: 05$ & $1 / 30 @$ \\
\hline $24.0 \quad I 580$ & & VERNALIS & $W$ & I5 & I580 & $C A$ & 27.0 & $0: 31$ & $1 / 30 @$ \\
\hline 196.0 I5 & & STOCKDALE HWY & $W$ & I5 & LOCL & $C A$ & 223.0 & 4: & $1 / 30 @ 13$ \\
\hline $17.0 \mathrm{LOCAL}$ & & BAKERSFIELD & SW & S58 & $\$ 99$ & $C A$ & 240.0 & $5: 0$ & $1 / 30$ a 1 \\
\hline $61.0 \quad 558$ & & MOJAVE & $N$ & S14 & $S 58$ & $C A$ & 301.0 & & $.30 @ 1$ \\
\hline $1.0 S 14$ & S58 & MOJAVE & & S14 & S58 & $C A$ & 302.0 & & $1 / 30 @ 1$ \\
\hline $71.0 \mathrm{~S} 58$ & & BARSTOW & $E$ & I15 & S58 & CA & 373.0 & $7: 48$ & a 1 \\
\hline $151.0 \mathrm{I15}$ & & LAS VEGAS & & & & NV & 524.0 & $11: 02$ & 002 \\
\hline 1.0 & & LAS VEGAS & W & U95 & U95B & NV & 525.0 & & a 2 \\
\hline 7.0 & & LAS VEGAS & $\mathrm{NW}$ & U95 & U95B & NV & 532.0 & & (a) 2 \\
\hline 51.0 U95 & & MERCURY & $S$ & U95 & LOCL & NV & 583.0 & $12: 08$ & 0 a \\
\hline $6.0 \mathrm{LOCAL}$ & & MERCURY & & & & NV & 589.0 & $12: 17$ & $1 / 30 @ 21$ \\
\hline
\end{tabular}

From: MOUND FACILITY

OH Leaving: $1 / 30 / 99$ at $8: 30$ EST

to : MERCURY

NV Arriving: $1 / 31 / 99$ at 20:44 PST

Routing through:

\begin{tabular}{|c|c|c|c|c|c|c|c|c|c|c|}
\hline .0 & & MOUND FACILITY & & & & $\mathrm{OH}$ & .0 & $0: 00$ & $1 / 30 a$ & $8: 30$ \\
\hline $1.0 \mathrm{LOCAL}$ & & MIAMISBURG & & $\$ 725$ & LOCL & $\mathrm{OH}$ & 1.0 & $0: 02$ & $1 / 30$ & $8: 32$ \\
\hline $3.0 \$ 725$ & & MIAMISBURG & $E$ & 175 & $\times 44$ & $\mathrm{OH}$ & 4.0 & $0: 06$ & $1 / 30 a$ & $8: 36$ \\
\hline $8.0 \quad 175$ & & DAYTON & & 175 & $\times 52$ & $\mathrm{OH}$ & 12.0 & & $1 / 30 @$ & \\
\hline $31.0 \cup 35$ & & NEW WESTVILLE & NE & 170 & $X 1$ & $\mathrm{OH}$ & 43.0 & & 300 & \\
\hline $75.0 \quad 170$ & & INDIANAPOLIS & NE & I 65 & 170 & IN & 118.0 & & & \\
\hline $2.0 \mathrm{I} 65$ & 170 & IND & SE & I65 & $I 70$ & IN & 120.0 & & & \\
\hline $38.0 \quad 170$ & & TEUTC & $\mathrm{NW}$ & I57 & 170 & IL & 258.0 & $5: 1$ & & \\
\hline $6.0 \quad 157$ & 170 & EFFINGHAM & SW & I57 & I70 & IL & 264.0 & & & \\
\hline $77.0 \quad 170$ & & EDWARDSVILLE & SE & 1270 & 155 & $\mathrm{IL}$ & 341.0 & $6: 41$ & & \\
\hline $20.0 \quad 155$ & 170 & ST LOUIS & & I55 & I64 & MO & 361.0 & $7: 03$ & & \\
\hline $1.0 I 55$ & & ST LOUIS & S & I 44 & $\mathrm{I} 55$ & MO & 362.0 & $7: 04$ & & \\
\hline 90.0 I 44 & & JOPLIN & SW & I 44 & $X_{1}$ & MO & 652.0 & $12: 05$ & $1 / 30 @$ & 21: \\
\hline
\end{tabular}




\begin{tabular}{|c|c|c|c|c|c|c|c|c|c|}
\hline $17.0 \mathrm{I} 44 \$$ & $\$$ & MIAMI & $E$ & I 44 & $x 313$ & OK & 669.0 & $12: 21$ & 1/30 a 21:51 \\
\hline 72.0 I44 \$ & \$ TWRT\$ & CATOOSA & S & I44 & $\times 241$ & OK & 741.0 & $13: 27$ & $1 / 30 @ 22: 57$ \\
\hline $20.0 \mathrm{I} 44$ & & OAKHURST & $E$ & I44 & $\times 221$ & OK & 761.0 & $14: 17$ & $1 / 30 @ 23: 47$ \\
\hline $86.0 \mathrm{I} 44 \$$ & $\$$ TTRT\$ & EDMOND & SE & I35 & I44 & OK & 847.0 & $15: 38$ & 1/31 @ 1:07 \\
\hline 5.0 I35 & I44 & OKLAHOMA CITY & NE & I35 & 144 & OK & 852.0 & $15: 43$ & $1 / 31$ \\
\hline $10.0 \mathrm{I} 44$ & & OKLAHOMA CITY & $W$ & $I 40$ & 144 & OK & 862.0 & $15: 54$ & $1 / 31 @ 1: 2$ \\
\hline $1004.0 \quad 140$ & & KINGMAN & NW & I40 & $X 48$ & $A Z$ & 1866.0 & $33: 26$ & 1/31 @ 17:5 \\
\hline 83.0 U93 & & ALUNITE & & U93 & U95 & NV & 1949.0 & $35: 05$ & 1/31@ @ 18:3 \\
\hline $22.0 \cup 93$ & U95 & LAS VEGAS & & & & NV & 1971.0 & $35: 29$ & a 18 \\
\hline $1.0 \cup 95$ & & LAS VEGAS & $W$ & U95 & U95B & NV & 1972.0 & $35: 30$ & $1 / 31$ a 18 \\
\hline $7.0 \mathrm{U} 95 \mathrm{BU}$ & & LAS VEGAS & $N W$ & U95 & U95B & NV & 1979.0 & $36: 10$ & 1/31 @ 19: \\
\hline 51.0 U95 & & MERCURY & S & U95 & LOCL & NV & 2030.0 & $37: 06$ & $1 / 31$ \\
\hline 6.0 LOCAL & & MERCURY & & & & NV & 2036.0 & $37: 15$ & $1 / 31$ @20:4 \\
\hline
\end{tabular}

From: PADUCAH GDP to : MERCURY
KY Leaving : $1 / 30 / 99$ at $8: 38$ CST

NV Arriving: $1 / 31 / 99$ at 15:21 PST

Routing through:

\begin{tabular}{|c|c|c|c|c|c|c|c|c|c|c|}
\hline .0 & & PADUCAH GDP & & & & $K Y$ & .0 & $0: 00$ & $1 / 30$ & $8: 38$ \\
\hline $3.0 \mathrm{LOCAL}$ & & KEVIL & E & U60 & LOCL & KY & 3.0 & $0: 06$ & $1 / 30$ & $8: 44$ \\
\hline 19.0 U60 & & WICKLIFFE & & U51 & U60 & $K Y$ & 22.0 & $0: 29$ & $1 / 30$ & 9:07 \\
\hline 6.0 U51 & U60 & CAIRO & $S$ & U51 & U60 & IL & 28.0 & $0: 36$ & $1 / 30$ & $9: 14$ \\
\hline $12.0 \cup 60$ & U62 & CHARLESTON & E & I57 & $\mathrm{X} 12$ & MO & 40.0 & $0: 50$ & $1 / 30$ & \\
\hline $13.0 \quad I 57$ & & SIKESTON & E & I55 & I57 & MO & 53.0 & $1: 02$ & $1 / 30$ & \\
\hline $51.0 \cup 60$ & & POPLAR BLUFF & W & U160 & U60 & MO & 104.0 & $2: 04$ & $1 / 30$ & $10: 42$ \\
\hline $8.0 \cup 60$ & U67 & POPLAR BLUFF & $\mathrm{NW}$ & U60 & U67 & MO & 112.0 & $2: 12$ & $1 / 30$ & 10: \\
\hline $96.0 \cup 60$ & & WILLOW SPRINGS & SE & U60 & U63 & MO & 208.0 & $4: 08$ & $1 / 30$ & \\
\hline $14.0 \cup 60$ & U63 & CABOOL & SE & U60 & U63 & MO & 222.0 & $4: 53$ & $1 / 30$ & 13: \\
\hline $29.0 \cup 60$ & & MANSFIELD & $\mathrm{N}$ & U60 & S5 & MO & 251.0 & $5: 24$ & $1 / 30$ & $14: 03$ \\
\hline $1.0 \mathrm{U} 60$ & S5 & MANSFIELD & NW & U60 & S5 & MO & 252.0 & $5: 26$ & $1 / 3$ & 14. \\
\hline $38.0 \cup 60$ & & SPRINGFIELD & SE & U60 & U65 & MO & 290.0 & $6: 07$ & & \\
\hline $9.0 \cup 65$ & & SPRINGFIELD & NE & I44 & $x 82$ & MO & 299.0 & $6: 17$ & & \\
\hline 82.0 I44 & & JOPLIN & SW & I44 & $X 1$ & MO & 381.0 & $7: 34$ & $1 / 3$ & 16 : \\
\hline 17.0 I $44 \$$ & & MIAMI & $E$ & I 44 & $\times 313$ & OK & 398.0 & $7: 49$ & 30 & $16: 28$ \\
\hline $72.0 \mathrm{I} 44 \$$ & TWRT\$ & CATOOSA & S & I44 & X241 & OK & 470.0 & $8: 56$ & $1 / 30$ & 17: \\
\hline 20.0 I44 & & OAKHURST & E & I44 & $\times 221$ & OK & 490.0 & $9: 46$ & $1 / 30$ & 18: \\
\hline 86.0 I $44 \$$ & TTRT\$ & EDMOND & SE & I35 & I44 & $\mathrm{OK}$ & 576.0 & $11: 06$ & $1 / 30$ & $19: 44$ \\
\hline 5.0 I35 & I44 & OKLAHOMA CITY & NE & I35 & I44 & OK & 581.0 & & & \\
\hline $10.0 \quad \mathrm{I} 44$ & & OKLAHOMA CITY & $W$ & I 40 & I44 & OK & 591.0 & 23 & & $20: 01$ \\
\hline $04.0 \quad 140$ & & KINGMAN & NW & I 40 & $\times 48$ & $A Z$ & 1595.0 & $28: 54$ & $1 / 31$ & $12: 32$ \\
\hline 83.0 U93 & & ALUNITE & & U93 & U95 & NV & 1678.0 & & & $13: 11$ \\
\hline 22.0 U93 & U95 & LAS VEGAS & & & & NV & 1700.0 & $30: 58$ & & $13: 35$ \\
\hline 1.0 U95 & & LAS VEGAS & $W$ & U95 & U95B & NV & 1701.0 & & & $13: 36$ \\
\hline 7.0 U95BU & & LAS VEGAS & $\mathrm{NW}$ & U95 & U95B & NV & 1708.0 & & & \\
\hline 51.0 U95 & & MERCURY & $S$ & 095 & LOCL & NV & 1759.0 & $32: 34$ & $1 / 31$ & $15: 12$ \\
\hline $6.0 \mathrm{LOCAL}$ & & MERCURY & & & & NV & 1765.0 & $32: 43$ & $1 / 31$ & $15: 21$ \\
\hline
\end{tabular}




\begin{tabular}{|c|c|c|c|c|c|c|c|c|c|c|}
\hline \multicolumn{3}{|c|}{ From: PORTSMOUTH GDP } & \multicolumn{2}{|l|}{$\mathrm{OH}$} & \multicolumn{2}{|c|}{ Leaving } & \multicolumn{4}{|c|}{$1 / 30 / 99$ at $8: 43$ EST } \\
\hline to : MERCUR & & & NV & & Arriv & ving & $1 / 31$ & 99 at 2 & :09 PST & \\
\hline & & & & & & & & & & \\
\hline .0 & & PORTSMOUTH GDP & & & & $\mathrm{OH}$ & .0 & $0: 00$ & $1 / 30 @$ & $8: 43$ \\
\hline $3.0 \cup 23$ & & PIKETON & $S$ & U23 & S32 & $\mathrm{OH}$ & 3.0 & $0: 03$ & $1 / 30 @$ & $8: 47$ \\
\hline $75.0 \quad 532$ & & MT CARMEL HGTS & $E$ & 1275 & $\times 63$ & $\mathrm{OH}$ & 78.0 & $1: 25$ & $1 / 30 a$ & $10: 08$ \\
\hline $21.0 \quad 1275$ & & ERLANGER & $N$ & I 275 & I71 & KY & 99.0 & $1: 48$ & $1 / 30 a$ & $10: 31$ \\
\hline $12.0 I 71$ & I75 & WALTON & $\mathrm{NW}$ & I71 & 175 & KY & 111.0 & $1: 59$ & $1 / 300$ & $10: 42$ \\
\hline 76.0 I71 & & LOUISVILLE & $E$ & I64 & I71 & KY & 187.0 & $3: 10$ & $1 / 30 @$ & $11: 53$ \\
\hline 181.0164 & & MT VERNON & SW & 157 & I64 & IL & 368.0 & $6: 49$ & $1 / 30$ a & $16: 32$ \\
\hline 5.0 I57 & 164 & MT VERNON & $\mathrm{NW}$ & 157 & I 64 & IL & 373.0 & $6: 54$ & $1 / 30 @$ & $16: 37$ \\
\hline 71.0164 & & EAST ST LOUIS & NE & I55 & I 64 & IL & 444.0 & $8: 12$ & $1 / 300$ & $17: 55$ \\
\hline $3.0 \quad 155$ & 170 & ST LOUIS & & I55 & I 64 & MO & 447.0 & $8: 15$ & $1 / 30 a$ & $17: 58$ \\
\hline 1.0 I55 & & ST LOUIS & $S$ & I44 & 155 & MO & 448.0 & $8: 16$ & $1 / 30 @$ & $17: 59$ \\
\hline 290.0 I44 & & JOPLIN & SW & I44 & $\mathrm{X} 1$. & MO & 738.0 & $13: 48$ & $1 / 30 @$ & $23: 30$ \\
\hline 17.0 I $44 \$$ & & MIAMI & $E$ & I44 & $\times 313$ & OK & 755.0 & $14: 03$ & $1 / 300$ & $23: 46$ \\
\hline 72.0 I44 \$ & TWRT\$ & CATOOSA & $S$ & I44 & $\times 241$ & OK & 827.0 & & $1 / 31$ a & $0: 53$ \\
\hline $20.0 \mathrm{I} 44$ & & OAKHURST & $E$ & I44 & $\times 221$ & OK & 847.0 & $15: 30$ & $1 / 31 @$ & $1: 13$ \\
\hline 86.0 I $44 \$$ & TTRT\$ & EDMOND & SE & I35 & I44 & OK & 933.0 & 16: & $1 / 31 @$ & $2: 33$ \\
\hline $5.0 \mathrm{I} 35$ & $I 44$ & OKLAHOMA CITY & NE & 135 & I 44 & OK & 938.0 & & $1 / 31$ & \\
\hline $10.0 \mathrm{I} 44$ & & OKLAHOMA CITY & $W$ & I 40 & $I 44$ & OK & 948.0 & $17: 06$ & $1 / 31 @$ & $2: 49$ \\
\hline $1004.0 \mathrm{I} 40$ & & KINGMAN & $\mathrm{NW}$ & 140 & $x<8$ & $A Z$ & 1952.0 & $34: 38$ & $1 / 31$ & $19: 20$ \\
\hline $83.0 \cup 93$ & & ALUNITE & & U93 & U95 & NV & 2035.0 & $36: 47$ & $1 / 31$ & $20: 29$ \\
\hline 22.0 U93 & U95 & LAS VEGAS & & & & NV & 2057.0 & $37: 12$ & $1 / 310$ & $20: 54$ \\
\hline 1.0 U95 & & LAS VEGAS & $W$ & U95 & U95B & NV & 2058.0 & $37: 13$ & $1 / 31 @$ & $20: 55$ \\
\hline $7.0 \mathrm{U} 95 \mathrm{BU}$ & & LAS VEGAS & $\mathrm{NW}$ & U95 & U95B & NV & 2065.0 & $37: 22$ & & $21: 04$ \\
\hline 51.0 U95 & & MERCURY & $S$ & U95 & LOCL & NV & 2116.0 & $38: 18$ & $1 / 310$ & $22: 00$ \\
\hline $6.0 \mathrm{LOCAL}$ & & MERCURY & & & & NV & 2122.0 & $38: 27$ & $1 / 31 @$ & $22: 09$ \\
\hline
\end{tabular}

From: PANTEX PLANT to : MERCURY
F245 F683 TX Leaving : $1 / 30 / 99$ at $8: 45$ CST

NV Arriving: $1 / 30 / 99$ at $23: 33$ PST

Routing through:

\begin{tabular}{|c|c|c|c|c|c|c|c|c|c|c|}
\hline .0 & & PANTEX PLANT & & F245 & F683 & TX & 0 & $0: 00$ & $1 / 30$ & $8: 45$ \\
\hline 4.0 F683 & & PANTEX & S & U60 & $F 683$ & $T X$ & 4.0 & $0: 08$ & $1 / 30$ & $8: 53$ \\
\hline $7.0 \cup 60$ & & AMARILLO & $E$ & U60 & L335 & TX & 11.0 & $0: 16$ & $1 / 30$ & $9: 01$ \\
\hline $2.0\llcorner 335$ & & AMARILLO & $E$ & I40 & X75 & TX & 13.0 & $0: 19$ & $1 / 300$ & $9: 04$ \\
\hline 756.0 I40 & & KINGMAN & $\mathrm{NW}$ & I 40 & $\times 48$ & $A Z$ & 769.0 & $12: 59$ & $1 / 300$ & $20: 44$ \\
\hline 83.0 U93 & & ALUNITE & & U93 & U95 & NV & 852.0 & $15: 09$ & $1 / 30$ & $21: 53$ \\
\hline 22.0 u93 & U95 & LAS VEGAS & & & & NV & 874.0 & $15: 33$ & $1 / 300$ & $22: 18$ \\
\hline $1.0 \cup 95$ & & LAS VEGAS & $W$ & U95 & U95B & NV & 875.0 & $15: 34$ & $1 / 30$ & $22: 19$ \\
\hline 7.0 U95BU & & LAS VEGAS & $\mathrm{NW}$ & U95 & U95B & NV & 882.0 & $15: 44$ & $1 / 30$ & $22: 28$ \\
\hline 51.0 U95 & & MERCURY & $S$ & U95 & LOCL & NV & 933.0 & $16: 39$ & $1 / 30$ & $23: 24$ \\
\hline $6.0 \mathrm{LOCAL}$ & & MERCURY & & & & NV & 939.0 & $16: 48$ & $1 / 300$ & $23: 33$ \\
\hline
\end{tabular}


From: PRINCTN PLASMA U1 LOCL NJ Leaving: $1 / 30 / 99$ at $8: 44$ EST to : MERCURY NV Arriving: 2/01/99 at 8:04 PST

\begin{tabular}{|c|c|c|c|c|c|c|c|c|c|c|}
\hline .0 & & PRINCTN PLASMA & & U1 & LOCL & & .0 & $0: 00$ & $1 / 30 @$ & $8: 44$ \\
\hline 12.0 U1 & & TRENTON & & U1 & S29 & NJ & 12.0 & $0: 14$ & $1 / 30 a$ & $8: 59$ \\
\hline $3.0 \mathrm{Ul} \#$ & & MORRISVILLE & SW & U1 & U13 & PA & 15.0 & $0: 18$ & $1 / 30 a$ & $9: 02$ \\
\hline $6.0 \mathrm{U} 13$ & & BRISTOL & $\mathrm{N}$ & I276 & X29 & PA & 21.0 & $0: 25$ & $1 / 30 @$ & $9: 09$ \\
\hline $31.0 \mathrm{I} 276 \$$ & & VALLEY FORGE & SE & I276 & I76 & PA & 52.0 & $0: 58$ & $1 / 300$ & $9: 43$ \\
\hline $84.0176 \$$ & & NEW CUMBERLND & S & I76 & X18 & PA & 136.0 & $2: 30$ & $1 / 30 @$ & $11: 14$ \\
\hline 2.0183 & & HARRISBURG & SW & I83 & $x 20$ & PA & 138.0 & $2: 32$ & $1 / 30 a$ & $11: 16$ \\
\hline $2.0 \mathrm{S581}$ & & CAMP HILL & SW & U11 & U15 & PA & 140.0 & $2: 34$ & $1 / 30 @$ & $11: 18$ \\
\hline 10.0 U11 & & CARLISLE & NE & I76 & $X 16$ & $\dot{P A}$ & $150: 0$ & $2: 48$ & $1 / 30 @$ & $11: 32$ \\
\hline $66.0176 \$$ & & BREEZEWOOD & SW & I70 & 176 & PA & 216.0 & $4: 00$ & $1 / 300$ & $12: 44$ \\
\hline $71.0 \mathrm{I} 70 \$$ & $\$ 176 \$$ & DONEGAL & & I70 & $x \dot{9}$ & PA & 287.0 & $5: 47$ & $1 / 30 a$ & $14: 31$ \\
\hline $.0 \quad \mathrm{I} 70$ & XRAMP & DONEGAL & $\mathrm{S}$ & 170 & S31 & PA & 287.0 & $5: 47$ & $1 / 300$ & $14: 31$ \\
\hline $17.0 \mathrm{~S} 31$ & & WYANO & S & I70 & X24 & PA & 304.0 & $6: 13$ & $1 / 30 a$ & $14: 57$ \\
\hline $32.0 \quad I 70$ & & LABORATORY & NE & I70 & I79 & PA & 336.0 & $6: 48$ & $1 / 300$ & $15: 32$ \\
\hline $5.0 \quad \mathrm{I} 70$ & I79 & WASHINGTON & N & I70 & I79 & PA & 341.0 & $6: 53$ & $1 / 30 a$ & $15: 37$ \\
\hline $157.0 \quad 170$ & & COLUMBUS & SE & I70 & I71 & $\mathrm{OH}$ & 498.0 & $10: 14$ & $1 / 300$ & $18: 58$ \\
\hline $2.0 \quad I 70$ & I71 & COLUMBUS & SW & I70 & 171 & $\mathrm{OH}$ & 500.0 & $10: 16$ & $1 / 30$ & $19: 00$ \\
\hline $172.0 \mathrm{I} 70$ & & INDIANAPOLIS & NE & I65 & 170 & IN & 672.0 & $13: 49$ & $1 / 30 @$ & $22: 32$ \\
\hline $2.0 \quad 165$ & 170 & INDIANAPOL IS & SE & I65 & I70 & IN & 674.0 & $13: 51$ & $1 / 30 @$ & $22: 35$ \\
\hline $138.0 \quad 170$ & & TEUTOPOLIS & NW & I57 & I70 & IL & 812.0 & $16: 17$ & $1 / 31 @$ & $2: 00$ \\
\hline 6.0 I57 & I70 & EFFINGHAM & SW & I57 & 170 & IL & 818.0 & $16: 23$ & $1 / 31$ a & $2: 07$ \\
\hline $77.0 \quad 170$ & & EDWARDSVILLE & SE & I270 & I55 & IL & 895.0 & $17: 47$ & $1 / 31$ & $3: 31$ \\
\hline 20.0 I55 & I70 & ST LOUIS & & I55 & I64 & MO & 915.0 & $18: 39$ & $1 / 31 @$ & $4: 23$ \\
\hline $1.0 \mathrm{I} 55$ & & ST LOUIS & S & I44 & I55 & MO & 916.0 & 18 & $31 @$ & $4: 24$ \\
\hline 290.0 I44 & & JOPLIN & SW & I44 & X1 & MO & 1206.0 & $23: 42$ & $1 / 31$ & $9: 25$ \\
\hline $17.0 \mathrm{I} 44 \$$ & & MIAMI & $E$ & I44 & X313 & OK & 1223.0 & $23: 58$ & $1 / 31 @$ & $9: 41$ \\
\hline $72.0144 \$$ & \$ TWRT\$ & CATOOSA & s & I44 & X241 & OK & 1295.0 & 25: & $1 / 31 @$ & $10: 47$ \\
\hline 20.0 I 44 & & OAKHURST & $\mathrm{E}$ & I 44 & X221 & OK & 1315.0 & $25: 24$ & $1 / 31 @$ & $11: 07$ \\
\hline 86.0 I44 \$ & \$ TTRT\$ & EDMOND & SE & I35 & I44 & OK & 1401.0 & $26: 44$ & $1 / 31 @$ & $12: 28$ \\
\hline 5.0 I35 & I44 & OKLAHOMA CITY & NE & I35 & I44 & OK & 1406.0 & & & $13: 03$ \\
\hline $10.0 \mathrm{I} 44$ & & OKLAHOMA CITY & W & I 40 & I44 & OK & 1416.0 & 27 & $1 / 31$ & $13: 14$ \\
\hline $004.0 \mathrm{I} 40$ & & KINGMAN & NW & I 40 & $\times 48$ & $A Z$ & 2420.0 & $44: 32$ & $2 / 01 @$ & $5: 15$ \\
\hline 83.0 U93 & & ALUNITE & & U93 & U95 & NV & 2503.0 & $46: 41$ & 2/01 a & $6: 24$ \\
\hline 22.0 U93 & U95 & LAS VEGAS & & & & NV & 2525.0 & 47: & $2 / 01$ & $6: 49$ \\
\hline 1.0 U95 & & LAS VEGAS & W & U95 & U95B & NV & 2526.0 & $47: 07$ & $2 / 01 @$ & $6: 50$ \\
\hline $7.0 \mathrm{Ug5BU}$ & & LAS VEGAS & NW & U95 & U95B & NV & 2533.0 & $47: 17$ & $2 / 01$ & \\
\hline 51.0 U95 & & MERCURY & $S$ & U95 & LOCL & NV & 2584.0 & 48: & $2 / 010$ & $7: 55$ \\
\hline 6.0 LOCAL & & MERCURY & & & & NV & 2590.0 & $48: 21$ & $2 / 01 @$ & $8: 04$ \\
\hline
\end{tabular}

From: ROCKY FLATS to : MERCURY
Co Leaving : $1 / 30 / 99$ at $8: 26$ MST

NV Arriving: $1 / 30 / 99$ at 23:01 PST

Routing through: $.0 \quad$ ROCKY FLATS

$\begin{array}{lllll}C 0 & .0 & 0: 00 \quad 1 / 30 @ 8: 26\end{array}$ 


\begin{tabular}{|c|c|c|c|c|c|c|c|c|c|}
\hline $5.0 \mathrm{LOCAL}$ & ARVADA & NW & S72 & LOCL & $\mathrm{CO}$ & 5.0 & $.0: 09$ & $1 / 30$ & $8: 35$ \\
\hline $9.0 \mathrm{~S} 72$ & WHEAT RIDGE & NW & 170 & $\times 266$ & $\mathrm{CO}$ & 14.0 & $0: 25$ & $1 / 30$ & $8: 5$ \\
\hline $498.0 \quad I 70$ & COVE FORT & W & I15 & 170 & UT & 512.0 & $10: 05$ & $1 / 30 @$ & 18: \\
\hline $242.0 \quad 115$ & LAS VEGAS & & & & NV & 754.0 & $14: 20$ & $1 / 30$ & \\
\hline 1.0 U95 & LAS VEGAS & $W$ & U95 & U95B & NV & 755.0 & $14: 22$ & $1 / 30$ & \\
\hline 7.0 U95BU & LAS VEGAS & NW & U95 & U95B & NV & 762.0 & $14: 31$ & $1 / 30 @$ & \\
\hline 51.0 U95 & MERCURY & $S$ & U95 & LOCL & NV & 813.0 & $15: 27$ & $1 / 30$ Q & \\
\hline 6.0 LOCAL & MERCURY & & & & NV & 819.0 & $15: 36$ & $1 / 30 @$ & 23 \\
\hline
\end{tabular}

From: SANDIA NATL LBS

NM Leaving: 1/30/99 at 8:38 MST

to : MERCURY

NV Arriving: $1 / 30 / 99$ at 19:23 PST

\begin{tabular}{|c|c|c|c|c|c|c|c|c|c|c|}
\hline .0 & & SANDIA NATL & & & & NM & .0 & $0: 00$ & 1/30@ & $8: 38$ \\
\hline $3.0 \mathrm{LOCAL}$ & & ALBUQUERQUE & $E$ & I 40 & $\times 165$ & NM & 3.0 & $0: 07$ & $1 / 30$ & $8: 45$ \\
\hline $474.0 \quad 140$ & & KINGMAN & $\mathrm{NW}$ & I 40 & $\times 48$ & $A Z$ & 477.0 & $7: 56$ & $1 / 30$ a & $16: 34$ \\
\hline 83.0 U93 & & ALUNITE & & U93 & U95 & NV & 560.0 & $10: 05$ & $1 / 30 @$ & $17: 43$ \\
\hline 22.0 U93 & U95 & LAS VEGAS & & & & NV & 582.0 & $10: 30$ & 1/30 @ & $18: 07$ \\
\hline 1.0 U95 & & LAS VEGAS & $W$ & U95 & U95B & NV & 583.0 & $10: 31$ & $1 / 300$ & $18: 08$ \\
\hline 7.0 U95BU & & LAS VEGAS & NW & U95 & U95B & NV & 590.0 & $10: 41$ & $1 / 30 @$ & $18: 18$ \\
\hline 51.0 U95 & & MERCURY & $S$ & U95 & LOCL & NV & 641.0 & $11: 36$ & $1 / 30$ & $19: 14$ \\
\hline $6.0 \mathrm{LOCAL}$ & & MERCURY & & & & NV & 647.0 & $11: 45$ & $1 / 30$ & $19: 23$ \\
\hline
\end{tabular}

From: WEST VALLEY RP

to : MERCURY
NY Leaving : $1 / 30 / 99$ at $8: 34$ EST

NV Arriving: $2 / 01 / 99$ at 3:20 PST

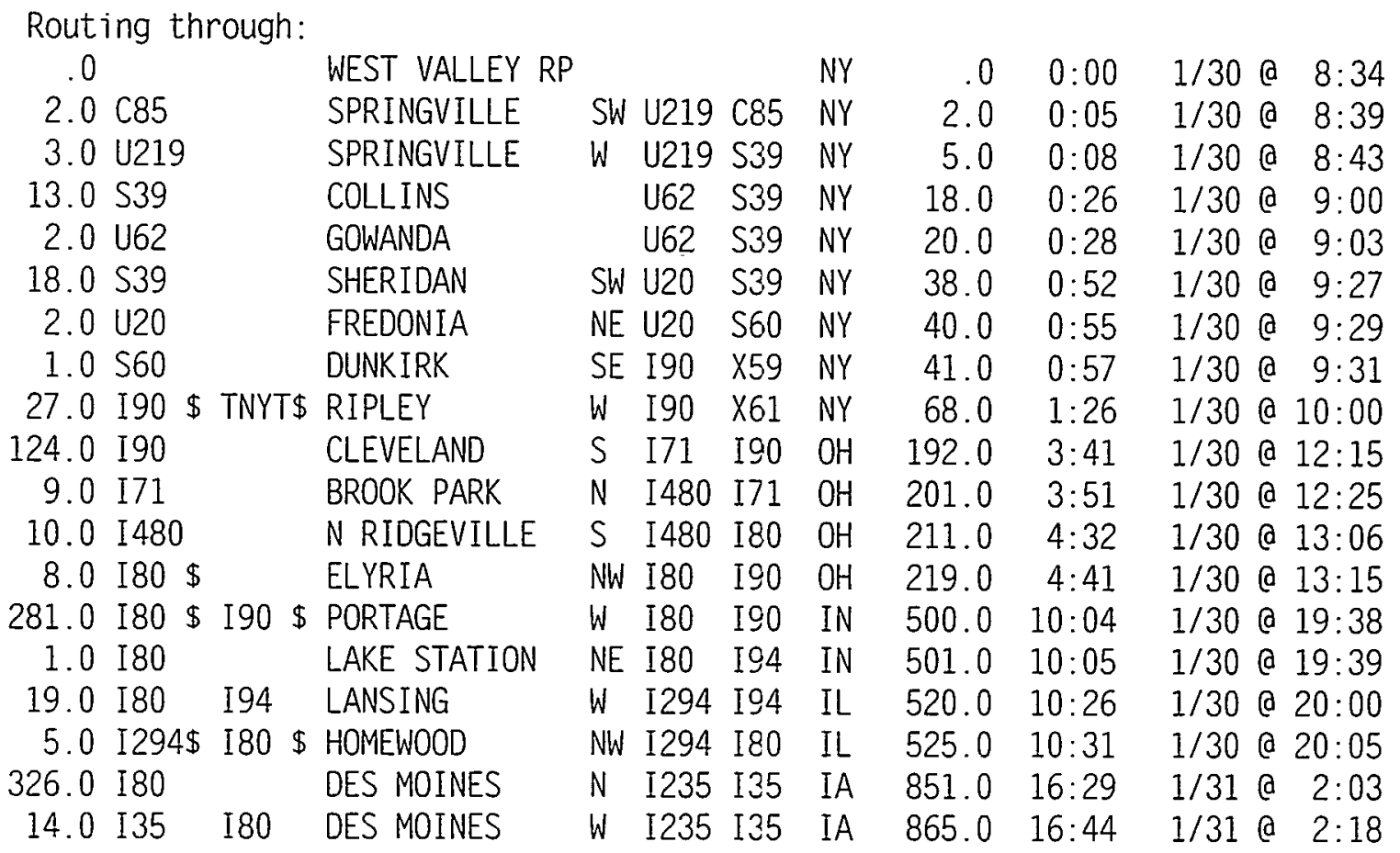




\begin{tabular}{|c|c|c|c|c|c|c|c|c|c|c|}
\hline $119.0 \mathrm{I} 80$ & & COUNCIL BLUFFS & SE & 129 & 180 & IA & 984.0 & $19: 04$ & $1 / 310$ & $4: 38$ \\
\hline 3.0129 & I80 & COUNCIL BLUFFS & SW & 129 & I80 & IA & 987.0 & $19: 07$ & $1 / 31 @$ & $4: 41$ \\
\hline $354.0 \quad 180$ & & BIG SPRINGS & SW & 176 & 180 & NE & 1341.0 & $25: 07$ & $1 / 310$ & $9: 41$ \\
\hline $186.0 \mathrm{I} 76$ & & ARVADA & S & 170 & 176 & $\mathrm{CO}$ & 1527.0 & $28: 31$ & $1 / 31$ & $13: 05$ \\
\hline $502.0 \quad 170$ & & COVE FORT & $W$ & I15 & 170 & UT & 2029.0 & $38: 16$ & $1 / 31$ & $22: 49$ \\
\hline $242.0 \quad I 15$ & & LAS VEGAS & & & & NV & 2271.0 & $42: 31$ & $2 / 01$ & $2: 05$ \\
\hline $1.0 \cup 95$ & & LAS VEGAS & $W$ & U95 & U95B & NV & 2272.0 & $42: 33$ & $2 / 01$ & $2: 06$ \\
\hline 7.0 U95BU & & LAS VEGAS & $\mathrm{NW}$ & U95 & U95B & NV & 2279.0 & $42: 42$ & $2 / 01 @$ & $2: 15$ \\
\hline $51.0 \cup 95$ & & MERCURY & S & U95 & LOCL & NV & 2330.0 & $43: 38$ & $2 / 01$ & $3: 11$ \\
\hline $6.0 \mathrm{LOCAL}$ & & MERCURY & & & & NV & 2336.0 & $43: 47$ & $2 / 01$ & $3: 20$ \\
\hline rom: $Y-12$ & & & TN & & & ing & & 9 at & ST & \\
\hline to : MERCURY & & & NV & & rris & ving & $1 / 31 /$ & 99 at 1 & ST & \\
\hline Routil & & & & & & & & & & \\
\hline .0 & & $Y-12$ & & & & TN & .0 & $0: 00$ & $1 / 30 @$ & $8: 21$ \\
\hline 7.0 LOCAL & & BEAR CREEK & & S95 & LOCL & TN & 7.0 & $0: 10$ & $1 / 30 @$ & $8: 30$ \\
\hline 2.0595 & & OAK RIDGE & $\mathrm{SW}$ & S58 & S95 & TN & 9.0 & $0: 13$ & $1 / 30$ & $8: 33$ \\
\hline $7.0 S 58$ & & KINGSTON & $E$ & 140 & $\times 356$ & TN & 16.0 & $0: 21$ & $1 / 30 @$ & $8: 42$ \\
\hline $145.0 \mathrm{I} 40$ & & NASHVILLE & $E$ & I24 & $\mathrm{I} 40$ & TN & 161.0 & $2: 37$ & $1 / 30$ & $9: 58$ \\
\hline $2.0 \mathrm{I} 24$ & I40 & NASHVILLE & SE & I24 & 140 & TN & 163.0 & $2: 39$ & $1 / 30$ a & $10: 00$ \\
\hline $1.0 \mathrm{I} 40$ & I65 & NASHVILLE & $S$ & I40 & I65 & TN & 164.0. & $2: 41$ & 1/30 & $10: 01$ \\
\hline $218.0 \quad 140$ & & WEST MEMPHIS & $E$ & I40 & I55 & AR & 382.0 & $6: 36$ & $1 / 30$ & $13: 56$ \\
\hline $3.0 \mathrm{I} 40$ & I55 & WEST MEMPHIS & $N$ & 140 & I55 & AR & 385.0 & $6: 39$ & 1/30@ & $13: 59$ \\
\hline $455.0 \mathrm{I} 40$ & & OKLAHOMA CITY & $E$ & 135 & 140 & OK & 840.0 & $14: 43$ & $1 / 30$ & $22: 03$ \\
\hline $2.0 \mathrm{I} 35$ & I40 & OKLAHOMA CITY & S & I235 & I35 & OK & 842.0 & $14: 45$ & 1/30@ & $22: 05$ \\
\hline $1009.0 \quad I 40$ & & KINGMAN & $\mathrm{NW}$ & 140 & $X 48$ & $A Z$ & 1851.0 & $32: 22$ & 1/31@ & $14: 41$ \\
\hline $83.0 \cup 93$ & & ALUNITE & & U93 & U95 & NV & 1934.0 & $34: 01$ & 1/31@ & $15: 20$ \\
\hline $22.0 \cup 93$ & U95 & LAS VEGAS & & & & NV & 1956.0 & $34: 25$ & 1/31@ & $15: 45$ \\
\hline $1.0 \cup 95$ & & LAS VEGAS & $W$ & U95 & U95B & NV & 1957.0 & $34: 26$ & $1 / 31$ & $15: 46$ \\
\hline 7.0 U95BU & & LAS VEGAS & $\mathrm{NW}$ & U95 & U95B & NV & 1964.0 & $34: 36$ & $1 / 31$ & $15: 56$ \\
\hline 51.0 U95 & & MERCURY & $S$ & U95 & LOCL & NV & 2015.0 & $35: 32$ & $1 / 31$ & $16: 51$ \\
\hline 6.0 LOCAL & & MERCURY & & & & NV & 2021.0 & $36: 11$ & $1 / 31$ & $17: 30$ \\
\hline
\end{tabular}




\section{TRUCK ROUTES FROM LLW GENERATORS TO NTS - AVOID LAS VEGAS}

From: AMES LAB

to : MERCURY
IA Leaving : 2/01/99 at 9:21 CST

NV Arriving: 2/02/99 at 17:50 PST

Routing through:

\begin{tabular}{|c|c|c|c|c|c|c|c|c|c|c|}
\hline .0 & & AMES LAB & & & & IA & .0 & $0: 00$ & $2 / 01 @$ & $9: 21$ \\
\hline $3.0 \mathrm{LOCAL}$ & & AMES & SW & U30 & LOCL & IA & 3.0 & $0: 09$ & $2 / 01$ & $9: 30$ \\
\hline $4.0 \cup 30$ & & AMES & $E$ & I35 & X111 & IA & 7.0 & $0: 13$ & $2 / 01 @$ & $9: 35$ \\
\hline $25.0 \quad 135$ & & DES MOINES & $N$ & I235 & I35 & IA & 32.0 & $0: 36$ & $2 / 01$ & $9: 58$ \\
\hline $14.0 \quad 135$ & I80 & DES MOINES & $W$ & I235 & 135 & IA & 46.0 & $0: 51$ & $2 / 01$ & $10: 13$ \\
\hline $119.0 \quad 180$ & & COUNCIL BLUFFS & SE & 129 & I80 & IA & 165.0 & $2: 41$ & $2 / 01$ & $12: 03$ \\
\hline $3.0 \quad 129$ & I80 & COUNCIL BLUFFS & SW & I29 & I80 & IA & 168.0 & $2: 44$ & $2 / 01$ & $12: 06$ \\
\hline $354.0 \quad 180$ & & BIG SPRINGS & SW & 176 & I80 & NE & 522.0 & $8: 44$ & $2 / 01 @$ & \\
\hline $186.0 \mathrm{I} 76$ & & ARVADA & S & 170 & 176 & $\mathrm{CO}$ & 708.0 & $12: 08$ & $2 / 01$ & $20: 29$ \\
\hline $502.0 \quad 170$ & & COVE FORT & W & 115 & 170 & UT & 1210.0 & $21: 53$ & $2 / 02 @$ & $6: 13$ \\
\hline $221.0 \quad 115$ & & GARNET & & I15 & $x 64$ & NV & 1431.0 & $25: 47$ & $2 / 02$ & $9: 0$ \\
\hline 85.0 U93 & & HIKO & $S$ & U93 & S375 & NV & 1516.0 & $27: 29$ & $2 / 02 a$ & $10: 49$ \\
\hline 98.05 & & WARM SPRINGS & & & & NV & 1614.0 & $29: 56$ & 2/02@ & $13: 17$ \\
\hline 50.0 U6 & & TONOPAH & & & & NV & 1664.0 & $30: 56$ & $2 / 02$ & $14: 17$ \\
\hline 146.0 U95 & & MERCURY & S & U95 & LOCL & NV & 1810.0 & $34: 21$ & $2 / 02$ & $17: 41$ \\
\hline $6.0 \mathrm{LOCAL}$ & & MERCI & & & & NV & 1816.0 & $34: 30$ & $2 / 020$ & $17: 50$ \\
\hline
\end{tabular}

From: ARGONNE NATL L to : MERCURY
IL Leaving : 2/01/99 at 9:01 CST

NV Arriving: 2/02/99 at 22:46 PST

Routing through:

\begin{tabular}{|c|c|c|c|c|c|c|c|c|c|c|}
\hline .0 & & ARGONNE NATL $L$ & & & & IL & .0 & $0: 00$ & $2 / 01$ & $9: 01$ \\
\hline $1.0 \mathrm{LOCAL}$ & & DARIEN & $S$ & I55 & $\times 273$ & IL & 1.0 & $0: 03$ & $2 / 01$ & $9: 04$ \\
\hline 4.0 I55 & & LEMONT & $\mathrm{NW}$ & I355 & I55 & IL & 5.0 & $0: 07$ & $2 / 01$ & $9: 08$ \\
\hline $8.0 I 355 \$$ & & DOWNERS GROVE & $W$ & I355 & U34 & IL & 13.0 & $0: 16$ & $2 / 01 @$ & $9: 17$ \\
\hline $1.0 \mathrm{U} 34$ & & LISLE & & U34 & S53 & IL & 14.0 & $0: 18$ & $2 / 01 @$ & $9: 19$ \\
\hline $1.0 \mathrm{S53}$ & & LISLE & $N$ & I88 & S53 & IL & 15.0 & $0: 20$ & $2 / 010$ & $9: 20$ \\
\hline 86.0 I88 $\$$ & TEWT\$ & ROCK FALLS & SE & I88 & $\times 44$ & IL & 101.0 & $1: 53$ & 2/01@ & $10: 54$ \\
\hline $44.0 I 88$ & & RAPIDS CITY & $S$ & I80 & I88 & IL & 145.0 & $2: 41$ & 01 a & $11: 42$ \\
\hline 173.0180 & & DES MOINES & N & I 235 & I35 & IA & 318.0 & $5: 53$ & $2 / 01$ & $14: 53$ \\
\hline $14.0 \quad 135$ & 180 & DES MOINES & $W$ & I 235 & I35 & IA & 332.0 & $6: 08$ & $2 / 01$ & $15: 0$ \\
\hline $119.0 \quad 180$ & & COUNCIL BLUFFS & SE & 129 & I80 & IA & 451.0 & $7: 58$ & & \\
\hline 3.0129 & I80 & COUNCIL BLUFFS & SW & I 29 & I80 & IA & 454.0 & $8: 01$ & $2 / 01$ & $17: 01$ \\
\hline $354.0 I 80$ & & BIG SPRINGS & SW & I76 & I80 & NE & 808.0 & 0 & $2 / 01$ & $22: 31$ \\
\hline 86.0176 & & ARVADA & $S$ & 170 & I76 & $\mathrm{CO}$ & 994.0 & $17: 25$ & $2 / 02$ & $1: 25$ \\
\hline 02.0170 & & COVE FORT & $W$ & I15 & 170 & UT & 1496.0 & $27: 39$ & $2 / 02$ & $11: 39$ \\
\hline 221.0 I15 & & GARNET & & 115 & $\times 64$ & NV & 1717.0 & $31: 03$ & $2 / 02$ & $14: 03$ \\
\hline 85.0 U93 & & HIKO & S & U93 & S375 & NV & 1802.0 & $33: 15$ & $2 / 0$ & $16: 15$ \\
\hline $98.0 \quad 5375$ & & WARM SPRINGS & & & & NV & 1900.0 & $35: 13$ & & $18: 13$ \\
\hline $50.0 \mathrm{U}$ & & TONOPAH & & & & NV & 1950.0 & $36: 43$ & $2 / 02$ & $19: 43$ \\
\hline 146.0 U95 & & MERCURY & S & U95 & LOCL & NV & 2096.0 & $39: 37$ & $2 / 02 @$ & $22: 37$ \\
\hline
\end{tabular}



6.0 LOCAL
MERCURY
NV 2102.0 $39: 46 \quad 2 / 02$ @ 22:46

From: COLUMBUS

to : MERCURY
NE I670 I71

$\mathrm{OH}$
Leaving : $2 / 01 / 99$ at 9:08 EST

Arriving: $2 / 03 / 99$ at 2:57 PST

Routing through:

\begin{tabular}{|c|c|c|c|c|c|c|c|c|c|c|}
\hline 0 & & COLUMBUS & NE & I670 & I71 & $\mathrm{OH}$ & .0 & $0: 00$ & 2/01@ & $9: 08$ \\
\hline $4.0 \quad I 670$ & & COLUMBUS & $W$ & I670 & I70 & $\mathrm{OH}$ & 4.0 & $0: 04$ & $2 / 01$ a & $9: 12$ \\
\hline $169.0 \quad \mathrm{I} 70$ & & INDIANAPOLIS & NE & I65 & I70 & IN & 173.0 & $3: 03$ & $2 / 01$ & $12: 1$ \\
\hline $2.0 \mathrm{I} 65$ & I70 & INDIANAPOLIS & SE & I65 & I70 & IN & 175.0 & $3: 06$ & $2 / 01 @$ & $12: 13$ \\
\hline 138.0170. & & TEUTOPOLIS & NW & 157 & I70 & IL & 313.0 & $6: 0$ & $2 / 0$ & 19 \\
\hline $6.0 \mathrm{I} 57$ & I70 & EFFINGHAM & SW & I57 & I70 & IL & 319.0 & & & \\
\hline $77.0 \quad \mathrm{I} 70$ & & EDWARDSVILLE & SE & I270 & I55 & IL & 396.0 & $7: 32$ & & \\
\hline $20.0 \quad 155$ & I70 & ST LOUIS & & I55 & I64 & MO & 416.0 & $7: 5$ & & \\
\hline 1.0155 & & ST LOUIS & S & I44 & 155 & MO & 417.0 & & & \\
\hline 290.0 I44 & & JOPLIN & SW & I44 & X1 & MO & 707.0 & $12: 5$ & & \\
\hline 17.0 I $44 \$$ & & MIAMI & E & I44 & $\times 313$ & $O K^{\prime}$ & 724.0 & 13: & & \\
\hline $72.0 \mathrm{I} 44 \$$ & TWRT\$ & CATOOSA & $\mathrm{s}$ & I44 & $\times 241$ & OK & 796.0 & $14: 4$ & & \\
\hline 20.0 I44 & & OAKHURST & E & I44 & $\times 221$ & OK & 816.0 & $15:($ & & \\
\hline 86.0 I44 \$ & TTRT\$ & EDMOND & SE & I3! & I44 & OK & 902.0 & & & \\
\hline $5.0 \quad I 35$ & I44 & OKLAHOMA CITY & NE & I35 & I44 & OK & 907.0 & $16:$ & & \\
\hline $10.0 \mathrm{I} 44$ & & OKLAHOMA CITY & W & I40 & I44 & OK & 917.0 & $16: 4$ & & \\
\hline $217.0 \mathrm{I} 40$ & & BARSTOW & & & I 40 & $\mathrm{CA}$ & 2134.0 & & & \\
\hline $63.0 \mathrm{I} 15$ & & BAKER & & & S127 & CA & 2197.0 & $39: 3$ & & \\
\hline $56.0 \quad S 127$ & & SHOSHONE & & S127 & S178 & & 2253.0 & $40: 43$ & & \\
\hline $50.0 \quad \mathrm{~S} 127$ & S373 & AMARGOSA VALLY & & & S373 & NV & 2303.0 & $42: 13$ & & \\
\hline $24.0 \mathrm{U}$ & & MERCURY & S & U95 & LOC & NV & 2327.0 & $42: 41$ & $2 / 03$ & \\
\hline $6.0 \mathrm{LOCAL}$ & & MERCURY & & & & NV & 2333.0 & $42: 50$ & 2/03@ & \\
\hline
\end{tabular}

From: BROOKHAVEN LAB

to : MERCURY
NY Leaving : 2/02/99 at 7:28 EST

NV Arriving: 2/04/99 at 15:42 PST

Routing through:

$\begin{array}{rl}.0 & \\ 1.0 & \text { LOCAL } \\ 2.0 & \text { C46 } \\ 49.0 & \text { I } 495 \\ 4.0 & \text { TCIP } \\ 3.0 & \text { I295\# } \\ 1.0 & \text { I295 } \\ 1.0 & 195 \quad \text { I } 278 \\ 7.0 & \text { I } \\ 1.0 & \text { I } \\ 4.0 & \text { I } \# \\ 64.0 & \text { I } \\ 2.0 & \text { I } \\ 330.0 & \text { I } \#\end{array}$

\begin{tabular}{|c|c|c|c|c|c|c|c|}
\hline BROOKHAVEN LAB & & & NY & .0 & $0: 00$ & $2 / 02 @$ & $7: 28$ \\
\hline YAPHANK & NE C46 & LOCL & NY & 1.0 & $0: 02$ & $2 / 02 @$ & $7: 30$ \\
\hline UPTON & SW I495 & $x 68$ & NY & 3.0 & $0: 04$ & $2 / 02 a$ & \\
\hline LITTLE NECK & S I I 495 & $\times 30$ & NY & 52.0 & $0: 58$ & $2 / 02 @$ & \\
\hline BAYSIDE & NW I 295 & TCIP & NY & 56.0 & $1: 03$ & $2 / 02$ & 8: \\
\hline LOCUST POINT & I295 & I695 & NY & 59.0 & $1: 06$ & $2 / 02$ & \\
\hline BRONX & SE I678 & I95 & NY & 60.0 & $1: 07$ & $2 / 02 @$ & \\
\hline BRONX & E I278 & 195 & NY & 61.0 & $1: 09$ & $2 / 02 a$ & \\
\hline W BRIDGE & I95 & X1A & NY & 68.0 & $1: 20$ & $2 / 02 a$ & $8: 4$ \\
\hline T LEE & NE TPAL & I95 & NJ & 69.0 & $1: 26$ & $2 / 02 a$ & $8: 54$ \\
\hline DGOTA & SE I80 & I95 & NJ & 73.0 & $1:$ & $2 / 02 a$ & \\
\hline AHAQUARRY & S I80 & X1 & NJ & 137.0 & $2: 40$ & $2 / 02$ & \\
\hline STROUDSBURG & E I80 & $x 52$ & PA & 139.0 & $2: 43$ & $2 / 02$ & \\
\hline PTH & NE I76 & I80 & $\mathrm{OH}$ & 469.0 & $9: 43$ & & \\
\hline
\end{tabular}




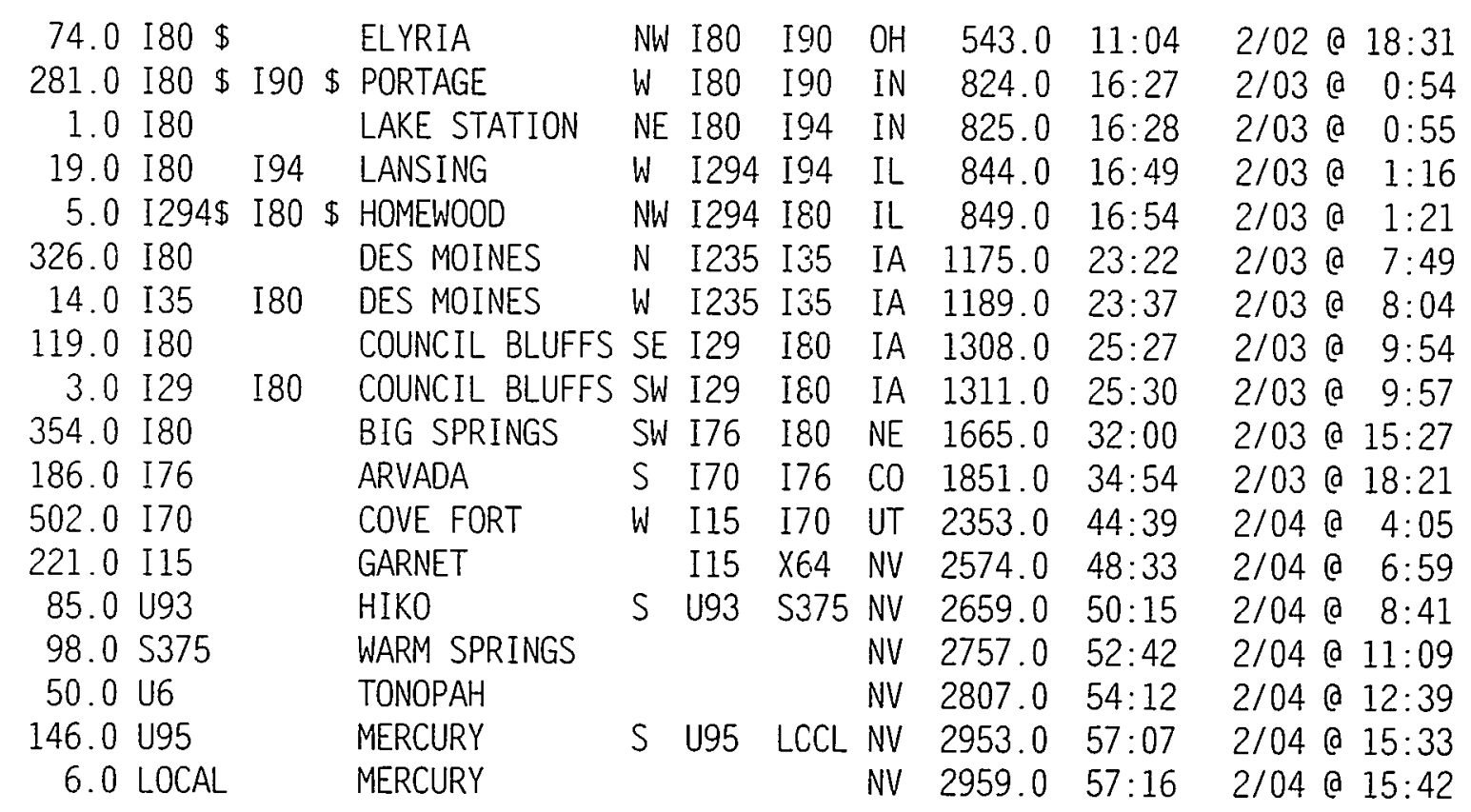

From: CANOGA PARK to : MERCURY
S27 LOCL CA Leaving : $1 / 30 / 99$ at $8: 39$ PST

NV Arriving: $1 / 30 / 99$ at 15:41 PST

Routing through:

\begin{tabular}{|c|c|c|c|c|c|c|c|c|c|c|}
\hline .0 & & CANOGA PARK & & S27 & LOCL & CA & .0 & $0: 00$ & $1 / 300$ & $8: 39$ \\
\hline $3.0 \quad 527$ & & WOODLAND HILLS & & U101 & S27 & CA & 3.0 & $0: 04$ & $1 / 30$ & $8: 43$ \\
\hline 25.0 U101 & & LOS ANGELES & & I10 & I5 & CA & 28.0 & $0: 31$ & $1 / 30$ & $9: 1$ \\
\hline $41.0 \mathrm{I} 10$ & & ONTARIO & $E$ & I10 & I15 & $\mathrm{CA}$ & 69.0 & $1: 16$ & $1 / 30$ & \\
\hline $137.0 \quad$ I15 & & BAKER & & $\mathrm{I} 15$ & S127 & $\mathrm{CA}$ & 206.0 & $3: 47$ & $1 / 30$ & \\
\hline $56.0 \quad S 127$ & & SHOSHONE & & S127 & S178 & CA & 262.0 & $4: 55$ & $1 / 30$ & \\
\hline $50.0 \quad S 127$ & S373 & AMARGOSA VALLY & & U95 & S373 & NV & 312.0 & $6: 25$ & & \\
\hline 24.0 U95 & & MERCURY & S & U95 & LOCL & NV & 336.0 & $6: 53$ & $1 / 30$ a & \\
\hline $6.0 \mathrm{LOCAL}$ & & MERCURY & & & & NV & 342.0 & $7: 02$ & $1 / 30$ & 15 \\
\hline
\end{tabular}

From: FERNALD PLANT to : MERCURY
$\mathrm{OH} \quad$ Leaving : 2/01/99 at 8:34 EST

NV Arriving: 2/03/99 at 0:59 PST

Routing through:

\begin{tabular}{|c|c|c|c|c|c|c|c|c|c|c|}
\hline .0 & & FERNALD PLANT & & & & $\mathrm{OH}$ & .0 & $0: 00$ & $2 / 01 @$ & $8: 34$ \\
\hline $7.0 \$ 128$ & & MIAMITOWN & $S$ & 174 & $x 7$ & $\mathrm{OH}$ & 7.0 & $0: 11$ & 2/01 & $8: 45$ \\
\hline $2.0 \quad 1275$ & I74 & HARRISON & SE & 1275 & I74 & $\mathrm{OH}$ & 9.0 & $0: 13$ & $2 / 01$ & $8: 47$ \\
\hline $81.0 \quad 174$ & & INDIANAPOLIS & SE & I 465 & 174 & IN & 90.0 & $1: 34$ & $2 / 01$ & $10: 08$ \\
\hline $14.0 \mathrm{I} 465$ & I74 & INDIANAPOLIS & SW & I 465 & $I 70$ & IN & 104.0 & $1: 49$ & $2 / 01$ & $10: 23$ \\
\hline $31.0 \quad 170$ & & TEUTOPOLIS & $\mathrm{NW}$ & I57 & I70 & IL & 235.0 & $4: 06$ & $2 / 01$ & $13: 41$ \\
\hline 6.0157 & 170 & EFFINGHAM & SW & I57 & I70 & $\mathrm{IL}$ & 241.0 & $4: 43$ & $2 / 0$ & $14: 17$ \\
\hline $77.0 \quad 170$ & & EDWARDSVILLE & SE & $\mathrm{I} 270$ & I55 & IL & 318.0 & $6: 07$ & 2/01 @ & $15: 41$ \\
\hline $20.0 \quad I 55$ & 170 & ST LOUIS & & I55 & 164 & MO & 338.0 & $6: 29$ & 2/01@ & $16: 03$ \\
\hline 1.0155 & & ST LOUIS & S & I44 & 155 & MO & 339.0 & $6: 30$ & 2/01@ & $16: 04$ \\
\hline
\end{tabular}




\begin{tabular}{|c|c|c|c|c|c|c|c|c|c|}
\hline $290.0 I 44$ & & JOPLIN & SW & I44 & $X 1$ & MO & 629.0 & $11: 32$ & $2 / 01 @ 21: 05$ \\
\hline $17.0 \mathrm{I} 44 \$$ & & MIAMI & $E$ & I44 & $\times 313$ & OK & 646.0 & $11: 47$ & 2/01@21:21 \\
\hline $72.0 \mathrm{I} 44 \$$ & TWRT\$ & CATOOSA & S & I 44 & $\times 241$ & OK & 718.0 & $12: 54$ & $2 / 01$ a 22:28 \\
\hline $20.0 \mathrm{I} 44$ & & OAKHURST & $E$ & I44 & $\times 221$ & OK & 738.0 & $13: 44$ & $2 / 01$ @ 23:1 \\
\hline 86.0 I $44 \$$ & TTRT\$ & EDMOND & SE & I35 & I44 & OK & 824.0 & $15: 04$ & $2 / 02 @ 0: 38$ \\
\hline $5.0 \mathrm{I} 35$ & I44 & OKLAHOMA CITY & NE & 135 & I 44 & OK & 829.0 & $15: 10$ & $2 / 02 @$ \\
\hline $10.0 \mathrm{I} 44$ & & OKLAHOMA CITY & $W$ & I 40 & I 44 & OK & 839.0 & $15: 20$ & $2 / 02$ \\
\hline $217.0 \quad 140$ & & BARSTOW & & I15 & 140 & $C A$ & 2056 & $37: 02$ & $2 / 02 @ 20: 36$ \\
\hline $63.0 \mathrm{I} 15$ & & BAKER & & I15 & S127 & $\mathrm{CA}$ & & & 2/02 @ 21: \\
\hline $56.0 \quad 5127$ & & SHOSHONE & & S127 & S178 & $\mathrm{CA}$ & 2175.0 & $39: 18$ & $2 / 02 @ 22: 5$ \\
\hline $50.0 \quad S 127$ & S373 & AMARGOSA VALLY & & U95 & \$373 & NV & 2225.0 & $40: 18$ & $2 / 02$ @ $23: 5$ \\
\hline 24.0 U95 & & MERCURY & $S$ & U95 & LOCL & NV & & $41: 16$ & $2 / 03 @ 0: 5$ \\
\hline $6.0 \mathrm{LOCAL}$ & & MERCURY & & & & NV & 2255.0 & $41: 25$ & $2 / 03$ \\
\hline
\end{tabular}

From: GE VALLECITOS to : MERCURY
CA Leaving : 2/01/99 at 9:23 PST

NV Arriving: $2 / 01 / 99$ at 21:41 PST

Routing through:

\begin{tabular}{|c|c|c|c|c|c|c|c|c|c|c|}
\hline .0 & & GE VALLECITOS & & & & $C A$ & .0 & $0: 00$. & $2 / 01 @$ & $9: 23$ \\
\hline $10.0 \mathrm{~S} 84$ & & LIVERMORE & NE & I580 & S84 & $\mathrm{CA}$ & 10.0 & $0: 14$ & $2 / 01$ & $9: 37$ \\
\hline $26.0 I 580$ & & VERNALIS & W & I5 & I580 & $\mathrm{CA}$ & 36.0 & $0: 42$ & $2 / 01 @$ & $10: 05$ \\
\hline 196.0 I5 & & STOCKDALE HWY & W & 15 & $\mathrm{LOCL}$ & $\mathrm{CA}$ & 232.0 & $4: 46$ & $2 / 01$ & $14: 09$ \\
\hline $17.0 \mathrm{LOCAL}$ & & BAKERSFIELD & SW & S58 & S99 & $C A$. & 249.0 & $5: 15$ & $2 / 01$ & $14: 38$ \\
\hline $61.0 \$ 58$ & & MOJAVE & $N$ & S14 & S58 & $\mathrm{CA}$ & 310.0 & $6: 22$ & $2 / 01 @$ & $15: 45$ \\
\hline $1.0 S 14$ & S58 & MOJAVE & & S14 & S58 & $\mathrm{CA}$ & 311.0 & $6: 23$ & $2 / 01$ & $15: 46$ \\
\hline $71.0 \mathrm{~S} 58$ & & BARSTOW & $E$ & I15 & S58 & $\mathrm{CA}$ & 382.0 & $7: 59$ & $2 / 01 @$ & $17: 22$ \\
\hline $60.0 I 15$ & & BAKER & & 115 & S127 & $\mathrm{CA}$ & 442.0 & $9: 04$ & $2 / 01$ & $18: 27$ \\
\hline $56.0 \quad \mathrm{~S} 127$ & & SHOSHONE & & S127 & S178 & $\mathrm{CA}$ & 498.0 & $10: 42$ & $2 / 01$ & $20: 04$ \\
\hline $50.0 \quad S 127$ & S373 & AMARGOSA VALLY & & U95 & S373 & NV & 548.0 & $11: 42$ & $2 / 01 @$ & $21: 04$ \\
\hline $24.0 \cup 95$ & & MERCURY & $\mathrm{S}$ & U95 & LOCL & NV & 572.0 & $12: 10$ & $2 / 01$ & $21: 32$ \\
\hline 6.0 LOCAL & & MERCURY & & & & NV & 578.0 & $12: 19$ & 2/01@ & $21: 41$ \\
\hline
\end{tabular}

From: GRAND JCT to : MERCURY
U50 U6

$\mathrm{CO}$

Leaving : 2/01/99 at 9:22 MST

Arriving: $2 / 02 / 99$ at $1: 19$ PST

Routing through:

\begin{tabular}{|c|c|c|c|c|c|c|c|c|c|c|}
\hline .0 & & GRAND JCT & & U50 & U6 & $\mathrm{CO}$ & .0 & $0: 00$ & $2 / 01$ & $9: 22$ \\
\hline $6.0 \cup 50$ & U6 & GRAND JCT & $\mathrm{NW}$ & 170 & $\times 26$ & $\mathrm{CO}$ & 6.0 & $0: 07$ & $2 / 01$ & $9: 29$ \\
\hline $258.0 \quad 170$ & & COVE FORT & $W$ & I 15 & 170 & UT & 264.0 & $4: 50$ & $2 / 01$ & $14: 13$ \\
\hline 221.0 I15 & & GARNET & & I15 & $x 64$ & NV & 485.0 & $8: 14$ & $2 / 01 @$ & \\
\hline 85.0 U93 & & HIKO & $S$ & U93 & S375 & NV & 570.0 & 9: & $2 / 01$ & 18 \\
\hline $98.0 \quad 5375$ & & WARM SPRINGS & & & & NV & 668.0 & $12: 24$ & $2 / 01$ & $20: 46$ \\
\hline 50.0 U6 & & TONOPAH & & & & NV & 718.0 & $13: 54$ & $2 / 01$ & $22: 16$ \\
\hline 146.0 U95 & & MERCURY & $S$ & U95 & LOCL & NV & $864: 0$ & $16: 48$ & $2 / 02$ & $1: 10$ \\
\hline $6.0 \mathrm{LOCAL}$ & & MERCURY & & & & NV & 870.0 & $16: 57$ & $2 / 02$ & $1: 19$ \\
\hline
\end{tabular}


From: ID NATL ENG LAB U20 LOCL ID to : MERCURY
Leaving : $2 / 01 / 99$ at 9:06 MST

Arriving: $2 / 02 / 99$ at $3: 14$ PST

Routing through:

\begin{tabular}{|c|c|c|c|c|c|c|c|c|c|}
\hline .0 & & ID NATL ENG & & U20 & LOCL & ID & .0 & $0: 00$ & $2 / 01 @$ \\
\hline $63.0 \cup 20$ & U26 & CAREY & & U20 & U26 & ID & 63.0 & $1: 16$ & $2 / 01 @ 10: 21$ \\
\hline $39.0 \mathrm{U} 26$ & U93 & SHOSHONE & & U26 & U93 & ID & 102.0 & $2: 02$ & $2 / 01$ @ $11: 08$ \\
\hline 27.0 U26 & & BLISS & & I84 & X141 & ID & 129.0 & $2: 35$ & $2 / 01 @ 11: 41$ \\
\hline 106.0 I84 & & NAMPA & N & I84 & X35 & ID & 235.0 & $4: 45$ & $2 / 01$ a $13: 50$ \\
\hline $19.0 \$ 55$ & & MARSING & W & U95 & S55 & ID & 254.0 & 5: & $2 / 01 @ 14$ \\
\hline 220.0 U95 & & WINNEMUCCA & & I 80 & X178 & NV & 474.0 & $10: 07$ & $2 / 01 @ 18$ \\
\hline 54.0 I80 & & BATTLE MTN & NW & I 80 & X229 & NV & 528.0 & $10: 57$ & $2 / 01 @ 1$ \\
\hline $89.0 \quad \$ 305$ & & AUSTIN & & & & NV & 617.0 & $12: 44$ & $2 / 01 @ 2$ \\
\hline $12.0 \cup 50$ & & AUSTIN & SE & U50 & S376 & NV & 629.0 & $12: 5$ & 2/01@21: \\
\hline $100.0 \$ 376$ & & TONOPAH & E. & U6 & S376 & NV & 729.0 & $14: 5$ & $2 / 01 @ 23$ \\
\hline 6.0 U6 & & TONOPAH & & & & NV & 735.0 & $15: 35$ & $2 / 01 @ 23$ \\
\hline $146.0 \mathrm{U}$ & & MERCURY & S & U95 & LOCL & NV & 881.0 & $19: 00$ & $2 / 02 @$ \\
\hline 6.0 LOCAL & & MERCURY & & & & NV & 887.0 & 19:09 & $2 / 02$ \\
\hline
\end{tabular}

From: SANDIA NATL LBS to : MERCURY

NM Leaving : 2/01/99 at 9:10 MST

NV Arriving: 2/02/99 at 0:39 PST

Routing through:

\begin{tabular}{|c|c|c|c|c|c|c|c|c|c|}
\hline .0 & & SANDIA NATL LBS & & & NM & .0 & $0: 00$ & $2 / 01 a$ & $9: 10$ \\
\hline $3.0 \mathrm{LOCAL}$ & & ALBUQUERQUE & I 40 & $\times 165$ & NM & 3.0 & $0: 07$ & $2 / 01 @$ & \\
\hline 687.0 I40 & & BARSTOW & I15 & 140 & $C A$ & 690.0 & $12: 07$ & $2 / 01$ & \\
\hline $63.0 \mathrm{I} 15$ & & BAKER & I15 & S127 & CA & 753.0 & $13: 16$ & $2 / 01$ & \\
\hline $56.0 \quad \$ 127$ & & SHOSHONE & S127 & S178 & CA & 809.0 & $14: 53$ & & \\
\hline $50.0 \quad S 127$ & S373 & AMARGOSA VALLY & U95 & S373 & NV & 859.0 & $15: 53$ & & \\
\hline 24.0 U95 & & MERCURY & U95 & LOCL & NV & 883.0 & $16: 21$ & $2 / 0$ & \\
\hline $6.0 \mathrm{LOCAL}$ & & MERCURY & & & NV & 889.0 & $16: 30$ & $2 / 02$ & \\
\hline
\end{tabular}

From: KAPL-KNOLLS

to : MERCURY
NY Leaving : $2 / 02 / 99$ at $7: 29$ EST

NV Arriving: $2 / 04 / 99$ at 14:41 PST

Routing through:

\begin{tabular}{|c|c|c|c|c|c|c|c|c|}
\hline .0 & KAPL-KNOLLS & & & NY & .0 & $0: 00$ & $2 / 02 @$ & $7: 29$ \\
\hline 4.0 LOCAL & SCHENECTADY & $E$ & S146 S7 & NY & 4.0 & $0: 08$ & $2 / 02 @$ & $7: 37$ \\
\hline $2.0 \mathrm{S7}$ & SCHENECTADY & SE & $1890 \times 7$ & NY & 6.0 & $0: 10$ & $2 / 02 @$ & $7: 40$ \\
\hline $2.0 \quad 1890$ & SCHENECTADY & $\mathrm{NW}$ & $1890 \times 1$ & NY & 8.0 & $0: 12$ & $2 / 02 @$ & $7: 42$ \\
\hline $1.0 \mathrm{I890 \$}$ & SCHENECTADY & $\mathrm{NW}$ & I890 I90 & NY & 9.0 & 0: & 2/02.@ & $7: 43$ \\
\hline $258.0190 \$$ TNYT\$ & BUFFALO & NE & I290 I90 & NY & 267.0 & $5: 2$ & $2 / 02 @$ & $12: 54$ \\
\hline $9.0 \mathrm{I} 90 \quad$ TNYT & LACKAWANNA & E & $190 \times 55$ & NY & 276.0 & $5: 35$ & $2 / 02 a$ & $13: 04$ \\
\hline 66.0 I90\$ TNYT\$ & RIPLEY & W & $x 61$ & NY & & & $2 / 02$ & $14: 16$ \\
\hline $124.0 \quad \mathrm{I} 90$ & CLEVELAND & S & I71 I90 & $\mathrm{OH}$ & 466.0 & $9: 32$ & $2 / 02$ & 17:01 \\
\hline $9.0 \mathrm{I} 71$ & BROOK PARK & $\mathrm{N}$ & I480 I71 & $\mathrm{OH}$ & 475.0 & $9: 42$ & $2 / 02$ & $17: 11$ \\
\hline $10.0 \mathrm{I}$ & N RIDGEVILLE & $\mathrm{s}$ & I 480 I 80 & $\mathrm{OH}$ & 485.0 & $9: 53$ & $2 / 02$ & $17: 22$ \\
\hline
\end{tabular}




\begin{tabular}{|c|c|c|c|c|c|c|c|c|c|}
\hline $8.0180 \$$ & & ELYRIA & $\mathrm{NW}$ & I80 & I90 & $\mathrm{OH}$ & 493.0 & $10: 01$ & $2 / 02 @ 17: 30$ \\
\hline $281.0180 \$$ & $190 \$$ & PORTAGE & $W$ & 180 & 190 & IN & 774.0 & $15: 24$ & $2 / 02$ a 23:53 \\
\hline $1.0 \mathrm{I} 80$ & & LAKE STATION & NE & 180 & I94 & IN & 775.0 & $15: 26$ & $2 / 02 @ 23: 54$ \\
\hline 19.0180 & 194 & LANSING & $W$ & I294 & 194 & IL & 794.0 & $15: 46$ & $2 / 03 @ 0: 15$ \\
\hline $5.0 \mathrm{I} 294 \$$ & $180 \$$ & HOMEWOOD & NW & I294 & 180 & IL & 799.0 & $15: 52$ & 2/03@ \\
\hline $326.0 \quad I 80$ & & DES MOINES & $\mathrm{N}$ & I235 & 135 & IA & 1125.0 & $21: 50$ & 2/03@ \\
\hline $14.0 \mathrm{I} 35$ & I80 & DES MOINES & $W$ & I235 & 135 & IA & 1139.0 & $22:$ & $2 / 03$ \\
\hline $119.0 \quad 180$ & & COUNCIL BLUFFS & SE & I29 & 180 & $I A$ & 1258.0 & $24: 25$ & $2 / 03$ \\
\hline 3.0129 & I 80 & COUNCIL BLUFFS & SW & I29 & I80 & IA & 1261.0 & 3 & 3 a 8 \\
\hline $354.0 \quad$ I80 & & BIG SPRINGS & SW & 176 & 180 & $\mathrm{NE}$ & 1615.0 & $30: 2$ & 2/03@ 13: \\
\hline 186.0176 & & ARVADA & $S$ & I70 & 176 & $\mathrm{CO}$ & 1801.0 & 33: & 3 a 17 \\
\hline $502.0 \quad 170$ & & COVE FORT & $W$ & I15 & $I 70$ & UT & 2303.0 & 43: & (a) 3 \\
\hline $221.0 \mathrm{I} 15$ & & GARNET & & I.15 & $x 64$ & NV & 2524.0 & & $2 / 04 @$ \\
\hline 85.0 บ93 & & HIKO & S & U93 & S375 & NV & 2609.0 & $49: 1$ & 2/04 @ \\
\hline $98.0 \mathrm{~s}$ & & WARM SPRINGS & & & & NV & & & 2/04 @ 10: \\
\hline $50.0 U$ & & TONOPAH & & & & NV & 275 & $52: 40$ & $2 / 04$ \\
\hline 146.0 U95 & & MERCURY & S & U95 & LOCL & NV & 2903.0 & $56: 04$ & 2/04@14: \\
\hline 6.0 LOCA & & MERCURY & & & & NV & 2909.0 & $56: 13$ & $2 / 04$ \\
\hline
\end{tabular}

From: LOS ALAMOS to : MERCURY

NM Leaving : 2/01/99 at 8:34 MST

NV Arriving: 2/02/99 at 2:03 PST

Routing through:

\begin{tabular}{|c|c|c|c|c|c|c|c|c|c|c|}
\hline .0 & & LOS ALAMOS & & & & NM & .0 & $0: 00$ & $2 / 01$ a & $8: 34$ \\
\hline 6.0 LTRKR & & BANDELIER N M & W & \$4 & LTRK & NM & 6.0 & $0: 10$ & $2 / 01$ & $8: 44$ \\
\hline $1.0 \mathrm{~S} 4$ & & BANDELIER N M & N & S4 & S502 & NM & 7.0 & $0: 12$ & $2 / 01 @$ & $8: 46$ \\
\hline $12.0 \mathrm{~S} 502$ & & POJOAQUE & & U285 & $\mathrm{S} 502$ & NM & 19.0 & $0: 27$ & $2 / 01$ & $9: 01$ \\
\hline 18.0 U285 & U84 & SANTA FE & & U285 & U84 & NM & 37.0 & $0: 47$ & $2 / 01$ & $9: 21$ \\
\hline 2.0 U84 & & SANTA FE & S & I25 & $\times 282$ & NM & 39.0 & $0: 50$ & $2 / 01 @$ & $9: 23$ \\
\hline $56.0 \quad 125$ & & ALBUQUERQUE & $E$ & 125 & I40 & NM & 95.0 & $1: 43$ & $2 / 01$ & 10: \\
\hline $681.0 \mathrm{I} 40$ & & BARSTOW & & 115 & I40 & $\mathrm{CA}$ & 776.0 & $14: 07$ & $2 / 0$ & $21:$ \\
\hline 63.0115 & & BAKER & & 115 & S127 & $C A$ & 839.0 & $15: 15$ & $2 / 01$ & $22: 49$ \\
\hline $56.0 \quad \mathrm{~S} 127$ & & SHOSHONE & & S127 & S178 & $\mathrm{CA}$ & 895.0 & $16: 22$ & $2 / 01$ & 23: \\
\hline $50.0 \mathrm{~S} 127$ & S373 & AMARGOSA VALLY & & U95 & S373 & NV & 945.0 & $17: 22$ & $2 / 02 @$ & \\
\hline 24.0 U95 & & MERCURY & $S$ & U95 & $\mathrm{LOCL}$ & NV & 969.0 & $18: 20$ & 21.02 & $1: 5$ \\
\hline $6.0 \mathrm{LOCAL}$ & & MERCURY & & & & NV & 975.0 & $18: 29$ & $2 / 02$ a & $2: 0$ \\
\hline
\end{tabular}

From: L BERKELEY LAB CA Leaving : 2/02/99 at 9:06 PST to : MERCURY NV Arriving: 2/02/99 at 22:00 PST

Routing through:

\begin{tabular}{|c|c|c|c|c|c|c|c|c|}
\hline .0 & L BERKELEY LA & & & $C A$ & .0 & $0: 00$ & $2 / 02$ & $9: 06$ \\
\hline $3.0 \mathrm{LOCAL}$ & BERKELEY & $W$ & I580 LOCL & $C A$ & 3.0 & $0: 07$ & $2 / 02 @$ & $9: 13$ \\
\hline $2.0 \mathrm{I} 580 \quad \mathrm{I} 80$ & OAKLAND & $\mathrm{NW}$ & I580 I80 & $C A$ & 5.0 & $0: 09$ & $2 / 02 @$ & $9: 15$ \\
\hline 1.01580 & PIEDMONT & $\mathrm{NW}$ & I580 I980 & $C A$ & 6.0 & $0: 10$ & $2 / 02$ & $9: 16$ \\
\hline 2.01980 & OAKLAND & & I880 I980 & $C A$ & 8.0 & $0: 13$ & $2 / 02$ & $9: 18$ \\
\hline 1.01880 & SAN LEANDRO & & I238 I880 & $C A$ & 19.0 & $0: 25$ & $2 / 02 @$ & $9:$ \\
\hline
\end{tabular}




\begin{tabular}{|c|c|c|c|c|c|c|c|c|c|}
\hline $2.0 \quad 1238$ & & CASTRO VALLEY & W & I238 & I580 & $C A$ & 21.0 & $0: 27$ & $2 / 02$ \\
\hline $47.0 \quad 1580$ & & VERNALIS & W & I5 & 1580 & $C A$ & 68.0 & $1: 18$ & $2 / 02 @ 10: 24$ \\
\hline 196.0 I5 & & STOCKDALE HWY & W & 15 & LOCL & CA & 264.0 & $5: 22$ & $2 / 02 @ 14: 27$ \\
\hline $17.0 \mathrm{LOCAL}$ & & BAKERSFIELD & SW & S58 & $\$ 99$ & $C A$ & 281.0 & $5: 51$ & $2 / 02 @ 14: 56$ \\
\hline $61.0 \$ 58$ & & MOJAVE & $\mathrm{N}$ & S14 & $\$ 58$ & $C A$ & 342.0 & $6: 58$ & $2 / 02$ a $16: 03$ \\
\hline $1.0 S 14$ & S58 & MOJAVE & & S14 & $\$ 58$ & $C A$ & 343.0 & $6: 59$ & $2 / 02 @ 16: 04$ \\
\hline $71.0 \$ 58$ & & BARSTOW & $E$ & $\mathrm{I} 15$ & 558 & $C A$ & 414.0 & $8: 35$ & $2 / 02$ a $17: 40$ \\
\hline $60.0 \mathrm{I} 15$ & & BAKER & & I15 & S1.27 & CA & 474.0 & $10: 10$ & $2 / 02$ @ $19: 15$ \\
\hline $56.0 \$ 127$ & & SHOSHONE & & \$127 & $\$ 178$ & CA & 530.0 & $11: 17$ & $2 / 02$ a $20: 23$ \\
\hline $50.0 \quad S 127$ & S373 & AMARGOSA VALLY & & U95 & S373 & NV & 580.0 & $12: 17$ & $2 / 02$ a $21: 23$ \\
\hline 24.0 U95 & & MERCURY & S & U95 & LOCL & NV & 604.0 & $12: 45$ & $2 / 02 @ 21: 51$ \\
\hline $6.0 \mathrm{LOCAL}$ & & MERCURY & & & & NV & 610.0 & $12: 54$ & $2 / 02$ @ 22:00 \\
\hline
\end{tabular}

From: L LIVERMORE LB CA Leaving : 1/30/99 at 8:31 PST to : MERCURY

NV Arriving: $1 / 30 / 99$ at $20: 38$ PST

Routing through:

\begin{tabular}{|c|c|c|c|c|c|c|c|c|c|c|}
\hline .0 & & L LIVERMORE LB & & & & CA & .0 & $0: 00$ & $1 / 30$ & $8: 31$ \\
\hline $3.0 \mathrm{LOCAL}$ & & ALTAMONT & SW & I580 & LOCL & $\mathrm{CA}$ & 3.0 & $0: 05$ & $1 / 30$ & $8: 36$ \\
\hline $24.0 \quad I 580$ & & VERNALIS & $W$ & I5 & I580 & CA & 27.0 & $0: 31$ & $1 / 30 @$ & $9: 02$ \\
\hline 196.0 I5 & & STOCKDALE HWY & $W$ & I5 & $\mathrm{LOCL}$ & CA & 223.0 & $4: 05$ & $1 / 30 @$ & $12: 36$ \\
\hline 17.0 LOCAL & & BAKERSF IELD & SW & S58 & S99 & CA & 240.0 & $5: 04$ & $1 / 30$ & $13: 35$ \\
\hline $61.0 \quad 558$ & & MOJAVE & $N$ & S14 & S58 & CA & 301.0 & $6: 11$ & $1 / 30$ & $14: 42$ \\
\hline $1.0 \mathrm{~S} 14$ & S58 & MOJAVE & & S14 & S58 & $\mathrm{CA}$ & 302.0 & $6: 12$ & $1 / 30$ & $14: 43$ \\
\hline $71.0 \quad 558$ & & BARSTOW & $E$ & I15 & S58 & $\mathrm{CA}$ & 373.0 & $7: 48$ & $1 / 30$ & $16: 19$ \\
\hline $60.0 I 15$ & & BAKER & & I15 & S127 & $C A$ & 433.0 & $8: 53$ & $1 / 30$ & $17: 24$ \\
\hline $56.0 \quad \$ 127$ & & SHOSHONE & & S127 & S178 & $\mathrm{CA}$ & 489.0 & $10: 31$ & $1 / 30$ & $19: 02$ \\
\hline $50.0 \quad S 127$ & S373 & AMARGOSA VALLY & & U95 & S373 & NV & 539.0 & $11: 31$ & $1 / 300$ & $20: 02$ \\
\hline 24.0 U95 & & MERCURY & S & U95 & LOCL & NV & 563.0 & $11: 58$ & $1 / 30 @$ & $20: 29$ \\
\hline $6.0 \mathrm{LOCAL}$ & & MERCURY & & & & NV & 569.0 & $12: 07$ & $1 / 30$ & $20: 38$ \\
\hline
\end{tabular}

From: MOUND FACILITY

to : MERCURY
$\mathrm{OH} \quad$ Leaving : $2 / 01 / 99$ at $8: 36$ EST

NV Arriving: $2 / 03 / 99$ at $1: 34$ PST

Routing through:

\begin{tabular}{|c|c|c|c|c|c|c|c|c|c|c|}
\hline .0 & & MOUND FACILITY & & & & $\mathrm{OH}$ & .0 & $0: 00$ & $2 / 01$ & $8: 36$ \\
\hline 1.0 LOCAL & & MIAMISBURG & & S725 & LOCL & $\mathrm{OH}$ & 1.0 & $0: 02$ & $2 / 01 @$ & $8: 38$ \\
\hline $3.0 \$ 725$ & & MIAMISBURG & $E$ & 175 & $X 44$ & $\mathrm{OH}$ & 4.0 & $0: 06$ & $2 / 01 @$ & $8: 42$ \\
\hline $8.0 I 75$ & & DAYTON & & I75 & $\times 52$ & $\mathrm{OH}$ & 12.0 & $0: 14$ & $2 / 01 @$ & $8: 51$ \\
\hline 31.0 U35 & & NEW WESTVILLE & NE & 170 & X1 & $\mathrm{OH}$ & 43.0 & $0: 56$ & $2 / 01 @$ & $9: 32$ \\
\hline $75.0 \quad 170$ & & INDIANAPOLIS & NE & 165 & I70 & IN & 118.0 & $2: 12$ & $2 / 01$ & $10: 48$ \\
\hline $2.0 I 65$ & 170 & INDIANAPOLIS & SE & I65 & I70 & IN & 120.0 & $2: 14$ & $2 / 01$ & $10: 51$ \\
\hline $138.0 \quad 170$ & & TEUTOPOLIS & $\mathrm{NW}$ & I57 & I70 & IL & 258.0 & $5: 10$ & $2 / 01$ a & $14: 46$ \\
\hline $6.0 \quad 157$ & I70 & EFF INGHAM & SW & 157 & I70 & IL & 264.0 & $5: 17$ & $2 / 01 @$ & $14: 5$ \\
\hline $77.0 \quad 170$ & & EDWARDSVILLE & SE & I 270 & I55 & IL & 341.0 & $6: 41$ & $2 / 01 @$ & $16: 1$ \\
\hline $20.0 \quad 155$ & 170 & ST LOUIS & & 155 & I64 & MO & 361.0 & $7: 03$ & $2 / 01 @$ & $16: 39$ \\
\hline 1.0155 & & ST LOUIS & S & I44 & I55 & MO & 362.0 & $7: 04$ & $2 / 01 @$ & $16: 40$ \\
\hline
\end{tabular}




\begin{tabular}{|c|c|c|c|c|c|c|c|c|c|}
\hline 290.0 I44 & & JOPLIN & SW & I 44 & $x_{1}$ & MO & 652.0 & $12: 05$ & $2 / 01 @ 21: 41$ \\
\hline $17.0 I 44 \$$ & & MIAMI & $E$ & I 44 & X313 & OK & 669 & 12: & $2 / 01 @ 21: 57$ \\
\hline 72.0 I $44 \$$ & TWRT\$ & CATOOSA & & I 44 & $\times 241$ & OK & & 7 & \\
\hline 20.0 I44 & & OAKHURST & & I 44 & $\times 221$ & OK & & & \\
\hline 86.0 I $44 \$$ & TTRT\$ & EDMOND & SE & I35 & I44 & OK & & & 2/02 @ \\
\hline & I44 & MA CITY & NE & I35 & I44 & OK. & & & \\
\hline $10.0 \mathrm{I} 44$ & & DMA CITY & W & I 40 & I 44 & OK & & & \\
\hline $217.0 \mathrm{I}$ & & BARSTOW & & I15 & I 40 & CA & 207 & & \\
\hline & & BAKER & & I15 & S127 & CA & & & \\
\hline & & SHOSHONE & & S127 & S178 & CA & & & \\
\hline 50.0 & S373 & AMARGOSA VALLY & & U95 & S373 & NV & & & \\
\hline 24.0 & & MERCURY & $\mathrm{s}$ & U95 & LOCL & & 2272.0 & $41: 50$ & $2 / 0$ \\
\hline & & & & & & & & & \\
\hline
\end{tabular}

From: $Y-12$

to : MERCURY
TN Leaving : 2/01/99 at 8:33 EST

NV Arriving: 2/02/99 at 22:27 PST

Routing through:

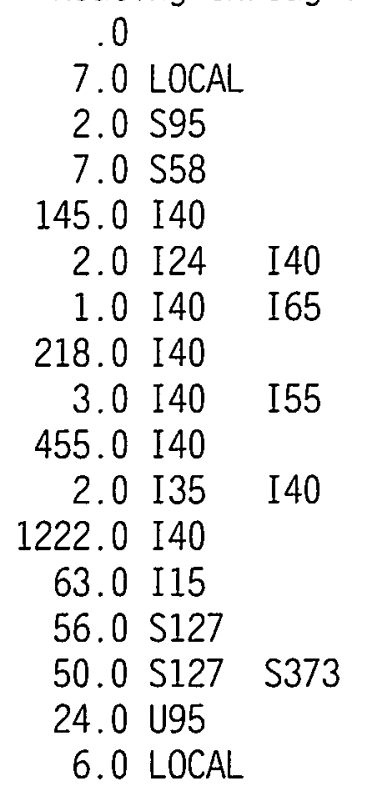

From: PADUCAH GDP to : MERCURY

Y-12
BEAR CREEK
OAK RIDGE
KINGSTON
NASHVILLE
NASHVILLE
NASHVILLE
WEST MEMPHIS
WEST MEMPHIS
OKLAHOMA CITY
OKLAHOMA CITY
BARSTOW
BAKER
SHOSHONE
AMARGOSA VALLY
MERCURY
MERCURY

$\begin{array}{llllrrrrr} & & & \text { TN } & .0 & 0: 00 & 2 / 01 & \text { a } & 8: 33 \\ & \text { S95 } & \text { LOCL TN } & 7.0 & 0: 10 & 2 / 01 & \text { a } & 8: 43 \\ \text { SW } & \text { S58 } & \text { S95 } & \text { TN } & 9.0 & 0: 13 & 2 / 01 & \text { a } & 8: 46 \\ \text { E } & \text { I40 } & \text { X356 } & \text { TN } & 16.0 & 0: 21 & 2 / 01 & \text { a } & 8: 54 \\ \text { E } & \text { I24 } & \text { I40 } & \text { TN } & 161.0 & 2: 37 & 2 / 01 & \text { a } & 10: 10 \\ \text { SE } & \text { I24 } & \text { I40 } & \text { TN } & 163.0 & 2: 39 & 2 / 01 & \text { a } & 10: 12 \\ \text { S } & \text { I40 } & \text { I65 } & \text { TN } & 164.0 & 2: 41 & 2 / 01 & \text { a } & 10: 13 \\ \text { E } & \text { I40 } & \text { I55 } & \text { AR } & 382.0 & 6: 36 & 2 / 01 & \text { a } & 14: 08 \\ \text { N } & \text { I40 } & \text { I55 } & \text { AR } & 385.0 & 6: 39 & 2 / 01 & \text { a } & 14: 11 \\ \text { E } & \text { I35 } & \text { I40 } & \text { OK } & 840.0 & 14: 43 & 2 / 01 & \text { a } & 22: 15 \\ \text { S } & \text { I235 } & \text { I35 } & \text { OK } & 842.0 & 14: 45 & 2 / 01 & \text { a } & 22: 17 \\ & \text { I15 } & \text { I40 } & \text { CA } & 2064.0 & 36: 32 & 2 / 02 & \text { a } & 18: 04 \\ & \text { I15 } & \text { S127 } & \text { CA } & 2127.0 & 37: 41 & 2 / 02 & \text { a } & 19: 13 \\ & \text { S127 } & \text { S178 } & \text { CA } & 2183.0 & 38: 48 & 2 / 02 & \text { a } & 20: 20 \\ & \text { U95 } & \text { S373 NV } & 2233.0 & 39: 48 & 2 / 02 & \text { a } & 21: 20 \\ \text { S } & \text { U95 } & \text { LOCL NV } & 2257.0 & 40: 46 & 2 / 02 & \text { a } & 22: 18 \\ & & & \text { NV } & 2263.0 & 40: 55 & 2 / 02 & \text { a } & 22: 27\end{array}$

Routing through:

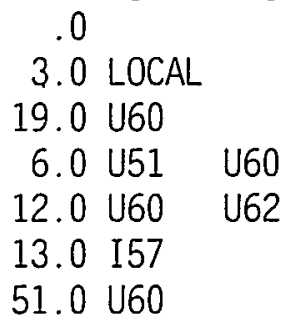

\begin{tabular}{|c|c|c|c|}
\hline PADUCAH GDP & & & \\
\hline KEVIL & $E$ & & LOCL \\
\hline WICKLIFFE & & U51 & U60 \\
\hline CAIRO & S & U51 & U60 \\
\hline CHARLESTON & $E$ & I57 & $X 12$ \\
\hline SIKESTON & $\mathrm{E}$ & I55 & I57 \\
\hline
\end{tabular}

KY Leaving : 2/01/99 at 9:11 CST NV Arriving: 2/02/99 at 20:38 PST

$\begin{array}{rrrr}.0 & 0: 00 & 2 / 01 @ a & 9: 11 \\ 3.0 & 0: 06 & 2 / 01 @ a & 9: 17 \\ 22.0 & 0: 29 & 2 / 01 @ a & 9: 40 \\ 28.0 & 0: 36 & 2 / 01 @ a & 9: 47 \\ 40.0 & 0: 50 & 2 / 01 \cdot a & 10: 02 \\ 53.0 & 1: 02 & 2 / 01 @ 10 & 10: 14 \\ 104.0 & 2: 04 & 2 / 01 @ 11: 15\end{array}$




\begin{tabular}{|c|c|c|c|c|c|c|c|c|c|}
\hline $8.0 \cup 60$ & U67 & POPLAR BLUFF & $\mathrm{NW}$ & U60 & U67 & MO & 112.0 & $2: 12$ & 2/01@11:23 \\
\hline $96.0 \mathrm{U} 60$ & & WILLOW SPRINGS & SE & U60 & U63 & MO & 208.0 & $4: 08$ & $2 / 01$ @ $13: 19$ \\
\hline $14.0 \cup 60$ & U63 & CABOOL & SE & U60 & U63 & MO & 222.0 & & $2 / 01 @ 14: 04$ \\
\hline $29.0 \cup 60$ & & MANSFIELD & $N$ & U60 & S5 & M & 251.0 & $5:$ & $2 / 01 @ 14$ \\
\hline $1.0 \cup 60$ & S5 & MANSF IELD & NW & U60 & S5 & MC & 252. & & 01 d 1 \\
\hline $38.0 \cup 60$ & & FFIELD & SE & U60 & U65 & MO & 290.0 & $6: 0$ & $6101+10$. \\
\hline $9.0 \cup 65$ & & SPRIN & $N E$ & I 44 & $x 82$ & MC & 299.0 & & \\
\hline $82.0 \quad[44$ & & & SW & I 44 & $x$ & & .0 & & \\
\hline $44 \$$ & 5 & MIAMI & $E$ & I 44 & $x 313$ & OK & 98.0 & 7: & \\
\hline $44 \$$ & TWRT\$ & CATOOSA & S & I44 & X241 & OK & 70.0 & & \\
\hline$[44$ & & OAKH & $E$ & I 44 & X221 & OK & & & \\
\hline $144 \$$ & TTRT\$ & EDMON & SE & 135 & I44 & OK & & 1: & \\
\hline 135 & I44 & OMA CITY & NE & I35 & I44 & OK & & & $A$ \\
\hline $10.0 \quad 144$ & & OKLAHOMA CITY & $W$ & 140 & & OK & & & \\
\hline $17.0 \quad 140$ & & BARSTOW & & I15 & I4 & CA & & & \\
\hline & & BAKER & & I15 & S127 & $C A$ & & $34:$ & (a $17: 24$ \\
\hline $56.0 \quad \$ 127$ & & SHOSHONE & & S127 & S178 & CA & & & \\
\hline $50.0 \$ 127$ & S373 & AMARGOSA VALLY & & U95 & S373 & NV & & & \\
\hline $24.0 \mathrm{l}$ & & MERCURY & S & U95 & LOCL & NV & 2001.0 & $37: 19$ & $2 / 02 @ 20: 2$ \\
\hline $6.0 \mathrm{LOCAL}$ & & MERCURY & & & & NV & 2007.0 & $37: 28$ & $2 / 02$ a $20: 3$ \\
\hline
\end{tabular}

From: PORTSMOUTH GDP

to : MERCURY

OH Leaving : 2/01/99 at 9:10 EST

NV Arriving: $2 / 03 / 99$ at $3: 21$ PST

\begin{tabular}{|c|c|c|c|c|c|c|c|c|c|c|}
\hline \multicolumn{11}{|c|}{ Routing through: } \\
\hline .0 & & PORTSMOUTH GDP & & & & $\mathrm{OH}$ & .0 & $0: 00$ & $2 / 010$ & $9: 10$ \\
\hline $3.0 \mathrm{U} 23$ & & PIKETON & $S$ & U23 & S32 & $\mathrm{OH}$ & 3.0 & $0: 03$ & $2 / 01$ & $9: 14$ \\
\hline $75.0 \quad S 32$ & & MT CARMEL HGTS & $E$ & I275 & $\times 63$ & $\mathrm{OH}$ & 78.0 & $1: 25$ & $2 / 01$ & $10: 35$ \\
\hline $21.0 \quad 1275$ & & ERLANGER & $N$ & $\mathrm{I} 275$ & I71 & KY & 99.0 & $1: 48$ & $2 / 01$ & $10: 58$ \\
\hline $12.0 \mathrm{I} 71$ & $\mathrm{I} 75$ & WALTON & NW & I71 & $I 75$ & KY & 111.0 & $1: 59$ & $2 / 01$ & $11: 09$ \\
\hline $76.0 \quad 171$ & & LOUISVILLE & $E$ & I64 & I71 & KY & 187.0 & $3: 10$ & $2 / 01$ & $12: 20$ \\
\hline $181.0 \quad 164$ & & MT VERNON & SW & 157 & I64 & IL & 368.0 & $6: 49$ & $2 / 01$ & $16: 59$ \\
\hline $5.0 \quad \mathrm{I} 57$ & I64 & MT VERNON & NW & I57 & I64 & IL & 373.0 & $6: 54$ & $2 / 01$ & $17: 04$ \\
\hline $71.0 \quad 164$ & & EAST ST LOUIS & NE & I55 & I64 & IL & 444.0 & $8: 12$ & $2 / 01 @$ & $18: 22$ \\
\hline $3.0 I 55$ & 170 & ST LOUIS & & I55 & I64 & MO & 447.0 & $8: 15$ & $2 / 01$ & \\
\hline $1.0 \quad 155$ & & ST LOUIS & S & 144 & 155 & MO & 448.0 & $8: 16$ & a & $18: 26$ \\
\hline 290.0 I 44 & & JOPLIN & SW & I 44 & $X 1$ & MO & 738.0 & $13: 48$ & $2 / 01 @$ & $23: 57$ \\
\hline 17.0 I $44 \$$ & & MIAMI & $E$ & I44 & $\times 313$ & OK & 755.0 & $14: 03$ & $2 / 02$ @ & $0: 13$ \\
\hline $72.0 \quad I 44 \$$ & TWRT\$ & CATOOSA & S & I44 & $\times 241$ & OK & 827.0 & $15: 10$ & $2 / 02$ & $1: 20$ \\
\hline $20.0 \quad 144$ & & OAKHURST & $E$ & I 44 & $\times 221$ & OK & 847.0 & $15: 30$ & 2/02@ & $1: 40$ \\
\hline $86.0 \mathrm{I} 44 \$$ & TTRT\$ & EDMOND & SE & 135 & I44 & OK & 933.0 & $16: 50$ & 2/02@ & $3: 00$ \\
\hline $5.0 \mathrm{I} 35$ & I44 & OKLAHOMA CITY & $N E$ & 135 & I44 & OK & 938.0 & $16: 56$ & 20 & $3: 05$ \\
\hline $10.0 \mathrm{I} 44$ & & OKLAHOMA CITY & $W^{-}$ & 140 & I 44 & OK & 948.0 & $17: 06$ & $2 / 02$ & $3: 16$ \\
\hline $217.0 \quad \mathrm{I} 40$ & & BARSTOW & & I15 & I40 & $\mathrm{CA}$ & 2165.0 & $38: 49$ & 2/02@ & $22: 58$ \\
\hline $63.0 \mathrm{I} 15$ & & BAKER & & I15 & S127 & CA & 2228.0 & $39: 57$ & $2 / 03$ & $0: 06$ \\
\hline $56.0 \quad \$ 127$ & & SHOSHONE & & S127 & S178 & CA & 2284.0 & $41: 04$ & $2 / 03 @$ & $1: 14$ \\
\hline $50.0 \quad \$ 127$ & S373 & AMARGOSA VALLY & & U95 & S373 & NV & 2334.0 & $42: 34$ & $2 / 03$ & $2: 44$ \\
\hline
\end{tabular}




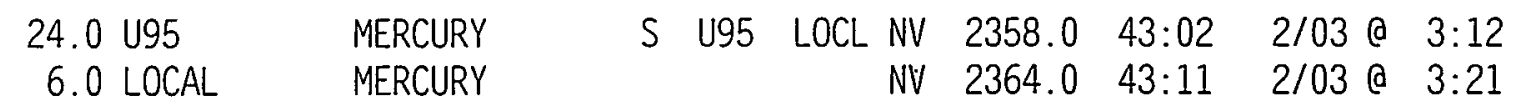

From: PANTEX PLANT to : MERCURY
F245 F683 TX Leaving : 2/01/99 at 9:20 CST NV Arriving: $2 / 02 / 99$ at $4: 52$ PST

Routing through:

\begin{tabular}{|c|c|c|c|c|c|c|c|c|c|}
\hline .0 & & PANTEX PLANT & & $F 245$ & F683 & .0 & $0: 00$ & $2 / 010$ & $9: 20$ \\
\hline $4.0 F 683$ & & PANTEX & S & U60 & $F 683$ & 4.0 & $0: 08$ & $2 / 01 a$ & $9: 28$ \\
\hline $7.0 \cup 60$ & & AMARILLOO & $E$ & U60 & L335 & 11.0 & $0: 16$ & $2 / 01$ & $9: 36$ \\
\hline $2.0\llcorner 335$ & & AMARILLO & $E$ & I 40 & $\times 75$ & 13.0 & $0: 19$ & $2 / 01$ & $: 39$ \\
\hline 969.0 I 40 & & BARSTOW & & I15 & I 40 & 982.0 & $17: 10$ & $2 / 02$ & $0: 30$ \\
\hline $63.0 \mathrm{I} 15$ & & BAKER & & I15 & S127 & 1045.0 & $18: 19$ & $2 / 0$ & $1:$ \\
\hline $56.0 \quad S 127$ & & SHOSHONE & & S127 & S178 & 1101.0 & $19: 56$ & $2 / 02$ & $3: 15$ \\
\hline $50.0 \quad 5127$ & S373 & AMARGOSA VALLY & & U95 & S373 & 1151.0 & & & \\
\hline 24.0 U95 & & MERCURY & $\mathrm{S}$ & U95 & LOCL & 1175.0 & $21: 24$ & $2 / 02$ & \\
\hline 6.0 LOCAL & & MERCURY & & & & 1181.0 & $21: 33$ & $2 / 02 @$ & \\
\hline
\end{tabular}

From: PRINCTN PLASMA U1 LOCL NJ Leaving : 2/01/99 at 9:19 EST . to : MERCURY

NV Arriving: $2 / 03 / 99$ at $13: 23$ PST

Routing through:

\begin{tabular}{|c|c|c|c|c|c|c|c|c|c|c|}
\hline .0 & & PRINCTN PLASMA & & U1 & LOCL & & .0 & $0: 00$ & $2 / 01$ & \\
\hline $2.0 \mathrm{UI}$ & & TRENTON & & U1 & $\mathrm{S} 29$ & NJ & 12.0 & & & \\
\hline $0 \mathrm{U1}$ & \# & MORRISVILLE & SW & U1 & U13 & PA & 15.0 & & $101 \mathrm{a}$ & $9: 3$ \\
\hline $5.0 \mathrm{U13}$ & & RISTOL & $\mathrm{N}$ & I276 & X29 & PA & & & $2 / 010$ & \\
\hline $1.0 \mathrm{I} 276 \$$ & & LLLEY FORGE & SE & I276 & I76 & & 52 & & $2 / 01$ & \\
\hline $176 \$$ & & NEW CUMBERLND & $S$ & 176 & X18 & & 136 & & $2 / 01$ & \\
\hline & & & SW & I83 & $\times 20$ & & & & & \\
\hline S581 & & & SW & U11 & U15 & & & & & \\
\hline & & & NE & 176 & X16 & & & & & \\
\hline & & & SW & 170 & I76 & & & & & \\
\hline & $\$ I 76 \$$ & DONEC & & $I 70$ & X9 & & 287.0 & & & \\
\hline & XRAMP & & S & I70 & S31 & & & & & \\
\hline & & & S & 170 & $\times 24$ & & & & & \\
\hline & & & NE & 170 & 179 & & & & & \\
\hline & I79 & & $\mathrm{N}$ & 170 & I79 & & & & & \\
\hline & & & SE & 170 & I71 & & 498.0 & & & \\
\hline & I71 & & SW & 70 & I71 & $\mathrm{OH}$ & & & & \\
\hline & & & NE & & & IN & & & & \\
\hline & I70 & LIS & SE & & & I & 674 & & & \\
\hline & & & $\mathrm{NW}$ & & & IL & & & & \\
\hline & 170 & & SW & & & IL & & & & \\
\hline & & ILLE & SE. & 1270 & Is & & & & & \\
\hline & I70 & ST LO & & & It & & & & & \\
\hline & & & & & & & & & & \\
\hline & & & & & & & 1206.0 & $23: 4$ & & \\
\hline
\end{tabular}




\begin{tabular}{|c|c|c|c|c|c|c|c|c|c|}
\hline $17.0144 \$$ & 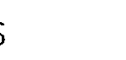 & MIAMI & $E$ & I 44 & $\times 313$ & OK & 1223.0 & $23: 58$ & 2/02 a 10:16 \\
\hline $72.0144 \$$ & TWRT\$ & CATOOSA & S & I44 & $\times 241$ & OK & 1295.0 & $25: 04$ & $2 / 02$ a $11: 22$ \\
\hline $20.0 \quad 144$ & & OAKHURST & $E$ & I44 & $\times 221$ & OK & 1315.0 & $25: 24$ & $2 / 02 @ 11: 42$ \\
\hline 86.0 I $44 \$$ & TTRT\$ & EDMOND & SE & I35 & I 44 & OK & 1401.0 & $26: 44$ & $2 / 02 @ 13: 02$ \\
\hline 5.0135 & I 44 & OKLAHOMA CITY & NE & I35 & I 44 & OK & 1406.0 & $27: 20$ & 2/02 a 13:3 \\
\hline $10.0 \quad I 44$ & & OKLAHOMA CITY & $W$ & I40 & I44 & OK & 1416.0 & $27: 3$ & $2 / 02 @ 13: 4$ \\
\hline $217.0 \quad 140$ & & BARSTOW & & I15 & I40 & CA & 2633.0 & $48: 4$ & 2/03 a 9:0 \\
\hline 63.0 & & BAKER & & I15 & S127 & CA & 2696.0 & $49:$ & $2 / 03 @ 10: 0$ \\
\hline $56.0 \Im$ & & SHOSHONE & & S127 & S178 & $\mathrm{CA}$ & & & \\
\hline 50.0 & S373 & AMARGOSA VALLY & & U95 & $\$ 373$ & NV & 2802.0 & $52: 29$ & $2 / 03$ \\
\hline 24.0 U95 & & MERCURY & S & U95 & LOCL & NV & 2826.0 & $52: 57$ & 2/03 \& 13: \\
\hline $6.0 \mathrm{LOCAL}$ & & MERCURY & & & & NV & 2832.0 & $53: 06$ & 2/03 @ 13: \\
\hline
\end{tabular}

From: ROCKY FLATS to : MERCURY
Co Leaving : 2/01/99 at 8:35 MST

NV Arriving: 2/02/99 at 6:16 PST

Routing through:

$\begin{aligned} .0 & \text { ROCKY FLATS } \\ 5.0 \text { LOCAL } & \text { ARVADA } \\ 9.0 \text { S72 } & \text { WHEAT RIDGE } \\ 498.0 \mathrm{I70} & \text { COVE FORT } \\ 221.0 \mathrm{I} 15 & \text { GARNET } \\ 85.0 \cup 93 & \text { HIKO } \\ 98.0 \mathrm{~S} 375 & \text { WARM SPRINGS } \\ 50.0 \text { U6 } & \text { TONOPAH } \\ 146.0 \text { U95 } & \text { MERCURY } \\ 6.0 \text { LOCAL } & \text { MERCURY }\end{aligned}$

\begin{tabular}{|c|c|c|c|c|c|c|c|}
\hline & & & $\mathrm{CO}$ & .0 & $0: 00$ & $2 / 01$ & $8: 35$ \\
\hline NW & 572 & LOCL & $\mathrm{CO}$ & 5.0 & $0: 09$ & $2 / 01$ & $8: 44$ \\
\hline $\mathrm{NW}$ & I70 & $\times 266$ & $\mathrm{CO}$ & 14.0 & $0: 25$ & $2 / 01$ & $8: 59$ \\
\hline W & $I 15$ & I70 & UT & 512.0 & $10: 05$ & $2 / 01$ & $18: 39$ \\
\hline & I15 & $\times 64$ & NV & 733.0 & $13: 59$ & $2 / 01$ & $21: 33$ \\
\hline S & U93 & S375 & NV & 818.0 & $15: 41$ & $2 / 01$ & 23: \\
\hline & & & NV & 916.0 & $17: 38$ & $2 / 02$ & $1: 13$ \\
\hline & & & NV & 966.0 & $19: 08$ & $2 / 02$ & \\
\hline 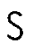 & U95 & $\mathrm{LOCL}$ & NV & 1112.0 & $22: 02$ & $2 / 02$ & \\
\hline & & & NV & 1118.0 & $22: 41$ & $2 / 02$ & \\
\hline
\end{tabular}

From: SANDIA NATL LBS to : MERCURY

NM Leaving : 2/01/99 at 9:10 MST

NV Arriving: 2/02/99 at 0:39 PST

Routing through:

\begin{tabular}{|c|c|c|c|c|c|c|c|c|c|c|}
\hline .0 & & SANDIA NATL LBS & & & & NM & .0 & $0: 00$ & $2 / 01$ & $9: 10$ \\
\hline $3.0 \mathrm{LOCAL}$ & & ALBUQUERQUE & $E$ & I 40 & $\times 165$ & MM & 3.0 & $0:$ & $2 / 01 @$ & $9: 17$ \\
\hline $587.0 \quad 140$ & & BARSTOW & & 115 & 140 & $\mathrm{CA}$ & 690.0 & 12: & $2 / 01$ & 20 : \\
\hline $63.0 \quad 115$ & & BAKER & & I15 & S127 & CA & 53.0 & & & \\
\hline 56.0 & & SHOSHONE & & S127 & $\$ 178$ & $\mathrm{CA}$ & 309.0 & & $2 / 01$ & \\
\hline 50.0 & S373 & SSA VALLY & & U95 & S373 & NV & 859.0 & & & \\
\hline 24.0 & & MERCURY & $S$ & U95 & LOCL & NV & 883.0 & & & \\
\hline 6.0 & & MERCURY & & & & NV & 889.0 & $16: 30$ & $2 / 02 @$ & \\
\hline
\end{tabular}

From: WEST VALLEY RP

to : MERCURY
NY Leaving : 2/02/99 at 7:30 EST

NV Arriving: 2/04/99 at 9:21 PST

Routing through:

.0 WEST VALLEY RP

$\begin{array}{lllll}\text { NY } & .0 & 0: 00 & 2 / 02 \text { a } & 7: 30\end{array}$ 


\begin{tabular}{|c|c|c|c|c|c|c|c|c|c|c|}
\hline $2.0<85$ & & SPRINGVILLE & SW & U219 & C85 & NY & 2.0 & $0: 05$ & $2 / 02$ & $7: 35$ \\
\hline $3.0 \cup 219$ & & SPRINGVILLE & $W$ & U219 & $\$ 39$ & NY & 5.0 & & $2 / 02$ & $7: 38$ \\
\hline $13.0 \$ 39$ & & COLLINS & & U62 & S39 & NY & 18.0 & $0: 26$ & $2 / 02$ & $7: 56$ \\
\hline 2.0 U62 & & GOWANDA & & U62 & S39 & NY & 20.0 & $0: 28$ & $2 / 02$ & $7: 58$ \\
\hline $18.0 \$ 39$ & & SHERIDAN & SW & U20 & S39 & NY & 38.0 & & 1020 & $8: 22$ \\
\hline $2.0 \mathrm{U} 20$ & & FREDONIA & NE & U20 & S60 & NY & 40.0 & 0 : & $2 / 02 @$ & $8: 25$ \\
\hline $1.0 S 60$ & & DUNKIRK & SE & I90 & $\times 59$ & NY & 41.0 & & 1020 & $8: 26$ \\
\hline $27.0190 \$$ & TNYT\$ & \$ RIPLEY & $W$ & 190 & $x 61$ & NY & 68.0 & $1: 26$ & $2 / 02$ & $8: 56$ \\
\hline $124.0 \quad 190$ & & CLEVELAND & $S$ & 171 & 190 & $\mathrm{OH}$ & 192.0 & & $2 / 02 a$ & $11: 11$ \\
\hline $9.0 \mathrm{I71}$ & & BROOK PARK & $N$ & 1480 & I71 & $\mathrm{OH}$ & 201.0 & & 2 & \\
\hline $10.0 \quad \mathrm{I} 480$ & & N RIDGEVILLE & S & 1480 & I80 & $\mathrm{OH}$ & 211.0 & $4: 32$ & 210 & $12: 02$ \\
\hline $8.0 \mathrm{I} 80 \$$ & & ELYRIA & $\mathrm{NW}$ & I80 & 190 & $\mathrm{OH}$ & 219.0 & 4: & $2 / 02$ & $12: 10$ \\
\hline $281.0180 \$$ & $190 \$$ & \$ PORTAGE & W & 180 & 190 & IN & 500.0 & & $2 / 0$ & \\
\hline $1.0 \mathrm{I} 80$ & & LAKE STATION & NE & 180 & I94 & IN & 501.0 & & $2 / 0$ & $18: 34$ \\
\hline 19.0180 & 194 & LANSING & $W$ & I294 & I94 & IL & 520.0 & & $2 / 02$ & $18: 55$ \\
\hline $5.01294 \$$ & I80\$ & \$ HOMEWOOD & $\mathrm{NW}$ & 129 & I80 & IL & 525.0 & & $2 / 02$ & $19: 0$ \\
\hline $326.0 \quad 180$ & & DES MOINES & $N$ & I 235 & 135 & $\mathrm{IA}$ & 851.0 & & $2 / 03$ & $0: 59$ \\
\hline 14.0 I35 & I80 & DES MOINES & $W$ & 1235 & I35 & IA & 865.0 & & $2 / 0$ & $1: 14$ \\
\hline $119.0 \quad 180$ & & COUNCIL BLUFFS & SE & I29 & I80 & IA & 984.0 & & $2 / 03$ & $3: 33$ \\
\hline $3.0 \mathrm{I} 29$ & I80 & COUNCIL BLUFFS & SW & 129 & 180 & IA & 987.0 & & $2 / 030$ & $3: 36$ \\
\hline $354.0 \quad$ I80 & & BIG SPRINGS & SW & I76 & 180 & NE & 1341.0 & & $2 / 0$ & $8: 36$ \\
\hline $186.0 \mathrm{I} 76$ & & ARVADA & S & 170 & I76 & $\mathrm{CO}$ & 1527.0 & $28: 31$ & $2 / 03$ & $12: 00$ \\
\hline $502.0 \quad 170$ & & COVE FORT & W & & 170 & UT & 2029.0 & & $2 / 03$ & $21: 44$ \\
\hline $221.0 \mathrm{I} 15$ & & GARNET & & & $x 64$ & NV & 2250.0 & & $2 / 04 @$ & $0: 38$ \\
\hline 85.0 U93 & & HIKO & $S$ & U93 & S375 & NV & 2335.0 & $43: 52$ & $2 / 04 @$ & $2: 20$ \\
\hline $98.0 \quad \mathrm{~S} 375$ & & WARM SPRINGS & & & & NV & 2433.0 & $45: 49$ & $2 / 040$ & $4: 18$ \\
\hline $50.0 \cup 6$ & & TONOPAH & & & & NV & 2483.0 & & $2 / 04$ & $5: 48$ \\
\hline 146.0 U95 & & MERCURY & S & U95 & LOCL & NV & 2629.0 & $50: 44$ & $2 / 04$ & $9: 12$ \\
\hline $6.0 \mathrm{LOCAL}$ & & MERCURY & & & & NV & 2635.0 & $50: 53$ & 2/04@ & $9: 21$ \\
\hline
\end{tabular}


HIGHWAY ROUTES FROM INTERMODAL FACILITIES TO NTS

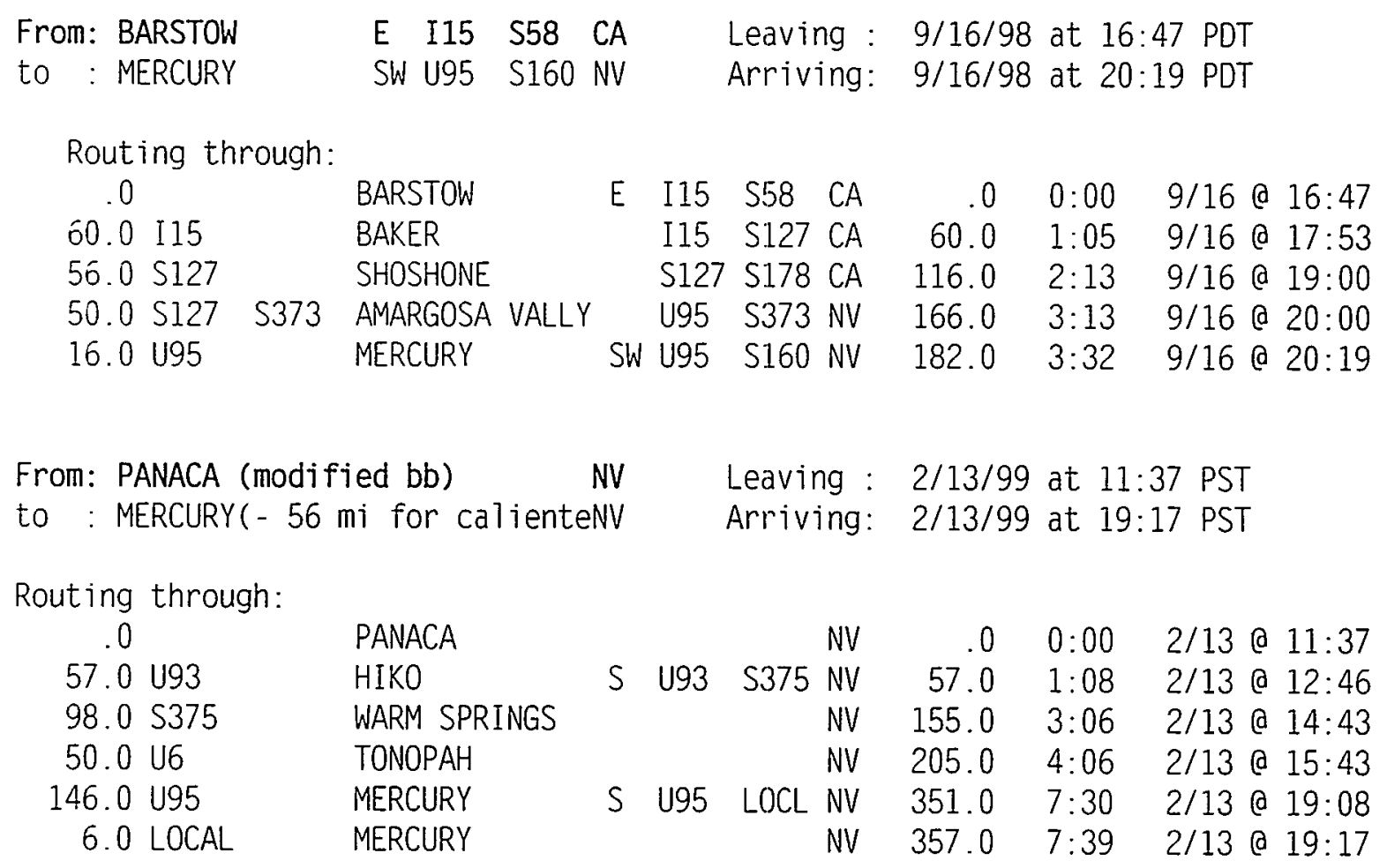


ROUTE FROM: BNSF 4219-LEMONT

T0: BNSF 14664-BARSTOW
IL LENGTH: 2031.3 MILES

CA POTENTIAL: 1625.0

\begin{tabular}{|c|c|c|c|}
\hline RR & NODE & STATE & DIST \\
\hline BNSF & 4219-LEMONT & IL & 0 \\
\hline NSF & 4193-JOLIET & IL & 12 \\
\hline NSF & 4389-STREATOR & IL & 64 \\
\hline NSF & 4478-GALESBURG & IL & 148 \\
\hline NSF & 4491-LOMAX & IL & 187 \\
\hline NSF & 10380-FORT MADISOI & IA & 203 \\
\hline BNSF & 10501-BUCKLIN & MO & 320 \\
\hline VSF & 10560-CARROLLTON & MO & 366 \\
\hline NNSF & 10561-NORBORNE & MO & 375 \\
\hline NSF & 10562-HARDIN & MO & 384 \\
\hline JSF & 10563-HENRIETTA & MO & 390 \\
\hline SNSF & 10564-C A JCT & MO & 398 \\
\hline NNSF & 15708-SHEFFIELD & MO & 425 \\
\hline JSF & 15709-KANSAS CTY & IONMO & 430 \\
\hline SNSF & 10624-OLATHE & KS & 442 \\
\hline 3NSF & 11816-EMPORIA & KS & 525 \\
\hline BNSF & 11847-AUGUSTA & KS & 600 \\
\hline NSF & 11920-MULVANE . & KS & 622 \\
\hline 3NSF & 11918-WELLINGTON & KS & 639 \\
\hline BNSF & 11923-HARPER & KS & 676 \\
\hline NSSF & 12206-AVARD & OK & 740 \\
\hline BNSF & 12207-WAYNOKA & OK & 750 \\
\hline BNSF & 12792-AMARILLO & TX & 955 \\
\hline NNSF & 12793-CANYON & TX & 972 \\
\hline BNSF & 12806-FARWELL & TX & 1048 \\
\hline BNSF & 13025-CLOVIS & NM & 1059 \\
\hline BNSF & 13024-VAUGHN & NM & 1188 \\
\hline BNSF & 12995-BELEN & NM & 1300 \\
\hline BNSF & 12996-DALIES & NM & 1309 \\
\hline BNSF & 16077-GRANTS & NM & 1369 \\
\hline BNSF & 12999-GALLUP & NM & 1438 \\
\hline BNSF & 12949-HOLBROOK & $A Z$ & 1532 \\
\hline BNSF & 12945-WINSLOW & $A Z$ & 1568 \\
\hline BNSF & 12959-FLAGSTAFF & $A Z$ & 1627 \\
\hline BNSF & 12964-WILLIAMS & $A Z$ & \\
\hline BNSF & 12963-KINGMAN & $A Z$ & \\
\hline BNSF & 16320-NEEDLES & CA & \\
\hline BNSF & 14664-BARSTOW & $C A$ & \\
\hline
\end{tabular}


ROUTE FROM: NYA 1154-CALVERTON

T0: BNSF 14664-BARSTOW
NY LENGTH: 3078.4 MILES

CA POTENTIAL: 3913.2

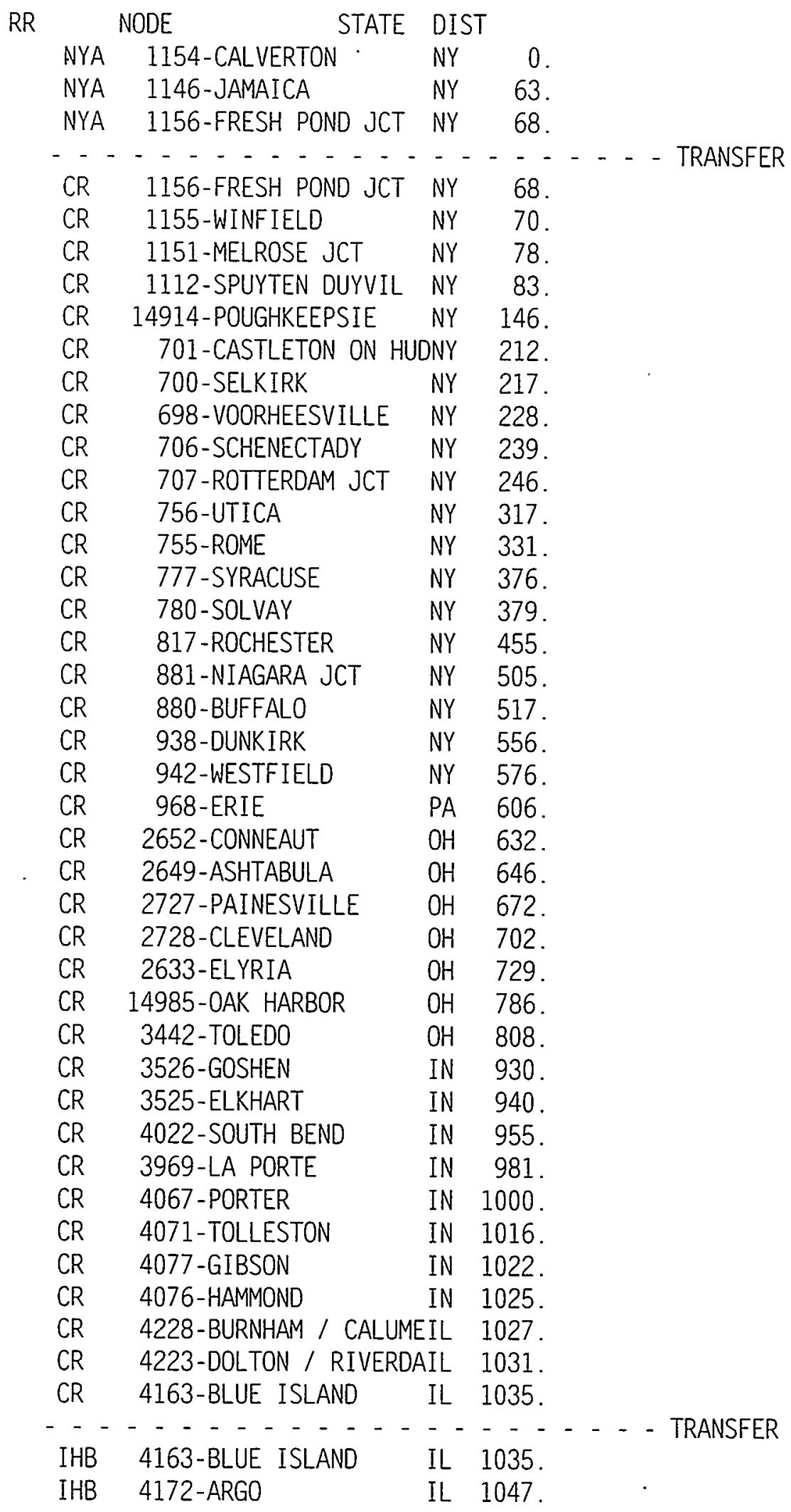




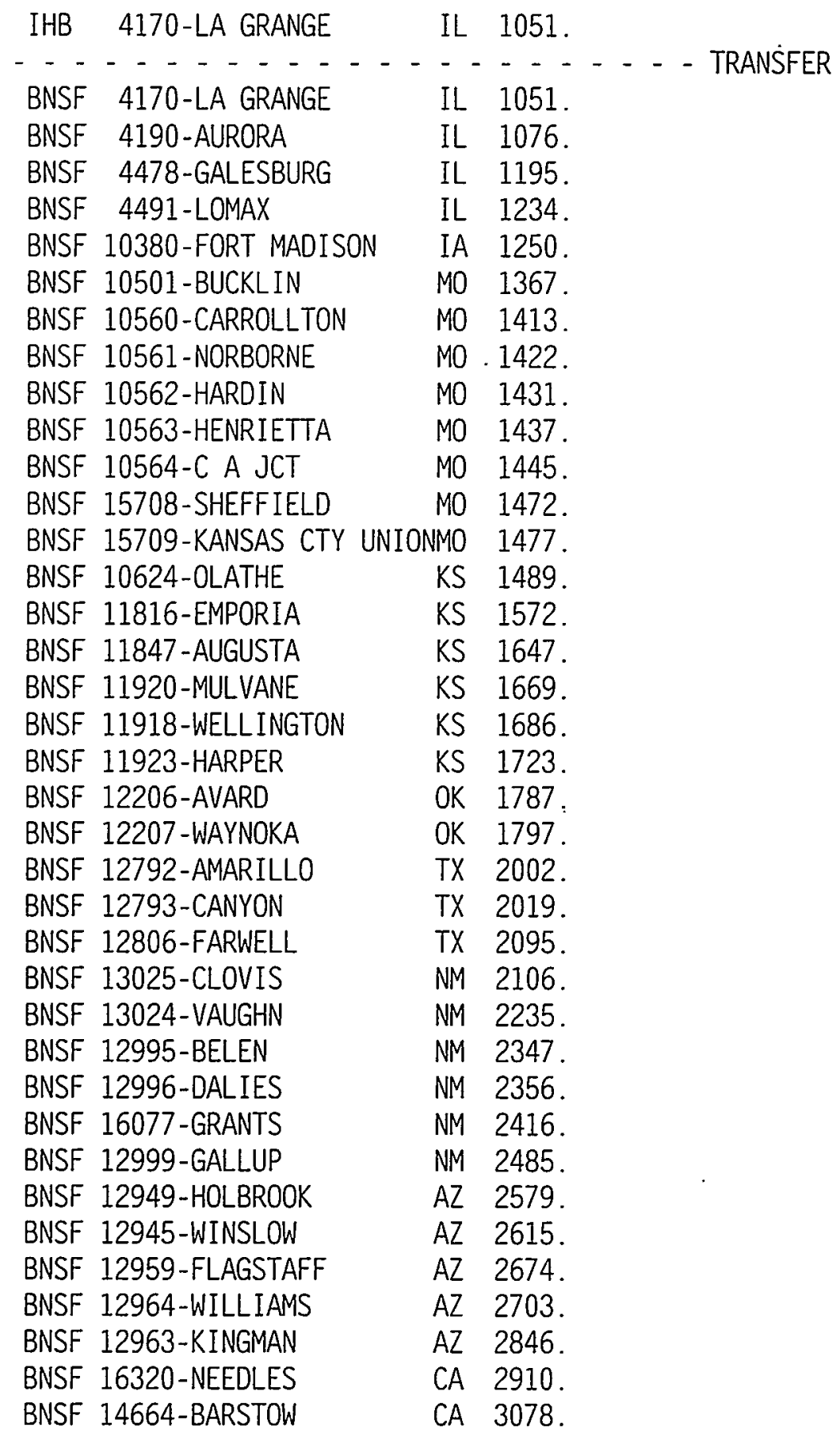

ROUTE FROM: CSXT 3198-FERNALD

TO: BNSF 14664-BARSTOW
OH LENGTH: 2339.4 MILES

CA POTENTIAL: 2650.3

\begin{tabular}{clcr} 
RR & \multicolumn{1}{c}{ NODE } & STATE & DIST \\
CSXT & 3198-FERNALD & OH & 0. \\
CSXT & $3692-$ COTTAGE GROVE & IN & 23. \\
CSXT & 3251-HAMILTON & OH & 46. \\
CSXT & 3234-IVORYDALE & OH & 63.
\end{tabular}




\begin{tabular}{|c|c|c|c|c|}
\hline CSXT & 3228-CINCINNATI & $\mathrm{OH}$ & 70. & \\
\hline CSXT & 3718-SEYMOUR & IN & 156. & \\
\hline CSXT & 3824-MITCHELL & IN & 198. & \\
\hline CSXT & 3812-VINCENNES & IN & 260. & \\
\hline CSXT & 4952-SALEM & IL & 338. & \\
\hline CSXT & 10825-WASHINGTON PARK & IL & 399. & \\
\hline CSXT & 10879-NATIONAL STOCK Y & IIL & 402. & \\
\hline CSXT & 10878-NATIONAL CITY & IL & 404. & \\
\hline CSXT & 10859-EAST ST LOUIS & IL & 405 . & $\cdot$ \\
\hline-- & $\ldots \ldots-\ldots$ & - & -- & - - - - TRANSFER \\
\hline TRRA & 10859-EAST ST LOUIS & IL & 405 & \\
\hline TRRA & 10878-NATIONAL CITY & IL & 406. & \\
\hline TRRA & 10880-MADISON & IL & 410 & \\
\hline BNSF & 10880-MADISON & -- & --- & - - - TRANSFER \\
\hline BNSF & 10877-MERCHANTS BRIDGE & & 412 . & \\
\hline BNSF & 10492-LOUISIANA & MO & 499. & \\
\hline BNSF & 10503-HANNIBAL & MO & 523. & - \\
\hline BNSF & 10501-BUCKLIN & MO & 628. & \\
\hline BNSF & $10560-$ CARROLLTON & MO & 674. & \\
\hline BNSF & 10561 -NORBORNE & MO & 683. & \\
\hline BNSF & 10562-HARDIN & MO & 692. & \\
\hline BNSF & 10563-HENRIETTA & MO & 698. & \\
\hline BNSF & 10564-C A JCT & MO & 706. & \\
\hline BNSF & 15708-SHEFFIELD & MO & 733. & \\
\hline BNSF & 15709-KANSAS CTY UNION & VMO & 738. & \\
\hline BNSF & 10624-OLATHE & KS & 750. & \\
\hline BNSF & 11816-EMPORIA & KS & 833. & \\
\hline BNSF & 11847-AUGUSTA & KS & 908. & \\
\hline BNSF & 11920-MULVANE & KS & 930. & \\
\hline BNSF & 11918-WELLINGTON & KS & 947. & \\
\hline BNSF & 11923-HARPER & KS & 984. & \\
\hline BNSF & 12206-AVARD & OK & 1048. & \\
\hline BNSF & 12207-WAYNOKA & OK & 1058. & \\
\hline BNSF & 12792-AMARILLO & TX & 1263. & \\
\hline BNSF & 12793-CANYON & $T X$ & 1280. & \\
\hline BNSF & 12806-FARWELL & TX & 1356. & \\
\hline BNSF & 13025-CLOVIS & NM & 1367. & \\
\hline BNSF & 13024-VAUGHN & NM & 1496. & \\
\hline BNSF & 12995-BELEN & NM & 1608. & \\
\hline BNSF & 12996-DALIES & NM & 1617. & \\
\hline BNSF & 16077-GRANTS & NM & 1677. & \\
\hline BNSF & 12999-GALLUP & NM & 1746. & \\
\hline BNSF & 12949-HOLBROOK & $A Z$ & 1840 . & \\
\hline BNSF & 12945-WINSLOW & $A Z$ & 1876. & \\
\hline BNSF & 12959-FLAGSTAFF & $A Z$ & 1935. & \\
\hline BNSF & 12964-WILLIAMS & $A Z$ & 1964. & \\
\hline BNSF & 12963-KINGMAN & $A Z$ & 2107 . & \\
\hline BNSF & 16320-NEEDLES & $C A$ & 2171. & \\
\hline
\end{tabular}


BNSF 14664-BARSTOW CA 2339.

ROUTE FROM: UP 13336-SCOVILLE

TO: BNSF 14664-BARSTOW
ID LENGTH: 1275.5 MILES

CA POTENTIAL: 1500.8

\begin{tabular}{|c|c|c|c|}
\hline$R R$ & NODE & STATE & DIST \\
\hline UP & 13336-SCOVILLE & ID & 0 \\
\hline UP & 13370-POCATELLO & ID & 56. \\
\hline UP & 13369-MC CAMMON & ID & 79 . \\
\hline UP & 13568-OGDEN & UT & 193. \\
\hline UP & 14795-WELLS & NV & 362 . \\
\hline UP & 14794-ALAZON & NV & 366. \\
\hline UP & 14793-ELKO & NV & 416. \\
\hline UP & 14792-CARLIN & NV & 436 . \\
\hline UP & 14791-BEOWAWE & NV & 461. \\
\hline UP & 14813-WINNEMUCCA & NV & 545. \\
\hline UP & 14812-HAZEN & NV & 679. \\
\hline UP & 14816-SPARKS & NV & 711. \\
\hline UP & 14821 -RENO & NV & 726. \\
\hline UP & 14415-ROSEVILLE & $\mathrm{CA}$ & 843. \\
\hline UP & 14411-SACRAMENTO & $\mathrm{CA}$ & 858. \\
\hline UP & 14499-STOCKTON & $\mathrm{CA}$ & 902. \\
\hline UP & 14498-LATHROP & $C A$ & 911. \\
\hline UP & 14529-MODESTO & $\mathrm{CA}$ & 938. \\
\hline UP & 14570-FRESNO & $\mathrm{CA}$ & 1036. \\
\hline UP & 14607-GOSHEN JCT & $\mathrm{CA}$ & 1066. \\
\hline UP & 14622-BAKERSFIELD & $C A$ & 1141. \\
\hline UP & 14621-MOJAVE & $C A$ & 1206. \\
\hline UP & 14664-BARSTOW & $\mathrm{CA}$ & 1276 . \\
\hline
\end{tabular}

BNSF 14664-BARSTOW

ROUTE FROM: BNSF 13028-ALBUQUERQUE

TO: BNSF 14664-BARSTOW
NM LENGTH: 765.4 MILES

CA POTENTIAL: $\quad 617.70$

\begin{tabular}{llcr} 
RR & \multicolumn{1}{c}{ NODE } & STATE & DIST \\
BNSF & 13028 -ALBUQUERQUE & NM & 0. \\
BNSF & $12995-$ BELEN & NM & 34. \\
BNSF & $12996-$ DALIES & NM & 43. \\
BNSF & $16077-$ GRANTS & NM & 103. \\
BNSF & $12999-$ GALLUP & NM & 172. \\
BNSF & $12949-$ HOLBROOK & AZ & 266. \\
BNSF & $12945-$ WINSLOW & AZ & 302. \\
BNSF & $12959-$ FLAGSTAFF & AZ & 361. \\
BNSF & $12964-$ WILLIAMS & AZ & 390. \\
BNSF & $12963-$ KINGMAN & AZ & 533.
\end{tabular}


BNSF 16320-NEEDLES CA 597.

BNSF 14664-BARSTOW CA 765.

ROUTE FROM: UP 14473-LIVERMORE

TO: BNSF 14664-BARSTOW
CA LENGTH: 401.0 MILES

CA POTENTIAL: 626.56

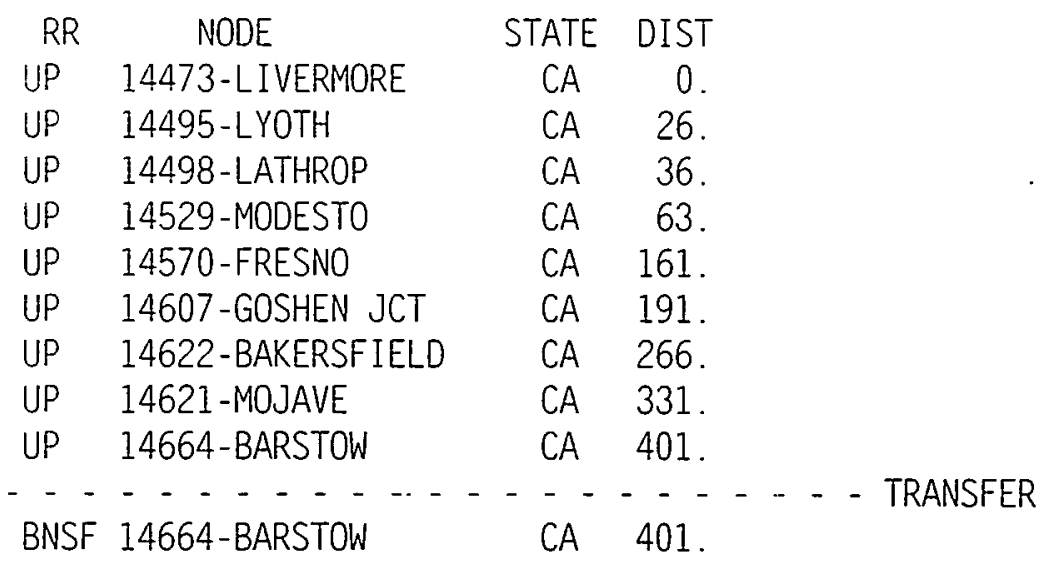

ROUTE FROM: CR 3185-MIAMISBURG

TO: BNSF 14664-BARSTOW
OH LENGTH: 2453.6 MILES

CA POTENTIAL: 2665.3

\begin{tabular}{|c|c|c|c|c|}
\hline $\mathrm{RR}$ & NODE & STATE & DIST & \\
\hline CR & 3185-MIAMISBURG & $\mathrm{OH}$ & 0. & \\
\hline CR & 3282-DAYTON & $\mathrm{OH}$ & 12. & \\
\hline CR & 3300 -SPRINGF IELD & $\mathrm{OH}$ & 33. & \\
\hline CR & 14993-COLUMBUS (BUCKE) & EYOH & 75 . & \\
\hline CR & 3340 -SIDNEY & $\mathrm{OH}$ & 167. & \\
\hline$C R$ & 3650-MUNCIE & IN & 231. & \\
\hline$C R$ & 3662-ANDERSON & IN & 249. & \\
\hline$C R$ & 3738-INDIANAPOLIS & IN & 278 . & \\
\hline$C R$ & $3884-G R E E N C A S T L E$ & IN & 316. & \\
\hline CR & 3863-TERRE HAUTE & IN & 348. & \\
\hline$C R$ & 4787-EFF INGHAM & IL & 419. & \\
\hline$C R$ & 4951-ST ELMO & IL & 437. & \\
\hline $\mathrm{CR}$ & 10825-WASHINGTON PARK & K IL & 511. & \\
\hline $\begin{array}{l}-- \\
\langle T R>\end{array}$ & 10825-WASHINGTON PARK & -- & -- & - - - - TRANSFER \\
\hline$\langle T R\rangle$ & 10867-VINER & IL & 518 & \\
\hline$\langle T R>$ & 10827-VALLEY JCT & IL & 519. & \\
\hline$<T R>$ & 10859-EAST ST LOUIS & IL & 521. & \\
\hline$<T R>$ & 10858-ST LOUIS & MO & 522. & \\
\hline - - - & $\begin{array}{l}------{ }^{-}- \\
\text {10858-ST I OUIS }\end{array}$ & MO & --- & $\cdots$ TRANSFER \\
\hline BNSF & 10840-EADS BRIDGE & MO & 523. & \\
\hline BNSF & 10877-MERCHANTS BRIDGE & SEMO & 526. & \\
\hline BNSF & 10492-LOUISIANA & MO & 613. & \\
\hline
\end{tabular}




\begin{tabular}{|c|c|c|c|}
\hline BNSF & 10503-HANNIBAL & MO & 637. \\
\hline BNSF & 10501 -BUCKLIN & MO & 742 . \\
\hline BNSF & 10560-CARROLLTON & MO & 788. \\
\hline BNSF & 10561-NORBORNE & MO & 797. \\
\hline BNSF & 10562-HARDIN & MO & 806. \\
\hline BNSF & 10563-HENRIETTA & MO & 812 . \\
\hline BNSF & 10564-C A JCT & MO & 820 . \\
\hline BNSF & 15708-SHEFFIELD & MO & 847. \\
\hline BNSF & 15709-KANSAS CTY & NMO & 852 . \\
\hline BNSF & 10624-OLATHE & KS & 864. \\
\hline BNSF & 11816-EMPORIA & KS & 947. \\
\hline BNSF & 11847-AUGUSTA & KS & 1022. \\
\hline BNSF & 11920-MULVANE & KS & 1045. \\
\hline BNSF & 11918-WELLINGTON & KS & 1062. \\
\hline BNSF & 11923-HARPER & KS & 1099. \\
\hline BNSF & 12206-AVARD & OK & 1162. \\
\hline BNSF & 12207-WAYNOKA & OK & 1172 . \\
\hline BNSF & 12792-AMARILLO & $T X$ & 1377 . \\
\hline BNSF & 12793-CANYON & $T X$ & 1394. \\
\hline BNSF & 12806-FARWELL & TX & 1470 \\
\hline BNSF & 13025-CLOVIS & NM & 1481 \\
\hline BNSF & 13024-VAUGHN & NM & 1610. \\
\hline BNSF & 12995-BELEN & NM & 1722. \\
\hline BNSF & 12996-DALIES & NM & 1731 \\
\hline BNSF & 16077-GRANTS & NM & 1791 \\
\hline BNSF & 12999-GALLUP & NM & 1860. \\
\hline BNSF & 12949-HOLBROOK & $A Z$ & 1954 \\
\hline BNSF & 12945-WINSLOW & $A Z$ & 1990 \\
\hline BNSF & 12959-FLAGSTAFF & $A Z$ & 2049. \\
\hline BNSF & 12964-WILLIAMS & $A Z$ & 2078. \\
\hline BNSF & 12963-KINGMAN & $A Z$ & 2221 \\
\hline BNSF & 16320-NEEDLES & $C A$ & 2285 \\
\hline BNSF & 14664-BARSTOW & CA & 2454 \\
\hline
\end{tabular}

ROUTE FROM: NS 15316-K 25

TO: BNSF 14664-BARSTOW

TN LENGTH: 2337.6 MILES

CA POTENTIAL: 2608.3

\begin{tabular}{clcr} 
RR & \multicolumn{1}{c}{ NODE } & STATE & DIST \\
NS & $15316-\mathrm{K} 25$ & TN & 0. \\
NS & $7260-$ HARRIMAN & TN & 15. \\
NS & $7259-$ ROCKWOOD & TN & 20. \\
NS & $7233-$ CITICO JCT. & TN & 87. \\
NS & $7235-$ CHATTANOOGA & TN & 94. \\
NS & $7224-$ WAUHATCHIE & TN & 99. \\
NS & $8791-$ HUNTSVILLE & AL & 185. \\
NS & $8786-$ DECATUR & AL & 209. \\
NS & $8768-$ TUSCUMBIA & AL & 261. \\
NS & $8846-$ CORINTH & MS & 303.
\end{tabular}


NS 17475-NS FORREST YARD TN 392.

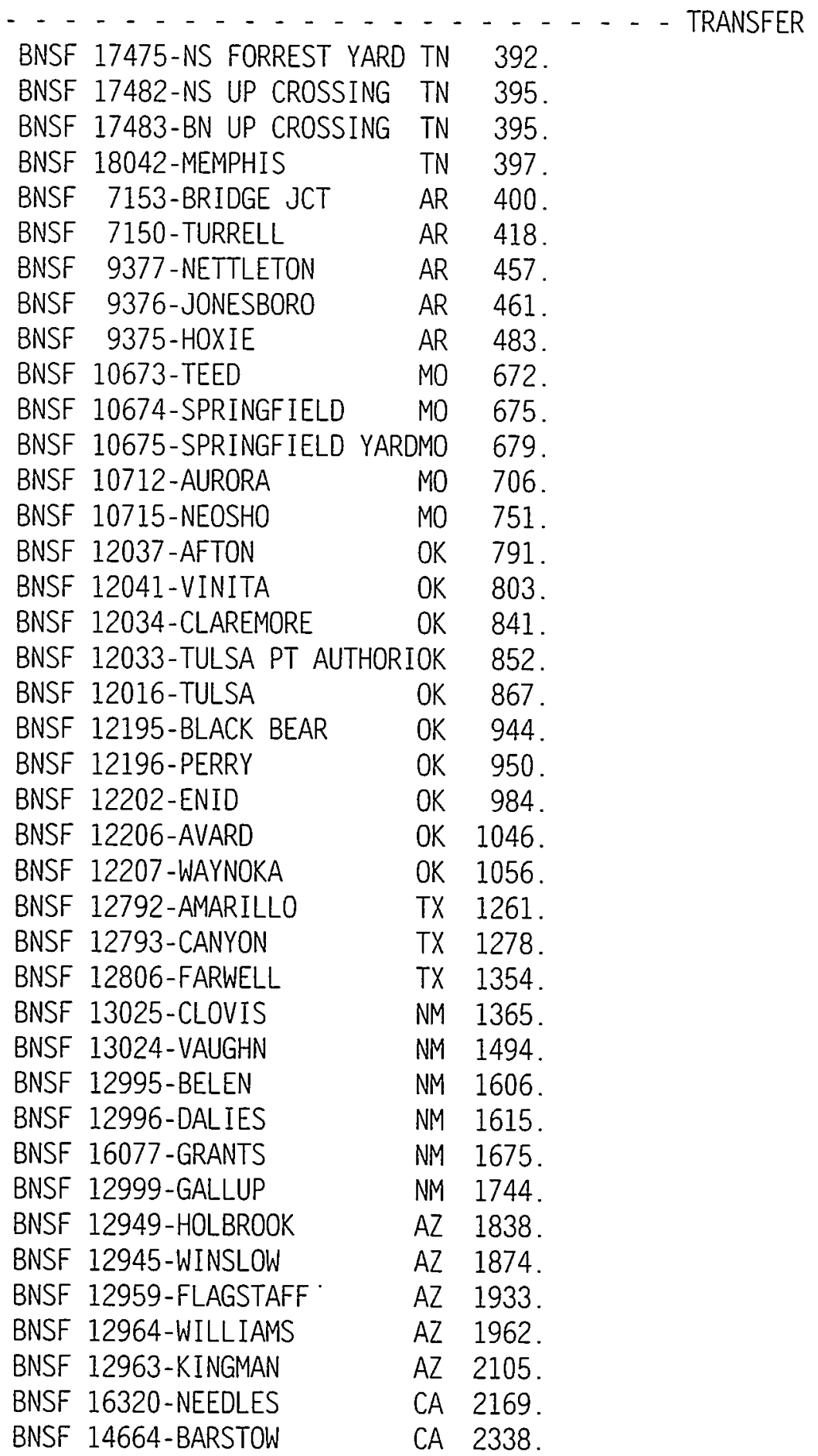

ROUTE FROM: BNSF 13653-PINE CLIFF TO: BNSF 14664-BARSTOW
CO LENGTH: 1271.3 MILES

CA POTENTIAL: $\quad 1214.8$ 


\begin{tabular}{|c|c|c|c|}
\hline BNSF & 16175-NORTH YARD & $\mathrm{CO}$ & 30 \\
\hline BNSF & 13727-DENVER & $\mathrm{CO}$ & 33 \\
\hline BNSF & 13760-COLORADO SPF & $\mathrm{SCO}$ & 107 \\
\hline BNSF & 13764-PUEBLO & $\mathrm{CO}$ & 151 \\
\hline BNSF & 13777-WALSENBURG & $\mathrm{CO}$ & 204 \\
\hline BNSF & 13750-TRINIDAD & $\mathrm{CO}$ & 239 \\
\hline BNSF & 16080-LAS VEGAS & NM & 374 \\
\hline BNSF & 13028-ALBUQUERQUE & NM & 506 \\
\hline BNSF & 12995-BELEN & NM & 540 \\
\hline BNSF & 12996-DAL IES & NM & 549 \\
\hline BNSF & 16077-GRANTS & NM & 609 \\
\hline BNSF & 12999-GALLUP & NM & 678 \\
\hline BNSF & 12949-HOLBROOK & $A Z$ & 772 \\
\hline BNSF & 12945-WINSLOW & $A Z$ & 808 \\
\hline BNSF & 12959-FLAGSTAFF & $A Z$ & 86 \\
\hline BNSF & 12964-WILLIAMS & $A Z$ & 89 \\
\hline BNSF & 12963-KINGMAN & $A Z$ & 103 \\
\hline BNSF & 16320-NEEDLES & $C A$ & \\
\hline BNSF & 14664-BARSTOW & CA & \\
\hline
\end{tabular}


RAIL ROUTES FROM LLW GENERATORS TO CALIENTE

ROUTE FROM: BNSF 4219-LEMONT

T0: USG 14770-CALIENTE
IL LENGTH: 1835.9 MILES

NV POTENTIAL: 2230.7

\begin{tabular}{|c|c|c|c|}
\hline$R R$ & NODE & STATE & DIST \\
\hline BNSF & 4219-LEMONT & IL & \\
\hline BNSF & 4193-JOL IET & IL & 12 \\
\hline BNSF & 4389-STREATOR & IL & 64 \\
\hline BNSF & 4478-GALESBURG & IL & 148 \\
\hline BNSF & 10381 -BURLINGTON & IA & 190 \\
\hline BNSF & 10373-0TTUMWA & IA & 265 \\
\hline BNSF & 10367-ALBIA & IA & 289 \\
\hline BNS & 10443-CRESTON & IA & 381 \\
\hline BNSF & 10435-PACIFIC JCT & IA & 463 \\
\hline BNSF & 11537-OREAPOLIS & NE & 472 \\
\hline BNSF & 11470-ASHLAND & NE & 497 \\
\hline & 11504-LINCOLN & NE & \\
\hline BNS & 11479-FAIRMONT & NE & \\
\hline BNS & 11405-HASTINGS & NE & 616 \\
\hline & $11348-M C$ COOK & NE & \\
\hline & 13706-BRUSH & CO & \\
\hline$B N$ & 13722-COMMERCE CITY & $\mathrm{CO}$ & 1021 \\
\hline & 13727-DENVER & $\mathrm{CO}$ & \\
\hline
\end{tabular}

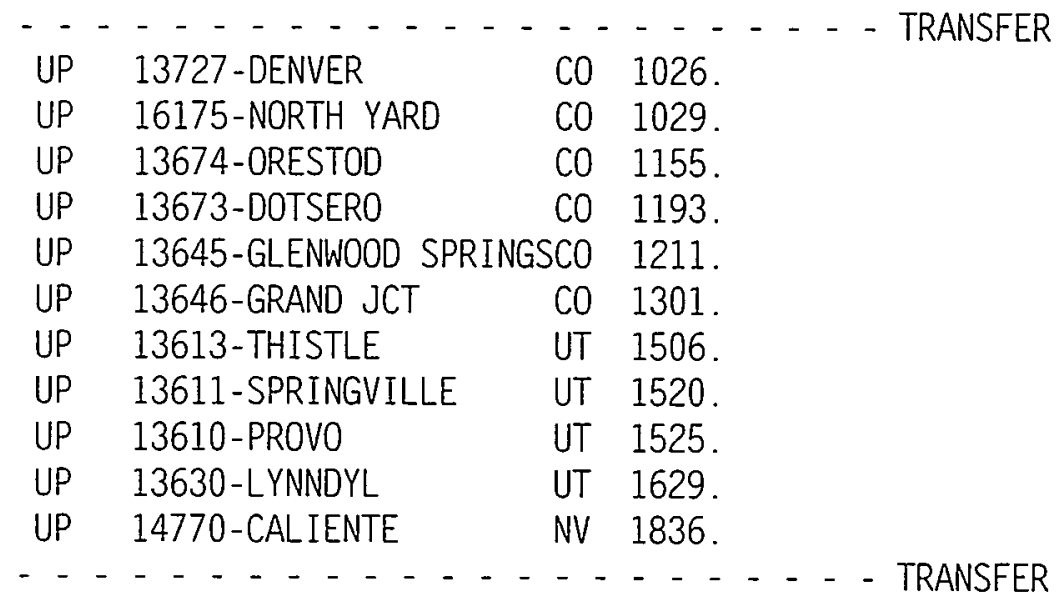

USG 14770 -CALIENTE NV 1836.

ROUTE FROM: NYA 1154-CALVERTON

TO: USG 14770-CALIENTE
NY LENGTH: 2844.9 MILES

NV POTENTIAL: 3979.7

\begin{tabular}{rlcr} 
RR & \multicolumn{1}{c}{ NODE } & STATE & DIST \\
NYA & 1154 -CALVERTON & NY & 0. \\
NYA & $1146-J A M A I C A$ & NY & 63. \\
NYA & $1156-$ FRESH POND JCT & NY & 68.
\end{tabular}




\begin{tabular}{|c|c|c|c|c|}
\hline$C R$ & 1156-FRESH POND JCT & NY & 68. & \\
\hline CR & 1155-WINFIELD & NY & 70. & \\
\hline$C R$ & 1151-MELROSE JCT & NY & 78. & \\
\hline CR & 1112-SPUYTEN DUYVIL & NY & 83. & \\
\hline CR & 14914-POUGHKEEPSIE & NY & 146. & \\
\hline$C R$ & 701-CASTLETON ON HUD & DNY & 212. & \\
\hline CR & $700-$ SELKIRK & NY & 217. & \\
\hline$C R$ & 698-VOORHEESVILLE & NY & 228. & \\
\hline$C R$ & 706-SCHENECTADY & NY & 239. & \\
\hline CR & 707-ROTTERDAM JCT & NY & 246. & \\
\hline CR & 756-UTICA & NY & 317. & \\
\hline CR & 755-ROME & NY & 331. & \\
\hline CR & 777-SYRACUSE & NY & 376. & \\
\hline$C R$ & 780-SOLVAY & NY & 379. & \\
\hline CR & 817-ROCHESTER & NY & 455. & \\
\hline CR & 881 -NIAGARA JCT & NY & 505. & \\
\hline CR & 880-BUFFALO & NY & 517. & \\
\hline CR & 938-DUNKIRK & NY & 556. & \\
\hline CR & 942-WESTFIELD & NY & 576. & \\
\hline$C R$ & 968-ERIE & PA & 606. & \\
\hline CR & 2652-CONNEAUT & $\mathrm{OH}$ & 632. & \\
\hline CR & 2649-ASHTABULA & $\mathrm{OH}$ & 646. & \\
\hline$C R$ & 2727-PAINESVILLE & $\mathrm{OH}$ & 672. & \\
\hline CR & 2728-CLEVELAND & $\mathrm{OH}$ & 702. & \\
\hline CR & 2633-ELYRIA & $\mathrm{OH}$ & 729. & \\
\hline CR & 14985-OAK HARBOR & $\mathrm{OH}$ & 786. & \\
\hline CR & 3442-TOLEDO & $\mathrm{OH}$ & 808. & \\
\hline CR & 3526-GOSHEN & IN & 930. & \\
\hline CR & 3525-ELKHART & IN & 940. & \\
\hline CR & 4022-SOUTH BEND & IN & 955. & \\
\hline CR & 3969-LA PORTE & IN & 981. & \\
\hline CR & 4067-PORTER & IN & 1000 . & \\
\hline CR & 4071-TOLLESTON & IN & 1016. & \\
\hline CR & 4077-GIBSON & IN & 1022. & \\
\hline CR & 4076-HAMMOND & IN & 1025. & \\
\hline CR & 4228-BURNHAM / CALUME & EIL & 1027. & \\
\hline CR & 4223-DOLTON / RIVERDA & AIL & 1031. & \\
\hline CR & 4163-BLUE ISLAND & IL & 1035. & \\
\hline- & $-\ldots-\ldots-\ldots$ & - - & -- & - - - TRANSFER \\
\hline IHB & 4163-BLUE ISLAND & IL & 1035. & \\
\hline IHB & 4172-ARGO & IL & 1047. & \\
\hline IHB & 4234-PROVISO & IL & 1058 . & \\
\hline-- & $-\cdots-\cdots$ & -- & -- & - - - - TRANSFER \\
\hline UP & 4234-PROVISO & IL & 1058. & \\
\hline UP & 4214-WEST CHICAGO & IL & 1073. & \\
\hline UP & 4311-DE KALB & IL & 1100. & \\
\hline UP & 4324-NELSON & IL & 1145. & \\
\hline UP & 10304-CLINTON & IA & 1180. & \\
\hline UP & 10289-CEDAR RAPIDS & IA & 1262. & \\
\hline
\end{tabular}




\begin{tabular}{|c|c|c|c|}
\hline UP & 10265-MARSHALLTOWN & IA & 1331. \\
\hline UP & 10246-NEVADA & IA & 1358. \\
\hline UP & 10271 -AMES & IA & 1369. \\
\hline UP & 10177-ARION & IA & 1467. \\
\hline UP & 10176-MISSOURI VALLEY & IA & 1503. \\
\hline UP & 10198-CALIFORNIA JCT & IA & 1509. \\
\hline UP & 11340-FREMONT & NE & 1537. \\
\hline UP & 11473-CENTRAL CITY & NE & 1624. \\
\hline UP & 11406-GRAND ISLAND & NE & 1646 . \\
\hline UP & 11410-GIBBON & NE & 1672. \\
\hline UP & 11352-NORTH PLATTE & NE & 1791. \\
\hline UP & 11358-0 FALLONS & NE & 1802. \\
\hline UP & 13703-JULESBURG & $\mathrm{CO}$ & 1870. \\
\hline UP & 11287-SIDNEY & NE & 1913. \\
\hline UP & 13465-CHEYENNE & WY & 2016. \\
\hline UP & 13462-LARAMIE & WY & 2068. \\
\hline UP & 13494-GRANGER & WY & 2344. \\
\hline UP & 13568-OGDEN & UT & 2487. \\
\hline UP & 13595-SALT LAKE CITY & UT & 2523. \\
\hline UP & 13594-GARFIELD & UT & 2535. \\
\hline UP & 13630-LYNNDYL & UT & 2638 . \\
\hline UP & 14770-CALIENTE & NV & 2845 . \\
\hline USG & $\begin{array}{l}\text { 14770-CALIENTE } \\
\end{array}$ & NV & 2845. \\
\hline
\end{tabular}

ROUTE FROM: CSXT 3198-FERNALD

TO: USG 14770-CALIENTE
OH LENGTH: 2164.8 MILES

NV POTENTIAL: 2775.7

\begin{tabular}{|c|c|c|c|}
\hline RR & NODE & STATE & DIST \\
\hline CSXT & 3198-FERNALD & $\mathrm{OH}$ & 0 \\
\hline CSXT & 3692-COTTAGE GROVE & IN & 23. \\
\hline CSXT & 3251-HAMILTON & $\mathrm{OH}$ & 46. \\
\hline CSXT & 3234-IVORYDALE & $\mathrm{OH}$ & 63. \\
\hline CSXT & 3228-CINCINNATI & $\mathrm{OH}$ & 70. \\
\hline CSXT & 3718-SEYMOUR & IN & 156. \\
\hline CSXT & 3824-MITCHELL & IN & 198. \\
\hline CSXT & 3812-VINCENNES & IN & 260. \\
\hline CSXT & 4952-SALEM & IL & 338. \\
\hline CSXT & 10825-WASHINGTON PAR & $\mathrm{K}$ IL & 399. \\
\hline CSXT & 10879-NATIONAL STOCK & YIL & 402. \\
\hline CSXT & 10878-NATIONAL CITY & IL & 404. \\
\hline CSXT & 10859-EAST ST LOUIS & IL & 405. \\
\hline TRRA & 10859-EAST ST LOUIS & $\overline{\mathrm{IL}}$ & - . - TRANSFER \\
\hline-- & & -- & - - . - - TRANSFER \\
\hline UP & 10859-EAST ST LOUIS & IL & 405. \\
\hline UP & 10858-ST LOUIS & MO & 406. \\
\hline UP & 10875-GRAND AVE (ST & LOMO & 409. \\
\hline
\end{tabular}




\begin{tabular}{|c|c|c|c|}
\hline UP & 10860-PACIFIC & MO & 433. \\
\hline UP & 10656-JEFFERSON CITY & MO & 531. \\
\hline UP & 10659-MARSHALL & MO & 623. \\
\hline UP & 15708-SHEFFIELD & MO & 703. \\
\hline UP & 15709-KANSAS CTY UNIO & MMO & 708. \\
\hline UP & 10617-KANSAS CITY & KS & 709. \\
\hline UP & 11823-LAWRENCE & KS & 748. \\
\hline UP & 11697-TOPEKA & KS & 778. \\
\hline UP & 11696 -MENOKEN & KS & 783. \\
\hline UP & 11681-MARYSVILLE & KS & 858. \\
\hline UP & 11487-ENDICOTT & NE & 890. \\
\hline UP & 11405-HASTINGS & NE & 966. \\
\hline UP & 11410-GIBBON & NE & 992. \\
\hline UP & 11352-NORTH PLATTE & NE & 1111. \\
\hline UP & 11358-0 FALLONS & NE & 1122. \\
\hline UP & 13703-JULESBURG & $\mathrm{CO}$ & 1190. \\
\hline UP & 11287-SIDNEY & $N E$ & 1233. \\
\hline UP & 13465-CHEYENNE & WY & 1336. \\
\hline UP & 13462-LARAMIE & WY & 1388. \\
\hline UP & 13494-GRANGER & WY & 1664. \\
\hline UP & 13568-OGDEN & UT & 1807. \\
\hline UP & 13595-SALT LAKE CITY & UT & 1843. \\
\hline UP & 13594-GARFIELD & UT & 1855. \\
\hline UP & 13630-LYNNDYL & UT & 1958. \\
\hline UP & 14770-CALIENTE & NV & 2165. \\
\hline USG & $\begin{array}{l}-\cdots-{ }^{-}- \\
14770-\text { CALIENTE }\end{array}$ & -- & $\begin{array}{l}--- \\
2165 .\end{array}$ \\
\hline
\end{tabular}

ROUTE FROM: UP 13336-SCOVILLE

T0: USG 14770-CALIENTE

ID LENGTH: 550.1 MILES

NV POTENTIAL: 845.60

\begin{tabular}{|c|c|c|c|}
\hline RR & NODE & STATE & DIST \\
\hline UP & 13336-SCOVILLE & ID & 0. \\
\hline UP & 13370-POCATELLO & ID & 56. \\
\hline UP & 13369-MC CAMMON & ID & 79 \\
\hline UP & 13568-OGDEN & UT & 193. \\
\hline UP & 13595-SALT LAKE CITY & UT & 228. \\
\hline UP & 13594-GARFIELD & UT & 240 . \\
\hline UP & 13630-LYNNDYL & UT & 343. \\
\hline UP & 14770-CALIENTE & NV & 550. \\
\hline 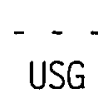 & $\begin{array}{l}----^{-}-\cdots \\
14770 \text {-CALIENTE }\end{array}$ & --- & 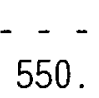 \\
\hline
\end{tabular}


ROUTE FROM: BNSF 13028-ALBUQUERQUE TO: USG 14770-CALIENTE
NM LENGTH: 1284.5 MILES

NV POTENTIAL: 1982.0

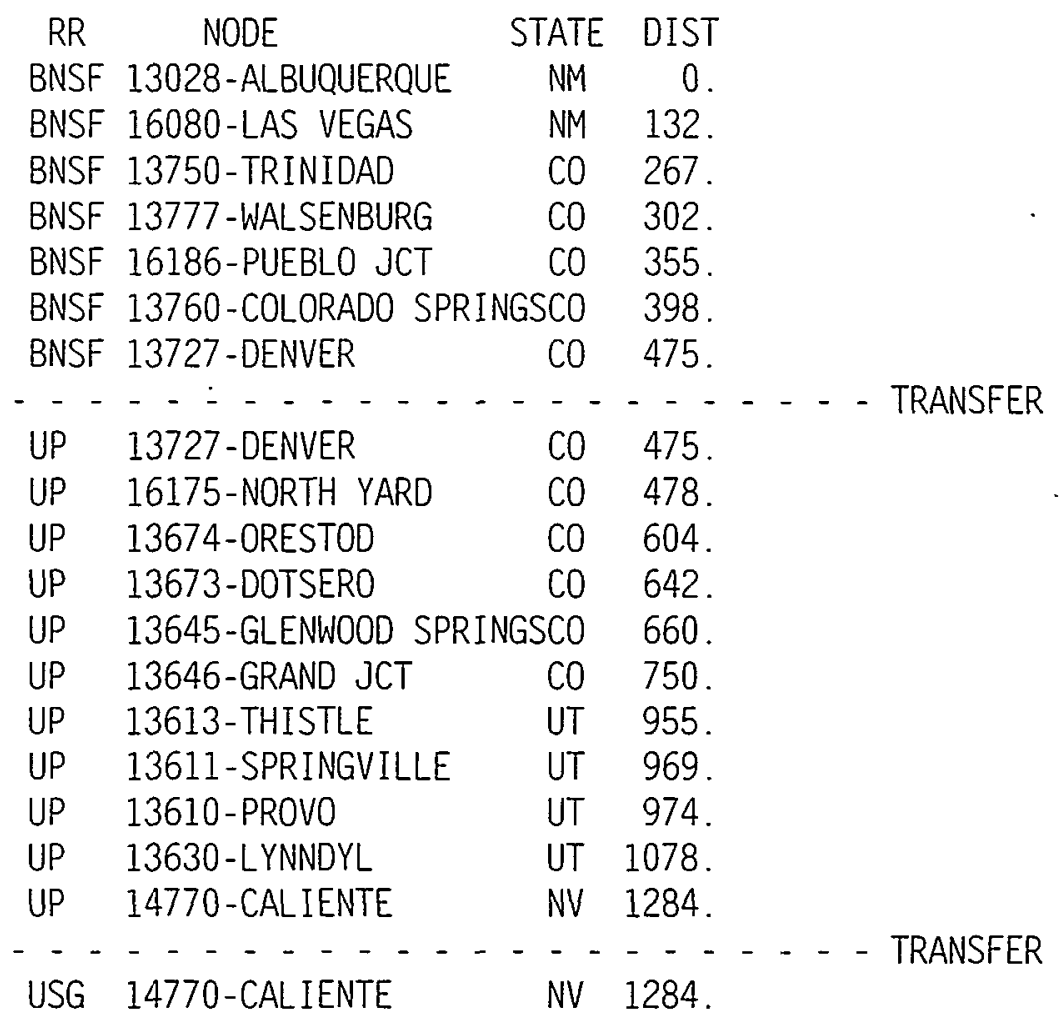

ROUTE FROM: UP 14473-LIVERMORE TO: USG 14770-CALIENTE
CA LENGTH: 1086.0 MILES

NV POTENTIAL: 1222.4

\begin{tabular}{llrr} 
RR & \multicolumn{1}{c}{ NODE } & STATE & DIST \\
UP & $14473-$ LIVERMORE & CA & 0. \\
UP & $14495-$ LYOTH & CA & 26. \\
UP & $14498-$ LATHROP & CA & 36. \\
UP & $14499-$ STOCKTON & CA & 45. \\
UP & $14411-$ SACRAMENTO & CA & 88. \\
UP & $14415-$ ROSEVILLE & CA & 103. \\
UP & $14821-$ RENO & NV & 220. \\
UP & $14816-$ SPARKS & NV & 235. \\
UP & $14812-$ HAZEN & NV & 268. \\
UP & $14813-$ WINNEMUCCA & NV & 402. \\
UP & $14791-$ BEOWAWE & NV & 482. \\
UP & $14792-$ CARLIN & NV & 506. \\
UP & $14793-$ ELKO & NV & 526. \\
UP & $14794-$ ALAZON & NV & 577. \\
UP & $14795-$ WELLS & NV & 581. \\
UP & $14797-$ SHAFTER & NV & 627. \\
UP & $13594-$ GARFIELD & UT & 776. \\
UP & $13630-$ LYNNDYL & UT & 879.
\end{tabular}




\begin{tabular}{llll} 
UP & 14770 -CALIENTE & NV 1086. & \\
\hdashline$-1-\ldots-\ldots$ & TRANSFER \\
USG 14770 -CALIENTE & NV 1086.
\end{tabular}

ROUTE FROM: CR 3185-MIAMISBURG

TO: USG 14770-CALIENTE
OH LENGTH: 2245.8 MILES

NV POTENTIAL: 2772.3

\begin{tabular}{|c|c|c|c|}
\hline RR & NODE & STATE & \\
\hline CR & 3185-MIAMISBURG & $\mathrm{OH}$ & . \\
\hline$C R$ & 3282-DAYTON & $\mathrm{OH}$ & \\
\hline$C R$ & 3300-SPRINGFIELD & 33. & \\
\hline$C R$ & 14993-COLUMBUS (BUCKEY & EYOH & \\
\hline$C R$ & 3006-FINDLAY & 165. & \\
\hline$C R$ & 3446-WALBRIDGE & 207. & \\
\hline$C R$ & 3442-TOLEDO & 210. & \\
\hline$C R$ & 3526-GOSHEN & 332. & \\
\hline$C R$ & 3525-ELKHART & 342. & \\
\hline$C R$ & 4022-SOUTH BEND & 357. & \\
\hline$C R$ & 3969-LA PORTE & 383. & \\
\hline$C R$ & 4067-PORTER & 402. & \\
\hline CR & 4069-MILLER & 413. & \\
\hline$C R$ & 4070-GARY & 418. & \\
\hline$C R$ & 4073-CLARKE & 422. & \\
\hline$C R$ & 4074-INDIANA HARBOR & 425. & \\
\hline$C R$ & 4035-WHITING LAKE FRO & 428. & \\
\hline$C R$ & 4232-SOUTH CHICAGO & 432. & \\
\hline$C R$ & 4217-CHICAGO & 445. & \\
\hline & $\ldots \ldots$ & $\cdots \cdots$ & $\cdots \cdots$ TRANSFER \\
\hline UP & 4217-CHICAGO & IL $\quad 445$. & \\
\hline UP & 4234-PROVISO & 459. & \\
\hline UP & 4214-WEST CHICAGO & 474. & \\
\hline UP & 4311-DE KALB & 501. & \\
\hline UP & 4324-NELSON & 546. & \\
\hline UP & 10304-CLINTON & 581. & \\
\hline UP & 10289-CEDAR RAPIDS & 663. & \\
\hline UP & 10265-MARSHALLTOWN & 732. & \\
\hline UP & 10246-NEVADA & 759. & \\
\hline UP & 10271-AMES & 770. & \\
\hline UP & 10177-ARION & 868. & \\
\hline UP & 10176-MISSOURI VALLEY & 904. & \\
\hline UP & 10198-CALIFORNIA JCT & 910. & \\
\hline UP & 11340-FREMONT & 938. & \\
\hline UP & 11473-CENTRAL CITY & 1025. & \\
\hline UP & 11406-GRAND ISLAND & 1047. & \\
\hline UP & 11410-GIBBON & 1073. & \\
\hline UP & 11352-NORTH PLATTE & 1192. & \\
\hline UP & $11358-0$ FALLONS & 1203. & \\
\hline UP & 13703-JULESBURG & co 1271. & \\
\hline
\end{tabular}




\begin{tabular}{|c|c|c|c|}
\hline UP & 11287-SIDNEY & NE & 1314. \\
\hline UP & 13465-CHEYENNE & WY & 1417. \\
\hline UP & 13462-LARAMIE & WY & 1469. \\
\hline UP & 13494-GRANGER & WY & 1745. \\
\hline UP & $13568-O G D E N$ & UT & 1888. \\
\hline UP & 13595-SALT LAKE CITY & UT & 1924. \\
\hline UP & $13594-G A R F I E L D$ & UT & 1936. \\
\hline UP & 13630-LYNNOYL & UT & 2039. \\
\hline UP & 14770-CALIENTE & NV & 2246 \\
\hline USG & $\begin{array}{l}---\ldots-\ldots \\
14770-\text { CALIENTE }\end{array}$ & -- & $\begin{array}{l}--\cdots \\
2246 .\end{array}$ \\
\hline
\end{tabular}

ROUTE FROM: NS 15316-K 25

TO: USG 14770-CALIENTE
TN LENGTH: 2289.6 MILES

NV POTENTIAL: 2794.1

\begin{tabular}{|c|c|c|c|}
\hline$R R$ & NODE & STATE & DIST \\
\hline NS & $15316-K 25$ & TN & 0. \\
\hline NS & 7260-HARRIMAN & TN & 15. \\
\hline NS & 6979-DANVILLE & KY & 177. \\
\hline NS & 7008-LOUISVILLE & KY & 277. \\
\hline NS & 7009-JEFFERSONVILLE & IN & 281. \\
\hline NS & 3821-HUNTINGBURG & IN & 355. \\
\hline NS & 3815-OAKLAND CITY & IN & 379. \\
\hline NS & 3813-PRINCETON & IN & 392. \\
\hline NS & 4797-MOUNT CARMEL & $\mathrm{IL}$ & 406. \\
\hline NS & 4954-MOUNT VERNON & IL & 469. \\
\hline NS & 4953-CENTRALIA & IL & 491. \\
\hline NS & 10867-VINER & $\mathrm{IL}$ & 549. \\
\hline NS & 10827-VALLEY JCT & IL & 551. \\
\hline NS & 10879-NATIONAL STOCK & YIL & 554. \\
\hline NS & 10880-MADISON & IL & 558. \\
\hline NS & 10877-MERCHANTS BRIDG & SEMO & 560. \\
\hline NS & 10493-MEXICO & MO & 662. \\
\hline NS & 10494 -CENTRALIA & MO & 677. \\
\hline NS & 10468-CLARK & MO & 688. \\
\hline NS & 10498-MOBERLY & MO & 700 \\
\hline NS & 10560 -CARROLLTON & MO & 766. \\
\hline NS & 10561-NORBORNE & MO & 775. \\
\hline NS & 10562-HARDIN & MO & 784. \\
\hline NS & 10563-HENRIETA & MO & 790. \\
\hline NS & 10564-C A JCT & MO & 798. \\
\hline NS & 15707-BIRMINGHAM & MO & 822. \\
\hline NS & 10616-KANSAS CITY & MO & 832. \\
\hline- - & ------ & -- & -- \\
\hline UP & 10616-KANSAS CITY & MO & 832. \\
\hline UP & 10617-KANSAS CITY & KS & 834. \\
\hline UP & 11823-LAWRENCE & KS & 872. \\
\hline UP & 11697-TOPEKA & KS & 902. \\
\hline
\end{tabular}




\begin{tabular}{|c|c|c|c|}
\hline UP & 11696-MENOKEN & KS & 907. \\
\hline UP & 11681-MARYSVILLE & KS & 982. \\
\hline UP & 11487-ENDICOTT & NE & 1014. \\
\hline UP & 11405-HASTINGS & NE & 1090. \\
\hline UP & 11410-GIBBON & NE & 1116. \\
\hline UP & 11352-NORTH PLATTE & NE & 1235. \\
\hline UP & 11358-0 FALLONS & NE & 1247. \\
\hline UP & 13703-JULESBURG & $\mathrm{CO}$ & 1315. \\
\hline UP & 11287-SIDNEY & NE & 1358. \\
\hline UP & 13465-CHEYENNE & WY & 1461. \\
\hline UP & 13462-LARAMIE & WY & 1513. \\
\hline UP & 13494-GRANGER & WY & 1789. \\
\hline UP & 13568-OGDEN & UT & 1932. \\
\hline UP & 13595-SALT LAKE CITY & UT & 1967. \\
\hline UP & 13594-GARFIELD & UT & 1980. \\
\hline UP & 13630-LYNNDYL & UT & 2083. \\
\hline UP & 14770-CAL IENTE & NV & 2290. \\
\hline USG & $\begin{array}{l}--\overline{-}-\overline{-}- \\
14770-\text { CAL IENTE }\end{array}$ & NV & $\begin{array}{l}-- \\
2290 .\end{array}$ \\
\hline
\end{tabular}

ROUTE FROM: UP 13653-PINE CLIFF

TO: USG 14770-CALIENTE
CO LENGTH: 776.7 MILES

NV POTENTIAL: 921.36

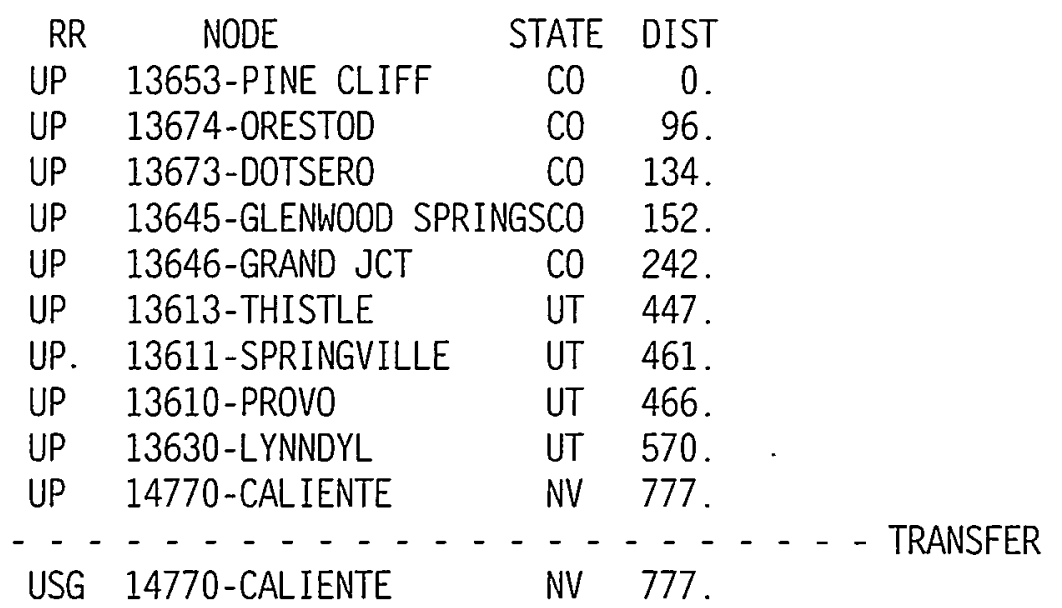


This Page Intentionally Left Blank 


\section{APPENDIX B}

SELECTED DETAILED RESULTS OF TRANSPORTATION RISK ANALYSIS RESULTS SORTED FIRST BY STATE AND THEN BY SITE 
This Page Intentionally Left Blank 


\section{APPENDIX B}

\section{SELECTED DETAILED REUSLTS OF TRANSPORTATION RISK ANALYSIS - RESULTS SORTED FIRST BY STATE AND THEN BY SITE}

This appendix contains raw output data from the RADTRAN 4 risk analyses performed for the various shipping configuration options and waste loading cases in this study. The data that is provided in this appendix includes a summary table of the total risks for the specified shipping campaign (e.g., total risks for transporting all LLW by truck to NTS via routes that avoid Las Vegas). In addition, a table of detailed state-level risk information is provided for each shipping configuration. In these tables, the results are first sorted by the state in which they occur and then by the LLW generator site that is shipping the LLW through the specified state. In Appendix C, the results are first sorted by LLW generator and then the impacts in each state along the transportation corridor between the LLW generator and the NTS are presented.

This appendix is organized as follows:

\section{Example RADTRAN 4 output file}

\section{High Waste Volume Case Results}
B.1 High Volume Rail Transport to Barstow
B.2 High Volume Truck Transport from Barstow to NTS
B.3 High Volume Rail Transport to Caliente
B.4 High Volume Truck Transport from Caliente to NTS
B.5 High Volume Truck Transport from Generators to NTS - Avoid Las Vegas
B.6 High Volume Truck Transport to NTS - Travel Through Las Vegas

\section{Low Waste Volume Case Results}

\section{B.7 Low Volume Rail Transport to Barstow \\ B.8 Low Volume Truck Transport from Barstow to NTS \\ B.9 Low Volume Rail Transport to Caliente \\ B.10 Low Volume Truck Transport from Caliente to NTS \\ B.11 Low Volume Truck Transport to NTS - Avoid Las Vegas \\ B.12 Low Volume Truck Transport to NTS - Travel Through Las Vegas}

Note that the rail transportation impact results in this appendix do not include the non-linear component of the rail impacts. The non-linear component accounts for marshalling of the cars at the beginning and end of the trip (it is part of the doses at stops in each case. To account for this, a worker dose component equal to 3.25E-03 person-rem/shipment and a public component of $2.11 \mathrm{E}-03$ person-rem/shipment were added to each rail shipment. These are per shipment numbers; half can be attributed to the originating state and the other half to the destination state. The non-linear dose component is included in the summary tables in Chapter 5.

The table below summarizes the route segments included in the calculation of life-cycle risks for each shipping configuration. Note that the risks for the intermodal shipping configurations include the risks of transporting LLW by truck from small generator sites to the NTS, either though or avoiding Las Vegas. The 
direct truck shipment risks in the intermodal configurations were extracted from the output files for truck transport from all LLW generators to NTS.

\begin{tabular}{|c|c|c|c|c|c|c|}
\hline \multicolumn{7}{|c|}{ High LLW Volume Case } \\
\hline \multirow[t]{2}{*}{$\begin{array}{l}\text { Configura- } \\
\text { tion }\end{array}$} & \multirow{2}{*}{$\begin{array}{l}\text { Truck from } \\
\text { LLW Gener- } \\
\text { ators to NTS }\end{array}$} & \multicolumn{2}{|c|}{$\begin{array}{l}\text { Rail from LLW Generators } \\
\text { to Intermodal Facility* }\end{array}$} & \multicolumn{2}{|c|}{$\begin{array}{l}\text { Truck from Intermodal } \\
\text { Facility to NTS* }\end{array}$} & \multirow{2}{*}{$\begin{array}{c}\text { Intermodal } \\
\text { Transfer } \\
\text { Operations }\end{array}$} \\
\hline & & Barstow & Caliente & Barstow & Caliente & \\
\hline $1 \mathrm{~A}$ & $\begin{array}{c}\text { Table B.5 } \\
\text { (small } \\
\text { generators) }\end{array}$ & Table B.1 & & Tale B.2 & & $\begin{array}{l}\text { See Section } \\
5.1 .2\end{array}$ \\
\hline lB & $\begin{array}{c}\text { Table B.5 } \\
\text { (small } \\
\text { generators) }\end{array}$ & $\because$ & Table B.3 & & Table B.4 & $\begin{array}{l}\text { See Section } \\
5.1 .2\end{array}$ \\
\hline 2 & $\begin{array}{c}\text { Table B.5 } \\
\text { (all } \\
\text { generators) }\end{array}$ & & & & & $\begin{array}{l}\because \cdots \\
\vdots \\
\vdots\end{array}$ \\
\hline 3 & $\begin{array}{c}\text { Table B.6 } \\
\text { (all } \\
\text { generators) } \\
\end{array}$ & & & & & \\
\hline \multicolumn{7}{|c|}{ Low LLW Volume Case } \\
\hline $1 \mathrm{~A}$ & $\begin{array}{l}\text { Table B.11 } \\
\text { (small } \\
\text { generators) }\end{array}$ & Table B.7 & & Table B.8 & & $\begin{array}{l}\text { See Section } \\
5.1 .2\end{array}$ \\
\hline $1 \mathrm{~B}$ & $\begin{array}{l}\text { Table B.11 } \\
\text { (small } \\
\text { generators) }\end{array}$ & 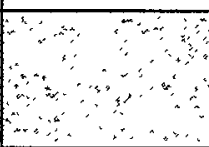 & Table B.9 & & Táble B.10 & $\begin{array}{l}\text { See Section } \\
5.1 .2\end{array}$ \\
\hline 2 & $\begin{array}{l}\text { Table B.11 } \\
\text { (all } \\
\text { generators) }\end{array}$ & 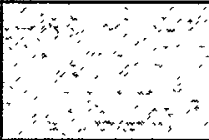 & & & & 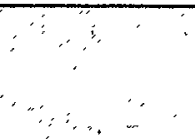 \\
\hline 3 & $\begin{array}{c}\text { Table B.12 } \\
\text { (all } \\
\text { generators) }\end{array}$ & 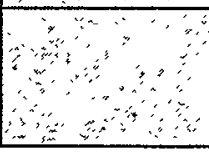 & & & & $\begin{array}{l}\ddots \\
\cdots \\
\cdots\end{array}$ \\
\hline
\end{tabular}

Also include non-linear component of public and crew doses to account for marshalling of the shipment at the origin and destination railyards.

To calculate the total risks of a shipping configuration, the components shown above are added together. The following example was prepared to illustrate the calculation process.

Example: Calculate incident-free risks to workers for transportation within the State of Nevada for Configuration 1B, Intermodal at Caliente.

This example was chosen because it illustrates most of the calculations performed to estimate the total risks in a single state. All of the components of the total state-level risk are non-zero in this example. For the Barstow, $\mathrm{CA}$, intermodal configurations, worker risks for the intermodal transfer and rail marshalling/inspection components in Nevada are zero because the activities do not occur in Nevada. 
The risk components that are included in this calculation, the sources of component-level risk results, and supplemental calculations leading to the risk estimate within Nevada are shown below. Detailed spreadsheets were developed to automate the calculations.

\begin{tabular}{|c|c|c|}
\hline \multicolumn{3}{|c|}{ Example Calculation - Worker Risks in Nevada for High Waste Volume/Configuration 1B } \\
\hline Component & Source of Data/Calculation & $\begin{array}{c}\text { Result } \\
\text { (Fatalities) }\end{array}$ \\
\hline $\begin{array}{l}\text { Truck transport } \\
\text { from small } \\
\text { generators to NTS } \\
\text { via routes that } \\
\text { avoid Las Vegas. }\end{array}$ & $\begin{array}{l}\text { Find entry for NV, "Small Generators," in Table B.5. This is the } \\
\text { sum of the incident-free crew risks (3rd column) for shipments } \\
\text { from WVDP, BCL, Knolls (SPRU), SNL, PGDP, ETEC, ITRI, } \\
\text { PORT, PPPL, Pantex, LBNL, Ames, GJPO, and GE-Val. }\end{array}$ & $1.90 \mathrm{E}-03$ \\
\hline $\begin{array}{l}\text { Rail transport from } \\
\text { large generators to } \\
\text { Caliente. }\end{array}$ & $\begin{array}{l}\text { Find entry for NV in Table B.3. The "state total" entry in column } \\
3 \text { for NV is taken directly from the table. }\end{array}$ & $1.07 \mathrm{E}-03$ \\
\hline $\begin{array}{l}\text { Truck transport } \\
\text { from Caliente to } \\
\text { NTS. }\end{array}$ & $\begin{array}{l}\text { Find entry for Nevada in Table B.4. As shown in the table, all } \\
\text { transport from Caliente to NTS is within NV. Therefore, the } \\
\text { "state total" entry is taken directly from column } 3 \text { of the table. }\end{array}$ & 3.87E-02 \\
\hline $\begin{array}{l}\text { Marshalling, } \\
\text { inspection. }\end{array}$ & $\begin{array}{l}\text { This calculation was performed external to the RADTRAN code. } \\
\text { This component is the product of the number of rail shipments } \\
\text { (see Table B.3) and the risk per shipment, as follows: } \\
\text { Risk }=(6.5 \mathrm{E}-07 \text { fatalities/rail shipment }) *(8622 \text { rail shipments) } \\
\quad=5.60 \mathrm{E}-03 \text { fatalities. }\end{array}$ & $5.60 \mathrm{E}-03$ \\
\hline Intermodal transfer. & $\begin{array}{l}\text { This calculation was performed external to the RADTRAN code. } \\
\text { This component is the product of the number of containers } \\
\text { handled (same as the number of truck shipments from Caliente to } \\
\text { NTS - see Table B.4) and the risk per shipment, as follows: } \\
\text { Risk }=(1.36 \mathrm{E}-07 \text { fatalities/container }) *(25,858 \text { truck } \\
\text { shipments })=3.52 \mathrm{E}-03 \text { fatalities }\end{array}$ & $3.52 \mathrm{E}-03$ \\
\hline TOTAL & Add together the five components of worker risk in Nevada. & $\begin{array}{l}\text { 5.1E-02 } \\
\text { (See NV entry } \\
\text { in Table } 5.20 \text { ) }\end{array}$ \\
\hline
\end{tabular}


The following is an excerpt from the RADTRAN 4 output file that was developed for this study. Only the input echo, incident-free and accident risk: output pages are presented. Intermediate results are not included:

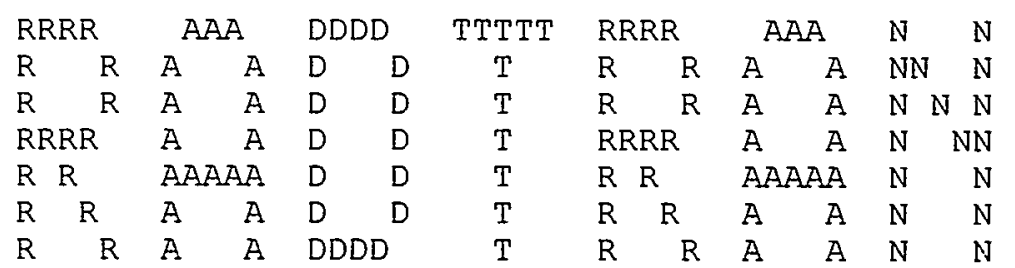

RADTRAN 4.0.19 VERSION DATE: NOVEMBER 14, 1996

MODE DESCRIPTIONS

$\begin{array}{cll}\text { NUMBER } & \text { NAME } & \text { CHARACTERIZATION } \\ 1 & \text { TRUCK } & \text { LONG HAUL VEHICLE } \\ 2 & \text { RAIL } & \text { COMMERCIAL TRAIN } \\ 3 & \text { BARGE } & \text { INLAND VESSEL } \\ 4 & \text { SHIP } & \text { OPEN SEA VESSEL } \\ 5 & \text { CARGO AIR } & \text { CARGO AIRCRATT } \\ 6 & \text { PASS AIR } & \text { PASSENGER AIRCRAFT } \\ 7 & \text { P-VAN } & \text { PASSENGER VAN } \\ 8 & \text { CVAN-T } & \text { COMMERCIAL VAN } \\ 9 & \text { CVAN-R } & \text { COMMERCIAL VAN } \\ 10 & \text { CVAN-CA } & \text { COMMERCIAL VAN }\end{array}$




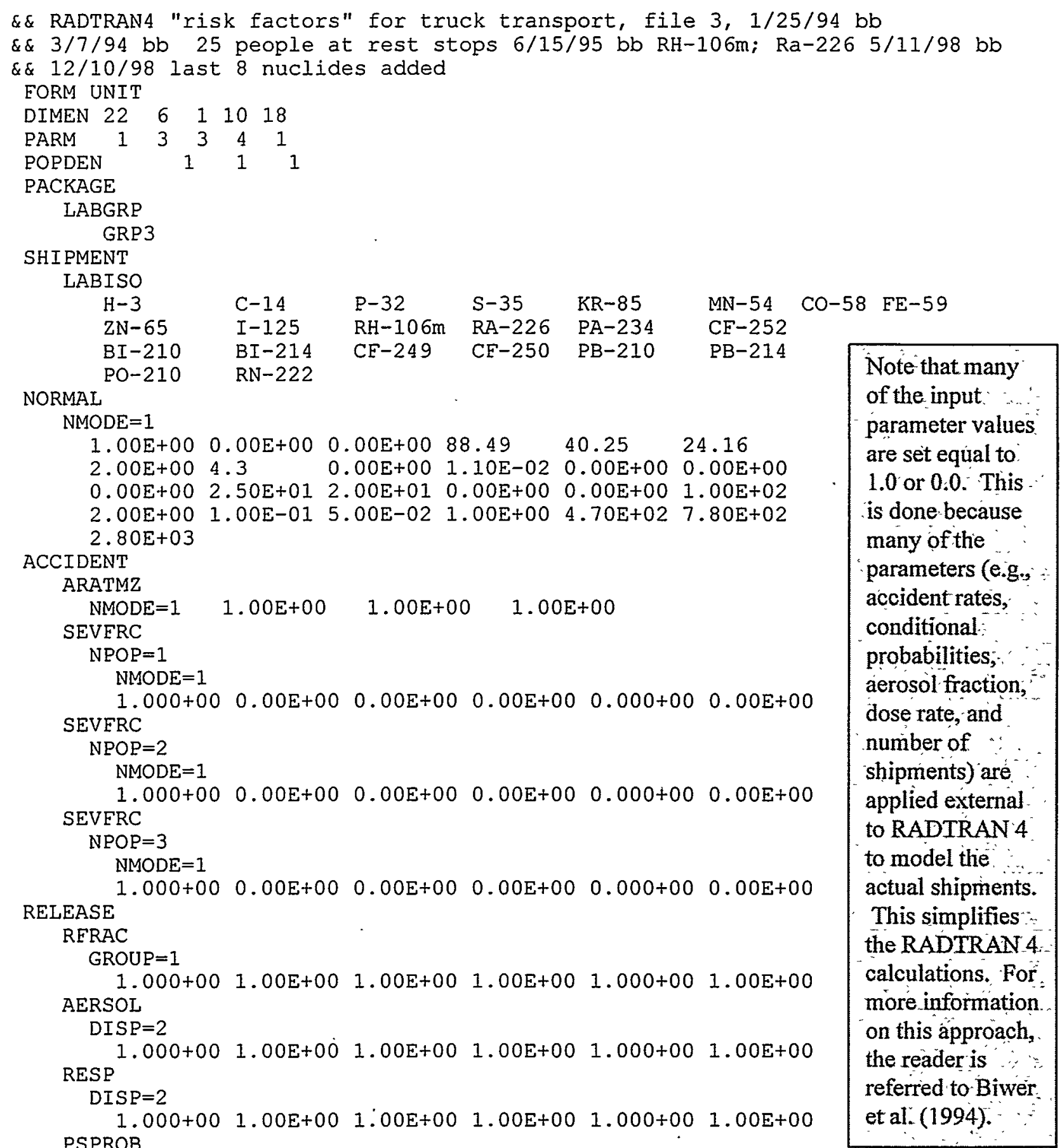




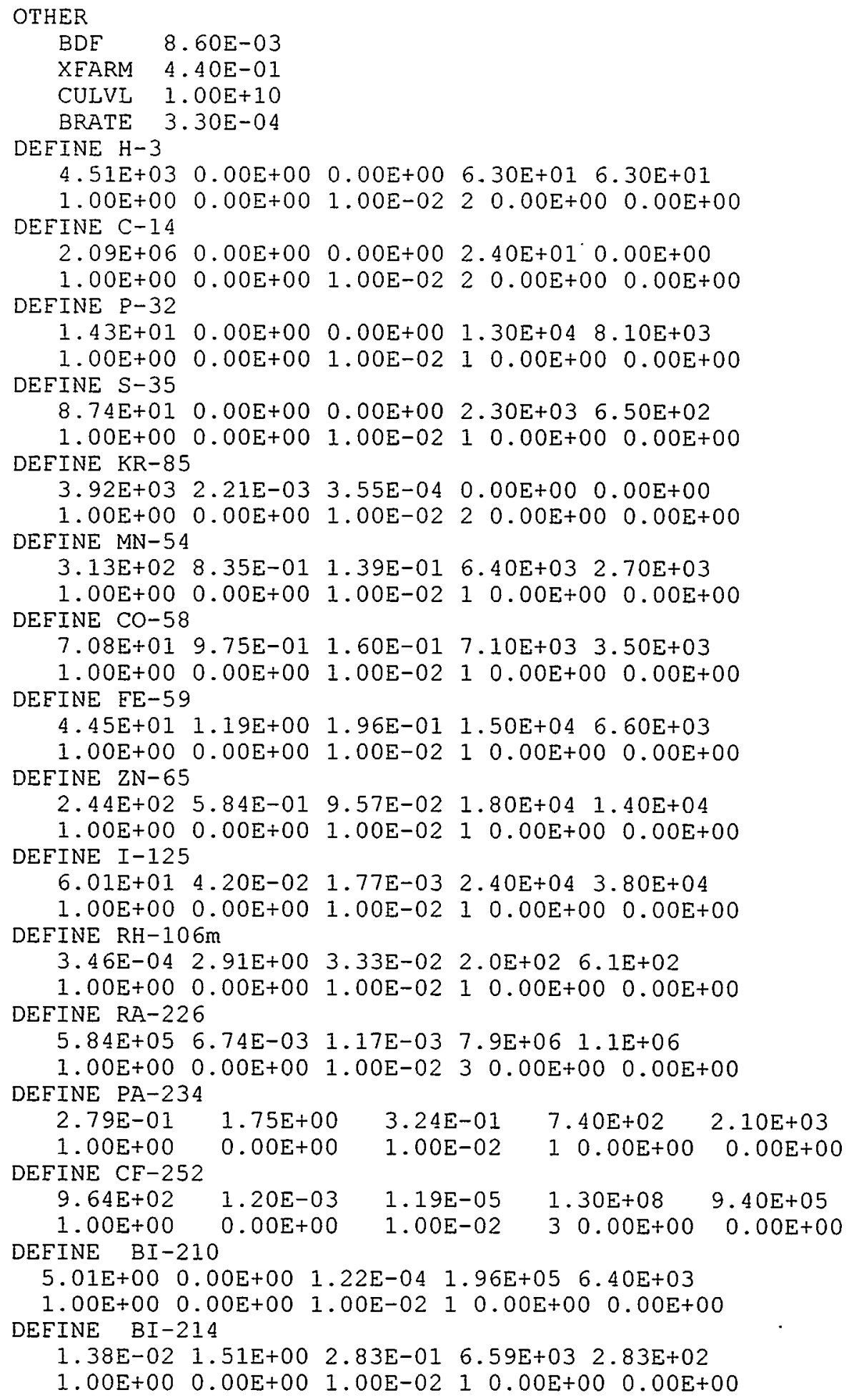




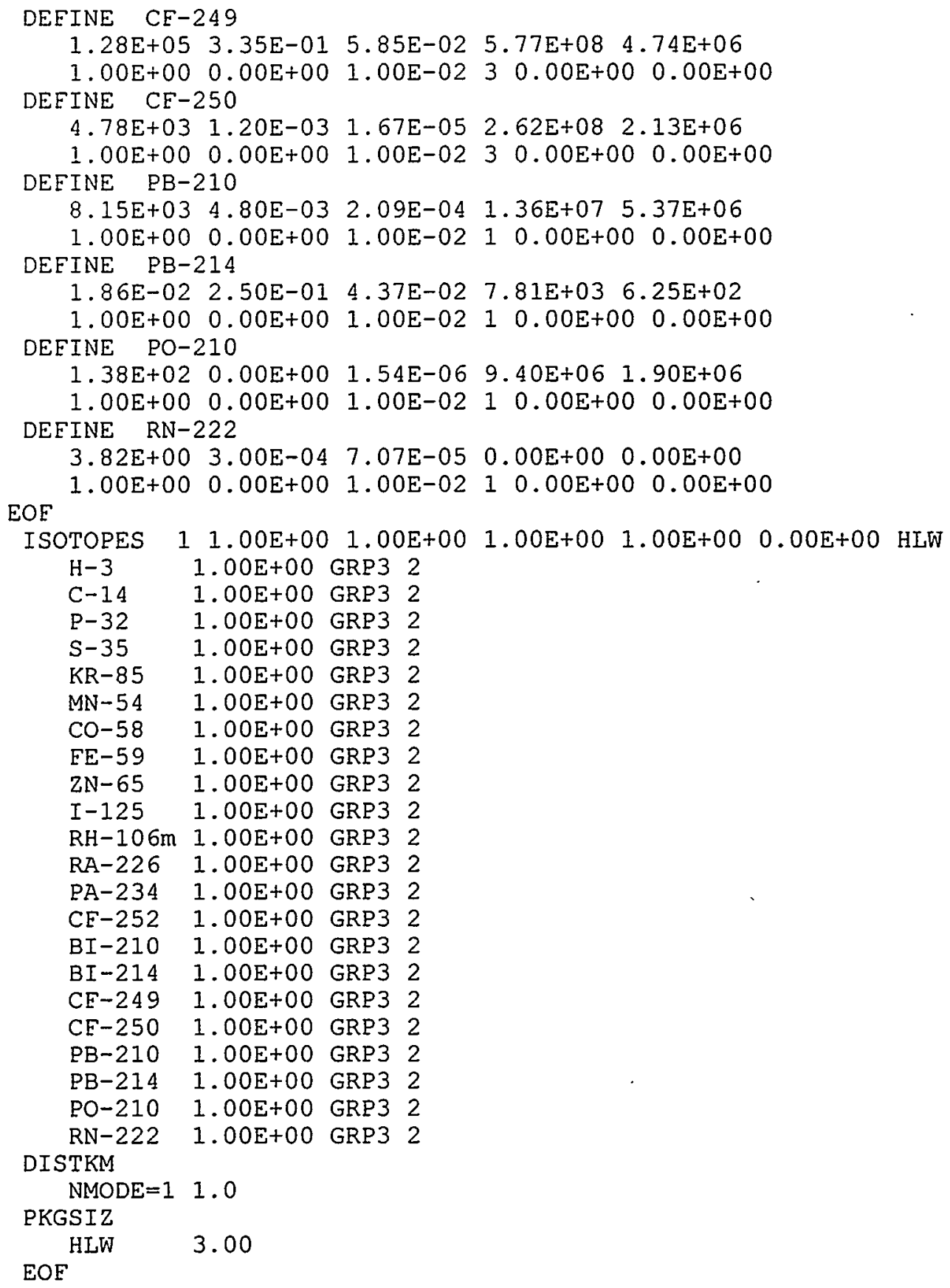




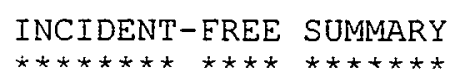

MAXIMUM INDIVIDUAL IN-TRANSIT DOSE

LINK $12.39 E-08$ REM 
INCIDENT-FREE IMPORTANCE ANALYSIS SUMMARY FOR LINK 1

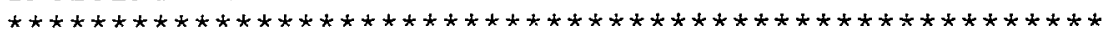

INDEX DESCRIPTION OF PARAMETER

DISTANCE TRAVELED

PACKAGES PER SHIPMENT

DOSE RATE (TRANSPORT INDEX)

K ZERO

NUMBER OF SHIPMENTS

FRACTION OF TRAVEL - RURAL

NUMBER OF CREW MEMBERS

PERSONS EXPOSED WHILE STOPPED

STOP TIME

FRACTION OF TRAVEL ON FREEWAYS

TRAFFIC COUNT - RURAI

NUMBER OF PEOPLE PER VEHICLE

POPULATION DENSITY - RURAL

STORAGE EXPOSURE DISTANCE

NUMBER OF HANDLINGS

EXPOSURE TIME FOR HANDLERS

PERSONS EXPOSED PER HANDLING

NUMBER OF ELIGHT ATTENDANTS

TRAFEIC COUNT - URBAN

TRAFEIC COUNT - SUBURBAN

HANDLER EXPOSURE DISTANCE

NUMBER OF PERSONS EXPOSED

STORAGE TIME PER SHIPMENT

SUBURBAN SHIELDING FACTOR (RS)

VELOCITY - SUBURBAN

POPULATION DENSITY - SUBURBAN

FRACTION OF TRAVEL - SUBURBAN

RATIO OE PEDESTRIAN DENSITY (RPD)

FRACTION OF TRAVEL - URBAN

POPULATION DENSITY - URBAN

URBAN SHIELDING FACTOR (RU)

FRACTION OF TRAVEL ON CITY STREETS

VELOCITY - URBAN

RURAI SHIELDING FACTOR (RR)

FRACTION OF RUSH HOUR TRAVEL

VELOCITY - RURAL

EXPOSURE DISTANCE WHILE STOPPED

DISTANCE EROM SOURCE TO CREW
IMPORTANCE

$1.236 \mathrm{E}-07$

$1.236 \mathrm{E}-07$

$1.236 \mathrm{E}-07$

$1.236 \mathrm{E}-07$

$1.236 \mathrm{E}-07$

$8.062 \mathrm{E}-08$

$7.701 \mathrm{E}-08$

$4.297 \mathrm{E}-08$

4. $297 \mathrm{E}-08$

3. $607 \mathrm{E}-09$

3. $592 \mathrm{E}-09$

3. 592E-09

1. $469 \mathrm{E}-11$

$0.000 \mathrm{E}+00$

$0.000 E+00$

$0.000 E+00$

$0.000 E+00$

$0.000 \mathrm{E}+00$

$0.000 \mathrm{E}+00$

$0.000 \mathrm{E}+00$

$0.000 \mathrm{E}+00$

$0.000 \mathrm{E}+00$

$0.000 \mathrm{E}+00$

$0.000 E+00$

$0.000 \mathrm{E}+00$

$0.000 \mathrm{E}+00$

$0.000 \mathrm{E}+00$

$0.000 E+00$

$0.000 E+00$

$0.000 \mathrm{E}+00$

$0.000 \mathrm{E}+00$

$0.000 E+00$

$0.000 \mathrm{E}+00$

$0.000 \mathrm{E}+00$

$-2.831 \mathrm{E}-17$

$-8.421 E-08$

$-8.594 \mathrm{E}-08$

$-1.540 \mathrm{E}-07$

THE IMPORTANCE VALUE ESTIMATES THE PERSON-REM INELUENCE' OF A ONE PERCENT INCREASE IN THE PARAMETER 


\section{EXPECTED VALUES OF POQULAIION RISK IN PERSON REM}

\begin{tabular}{|c|c|c|c|c|c|c|}
\hline HLW & GROUND & INHALED & RESUSPD & CLOUDSH & *INGEST ION & TOTAL \\
\hline$H-3$ & $0.00 E \div 00$ & $1.05 \mathrm{E}-06$ & $4.44 E-06$ & $0.00 E+00$ & $2.56 \mathrm{E}+01$ & $2.56 E+01$ \\
\hline$C-14$ & $0.00 E+00$ & & & $0.00 \mathrm{E}+00$ & $0.00 \mathrm{E}+00$ & \\
\hline$P-32$ & $0.00 E+00$ & & & $0.00 E+00$ & & $3.29 E+03$ \\
\hline$s-35$ & $D E+00$ & & & $0.00 E+00$ & & \\
\hline$K R-85$ & $7 E-04$ & & $0 E+00$ & $1.80 \mathrm{E}-08$ & & \\
\hline$M N-54$ & & & & & & \\
\hline & & & & -06 & & +03 \\
\hline$F E-59$ & & & & & & \\
\hline $\mathrm{ZN}-65$ & 1. & & & & & \\
\hline & & & & & & \\
\hline$H-106 r$ & & & & & & \\
\hline$A-226$ & 4.8 & & & & & \\
\hline$P A-234$ & & & & & & \\
\hline-252 & & & & -10 & & \\
\hline-210 & & 3.2 & & & & \\
\hline BI -214 & & & & & & \\
\hline$C F-249$ & & & & & & $8+06$ \\
\hline$C E-250$ & & & & & & \\
\hline & & & & & & \\
\hline$P B-214$ & & & & & & \\
\hline PO- 210 & 0.0 & & & & & \\
\hline $\mathrm{RN}-222$ & & $0.00 E+00$ & $0.00 E+00$ & $3.58 \mathrm{E}-09$ & $0.00 E+00$ & $6.98 \mathrm{E}-08$ \\
\hline & $3.00 E-01$ & $1.67 E+01$ & $7.14 E+01$ & $E-05$ & $6.61 E+06$ & $6.61 E+0$ \\
\hline
\end{tabular}

* NOTE THAT INGESTION RISK IS A SOCIETAL RISK;

THE USER MAY WISH TO TREAT THIS VALUE SEPARATELY. 
Table B.1 RADTRAN 4 Results - High Volume Rail Transport To Barstow Expected Fatalities for the Shipping Campaign

\begin{tabular}{ll}
\hline Exposure Group & Rail \\
\hline Radiological & \\
Normal Crew & $4.2 \mathrm{E}-02$ \\
Normal Public & $5.1 \mathrm{E}-02$ \\
Accident Public & $4.9 \mathrm{E}-06$ \\
Nonradiological & \\
Emission & $1.0 \mathrm{E}-01$ \\
Accident & $4.1 \mathrm{E}+00$ \\
\hline
\end{tabular}

Note: Results are given in abbreviated scièntific notation. For example, $4.2 \mathrm{E}-02=-4.2 \times 10^{-2}=$ 0.042

\section{Alternative Risks Per State (fatalities)}

\begin{tabular}{|c|c|c|c|c|c|c|c|}
\hline \multirow[t]{3}{*}{ State } & \multirow[t]{3}{*}{ Generator } & \multirow{3}{*}{$\begin{array}{l}\text { No. } \\
\text { Ship- } \\
\text { ments }\end{array}$} & \multicolumn{3}{|c|}{ Cargo-Related Risks } & \multirow{2}{*}{\multicolumn{2}{|c|}{$\begin{array}{l}\text { Vehicle-Related } \\
\text { Risks (Round-Tip) }\end{array}$}} \\
\hline & & & \multicolumn{2}{|c|}{ Incident-Free } & \multirow{2}{*}{$\begin{array}{l}\text { Accident } \\
\text { Public }\end{array}$} & & \\
\hline & & & Crew & Public & & Emission & Acciden \\
\hline \multicolumn{8}{|l|}{ Rail } \\
\hline \multicolumn{8}{|l|}{$A L$} \\
\hline & Oak Ridge Reserv. & 3283 & $9.89 E-04$ & $1.49 E-03$ & $5.40 \mathrm{E}-08$ & $2.34 \mathrm{E}-03$ & $1.32 E-01$ \\
\hline \multicolumn{8}{|c|}{$A Z$} \\
\hline & Oak Ridge Reserv. & 3283 & $2.41 E-03$ & $1.91 \mathrm{E}-03$ & $2.17 E-08$ & $3.16 \mathrm{E}-03$ & $3.23 E-01$ \\
\hline & Los ATamos NL & 1277 & $9.38 E-04$ & $7.44 E-04$ & $8.42 E-09$ & 1.23E-03 & $1.25 E-01$ \\
\hline & Fernald (FEMP) & 1046 & $7.69 E-04$ & $6.09 E-04$ & $6.90 \mathrm{E}-09$ & $1.01 E-03$ & $1.03 \mathrm{E}-01$ \\
\hline & Rocky Flats Plant & 814 & $5.98 \mathrm{E}-04$ & $4.74 \mathrm{E}-04$ & $5.37 E-09$ & $7.83 \mathrm{E}-04$ & 8.00E-02 \\
\hline & Mound Plant & 803 & $5.90 E-04$ & $4.68 E-04$ & $5.29 E-09$ & $7.73 \mathrm{E}-04$ & $7.89 \mathrm{E}-02$ \\
\hline & Brookhaven NL & 446 & $3.28 E-04$ & 2. $60 E-04$ & $2.94 \mathrm{E}-09$ & $4.29 \mathrm{E}-04$ & $4.38 \mathrm{E}-02$ \\
\hline & Argonne - East & 176 & 1.29E-04 & $1.03 E-04$ & 1.16E-09 & $1.69 \mathrm{E}-04$ & $1.73 \mathrm{E}-02$ \\
\hline & tate Total & 7845 & $5.77 E-03$ & $4.57 E-03$ & $5.17 E-08$ & $7.55 \mathrm{E}-03$ & $7.71 E-0$ \\
\hline \multicolumn{8}{|c|}{ 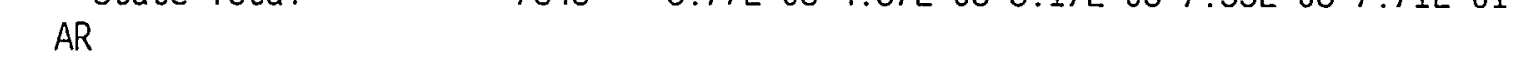 } \\
\hline & Oak Ridge Reserv. & 3283 & $8.62 E-04$ & 8.37E-04 & $1.22 \mathrm{E}-07$ & $8.24 E-04$ & 1.15E-01 \\
\hline \multirow{2}{*}{\multicolumn{8}{|c|}{ 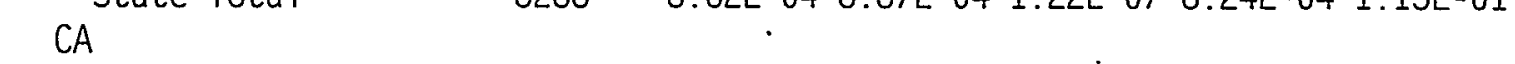 }} \\
\hline & & & & & & & \\
\hline & Oak Ridge Reserv. & 3283 & 1.12E-03 & $6.06 \mathrm{E}-04$ & $7.19 E-08$ & $1.37 E-04$ & $1.50 E-01$ \\
\hline & Los Alamos NL & 1277 & 4.37E-04 & $2.36 E-04$ & $2.80 E-08$ & $5.34 E-05$ & $5.84 \mathrm{E}-0$ \\
\hline & Fernald (FEMP) & 1046 & $3.58 E-04$ & $1.93 E-04$ & $2.29 E-08$ & $4.38 \mathrm{E}-05$ & $4.78 \mathrm{E}-0$ \\
\hline & Rocky Flats Plant & 814 & $2.78 E-04$ & $1.50 E-04$ & $1.78 E-08$ & $3.41 \mathrm{E}-05$ & $3.7 .2 \mathrm{E}-0$ \\
\hline & Mound Plant & 803 & $2.75 E-04$ & $1.48 E-04$ & $1.76 \mathrm{E}-08$ & $3.36 \mathrm{E}-05$ & $3.67 E-0$ \\
\hline & Lawrence Livermore & 466 & $3.52 E-04$ & $1.26 E-03$ & $6.09 E-08$ & $5.44 \mathrm{E}-03$ & $4.70 E-0$ \\
\hline & Brookhaven $\mathrm{NL}$ & 446 & $1.52 E-04$ & $8.23 E-05$ & $9.76 E-09$ & $1.87 E-05$ & $2.04 E-0$ \\
\hline & INEL & 311 & $3.14 \mathrm{E}-04$ & $1.35 E-03$ & $6.13 E-08$ & $5.79 \mathrm{E}-03$ & $4.20 E-0$ \\
\hline & Argonne - East & 176 & $6.02 E-05$ & $3.25 E-05$ & $3.85 E-09$ & $7.36 \mathrm{E}-06$ & $8.04 E-0$ \\
\hline & tate Total & 8622 & $3.35 E-03$ & $4.06 \mathrm{E}-03$ & $2.94 \mathrm{E}-07$ & 1.16E-02 & $4.48 E-0$ \\
\hline
\end{tabular}




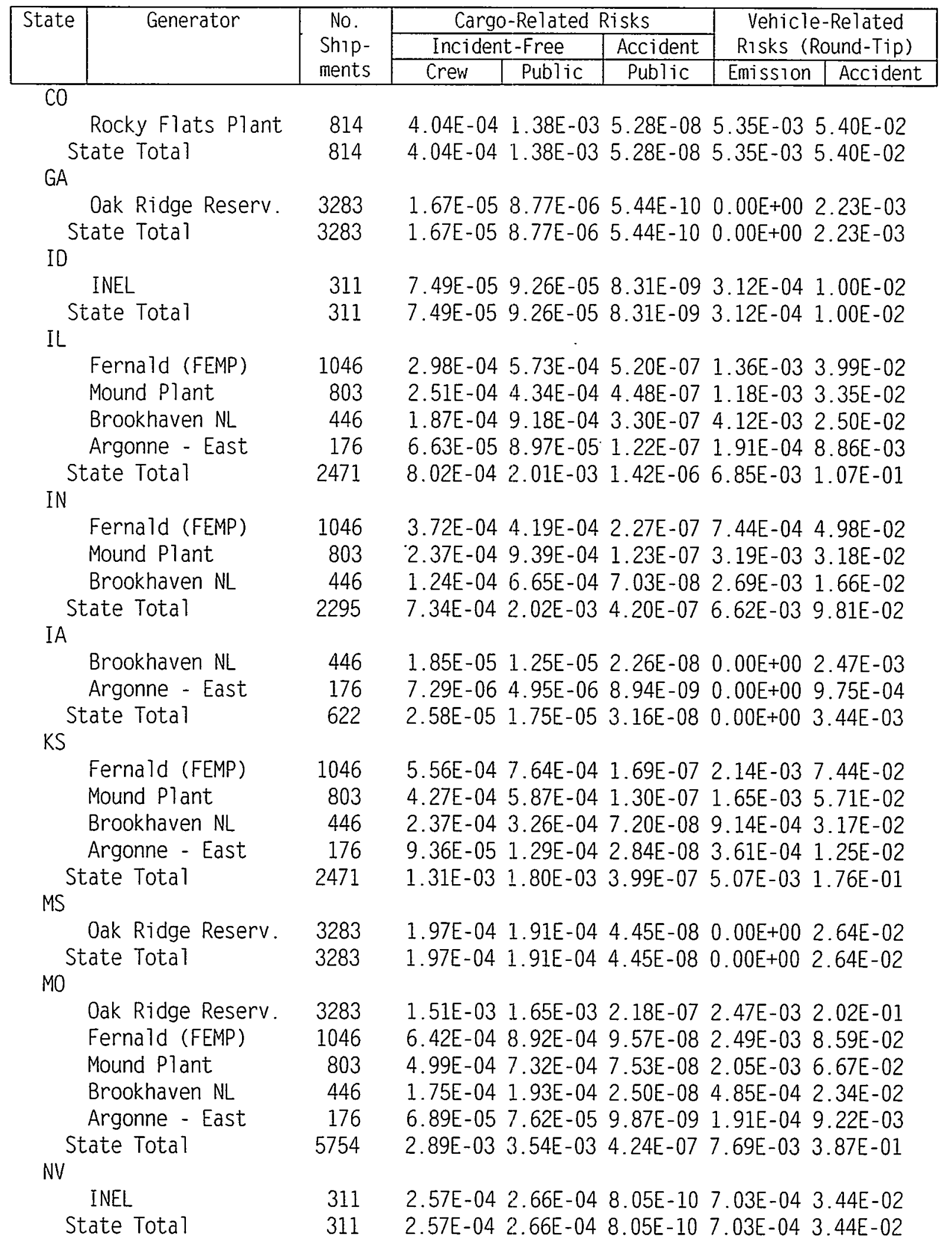




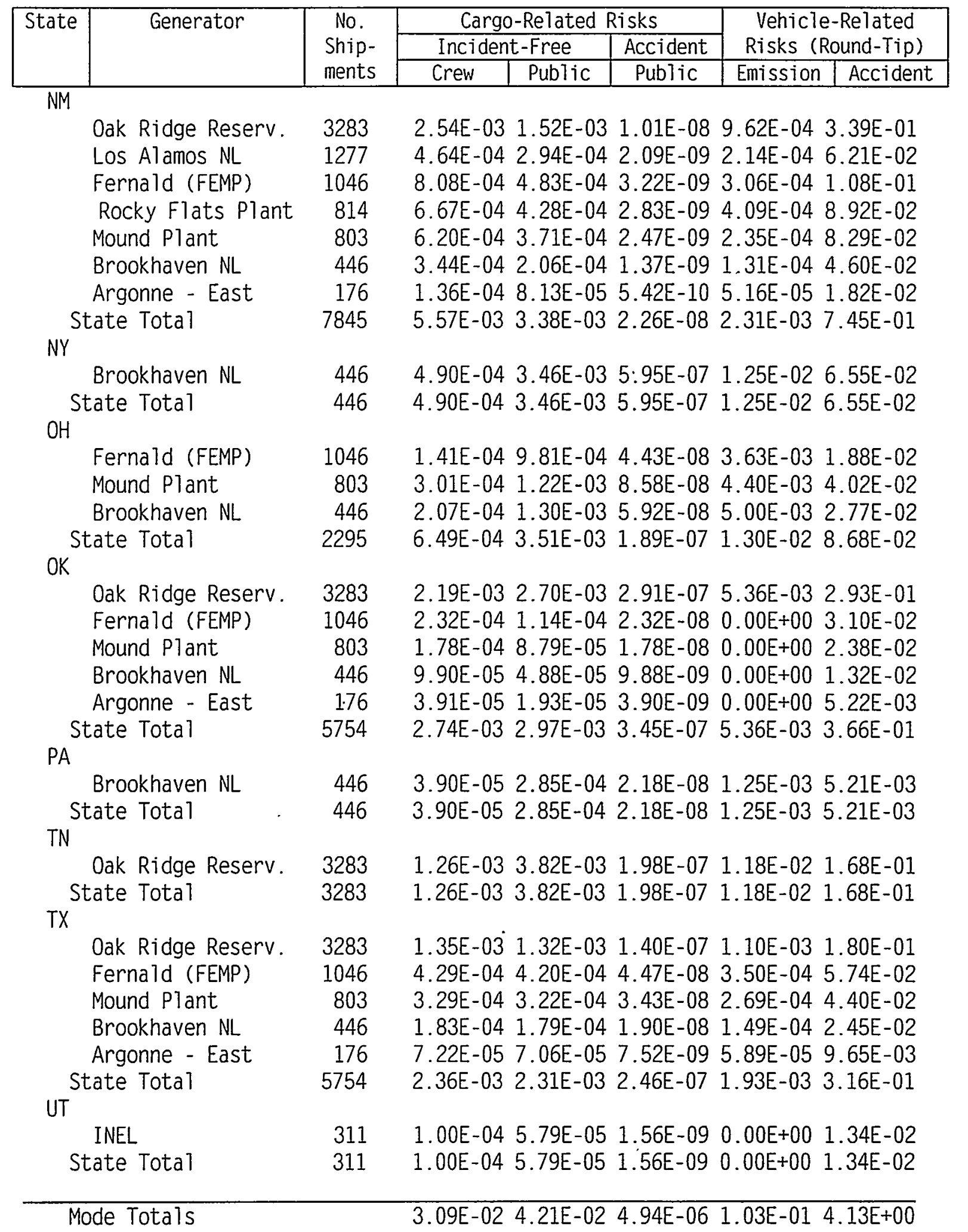


Table B.2 RADTRAN 4 Results - High Volume Truck Transport From Barstow To NTS accident rate for primary highways in NV alternate route files used

\begin{tabular}{lc}
\multicolumn{2}{l}{ Expected Fatalities for the Shipping C } \\
\hline Exposure Group & Truck \\
\hline Radrological & \\
$\quad$ Normal Crew & $2.6 \mathrm{E}-02$ \\
$\quad$ Normal Public & $4.0 \mathrm{E}-02$ \\
Accident Public & $4.9 \mathrm{E}-07$ \\
Nonradiological & \\
Emission & $5.8 \mathrm{E}-03$ \\
Accident & $1.5 \mathrm{E}-01$ \\
\hline
\end{tabular}

\section{Alternative Risks Per State (fatalities)}

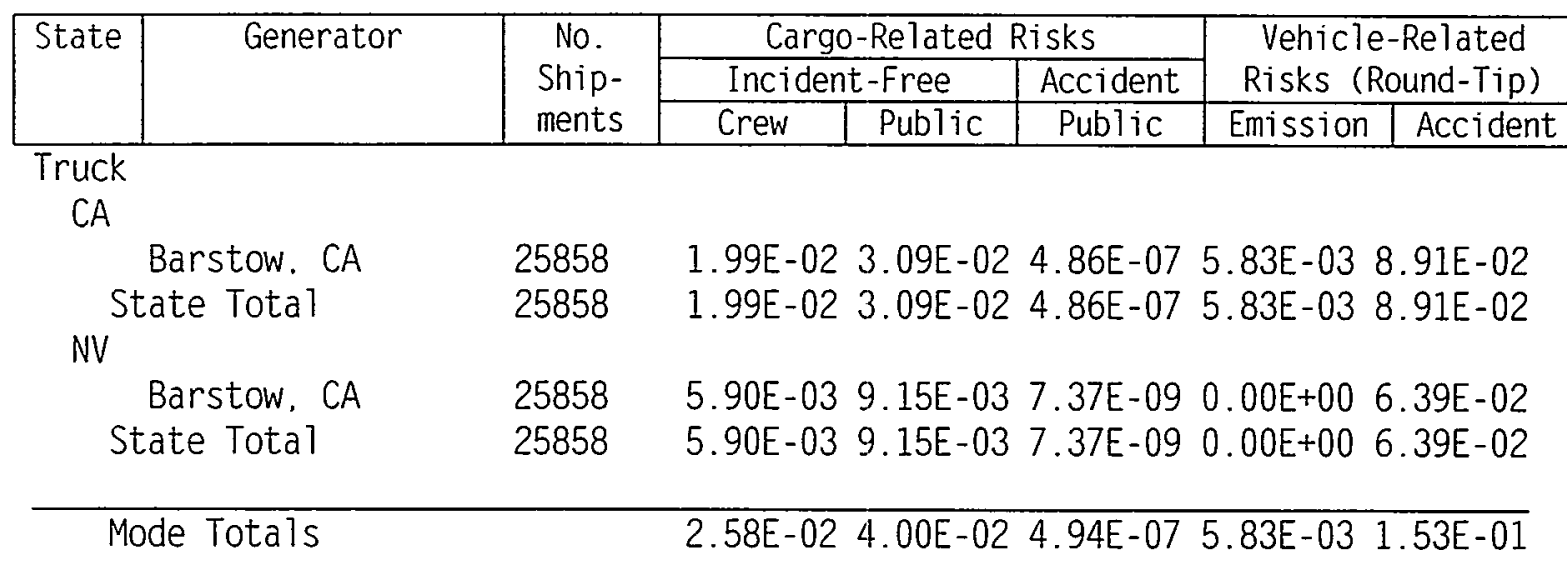


Table B.3 RADTRAN 4 Results - High Volume Rail Transport To Caliente Expected Fatalities for the Shipping Campaign

\begin{tabular}{lc}
\hline Exposure Group & Rail \\
\hline Radiological & \\
Normal Crew & $4.2 \mathrm{E}-02$ \\
Normal Public & $6.1 \mathrm{E}-02$ \\
Accident Public & $9.3 \mathrm{E}-06$ \\
Nonradiological & \\
Emission & $1.4 \mathrm{E}-01$ \\
Accident & $4.1 \mathrm{E}+00$ \\
\hline
\end{tabular}

\section{Alternative Risks Per State (fatalities)}

\begin{tabular}{|c|c|c|c|c|c|c|}
\hline \multirow[t]{3}{*}{ State } & \multirow[t]{3}{*}{ Generator } & \multirow{3}{*}{$\begin{array}{l}\text { No. } \\
\text { Ship- } \\
\text { ments }\end{array}$} & \multicolumn{3}{|c|}{ Cargo-Related Risks } & \multirow{2}{*}{$\begin{array}{c}\text { Vehicle-Related } \\
\text { Risks (Round-Tip) }\end{array}$} \\
\hline & & & \multicolumn{2}{|c|}{ Incident-Free } & \multirow{2}{*}{$\begin{array}{l}\text { Accident } \\
\text { Public } \\
\end{array}$} & \\
\hline & & & Crew & Public & & \begin{tabular}{l|l} 
Emission & Accident \\
\end{tabular} \\
\hline \multicolumn{7}{|l|}{$\overline{\text { Rail }}$} \\
\hline \multicolumn{7}{|l|}{ CA } \\
\hline & Lawrence Livermore & 466 & $1.82 E-04$ & $1.22 \mathrm{E}-03$ & $4.94 \mathrm{E}-08$ & $5.42 E-03 \quad 2.43 E-02$ \\
\hline & tate Total & 466 & $1.82 \mathrm{E}-04$ & $1.22 \mathrm{E}-03$ & $4.94 \mathrm{E}-08$ & $5.42 \mathrm{E}-032.43 \mathrm{E}-02$ \\
\hline \multicolumn{7}{|c|}{ 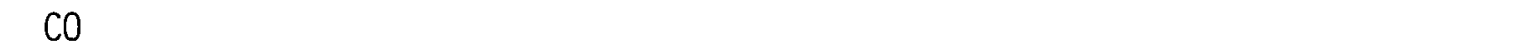 } \\
\hline & Oak Ridge Reserv. & 3283 & $6.18 \mathrm{E}-05$ & $5.23 \mathrm{E}-05$ & $3.21 \mathrm{E}-09$ & $0.00 E+008.26$ \\
\hline & Los Alan & 1277 & $1.30 \mathrm{E}-03$ & $2.49 \mathrm{E}-03$ & $1.11 \mathrm{E}-07$ & 7.37E-03 1.7 \\
\hline & Fernald & 1046 & $1.97 \mathrm{E}-05$ & 1.67E-05 & $1.02 E-09$ & $0.00 E+002.63$ \\
\hline & Rocky Flat & 814 & 4.20E-04 & $3.33 \mathrm{E}-04$ & $2.14 \mathrm{E}-08$ & $2.38 \mathrm{E}-04 \quad 5.61$ \\
\hline & Mound Plar & 803 & 1.51E-05 & $1.28 \mathrm{E}-05$ & $7.84 E-10$ & $0.00 E+002.02$ \\
\hline & Brookhave & 446 & $8.40 \mathrm{E}-06$ & 7.11E-06 & $4.36 \mathrm{E}-10$ & $0.00 E+001.12$ \\
\hline & Argonne - East & 176 & $1.59 \mathrm{E}-04$ & $2.15 \mathrm{E}-04$ & 1.03E-08 & $6.04 \mathrm{E}-042.12$ \\
\hline & tate Total & 7845 & $1.98 \mathrm{E}-03$ & $3.13 \mathrm{E}-03$ & $1.48 \mathrm{E}-07$ & 8.22E-03 2.65E-01 \\
\hline \multicolumn{7}{|c|}{ ID } \\
\hline & INEL & 311 & $7.49 E-05$ & $9.68 E-05$ & & $3.12 \mathrm{E}$ \\
\hline I! & tate Total & 311 & 7.49E-05 & $9.68 \mathrm{E}-05$ & E-09 & $3.12 E-04 \quad 1.00 E-02$ \\
\hline & Oak Ridge & 3283 & 9.71E-04 & 2.74E-03 & & 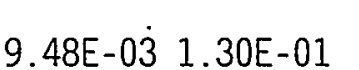 \\
\hline & Fernald & 1046 & $2.86 \mathrm{E}-04$ & $5.29 \mathrm{E}-04$ & $E-07$ & $1.18 \mathrm{E}$ \\
\hline & Mound Pla & 803 & $2.28 \mathrm{E}-04$ & $2.74 \mathrm{E}-03$ & $4.05 E-07$ & 1.16E-02 3.05E-02 \\
\hline & Brookha & 446 & $1.28 \mathrm{E}-04$ & $1.02 \mathrm{E}-03$ & $E-07$ & $4.57 \mathrm{E}-03 \quad 1.72 \mathrm{E}-02$ \\
\hline & Argonne - East & 176 & $5.99 E-05$ & $9.51 E-05$ & $1.11 \mathrm{E}-07$ & $2.43 \mathrm{E}-04 \quad 8.01 \mathrm{E}-03$ \\
\hline & tate Total & 5754 & $1.67 \mathrm{E}-03$ & $7.12 E-03$ & $2.95 E-06$ & $2.71 \mathrm{E}-02 \quad 2.24 \mathrm{E}-01$ \\
\hline \multicolumn{7}{|c|}{ 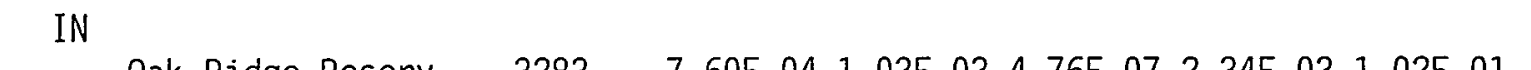 } \\
\hline & Oak Ridge Rese & 3283 & OE-04 & & & $1.02 \mathrm{E}-01$ \\
\hline & Fernald (FEMP) & 1046 & E-04 & E-04 & $7 \mathrm{~F}-07$ & $7.44 \mathrm{E}-04 \quad 4.98 \mathrm{E}-02$ \\
\hline & & & & & & 3.49E-03 3.00E-02 \\
\hline
\end{tabular}

B. 15 


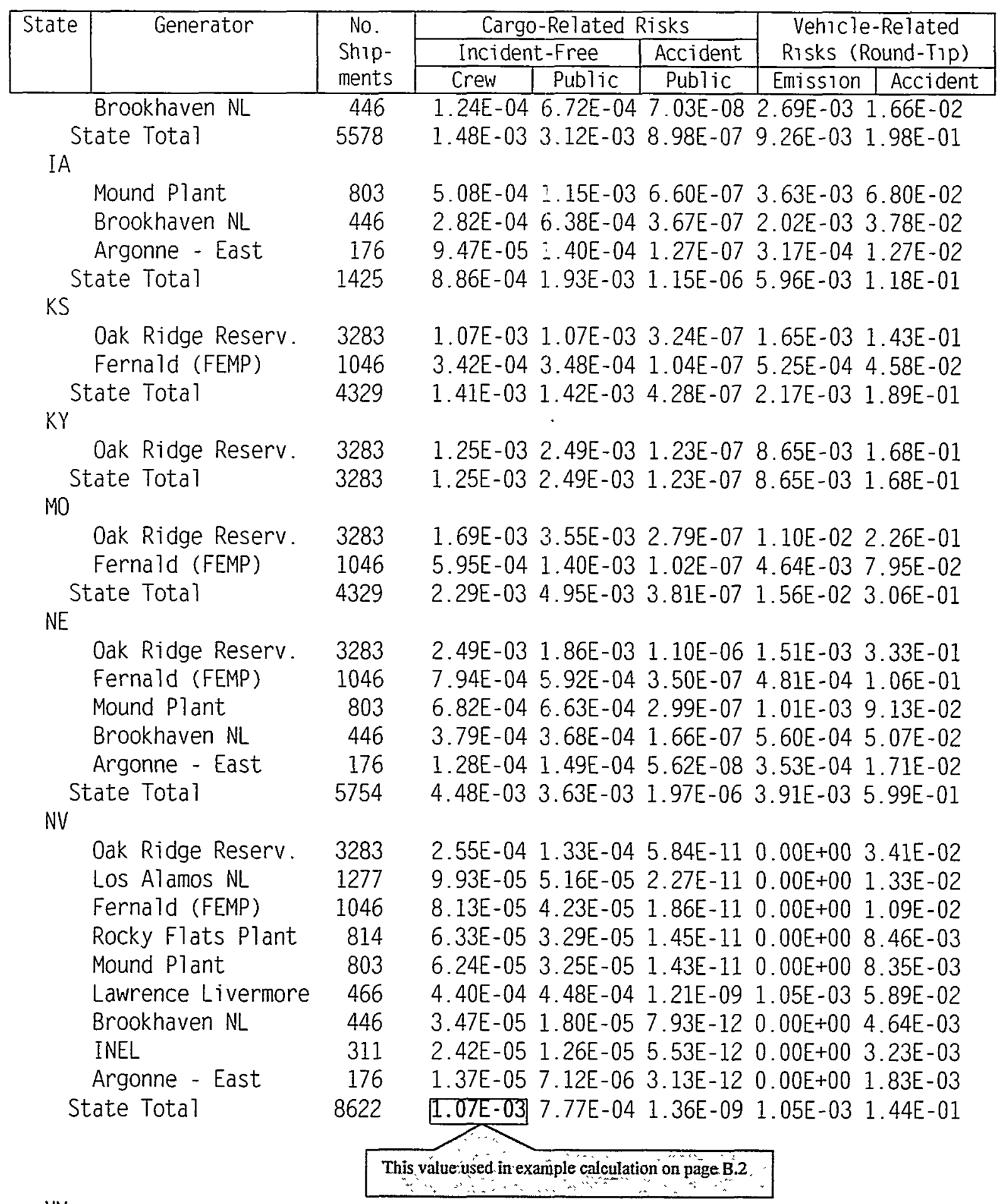

NM

Los Alamos NL $\quad 1277 \quad 5.82 E-04$ 4.00E-04 2.27E-09 $3.74 E-04 \quad 7.79 E-02$ State Total $\quad 1277 \quad 5.82 E-04 \quad 4.00 E-042.27 E-093.74 E-04 \quad 7.79 E-02$ NY

Brookhaven NL $\quad 446 \quad 4.90 \mathrm{E}-04 \quad 3.49 \mathrm{E}-03 \quad 5.95 \mathrm{E}-07 \quad 1.25 \mathrm{E}-02 \quad 6.55 \mathrm{E}-02$ $\begin{array}{llllllllll}\text { State Total } & 446 & 4.90 \mathrm{E}-04 & 3.49 \mathrm{E}-03 & 5.95 \mathrm{E}-07 & 1.25 \mathrm{E}-02 & 6.55 \mathrm{E}-02\end{array}$

B. 16 


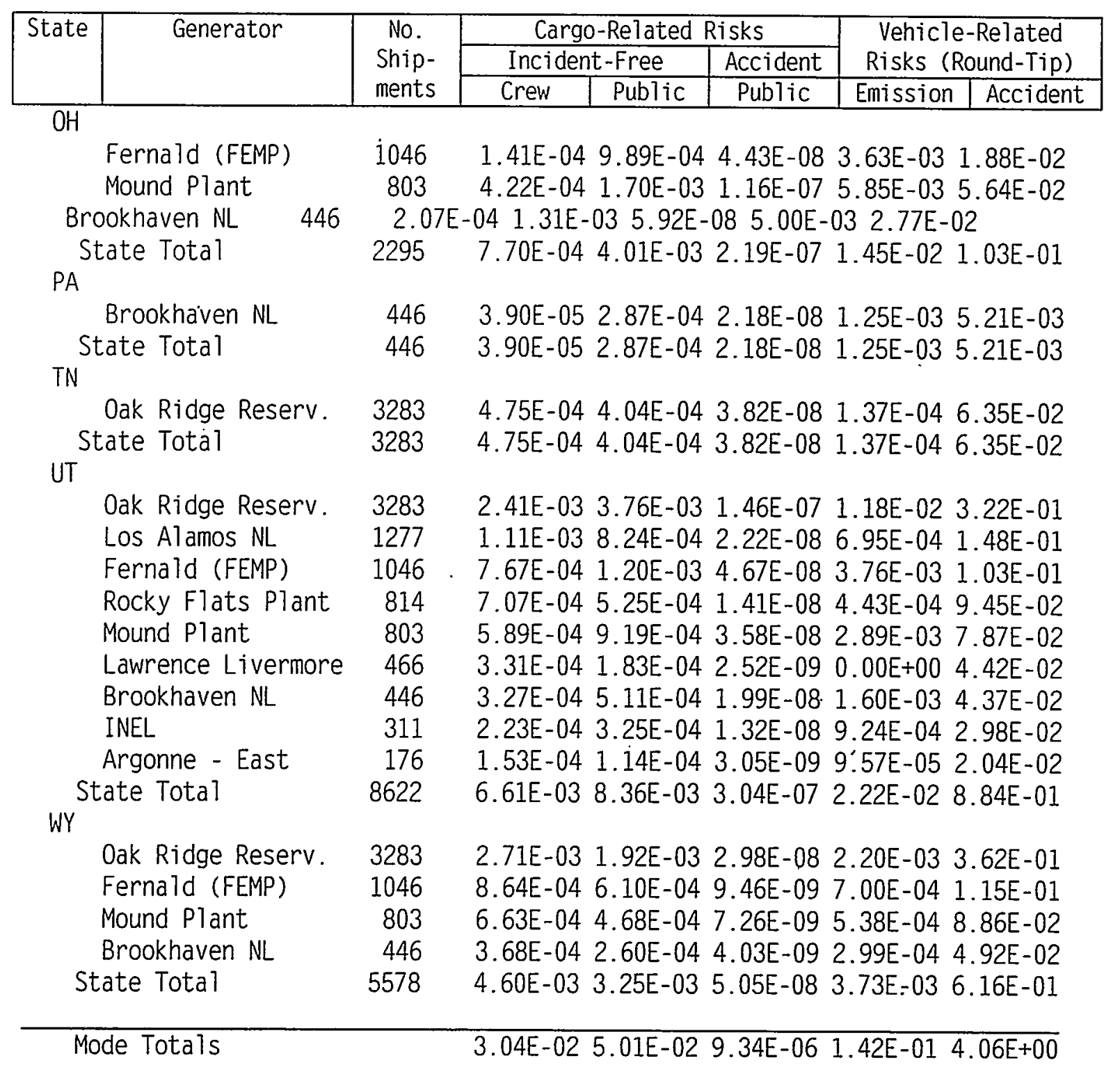


Table B.4 RADTRAN 4 Results - High Volume Truck Transport From Caliente To NTS accident rate for primary highways in NV alternate route files used

Expected Fatalities for the Shipping Campaign

\begin{tabular}{ll}
\hline Exposure Group & Truck \\
\hline Radiological & \\
Normal Crew & $3.9 \mathrm{E}-02$ \\
Normal Public & $6.0 \mathrm{E}-02$ \\
Accident Public & $5.9 \mathrm{E}-08$ \\
Nonradiological & \\
Emission & $0.0 \mathrm{E}+00$ \\
Accident & $4.2 \mathrm{E}-01$ \\
\hline
\end{tabular}

\section{Alternative Risks Per State (fatalities)}

\begin{tabular}{|c|c|c|c|c|c|c|c|}
\hline \multirow[t]{3}{*}{ State } & \multirow[t]{3}{*}{ Generator } & \multirow{3}{*}{$\begin{array}{l}\text { No. } \\
\text { Ship- } \\
\text { ments }\end{array}$} & \multicolumn{3}{|c|}{ Cargo-Related Risks } & \multirow{2}{*}{\multicolumn{2}{|c|}{$\begin{array}{l}\text { Vehicle-Related } \\
\text { Risks (Round-Tip) }\end{array}$}} \\
\hline & & & Inc & -Free & Accident & & \\
\hline & & & Crew & Public & Public & Emission & Accident \\
\hline
\end{tabular}

Truck

NV

Caliente, NV $25858 \quad 3.87 \mathrm{E}-02$ 5.99E-02 5.89E-08 $0.00 \mathrm{E}+00 \quad 4.18 \mathrm{E}-01$

State Total $25858 \quad$ 3.87E-02 $5.99 \mathrm{E}-02$ 5.89E-08 $0.00 \mathrm{E}+00 \quad 4.18 \mathrm{E}-01$

This value used in example calculation on page $B .2$

Mode Totals

3.87E-02 5.99E-02 5.89E-08 $0.00 \mathrm{E}+00 \quad 4.18 \mathrm{E}-01$

B. 18 
Table B.5 RADTRAN 4 Results - High Volume Truck Transport From Generators To NTS Avoid Las Vegas

accident rate for primary highways in NV

alternate route files used

Expected Fatalities for the Shipping Campaign

\begin{tabular}{ll}
\hline Exposure Group & Truck \\
\hline Radiological & \\
Normal Crew & $2.9 \mathrm{E}-01$ \\
Normal Public & $4.2 \mathrm{E}-01$ \\
Accident Public & $1.9 \mathrm{E}-05$ \\
Nonradiological & \\
Emission & $2.1 \mathrm{E}-01$ \\
Accident & $1.8 \mathrm{E}+00$ \\
\hline
\end{tabular}

Alternative Risks Per State (fatalities)

\begin{tabular}{|c|c|c|c|c|c|}
\hline \multirow[t]{3}{*}{ State } & \multirow[t]{3}{*}{ Generator } & \multirow{3}{*}{$\begin{array}{l}\text { No. } \\
\text { Ship- } \\
\text { ments }\end{array}$} & \multicolumn{2}{|c|}{ Cargo-Related Risks } & \multirow{2}{*}{$\begin{array}{l}\text { Vehicle-Related } \\
\text { Risks (Round-Tip) }\end{array}$} \\
\hline & & & Incident-Free & Accident & \\
\hline & & & \begin{tabular}{l|l} 
Crew & Public \\
\end{tabular} & Public & \\
\hline
\end{tabular}

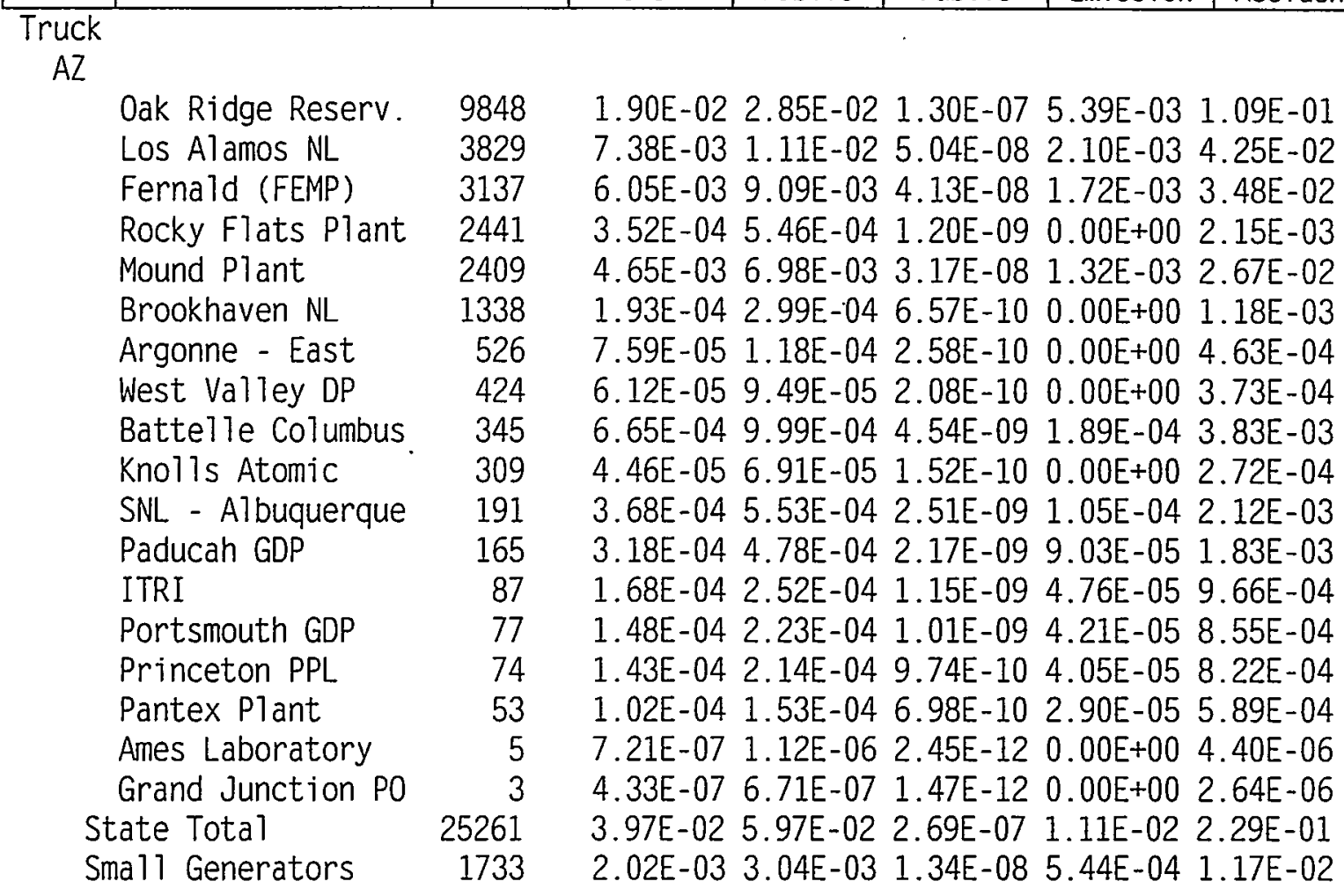




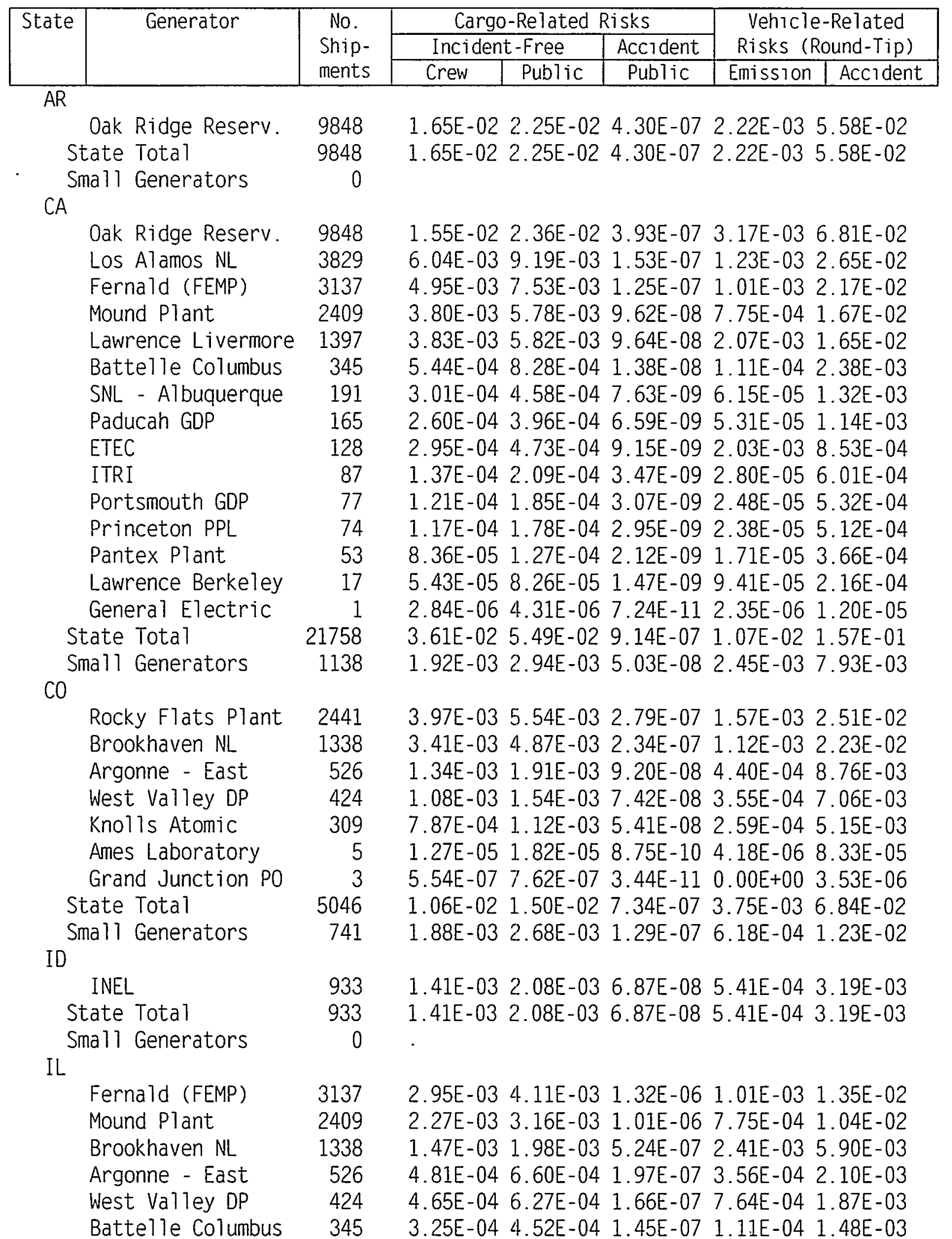




\begin{tabular}{|c|c|c|c|c|c|c|c|}
\hline \multirow[t]{3}{*}{ State } & \multirow[t]{3}{*}{ Generator } & \multirow{3}{*}{$\begin{array}{l}\text { No. } \\
\text { Ship- } \\
\text { ments }\end{array}$} & \multicolumn{3}{|c|}{ Cargo-Related Risks } & \multirow{2}{*}{\multicolumn{2}{|c|}{$\begin{array}{l}\text { Vehicle-Related } \\
\text { Risks (Round-Tip) }\end{array}$}} \\
\hline & & & \multicolumn{2}{|c|}{ Incident-Free } & \multirow{2}{*}{\begin{tabular}{|c|} 
Accident \\
Public
\end{tabular}} & & \\
\hline & & & Crew & Public & & Emission & Accident \\
\hline & Knolls Atomic & 309 & $3.39 E-04$ & $4.57 E-04$ & $1.21 \mathrm{E}-07$ & $5.57 \mathrm{E}-04$ & $1.36 \mathrm{E}-03$ \\
\hline & Paducah GDP & 165 & $1.64 E-06$ & $2.54 E-06$ & $9.65 E-10$ & $0.00 E+00$ & $8.82 E-06$ \\
\hline & Portsmouth GDP & 77 & $6.04 E-05$ & $8.69 E-05$ & $2.66 \mathrm{E}-08$ & $8.43 E-05$ & $2.71 E-04$ \\
\hline & Princeton PPL & 74 & $6.97 E-05$ & $9.70 E-05$ & $3.11 E-08$ & $2.38 E-05$ & $3.18 E-04$ \\
\hline & tate Total & 8804 & $8.43 E-03$ & $1.16 \mathrm{E}-02$ & $3.54 \mathrm{E}-06$ & $6.09 E-03$ & $3.71 E-02$ \\
\hline & nall Generators & 1394 & $1.26 \mathrm{E}-03$ & $1.72 E-03$ & $4.91 E-07$ & $1.54 \mathrm{E}-03$ & $5.31 E-03$ \\
\hline \multicolumn{8}{|c|}{ - } \\
\hline & Fernald (FEMP) & 3137 & $3.26 E-03$ & 4.22E-03 & $8.65 E-07$ & $7.07 E-04$ & $1.10 \mathrm{E}-02$ \\
\hline & Mound Plant & 2409 & $2.51 E-03$ & $3.39 E-03$ & $6.30 E-07$ & $4.42 E-03$ & $8.05 E-03$ \\
\hline & Brookhaven NL & 1338 & $1.45 E-03$ & $1.85 E-03$ & $3.26 E-07$ & $1.94 E-03$ & 4. $42 E-03$ \\
\hline & West Valley DP & 424 & $4.60 E-04$ & $5.87 E-04$ & $1.03 E-07$ & $6.14 E-04$ & $1.40 \mathrm{E}-03$ \\
\hline & Battelle Columbus & 345 & $3.60 E-04$ & $4.85 E-04$ & $9.02 E-08$ & $6.33 E-04$ & $1.15 E-03$ \\
\hline & Knolls Atomic & 309 & $3.35 E-04$ & $4.28 \mathrm{E}-04$ & $7.54 \mathrm{E}-08$ & 4. $48 \mathrm{E}-04$ & $1.02 \mathrm{E}-03$ \\
\hline & Portsmouth GDP & 77 & $5.21 E-05$ & $7.43 \mathrm{E}-05$ & $1.76 E-08$ & $4.96 \mathrm{E}-06$ & $2.03 E-04$ \\
\hline & Princeton PPL & 74 & $7.71 E-05$ & $1.04 \mathrm{E}-04$ & $1.94 \mathrm{E}-08$ & $1.36 \mathrm{E}-04$ & $2.47 E-04$ \\
\hline & cate Total & 8113 & $8.50 E-03$ & 1. $11 \mathrm{E}-02$ & $2.13 E-06$ & 8.90E-03? & $2.75 E-02$ \\
\hline & nall Generators & 1229 & $1.28 \mathrm{E}-03$ & $1.68 \mathrm{E}-03$ & $3.06 \mathrm{E}-07$ & $1.84 \mathrm{E}-03$ & $4.02 E-03$ \\
\hline \multicolumn{8}{|c|}{ 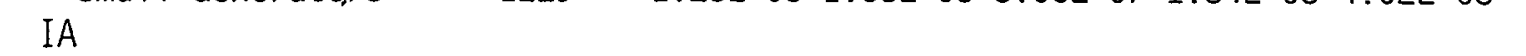 } \\
\hline & Brookhaven NL & 1338 & $2.32 E-03$ & $3.25 E-03$ & $5.93 E-07$ & $1.72 E-04$ & $1.24 E-02$ \\
\hline & Argonne - East & 526 & $9.12 E-04$ & $1.28 \mathrm{E}-03$ & $2.33 \mathrm{E}-07$ & $6.77 \mathrm{E}-05$ & $4.87 E-03$ \\
\hline & West Valley DP & 424 & $7.36 E-04$ & $1.03 E-03$ & $1.88 E-07$ & $5.46 \mathrm{E}-05$ & $3.93 E-03$ \\
\hline & Knolls Atomic & 309 & $5.36 E-04$ & $7.51 E-04$ & $1.37 E-07$ & $3.98 \mathrm{E}-05$ & $2.86 E-03$ \\
\hline & Ames Laboratory & 5 & $5.05 E-06$ & $6.99 E-06$ & $1.18 E-09$ & $3: 38 E-06$ & $2.56 E-05$ \\
\hline & tate Tota] & 2602 & $4.51 E-03$ & $6.32 E-03$ & $1.15 \mathrm{E}-06$ & $3.38 E-042$ & $2.41 E-02$ \\
\hline & nall Generators & 738 & $1.28 \mathrm{E}-03$ & $1.79 E-03$ & $3.26 \mathrm{E}-07$ & $9.78 \mathrm{E}-05$ & $6.82 E-03$ \\
\hline \multicolumn{8}{|c|}{ 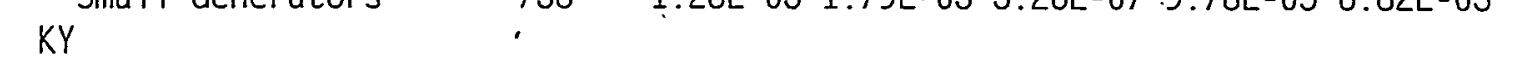 } \\
\hline & Paducah GDP & 165 & $2.40 E-05$ & $3.47 E-05$ & $2.14 \mathrm{E}-09$ & $0.00 E+00$ & $1.83 E-04$ \\
\hline & Portsmouth GDP & 77 & $6.25 E-05$ & $8.15 E-05$ & $5.79 E-09$ & $1.83 \mathrm{E}-04$ & $3.33 \mathrm{E}-04$ \\
\hline & tate Total & 242 & $8.64 E-05$ & $1.16 \mathrm{E}-04$ & 7.93E-09 & $1.83 E-045$ & $5.16 E-04$ \\
\hline & ma11 Generators & 242 & $8.65 E-05$ & $1.16 \mathrm{E}-04$ & $7.93 E-09$ & $1.83 E-04$ & $5.16 E-04$ \\
\hline \multicolumn{8}{|c|}{ 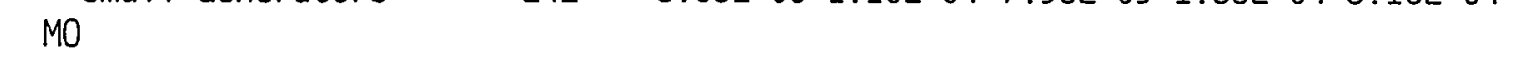 } \\
\hline & Fernald (FEMP) & 3137 & $6.00 E-03$ & $8.24 E-03$ & $1.00 E-06$ & $1.08 \mathrm{E}-023$ & $3.64 \mathrm{E}-02$ \\
\hline & Mound Plant & 2409 & $4.60 E-03$ & $6.33 E-03$ & $7.71 E-07$ & $8.30 \mathrm{E}-03$ & $2.79 \mathrm{E}-02$ \\
\hline & Battelle Columbus & 345 & $6.59 E-04$ & $9.06 E-04$ & $1.10 E-07$ & $1.19 E-03$ & $4.00 \mathrm{E}-03$ \\
\hline & Paducah GDP & 165 & $3.45 E-04$ & $4.75 E-04$ & $6.41 E-08$ & 1.43E-04? & $2.32 E-03$ \\
\hline & Portsmouth GDP & 77 & $1.47 E-04$ & $2.02 E-04$ & $2.47 E-08$ & $2.65 E-048$ & 8. $93 \mathrm{E}-04$ \\
\hline & Princeton PPL & 74 & $1.41 E-04$ & $1.94 E-04$ & 2.37E-08 & $2.55 \mathrm{E}-04$ & $8.58 \mathrm{E}-04$ \\
\hline & tate Total & 6207 & 1. 19E-02 & $1.63 E-02$ & $2.00 E-06$ & $2.10 \mathrm{E}-027$ & $7.24 E-02$ \\
\hline & nal1 Generators & 661 & $1.29 E-03$ & $1.78 E-03$ & $2.23 E-07$ & $1.85 E-03$ & 8.07E-03 \\
\hline \multicolumn{8}{|c|}{ 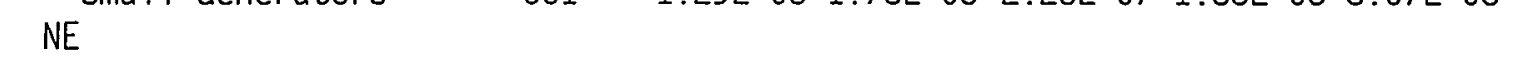 } \\
\hline & Brookhaven NL & 1338 & $2.59 E-03$ & $3.90 \mathrm{E}-03$ & & $2.58 \mathrm{E}-03$ & $2.10 \mathrm{E}-02$ \\
\hline & Argonne - East & 526 & $1.02 E-03$ & $1.53 E-03$ & $3.46 E-07$ & $1.02 E-038$ & $8.24 E-03$ \\
\hline & West Valley DP & 424 & $8.21 E-04$ & $1.24 \mathrm{E}-03$ & $2.79 E-07$ & $8.19 \mathrm{E}-04$ & $6.64 E-03$ \\
\hline
\end{tabular}




\begin{tabular}{|c|c|c|c|c|c|c|c|}
\hline \multirow[t]{3}{*}{ State } & \multirow[t]{3}{*}{ Generator } & \multirow{3}{*}{$\begin{array}{l}\text { No. } \\
\text { Ship- } \\
\text { ments }\end{array}$} & \multicolumn{3}{|c|}{ Cargo-Related Risks } & \multirow{2}{*}{\multicolumn{2}{|c|}{$\begin{array}{c}\text { Vehrcle-Related } \\
\text { Risks (Round-Tip) }\end{array}$}} \\
\hline & & & \multicolumn{2}{|c|}{ Incident-Free } & \multirow{2}{*}{\begin{tabular}{|c|} 
Accident \\
Public \\
\end{tabular}} & & \\
\hline & & & Crew & Public & & Emission & Accident \\
\hline & Knolls Atomic & 309 & $5.98 \mathrm{E}-04$ & $9.00 \mathrm{E}-04$ & $2.03 E-07$ & $5.97 \mathrm{E}-04$ & $4.84 E-03$ \\
\hline & Ames Laboratory & 5 & $9.68 \mathrm{E}-06$ & $1.46 \mathrm{E}-05$ & $3.29 E-09$ & $9.66 \mathrm{E}-06$ & 7. $.83 E-05$ \\
\hline & tate Total & 2602 & $5.04 \mathrm{E}-03$ & $7.58 E-03$ & $1.71 E-06$ & $5.03 E-03$ & $4.07 \mathrm{E}-02$ \\
\hline & nall Generators & 738 & 1. $43 \mathrm{E}-03$ & $2.15 E-03$ & $4.85 E-07$ & $1.43 E-03$ & $1.16 \mathrm{E}-02$ \\
\hline \multicolumn{8}{|c|}{ 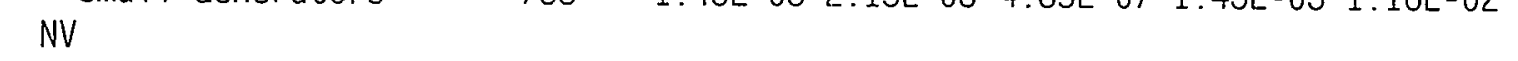 } \\
\hline & Oak Ridge Reserv. & 9848 & $2.25 E-03$ & $3.48 E-03$ & $2.81 E-09$ & $0.00 \mathrm{E}+00$ & $2.44 E-02$ \\
\hline & Los Alamos NL & 3829 & $8.73 E-04$ & $1.35 E-03$ & $1.09 E-09$ & $0.00 E+00$ & $9.47 \mathrm{E}-03$ \\
\hline & Fernald (FEMP) & 3137 & $7.15 E-04$ & $1.11 E-03$ & $8.95 E-10$ & $0.00 E+00$ & $7.76 \mathrm{E}-03$ \\
\hline & Rocky Flats Plant & 2441 & 5.39E-03 & $8.36 E-03$ & $7.96 E-09$ & $0.00 E+00$ & $5.84 \mathrm{E}-02$ \\
\hline & Mound Plant & 2409 & $5.49 E-04$ & $8.52 E-04$ & $6.87 \mathrm{E}-10$ & $0.00 E+00$ & $5.96 E-03$ \\
\hline & Lawrence Livermore & 1397 & $3.19 E-04$ & $4.94 E-04$ & $3.98 \mathrm{E}-10$ & $0.00 E+00$ & $3.45 E-03$ \\
\hline & Brookhaven NL & 1338 & $2.96 \mathrm{E}-03$ & $4.58 \mathrm{E}-03$ & $4.36 E-09$ & $0.00 E+00$ & $3.20 E-02$ \\
\hline & INEL & 933 & $2.29 \mathrm{E}-03$ & $3.51 E-03$ & $9.35 E-09$ & $1.50 \mathrm{E}-04$ & $2.44 E-02$ \\
\hline & Argonne - East & 526 & $1.16 \mathrm{E}-03$ & $1.80 E-03$ & $1.72 E-09$ & $0.00 E+00$ & $1.26 \mathrm{E}-02$ \\
\hline & West Valley DP & 424 & $9.37 E-04$ & $1.45 \mathrm{E}-03$ & $1.38 \mathrm{E}-09$ & $0.00 E+00$ & $1.01 E-02$ \\
\hline & Battel le Columbus & 345 & $7.87 E-05$ & $1.22 E-04$ & $9.84 E-11$ & $0.00 E+00$ & $8.53 E-04$ \\
\hline & Knolls Atomic & 309 & $6.83 E-04$ & $1.06 E-03$ & $1.01 E-09$ & $0.00 E+00$ & 7. $39 \mathrm{E}-03$ \\
\hline & SNL - Albuquerque & 191 & $4.36 E-05$ & $6.76 E-05$ & $5.45 E-11$ & $0.00 E+00$ & $4.72 E-04$ \\
\hline & Paducah GDP & 165 & $3.76 \mathrm{E}-05$ & $5.84 \mathrm{E}-05$ & $4.71 E-11$ & $0.00 E+00$ & $4.08 E-04$ \\
\hline & ETEC & 128 & $2.92 E-05$ & $4.53 E-05$ & $3.65 E-11$ & $0.00 E+00$ & $3.16 E-04$ \\
\hline & ITRI & 87 & $1.98 E-05$ & $3.08 E-05$ & $2.48 E-11$ & $0.00 E+00$ & $2.15 E-04$ \\
\hline & Portsmouth GDP & 77 & $1.76 \mathrm{E}-05$ & $2.72 E-05$ & $2.20 E-11$ & $0.00 E+00$ & 1.90E-04 \\
\hline & Princeton PPL & 74 & $1.69 E-05$ & $2.62 E-05$ & $2.11 E-11$ & $0.00 E+00$ & $1.83 E-04$ \\
\hline & Pantex Plant & 53 & $1.21 E-05$ & $1.87 \mathrm{E}-05$ & $1.51 E-11$ & $0.00 E+00$ & $1.31 E-04$ \\
\hline & Lawrence Berkeley & 17 & $3.88 E-06$ & $6.01 E-06$ & $4.85 E-12$ & $0.00 E+00$ & 4.20E-05 \\
\hline & Ames Laboratory & 5 & 1. $10 E-05$ & $1.71 E-05$ & $1.63 E-11$ & $0.00 E+00$ & $1.20 E-04$ \\
\hline & Grand Junction PO & 3 & $6.63 E-06$ & $1.03 E-05$ & $9.79 E-12$ & $0.00 \mathrm{E}+00$ & $7.18 \mathrm{E}-05$ \\
\hline & General Electric & 1 & $2.28 E-07$ & $3.54 E-07$ & $2.85 E-13$ & $0.00 E+00$ & $2.47 E-06$ \\
\hline & tate Total & 27737 & $1.84 \mathrm{E}-02$ & $2.85 E-02$ & $3.20 \mathrm{E}-08$ & $1.50 E-04]$ & $1.99 E-01$ \\
\hline \multirow{2}{*}{\multicolumn{2}{|c|}{ Sma11 Generators }} & 1879 & $1.90 E-03$ & ]2.94E-03 & $2.74 \mathrm{E}-09$ & $0.00 \mathrm{E}+00$ & $2.05 E-02$ \\
\hline & & & & & 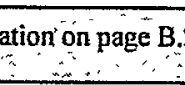 & & \\
\hline
\end{tabular}

NJ

Brookhaven NL $\quad 1338 \quad 9.46 E-04 \quad 1.27 E-03 \quad 1.28 E-07 \quad 5.81 E-03 \quad 3.60 E-03$

Princeton PPL $\quad 74 \quad 1.02 E-05 \quad 1.27 \mathrm{E}-05 \quad 1.48 \mathrm{E}-09 \quad 4.76 \mathrm{E}-05 \quad 3.75 \mathrm{E}-05$

State Total $1412 \quad 9.57 E-041.28 E-031.30 E-07 \quad 5.86 E-03 \quad 3.63 E-03$ NM

Sma11 Generators $\quad 74$

Oak Ridge Reserv. 9848

LOS Alamos NL $\quad 3829$

Fernald (FEMP) 3137

Mound Plant 2409

Battelle Columbus $\quad 345 \quad 7.07 \mathrm{E}-04$ 1.07E-03 $4.93 \mathrm{E}-09$ 8.66E-04 $4.89 \mathrm{E}-03$

B.22 


\begin{tabular}{|c|c|c|c|c|c|c|c|}
\hline \multirow[t]{3}{*}{ State } & \multirow[t]{3}{*}{ Generator } & \multirow{3}{*}{$\begin{array}{l}\text { No. } \\
\text { Ship- } \\
\text { ments }\end{array}$} & \multicolumn{3}{|c|}{ Cargo-Related Risks } & \multirow{2}{*}{\multicolumn{2}{|c|}{$\begin{array}{l}\text { Vehicle-Related } \\
\text { Risks (Round-Tip) }\end{array}$}} \\
\hline & & & \multicolumn{2}{|c|}{ Incident-Free } & \multirow{2}{*}{\begin{tabular}{|c|} 
Accident \\
Public \\
\end{tabular}} & & \\
\hline & & & Crew & Public & & Emission & Accident \\
\hline & SNL - Albuquerque & 191 & $1.91 \mathrm{E}-04$ & $2.80 \mathrm{E}-04$ & $2.13 E-09$ & $3.32 E-04$ & $1.23 E-03$ \\
\hline & Paducah GDP & 165 & $3.38 \mathrm{E}-04$ & $5.12 \mathrm{E}-04$ & $2.36 \mathrm{E}-09$ & $4.14 \mathrm{E}-04$ & $2.34 E-03$ \\
\hline & ITRI & 87 & $8.69 E-05$ & $1.28 \mathrm{E}-04$ & $9.70 E-10$ & $1.51 E-04$ & $5.59 E-04$ \\
\hline & Portsmouth GDP & 77 & $1.58 \mathrm{E}-04$ & $2.39 E-04$ & 1.10E-09 & $1.93 E-04$ & $1.09 E-03$ \\
\hline & Princeton PPL & 74 & $1.52 \mathrm{E}-04$ & $2.29 E-04$ & $1.06 \mathrm{E}-09$ & $1.86 E-04$ & $1.05 E-03$ \\
\hline & Pantex Plant & 53 & $1.09 \mathrm{E}-04$ & $1.64 E-04$ & $7.57 \mathrm{E}-10$ & 1.33E-04 & $7.51 E-04$ \\
\hline & tate Total & 20215 & $3.88 E-02$ & $5.83 E-02$ & $2.89 \mathrm{E}-07$ & $4.41 E-02$ & $2.67 E-01$ \\
\hline & mall Generators & 992 & $1.74 \mathrm{E}-03$ & $2.62 E-03$ & $1.33 E-08$ & $2.28 E-03$ & 1. $19 \mathrm{E}-02$ \\
\hline \multicolumn{8}{|c|}{ 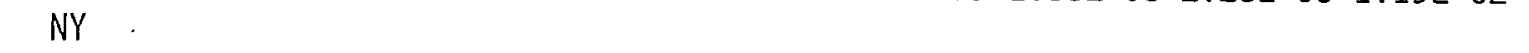 } \\
\hline & Brookhaven NL & 1338 & $1.15 E-03$ & $1.62 \mathrm{E}-03$ & $1.85 \mathrm{E}-07$ & $9.56 \mathrm{E}-03$ & $5.78 E-03$ \\
\hline & West Valley DP & 424 & $2.09 E-04$ & $2.47 E-04$ & $1.37 E-08$ & $5.46 \mathrm{E}-05$ & $1.53 E-03$ \\
\hline & Knolls Atomic & 309 & $8.27 E-04$ & $9.65 E-04$ & $7.22 \mathrm{E}-08$ & $8.75 E-04$ & $5.72 E-03$ \\
\hline & tate Total & 2071 & $2.19 E-03$ & $2.84 E-03$ & $2.71 E-07$ & $1.05 E-02$ & $1.30 E-02$ \\
\hline & mall Generators & 733 & $1.04 \mathrm{E}-03$ & $1.21 \mathrm{E}-03$ & $8.59 E-08$ & $9.30 E-04$ & $7.25 E-03$ \\
\hline \multicolumn{8}{|c|}{ 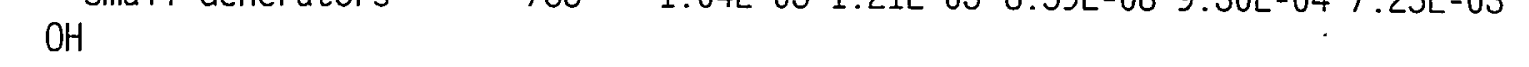 } \\
\hline & Fernald (FEMP) & 3137 & $3.85 E-04$ & $3.85 E-04$ & $2.02 E-08$ & $0.00 \mathrm{E}+00$ & $5.51 E-04$ \\
\hline & Mound Plant & 2409 & $9.54 \mathrm{E}-04$ & $1.16 E-03$ & $7.35 E-08$ & $2.79 E-03$ & $1.36 E-03$ \\
\hline & Brookhaven NL & 1338 & $2.38 E-03$ & $2.80 \mathrm{E}-03$ & $1.96 \mathrm{E}-07$ & $1.38 \mathrm{E}-03$ & 4.01E-03 \\
\hline & West Valley DP & 424 & $8.06 \mathrm{E}-04$ & $1.04 \mathrm{E}-03$ & $6.90 E-08$ & $2.10 \mathrm{E}-03$ & 1.32E-03 \\
\hline & Battelle Columbus & 345 & $2.57 \mathrm{E}-04$ & $3.22 E-04$ & $2.22 E-08$ & $4.44 E-04$ & 4. 33E-04 \\
\hline & Knolls Atomic & 309 & $5.88 E-04$ & $7.60 \mathrm{E}-04$ & $5.03 \mathrm{E}-08$ & $1.53 \mathrm{E}-03$ & $9.62 E-04$ \\
\hline & Portsmouth GDP & 77 & 4. $38 E-05$ & $5.64 E-05$ & $4.69 E-09$ & $9.91 E-06$ & $8.50 \mathrm{E}-05$ \\
\hline & Princeton PPL & 74 & $1.23 E-04$ & $1.59 E-04$ & $1.06 \mathrm{E}-08$ & $2.67 \mathrm{E}-04$ & 2.10E-04 \\
\hline & tate Total & 8113 & $5.53 E-03$ & $6.69 E-03$ & 4. $47 E-07$ & $8.52 E-03 \varepsilon$ & $8.94 E-03$ \\
\hline & mall Generators & 1229 & $1.82 E-03$ & $2.34 E-03$ & $1.57 E-07$ & $4.35 \mathrm{E}-03$ & $3.01 E-03$ \\
\hline \multicolumn{8}{|c|}{ 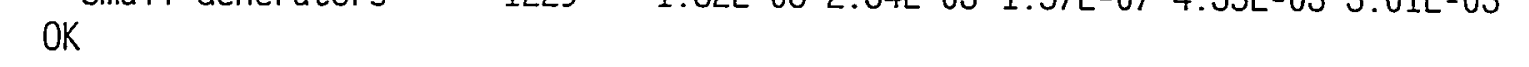 } \\
\hline & Oak Ridge Reserv. & 9848 & 1.91E-02 & $2.64 \mathrm{E}-02$ & $1.21 E-06$ & $6.66 \mathrm{E}-03$ & $1.40 \mathrm{E}-01$ \\
\hline & Fernald (FEMP) & 3137 & $6.75 E-03$ & $9.36 E-03$ & $4.40 E-07$ & $5.96 \mathrm{E}-03$ & $4.78 E-02$ \\
\hline & Mound Plant & 2409 & $5.19 E-03$ & $7.19 E-03$ & $3.38 \mathrm{E}-07$ & 4.57E-03 & $3.67 E-02$ \\
\hline & Battelle Columbus & 345 & $7.43 E-04$ & $1.03 E-03$ & $4.84 E-08$ & $6.55 E-04$ & $5.25 E-03$ \\
\hline & Paducah GDP & 165 & $3.55 E-04$ & $4.92 E-04$ & $2.32 E-08$ & $3.13 E-04$ & $2.51 E-03$ \\
\hline & Portsmouth GDP & 77 & $1.66 \mathrm{E}-04$ & 2.30E-04 & $1.08 \mathrm{E}-08$ & $1.46 E-04]$ & $1.17 E-03$ \\
\hline & Princeton PPL & 74 & $1.59 \mathrm{E}-04$ & $2.21 E-04$ & $1.04 E-08$ & 1.41E-04] & 1.13E-03 \\
\hline & tate Total & 16055 & $3.24 \mathrm{E}-02$ & 4. 49E-02 & 2.09E-06 & $1.84 \mathrm{E}-022$ & $2.34 \mathrm{E}-01$ \\
\hline & na11 Generators & 661 & 1. $42 E-03$ & $1.97 \mathrm{E}-03$ & $9.28 \mathrm{E}-08$ & $1.26 \mathrm{E}-03$ & $1.01 E-02$ \\
\hline \multicolumn{8}{|c|}{ 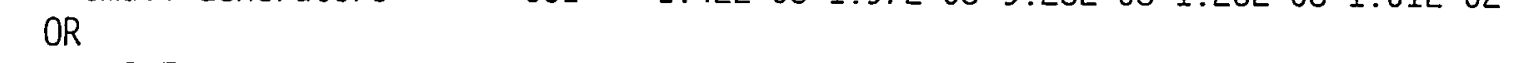 } \\
\hline & INEL & 933 & $5.60 E-04$ & $8.68 \mathrm{E}-04$ & $5.55 E-09$ & $0.00 E+00$ & 4.07E-03 \\
\hline & tate Total & 933 & $5.60 E-04$ & $8.68 E-04$ & $5.55 E-09$ & $0.00 E+004$ & $4.07 E-03$ \\
\hline \multirow{2}{*}{\multicolumn{8}{|c|}{ PA }} \\
\hline & & & & & & & \\
\hline & Brookhaven NL & 1338 & $2.46 \mathrm{E}-03$ & 3.37E-03 & $1.94 \mathrm{E}-07$ & 7.32E-04 1 & $1.81 E-02$ \\
\hline & West Valley DP & 424 & $1.49 \mathrm{E}-04$ & $1.66 \mathrm{E}-04$ & 9.92E-09 & $0.00 E+008$ & $8.64 \mathrm{E}-04$ \\
\hline & Knolls Atomic & 309 & $1.09 E-04$ & $1.21 E-04$ & 7.23E-09 & $0.00 E+006$ & $6.30 E-04$ \\
\hline
\end{tabular}




\begin{tabular}{|c|c|c|c|c|c|c|}
\hline \multirow[t]{3}{*}{ State } & \multirow[t]{3}{*}{ Generator } & \multirow{3}{*}{$\begin{array}{l}\text { No. } \\
\text { Ship- } \\
\text { ments }\end{array}$} & \multicolumn{3}{|c|}{ Cargo-Related Risks } & \multirow{2}{*}{$\begin{array}{l}\text { Vehicle-Related } \\
\text { Risks (Round-Tip) }\end{array}$} \\
\hline & & & \multicolumn{2}{|c|}{ Incident-Free } & \multirow{2}{*}{\begin{tabular}{|c|} 
Accident \\
Public \\
\end{tabular}} & \\
\hline & & & Crew & Public & & \begin{tabular}{l|l} 
Emission & Accident
\end{tabular} \\
\hline & Princeton PPL & 74 & $2.09 \mathrm{E}-04$ & $2.40 E-04$ & $2.08 \mathrm{E}-08$ & $2.72 E-041.11 E-03$ \\
\hline & tate Total & 2145 & $2.93 E-03$ & $3.90 E-03$ & $2.32 E-07$ & 1.00E-03 2.07E-02 \\
\hline & mall Generators & 807 & $4.67 E-04$ & $5.27 E-04$ & $3.80 E-08$ & $2.72 E-042.60 E-03$ \\
\hline \multicolumn{7}{|c|}{ 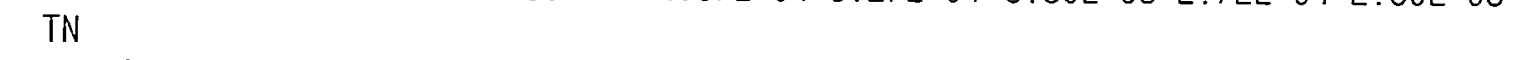 } \\
\hline & Oak Ridge Reserv. & 9848 & $2.38 E-02$ & $3.26 \mathrm{E}-02$ & $5.85 E-07$ & $3.49 E-02 \quad 1.20 E-01$ \\
\hline & tate Total & 9848 & $2.38 E-02$ & $3.26 \mathrm{E}-02$ & $5.85 E-07$ & $3.49 \mathrm{E}-021.20 \mathrm{E}-01$ \\
\hline & mall Generators & 0 & & & & \\
\hline \multicolumn{7}{|c|}{$T X$} \\
\hline & Oak Ridge Reserv. & 9848 & $9.54 E-03$ & 1. $43 E-02$ & $1.21 E-06$ & $8.24 E-037.29 E-02$ \\
\hline & Fernald (FEMP) & 3137 & $3.04 \mathrm{E}-03$ & $4.55 E-03$ & $3.85 E-07$ & $2.63 E-032.32 E-02$ \\
\hline & Mound Plant & 2409 & $2.33 E-03$ & $3.49 E-03$ & $2.96 E-07$ & $2.02 \mathrm{E}-03 \quad 1.78 \mathrm{E}-02$ \\
\hline & Battelle Columbus & 345 & $3.34 E-04$ & $5.00 E-04$ & $4.23 E-08$ & $2.89 E-042.56 E-03$ \\
\hline & Paducah GDP & 165 & $1.60 \mathrm{E}-04$ & $2.39 E-04$ & $2.03 E-08$ & $1.38 \mathrm{E}-041.22 \mathrm{E}-03$ \\
\hline & Portsmouth GDP & 77 & $7.46 E-05$ & $1.12 E-04$ & $9.45 E-09$ & $6.44 \mathrm{E}-055.70 \mathrm{E}-04$ \\
\hline & Princeton PPL & 74 & $7.17 E-05$ & $1.07 E-04$ & $9.08 E-09$ & $6.19 E-05 \quad 5.48 E-04$ \\
\hline & Pantex Plant & 53 & $2.84 \mathrm{E}-05$ & $4.07 E-05$ & 4.02E-09 & 4.44E-05 1.95E-04 \\
\hline & tate Total & 16108 & $1.56 E-02$ & $2.33 E-02$ & $1.97 E-06$ & $1.35 \mathrm{E}-021.19 \mathrm{E}-01$ \\
\hline & mall Generators & 714 & $6.69 E-04$ & $9.99 E-04$ & $8.52 E-08$ & $5.98 \mathrm{E}-045.09 \mathrm{E}-03$ \\
\hline \multicolumn{7}{|c|}{ (2) } \\
\hline & Rocky Flats Plant & 2441 & 4. $65 E-03$ & $6.98 \mathrm{E}-03$ & $4.78 E-08$ & 1. $10 \mathrm{E}-03 \quad 3.40 \mathrm{E}-02$ \\
\hline & Brookhaven NL & 1338 & $2.55 E-03$ & $3.83 E-03$ & $2.62 E-08$ & $6.03 E-04 \quad 1.86 \mathrm{E}-02$ \\
\hline & Argonne - East & 526 & $1.00 E-03$ & $1.50 E-03$ & $1.03 E-08$ & $2.37 \mathrm{E}-047.33 \mathrm{E}-03$ \\
\hline & West Valley DP & 424 & $8.07 E-04$ & $1.21 E-03$ & $8.30 E-09$ & 1.91E-04 5.91E-03 \\
\hline & Knolls Atomic & 309 & $5.88 E-04$ & $8.84 E-04$ & $6.05 E-09$ & 1. $39 E-04 \quad 4.31 E-03$ \\
\hline & Ames Laboratory & 5 & $9.52 E-06$ & $1.43 E-05$ & $9.79 E-11$ & $2.25 E-06 \quad 6.97 E-05$ \\
\hline & Grand Junction PO & 3 & $5.71 E-06$ & $8.58 \mathrm{E}-06$ & $5.87 \mathrm{E}-11$ & $1.35 \mathrm{E}-06 \quad 4.18 \mathrm{E}-05$ \\
\hline & tate Total & 5046 & $9.61 E-03$ & 1. $44 \mathrm{E}-02$ & $9.88 E-08$ & 2.27E-03 7.03E-02 \\
\hline & mal1 Generators & 741 & $1.41 E-03$ & $2.12 E-03$ & 1. $45 \dot{\mathrm{E}}-08$ & $3.34 E-041.03 E-02$ \\
\hline \multicolumn{7}{|c|}{ 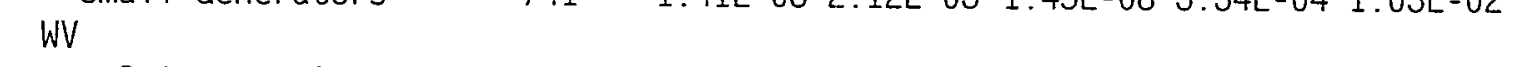 } \\
\hline & Princeton PPL & 74 & $9.53 E-06$ & 1.29E-05 & $3.30 E-10$ & $5.48 \mathrm{E}-05$ 5.64E-05 \\
\hline & tate Total & 74 & $9.53 E-06$ & $1.29 \mathrm{E}-05$ & $3.30 E-10$ & $5.48 \mathrm{E}-055.64 \mathrm{E}-05$ \\
\hline & nall Generators & 74 & $9.53 \mathrm{E}-06$ & I. $29 E-05$ & $3.30 E-10$ & $5.48 E-055.64 E-05$ \\
\hline \multicolumn{7}{|c|}{ Mode Totals } \\
\hline & 11 Generators & & $2.93 E-01$ & 4.25E-01 & $1.91 E-05$ & $2.09 E-01 \quad 1.78 E+00$ \\
\hline & nall Generators & & $2.29 E-02$ & $3.26 \mathrm{E}-02$ & $2.52 E-06$ & $2.07 \mathrm{E}-02 \quad 1.39 \mathrm{E}-01$ \\
\hline
\end{tabular}


Table B.6 RADTRAN 4 Results - High Volume Truck Transport To NTS Trave7 Through Las Vegas

Expected Fatalities for the Shipping Campaign

\begin{tabular}{ll}
\hline Exposure Group & Truck \\
\hline Radiological & \\
Normal Crew & $2.7 \mathrm{E}-01$ \\
Normal Pub7ic & $3.8 \mathrm{E}-01$ \\
Accident Public & $1.9 \mathrm{E}-05$ \\
Nonradiological & \\
Emission & $2.8 \mathrm{E}-01$ \\
Accident & $1.5 \mathrm{E}+00$ \\
\hline
\end{tabular}

A7ternative Risks Per State (fatalities)

\begin{tabular}{|c|c|c|c|c|c|c|c|}
\hline \multirow[t]{3}{*}{ State } & \multirow[t]{3}{*}{ Generator } & \multirow{3}{*}{$\begin{array}{l}\text { No. } \\
\text { Ship- } \\
\text { ments }\end{array}$} & \multicolumn{3}{|c|}{ Cargo-Related Risks } & \multirow{2}{*}{\multicolumn{2}{|c|}{$\begin{array}{l}\text { Vehicle-Related } \\
\text { Risks (Round-Tip) }\end{array}$}} \\
\hline & & & \multicolumn{2}{|c|}{ Incident-Free } & \multirow{2}{*}{$\begin{array}{c}\text { Accident } \\
\text { Public } \\
\end{array}$} & & \\
\hline & & & Crew & Public. & & Emission & Accident \\
\hline \multicolumn{8}{|l|}{ Truck } \\
\hline \multicolumn{8}{|l|}{$A Z$} \\
\hline & Oak Ridge Reserv. & 9848 & $1.97 \mathrm{E}-02$ & 2.95E-02 & $1.33 \mathrm{E}-07$ & 5.39E-03 & 1.13E-01 \\
\hline & Los Alam & 3829 & $7.65 \mathrm{E}-03$ & 1. $15 E-0 \angle$ & & C.IUE-US & \\
\hline & Fernald ( & 3137 & $6.27 \mathrm{E}-03$ & $9.40 E-03$ & $4.25 E-08$ & $1.72 \mathrm{E}-03$ & $3.61 E-02$ \\
\hline & Rocky Flat & 2441 & $3.52 \mathrm{E}-04$ & $5.46 \mathrm{E}-04$ & $1.20 \mathrm{E}-09$ & $0.00 \mathrm{E}+00$ & $2.15 E-03$ \\
\hline & Mound Plat & 2409 & 4.81E-03 & 7.22E-03 & $3.26 \mathrm{E}-08$ & 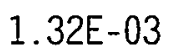 & \\
\hline & Brookhave & 1338 & $1.93 \mathrm{E}-04$ & $2.99 \mathrm{E}-04$ & & $0.00 E+00$ & -03 \\
\hline & INEL & 933 & $1.35 \mathrm{E}-04$ & $2.09 \mathrm{E}-04$ & $4.58 \mathrm{E}-10$ & $0.00 \mathrm{E}+00$ & $8.21 E-04$ \\
\hline & Argonne - East & 526 & $7.59 \mathrm{E}-05$ & $1.18 \mathrm{E}-04$ & $2.58 \mathrm{E}-10$ & $0.00 E+00$ & $4.63 \mathrm{E}-04$ \\
\hline & West Valley & 424 & $6.12 \mathrm{E}-05$ & $9.49 \mathrm{E}-05$ & $2.08 \mathrm{E}-10$ & $0.00 \mathrm{E}+00$ & $3.73 E-04$ \\
\hline & Battelle Col & 345 & $6.89 \mathrm{E}-04$ & $1.03 \mathrm{E}-03$ & $E-09$ & 1.89 & $=-03$ \\
\hline & Knolls At & 309 & 4. $46 \mathrm{E}-05$ & $6.91 \mathrm{E}-05$ & $1.52 \mathrm{E}-10$ & $0.00 \mathrm{E}+00$ & $2.72 \mathrm{E}-04$ \\
\hline & SNL - Albuquerque & 191 & $3.82 \mathrm{E}-04$ & $5.73 \mathrm{E}-04$ & $2.59 \mathrm{E}-09$ & & -03 \\
\hline & Paducah GDP & 165 & $3.30 \mathrm{E}-04$ & $4.95 \mathrm{E}-04$ & 2.23 & 9.0 & $\mathrm{OE}-03$ \\
\hline & ITRI & 87 & $1.74 \mathrm{E}-04$ & $2.61 \mathrm{E}-04$ & $1.18 \mathrm{E}-09$ & $4.76 \mathrm{E}-05$ & $1.00 E-03$ \\
\hline & Portsmou & 77 & $1.54 \mathrm{E}-04$ & $2.31 \mathrm{E}-04$ & $1.04 \mathrm{E}-09$ & & $8.85 E-04$ \\
\hline & & 74 & $1.48 \mathrm{E}-04$ & $2.22 \mathrm{E}-04$ & $1.00 \mathrm{E}-09$ & & \\
\hline & Pantex Plant & 53 & $1.06 \mathrm{E}-04$ & 1.59E-04 & $7.18 \mathrm{E}-10$ & $2.90 \mathrm{E}-05$ & $6.09 \mathrm{E}-04$ \\
\hline & Ames Laboratory & 5 & $7.21 \mathrm{E}-07$ & & $2.45 E-12$ & & $4.40 E-06$ \\
\hline & Grand Jur & 3 & 4. $33 \mathrm{E}-07$ & $6.71 \mathrm{E}-07$ & $1.47 \mathrm{E}-12$ & $0.00 \mathrm{E}+00$ & $2.64 \mathrm{E}-06$ \\
\hline & cate Tota & 26194 & 4 13E-02 & & & & 2.38E-01 \\
\hline
\end{tabular}




\begin{tabular}{|c|c|c|c|c|c|c|c|}
\hline \multirow[t]{3}{*}{ State } & \multirow[t]{3}{*}{ Generator } & \multirow{3}{*}{$\begin{array}{l}\text { No. } \\
\text { Ship- } \\
\text { ments }\end{array}$} & \multicolumn{3}{|c|}{ Cargo-Related Risks } & \multirow{2}{*}{\multicolumn{2}{|c|}{$\begin{array}{l}\text { Vehicle-Related } \\
\text { Risks (Round-Tip) }\end{array}$}} \\
\hline & & & \multicolumn{2}{|c|}{ Incident-Free } & \multirow{2}{*}{\begin{tabular}{|c|} 
Accident \\
Public \\
\end{tabular}} & & \\
\hline & & & Crew & Public & & Emission & Accident \\
\hline \multicolumn{8}{|l|}{$A R$} \\
\hline & Oak Ridge Reserv. & 9848 & 1. $65 E-02$ & $2.25 E-02$ & 4.30E-07 & $2.22 \mathrm{E}-03$ & $5.58 \mathrm{E}-02$ \\
\hline \multicolumn{8}{|c|}{$C A$} \\
\hline & Lawrence Livermore & 1397 & $3.55 E-03$ & $5.37 \mathrm{E}-03$ & $8.96 \mathrm{E}-08$ & $2.07 E-03$ & $1.52 \mathrm{E}-02$ \\
\hline & ETEC & 128 & $2.69 E-04$ & $4.33 E-04$ & $8.52 E-09$ & $2.03 E-03$ & $7.35 E-04$ \\
\hline & Lawrence Berkeley & 17 & $5.08 \mathrm{E}-05$ & $7.72 E-05$ & $1.39 E-09$ & $9.41 E-05$ & $2.00 E-04$ \\
\hline & General Electric & 1 & $2.64 \mathrm{E}-06$ & $3.99 E-06$ & $6.76 \mathrm{E}-11$ & $2.35 E-06$ & $1.11 E-05$ \\
\hline & tate Total & 1543 & $3.87 E-03$ & $5.89 E-03$ & $9.96 \mathrm{E}-08$ & $4.20 E-03$ & $1.61 \mathrm{E}-02$ \\
\hline \multicolumn{8}{|c|}{ 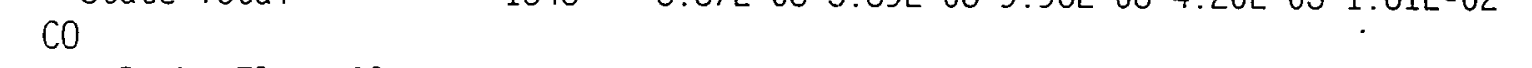 } \\
\hline & Rocky Flats Plant & 2441 & $3.97 E-03$ & $5.54 \mathrm{E}-03$ & $2.79 E-07$ & $1.57 \mathrm{E}-03$ & $2.51 E-02$ \\
\hline & Brookhaven NL & 1338 & $3.41 E-03$ & $4.87 E-03$ & $2.34 \mathrm{E}-07$ & $1.12 \mathrm{E}-03$ & $2.23 E-02$ \\
\hline & Argonne - East & 526 & $1.34 \mathrm{E}-03$ & -. $91 \mathrm{E}-03$ & $9.20 \mathrm{E}-08$ & 4. $40 \mathrm{E}-04$ & $8.76 \mathrm{E}-03$ \\
\hline & West Valley DP & 424 & $1.08 \mathrm{E}-03$ & I. $54 \mathrm{E}-03$ & $7.42 E-08$ & $3.55 E-04$ & $7.06 \mathrm{E}-03$ \\
\hline & Knolls Atomic & 309 & $7.87 E-04$ & 1. $12 E-03$ & $5.41 E-08$ & $2.59 E-04$ & $5.15 E-03$ \\
\hline & Ames Laboratory & 5 & $1.27 \mathrm{E}-05$ & 1.82E-05 & $8.75 E-10$ & $4.18 E-06$ & $8.33 E-05$ \\
\hline & Grand Junction PO & 3 & $5.54 E-07$ & $7.62 E-07$ & $3.44 \mathrm{E}-11$ & $0.00 E+00$ & $3.53 E-06$ \\
\hline & tate Total & 5046 & $1.06 \mathrm{E}-02$ & $1.50 E-02$ & $7.34 \mathrm{E}-07$ & $3.75 E-03$ & $6.84 E-02$ \\
\hline \multicolumn{8}{|c|}{ 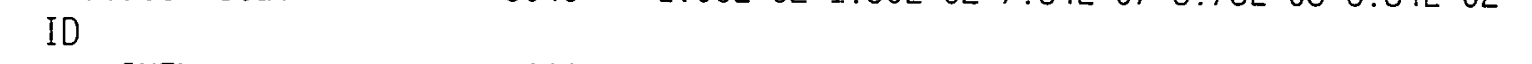 } \\
\hline & INEL & 933 & $6.70 E-04$ & $9.79 E-04$ & $3.25 E-08$ & $1.80 E-04$ & $1.51 E-03$ \\
\hline & tate Total & 933 & $6.70 E-04$ & $9.79 E-04$ & $3.25 E-08$ & $1.80 \mathrm{E}-04$ & $1.51 E-03$ \\
\hline \multicolumn{8}{|c|}{ 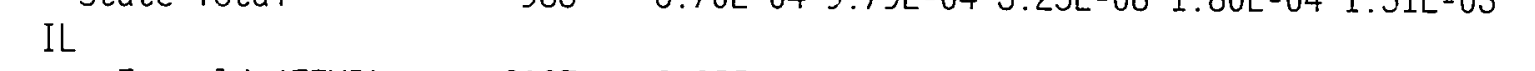 } \\
\hline & Fernald (FEMP) & 3137 & $2.95 \mathrm{E}-03$ & 4.11E-03 & $1.32 E-06$ & $1.01 E-03$ & $1.35 E-02$ \\
\hline & Mound Plant & 2409 & $2.27 E-03$ & $3.16 E-03$ & $1.01 \mathrm{E}-06$ & $7.75 \mathrm{E}-04$ & $1.04 \mathrm{E}-02$ \\
\hline & Brookhaven NL & 1338 & $1.47 E-03$ & 1. $.98 \mathrm{E}-03$ & $5.24 E-07$ & $2.41 E-03$ & $5.90 E-03$ \\
\hline & Argonne - East & 526 & $4.81 E-04$ & $6.60 E-04$ & $1.97 E-07$ & $3.56 \mathrm{E}-04$ & $2.10 E-03$ \\
\hline & West Valley DP & 424 & 4. $65 E-04$ & $6.27 E-04$ & $1.66 \mathrm{E}-07$ & $7.64 E-04$ & $1.87 E-03$ \\
\hline & Battel le Columbus & 345 & $3.25 E-04$ & $\angle .52 E-04$ & $1.45 \mathrm{E}-07$ & 1. $11 E-04$ & $1.48 E-03$ \\
\hline & Knolls Atomic & 309 & $3.39 E-04$ & $4.57 E-04$ & $1.21 E-07$ & $5.57 E-04$ & 1. $36 E-03$ \\
\hline & Paducah GDP & 165 & $1.64 \mathrm{E}-06$ & $2.54 E-06$ & $9.65 E-10$ & $0.00 \mathrm{E}+00$ & $8.82 E-06$ \\
\hline & Portsmouth GOP & 77 & $6.04 \mathrm{E}-05$ & $8.69 E-05$ & $2.66 \mathrm{E}-08$ & $8.43 E-05$ & $2.71 E-04$ \\
\hline & Princeton PPL & 74 & $6.97 E-05$ & $9.70 E-05$ & $3.11 E-08$ & $2.38 \mathrm{E}-05$ & $3.18 E-04$ \\
\hline & cate Total & 8804 & $8.43 E-03$ & $1.16 \mathrm{E}-02$ & $3.54 E-06$ & $6.09 E-03$ & $3.71 E-02$ \\
\hline \multicolumn{8}{|c|}{ 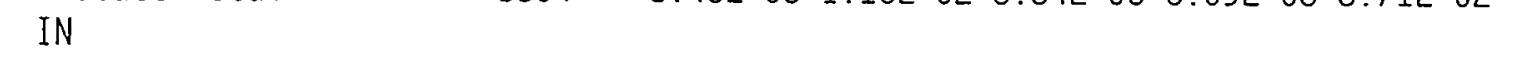 } \\
\hline & Fernald (FEMP) & 3137 & $3.26 \mathrm{E}-03$ & $4.22 E-03$ & $8.65 E-07$ & $7.07 E-04$ & 1. 10E-02 \\
\hline & Mound Plant & 2409 & $\dot{2} .51 E-03$ & $3.39 E-03$ & $6.30 E-07$ & 4. $42 \mathrm{E}-03$ & $8.05 E-03$ \\
\hline & Brookhaven NL & 1338 & 1. $45 E-03$ & $1.85 E-03$ & $3.26 \mathrm{E}-07$ & $1.94 \mathrm{E}-03$ & $4.42 E-03$ \\
\hline & West Valley DP & 424 & 4. $60 \mathrm{E}-04$ & $5.87 E-04$ & $1.03 \mathrm{E}-07$ & $6.14 E-04$ & 1. $40 E-03$ \\
\hline & Battelle Columbus & 345 & $3.60 E-04$ & $4.85 E-04$ & $9.02 E-08$ & $6.33 E-04$ & 1.15E-03 \\
\hline & Knolls Atomic & 309 & $3.35 E-04$ & 4. $28 E-04$ & $7.54 \mathrm{E}-08$ & 4. $48 E-04$ & $1.02 E-03$ \\
\hline & Portsmouth GDP & 77 & $5.21 E-05$ & $7.43 \mathrm{E}-05$ & $1.76 \mathrm{E}-08$ & 4.96E-06 & $2.03 \mathrm{E}-04$ \\
\hline & Princeton PPL & 74 & $7.71 E-05$ & $1.04 \mathrm{E}-04$ & 1. $94 \mathrm{E}-08$ & $1.36 E-04$ & $2.47 \mathrm{E}-04$ \\
\hline & cate Total & 8113 & $8.50 E-03$ & $1.11 E-02$ & $2.13 \mathrm{E}-06$ & $8.90 E-03$ & $2.75 \mathrm{E}-02$ \\
\hline
\end{tabular}




\begin{tabular}{|c|c|c|c|c|c|c|c|}
\hline \multirow{3}{*}{ State } & \multirow[t]{3}{*}{ Generator } & \multirow{3}{*}{$\begin{array}{l}\text { No. } \\
\text { Ship- } \\
\text { ments }\end{array}$} & \multicolumn{3}{|c|}{ Cargo-Related Risks } & \multirow{2}{*}{\multicolumn{2}{|c|}{$\begin{array}{l}\text { Vehicle-Related } \\
\text { Risks (Round-Tip) }\end{array}$}} \\
\hline & & & \multicolumn{2}{|c|}{ Incident-Free } & \multirow{2}{*}{$\begin{array}{c}\text { Accident } \\
\text { Public } \\
\end{array}$} & & \\
\hline & & & Crew & Public & & Emission & 1 Accident \\
\hline \\
\hline & Brookhaven NL & 1338 & $2.32 \mathrm{E}-03$ & $33.25 \mathrm{E}-03$ & $5.93 \mathrm{E}-07$ & $1.72 \mathrm{E}-04$ & $1.24 E-02$ \\
\hline & Argonne - East & 526 & $9.12 \mathrm{E}-04$ & $+1.28 \mathrm{E}-03$ & 2.33E- -07 & $6.77 \mathrm{E}-05$ & 4.87E-03 \\
\hline & West Valley DP & 424 & 7.36E-04 & $+1.03 \mathrm{E}-03$ & $1.88 \mathrm{E}-07$ & $5.46 \mathrm{E}-05$ & $3.93 \mathrm{E}-03$ \\
\hline & Knolls Atomic & 309 & $5.36 \mathrm{E}-04$ & $+7.51 \mathrm{E}-04$ & 1.37E-07 & $3.98 \mathrm{E}-05$ & $2.86 \mathrm{E}-03$ \\
\hline & Ames Laboratory & 5 & $5.05 \mathrm{E}-06$ & $6.99 \mathrm{E}-06$ & $1.18 \mathrm{E}-09$ & $3.38 E-06$ & $2.56 E-05$ \\
\hline & tate Total & 2602 & $4.51 \mathrm{E}-03$ & $6.32 \mathrm{E}-03$ & $1.15 E-06$ & $3.38 \mathrm{E}-04$ & $2.41 \mathrm{E}-02$ \\
\hline \multicolumn{8}{|c|}{ 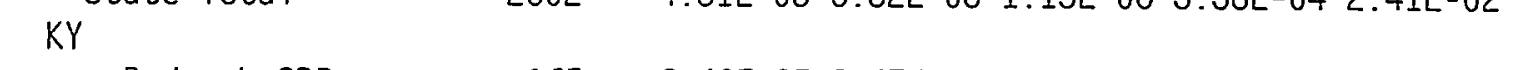 } \\
\hline & Paducah GDP & 165 & $2.40 E-05$ & $3.47 E-05$ & 2. $14 \mathrm{E}-09$ & $0.00 E+00$ & $1.83 \mathrm{E}-04$ \\
\hline & Portsmouth GDP & 77 & $6.25 E-05$ & $8.15 E-05$ & $5.79 \mathrm{E}-09$ & $1.83 \mathrm{E}-04$ & $3.33 \mathrm{E}-04$ \\
\hline & tate Total & 242 & $8.64 \mathrm{E}-05$ & $1.16 E-04$ & 7.93̈E-09 & $1.83 \mathrm{E}-04$ & $5.16 E-04$ \\
\hline \multicolumn{8}{|c|}{ 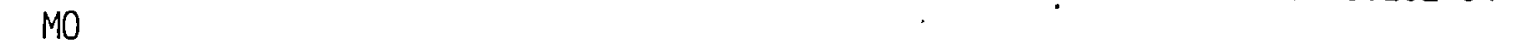 } \\
\hline & Fernald (FEMP) & 3137 & $6.00 E-03$ & $8.24 E-03$ & 1.00E-06 & 1.08E-02 & $3.64 \mathrm{E}-02$ \\
\hline & Mound Plant & 2409 & $4.60 E-03$ & $6.33 \mathrm{E}-03$ & $7.71 \mathrm{E}-07$ & 8.30E-03 & $2.79 \mathrm{E}-02$ \\
\hline & Battelle Columbus & 345 & $6.59 \mathrm{E}-04$ & 9.06E-04 & 1.10E-07 & $1.19 \mathrm{E}-03$ & 4.00E-03 \\
\hline & Paducah GDP & 165 & $3.45 \mathrm{E}-04$ & $4.75 E-04$ & $6.41 \mathrm{E}-08$ & $1.43 \mathrm{E}-04$ & $2.32 \mathrm{E}-03$ \\
\hline & Portsmouth GDP & 77 & $1.47 \mathrm{E}-04$ & $2.02 E-04$ & $2.47 \mathrm{E}-08$ & $2.65 \mathrm{E}-04$ & 8.93E-04 \\
\hline & Princeton PPL & 74 & $1.41 \mathrm{E}-04$ & $1.94 \mathrm{E}-04$ & $2.37 E-08$ & $2.55 E-04$ & $8.58 E-04$ \\
\hline \multirow{2}{*}{\multicolumn{8}{|c|}{$1.19 E-U<1.00 E-U \angle<.00 E-00<.10 E-0<1 . \angle 4 E-0 L$}} \\
\hline & & & & & & & \\
\hline & Brookhaven NL & 1338 & 2.59E-03 & 3.90E-03 & $8.80 \mathrm{E}-07$ & $2.58 \mathrm{E}-03$ & 2.10E-02 \\
\hline & Argonne - East & 526 & $1.02 \mathrm{E}-03$ & 1.53E-03 & 3.46E-07 & 1.02E-03 & $8.24 \mathrm{E}-03$ \\
\hline & $\begin{array}{l}\text { West Valley DP } \\
\text { Knolls Atomic }\end{array}$ & $\begin{array}{l}424 \\
309\end{array}$ & $\begin{array}{l}8.21 \mathrm{E}-04 \\
5.98 \mathrm{E}-04\end{array}$ & $\begin{array}{l}1.24 \mathrm{E}-03 \\
9.00 \mathrm{~F}_{-04}\end{array}$ & $\begin{array}{l}2.79 E-07 \\
2.03 E-07\end{array}$ & 8.19E-04 & $\begin{array}{l}6.64 \mathrm{E}-03 \\
4.84 \mathrm{~F}-03\end{array}$ \\
\hline & Ames Laboratory & 5 & $9.68 \mathrm{E}-06$ & $1.46 \mathrm{E}-05$ & $3.29 \mathrm{E}-09$ & $9.66 \mathrm{E}-06$ & 7.83E-05 \\
\hline & ate Total & 2602 & $5.04 \mathrm{E}-03$ & 7.58E-03 & $1.71 \mathrm{E}-06$ & $5.03 \mathrm{E}-03$ & 4.07E-02 \\
\hline \multicolumn{8}{|c|}{ 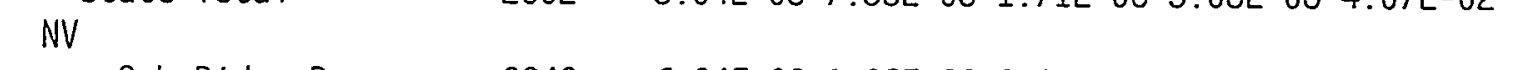 } \\
\hline & Oak Ridge Reserv. & 9848 & $6.94 \mathrm{E}-03$ & 1.02E-02 & $2.20 \mathrm{E}-07$ & $3.04 E-02$ & $2.05 E-02$ \\
\hline & Los Alamos NL & 3829 & $2.70 E-03$ & $3.97 \mathrm{E}-03$ & $8.54 \mathrm{E}-08$ & $1.18 \mathrm{E}-02$ & $7.97 \mathrm{E}-03$ \\
\hline & Fernald (FEMP) & 3137 & $2.21 \mathrm{E}-03$ & $3.25 E-03$ & $7.00 \mathrm{E}-08$ & 9.69E-03 & $6.53 E-03$ \\
\hline & Rocky Flats Plant & 2441 & $2.06 \mathrm{E}-03$ & $3.04 \mathrm{E}-03$ & $4.82 E-08$ & $2.67 \mathrm{E}-03$ & $7.58 \mathrm{E}-03$ \\
\hline & Mound Plant & 2409 & $1.70 \mathrm{E}-03$ & $2.50 \mathrm{E}-03$ & $5.37 \mathrm{E}-08$ & $7.44 \mathrm{E}-03$ & $5.02 E-03$ \\
\hline & Lawrence Livermore & 1397 & $8.75 E-04$ & $1.26 \mathrm{E}-03$ & $1.68 \mathrm{E}-08$ & 8.54E-04 & $3.18 \mathrm{E}-03$ \\
\hline & Brookhaven NL & 1338 & $1.13 \mathrm{E}-03$ & $1.67 \mathrm{E}-03$ & $2.64 \mathrm{E}-08$ & $1.46 \mathrm{E}-03$ & 4.15E-03 \\
\hline & INEL & 933 & $7.88 \mathrm{E}-04$ & $1.16 \mathrm{E}-03$ & $1.84 \mathrm{E}-08$ & $1.02 \mathrm{E}-03$ & $2.90 E-03$ \\
\hline & Argonne - East & 526 & 4.44E-04 & $6.55 E-04$ & $1.04 \mathrm{E}-08$ & $5.76 E-04$ & 1. $63 \mathrm{E}-03$ \\
\hline & West Valley DP & 424 & $3.58 \mathrm{E}-04$ & $5.28 \mathrm{E}-04$ & 8.37E-09 & $4.64 \mathrm{E}-04$ & 1.32E-03 \\
\hline & Battelle Columbus & 345 & $2.43 E-04$ & $3.58 \mathrm{E}-04$ & 7.70E-09 & 1.07E-03 & $7.18 E-04$ \\
\hline & Knolls Atomic & 309 & $2.61 E-04$ & $3.85 \mathrm{E}-04$ & $6.10 E-09$ & $3.38 \mathrm{E}-04$ & $9.59 \mathrm{E}-04$ \\
\hline & SNL - Albuquerque & 191 & $1.35 \mathrm{E}-04$ & $1.98 \mathrm{E}-04$ & $4.26 \mathrm{E}-09$ & $5.90 \mathrm{E}-04$ & $3.98 \mathrm{E}-04$ \\
\hline & Paducah GDP & 165 & $1.16 \mathrm{E}-04$ & $1.71 \mathrm{E}-04$ & $3.68 \mathrm{E}-09$ & $5.10 \mathrm{E}-04$ & $3.44 \mathrm{E}-04$ \\
\hline & ETEC & 128 & $8.01 E-05$ & $1.15 \mathrm{E}-04$ & $1.54 \mathrm{E}-09$ & $7.83 \mathrm{E}-05$ & $2.91 E-04$ \\
\hline & ITRI & 87 & $6.13 \mathrm{E}-05$ & $9.02 E-05$ & $1.94 \mathrm{E}-09$ & $2.69 \mathrm{E}-04$ & $1.81 E-04$ \\
\hline & & & & & & & \\
\hline
\end{tabular}




\begin{tabular}{|c|c|c|c|c|c|c|}
\hline \multirow[t]{3}{*}{ State } & \multirow[t]{3}{*}{ Generator } & \multirow{3}{*}{$\begin{array}{l}\text { No. } \\
\text { Ship- } \\
\text { ments }\end{array}$} & \multicolumn{3}{|c|}{ Cargo-Related Risks } & \multirow{2}{*}{$\begin{array}{c}\text { Vehicle-Related } \\
\text { Risks (Round-Tip) }\end{array}$} \\
\hline & & & \multicolumn{2}{|c|}{ Incident-Free } & \multirow{2}{*}{\begin{tabular}{|c|} 
Accident \\
Public \\
\end{tabular}} & \\
\hline & & & Crew & Public & & \begin{tabular}{|l|l|} 
Emission & Accident \\
\end{tabular} \\
\hline \multirow{7}{*}{$\begin{array}{l}\cdot \\
\text { St } \\
\text { St }\end{array}$} & Portsmouth GDP & 77 & $5.43 E-05$ & $7.98 E-05$ & $1.72 \mathrm{E}-09$ & $2.38 \mathrm{E}-041.60 \mathrm{E}-04$ \\
\hline & Princeton PPL & 74 & $5.21 E-05$ & $7.67 E-05$ & $1.65 E-09$ & $2.29 E-04 \quad 1.54 E-04$ \\
\hline & Pantex Plant & 53 & $3.73 E-05$ & $5.49 E-05$ & 1. $18 \mathrm{E}-09$ & $1.64 E-041.10 E-04$ \\
\hline & Lawrence Berkeley & 17 & $1.06 E-05$ & $1.53 E-05$ & $2.05 E-10$ & $1.04 \mathrm{E}-05 \quad 3.86 \mathrm{E}-05$ \\
\hline & Ames Laboratory & 5 & 4.22E-06 & $6.23 E-06$ & $9.87 E-11$ & $5.47 E-06 \quad 1.55 E-05$ \\
\hline & Grand Junction PO & 3 & $2.53 E-06$ & $3.74 E-06$ & $5.92 E-11$ & $3.28 E-069.31 E-06$ \\
\hline & General Electric & 1 & $6.26 E-07$ & $8.99 E-07$ & $1.21 E-11$ & $6.12 E-072.27 E-06$ \\
\hline \multicolumn{7}{|c|}{ NJ } \\
\hline & Brookhaven NL & 1338 & $9.46 E-04$ & $1.27 E-03$ & $1.28 \mathrm{E}-07$ & $5.81 E-03 \quad 3.60 E-03$ \\
\hline & Princeton PPL & 74 & $1.02 E-05$ & $1.27 E-05$ & $1.48 \mathrm{E}-09$ & $4.76 E-05 \quad 3.75 E-05$ \\
\hline & tate Total & 1412 & $9.57 E-04$ & $1.28 \mathrm{E}-03$ & $1.30 E-07$ & $5.86 E-03 \quad 3.63 E-03$ \\
\hline \multicolumn{7}{|c|}{ (20) } \\
\hline & Oak Ridge Reserv. & 9848 & $2.02 \mathrm{E}-02$ & $3.05 E-02$ & $1.41 E-07$ & $2.47 \mathrm{E}-021.40 \mathrm{E}-01$ \\
\hline & Los Alamos NL & 3829 & $5.52 E-03$ & $7.96 E-03$ & $5.60 E-08$ & $3.20 \mathrm{E}-03 \quad 3.71 \mathrm{E}-02$ \\
\hline & Fernald (FEMP) & 3137 & $6.43 E-03$ & $9.72 E-03$ & $4.48 E-08$ & $7.88 \mathrm{E}-03 \quad 4.44 \mathrm{E}-02$ \\
\hline & Mound Plant & 2409 & $4.94 E-03$ & 7. $47 \mathrm{E}-03$ & $3.44 E-08$ & $6.05 E-03 \quad 3.41 E-02$ \\
\hline & Battelle Columbus & 345 & $7.07 E-04$ & $1.07 E-03$ & $4.93 E-09$ & $8.66 E-04 \quad 4.89 E-03$ \\
\hline & SNL - Albuquerque & 191 & $1.91 E-04$ & $2.80 E-04$ & 2.13E-09 & $3.32 E-041.23 E-03$ \\
\hline & Paducah GDP & 165 & $3.38 E-04$ & $5.12 E-04$ & $2.36 E-09$ & 4.14E-04 2.34E-03 \\
\hline & ITRI & 87 & $8.69 E-05$ & $1.28 \mathrm{E}-04$ & $9.70 E-10$ & $1.51 E-045.59 E-04$ \\
\hline & Portsmouth GDP & 77 & $1.58 \mathrm{E}-04$ & 2.39E-04 & $1.10 \mathrm{E}-09$ & $1.93 \mathrm{E}-041.09 \mathrm{E}-03$ \\
\hline & Princeton PPL & 74 & $1.52 E-04$ & 2.29E-04 & $1.06 E-09$ & $1.86 \mathrm{E}-041.05 \mathrm{E}-03$ \\
\hline & Pantex Plant & 53 & 1.09E-04 & $1.64 \mathrm{E}-04$ & $7.57 E-10$ & $1.33 E-047.51 E-04$ \\
\hline & ate Total & 20215 & $3.88 E-02$ & $5.83 E-02$ & $2.89 E-07$ & $4.41 E-022.67 E-01$ \\
\hline \multicolumn{7}{|c|}{ 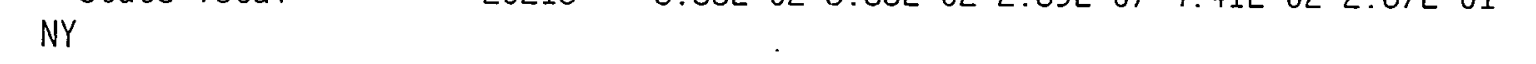 } \\
\hline & Brookhaven NL & 1338 & 1. $15 E-03$ & 1.62E-03 & $1.85 E-07$ & $9.56 \mathrm{E}-03 \quad 5.78 \mathrm{E}-03$ \\
\hline & West Valley DP & 424 & $2.09 E-04$ & 2. $47 E-04$ & 1. $37 \mathrm{E}-08$ & $5.46 E-05 \quad 1.53 E-03$ \\
\hline & Knolls Atomic & 309 & $8.27 E-04$ & $9.65 E-04$ & $7.22 E-08$ & $8.75 E-045.72 E-03$ \\
\hline \multicolumn{7}{|c|}{ 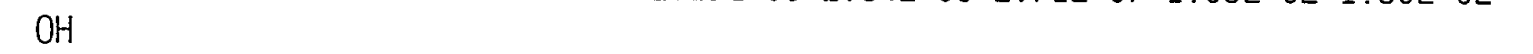 } \\
\hline & Fernald (FEMP) & 3137 & $3.85 E-04$ & $3.85 E-04$ & $2.02 E-08$ & $0.00 E+00 \quad 5.51 E-04$ \\
\hline & Mound Plant & 2409 & $9.54 E-04$ & 1. $16 E-03$ & $7.35 E-08$ & $2.79 E-031.36 E-03$ \\
\hline & Brookhaven NL & 1338 & $2.38 \mathrm{E}-03$ & $2.80 E-03$ & $1.96 \mathrm{E}-07$ & 1.38E-03 4.01E-03 \\
\hline & West Valley DP & 424 & $8.06 E-04$ & $1.04 E-03$ & $6.90 \mathrm{E}-08$ & 2. $10 \mathrm{E}-03$ 1.32E-03 \\
\hline & Battelle Columbus & 345 & $2.57 E-04$ & $3.22 E-04$ & $2.22 \mathrm{E}-08$ & 4. $44 E-04 \quad 4.33 E-04$ \\
\hline & Knolls Atomic & 309 & $5.88 E-04$ & $7.60 E-04$ & $5.03 E-08$ & $1.53 \mathrm{E}-039.62 \mathrm{E}-04$ \\
\hline & Portsmouth GDP & 77 & $4.38 E-05$ & $5.64 E-05$ & $4.69 E-09$ & $9.91 E-068.50 E-05$ \\
\hline & Princeton PPL & 74 & $1.23 E-04$ & $1.59 E-04$ & $1.06 \mathrm{E}-08$ & $2.67 E-042.10 E-04$ \\
\hline & ate Total & 8113 & $5.53 E-03$ & $6.69 E-03$ & $4.47 E-07$ & $8.52 E-038.94 E-03$ \\
\hline \multicolumn{7}{|c|}{ 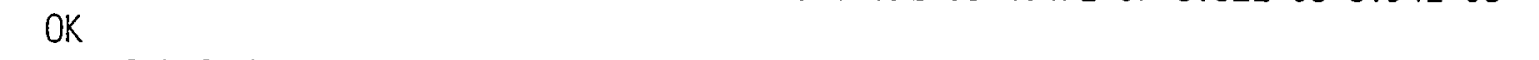 } \\
\hline & Oak Ridge Reserv. & 9848 & 1.91E-02 & 2.64E-02 & 1. $21 \mathrm{E}-06$ & 6.66E-03 1. $40 \mathrm{E}-01$ \\
\hline & Fernald (FEMP) & 3137 & $6.75 E-03$ & $9.36 E-03$ & $4.40 E-07$ & $5.96 E-03 \quad 4.78 E-02$ \\
\hline
\end{tabular}




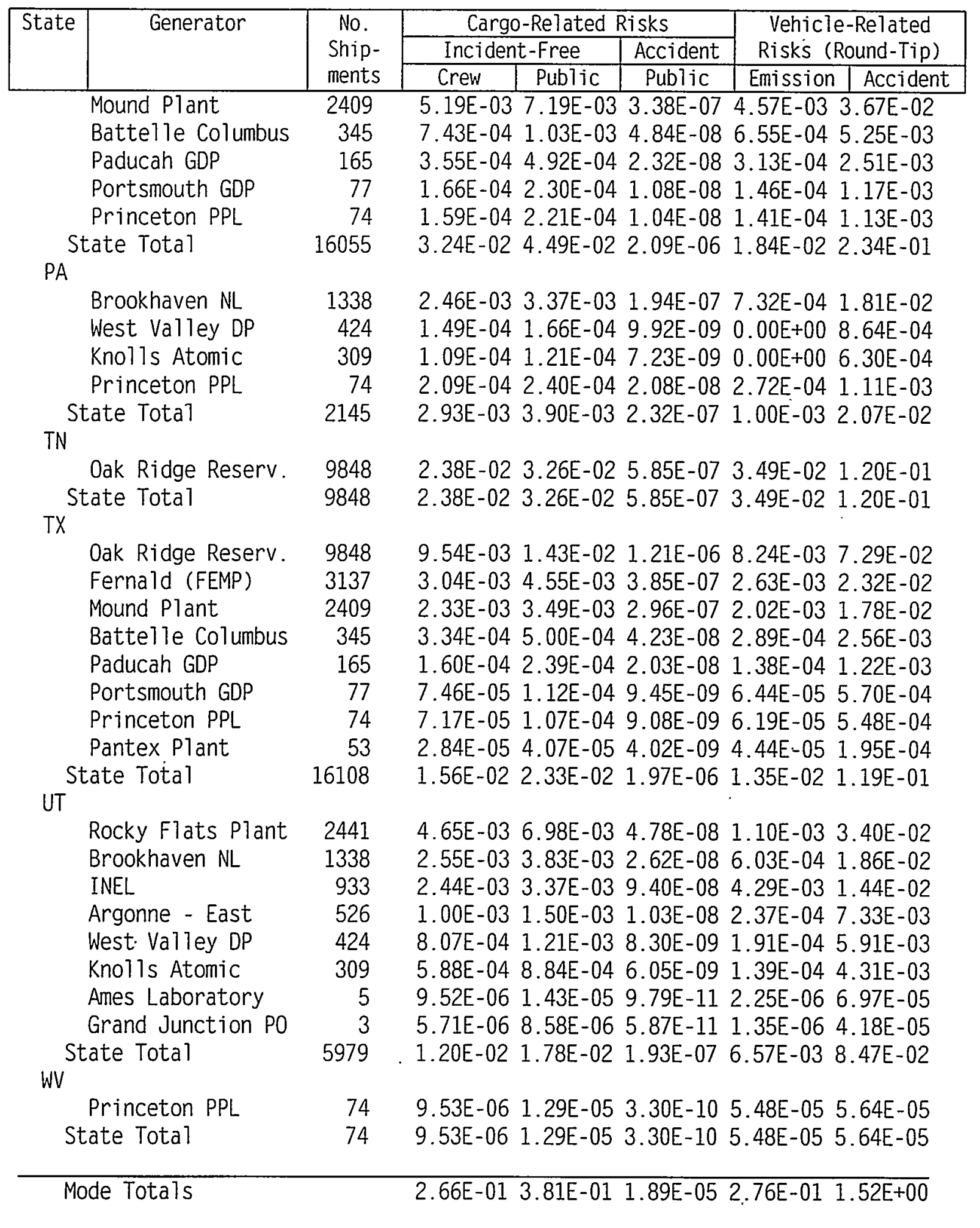


Table B.7 RADTRAN 4 Results - Low Volume Rail Transport To Barstow Expected Fatalities for the Shipping Campaign

\begin{tabular}{ll}
\hline Exposure Group & Rail \\
\hline Radiological & \\
Normal Crew & $1.2 \mathrm{E}-02$ \\
Normal Public & $1.4 \mathrm{E}-02$ \\
Accident Public & $1.1 \mathrm{E}-06$ \\
Nonradiological & \\
Emission & $2.7 \mathrm{E}-02$ \\
Accident & $1.0 \mathrm{E}+00$ \\
&
\end{tabular}

Alternative Risks Per State (fatalities)

\begin{tabular}{|c|c|c|c|c|c|c|c|}
\hline \multirow[t]{3}{*}{ State } & \multirow[t]{3}{*}{ Generator } & \multirow{3}{*}{$\begin{array}{l}\text { No. } \\
\text { Ship- } \\
\text { ments }\end{array}$} & \multicolumn{3}{|c|}{ Cargo-Related Risks } & \multirow{2}{*}{\multicolumn{2}{|c|}{$\begin{array}{l}\text { Vehicle-Related } \\
\text { Risks (Round-Tip) }\end{array}$}} \\
\hline & & & \multicolumn{2}{|c|}{ Incident-Free } & \multirow{2}{*}{\begin{tabular}{|c|} 
Accident \\
Public \\
\end{tabular}} & & \\
\hline & & & Crew & Public & & Emission & Accident \\
\hline \multicolumn{8}{|l|}{$A Z$} \\
\hline & Los Alamos NL & 1264 & $9.29 E-04$ & $7.65 \mathrm{E}-04$ & $8.34 E-09$ & $1.22 E-03$ & 1.24E-01 \\
\hline & Rocky Flats Plant & 814 & $5.98 E-04$ & $4.93 E-04$ & $5.37 E-09$ & $7.83 E-04$ & $8.00 E-02$ \\
\hline & Mound Plant & 803 & $5.90 E-04$ & $4.86 E-04$ & $5.29 E-09$ & $7.73 E-04$ & $7.89 E-02$ \\
\hline & Cate Total & 2881 & $2.12 \mathrm{E}-03$ & 1. $.74 \mathrm{E}-03$ & $1.90 \mathrm{E}-08$ & $2.77 E-03$ & $2.83 E-01$ \\
\hline \multicolumn{8}{|c|}{ 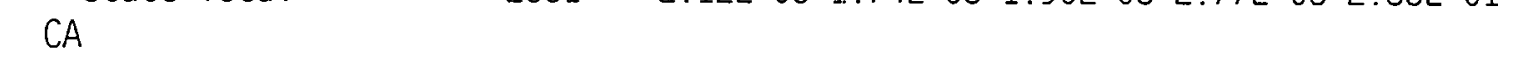 } \\
\hline & Los Alamos NL & 1264 & $4.32 E-04$ & $2.47 E-04$ & $2.77 \mathrm{E}-08$ & $5.29 E-05$ & $5.78 \mathrm{E}-02$ \\
\hline & Rocky Flats Plant & 814 & $2.78 \mathrm{E}-04$ & $1.59 E-04$ & $1.78 \mathrm{E}-08$ & $3.41 E-05$ & $3.72 E-02$ \\
\hline & Mound Plant & 803 & $2.75 E-04$ & $1.57 E-04$ & $1.76 \mathrm{E}-08$ & $3.36 E-05$ & $3.67 E-02$ \\
\hline & Lawrence Livermore & 466 & $3.52 E-04$ & 1. $.27 E-03$ & $6.09 E-08$ & $5.44 \mathrm{E}-03$ & $4.70 E-02$ \\
\hline & ate Total & 3347 & 1. $34 \mathrm{E}-03$ & $1.83 E-03$ & $1.24 E-07$ & $5.56 \mathrm{E}-03$ & $1.79 E-01$ \\
\hline \multicolumn{8}{|c|}{ 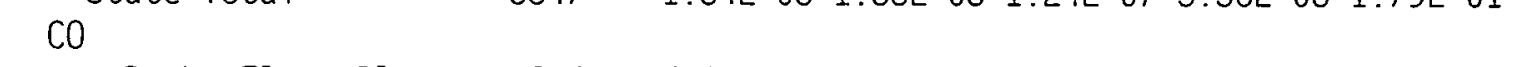 } \\
\hline & Rocky Flats Plant & 814 & $4.04 E-04$ & 1. $.39 E-03$ & $5.28 \mathrm{E}-08$ & $5.35 E-03$ & $5.40 E-02$ \\
\hline & ate Total & 814 & $4.04 E-04$ & $1.39 E-03$ & $5.28 \mathrm{E}-08$ & $5.35 E-03$ & $5.40 E-02$ \\
\hline \multicolumn{8}{|c|}{$\mathrm{C}$} \\
\hline & Mound Plant & 803 & $2.51 E-04$ & 4. $42 E-04$ & $4.48 \mathrm{E}-07$ & $1.18 \mathrm{E}-03$ & $3.35 E-02$ \\
\hline & ate Total & 803 & $2.51 E-04$ & $4.42 E-04$ & $4.48 E-07$ & $1.18 \mathrm{E}-03$ & $3.35 E-02$ \\
\hline \multicolumn{8}{|c|}{ 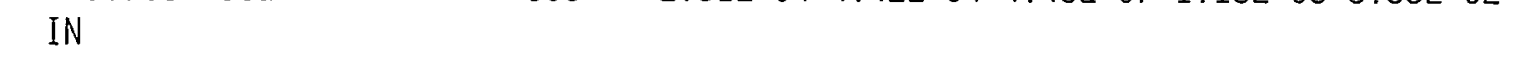 } \\
\hline & Mound Plant & 803 & $2.37 E-04$ & $9.47 E-04$ & $1.23 \mathrm{E}-07$ & $3.19 \mathrm{E}-03$ & $3.18 E-02$ \\
\hline & Late Total & 803 & $2.37 E-04$ & $9.47 E-04$ & $1.23 \mathrm{E}-07$ & $3.19 E-03$ & $3.18 \mathrm{E}-02$ \\
\hline \multicolumn{8}{|c|}{ 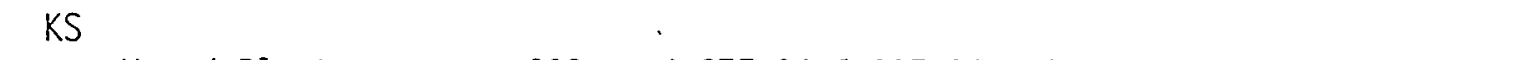 } \\
\hline & Mound Plant & 803 & $4.27 E-04$ & $6.00 E-04$ & $1.30 \mathrm{E}-07$ & $1.65 E-03$ & $5.71 E-02$ \\
\hline \multicolumn{8}{|c|}{ 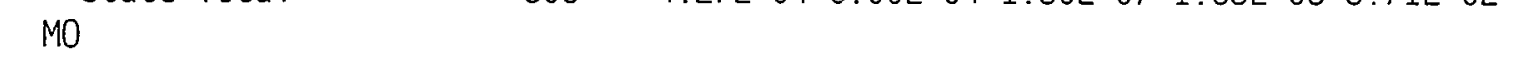 } \\
\hline & Mound Plant & 803 & $4.99 E-04$ & $7.48 E-04$ & 7.53E-08 & $2.05 E-03$ & $6.67 E-02$ \\
\hline & ate Total & 803 & $4.99 E-04$ & T. $48 \mathrm{E}-04$ & $7.53 E-08$ & $2.05 E-03$ & $6.67 \mathrm{E}-02$ \\
\hline
\end{tabular}




\begin{tabular}{|c|c|c|c|c|c|c|}
\hline \multirow[t]{3}{*}{ State } & \multirow[t]{3}{*}{ Generator } & \multirow{3}{*}{$\begin{array}{l}\text { No. } \\
\text { Ship- } \\
\text { ments }\end{array}$} & \multicolumn{3}{|c|}{ Cargo-Related Risks } & \multirow{2}{*}{$\begin{array}{l}\text { Vehicle-Related } \\
\text { Risks (Round-Tip) }\end{array}$} \\
\hline & & & \multicolumn{2}{|c|}{ Incident-Free } & \multirow{2}{*}{$\begin{array}{c}\text { Accident } \\
\text { Public } \\
\end{array}$} & \\
\hline & & & Crew & Public & & \begin{tabular}{l|l|} 
Emission & Accident \\
\end{tabular} \\
\hline \multicolumn{7}{|r|}{ (n) } \\
\hline & Los Alamos NL & 1264 & 4.59E-04 & $3.05 E-04$ & $2.07 E-09$ & $2.12 \mathrm{E}-04 \quad 6.14 \mathrm{E}-02$ \\
\hline & Rocky Flats Plant & 814 & $6.67 \mathrm{E}-04$ & $4.49 \mathrm{E}-04$ & $2.83 E-09$ & 4.09E-04 8.92E-02 \\
\hline & Mound Plant & 803 & $6.20 \mathrm{E}-04$ & $3.90 E-04$ & $2.47 \mathrm{E}-09$ & $2.35 E-04 \quad 8.29 E-02$ \\
\hline & tate Total & 2881 & $1.75 E-03$ & $1.14 \mathrm{E}-03$ & 7.37E-09 & 8.55E-04 2.34E-01 \\
\hline \multicolumn{7}{|c|}{ 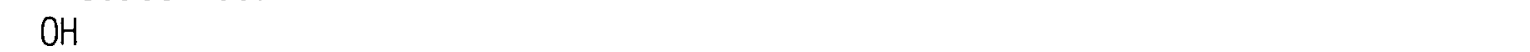 } \\
\hline & Mound Plant & 803 & $3.01 \mathrm{E}-04$ & $1.23 \mathrm{E}-03$ & $8.58 \mathrm{E}-08$ & 4. $40 \mathrm{E}-03 \quad 4.02 \mathrm{E}-02$ \\
\hline & tate Total & 803 & $3.01 E-04$ & $1.23 \mathrm{E}-03$ & $8.58 \mathrm{E}-08$ & 4.40E-03 4.02E-02 \\
\hline \multicolumn{7}{|c|}{ 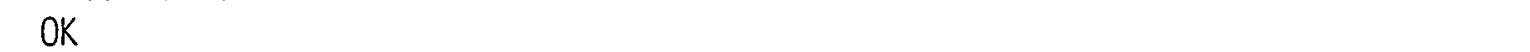 } \\
\hline & Mound Plant & 803 & $1.78 \mathrm{E}-04$ & $9.34 \mathrm{E}-05$ & $1.78 \mathrm{E}-08$ & $0.00 E+002.38 E-02$ \\
\hline & tate Total & 803 & $1.78 \mathrm{E}-04$ & $9.34 \mathrm{E}-05$ & $1.78 \mathrm{E}-08$ & $0.00 E+002.38 E-02$ \\
\hline \multicolumn{7}{|c|}{ ( } \\
\hline & Mound Plant & 803 & $3.29 \mathrm{E}-04$ & $3.32 E-04$ & $3.43 \mathrm{E}-08$ & $2.69 \mathrm{E}-04 \quad 4.40 \mathrm{E}-02$ \\
\hline & tate Total & 803 & $3.29 \mathrm{E}-04$ & 3. $32 \mathrm{E}-04$ & 3. $43 \mathrm{E}-08$ & $2.69 \mathrm{E}-04 \quad 4.40 \mathrm{E}-02$ \\
\hline & ode Totals & & $7.83 E-03$ & $1.05 \mathrm{E}-0$ & $1.12 \mathrm{E}-06$ & $2.73 E-021.05 E+00$ \\
\hline
\end{tabular}


Table B.8 RADTRAN 4 Results - Low Volume Truck Transport From Barstow To NTS accident rate for primary highways in NV

Expected Fatalities for the Shipping Campaign

\begin{tabular}{ll}
\hline Exposure Group & Truck \\
\hline Radiological & \\
$\quad$ Normal Crew & $1.0 \mathrm{E}-02$ \\
Normal Public & $1.6 \mathrm{E}-02$ \\
Accident Public & $1.9 \mathrm{E}-07$ \\
Nonradiological & \\
Emission & $2.3 \mathrm{E}-03$ \\
Accident & $5.9 \mathrm{E}-02$ \\
\end{tabular}

A7ternative Risks Per State (fatalities)

\begin{tabular}{|c|c|c|c|c|c|c|}
\hline \multirow[t]{3}{*}{ State } & \multirow[t]{3}{*}{ Generator } & \multirow{3}{*}{$\begin{array}{l}\text { No. } \\
\text { Ship- } \\
\text { ments }\end{array}$} & \multicolumn{3}{|c|}{ Cargo-Related Risks } & \multirow{3}{*}{$\begin{array}{l}\text { Vehicle-Related } \\
\text { Risks (Round-Tip) } \\
\text { Fmission I Accident }\end{array}$} \\
\hline & & & Incid & -Free & Accident & \\
\hline & & & Crew & Public & Public & \\
\hline \multicolumn{7}{|c|}{$\begin{array}{r}\text { Truck } \\
\text { CA }\end{array}$} \\
\hline & tow. CA & 10038 & $7.71 \mathrm{E}-$ & $1.20 \mathrm{E}$ & $21.89 \mathrm{E}-07$ & $2.26 \mathrm{E}-03 \quad 3.46 \mathrm{E}-02$ \\
\hline & Total & 10038 & $7.71 \mathrm{E}-$ & $1.20 \mathrm{E}$ & $21.89 \mathrm{E}-07$ & $2.26 \mathrm{E}-03 \quad 3.46 \mathrm{E}-02$ \\
\hline & \multicolumn{5}{|c|}{ 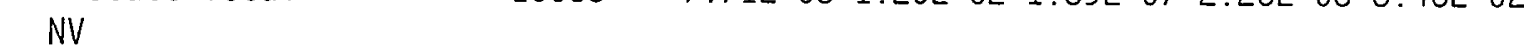 } & \\
\hline & Total & 10038 & $\begin{array}{l}\text { 2.29E- } \\
2.29 F_{-}\end{array}$ & $\begin{array}{l}3.55 \mathrm{E}-1 \\
3.55 \mathrm{~F}\end{array}$ & $\begin{array}{l}32.86 t-09 \\
32\end{array}$ & $0.00 \mathrm{E}+00 \quad 2.48 \mathrm{E}-02$ \\
\hline & & & 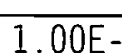 & & & 2265035 QAL 020 \\
\hline
\end{tabular}


TabTe B.9 RADTRAN 4 Results - Low Volume Rail Transport To Caliente Expected Fatalities for the Shipping Campaign

\begin{tabular}{lc}
\hline Exposure Group & Rail \\
\hline Radiological & \\
Normal Crew & $1.3 \mathrm{E}-02$ \\
Normal Public & $1.9 \mathrm{E}-02$ \\
Accident Public & $1.9 \mathrm{E}-06$ \\
Nonradiological & \\
Emission & $4.5 \mathrm{E}-02$ \\
Accident & $1.1 \mathrm{E}+00$ \\
\hline
\end{tabular}

Alternative Risks Per State (fatalities)

\begin{tabular}{|c|c|c|c|c|c|c|c|}
\hline \multirow{3}{*}{ State } & \multirow[t]{3}{*}{ Generator } & \multirow{3}{*}{$\begin{array}{l}\text { No. } \\
\text { Ship- } \\
\text { ments }\end{array}$} & \multicolumn{3}{|c|}{ Cargo-Related Risks } & \multirow{2}{*}{\multicolumn{2}{|c|}{$\begin{array}{c}\text { Vehicle-Related } \\
\text { Risks (Round-Tip) }\end{array}$}} \\
\hline & & & \multicolumn{2}{|c|}{ Incident-Free } & \multirow{2}{*}{\begin{tabular}{|c} 
Accident \\
Public
\end{tabular}} & & \\
\hline & & & Crew & Public & & Emission & Accident \\
\hline \multicolumn{8}{|l|}{$\mathrm{CA}$} \\
\hline & Lawrence Livermore & 466 & $1.82 E-04$ & $1.22 \mathrm{E}-03$ & $4.94 E-08$ & $5.42 \mathrm{E}-03$ & $2.43 E-02$ \\
\hline & tate Total & 466 & $1.82 E-04$ & $1.22 \mathrm{E}-03$ & $4.94 \mathrm{E}-08$ & $5.42 \mathrm{E}-03$ & $2.43 \mathrm{E}-02$ \\
\hline \multicolumn{8}{|c|}{$\mathrm{CO}$} \\
\hline & Los Alamos NL & 1264 & $1.28 \mathrm{E}-03$ & $2.52 E-03$ & 1.10E-07 & 7. $30 \mathrm{E}-03$ & $1.72 \mathrm{E}-01$ \\
\hline & Rocky Flats Plant & 814 & $4.20 E-04$ & $3.48 E-04$ & $2.14 \mathrm{E}-08$ & $2.38 \mathrm{E}-04$ & $5.61 \mathrm{E}-02$ \\
\hline & Mound Plant & 803 & $1.51 \mathrm{E}-05$ & $1.33 E-05$ & $7.84 \mathrm{E}-10$ & $0.00 E+00$ & $2.02 \mathrm{E}-03$ \\
\hline & tate Total & 2881 & $1.72 \mathrm{E}-03$ & $2.88 \mathrm{E}-03$ & $1.32 \mathrm{E}-07$ & $7.54 \mathrm{E}-03$ & 2.30E-01 \\
\hline \multicolumn{8}{|c|}{ (2)- } \\
\hline & Mound Plant & 803 & 2.28E-04 & $2.74 \mathrm{E}-03$ & 4.05E-07 & $1.16 \mathrm{E}-02$ & $3.05 \mathrm{E}-02$ \\
\hline & tate Total & 803 & $2.28 \mathrm{E}-04$ & 2.74E-03 & 4.05E-07 & $1.16 \mathrm{E}-02$ & $3.05 E-02$ \\
\hline \multicolumn{8}{|c|}{ 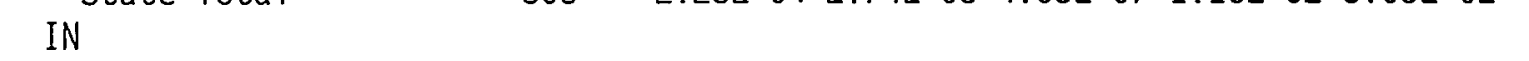 } \\
\hline & Mound Plant & 803 & 2.24E-04 & $9.87 E-04$ & $1.25 \mathrm{E}-07$ & $3.49 \mathrm{E}-03$ & $3.00 \mathrm{E}-02$ \\
\hline & tate Total & 803 & $2.24 \mathrm{E}-04$ & $9.87 \mathrm{E}-04$ & 1.25E-07 & $3.49 \mathrm{E}-03$ & 3.00E-02 \\
\hline \multicolumn{8}{|c|}{ IA } \\
\hline & Mound Plant & 803 & $5.08 \mathrm{E}-04$ & 1.17E-03 & $6.60 \mathrm{E}-07$ & $3.63 \mathrm{E}-03$ & $6.80 E-02$ \\
\hline & tate Total & 803 & $5.08 \mathrm{E}-04$ & 1.17E-03 & $6.60 \mathrm{E}-07$ & $3.63 \mathrm{E}-03$ & $6.80 \mathrm{E}-02$ \\
\hline \multicolumn{8}{|c|}{ NE } \\
\hline & Mound Plant & 803 & $6.82 \mathrm{E}-04$ & $6.87 \mathrm{E}-04$ & $2.99 \mathrm{E}-07$ & $1.01 E-03$ & $9.13 \mathrm{E}-02$ \\
\hline & tate Total & 803 & $6.82 E-04$ & $6.87 \mathrm{E}-04$ & $2.99 \mathrm{E}-07$ & $1.01 \mathrm{E}-03$ & $9.13 \mathrm{E}-02$ \\
\hline \multicolumn{8}{|c|}{ NV } \\
\hline & Los Alamos NL & 1264 & $9.83 \mathrm{E}-05$ & $5.46 \mathrm{E}-05$ & $2.25 E-11$ & $0.00 E+00$ & $1.31 E-02$ \\
\hline & Rocky Flats Plant & 814 & $6.33 \mathrm{E}-05$ & $3.52 E-05$ & $1.45 \mathrm{E}-11$ & $0.00 E+00$ & $8.46 E-03$ \\
\hline & Mound Plant & 803 & $6.24 \mathrm{E}-05$ & $3.47 \mathrm{E}-05$ & $1.43 \mathrm{E}-11$ & $0.00 E+00$ & $8.35 E-03$ \\
\hline & Lawrence Livermore & 466 & 4. $40 \mathrm{E}-04$ & $4.64 E-04$ & $1.21 \mathrm{E}-09$ & 1.05E-03 & $5.89 \mathrm{E}-02$ \\
\hline & tate Total & 3347 & $6.64 \mathrm{E}-04$ & $5.88 \mathrm{E}-04$ & $1.26 \mathrm{E}-09$ & $1.05 \mathrm{E}-03$ & $8.88 \mathrm{E}-02$ \\
\hline & & & & & & & \\
\hline
\end{tabular}




\begin{tabular}{|c|c|c|c|c|c|c|}
\hline \multirow[t]{3}{*}{ State } & \multirow[t]{3}{*}{ Generator } & \multirow{3}{*}{$\begin{array}{l}\text { No. } \\
\text { Ship- } \\
\text { ments }\end{array}$} & \multicolumn{3}{|c|}{ Cargo-Related Risks } & \multirow{2}{*}{$\begin{array}{l}\text { Vehicle-Related } \\
\text { Risks (Round-Tip) }\end{array}$} \\
\hline & & & \multicolumn{2}{|c|}{ Incident-Free } & \multirow{2}{*}{\begin{tabular}{|c|} 
Accident \\
Public \\
\end{tabular}} & \\
\hline & & & Crew & Public & & \begin{tabular}{l|l} 
Emission & Accident \\
\end{tabular} \\
\hline \multicolumn{7}{|l|}{ NM } \\
\hline & Los Alamos NL & 1264 & $5.77 E-04$ & $4.16 E-04$ & $2.25 E-09$ & $3.70 E-047.71 E-02$ \\
\hline & tate Total & 1264 & $5.77 E-04$ & $4.16 E-04$ & $2.25 E-09$ & $3.70 E-047.71 E-02$ \\
\hline \multicolumn{7}{|c|}{ 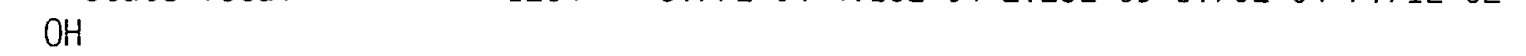 } \\
\hline & Mound Plant & 803 & $4.22 E-04$ & 1.72E-03 & $1.16 \mathrm{E}-07$ & $5.85 E-035.64 E-02$ \\
\hline & tate Total & 803 & $4.22 E-04$ & 1. $.72 \mathrm{E}-03$ & $1.16 E-07$ & $5.85 E-035.64 E-02$ \\
\hline \multicolumn{7}{|c|}{$\mathrm{C}_{3}$} \\
\hline & Los Alamos NL & 1264 & 1. $10 E-03$ & $8.55 E-04$ & $2.19 E-08$ & $6.88 \mathrm{E}-041.47 \mathrm{E}-01$ \\
\hline & Rocky Flats Plant & 814 & $7.07 E-04$ & $5.51 E-04$ & $1.41 E-08$ & 4. $43 E-049.45 E-02$ \\
\hline & Mound Plant & 803 & $5.89 E-04$ & $9.41 E-04$ & $3.58 E-08$ & $2.89 E-037.87 E-02$ \\
\hline & Lawrence Livermore & 466 & $3.31 E-04$ & $1.95 E-04$ & $2.52 \mathrm{E}-09$ & $0.00 E+00 \quad 4.42 E-02$ \\
\hline & tate Total & 3347 & $2.72 \mathrm{E}-03$ & $2.54 E-03$ & $7.44 \mathrm{E}-08$ & $4.02 E-033.64 E-01$ \\
\hline \multicolumn{7}{|c|}{ 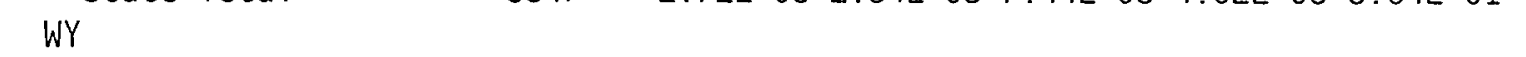 } \\
\hline & Mound Plant & 803 & $6.63 E-04$ & $4.92 E-04$ & $7.26 \mathrm{E}-09$ & $5.38 E-04 \quad 8.86 E-02$ \\
\hline & tate Total & 803 & $6.63 \mathrm{E}-04$ & $4.92 E-04$ & $7.26 E-09$ & $5.38 \mathrm{E}-048.86 \mathrm{E}-02$ \\
\hline & ode Totals & & $8.59 \mathrm{E}-03$ & $1.54 \mathrm{E}-02$ & $1.87 \mathrm{E}-06$ & $4.45 E-021.15 E+00$ \\
\hline
\end{tabular}


Table B.10 RADTRAN 4 Results - Low Volume Truck Transport From Caliente To NTS accident rate for primary highways in NV

alternate route files used

Expected Fatalities for the Shipping Campaign

\begin{tabular}{ll}
\hline Exposure Group & Truck \\
\hline Radiological & \\
$\quad$ Normal Crew & $1.5 \mathrm{E}-02$ \\
$\quad$ Normal Public & $2.3 \mathrm{E}-02$ \\
$\quad$ Accident Public & $2.3 \mathrm{E}-08$ \\
Nonradiological & \\
$\quad$ Emission & $0.0 \mathrm{E}+00$ \\
Accident & $1.6 \mathrm{E}-01$ \\
\hline
\end{tabular}

\section{A7ternative Risks Per State (fatalities)}

\begin{tabular}{|c|c|c|c|c|c|c|c|}
\hline \multirow{3}{*}{ State } & \multirow[t]{3}{*}{ Generator } & \multirow{3}{*}{$\begin{array}{l}\text { No. } \\
\text { Ship- } \\
\text { ments }\end{array}$} & \multicolumn{3}{|c|}{ Cargo-Related Risks } & \multirow{2}{*}{\multicolumn{2}{|c|}{$\begin{array}{l}\text { Vehicle-Related } \\
\text { Risks (Round-Tip) }\end{array}$}} \\
\hline & & & \multicolumn{2}{|c|}{ Incident-Free } & \multirow{2}{*}{$\begin{array}{c}\text { Accident } \\
\text { Public } \\
\end{array}$} & & \\
\hline & & & Crew & Public & & Emission & Accident \\
\hline \multicolumn{8}{|c|}{$\begin{array}{l}\text { Truck } \\
\text { NV }\end{array}$} \\
\hline & iente. NV & 10038 & $1.50 \mathrm{E}-0$ & $2.32 \mathrm{E}-0$ & $2.29 E-08$ & $0.00 E+00$ & 1.62E-01 \\
\hline \multicolumn{2}{|c|}{ State Total } & 10038 & $1.50 \mathrm{E}-0$ & $2.32 \mathrm{E}-0$ & $2.29 E-08$ & $0.00 E+00$ & 1.62E-01 \\
\hline \multicolumn{2}{|c|}{ Mode Totals } & & $1.50 \mathrm{E}-0$ & $2.32 \mathrm{E}-1$ & $2.29 \mathrm{E}-08$ & $0.00 E+00$ & $1.62 \mathrm{E}-01$ \\
\hline
\end{tabular}


Table B.11 RADTRAN 4 Results - Low Volume Truck Transport To NTS - Avoid Las Vegas accident rate for promary highways in NV alternate route files used

Expected Fatalities for the Shipping Campaign

\begin{tabular}{ll}
\hline Exposure Group & Truck \\
\hline Radiological & \\
Normal Crew & $7.5 \mathrm{E}-02$ \\
Normal Public & $1.1 \mathrm{E}-01$ \\
Accident Public & $4.2 \mathrm{E}-06$ \\
Nonradiological & \\
Emission & $4.7 \mathrm{E}-02$ \\
Accident & $4.7 \mathrm{E}-01$
\end{tabular}

Alternative Risks Per State (fatalities)

\begin{tabular}{|c|c|c|c|c|c|c|c|}
\hline \multirow[t]{3}{*}{ State } & \multirow[t]{3}{*}{ Generator } & \multirow{3}{*}{$\begin{array}{l}\text { No. } \\
\text { Ship- } \\
\text { ments }\end{array}$} & \multicolumn{3}{|c|}{ Cargo-Related Risks } & \multirow{2}{*}{\multicolumn{2}{|c|}{$\begin{array}{l}\text { Vehicle-Related } \\
\text { Risks (Round-Tip) }\end{array}$}} \\
\hline & & & \multicolumn{2}{|c|}{ Incident-Free } & \multirow{2}{*}{$\frac{\text { Accident }}{\text { Public }}$} & & \\
\hline & & & Crew & Public & & Emission & Accident \\
\hline \multicolumn{6}{|l|}{ Truck } & & \\
\hline & Los Alamos NL & 3791 & 7. $31 \mathrm{E}-03$ & 1.10E-02 & $4.99 E-08$ & 2.07E-03 & $4.21 \mathrm{E}-02$ \\
\hline & Rocky F & 2441 & $3.52 \mathrm{E}-04$ & $5.46 \mathrm{E}-04$ & $1.20 \mathrm{E}-09$ & $0.00 \mathrm{E}+00$ & $2.15 E-03$ \\
\hline & Mound Plan & 2409 & 4. $65 \mathrm{E}-03$ & $6.98 \mathrm{E}-03$ & $3.17 E-08$ & $1.32 \mathrm{E}-03$ & \\
\hline & SNL - Albur & 191 & $3.68 \mathrm{E}-04$ & $5.53 \mathrm{E}-04$ & $2.51 E-09$ & $.05 E-04$ & $2.12 \mathrm{E}-03$ \\
\hline & Paducah G & 165 & $3.18 \mathrm{E}-04$ & $4.78 \mathrm{E}-04$ & 2.1 & $9.03 \mathrm{E}-$ & $E-03$ \\
\hline & & 87 & $1.68 \mathrm{E}-04$ & $2.52 E-04$ & $1.15 E-09$ & $4.76 \mathrm{E}-05$ & $9.66 \mathrm{E}-04$ \\
\hline & Portsmouth & 77 & $1.48 \mathrm{E}-04$ & $2.23 E-04$ & $1.01 E-09$ & $4.21 E-05$ & $8.55 E-04$ \\
\hline & Pant & 53 & $1.02 \mathrm{E}-04$ & $1.53 \mathrm{E}-04$ & 6.98 & $2.90 \mathrm{E}-05$ & $5.89 E-04$ \\
\hline $\mathrm{CA}^{\mathrm{S}}$ & tate Total & 9214 & $1.34 \mathrm{E}-02$ & $2.02 E-02$ & $9.04 E-08$ & $3.71 E-03$ & $7.74 \mathrm{E}-02$ \\
\hline & Los Alamo & 3791 & $5.98 \mathrm{E}-03$ & $9.10 E-03$ & & $1.22 \mathrm{E}-$ & $2.62 \mathrm{E}-\mathrm{t}$ \\
\hline & Mound P1 & 2409 & 3. $80 \mathrm{E}-03$ & $5.78 \mathrm{E}-03$ & $9.62 \mathrm{E}$ & $7.75 \mathrm{E}-$ & 1. $67 \mathrm{E}-02$ \\
\hline & wrence & 1397 & $3.83 \mathrm{E}-03$ & $5.82 E-03$ & -08 & $2.07 \mathrm{E}$ & $1.65 E-02$ \\
\hline & SNL - ATB & 191 & $3.01 \mathrm{E}-04$ & $4.58 \mathrm{E}-04$ & 7.63E-09 & $6.15 E-05$ & $1.32 \mathrm{E}-03$ \\
\hline & Paducah GDP & 165 & 2. $60 \mathrm{E}-04$ & $3.96 \mathrm{E}-04$ & $6.59 E-09$ & $5.31 E-05$ & $1.14 \mathrm{E}-03$ \\
\hline & ETEC & 104 & 2.40E-04 & $3.84 \mathrm{E}-04$ & & $1.65 \mathrm{E}-$ & $6.93 \mathrm{E}-04$ \\
\hline & ITRI & 87 & $1.37 \mathrm{E}-04$ & $2.09 E-04$ & $3.47 E-09$ & $2.80 \mathrm{E}-1$ & $6.01 E-04$ \\
\hline & & 77 & $1.21 E-04$ & & & & $5.32 \mathrm{E}-04$ \\
\hline & Pantex Pla & 53 & $8.36 \mathrm{E}-05$ & 1. $.27 \mathrm{E}-04$ & & & $3.66 \mathrm{E}-04$ \\
\hline & tate Total & 8274 & $1.48 \mathrm{E}-02$ & $2.25 \mathrm{E}-02$ & $3.74 E-07$ & $5.90 E-03$ & $6.40 \mathrm{E}-02$ \\
\hline
\end{tabular}




\begin{tabular}{|c|c|c|c|c|c|c|c|}
\hline \multirow{3}{*}{ State } & \multirow[t]{3}{*}{ Generator } & \multirow{3}{*}{$\begin{array}{l}\text { No. } \\
\text { Ship- } \\
\text { ments }\end{array}$} & \multicolumn{3}{|c|}{ Cargo-Related Risks } & \multirow{2}{*}{\multicolumn{2}{|c|}{$\begin{array}{l}\text { Vehicle-Related } \\
\text { Risks (Round-Tip) }\end{array}$}} \\
\hline & & & \multicolumn{2}{|c|}{ Incident-Free } & \multirow{2}{*}{\begin{tabular}{|c|} 
Accident \\
Public \\
\end{tabular}} & & \\
\hline & & & Crew & Public & & Emission & 1 Accident \\
\hline \multicolumn{8}{|c|}{ 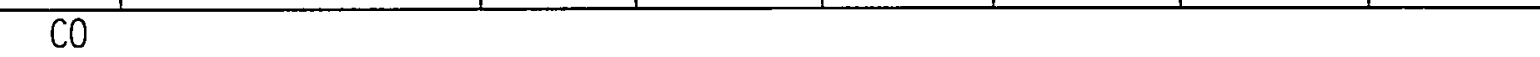 } \\
\hline \multirow{2}{*}{\multicolumn{2}{|c|}{$\begin{array}{l}\text { Rocky Flats Plant } \\
\text { State Total }\end{array}$}} & 2441 & \multirow{2}{*}{\multicolumn{5}{|c|}{$\begin{array}{lllll}3.97 \mathrm{E}-03 & 5.54 \mathrm{E}-03 & 2.79 \mathrm{E}-07 & 1.57 \mathrm{E}-03 & 2.51 \mathrm{E}-02 \\
3.97 \mathrm{E}-03 & 5.54 \mathrm{E}-03 & 2.79 \mathrm{E}-07 & 1.57 \mathrm{E}-03 & 2.51 \mathrm{E}-02\end{array}$}} \\
\hline & & 2441 & & & & & \\
\hline \multicolumn{8}{|c|}{ ( } \\
\hline & Mound Plant & $2409^{\circ}$ & $2.27 E-03$ & $3.16 \mathrm{E}-03$ & $1.01 \mathrm{E}-06$ & $7.75 E-04$ & $1.04 \mathrm{E}-02$ \\
\hline & Paducah GDP & 165 & $1.64 E-06$ & $2.54 \mathrm{E}-06$ & $9.65 E-10$ & $0.00 E+00$ & $8.82 \mathrm{E}-06$ \\
\hline & Portsmouth GDP & 77 & $6.04 E-05$ & 8.69E-05 & $2.66 \mathrm{E}-08$ & $8.43 E-05$ & $2.71 E-04$ \\
\hline & tate Total & 2651 & $2.33 \mathrm{E}-03$ & $3.25 E-03$ & $1.04 \mathrm{E}-06$ & $8.60 E-04$ & $1.06 \mathrm{E}-02$ \\
\hline \multicolumn{8}{|c|}{ 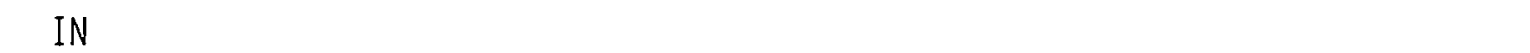 } \\
\hline & Mound Plant & 2409 & $2.51 E-03$ & $3.39 E-03$ & $6.30 \mathrm{E}-07$ & $4.42 E-03$ & $8.05 E-03$ \\
\hline & Portsmouth GDP & 77 & $5.21 E-05$ & $7.43 E-05$ & $1.76 \mathrm{E}-08$ & $4.96 E-06$ & $2.03 E-04$ \\
\hline & tate Total & 2486 & $2.56 \mathrm{E}-03$ & $3.46 E-03$ & $6.48 E-07$ & $4.42 \mathrm{E}-03$ & $8.25 E-03$ \\
\hline \multicolumn{8}{|c|}{ 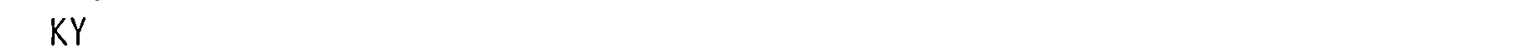 } \\
\hline & Paducah GDP & 165 & $2.40 E-05$ & $3.47 E-05$ & $2.14 \mathrm{E}-09$ & $0.00 \mathrm{E}+00$ & $1.83 E-04$ \\
\hline & Portsmouth GDP & 77 & $6.25 E-05$ & $8.15 E-05$ & $5.79 E-09$ & $1.83 \mathrm{E}-04$ & $3.33 E-04$ \\
\hline & tate Total & 242 & $8.64 E-05$ & $1.16 \mathrm{E}-04$ & $7.93 E-09$ & $1.83 E-04$ & $5.16 E-04$ \\
\hline \multicolumn{8}{|c|}{ 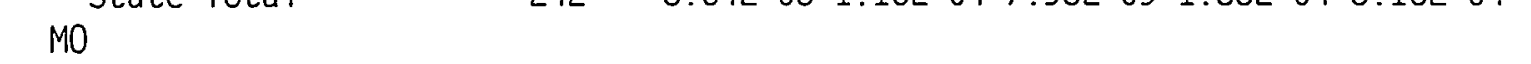 } \\
\hline & Mound Plant & 2409 & 4. $60 E-03$ & $6.33 E-03$ & $7.71 E-07$ & 8. $30 E-03$ & 2.79E-02 \\
\hline & Paducah GDP & 165 & $3.45 E-04$ & $4.75 E-04$ & $6.41 E-08$ & 1. $43 \mathrm{E}-04$ & $2.32 E-03$ \\
\hline & Portsmouth GDP & 77 & 1. $47 \mathrm{E}-04$ & $2.02 E-04$ & $2.47 \mathrm{E}-08$ & $2.65 E-04$ & $8.93 E-04$ \\
\hline & tate Total & 2651 & $5.10 E-03$ & 7.00E-03 & $8.60 E-07$ & $8.71 E-03$ & $3.12 E-02$ \\
\hline \multicolumn{8}{|c|}{ 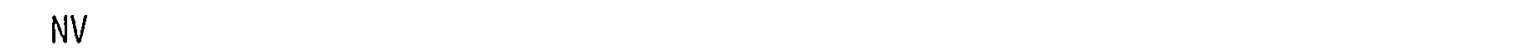 } \\
\hline & Los Alamos NL & 3791 & $8.64 E-04$ & $1.34 \mathrm{E}-03$ & $1.08 \mathrm{E}-09$ & $0.00 E+00$ & $9.37 E-03$ \\
\hline & Rocky Flats Plant & 2441 & $5.39 E-03$ & $8.36 E-03$ & $7.96 \mathrm{E}-09$ & $0.00 E+00$ & $5.84 \mathrm{E}-02$ \\
\hline & Mound Plant & 2409 & $5.49 E-04^{\circ}$ & $8.52 E-04$ & $6.87 \mathrm{E}-10$ & $0.00 E+00$ & $5.96 \mathrm{E}-03$ \\
\hline & Lawrence Livermore & 1397 & $3.19 E-04$ & $4.94 E-04$ & $3.98 \mathrm{E}-10$ & $0.00 E+00$ & $3.45 E-03$ \\
\hline & SNL - Albuquerque & 191 & $4.36 E-05$ & $6.76 \mathrm{E}-05$ & $5.45 E-11$ & $0.00 E+00$ & $4.72 E-04$ \\
\hline & Paducah GDP & 165 & $3.76 E-05$ & $5.84 \mathrm{E}-05$ & $4.71 E-11$ & $0.00 E+00$ & $4.08 E-04$ \\
\hline & ETEC & 104 & $2.37 E-05$ & $3.68 \mathrm{E}-05$ & $2.97 \mathrm{E}-11$ & $0.00 E+00$ & $2.57 E-04$ \\
\hline & ITRI & 87 & $1.98 E-05$ & $3.08 \mathrm{E}-05$ & $2.48 \mathrm{E}-11$ & $0.00 E+00$ & $2.15 E-04$ \\
\hline & Portsmouth GDP & 77 & $1.76 \mathrm{E}-05$ & $2.72 \mathrm{E}-05$ & $2.20 \mathrm{E}-11$ & $0.00 \mathrm{E}+00$ & $1.90 \mathrm{E}-04$ \\
\hline & Pantex Plant & 53 & $1.21 E-05$ & $1.87 \mathrm{E}-05$ & $1.51 \mathrm{E}-11$ & $0.00 \mathrm{E}+00$ & $1.31 E-04$ \\
\hline & tate Total & 10715 & $7.28 E-03$ & $1.13 \mathrm{E}-02$ & $1.03 E-08$ & $0.00 \mathrm{E}+00$ & $7.88 E-02$ \\
\hline \multicolumn{8}{|c|}{ 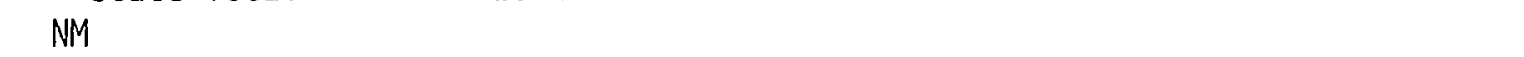 } \\
\hline & Los Alamos NL & 3791 & $5.47 E-03$ & $7.88 \mathrm{E}-03$ & $5.54 \mathrm{E}-08$ & $3.17 E-03$ & $3.67 E-02$ \\
\hline & Mound Plant & 2.409 & $4.94 E-03$ & $7.47 \mathrm{E}-03$ & $3.44 \mathrm{E}-08$ & $6.05 E-03$ & $3.41 E-02$ \\
\hline & SNL - ATbuquerque & 191 & $1.91 E-04$ & $2.80 \mathrm{E}-04$ & $2.13 E-09$ & $3.32 E-04$ & $1.23 E-03$ \\
\hline & Paducah GDP & 165 & $3.38 E-04$ & $5.12 E-04$ & $2.36 E-09$ & $4.14 \mathrm{E}-04$ & $2.34 \mathrm{E}-03$ \\
\hline & ITRI & 87 & $8.69 E-05$ & $1.28 \mathrm{E}-04$ & $9.70 E-10$ & $1.51 E-04$ & $5.59 E-04$ \\
\hline & Portsmouth GDP & 77 & $1.58 \mathrm{E}-04$ & $2.39 E-04$ & 1.10E-09 & $1.93 E-04$ & $1.09 \mathrm{E}-03$ \\
\hline & Pantex Plant & 53 & $1.09 E-04$ & $1.64 \mathrm{E}-04$ & $7.57 \mathrm{E}-10$ & $1.33 E-04$ & $7.51 E-04$ \\
\hline & tate Total & 6773 & 1.13E-02 & $1.67 \mathrm{E}-02$ & $9.71 E-08$ & $1.04 \mathrm{E}-02$ & 7. $68 \mathrm{E}-02$ \\
\hline
\end{tabular}




\begin{tabular}{|c|c|c|c|c|c|c|c|}
\hline \multirow[t]{3}{*}{ State } & \multirow[t]{3}{*}{ Generator } & \multirow{3}{*}{$\begin{array}{l}\text { No. } \\
\text { Ship- } \\
\text { ments }\end{array}$} & \multicolumn{3}{|c|}{ Cargo-Related Risks } & \multirow{2}{*}{\multicolumn{2}{|c|}{$\begin{array}{l}\text { Vehicle-Related } \\
\text { Risks (Round-Tip) }\end{array}$}} \\
\hline & & & \multicolumn{2}{|c|}{ Incident-Free } & \multirow{2}{*}{\begin{tabular}{|c|} 
Accident \\
Public \\
\end{tabular}} & & \\
\hline & & & Crew & Public & & Emission & Accident \\
\hline \multicolumn{8}{|l|}{$\mathrm{OH}$} \\
\hline & Mound Plant & 2409 & $9.54 E-04$ & 1. $16 E-03$ & $7.35 E-08$ & 2.79E-03 & 1. $36 \mathrm{E}-03$ \\
\hline & Portsmouth GDP & 77 & $4.38 E-05$ & $5.64 E-05$ & $4.69 E-09$ & $9.91 E-06$ & $8.50 E-05$ \\
\hline & tate Total & 2486 & $9.97 \mathrm{E}-04$ & $1.22 E-03$ & $7.82 E-08$ & $2.80 \mathrm{E}-03$ & $1.45 E-03$ \\
\hline \multicolumn{8}{|c|}{ G. } \\
\hline & Mound Plant & 2409 & 5. 19E-03 & $7.19 E-03$ & $3.38 \mathrm{E}-07$ & $4.57 E-03$ & $3.67 E-02$ \\
\hline & Paducah GDP & 165 & $3.55 E-04$ & $4.92 E-04$ & $2.32 \mathrm{E}-08$ & $3.13 E-04$ & $2.51 E-03$ \\
\hline & Portsmouth GDP & 77 & $1.66 E-04$ & $2.30 E-04$ & $1.08 \mathrm{E}-08$ & $1.46 E-04$ & $1.17 E-03$ \\
\hline & tate Total & 2651 & $5.71 E-03$ & $7.91 E-03$ & $3.72 E-07$ & $5.03 \mathrm{E}-03$ & $4.04 \mathrm{E}-02$ \\
\hline \multicolumn{8}{|c|}{ 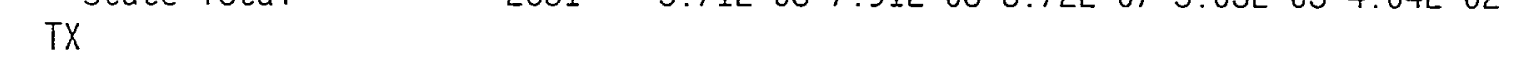 } \\
\hline & Mound Plant & 2409 & $2.33 E-03$ & $3.49 E-03$ & $2.96 \mathrm{E}-07$ & $2.02 \mathrm{E}-03$ & $1.78 \mathrm{E}-02$ \\
\hline & Paducah GDP & 165 & $1.60 E-04$ & $2.39 E-04$ & $2.03 E-08$ & $1.38 \mathrm{E}-04$ & $1.22 E-03$ \\
\hline & Portsmouth GDP & 77 & $7.46 E-05$ & 1. $12 E-04$ & $9.45 E-09$ & $6.44 \mathrm{E}-05$ & $5.70 E-04$ \\
\hline & Pantex Plant & 53 & $2.84 E-05$ & $4.07 E-05$ & $4.02 E-09$ & $4.44 \mathrm{E}-05$ & $1.95 E-04$ \\
\hline & tate Total & 2704 & $2.60 E-03$ & $3.88 \mathrm{E}-03$ & $3.29 E-07$ & $2.26 \mathrm{E}-03$ & $1.98 \mathrm{E}-02$ \\
\hline \multicolumn{8}{|c|}{ 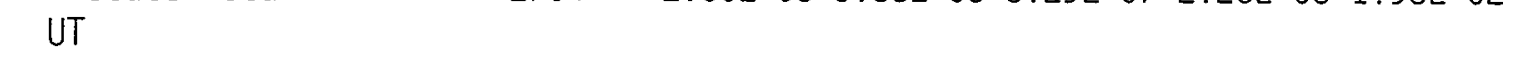 } \\
\hline & Rocky Flats Plant & 2441 & $4.65 E-03$ & $6.98 E-03$ & $4.78 \mathrm{E}-08$ & 1.10E-03 & $3.40 E-02$ \\
\hline & tate Total & 2441 & $4.65 E-03$ & $6.98 \mathrm{E}-03$ & $4.78 \mathrm{E}-08$ & 1. $10 \mathrm{E}-03$ & $3.40 E-02$ \\
\hline & ode Totals & & $7.47 \mathrm{E}-02$ & $1.10 \mathrm{E}-01$ & $4.23 E-06$ & $4.70 E-02$ & $4.68 E-01$ \\
\hline
\end{tabular}


Table B.12 RADTRAN 4 Results - Low Volume Truck Transport To NTS Travel Through Las Vegas

Expected Fatalities for the Shipping Campaign

\begin{tabular}{lc}
\hline Exposure Group & Truck \\
\hline Radiological & \\
Normal Crew & $6.5 \mathrm{E}-02$ \\
Normal Public & $9.4 \mathrm{E}-02$ \\
Accident Public & $4.2 \mathrm{E}-06$ \\
Nonradiological & \\
Emission & $6.9 \mathrm{E}-02$ \\
Accident & $3.7 \mathrm{E}-01$ \\
\hline
\end{tabular}

Alternative Risks Per State (fatalities)

\begin{tabular}{|c|c|c|c|c|c|c|}
\hline \multirow{3}{*}{ State } & \multirow[t]{3}{*}{ Generator } & \multirow{3}{*}{$\begin{array}{l}\text { No. } \\
\text { Ship- } \\
\text { ments }\end{array}$} & \multicolumn{3}{|c|}{ Cargo-Related Risks } & \multirow{2}{*}{$\begin{array}{l}\text { Vehicle-Related } \\
\text { Risks (Round-Tip) }\end{array}$} \\
\hline & & & Incic & Free & Accident & \\
\hline & & & Crew & Public & Public & \begin{tabular}{|l|l|} 
Emission & Accident \\
\end{tabular} \\
\hline
\end{tabular}

Truck

AZ

Los Alamos NL $\quad 3791 \quad 7.57 \mathrm{E}-03$ 1.14E-02 5.13E-08 2.07E-03 $4.36 \mathrm{E}-02$

Rocky Flats Plant $2441 \quad 3.52 \mathrm{E}-04 \quad 5.46 \mathrm{E}-04 \quad 1.20 \mathrm{E}-09 \quad 0.00 \mathrm{E}+00 \quad 2.15 \mathrm{E}-03$

Mound Plant . $2409 \quad 4.81 \mathrm{E}-03 \quad 7.22 \mathrm{E}-03 \quad 3.26 \mathrm{E}-08$ 1.32E-03 2.77E-02

SNL - Albuquerque $\quad 191 \quad 3.82 \mathrm{E}-04 \quad 5.73 \mathrm{E}-04 \quad 2.59 \mathrm{E}-09$ 1.05E-04 2.20E-03

$\begin{array}{lllllll}\text { Paducah GDP } & 165 & 3.30 \mathrm{E}-04 & 4.95 \mathrm{E}-04 & 2.23 \mathrm{E}-09 & 9.03 \mathrm{E}-05 & 1.90 \mathrm{E}-03\end{array}$

ITRI $\quad 87 \quad 1.74 \mathrm{E}-04 \quad 2.61 \mathrm{E}-04 \quad 1.18 \mathrm{E}-09 \quad 4.76 \mathrm{E}-05 \quad 1.00 \mathrm{E}-03$

Portsmouth GDP $\quad 77 \quad 1.54 \mathrm{E}-04 \quad 2.31 \mathrm{E}-04 \quad 1.04 \mathrm{E}-09 \quad 4.21 \mathrm{E}-05 \quad 8.85 \mathrm{E}-04$

Pantex Plant . $53 \quad 1.06 \mathrm{E}-04 \quad 1.59 \mathrm{E}-04 \quad 7.18 \mathrm{E}-102.90 \mathrm{E}-05 \quad 6.09 \mathrm{E}-04$

State.Total $9214 \cdot 1.39 \mathrm{E}-02 \quad 2.08 \mathrm{E}-02$ 9.29E-08 $3.71 \mathrm{E}-03 \quad 8.00 \mathrm{E}-02$

$\mathrm{CA}$

Lawrence Livermore $1397 \quad 3.55 \mathrm{E}-03 \quad 5.37 \mathrm{E}-03 \quad 8.96 \mathrm{E}-08$ 2.07E-03 $1.52 \mathrm{E}-02$

ETEC 104

State Tota] 1501

$\mathrm{CO}$

Rocky Flats Plant $2441 \quad 3.97 \mathrm{E}-03$ 5.54E-03 2.79E-07 1.57E-03 2.51E-02

State Total 2441

IL

Mound Plant 2409

Paducah GDP $\quad 165$

Portsmouth GDP $\quad 77$

State Total 2651

2.18E-04 3.52E-04 6.93E-09 1.65E-03 5.97E-04

3.77E-03 5.73E-03 9.66E-08 3.72E-03 $1.58 \mathrm{E}-02$

3.97E-03 5.54E-03 2.79E-07 1.57E-03 2.51E-02

2.27E-03 3.16E-03 1.01E-06 7.75E-04 1.04E-02

1.64E-06 2.54E-06 9.65E-10 $0.00 \mathrm{E}+00 \quad 8.82 \mathrm{E}-06$

6.04E-05 8.69E-05 2.66E-08 8.43E-05 2.71E-04

2.33E-03 3.25E-03 1.04E-06 8.60E-04 1.06E-02 


\begin{tabular}{|c|c|c|c|c|c|c|c|}
\hline \multirow[t]{3}{*}{ State } & \multirow[t]{3}{*}{ Generator } & \multirow{3}{*}{$\begin{array}{l}\text { No. } \\
\text { Ship- } \\
\text { ments }\end{array}$} & \multicolumn{3}{|c|}{ Cargo-Related Risks } & \multirow{2}{*}{\multicolumn{2}{|c|}{$\begin{array}{l}\text { Vehicle-Related } \\
\text { Risks (Round-Tip) }\end{array}$}} \\
\hline & & & \multicolumn{2}{|c|}{ Incident-Free } & \multirow{2}{*}{\begin{tabular}{|c|} 
Accident \\
Public \\
\end{tabular}} & & \\
\hline & & & Crew & Public & & Emission & Accident \\
\hline \multicolumn{8}{|l|}{ IN } \\
\hline & Mound Plant & 2409 & $2.51 E-03$ & $3.39 E-03$ & $6.30 E-07$ & $4.42 E-03$ & $8.05 E-03$ \\
\hline & Portsmouth GDP & 77 & $5.21 E-05$ & $7.43 E-05$ & $1.76 E-08$ & $4.96 E-06$ & $2.03 E-04$ \\
\hline & Late Total & 2486 & $2.56 \mathrm{E}-03$ & $3.46 \mathrm{E}-03$ & $6.48 \mathrm{E}-07$ & $4.42 \mathrm{E}-038$ & 8.25E-03 \\
\hline \multicolumn{8}{|c|}{ 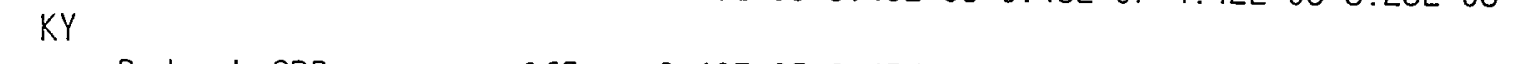 } \\
\hline & Paducah GDP & 165 & $2.40 E-05$ & $3.47 E-05$ & $2.14 \mathrm{E}-09$ & $0.00 E+00$ & $1.83 E-04$ \\
\hline & Portsmouth GDP & 77 & $6.25 E-05$ & $8.15 E-05$ & $5.79 \mathrm{E}-09$ & $1.83 \mathrm{E}-043$ & $3.33 E-04$ \\
\hline & tate Total & 242 & $8.64 \mathrm{E}-05$ & $1.16 \mathrm{E}-04$ & 7.93E-09 & $1.83 \mathrm{E}-045$ & $5.16 E-04$ \\
\hline \multicolumn{8}{|c|}{ 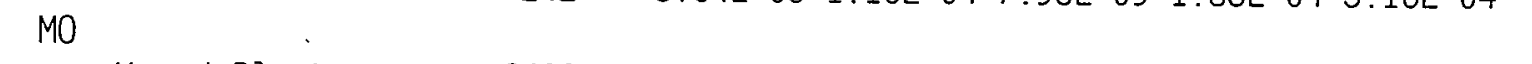 } \\
\hline & Mound Plant & 2409 & $4.60 E-03$ & $6.33 E-03$ & $7.71 \mathrm{E}-07$ & $8.30 E-03$ & $2.79 E-02$ \\
\hline & Paducah GDP & 165 & $3.45 E-04$ & $4.75 E-04$ & $6.41 E-08$ & $1.43 \mathrm{E}-04$ & $2.32 E-03$ \\
\hline & Portsmouth GDP & 77 & $1.47 E-04$ & $2.02 E-04$ & $2.47 E-08$ & $2.65 E-04$ & $8.93 E-04$ \\
\hline & Eate Total & 2651 & $5.10 E-03$ & $7.00 E-03$ & $8.60 E-07$ & $8.71 E-03$ & $3.12 \mathrm{E}-02$ \\
\hline \multicolumn{8}{|c|}{ 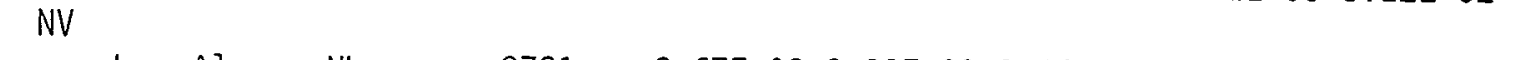 } \\
\hline & Los Alamos NL & 3791 & $2.67 E-03$ & $3.93 E-03$ & $8.46 E-08$ & $1.17 \mathrm{E}-027$ & $7.89 E-03$ \\
\hline & Rocky Flats Plant & 2441 & $2.06 E-03$ & $3.04 E-03$ & $4.82 E-08$ & 2.67E-037 & $7.58 \mathrm{E}-03$ \\
\hline & Mound Plant & 2409 & $1.70 E-03$ & $2.50 E-03$ & $5.37 E-08$ & 7.44E-03 & $5.02 E-03$ \\
\hline & Lawrence Livermore & 1397 & $8.75 E-04$ & $1.26 \mathrm{E}-03$ & $1.68 \mathrm{E}-08$ & $8.54 E-043$ & $3.18 \mathrm{E}-03$ \\
\hline & SNL - Albuquerque & 191 & $1.35 E-04$ & $1.98 \mathrm{E}-04$ & $4.26 E-09$ & $5.90 E-043$ & $3.98 E-04$ \\
\hline & Paducah GDP & 165 & $1.16 \mathrm{E}-04$ & $1.71 E-04$ & $3.68 \mathrm{E}-09$ & $5.10 E-043$ & $3.44 E-04$ \\
\hline & ETEC & 104 & $6.51 E-05$ & $9.34 E-05$ & $1.25 \mathrm{E}-09$ & $6.36 E-052$ & $2.36 E-04$ \\
\hline & ITRI & 87 & $6.13 E-05$ & $9.02 E-05$ & $1.94 E-09$ & $2.69 \mathrm{E}-04]$ & $1.81 E-04$ \\
\hline & Portsmouth GDP & 77 & $5.43 E-05$ & $7.98 \mathrm{E}-05$ & $1.72 \mathrm{E}-09$ & $2.38 \mathrm{E}-04$ & 1. $60 \mathrm{E}-04$ \\
\hline & Pantex Plant & 53 & $3.73 E-05$ & $5.49 \mathrm{E}-05$ & $1.18 E-09$ & $1.64 \mathrm{E}-041$ & 1.10E-04 \\
\hline & Late Total & 10715 & $7.77 \mathrm{E}-03$ & $1.14 \mathrm{E}-02$ & $2.17 E-07$ & $2.45 \mathrm{E}-022$ & $2.51 E-02$ \\
\hline \multicolumn{8}{|c|}{ 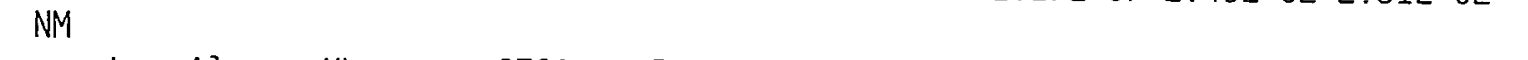 } \\
\hline & Los Alamos NL & 3791 & $5.47 \mathrm{E}-03$ & $7.88 \mathrm{E}-03$ & $5.54 E-08$ & $3.17 \mathrm{E}-033$ & $3.67 E-02$ \\
\hline & Mound Plant & 2409 & $4.94 \mathrm{E}-03$ & $7.47 E-03$ & $3.44 E-08$ & $6.05 E-033$ & $3.41 E-02$ \\
\hline & SNL - Albuquerque & 191 & $1.91 E-04$ & $2.80 \mathrm{E}-04$ & 2.13E-09 & 3.32E-04 1 & $1.23 E-03$ \\
\hline & Paducah GDP & 165 & $3.38 \mathrm{E}-04$ & $5.12 \mathrm{E}-04$ & 2.36E-09 & $4.14 \mathrm{E}-042$ & $2.34 E-03$ \\
\hline & ITRI & 87 & $8.69 E-05$ & $1.28 \mathrm{E}-04$ & $9.70 \mathrm{E}-10$ & $1.51 E-045$ & $5.59 E-04$ \\
\hline & Portsmouth GDP & 77 & $1.58 \mathrm{E}-04$ & $2.39 E-04$ & 1. $10 \mathrm{E}-09$ & $1.93 E-041$ & 1.09E-03 \\
\hline & Pantex Plant & 53 & $1.09 E-04$ & 1. $64 \mathrm{E}-04$ & $7.57 \mathrm{E}-10$ & 1.33E-04 7 & $7.51 E-04$ \\
\hline & ate Total & 6773 & 1. $13 \mathrm{E}-02$ & $1.67 \mathrm{E}-02$ & $9.71 E-08$ & $1.04 \mathrm{E}-027$ & $7.68 \mathrm{E}-02$ \\
\hline \multicolumn{8}{|c|}{ 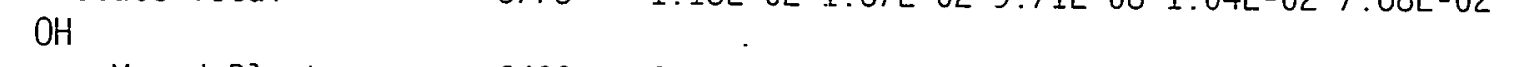 } \\
\hline & Mound Plant & 2409 & $9.54 E-04$ & $1.16 E-03$ & $7.35 E-08$ & $2.79 \mathrm{E}-031$ & 1. $36 \mathrm{E}-03$ \\
\hline & Portsmouth GDP & 77 & $4.38 E-05$ & $5.64 E-05$ & 4.69E-09 & $9.91 E-068$ & $3.50 E-05$ \\
\hline \multirow{2}{*}{\multicolumn{8}{|c|}{ 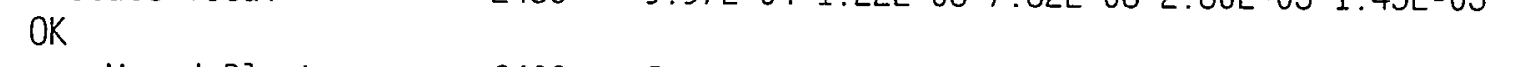 }} \\
\hline & & & & & & & \\
\hline & Mound Plant & 2409 & 5. 19E-03 & $7.19 E-03$ & $3.38 \mathrm{E}-07$ & 4.57E-033 & $3.67 E-02$ \\
\hline & Paducah GDP & 165 & $3.55 E-04$ & $4.92 E-04$ & $2.32 E-08$ & $3.13 E-042$ & $2.51 E-03$ \\
\hline & Portsmouth GDP & 77 & $1.66 E-04$ & $2.30 E-04$ & $1.08 \mathrm{E}-08$ & 1. $46 \mathrm{E}-041$ & $1.17 E-03$ \\
\hline & Eate Total & 2651 & $5.71 E-03$ & $7.91 E-03$ & $3.72 E-07$ & $5.03 E-034$ & 7.04E-02 \\
\hline
\end{tabular}

B. 40 


\begin{tabular}{|c|c|c|c|c|c|c|}
\hline \multirow[t]{3}{*}{ State } & \multirow[t]{3}{*}{ Generator } & \multirow{3}{*}{$\begin{array}{l}\text { No. } \\
\text { Ship- } \\
\text { ments }\end{array}$} & \multicolumn{3}{|c|}{ Cargo-Related Risks } & \multirow{2}{*}{$\begin{array}{l}\text { Vehicle-Related } \\
\text { Risks (Round-Tip) }\end{array}$} \\
\hline & & & \multicolumn{2}{|c|}{ Incident-Free } & \multirow{2}{*}{$\begin{array}{c}\text { Accident } \\
\text { Public }\end{array}$} & \\
\hline & & & Crew & Public & & \begin{tabular}{|l|l|} 
Emission & Accident \\
\end{tabular} \\
\hline \multicolumn{7}{|r|}{ (1) } \\
\hline & Mound Plant & 2409 & $2.33 \mathrm{E}-03$ & $3.49 \mathrm{E}-0$ & $2.96 E-07$ & $2.02 \mathrm{E}-03 \quad 1.78 \mathrm{E}-02$ \\
\hline & Paducah GDP & 165 & $1.60 \mathrm{E}-04$ & $2.39 \mathrm{E}-0$ & $2.03 E-08$ & $1.38 \mathrm{E}-04 \quad 1.22 \mathrm{E}-03$ \\
\hline & Portsmouth GDP & 77 & $7.46 \mathrm{E}-05$ & $1.12 \mathrm{E}-0$ & $9.45 E-09$ & $6.44 \mathrm{E}-05 \quad 5.70 \mathrm{E}-04$ \\
\hline & Pantex Plant & 53 & $2.84 \mathrm{E}-05$ & $4.07 \mathrm{E}-05$ & $4.02 E-09$ & 4. 44E-05 1.95E-04 \\
\hline & tate Total & 2704 & 2. $60 \mathrm{E}-03$ & $3.88 \mathrm{E}-03$ & $3.29 \mathrm{E}-07$ & $2.26 \mathrm{E}-03 \quad 1.98 \mathrm{E}-02$ \\
\hline \multicolumn{7}{|c|}{ 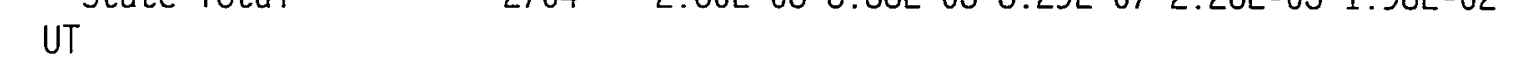 } \\
\hline & Rocky Flats Plant & 2441 & $4.65 E-03$ & $6.98 \mathrm{E}-03$ & $4.78 \mathrm{E}-08$ & $1.10 \mathrm{E}-033.40 \mathrm{E}-02$ \\
\hline & tate Total & 2441 & $4.65 \mathrm{E}-03$ & $6.98 \mathrm{E}-03$ & $4.78 \mathrm{E}-08$ & $1.10 E-03 \quad 3.40 E-02$ \\
\hline & ode Totals & & $6.47 \mathrm{E}-02$ & $9.40 \mathrm{E}-0$ & $4.17 \mathrm{E}-06$ & $6.93 \mathrm{E}-023.69 \mathrm{E}-01$ \\
\hline
\end{tabular}


This Page Intentionally Left Blank

B.42. 


\section{APPENDIX C \\ SELECTED RADTRAN 4 RISK ANALYSIS RESULTS SORTED BY LLW GENERATOR SITE AND THEN BY STATE IN WHICH IMPACTS OCCUR}


This Page Intentionally Left Blank 


\section{APPENDIX C \\ SELECTED RADTRAN 4 RISK ANA'LYSIS RESULTS SORTED BY LLW GENERATOR SITE AND THEN BY STATE IN WHICH IMPACTS OCCUR}

This appendix contains raw output data from the RADTRAN 4 risk analyses performed for the various shipping configuration options and waste loading cases in this study. The data provided in this appendix includes detailed state-level risk information for each shipping configuration. In these tables, the results are first sorted by LLW generator site and then the impacts in each state along the transportation corridor from the generator's site to the NTS are presented.

This appendix is organized as follows:

\section{High Waste Volume Cases}

Table C.1 Rail transport from LLW generators to Barstow

Table C.2 Rail transport from LLW generators to Caliente

Table C.3 Truck transport from LLW generators to NTS - Avoid Las Vegas

Table C.4 Truck transport from LLW generators to NTS - Travel through Las Vegas

\section{Low Waste Volume Cases}

Table C.5 Rail transport from LLW generators to Barstow

Table C.6 Rail transport from LLW generators to Caliente

Table C.7 Truck transport from LLW generators to NTS - Avoid Las Vegas

Table C.8 Truck transport from LLW generators to NTS - Travel through Las Vegas

Note that the truck transport segments from the intermodal facilities to NTS are not included in this appendix. The results for these legs are shown in Appendix B. Note also that the rail transportation impact results in this appendix do not include the non-linear component of the rail impacts. The non-linear component accounts for marshalling of the cars at the beginning and end of the trip (it is part of the stops dose in each case). Since all railcar shipments are equal in the analysis, each shipment (railcar) has a non-linear worker component of 3.25E-03 and a non-linear public component of 2.11E-03 person-rem/shipment. These are per shipment numbers; half can be attributed to the originating state and the other half to the destination state. 
Table C.1. Rail Transport From LLW Generators To Barstow - High Waste Volume Alternative Risks by Site (fatalities)

\begin{tabular}{|c|c|c|c|c|c|c|c|}
\hline \multirow[t]{3}{*}{ Site } & \multirow[t]{3}{*}{ State } & \multirow{3}{*}{$\begin{array}{c}\text { No. } \\
\text { of } \\
\text { Trips } \\
\end{array}$} & \multicolumn{3}{|c|}{ Cargo-Related Risks } & \multirow{2}{*}{\multicolumn{2}{|c|}{$\begin{array}{c}\text { Round-Trip Vehicle- } \\
\text { Related Risks }\end{array}$}} \\
\hline & & & \multicolumn{2}{|c|}{ Incident-Free } & \multirow{2}{*}{$\begin{array}{l}\text { Accident } \\
\text { Public }\end{array}$} & & \\
\hline & & & Crew & Public & & Emission & Accidént \\
\hline \multirow[t]{9}{*}{$A N L-E$} & $A Z$ & 176 & $1.3 E-04$ & 1. $0 E-04$ & 1.2E-09 & $1.7 E-04$ & $2.4 E-03$ \\
\hline & $\mathrm{CA}$ & 176 & $6.0 E-05$ & $3.3 E-05$ & $3.9 E-09$ & $7.4 E-06$ & $3.6 \mathrm{E}-03$ \\
\hline & IA & 176 & $7.3 E-06$ & $5.0 E-06$ & $8.9 E-09$ & $0.0 E+00$ & $2.9 \mathrm{E}-03$ \\
\hline & IL & 176 & $6.6 \mathrm{E}-05$ & $9.0 E-05$ & $1.2 \mathrm{E}-07$ & $1.9 E-04$ & $1.5 E-04$ \\
\hline & KS & 176 & $9.4 E-05$ & 1. $3 E-04$ & $2.8 \mathrm{E}-08$ & $3.6 E-04$ & $1.6 \mathrm{E}-03$ \\
\hline & MO & 176 & $6.9 E-05$ & $7.6 \mathrm{E}-05$ & $9.9 E-09$ & $1.9 E-04$ & 1. $4 \mathrm{E}-03$ \\
\hline & NM & 176 & $1.4 E-04$ & $8.1 E-05$ & $5.4 \mathrm{E}-10$ & $5.2 \mathrm{E}-05$ & $1.6 \mathrm{E}-03$ \\
\hline & OK & 176 & $3.9 E-05$ & 1.9E-05 & $3.9 E-09$ & $0.0 \mathrm{E}+00$ & $1.5 \mathrm{E}-03$ \\
\hline & TX & 176 & $7.2 E-05$ & $7.1 \mathrm{E}-05$ & 7.5E-09 & $5.9 E-05$ & $3.1 E-03$ \\
\hline Site & Total & 176 & $6.7 E-04$ & $6.1 \mathrm{E}-04$ & 1.9E-07 & 1.0E-03 & $1.8 E-02$ \\
\hline \multirow[t]{14}{*}{ BNL } & $A Z$ & 446 & $3.3 E-04$ & $2.6 \mathrm{E}-04$ & 2.9E-09 & 4. $3 E-04$ & $6.0 \mathrm{E}-03$ \\
\hline & $\mathrm{CA}$ & 446 & $1.5 \mathrm{E}-04$ & $8.2 E-05$ & $9.8 \mathrm{E}-09$ & $1.9 \mathrm{E}-05$ & $9.2 \mathrm{E}-03$ \\
\hline & IA & 446 & $1.9 E-05$ & 1. $3 E-05$ & $2.3 E-08$ & $0.0 \mathrm{E}+00$ & $8.2 E-03$ \\
\hline & IL & 446 & $1.9 E-04$ & $9.2 \mathrm{E}-04$ & $3.3 E-07$ & 4.1E-03 & $6.0 \mathrm{E}-03$ \\
\hline & IN & 446 & $1.2 E-04$ & $6.7 E-04$ & $7.0 \mathrm{E}-08$ & 2.7E-03 & $3.8 E-04$ \\
\hline & KS & 446 & $2.4 \mathrm{E}-04$ & 3. $3 E-04$ & $7.2 E-08$ & $9.1 E-04$ & 4. $0 \mathrm{E}-03$ \\
\hline & MO & 446 & $1.8 \mathrm{E}-04$ & 1.9E-04 & $2.5 E-08$ & $4.9 \mathrm{E}-04$ & $3.4 \mathrm{E}-03$ \\
\hline & NM & 446 & $3.4 E-04$ & $2.1 E-04$ & 1. $4 \mathrm{E}-09$ & 1. $3 \mathrm{E}-04$ & 4. $1 E-03$ \\
\hline & NY & 446 & $4.9 E-04$ & $3.5 E-03$ & $6.0 \mathrm{E}-07$ & 1. $3 \mathrm{E}-02$ & $5.1 E-02$ \\
\hline & $\mathrm{OH}$ & 446 & 2.1E-04 & 1. $3 E-03$ & $5.9 E-08$ & 5. $0 E-03$ & 7. $3 \mathrm{E}-03$ \\
\hline & OK & 446 & $9.9 \mathrm{E}-05$ & 4.9E-05 & $9.9 E-09$ & $0.0 E+00$ & $3.8 E-03$ \\
\hline & PA & 446 & $3.9 E-05$ & $2.9 E-04$ & $2.2 \mathrm{E}-08$ & $1.3 E-03$ & $1.5 E-03$ \\
\hline & $T X$ & 446 & $1.8 \mathrm{E}-04$ & $1.8 \mathrm{E}-04$ & 1.9E-08 & $1.5 E-04$ & 7. $7 \mathrm{E}-03$ \\
\hline & Total & 446 & 2. $6 \mathrm{E}-03$ & 7. $9 \mathrm{E}-03$ & $1.2 \mathrm{E}-06$ & $2.8 \mathrm{E}-02$ & 1.1E-01 \\
\hline \multirow[t]{10}{*}{ FEMP } & $A Z$ & 1046 & $7.7 E-04$ & 6. IE-04 & $6.9 E-09$ & 1.0E-03 & 1. $4 \mathrm{E}-02$ \\
\hline & CA & 1046 & $3.6 \mathrm{E}-04$ & 1.9E-04 & $2.3 E-08$ & 4. $4 E-05$ & $2.2 \mathrm{E}-02$ \\
\hline & IL & 1046 & 3. $0 E-04$ & $5.7 E-04$ & $5.2 \mathrm{E}-07$ & 1. $4 \mathrm{E}-03$ & 1. $3 \mathrm{E}-02$ \\
\hline & IN & 1046 & $3.7 E-04$ & $4.2 E-04$ & 2. $3 E-07$ & 7. $4 \mathrm{E}-04$ & $1.8 \mathrm{E}-02$ \\
\hline & KS & 1046 & $5.6 \mathrm{E}-04$ & $7.6 \mathrm{E}-04$ & $1.7 \mathrm{E}-07$ & 2.1E-03 & $9.4 \mathrm{E}-03$ \\
\hline & MO & 1046 & $6.4 E-04$ & 8.9E-04 & $9.6 E-08$ & $2.5 E-03$ & 1. $3 E-02$ \\
\hline & NM & 1046 & 8.1E-04 & $4.8 \mathrm{E}-04$ & $3.2 E-09$ & $3.1 E-04$ & $9.6 E-03$ \\
\hline & $\mathrm{OH}$ & 1046 & 1. $4 \mathrm{E}-04$ & $9.8 E-04$ & $4.4 E-08$ & $3.6 \mathrm{E}-03$ & $5.0 \mathrm{E}-03$ \\
\hline & OK & 1046 & $2.3 E-04$ & 1.1E-04 & 2. $3 E-08$ & $0.0 E+00$ & $9.0 \mathrm{E}-03$ \\
\hline & TX & 1046 & $4.3 E-04$ & 4. $2 E-04$ & $4.5 E-08$ & $3.5 E-04$ & 1.8E-02 \\
\hline Site & Total & 1046 & $4.6 E-03$ & 5. $4 \mathrm{E}-03$ & $1.2 E-06$ & 1. $2 \mathrm{E}-02$ & 1.3E-01 \\
\hline \multirow[t]{3}{*}{ INEL } & $C A$ & 311 & $3.1 E-04$ & 1. $4 \mathrm{E}-03$ & $6.1 E-08$ & $5.8 E-03$ & 1.9E-02 \\
\hline & ID & 311 & $7.5 \mathrm{E}-05$ & $9.3 \mathrm{E}-05$ & 8. 3E-09 & $3.1 E-04$ & 2. $3 E-03$ \\
\hline & NV & 311 & $2.6 E-04$ & 2.7E-04 & $8.1 E-10$ & 7. $0 \mathrm{E}-04$ & $1.2 \mathrm{E}-03$ \\
\hline
\end{tabular}




\begin{tabular}{|c|c|c|c|c|c|c|c|}
\hline \multirow[t]{3}{*}{ Site } & \multirow[t]{3}{*}{ State } & \multirow{3}{*}{$\begin{array}{c}\text { No. } \\
\text { of } \\
\text { Trips }\end{array}$} & \multicolumn{3}{|c|}{ Cargo-Related Risks } & \multirow{2}{*}{\multicolumn{2}{|c|}{$\begin{array}{c}\text { Round-Trip Vehicle- } \\
\text { Related Risks }\end{array}$}} \\
\hline & & & \multicolumn{2}{|c|}{ Incident-Free } & \multirow{2}{*}{$\begin{array}{l}\text { Accident } \\
\text { Public } \\
\end{array}$} & & \\
\hline & & & Crew & Public & & Emission & Accraen $\tau$ \\
\hline & UT & 311 & 1.0E-04 & $5.8 \mathrm{E}-05$ & $1.6 \mathrm{E}-09$ & $0.0 E+00$ & 4. $4 \mathrm{E}-03$ \\
\hline Site & Total & 311 & $7.5 E-04$ & $1.8 \mathrm{E}-03$ & $7.2 \mathrm{E}-08$ & $6.8 \mathrm{E}-03$ & $2.7 E-02$ \\
\hline LLNL & $C A$ & 466 & $3.5 E-04$ & 1.3E-03 & $6.1 E-08$ & $5.4 \mathrm{E}-03$ & $2.1 E-02$ \\
\hline Site & Total & 466 & $3.5 E-04$ & 1.3E-03 & $6.1 E-08$ & $5.4 \mathrm{E}-03$ & 2.1E-02 \\
\hline LANL & $A Z$ & 1277 & $9.4 \mathrm{E}-04$ & 7. $4 \mathrm{E}-04$ & $8.4 E-09$ & $1.2 \mathrm{E}-03$ & 1.7E-02 \\
\hline & $C A$ & 1277 & 4. $4 E-04$ & $2.4 E-04$ & $2.8 E-08$ & $5.3 E-05$ & $2.6 E-02$ \\
\hline & NM & 1277 & $4.6 E-04$ & $2.9 \mathrm{E}-04$ & $2.1 E-09$ & $2.1 E-04$ & $5.5 \mathrm{E}-03$ \\
\hline Site & Total & 1277 & $1.8 \mathrm{E}-03$ & 1. $3 \mathrm{E}-03$ & $3.9 E-08$ & $1.5 \mathrm{E}-03$ & 4.9E-02 \\
\hline Mound & $A Z$ & 803 & $5.9 E-04$ & 4.7E-04 & 5. 3E-09 & 7.7E-04 & 1.1E-02 \\
\hline & $C A$ & 803 & $2.8 \mathrm{E}-04$ & $1.5 \mathrm{E}-04$ & $1.8 \mathrm{E}-08$ & $3.4 E-05$ & 1.7E-02 \\
\hline & IL & 803 & $2.5 E-04$ & 4. 3E-04 & $4.5 E-07$ & 1. $2 E-03$ & 1.1E-02 \\
\hline & IN & 803 & $2.4 \mathrm{E}-04$ & 9. $4 \mathrm{E}-04$ & 1.2E-07 & $3.2 E-03$ & 1.2E-02 \\
\hline & KS & 803 & 4. $3 E-04$ & $5.9 \mathrm{E}-04$ & 1. $3 \mathrm{E}-07$ & $1.7 E-03$ & 7.2E-03 \\
\hline & MO & 803 & 5.0E-04 & 7. $3 E-04$ & 7.5E-08 & $2.1 E-03$ & $9.8 E-03$ \\
\hline & NM & 803 & $6.2 E-04$ & $3.7 E-04$ & 2.5E-09 & $2.4 \mathrm{E}-04$ & $7.4 \mathrm{E}-03$ \\
\hline & $\mathrm{OH}$ & 803 & 3. $0 E-04$ & 1.2E-03 & $8.6 E-08$ & 4. $4 E-03$ & 1.1E-02 \\
\hline & OK & 803 & $1.8 \mathrm{E}-04$ & $8.8 E-05$ & $1.8 \mathrm{E}-08$ & $0.0 \mathrm{E}+00$ & $6.9 E-03$ \\
\hline & $T X$ & 803 & $3.3 E-04$ & $3.2 E-04$ & $3.4 \mathrm{E}-08$ & 2.7E-04 & 1. $4 \mathrm{E}-02$ \\
\hline Site & Total & 803 & $3.7 E-03$ & $5.3 E-03$ & $9.4 \mathrm{E}-07$ & 1. $4 \mathrm{E}-02$ & 1. $1 E-01$ \\
\hline ORR & $A L$ & 3283 & $9.9 E-04$ & 1. $5 \mathrm{E}-03$ & $5.4 \mathrm{E}-08$ & 2.3E-03 & $3.6 \mathrm{E}-02$ \\
\hline & $A R$ & 3283 & $8.6 \mathrm{E}-04$ & $8.4 E-04$ & 1.2E-07 & $8.2 \mathrm{E}-04$ & 4. $4 E-02$ \\
\hline & $A Z$ & 3283 & $2.4 \mathrm{E}-03$ & 1.9E-03 & $2.2 E-08$ & $3.2 E-03$ & 4.0E-02 \\
\hline & $C A$ & 3283 & 1. IE-03 & $6.1 E-04$ & 7.2E-08 & 1. $4 \mathrm{E}-04$ & $6.7 E-02$ \\
\hline & GA & 3283 & 1.7E-05 & $8.8 \mathrm{E}-06$ & $5.4 E-10$ & $0.0 E+00$ & 4. $6 E-04$ \\
\hline & MO & 3283 & $1.5 E-03$ & $1.7 \mathrm{E}-03$ & 2.2E-07 & $2.5 \mathrm{E}-03$ & 1. $4 \mathrm{E}-02$ \\
\hline & MS & 3283 & 2.0E-04 & 1.9E-04 & $4.5 E-08$ & $0.0 \mathrm{E}+00$ & 3. $0 E-02$ \\
\hline & NM & 3283 & $2.5 \mathrm{E}-03$ & 1.5E-03 & 1.0E-08 & $9.6 E-04$ & $3.0 \mathrm{E}-02$ \\
\hline & OK & 3283 & 2. $2 E-03$ & 2.7E-03 & $2.9 E-07$ & $5.4 \mathrm{E}-03$ & $8.5 E-02$ \\
\hline & TN & 3283 & 1. $3 \mathrm{E}-03$ & $3.8 \mathrm{E}-03$ & 2.0E-07 & 1. $2 E-02$ & $3.9 \mathrm{E}-02$ \\
\hline & TX & 3283 & 1. $4 E-03$ & 1. $3 E-03$ & 1. $4 \mathrm{E}-07$ & 1.1E-03 & 5.7E-02 \\
\hline Site & Total & 3283 & $1.4 \mathrm{E}-02$ & 1. $6 \mathrm{E}-02$ & 1.2E-06 & $2.8 E-02$ & 4. $4 \mathrm{E}-01$ \\
\hline RFETS & $\mathrm{AZ}$ & 814 & 6.0E-04 & 4.7E-04 & 5. $4 \mathrm{E}-09$ & 7. $8 \mathrm{E}-04$ & 1.1E-02 \\
\hline & $C A$ & 814 & $2.8 \mathrm{E}-04$ & 1. $5 E-04$ & 1. $8 \mathrm{E}-08$ & $3.4 \mathrm{E}-05$ & $1.7 \mathrm{E}-02$ \\
\hline & $\mathrm{CO}$ & 814 & 4. $0 \mathrm{E}-04$ & 1. $4 \mathrm{E}-03$ & 5. $3 E-08$ & $5.4 \mathrm{E}-03$ & 7. $0 \mathrm{E}-03$ \\
\hline & NM & 814 & $6.7 \mathrm{E}-04$ & 4. 3E-04 & $2.8 \mathrm{E}-09$ & 4.1E-04 & 7.9E-03 \\
\hline Site & Total & 814 & 1.9E-03 & 2. $4 \mathrm{E}-03$ & 7. $9 \mathrm{E}-08$ & $6.6 \mathrm{E}-03$ & 4. $3 E-02$ \\
\hline
\end{tabular}


Table C.2. Rail Transport From LLW Generators To Caliente - High Waste Volume Alternative Risks by Site (fatalities)

\begin{tabular}{|c|c|c|c|c|c|c|c|}
\hline \multirow[t]{3}{*}{ Site } & \multirow[t]{3}{*}{ State } & \multirow{3}{*}{$\begin{array}{c}\text { No. } \\
\text { of } \\
\text { Trips } \\
\end{array}$} & \multicolumn{3}{|c|}{ Cargo-Related Risks } & \multirow{2}{*}{\multicolumn{2}{|c|}{$\begin{array}{c}\text { Round-Trip Vehicle- } \\
\text { Related Risks }\end{array}$}} \\
\hline & & & \multicolumn{2}{|c|}{ Incident-Free } & \multirow{2}{*}{$\begin{array}{l}\text { Accident } \\
\text { Public }\end{array}$} & & \\
\hline & & & Crew & Public & & Emission & Accident \\
\hline \multirow[t]{6}{*}{$A N L-E$} & $\mathrm{CO}$ & 176 & 1. $6 \mathrm{E}-04$ & 2. $2 \mathrm{E}-04$ & 1.0E-08 & $6.0 \mathrm{E}-04$ & $2.7 E-03$ \\
\hline & IA & 176 & $9.5 E-05$ & 1. $4 \mathrm{E}-04$ & $1.3 \mathrm{E}-07$ & $3.2 E-04$ & $2.6 E-03$ \\
\hline & IL & 176 & $6.0 E-05$ & $9.5 E-05$ & 1. $1 \mathrm{E}-07$ & $2.4 \mathrm{E}-04$ & $2.0 \mathrm{E}-03$ \\
\hline & NE & 176 & $1.3 E-04$ & $1.5 E-04$ & $5.6 E-08$ & $3.5 E-04$ & $1.6 \mathrm{E}-03$ \\
\hline & NV & 176 & $1.4 E-05$ & $7.1 E-06$ & 3. $1 E-12$ & $0.0 \mathrm{E}+00$ & $6.2 E-05$ \\
\hline & UT & 176 & $1.5 \mathrm{E}-04$ & 1.1E-04 & $3.1 E-09$ & $9.6 E-05$ & $6.6 \mathrm{E}-03$ \\
\hline \multicolumn{2}{|c|}{ Site Total } & & $6.1 E-04$ & 7. $2 \mathrm{E}-04$ & $3.1 E-07$ & $1.6 E-03$ & $1.6 E-02$ \\
\hline \multirow[t]{11}{*}{ BNL } & $\mathrm{CO}$ & 446 & $8.4 \mathrm{E}-06$ & $7.1 \mathrm{E}-06$ & 4. $4 E-10$ & $0.0 E+00$ & 1. $4 \mathrm{E}-04$ \\
\hline & IA & 446 & $2.8 E-04$ & $6.4 \mathrm{E}-04$ & $3.7 E-07$ & 2.0E-03 & $5.7 E-03$ \\
\hline & IL & 446 & 1. $3 E-04$ & $1.0 E-03$ & $2.1 E-07$ & $4.6 E-03$ & $6.0 \mathrm{E}-03$ \\
\hline & IN & 446 & $1.2 E-04$ & $6.7 E-04$ & 7.0E-08 & $2.7 E-03$ & $5.9 E-03$ \\
\hline & $N E$ & 446 & $3.8 E-04$ & $3.7 E-04$ & $1.7 E-07$ & $5.6 E-04$ & $4.8 E-03$ \\
\hline & NV & 446 & $3.5 E-05$ & $1.8 \mathrm{E}-05$ & $7.9 E-12$ & $0.0 E+00$ & $1.6 \mathrm{E}-04$ \\
\hline & NY & 446 & $4.9 E-04$ & $3.5 E-03$ & $6.0 \mathrm{E}-07$ & 1. $3 \mathrm{E}-02$ & 5.1E-02 \\
\hline & $\mathrm{OH}$ & 446 & 2.1E-04 & 1. $3 E-03$ & $5.9 E-08$ & $5.0 E-03$ & 7. $3 E-03$ \\
\hline & $P A$ & 446 & $3.9 E-05$ & $2.9 E-04$ & $2.2 \mathrm{E}-08$ & 1. $3 E-03$ & $1.5 E-03$ \\
\hline & UT & 446 & $3.3 E-04$ & $5.1 E-04$ & 2. $0 \mathrm{E}-08$ & 1. $6 \mathrm{E}-03$ & $1.4 E-02$ \\
\hline & $W Y$ & 446 & $3.7 E-04$ & $2.6 E-04$ & 4.0E-09 & $3.0 E-04$ & $1.5 E-03$ \\
\hline Site & Total & & $2.4 E-03$ & $8.6 E-03$ & $1.5 E-06$ & $3.0 E-02$ & $9.8 \mathrm{E}-02$ \\
\hline \multirow[t]{10}{*}{ FEMP } & $\mathrm{CO}$ & 1046 & 2.0E-05 & $1.7 E-05$ & 1.0E-09 & $0.0 \mathrm{E}+00$ & $3.4 E-04$ \\
\hline & IL & 1046 & $2.9 \mathrm{E}-04$ & $5.3 E-04$ & $5.0 \mathrm{E}-07$ & 1.2E-03 & 1. $3 \mathrm{E}-02$ \\
\hline & IN & 1046 & $3.7 E-04$ & $4.4 E-04$ & $2.3 E-07$ & $7.4 \mathrm{E}-04$ & $1.8 \mathrm{E}-02$ \\
\hline & KS & 1046 & $3.4 E-04$ & $3.5 E-04$ & 1.0E-07 & $5.3 E-04$ & $5.8 E-03$ \\
\hline & MO & 1046 & $6.0 \mathrm{E}-04$ & 1. $4 \mathrm{E}-03$ & 1. $0 \mathrm{E}-07$ & $4.6 E-03$ & $1.2 \mathrm{E}-02$ \\
\hline & NE & 1046 & $7.9 E-04$ & $5.9 E-04$ & $3.5 E-07$ & $4.8 E-04$ & 1.0E-02 \\
\hline & NV & 1046 & $8.1 E-05$ & 4.2E-05 & $1.9 \mathrm{E}-11$ & $0.0 E+00$ & $3.7 E-04$ \\
\hline & $\mathrm{OH}$ & 1046 & 1. $4 \mathrm{E}-04$ & $9.9 \mathrm{E}-04$ & 4. $4 \mathrm{E}-08$ & $3.6 E-03$ & $5.0 \mathrm{E}-03$ \\
\hline & UT & 1046 & $7.7 \mathrm{E}-04$ & 1. $2 \mathrm{E}-03$ & $4.7 E-08$ & $3.8 E-03$ & 3. $3 E-02$ \\
\hline & WY & 1046 & $8.6 E-04$ & $6.1 E-04$ & $9.5 E-09$ & $7.0 \mathrm{E}-04$ & $3.5 E-03$ \\
\hline \multicolumn{2}{|c|}{ Site Total } & & 4. $3 E-03$ & $6.2 \mathrm{E}-03$ & 1. $4 \mathrm{E}-06$ & $1.6 \mathrm{E}-02$ & 1. $0 E-01$ \\
\hline \multirow[t]{3}{*}{ INEL } & ID & 311 & $7.5 \mathrm{E}-05$ & $9.7 \mathrm{E}-05$ & 8. $3 E-09$ & $3.1 E-04$ & $2.3 E-03$ \\
\hline & NV & 311 & $2.4 \mathrm{E}-05$ & 1. $3 \mathrm{E}-05$ & $5.5 \mathrm{E}-12$ & $0.0 E+00$ & 1. $1 E-04$ \\
\hline & UT & 311 & $2.2 E-04$ & $3.3 E-04$ & 1. $3 E-08$ & $9.2 \mathrm{E}-04$ & $9.7 E-03$ \\
\hline Site & Total & & $3.2 E-04$ & $4.3 E-04$ & $2.2 E-08$ & 1.2E-03 & 1.2E-02 \\
\hline
\end{tabular}




\begin{tabular}{|c|c|c|c|c|c|c|c|}
\hline \multirow[t]{3}{*}{ Site } & \multirow[t]{3}{*}{ State } & \multirow{3}{*}{$\begin{array}{c}\text { No. } \\
\text { of } \\
\text { Trips }\end{array}$} & \multicolumn{3}{|c|}{ Cargo-Related Risks } & \multirow{2}{*}{\multicolumn{2}{|c|}{$\begin{array}{c}\text { Round-Trip Vehicle- } \\
\text { Related Risks }\end{array}$}} \\
\hline & & & \multicolumn{2}{|c|}{ Incident-Free } & \multirow{2}{*}{$\begin{array}{l}\text { Accident } \\
\text { Public } \\
\end{array}$} & & \\
\hline & & & Crew & Public & & Emission & Accident \\
\hline \multirow[t]{3}{*}{ LLNL } & CA & 466 & $1.8 \mathrm{E}-04$ & 1.2E-03 & $4.9 E-08$ & $5.4 \mathrm{E}-03$ & 1. $1 E-02$ \\
\hline & NV & 466 & 4. $4 E-04$ & 4.5E-04 & $1.2 E-09$ & $1.1 E-03$ & 2.0E-03 \\
\hline & UT & 466 & $3.3 E-04$ & $1.8 \mathrm{E}-04$ & $2.5 E-09$ & $0.0 \mathrm{E}+00$ & 1. $4 \mathrm{E}-02$ \\
\hline \multicolumn{2}{|c|}{ Site Total } & & $9.5 E-04$ & 1.9E-03 & $5.3 \mathrm{E}-08$ & $6.5 E-03$ & $2.7 E-02$ \\
\hline \multirow[t]{4}{*}{ LANL } & $\mathrm{CO}$ & 1277 & $1.3 E-03$ & $2.5 E-03$ & $1.1 \mathrm{E}-07$ & $7.4 E-03$ & $2.2 E-02$ \\
\hline & NM & 1277 & $5.8 E-04$ & $4.0 E-04$ & 2.3E-09 & $3.7 E-04$ & $4.5 E-04$ \\
\hline & NV & 1277 & $9.9 E-05$ & $5.2 E-05$ & $2.3 E-11$ & $0.0 \mathrm{E}+00$ & $6.9 E-03$ \\
\hline & UT & 1277 & $1.1 E-03$ & $8.2 E-04$ & 2.2E-08 & $7.0 \mathrm{E}-04$ & $4.8 E-02$ \\
\hline \multicolumn{2}{|c|}{ Site Total } & & $3.1 E-03$ & $3.8 E-03$ & $1.4 \mathrm{E}-07$ & $8.4 \mathrm{E}-03$ & $7.8 \mathrm{E}-02$ \\
\hline \multirow[t]{9}{*}{ Mound } & $\mathrm{CO}$ & 803 & $1.5 E-05$ & $1.3 E-05$ & $7.8 \mathrm{E}-10$ & $0.0 \mathrm{E}+00$ & $2.6 E-04$ \\
\hline & IA & 803 & $5.1 E-04$ & 1.2E-03 & $6.6 \mathrm{E}-07$ & $3.6 \mathrm{E}-03$ & 1. $0 \mathrm{E}-02$ \\
\hline & IL & 803 & $2.3 E-04$ & $2.7 E-03$ & 4.1E-07 & $1.2 \mathrm{E}-02$ & 1. $1 E-02$ \\
\hline & IN & 803 & $2.2 E-04$ & $9.8 \mathrm{E}-04$ & 1.3E-07 & $3.5 E-03$ & 1. $1 \mathrm{E}-02$ \\
\hline & NE & 803 & $6.8 E-04$ & $6.6 E-04$ & 3.0E-07 & $1.0 \mathrm{E}-03$ & $8.6 E-03$ \\
\hline & NV & 803 & $6.2 E-05$ & $3.3 E-05$ & $1.4 \mathrm{E}-11$ & $0.0 E+00$ & $2.8 \mathrm{E}-04$ \\
\hline & $\mathrm{OH}$ & 803 & $4.2 E-04$ & $1.7 E-03$ & 1. $2 \mathrm{E}-07$ & $5.9 E-03$ & 1. $5 \mathrm{E}-02$ \\
\hline & UT & 803 & $5.9 E-04$ & $9.2 E-04$ & $3.6 E-08$ & $2.9 E-03$ & $2.6 \mathrm{E}-02$ \\
\hline & WY & 803 & $6.6 E-04$ & $4.7 E-04$ & 7. $3 \mathrm{E}-09$ & $5.4 E-04$ & $2.7 E-03$ \\
\hline \multicolumn{2}{|c|}{ Site Tota } & & $3.4 \mathrm{E}-03$ & $8.7 E-03$ & $1.6 \mathrm{E}-06$ & $2.9 E-02$ & $8.4 E-02$ \\
\hline \multirow[t]{11}{*}{ ORR } & $\mathrm{CO}$ & 3283 & $6.2 E-05$ & $5.2 E-05$ & $3.2 E-09$ & $0.0 E+00$ & 1. $1 E-03$ \\
\hline & IL & 3283 & $9.7 E-04$ & $2: 7 E-03$ & $1.7 E-06$ & $9.5 E-03$ & 4. $3 E-02$ \\
\hline & IN & 3283 & $7.6 E-04$ & 1.0E-03 & $4.8 E-07$ & $2.3 E-03$ & $3.7 \mathrm{E}-02$ \\
\hline & KS & 3283 & 1. $1 E-03$ & $1.1 E-03$ & $3.2 E-07$ & $1.7 E-03$ & $1.8 \mathrm{E}-02$ \\
\hline & KY & 3283 & 1. $3 E-03$ & $2.5 E-03$ & 1.2E-07 & $8.7 E-03$ & $3.1 E-02$ \\
\hline & MO & 3283 & 1.7E-03 & $3.6 E-03$ & $2.8 \mathrm{E}-07$ & 1. $1 \mathrm{E}-02$ & 3. 3E-02 \\
\hline & $N E$ & 3283 & $2.5 E-03$ & 1.9E-03 & 1.1E-06 & 1.5E-03 & $3.1 E-02$ \\
\hline & NV & 3283 & $2.6 E-04$ & 1. $3 \mathrm{E}-04$ & $5.8 E-11$ & $0.0 \mathrm{E}+00$ & $1.2 \mathrm{E}-03$ \\
\hline & TN & 3283 & $4.8 E-04$ & 4.0E-04 & $3.8 \mathrm{E}-08$ & 1. $4 \mathrm{E}-04$ & $1.5 \mathrm{E}-02$ \\
\hline & UT & 3283 & $2.4 \mathrm{E}-03$ & $3.8 E-03$ & $1.5 \mathrm{E}-07$ & 1.2E-02 & 1. $0 \mathrm{E}-01$ \\
\hline & WY & 3283 & $2.7 \mathrm{E}-03$ & 1.9E-03 & 3.0E-08 & $2.2 E-03$ & 1. $1 E-02$ \\
\hline \multicolumn{2}{|c|}{ Site Total } & & 1. $4 \mathrm{E}-02$ & 1.9E-02 & $4.2 E-06$ & $4.9 E-02$ & 3. 3E-01 \\
\hline \multirow[t]{4}{*}{ RFETS } & $\mathrm{CO}$ & 814 & $4.2 E-04$ & $3.3 E-04$ & $2.1 \mathrm{E}-08$ & $2.4 \mathrm{E}-04$ & $7.3 E-03$ \\
\hline & NV & 814 & $6.3 E-05$ & $3.3 E-05$ & $1.5 \mathrm{E}-11$ & $0.0 \mathrm{E}+00$ & $2.9 E-04$ \\
\hline & UT & 814 & $7.1 E-04$ & $5.3 E-04$ & 1. $4 \mathrm{E}-08$ & 4. $4 \mathrm{E}-04$ & $3.1 E-02$ \\
\hline & Total & & 1.2E-03 & $8.9 E-04$ & $3.6 E-08$ & $6.8 E-04$ & $3.8 \mathrm{E}-02$ \\
\hline
\end{tabular}


Table C.3. Truck Transport From LLW Generators To NTS - High Waste Volume Avoid Las Vegas

Alternative Risks by Site (fatalities)

\begin{tabular}{|c|c|c|c|c|c|c|c|}
\hline \multirow[t]{3}{*}{ Site } & \multirow[t]{3}{*}{ State } & \multirow{3}{*}{$\begin{array}{c}\text { No. } \\
\text { of } \\
\text { Trips }\end{array}$} & \multicolumn{3}{|c|}{ Cargo-Related Risks } & \multirow{2}{*}{\multicolumn{2}{|c|}{$\begin{array}{c}\text { Round-Trip Vehicle- } \\
\text { Related Risks } \\
\end{array}$}} \\
\hline & & & \multicolumn{2}{|c|}{ Incident-Free } & \multirow{2}{*}{$\begin{array}{l}\text { Accident } \\
\text { Public } \\
\end{array}$} & & \\
\hline & & & Crew & Public & & Emission & Accident \\
\hline \multirow[t]{6}{*}{ Ames } & $A Z$ & 5 & $7.2 \mathrm{E}-07$ & $1.1 E-06$ & $2.5 E-12$ & $0.0 \mathrm{E}+00$ & 4. $4 \mathrm{E}-06$ \\
\hline & $\mathrm{CO}$ & 5 & 1. $3 E-05$ & $1.8 \mathrm{E}-05$ & $8.8 E-10$ & $4.2 E-06$ & $8.3 E-05$ \\
\hline & IA & 5 & $5.1 E-06$ & 7.0E-06 & 1.2E-09 & $3.4 E-06$ & $2.6 \mathrm{E}-05$ \\
\hline & NE & 5 & $9.7 E-06$ & $1.5 E-05$ & $3.3 E-09$ & $9.7 E-06$ & $7.8 \mathrm{E}-05$ \\
\hline & NV & 5 & $1.1 \mathrm{E}-05$ & $1.7 E-05$ & $1.6 \mathrm{E}-11$ & $0.0 \mathrm{E}+00$ & 1.2E-04 \\
\hline & UT & 5 & $9.5 E-06$ & $1.4 E-05$ & $9.8 \mathrm{E}-11$ & $2.3 \mathrm{E}-06$ & $7.0 \mathrm{E}-05$ \\
\hline Site & Total & & $4.9 E-05$ & $7.2 E-05$ & $5.5 E-09$ & $1.9 E-05$ & $3.8 E-04$ \\
\hline \multirow[t]{7}{*}{ ANL $-E$} & $A Z$ & 526 & $7.6 \mathrm{E}-05$ & 1. $2 E-04$ & $2.6 E-10$ & $0.0 \mathrm{E}+00$ & $4.6 E-04$ \\
\hline & $\mathrm{CO}$ & 526 & 1. $3 E-03$ & 1. $9 \mathrm{E}-03$ & $9.2 E-08$ & $4.4 E-04$ & $8.8 E-03$ \\
\hline & IA & 526 & $9.1 E-04$ & $1.3 E-03$ & $2.3 E-07$ & $6.8 \mathrm{E}-05$ & 4. $9 \mathrm{E}-03$ \\
\hline & IL & 526 & $4.8 E-04$ & $6.6 E-04$ & 2.0E-07 & $3.6 E-04$ & $2.1 E-03$ \\
\hline & $N E$ & 526 & 1. $.0 \mathrm{E}-03$ & $1.5 E-03$ & $3.5 E-07$ & 1. $.0 \mathrm{E}-03$ & 8.2E-03 \\
\hline & NV & 526 & 1.2E-03 & $1.8 \mathrm{E}-03$ & $1.7 E-09$ & $0.0 E+00$ & $1.3 \mathrm{E}-02$ \\
\hline & UT & 526 & $1.0 E-03$ & 1. $5 E-03$ & 1. $.0 \mathrm{E}-08$ & $2.4 \mathrm{E}-04$ & 7. $3 E-03$ \\
\hline Site & Total & & $6.0 E-03$ & $8.8 E-03$ & $8.8 E-07$ & 2.1E-03 & 4. $4 \mathrm{E}-02$ \\
\hline \multirow[t]{10}{*}{$\mathrm{BCL}$} & $A Z$ & 345 & $6.7 E-04$ & 1. $0 \mathrm{E}-03$ & $4.5 E-09$ & $1.9 E-04$ & $3.8 \mathrm{E}-03$ \\
\hline & CA & 345 & $5.4 \mathrm{E}-04$ & $8.3 E-04$ & 1. $4 \mathrm{E}-08$ & $1.1 E-04$ & $2.4 E-03$ \\
\hline & IL & 345 & $3.3 E-04$ & $4.5 E-04$ & 1. $5 E-07$ & $1.1 E-04$ & $1.5 E-03$ \\
\hline & IN & 345 & $3.6 E-04$ & $4.9 E-04$ & $9.0 E-08$ & $6.3 E-04$ & 1.2E-03 \\
\hline & MO & 345 & $6.6 \mathrm{E}-04$ & $9.1 \mathrm{E}-04$ & $1.1 \mathrm{E}-07$ & $1.2 \mathrm{E}-03$ & 4.0E-03 \\
\hline & NM & 345 & $7.1 \mathrm{E}-04$ & 1. $1 \mathrm{E}-03$ & 4.9E-09 & $8.7 E-04$ & $4.9 E-03$ \\
\hline & NV & 345 & $7.9 E-05$ & 1. $2 E-04$ & $9.8 E-11$ & $0.0 \mathrm{E}+00$ & $8.5 E-04$ \\
\hline & $\mathrm{OH}$ & 345 & $2.6 E-04$ & $3.2 E-04$ & $2.2 E-08$ & $4.4 E-04$ & 4. $3 E-04$ \\
\hline & OK & 345 & $7.4 \mathrm{E}-04$ & 1. $0 \mathrm{E}-03$ & $4.8 E-08$ & $6.6 E-04$ & 5. $3 E-03$ \\
\hline & TX & 345 & $3.3 E-04$ & 5.0E-04 & $4.2 E-08$ & $2.9 \mathrm{E}-04$ & $2.6 E-03$ \\
\hline Site & Total & & $4.7 E-03$ & $6.7 E-03$ & $4.8 E-07$ & $4.5 E-03$ & 2.7E-02 \\
\hline \multirow[t]{11}{*}{ BNL } & $A Z$ & 1338 & 1.9E-04 & 3.0E-04 & $6.6 E-10$ & $0.0 \mathrm{E}+00$ & $1.2 E-03$ \\
\hline & $\mathrm{CO}$ & 1338 & $3.4 \mathrm{E}-03$ & 4.9E-03 & $2.3 E-07$ & $1.1 E-03$ & 2.2E-02 \\
\hline & IA & 1338 & 2. $3 E-03$ & 3. $3 E-03$ & 5. $9 E-07$ & $1.7 E-04$ & 1. $2 \mathrm{E}-02$ \\
\hline & IL. & 1338 & $1.5 E-03$ & $2.0 E-03$ & $5.2 \mathrm{E}-07$ & $2.4 \mathrm{E}-03$ & $5.9 E-03$ \\
\hline & IN & 1338 & $1.5 \mathrm{E}-03$ & 1.9E-03 & $3.3 \mathrm{E}-07$ & 1.9E-03 & 4. $4 \mathrm{E}-03$ \\
\hline & $N E$ & 1338 & $2.6 \mathrm{E}-03$ & $3.9 E-03$ & $8.8 E-07$ & $2.6 \mathrm{E}-03$ & 2.1E-02 \\
\hline & $\mathrm{NJ}$ & 1338 & $9.5 E-04$ & $1.3 E-03$ & 1. $3 \mathrm{E}-07$ & $5.8 \mathrm{E}-03$ & $3.6 E-03$ \\
\hline & NV & 1338 & 3. $0 E-03$ & 4. $6 E-03$ & 4. $4 \mathrm{E}-09$ & $0.0 \mathrm{E}+00$ & $3.2 E-02$ \\
\hline & NY & 1338 & 1.2E-03 & $1.6 E-03$ & $1.9 \mathrm{E}-07$ & $9.6 \mathrm{E}-03$ & $5.8 E-03$ \\
\hline & $\mathrm{OH}$ & 1338 & $2.4 \mathrm{E}-03$ & $2.8 E-03$ & $2.0 \mathrm{E}-07$ & $1.4 \mathrm{E}-03$ & 4. $0 \mathrm{E}-03$ \\
\hline & PA & 1338 & $2.5 E-03$ & $3.4 E-03$ & $1.9 \mathrm{E}-07$ & $7.3 \mathrm{E}-04$ & $1.8 \mathrm{E}-02$ \\
\hline
\end{tabular}




\begin{tabular}{|c|c|c|c|c|c|c|c|}
\hline \multirow[t]{3}{*}{ Site } & \multirow[t]{3}{*}{ State } & \multirow{3}{*}{$\begin{array}{c}\text { No. } \\
\text { of } \\
\text { Trips }\end{array}$} & \multicolumn{3}{|c|}{ Cargo-Related Risks } & \multirow{2}{*}{\multicolumn{2}{|c|}{$\begin{array}{l}\text { Round-Trip Vehicle- } \\
\text { Related Risks }\end{array}$}} \\
\hline & & & \multicolumn{2}{|c|}{ Incident-Free } & \multirow{2}{*}{$\begin{array}{c}\text { Accident } \\
\text { Public } \\
\end{array}$} & & \\
\hline & & & Crew & Public & & Emission & Accident \\
\hline & UT & 1338 & $2.6 E-03$ & $3.8 E-03$ & $2.6 E-08$ & $6.0 E-04$ & 1.9E-02 \\
\hline Site & Total & & $2.4 \mathrm{E}-02$ & $3.4 E-02$ & $3.3 E-.06$ & $2.6 \mathrm{E}-02$ & $1.5 E-01$ \\
\hline \multirow[t]{2}{*}{ ETEC } & $\mathrm{CA}$ & 128 & 3.0E-04 & 4.7E-04 & $9.2 \mathrm{E}-09$ & $2.0 \mathrm{E}-03$ & $8.5 E-04$ \\
\hline & NV & 128 & $2.9 E-05$ & $4.5 E-05$ & $3.7 E-11$ & $0.0 \mathrm{E}+00$ & $3.2 E-04$ \\
\hline Site & Total & & $3.2 E-04$ & $5.2 E-04$ & $9.2 E-09$ & $2.0 \mathrm{E}-03$ & $1.2 \mathrm{E}-03$ \\
\hline \multirow[t]{10}{*}{ FEMP } & $A Z$ & 3137 & $6.1 \mathrm{E}-03$ & $9.1 E-03$ & 4. $1 E-08$ & 1.7E-03 & $3.5 E-02$ \\
\hline & CA & 3137 & $5.0 \mathrm{E}-03$ & $7.5 \mathrm{E}-03$ & $1.3 E-07$ & $1.0 \mathrm{E}-03$ & $2.2 \mathrm{E}-02$ \\
\hline & IL & 3137 & $3.0 \mathrm{E}-03$ & 4.1E-03 & $1.3 \mathrm{E}-06$ & 1.0E-03 & 1. $4 \mathrm{E}-02$ \\
\hline & IN & 3137 & 3. $3 \mathrm{E}-03$ & 4. $2 E-03$ & $8.7 E-07$ & $7.1 \mathrm{E}-04$ & $1.1 \mathrm{E}-02$ \\
\hline & MO & 3137 & $6.0 E-03$ & $8.2 E-03$ & $1.0 \mathrm{E}-06$ & 1.1E-02 & $3.6 E-02$ \\
\hline & NM & 3137 & $6.4 \mathrm{E}-03$ & $9.7 E-03$ & $4.5 E-08$ & $7.9 E-03$ & $4.4 \mathrm{E}-02$ \\
\hline & NV & 3137 & 7.2E-04 & 1.1E-03 & $9.0 \mathrm{E}-10$ & $0.0 E+00$ & $7.8 E-03$ \\
\hline & $\mathrm{OH}$ & 3137 & $3.9 \mathrm{E}-04$ & $3.9 E-04$ & $2.0 E-08$ & $0.0 E+00$ & $5.5 E-04$ \\
\hline & OK & 3137 & $6.8 \mathrm{E}-03$ & $9.4 E-03$ & 4. $4 \mathrm{E}-07$ & $6.0 \mathrm{E}-03$ & 4. $8 \mathrm{E}-02$ \\
\hline & TX & 3137 & $3.0 E-03$ & 4.6E-03 & $3.9 E-07$ & $2.6 \mathrm{E}-03$ & 2. $3 E-02$ \\
\hline \multicolumn{2}{|c|}{ Site Total } & & 4.1E-02 & $5.8 E-02$ & $4.2 E-06$ & $3.2 \mathrm{E}-02$ & 2. $4 E-01$ \\
\hline \multirow[t]{2}{*}{$G E-V$} & al $C A$ & 1 & $2.8 E-06$ & 4. $3 E-06$ & $7.2 \mathrm{E}-11$ & $2.4 E-06$ & $1.2 E-05$ \\
\hline & NV & 1 & 2. $3 \mathrm{E}-07$ & $3.5 E-07$ & $2.9 \mathrm{E}-13$ & $0.0 \mathrm{E}+00$ & $2.5 \mathrm{E}-06$ \\
\hline Site & Total & & $3.1 \mathrm{E}-06$ & 4.7E-06 & $7.3 E-11$ & $2.4 \mathrm{E}-06$ & 1. $4 \mathrm{E}-05$ \\
\hline \multirow[t]{4}{*}{ GJPO } & $A Z$ & 3 & 4. $3 E-07$ & $6.7 E-07$ & $1.5 \mathrm{E}-12$ & $0.0 E+00$ & $2.6 E-06$ \\
\hline & $\mathrm{CO}$ & 3 & $5.5 E-07$ & $7.6 \mathrm{E}-07$ & $3.4 \mathrm{E}-11$ & $0.0 \mathrm{E}+00$ & $3.5 E-06$ \\
\hline & NV & 3 & $6.6 \mathrm{E}-06$ & 1.0E-05 & $9.8 \mathrm{E}-12$ & $0.0 \mathrm{E}+00$ & $7.2 E-05$ \\
\hline & UT & 3 & $5.7 \mathrm{E}-06$ & $8.6 E-06$ & $5.9 E-11$ & 1. $4 \mathrm{E}-06$ & $4.2 E-05$ \\
\hline Site & Total & & 1. $3 \mathrm{E}-05$ & 2.0E-05 & 1. $0 \mathrm{E}-10$ & 1. $4 \mathrm{E}-06$ & 1.2E-04 \\
\hline \multirow[t]{3}{*}{ INEL } & I0 & 933 & 1. $4 \mathrm{E}-03$ & 2.1E-03 & $6.9 E-08$ & $5.4 \mathrm{E}-04$ & $3.2 E-03$ \\
\hline & NV & 933 & 2.3E-03 & $3.5 E-03$ & $9.4 \mathrm{E}-09$ & 1. $5 \mathrm{E}-04$ & $2.4 E-02$ \\
\hline & OR & 933 & $5.6 E-04$ & 8.7E-04 & $5.6 E-09$ & $0.0 E+00$ & 4.1E-03 \\
\hline Site & Total & & 4. $3 E-03$ & $6.5 E-03$ & $8.4 E-08$ & $6.9 \mathrm{E}-04$ & $3.2 E-02$ \\
\hline \multirow[t]{4}{*}{ ITRI } & $A Z$ & 87 & 1.7E-04 & $2.5 \mathrm{E}-04$ & 1.2E-09 & $4.8 E-05$ & $9.7 E-04$ \\
\hline & $\mathrm{CA}$ & 87 & 1. $4 \mathrm{E}-04$ & 2.1E-04 & $3.5 E-09$ & $2.8 \mathrm{E}-05$ & $6.0 E-04$ \\
\hline & NM & 87 & 8.7E-05 & 1. $3 \mathrm{E}-04$ & $9.7 E-10$ & $1.5 E-04$ & $5.6 E-04$ \\
\hline & NV & 87 & 2. $0 \mathrm{E}-05$ & $3.1 E-05$ & $2.5 E-11$ & $0.0 \mathrm{E}+00$ & 2. $2 E-04$ \\
\hline \multicolumn{2}{|c|}{ Site. Total } & & 4.1E-04 & $6.2 E-04$ & 5. $6 \mathrm{E}-09$ & $2.3 E-04$ & $2.3 E-03$ \\
\hline \multirow[t]{4}{*}{ SPRU } & $A Z$ & 309 & $4.5 E-05$ & $6.9 \mathrm{E}-05$ & 1. $5 \mathrm{E}-10$ & $0.0 \mathrm{E}+00$ & 2.7E-04 \\
\hline & $\mathrm{CO}$ & 309 & $7.9 \mathrm{E}-04$ & 1.1E-03 & $5.4 E-08$ & $2.6 \mathrm{E}-04$ & $5.2 E-03$ \\
\hline & IA & 309 & $5.4 E-04$ & 7.5E-04 & 1. $4 \mathrm{E}-07$ & 4. $0 E-05$ & $2.9 E-03$ \\
\hline & IL & 309 & $3.4 E-04$ & $4.6 E-04$ & $1.2 \mathrm{E}-07$ & $5.6 E-04$ & 1. $4 \mathrm{E}-03$ \\
\hline
\end{tabular}




\begin{tabular}{|c|c|c|c|c|c|c|c|}
\hline \multirow[t]{3}{*}{ Site } & \multirow[t]{3}{*}{ State } & \multirow{3}{*}{$\begin{array}{c}\text { No. } \\
\text { of } \\
\text { Trips }\end{array}$} & \multicolumn{3}{|c|}{ Cargo-Related Risks } & \multirow{2}{*}{\multicolumn{2}{|c|}{$\begin{array}{c}\text { Round-Trip Vehicle- } \\
\text { Related Risks }\end{array}$}} \\
\hline & & & \multicolumn{2}{|c|}{ Incident-Free } & \multirow{2}{*}{$\frac{\text { Accident }}{\text { Public }}$} & & \\
\hline & & & Crew & Public & & Emission & Accident \\
\hline & IN & 309 & $3.4 E-04$ & 4. $3 E-04$ & $7.5 E-08$ & $4.5 E-04$ & $1.0 E-03$ \\
\hline & NE & 309 & $6.0 \mathrm{E}-04$ & $9.0 E-04$ & 2.0E-07 & $6.0 \mathrm{E}-04$ & $4.8 E-03$ \\
\hline & NV & 309 & $6.8 E-04$ & $1.1 E-03$ & 1.0E-09 & $0.0 \mathrm{E}+00$ & 7. $4 \mathrm{E}-03$ \\
\hline & NY & 309 & $8.3 E-04$ & $9.7 E-04$ & $7.2 E-08$ & $8.8 E-04$ & $5.7 E-03$ \\
\hline & $\mathrm{OH}$ & 309 & $5.9 E-04$ & $7.6 E-04$ & 5. $0 \mathrm{E}-08$ & $1.5 E-03$ & $9.6 E-04$ \\
\hline & PA & 309 & $1.1 E-04$ & $1.2 \mathrm{E}-04$ & 7.2E-09 & $0.0 E+00$ & $6.3 E-04$ \\
\hline & UT & 309 & $5.9 E-04$ & $8.8 E-04$ & $6.1 \mathrm{E}-09$ & 1. $4 E-04$ & 4. $3 E-03$ \\
\hline Site & Total & & $5.4 \mathrm{E}-03$ & $7.5 \mathrm{E}-03$ & $7.3 \mathrm{E}-07$ & 4. $4 \mathrm{E}-03$ & $3.5 E-02$ \\
\hline \multirow[t]{4}{*}{ LBNL } & $C A$ & 17 & 5. $4 E-05$ & 8. 3E-05 & 1. $5 E-09$ & $9.4 E-05$ & 2.2E-04 \\
\hline & NV & 17 & $3.9 E-06$ & $6.0 \mathrm{E}-06$ & 4. $9 \mathrm{E}-12$ & $0.0 E+00$ & 4.2E-05 \\
\hline & $C A$ & 1397 & $3.8 \mathrm{E}-03$ & $5.8 E-03$ & $9.6 \mathrm{E}-08$ & $2.1 E-03$ & $1.7 E-02$ \\
\hline & NV & 1397 & $3.2 E-04$ & 4.9E-04 & 4. $0 E-10$ & $0.0 E+00$ & $3.5 E-03$ \\
\hline Site & Total & & 4. $2 E-03$ & $6.4 \mathrm{E}-03$ & $9.8 E-08$ & 2. $2 E-03$ & 2.0E-02 \\
\hline \multirow[t]{2}{*}{ LLNL } & CA & 1397 & $3.8 \mathrm{E}-03$ & $5.8 E-03$ & $9.6 E-08$ & 2.1E-03 & 1.7E-02 \\
\hline & NV & 1397 & $3.2 E-04$ & $4.9 E-04$ & 4. $0 E-10$ & $0.0 E+00$ & $3.5 E-03$ \\
\hline Site & Total & & $4.1 E-03$ & $6.3 E-03$ & 9.7E-08 & 2.1E-03 & 2.0E-02 \\
\hline \multirow[t]{4}{*}{ LANL } & $A Z$ & 3829 & $7.4 \mathrm{E}-03$ & 1.1E-02 & 5. $0 E-08$ & $2.1 E-03$ & 4. $3 E-02$ \\
\hline & CA & 3829 & $6.0 \mathrm{E}-03$ & $9.2 E-03$ & $1.5 E-07$ & $1.2 E-03$ & 2.7E-02 \\
\hline & NM & 3829 & $5.5 E-03$ & 8.0E-03 & $5.6 E-08$ & $3.2 \mathrm{E}-03$ & $3.7 E-02$ \\
\hline & NV & 3829 & 8.7E-04 & 1. $4 \mathrm{E}-03$ & 1.1E-09 & $0.0 \mathrm{E}+00$ & $9.5 E-03$ \\
\hline Site & Total & & 2.0E-02 & 3.0E-02 & $2.6 \mathrm{E}-07$ & $6.5 E-03$ & 1.2E-01 \\
\hline \multirow[t]{10}{*}{ Mounc } & $A Z$ & 2409 & 4.7E-03 & 7.0E-03 & 3.2E-08 & 1. $3 E-03$ & $2.7 E-02$ \\
\hline & $C A$ & 2409 & $3.8 E-03$ & $5.8 E-03$ & $9.6 \mathrm{E}-08$ & $7.8 \mathrm{E}-04$ & 1.7E-02 \\
\hline & IL & 2409 & $2.3 E-03$ & $3.2 E-03$ & 1. $0 E-06$ & $7.8 \mathrm{E}-04$ & 1.0E-02 \\
\hline & IN & 2409 & $2.5 E-03$ & $3.4 E-03$ & 6. $3 E-07$ & 4. $4 \mathrm{E}-03$ & 8.1E-03 \\
\hline & MO & 2409 & 4. $6 \mathrm{E}-03$ & $6.3 E-03$ & 7.7E-07 & $8.3 E-03$ & $2.8 E-02$ \\
\hline & NM & 2409 & 4. $9 E-03$ & $7.5 E-03$ & $3.4 \mathrm{E}-08$ & $6.1 E-03$ & $3.4 E-02$ \\
\hline & NV & 2409 & $5.5 E-04$ & $8.5 E-04$ & $6.9 \mathrm{E}-10$ & $0.0 E+00$ & 6. $0 \mathrm{E}-03$ \\
\hline & $\mathrm{OH}$ & 2409 & $9.5 E-04$ & 1.2E-03 & 7. $4 \mathrm{E}-08$ & $2.8 \mathrm{E}-03$ & $1.4 E-03$ \\
\hline & OK & 2409 & $5.2 E-03$ & $7.2 E-03$ & 3. $4 \mathrm{E}-07$ & $4.6 \mathrm{E}-03$ & $3.7 E-02$ \\
\hline & TX & 2409 & $2.3 E-03$ & $3.5 E-03$ & 3. OE-07 & 2. $0 \mathrm{E}-03$ & $1.8 \mathrm{E}-02$ \\
\hline Site & Total & & $3.2 E-02$ & 4. $6 \mathrm{E}-02$ & 3. $3 E-06$ & $3.1 E-02$ & 1. $9 E-01$ \\
\hline \multirow[t]{6}{*}{ ORR } & $A R$ & 9848 & 1.7E-02 & 2. $3 E-02$ & 4. 3E- 07 & $2.2 \mathrm{E}-03$ & 5. $6 \mathrm{E}-02$ \\
\hline & $A Z$ & 9848 & 1. $9 E-02$ & $2.9 E-02$ & 1. $3 E-07$ & $5.4 E-03$ & 1. $1 \mathrm{E}-01$ \\
\hline & CA & 9848 & $1.6 E-02$ & $2.4 E-02$ & $3.9 E-07$ & $3.2 E-03$ & $6.8 \mathrm{E}-02$ \\
\hline & NM & 9848 & 2. $0 E-02$ & $3.1 E-02$ & 1. $4 \mathrm{E}-07$ & $2.5 \mathrm{E}-02$ & 1. $4 \mathrm{E}-01$ \\
\hline & NV & 9848 & $2.3 \mathrm{E}-03$ & $3.5 E-03$ & $2.8 E-09$ & $0.0 \mathrm{E}+00$ & 2. $4 \mathrm{E}-02$ \\
\hline & OK & 9848 & $1.9 E-02$ & $2.6 E-02$ & $1.2 E-06$ & $6.7 E-03$ & 1. $4 \mathrm{E}-01$ \\
\hline
\end{tabular}




\begin{tabular}{|c|c|c|c|c|c|c|c|}
\hline \multirow[t]{3}{*}{ Site } & \multirow[t]{3}{*}{ State } & \multirow{3}{*}{$\begin{array}{l}\text { No. } \\
\text { of } \\
\text { Trips }\end{array}$} & \multicolumn{3}{|c|}{ Cargo-Related Risks } & \multirow{2}{*}{\multicolumn{2}{|c|}{$\begin{array}{c}\text { Round-Trip Vehicle- } \\
\text { Related Risks }\end{array}$}} \\
\hline & & & \multicolumn{2}{|c|}{ Incident-Free } & \multirow{2}{*}{$\begin{array}{c}\text { Accident } \\
\text { Public } \\
\end{array}$} & & \\
\hline & & & Crew & Public & & Emission & Accident \\
\hline & TN & 9848 & $2.4 \mathrm{E}-02$ & $3.3 E-02$ & $5.9 E-07$ & $3.5 E-02$ & 1.2E-01 \\
\hline & TX & 9848 & $9.5 E-03$ & $1.4 E-02$ & 1.2E-06 & $8.2 E-03$ & $7.3 \mathrm{E}-02$ \\
\hline \multicolumn{2}{|c|}{ Site Total } & & $1.3 E-01$ & $1.8 \mathrm{E}-01$ & 4.1E-06 & $8.5 E-02$ & 7. $3 E-01$ \\
\hline \multirow[t]{9}{*}{ PGDP } & $A Z$ & 165 & $3.2 E-04$ & $4.8 E-04$ & $2.2 E-09$ & $9.0 E-05$ & $1.8 \mathrm{E}-03$ \\
\hline & CA & 165 & $2.6 E-04$ & 4.0E-04 & $6.6 \mathrm{E}-09$ & $5.3 E-05$ & $1.1 \mathrm{E}-03$ \\
\hline & IL & 165 & $1.6 \mathrm{E}-06$ & $2.5 E-06$ & $9.7 \mathrm{E}-10$ & $0.0 E+00$ & $8.8 \mathrm{E}-06$ \\
\hline & KY & 165 & $2.4 \mathrm{E}-05$ & $3.5 E-05$ & 2.1E-09 & $0.0 \mathrm{E}+00$ & $1.8 \mathrm{E}-04$ \\
\hline & MO & 165 & $3.5 E-04$ & $4.8 E-04$ & $6.4 E-08$ & $1.4 \mathrm{E}-04$ & 2. $3 \mathrm{E}-03$ \\
\hline & NM & 165 & $3.4 \mathrm{E}-04$ & $5.1 E-04$ & 2. $4 \mathrm{E}-09$ & $4.1 E-04$ & 2. $3 \mathrm{E}-03$ \\
\hline & NV & 165 & $3.8 E-05$ & $5.8 E-05$ & $4.7 E-11$ & $0.0 E+00$ & 4.1E-04 \\
\hline & OK & 165 & $3.6 E-04$ & 4. $9 E-04$ & $2.3 \mathrm{E}-08$ & $3: 1 E-04$ & $2.5 E-03$ \\
\hline & TX & 165 & $1.6 \mathrm{E}-04$ & $2.4 \mathrm{E}-04$ & 2.0E-08 & 1. $4 \mathrm{E}-04$ & 1.2E-03 \\
\hline Site & Total & & $1.8 \mathrm{E}-03$ & $2.7 E-03$ & $1.2 \mathrm{E}-07$ & 1.2E-03 & 1. $2 \mathrm{E}-02$ \\
\hline \multirow[t]{5}{*}{ Pante } & $x A Z$ & 53 & 1.0E-04 & $1.5 E-04$ & 7. $.0 \mathrm{E}-10$ & $2.9 E-05$ & $5.9 E-04$ \\
\hline & CA & 53 & $8.4 E-05$ & 1. $3 E-04$ & 2.1E-09 & 1.7E-05 & $3.7 E-04$ \\
\hline & NM & 53 & 1. $1 E-04$ & $1.6 E-04$ & 7. $6 \mathrm{E}-10$ & 1. $3 \mathrm{E}-04$ & $7.5 E-04$ \\
\hline & NV & 53 & 1.2E-05 & $1.9 \mathrm{E}-05$ & 1.5E-11 & $0.0 \mathrm{E}+00$ & $1.3 E-04$ \\
\hline & TX & 53 & $2.8 E-05$ & 4.1E-05 & 4.0E-09 & 4. $4 E-05$ & 2.0E-04 \\
\hline \multicolumn{2}{|c|}{ Site Total } & & $3.4 \mathrm{E}-04$ & $5.0 E-04$ & $7.6 E-09$ & $2.2 E-04$ & 2.0E-03 \\
\hline \multirow[t]{11}{*}{ Ports } & $A Z$ & 77 & $1.5 E-04$ & 2. $2 E-04$ & 1.0E-09 & $4.2 E-05$ & $8.6 E-04$ \\
\hline & $C A$ & 77 & 1. $2 \mathrm{E}-04$ & 1.9E-04 & $3.1 E-09$ & $2.5 E-05$ & $5.3 E-04$ \\
\hline & IL & 77 & $6.0 E-05$ & 8.7E-05 & 2.7E-08 & $8.4 E-05$ & $2.7 E-04$ \\
\hline & IN & 77 & $5.2 E-05$ & 7. $4 \mathrm{E}-05$ & $1.8 \mathrm{E}-08$ & $5.0 \mathrm{E}-06$ & $2.0 E-04$ \\
\hline & $K Y$ & 77 & $6.3 E-05$ & $8.2 E-05$ & $5.8 E-09$ & $1.8 \mathrm{E}-04$ & $3.3 E-04$ \\
\hline & MO & 77 & $1.5 \mathrm{E}-04$ & $2.0 \mathrm{E}-04$ & $2.5 E-08$ & 2.7E-04 & $8.9 E-04$ \\
\hline & NM & 77 & $1.6 E-04$ & $2.4 \mathrm{E}-04$ & $1.1 E-09$ & $1.9 \mathrm{E}-04$ & $1.1 \mathrm{E}-03$ \\
\hline & NV & 77 & $1.8 \mathrm{E}-05$ & 2.7E-05 & 2.2E-11 & $0.0 E+00$ & $1.9 E-04$ \\
\hline & $\mathrm{OH}$ & 77 & $4.4 E-05$ & $5.6 E-05$ & 4.7E-09 & $9.9 E-06$ & $8.5 E-05$ \\
\hline & OK & 77 & 1.7E-04 & 2. $3 E-04$ & $1.1 \mathrm{E}-08$ & $1.5 E-04$ & 1.2E-03 \\
\hline & TX & 77 & $7.5 E-05$ & 1.1E-04 & $9.5 E-09$ & $6.4 \mathrm{E}-05$ & $5.7 \mathrm{E}-04$ \\
\hline Site & Total & & $1.1 E-03$ & $1.5 E-03$ & 1. $0 \mathrm{E}-07$ & 1.0E-03 & $6.2 \mathrm{E}-03$ \\
\hline \multirow[t]{9}{*}{ PPPL } & $A Z$ & 74 & $1.4 E-04$ & $2.1 E-04$ & $9.7 E-10$ & 4.1E-05 & 8.2E-04 \\
\hline & $C A$ & 74 & $1.2 E-04$ & $1.8 E-04$ & $3.0 E-09$ & $2.4 \mathrm{E}-05$ & $5.1 E-04$ \\
\hline & IL & 74 & 7.0E-05 & $9.7 E-05$ & $3.1 \mathrm{E}-08$ & $2.4 \mathrm{E}-05$ & $3.2 E-04$ \\
\hline & IN & 74 & $7.7 E-05$ & 1. $0 E-04$ & $1.9 \mathrm{E}-08$ & 1. $4 \mathrm{E}-04$ & $2.5 E-04$ \\
\hline & MO & 74 & $1.4 \mathrm{E}-04$ & 1. $9 \mathrm{E}-04$ & $2.4 \mathrm{E}-08$ & $2.6 \mathrm{E}-04$ & $8.6 \mathrm{E}-04$ \\
\hline & $\mathrm{NJ}$ & 74 & 1.0E-05 & 1. 3E-05 & $1.5 \mathrm{E}-09$ & $4.8 \mathrm{E}-05$ & $3.8 \mathrm{E}-05$ \\
\hline & NM & 74 & $1.5 E-04$ & 2.3E-04 & 1.1E-09 & 1.9E-04 & 1.1E-03 \\
\hline & NV & 74 & $1.7 \mathrm{E}-05$ & $2.6 \mathrm{E}-05$ & $2.1 E-11$ & $0.0 \mathrm{E}+00$ & $1.8 \mathrm{E}-04$ \\
\hline & $\mathrm{OH}$ & 74 & 1. $2 \mathrm{E}-04$ & $1.6 \mathrm{E}-04$ & 1.1E-08 & 2.7E-04 & 2.1E-04 \\
\hline
\end{tabular}




\begin{tabular}{|c|c|c|c|c|c|c|c|}
\hline \multirow[t]{2}{*}{ Site } & \multirow[t]{2}{*}{ State } & \multirow{2}{*}{$\begin{array}{c}\text { No. } \\
\text { of } \\
\text { Trips }\end{array}$} & \multicolumn{3}{|c|}{ Cargo-Related Risks } & \multicolumn{2}{|c|}{$\begin{array}{c}\text { Round-Trip Vehicle- } \\
\text { Related Risks }\end{array}$} \\
\hline & & & Crew & Public & $\begin{array}{l}\text { Accident } \\
\text { Public } \\
\end{array}$ & Emission & Accident \\
\hline & OK & 74 & $1.6 E-04$ & $2.2 E-04$ & 1.0E-08 & 1. $4 E-04$ & $1.1 \mathrm{E}-03$ \\
\hline & PA & 74 & $2.1 E-04$ & $2.4 \mathrm{E}-04$ & $2.1 E-08$ & $2.7 \mathrm{E}-04$ & 1.1E-03 \\
\hline & $T X$ & 74 & $7.2 E-05$ & 1.1E-04 & $9.1 E-09$ & $6.2 \mathrm{E}-05$ & $5.5 E-04$ \\
\hline & WV & 74 & $9.5 E-06$ & 1. $3 E-05$ & 3. $3 \mathrm{E}-10$ & $5.5 E-05$ & $5.6 E-05$ \\
\hline Site & Total & & 1. $3 E-03$ & $1.8 \mathrm{E}-03$ & $1.3 E-07$ & $1.5 \mathrm{E}-03$ & $7.1 E-03$ \\
\hline RFETS & $A Z$ & 2441 & $3.5 E-04$ & $5.5 E-04$ & 1.2E-09 & $0.0 E+00$ & $2.2 E-03$ \\
\hline & $\mathrm{CO}$ & 2441 & 4. $0 E-03$ & $5.5 E-03$ & 2. $8 \mathrm{E}-07$ & $1.6 \mathrm{E}-03$ & $2.5 E-02$ \\
\hline & NV & 2441 & $5.4 E-03$ & $8.4 E-03$ & 8.0E-09 & $0.0 E+00$ & $5.8 E-02$ \\
\hline & UT & 2441 & 4.7E-03 & 7. $.0 E-03$ & $4.8 \mathrm{E}-08$ & 1.1E-03 & $3.4 \mathrm{E}-02$ \\
\hline Site & Total & & 1. $4 \mathrm{E}-02$ & 2.1E-02 & 3. $4 \mathrm{E}-07$ & $2.7 E-03$ & 1. $2 \mathrm{E}-01$ \\
\hline SNLA & $A Z$ & 191 & $3.7 E-04$ & $5.5 E-04$ & $2.5 E-09$ & $1.1 E-04$ & $2.1 E-03$ \\
\hline & $C A$ & 191 & $3.0 E-04$ & 4. $6 \mathrm{E}-04$ & 7. $6 \mathrm{E}-09$ & $6.2 \mathrm{E}-05$ & 1. $3 E-03$ \\
\hline & NM & 191 & 1. $9 E-04$ & $2.8 \mathrm{E}-04$ & 2.1E-09 & $3.3 E-04$ & 1.2E-03 \\
\hline & NV & 191 & 4. $4 E-05$ & $6.8 E-05$ & $5.5 E-11$ & $0.0 E+00$ & $4.7 E-04$ \\
\hline Site & Total & & $9.0 E-04$ & 1. $4 \mathrm{E}-03$ & 1. $2 E-08$ & $5.0 E-04$ & 5.1E-03 \\
\hline WVDP & $A Z$ & 424 & $6.1 E-05$ & $9.5 E-05$ & $2.1 \mathrm{E}-10$ & $0.0 E \div 00$ & $3.7 E-04$ \\
\hline & $\mathrm{CO}$ & 424 & 1.1E-03 & $1.5 \mathrm{E}-03$ & 7. $4 E-08$ & $3.6 E-04$ & 7.1E-03 \\
\hline & IA & 424 & $7.4 E-04$ & 1. $.0 \mathrm{E}-03$ & $1.9 E-07$ & $5.5 E-05$ & $3.9 E-03$ \\
\hline & IL & 424 & 4.7E-04 & $6.3 E-04$ & $1.7 E-07$ & $7.6 E-04$ & 1.9E-03 \\
\hline & IN & 424 & 4. $6 \mathrm{E}-04$ & $5.9 E-04$ & 1. $0 \mathrm{E}-07$ & $6.1 \mathrm{E}-04$ & 1. $4 \mathrm{E}-03$ \\
\hline & NE & 424 & $8.2 E-04$ & 1.2E-03 & $2.8 E-07$ & $8.2 E-04$ & $6.6 E-03$ \\
\hline & NV & 424 & $9.4 \mathrm{E}-04$ & 1. $5 \mathrm{E}-03$ & 1. $4 E-09$ & $0.0 \mathrm{E}+00$ & 1.0E-02 \\
\hline & NY & 424 & $2.1 E-04$ & $2.5 E-04$ & 1. $4 \mathrm{E}-08$ & $5.5 E-05$ & $1.5 E-03$ \\
\hline & $\mathrm{OH}$ & 424 & $8.1 E-04$ & 1. $0 \mathrm{E}-03$ & $6.9 E-08$ & $2.1 E-03$ & $1.3 E-03$ \\
\hline & PA & 424 & $1.5 E-04$ & 1.7E-04 & $9.9 E-09$ & $0.0 \mathrm{E}+00$ & $8.6 E-04$ \\
\hline & UT & 424 & $8.1 E-04$ & 1. $2 \mathrm{E}-03$ & 8. 3E-09 & 1.9E-04 & $5.9 E-03$ \\
\hline Site & Total & & $6.5 \mathrm{E}-03$ & $9.2 \mathrm{E}-03$ & $9.1 \mathrm{E}-07$ & $5.0 E-03$ & 4.1E-02 \\
\hline
\end{tabular}


Table C.4 Truck Transport From LLW Generators To NTS - High Waste Volume Travel Through Las Vegas

Alternative Risks by Site (fatalities)

\begin{tabular}{|c|c|c|c|c|c|c|c|}
\hline \multirow[t]{3}{*}{ Site } & \multirow[t]{3}{*}{ State } & \multirow{3}{*}{$\begin{array}{c}\text { No. } \\
\text { of } \\
\text { Trips }\end{array}$} & \multicolumn{3}{|c|}{ Cargo-Related Risks } & \multirow{2}{*}{\multicolumn{2}{|c|}{$\begin{array}{l}\text { Round-Trip Vehicle- } \\
\text { Related Risks }\end{array}$}} \\
\hline & & & \multicolumn{2}{|c|}{ Incident-Free } & \multirow{2}{*}{$\begin{array}{l}\text { Accident } \\
\text { Public } \\
\end{array}$} & & \\
\hline & & & Crew & Public & & Enission & Accident \\
\hline \multirow[t]{6}{*}{ Ames } & $A Z$ & 5 & $7.2 E-07$ & 1.1E-06 & $2.5 \mathrm{E}-12$ & $0.0 \mathrm{E}+00$ & 4. $4 \mathrm{E}-06$ \\
\hline & $\mathrm{CO}$ & 5 & $1.3 E-05$ & $1.8 \mathrm{E}-05$ & $8.8 \mathrm{E}-10$ & 4.2E-06 & $8.3 E=05$ \\
\hline & IA & 5 & $5.1 E-06$ & $7.0 \mathrm{E}-06$ & $1.2 E-09$ & $3.4 E-06$ & $2.6 \mathrm{E}-05$ \\
\hline & NE & 5 & $9.7 E-06$ & $1.5 E-05$ & $3.3 E-09$ & $9.7 E-06$ & $7.8 E-05$ \\
\hline & NV & 5 & 4.2E-06 & $6.2 E-06$ & $9.9 \mathrm{E}-11$ & $5.5 E-06$ & $1.6 \mathrm{E}-05$ \\
\hline & UT & 5 & $9.5 E-06$ & 1. $4 E-05$ & $9.8 \mathrm{E}-11$ & $2.3 \mathrm{E}-06$ & 7.0E-05 \\
\hline \multicolumn{2}{|c|}{ Sité Total } & & $4.2 E-05$ & $6.1 E-05$ & $5.5 E-09$ & $2.5 E-05$ & $2.8 E-04$ \\
\hline \multirow[t]{7}{*}{ ANL -E } & $A Z$ & 526 & $7.6 E-05$ & $1.2 E-04$ & $2.6 \mathrm{E}-10$ & $0.0 \mathrm{E}+00$ & $4.6 E-04$ \\
\hline & $\mathrm{CO}$ & 526 & 1. $3 E-03$ & 1.9E-03 & $9.2 E-08$ & $4.4 E-04$ & $8.8 \mathrm{E}-03$ \\
\hline & IA & 526 & $9.1 E-04$ & $1.3 E-03$ & $2.3 E-07$ & $6.8 E-05$ & $4.9 E-03$ \\
\hline & IL & 526 & $4.8 E-04$ & $6.6 E-04$ & $2.0 E-07$ & $3.6 E-04$ & $2.1 E-03$ \\
\hline & NE & 526 & 1. $0 \mathrm{E}-03$ & $1.5 E-03$ & $3.5 E-07$ & 1. $0 \mathrm{E}-03$ & $8.2 E-03$ \\
\hline & NV & 526 & 4. $4 \mathrm{E}-04$ & $6.6 \mathrm{E}-04$ & 1. $0 \mathrm{E}-08$ & $5.8 E-04$ & 1. $6 \mathrm{E}-03$ \\
\hline & UT & 526 & 1. $0 \mathrm{E}-03$ & 1. $5 E-03$ & 1. $0 \mathrm{E}-08$ & $2.4 \mathrm{E}-04$ & 7. $3 E-03$ \\
\hline Site & Total & & $5.3 E-03$ & $7.7 \mathrm{E}-03$ & $8.9 E-07$ & $2.7 E-03$ & $3.3 E-02$ \\
\hline \multirow{9}{*}{$\mathrm{BCL}$} & $A Z$ & 345 & $6.9 E-04$ & 1.0E-03 & 4.7E-09 & $1.9 \mathrm{E}-04$ & 4. $0 E-03$ \\
\hline & IL & 345 & $3.3 E-04$ & $4.5 E-04$ & $1.5 \mathrm{E}-07$ & 1.1E-04 & $1.5 E-03$ \\
\hline & IN & 345 & $3.6 E-04$ & 4. $9 \mathrm{E}-04$ & $9.0 \mathrm{E}-08$ & $6.3 \mathrm{E}-04$ & 1.2E-03 \\
\hline & MO & 345 & $6.6 E-04$ & $9.1 E-04$ & 1. $1 E-07$ & 1. $2 E-03$ & 4. $0 \mathrm{E}-03$ \\
\hline & NM & 345 & $7.1 \mathrm{E}-04$ & 1.1E-03 & 4.9E-09 & 8.7E-04 & $4.9 E-03$ \\
\hline & NV & 345 & $2.4 \mathrm{E}-04$ & $3.6 E-04$ & 7.7E-09 & 1.1E-03 & $7.2 E-04$ \\
\hline & $\mathrm{OH}$ & 345 & $2.6 E-04$ & $3.2 E-04$ & $2.2 E-08$ & 4. $4 \mathrm{E}-04$ & 4. $3 E-04$ \\
\hline & OK & 345 & $7.4 E-04$ & 1.0E-03 & $4.8 E-08$ & $6.6 E-04$ & $5.3 E-03$ \\
\hline & $\mathrm{TX}$ & 345 & $3.3 E-04$ & 5. $0 \mathrm{E}-04$ & 4. $2 \mathrm{E}-08$ & $2.9 \mathrm{E}-04$ & $2.6 E-03$ \\
\hline \multicolumn{2}{|c|}{ Site Total } & & 4. $3 E-03$ & $6.2 E-03$ & $4.8 \mathrm{E}-07$ & $5.4 \mathrm{E}-03$ & $2.4 E-02$ \\
\hline \multirow[t]{11}{*}{ BNL } & $A Z$ & 1338 & 1.9E-04 & $3.0 E-04$ & $6.6 E-10$ & $0.0 \mathrm{E}+00$ & 1.2E-03 \\
\hline & $\mathrm{CO}$ & 1338 & $3.4 E-03$ & 4.9E-03 & 2. $3 \mathrm{E}-07$ & 1.1E-03 & $2.2 E-02$ \\
\hline & IA & 1338 & $2.3 E-03$ & 3. $3 E-03$ & $5.9 E-07$ & $1.7 E-04$ & 1.2E-02 \\
\hline & IL & 1338 & $1.5 E-03$ & 2.0E-03 & $5.2 E-07$ & $2.4 \mathrm{E}-03$ & $5.9 E-03$ \\
\hline & IN & 1338 & $1.5 E-03$ & 1. $9 E-03$ & $3.3 E-07$ & $1.9 \mathrm{E}-03$ & 4. $4 E-03$ \\
\hline & NE & 1338 & $2.6 \mathrm{E}-03$ & 3.9E-03 & $8.8 E-07$ & 2. $6 \mathrm{E}-03$ & $2.1 E-02$ \\
\hline & NJ & 1338 & $9.5 E-04$ & 1. $3 \mathrm{E}-03$ & 1. $3 E-07$ & $5.8 \mathrm{E}-03$ & $3.6 \mathrm{E}-03$ \\
\hline & NV & 1338 & $1.1 E-03$ & 1.7E-03 & $2.6 E-08$ & $1.5 E-03$ & 4.2E-03 \\
\hline & NY & 1338 & 1.2E-03 & $1.6 \mathrm{E}-03$ & $1.9 \mathrm{E}-07$ & $9.6 \mathrm{E}-03$ & $5.8 E-03$ \\
\hline & $\mathrm{OH}$ & 1338 & $2.4 E-03$ & $2.8 \mathrm{E}-03$ & 2. $0 \mathrm{E}-07$ & $1.4 \mathrm{E}-03$ & $4.0 E-03$ \\
\hline & PA & 1338 & $2.5 E-03$ & $3.4 \mathrm{E}-03$ & 1.9E-07 & $7.3 E-04$ & 1. $8 \mathrm{E}-02$ \\
\hline
\end{tabular}




\begin{tabular}{|c|c|c|c|c|c|c|c|}
\hline \multirow[t]{3}{*}{ Site } & \multirow[t]{3}{*}{ State } & \multirow{3}{*}{$\begin{array}{c}\text { No. } \\
\text { of } \\
\text { Trips }\end{array}$} & \multicolumn{3}{|c|}{ Cargo-Related Risks } & \multirow{2}{*}{\multicolumn{2}{|c|}{$\begin{array}{l}\text { Round-Trip Vehicle- } \\
\text { Related Risks }\end{array}$}} \\
\hline & & & \multicolumn{2}{|c|}{ Incident-Free } & \multirow{2}{*}{$\begin{array}{c}\text { Accident } \\
\text { Public } \\
\end{array}$} & & \\
\hline & & & Crew & Public & & Emission & Accident \\
\hline & UT & 1338 & $2.6 E-03$ & $3.8 E-03$ & $2.6 \mathrm{E}-08$ & $6.0 \mathrm{E}-04$ & 1.9E-02 \\
\hline Site & Total & & $2.2 E-02$ & $3.1 E-02$ & $3.3 E-06$ & $2.8 \mathrm{E}-02$ & 1.2E-01 \\
\hline ETEC & CA & 128 & $2.7 E-04$ & 4. $3 E-04$ & $8.5 E-09$ & $2.0 \mathrm{E}-03$ & $7.4 \mathrm{E}-04$ \\
\hline & NV & 128 & 8.0E-05 & $1.2 E-04$ & $1.5 E-09$ & $7.8 \mathrm{E}-05$ & $2.9 E-04$ \\
\hline Site & Total & & $3.5 E-04$ & $5.5 E-04$ & 1.0E-08 & $2.1 E-03$ & 1. $0 E-03$ \\
\hline FEMP & $A Z$ & 3137 & $6.3 E-03$ & $9.4 E-03$ & 4. $3 E-08$ & $1.7 E-03$ & $3.6 E-02$ \\
\hline & IL & 3137 & 3. $0 E-03$ & 4.1E-03 & $1.3 \mathrm{E}-06$ & 1.0E-03 & 1. $4 \mathrm{E}-02$ \\
\hline & IN & 3137 & 3. $3 E-03$ & $4.2 E-03$ & $8.7 E-07$ & $7.1 E-04$ & $1.1 E-02$ \\
\hline & MO & 3137 & $6.0 E-03$ & $8.2 E-03$ & $1.0 \mathrm{E}-06$ & 1. $1 \mathrm{E}-02$ & $3.6 E-02$ \\
\hline & NM & 3137 & $6.4 E-03$ & $9.7 E-03$ & $4.5 E-08$ & $7.9 E-03$ & 4. $4 \mathrm{E}-02$ \\
\hline & NV & 3137 & $2.2 E-03$ & $3.3 E-03$ & $7.0 E-08$ & $9.7 E-03$ & $6.5 E-03$ \\
\hline & $\mathrm{OH}$ & 3137 & $3.9 E-04$ & $3.9 E-04$ & 2. $0 \mathrm{E}-08$ & $0.0 E+00$ & $5.5 E-04$ \\
\hline & OK & 3137 & $6.8 E-03$ & $9.4 E-03$ & 4. $4 E-07$ & $6.0 E-03$ & $4.8 E-02$ \\
\hline & $T X$ & 3137 & 3. $0 E-03$ & $4.6 E-03$ & $3.9 E-07$ & $2.6 E-03$ & 2. $3 \mathrm{E}-02$ \\
\hline Site & Total & & $3.7 E-02$ & $5.3 E-02$ & $4.2 E-06$ & 4.0E-02 & 2.2E-01 \\
\hline GE-Va & $1 \mathrm{CA}$ & 1 & $2.6 \mathrm{E}-06$ & 4.0E-06 & $6.8 E-11$ & $2.4 E-06$ & 1.1E-05 \\
\hline & NV & 1 & $6.3 \mathrm{E}-07$ & $9.0 \mathrm{E}-07$ & $1.2 E-11$ & $6.1 E-07$ & $2.3 E-06$ \\
\hline Site & Total & & $3.3 E-06$ & $4.9 E-06$ & 8.0E-11 & $3.0 E-06$ & 1. $3 E-05$ \\
\hline GJPO & $A Z$ & 3 & 4. $3 E-07$ & $6.7 E-07$ & 1. $5 \mathrm{E}-12$ & $0.0 E+00$ & $2.6 E-06$ \\
\hline & $\mathrm{CO}$ & 3 & $5.5 E-07$ & $7.6 \mathrm{E}-07$ & $3.4 \mathrm{E}-11$ & $0.0 E+00$ & $3.5 E-06$ \\
\hline & NV & 3 & $2.5 E-06$ & $3.7 E-06$ & $5.9 E-11$ & $3.3 E-06$ & $9.3 E-06$ \\
\hline & UT & 3 & $5.7 E-06$ & $8.6 \mathrm{E}-06$ & $5.9 E-11$ & 1. $4 \mathrm{E}-06$ & $4.2 E-05$ \\
\hline Site & Total & & $9.2 E-06$ & 1. $4 \mathrm{E}-05$ & $1.5 E-10$ & $4.6 E-06$ & $5.7 E-05$ \\
\hline INEL & $A Z$ & 933 & 1. $4 \mathrm{E}-04$ & $2.1 E-04$ & $4.6 E-10$ & $0.0 \mathrm{E}+00$ & $8.2 E-04$ \\
\hline & ID & 933 & $6.7 E-04$ & $9.8 E-04$ & $3.3 E-08$ & $1.8 \mathrm{E}-04$ & $1.5 E-03$ \\
\hline & NV & 933 & $7.9 E-04$ & 1. $2 E-03$ & $1.8 \mathrm{E}-08$ & 1. $0 \mathrm{E}-03$ & $2.9 \mathrm{E}-03$ \\
\hline & UT & 933 & 2. $4 \mathrm{E}-03$ & $3.4 E-03$ & $9.4 E-08$ & 4. $3 E-03$ & 1. $4 \mathrm{E}-02$ \\
\hline Site & Total & & 4.0E-03 & 5.7E-03 & $1.5 E-07$ & $5.5 E-03$ & 2. $0 E-02$ \\
\hline ITRI & $A Z$ & 87 & $1.7 \mathrm{E}-04$ & $2.6 E-04$ & $1.2 \mathrm{E}-09$ & $4.8 E-05$ & 1. $0 \mathrm{E}-03$ \\
\hline & NM & 87 & $8.7 E-05$ & 1. $3 E-04$ & $9.7 E-10$ & $1.5 E-04$ & $5.6 E-04$ \\
\hline & NV & 87 & $6.1 E-05$ & $9.0 E-05$ & 1. $9 \mathrm{E}-09$ & $2.7 E-04$ & $1.8 E-04$ \\
\hline Site & Total & & $3.2 E-04$ & $4.8 E-04$ & 4. IE-09 & $4.7 E-04$ & $1.7 E-03$ \\
\hline SPRU & $A Z$ & 309 & $4.5 E-05$ & $6.9 E-05$ & $1.5 E-10$ & $0.0 E+00$ & $2.7 E-04$ \\
\hline & $\mathrm{CO}$ & 309 & $7.9 E-04$ & 1.1E-03 & $5.4 \mathrm{E}-08$ & $2.6 \mathrm{E}-04$ & $5.2 E-03$ \\
\hline & IA & 309 & $5.4 E-04$ & $7.5 E-04$ & 1. $4 \mathrm{E}-07$ & $4.0 E-05$ & $2.9 E-03$ \\
\hline & IL & 309 & $3.4 E-04$ & 4. $6 E-04$ & 1.2E-07 & $5.6 E-04$ & 1. $4 \mathrm{E}-03$ \\
\hline & IN & 309 & $3.4 E-04$ & $4.3 E-04$ & $7.5 E-08$ & $4.5 E-04$ & 1. $0 \mathrm{E}-03$ \\
\hline
\end{tabular}




\begin{tabular}{|c|c|c|c|c|c|c|c|}
\hline \multirow[t]{3}{*}{ Site } & \multirow[t]{3}{*}{ State } & \multirow{3}{*}{$\begin{array}{c}\text { No. } \\
\text { of } \\
\text { Trips }\end{array}$} & \multicolumn{3}{|c|}{ Cargo-Related Risks } & \multirow{2}{*}{\multicolumn{2}{|c|}{$\begin{array}{l}\text { Round-Trip Vehicle- } \\
\text { Related Risks } \\
\end{array}$}} \\
\hline & & & \multicolumn{2}{|c|}{ Incident-Free } & \multirow{2}{*}{$\begin{array}{c}\text { Accident } \\
\text { Public } \\
\end{array}$} & & \\
\hline & & & Crew & Public & & Emission & Accident \\
\hline & NE & 309 & $6.0 E-04$ & $9.0 E-04$ & 2.0E -07 & $6.0 \mathrm{E}-04$ & $4.8 E-03$ \\
\hline & NV & 309 & $2.6 E-04$ & $3.9 E-04$ & $6.1 E-09$ & $3.4 E-04$ & $9.6 E-04$ \\
\hline & NY & 309 & $8.3 E-04$ & $9.7 E-04$ & $7.2 E-08$ & $8.8 \mathrm{E}-04$ & $5.7 E-03$ \\
\hline & $\mathrm{OH}$ & 309 & $5.9 E-04$ & $7.6 \mathrm{E}-04$ & 5.0E-08 & $1.5 \mathrm{E}-03$ & $9.6 E-04$ \\
\hline & PA & 309 & $1.1 E-04$ & $1.2 E-04$ & $7.2 \mathrm{E}-09$ & $0.0 E+00$ & $6.3 E-04$ \\
\hline & UT & 309 & $5.9 E-04$ & $8.8 E-04$ & $6.1 E-09$ & $1.4 \mathrm{E}-04$ & 4.3E-03 \\
\hline Site & Total & & $5.0 E-03$ & $6.8 \mathrm{E}-03$ & $7.3 E-07$ & $4.8 \mathrm{E}-03$ & $2.8 E-02$ \\
\hline \multirow[t]{4}{*}{ LBNL } & CA & 17 & 5. $1 E-05$ & $7.7 E-05$ & $1.4 E-09$ & $9.4 E-05$ & $2.0 E-04$ \\
\hline & NV & 17 & $1.1 E-05$ & $1.5 E-05$ & $2.1 E-10$ & 1. $0 E-05$ & $3.9 E-05$ \\
\hline & CA & 1397 & $3.6 E-03$ & $5.4 E-03$ & $9.0 E-08$ & 2.1E-03 & $1.5 E-02$ \\
\hline & NV & 1397 & $8.8 E-04$ & 1. $3 E-03$ & 1.7E-08 & $8.5 E-04$ & $3.2 E-03$ \\
\hline \multicolumn{2}{|c|}{ Site Total } & & $4.5 E-03$ & $6.7 E-03$ & 1. $1 \mathrm{E}-07$ & 3. $0 E-03$ & 1.9E-02 \\
\hline \multirow[t]{2}{*}{ LLNL } & CA & 1397 & $3.6 E-03$ & $5.4 \mathrm{E}-03$ & $9.0 E-08$ & $2.1 E-03$ & $1.5 \mathrm{E}-02$ \\
\hline & NV & 1397 & $8.8 E-04$ & 1. $3 E-03$ & $1.7 \mathrm{E}-08$ & $8.5 E-04$ & $3.2 E-03$ \\
\hline \multicolumn{2}{|c|}{ Site Total } & & 4. $4 \mathrm{E}-03$ & $6.6 E-03$ & $1.1 E-07$ & $2.9 E-03$ & $1.8 \mathrm{E}-02$ \\
\hline \multirow[t]{3}{*}{ LANL } & $A Z$ & 3829 & $7.7 E-03$ & 1.2E-02 & $5.2 E-08$ & $2.1 E-03$ & 4. $4 \mathrm{E}-02$ \\
\hline & NM & 3829 & $5.5 E-03$ & 8.0E-03 & $5.6 E-08$ & $3.2 E-03$ & $3.7 E-02$ \\
\hline & NV & 3829 & $2.7 E-03$ & 4. $0 E-03$ & $8.5 E-08$ & $1.2 E-02$ & 8.0E-03 \\
\hline \multicolumn{2}{|c|}{ Site Total } & & $1.6 \mathrm{E}-02$ & $2.3 E-02$ & $1.9 \mathrm{E}-07$ & 1.7E-02 & $8.9 E-02$ \\
\hline \multirow[t]{9}{*}{ Mound } & $A Z$ & 2409 & $4.8 E-03$ & $7.2 E-03$ & $3.3 E-08$ & $1.3 E-03$ & $2.8 \mathrm{E}-02$ \\
\hline & IL & 2409 & $2.3 E-03$ & $3.2 E-03$ & 1.0E-06 & $7.8 \mathrm{E}-04$ & 1. $0 \mathrm{E}-02$ \\
\hline & IN & 2409 & $2.5 E-03$ & $3.4 \mathrm{E}-03$ & $6.3 E-07$ & 4. $4 \mathrm{E}-03$ & $8.1 \mathrm{E}-03$ \\
\hline & MO & 2409 & $4.6 E-03$ & $6.3 E-03$ & 7.7E-07 & $8.3 E-03$ & $2.8 E-02$ \\
\hline & NM & 2409 & $4.9 E-03$ & $7.5 E-03$ & $3.4 E-08$ & $6.1 E-03$ & $3.4 E-02$ \\
\hline & NV & 2409 & $1.7 E-03$ & $2.5 E-03$ & $5.4 E-08$ & $7.4 E-03$ & $5.0 E-03$ \\
\hline & $\mathrm{OH}$ & 2409 & $9.5 E-04$ & $1.2 E-03$ & $7.4 \mathrm{E}-08$ & $2.8 \mathrm{E}-03$ & 1. $4 \mathrm{E}-03$ \\
\hline & OK & 2409 & $5.2 E-03$ & 7.2E-03 & $3.4 \mathrm{E}-07$ & 4. $6 E-03$ & $3.7 E-02$ \\
\hline & TX & 2409 & $2.3 E-03$ & $3.5 E-03$ & $3.0 \mathrm{E}-07$ & 2.0E-03 & 1.8E-02 \\
\hline Site & Total & & 2.9E-02 & 4.2E-02 & $3.2 E-06$ & $3.8 \mathrm{E}-02$ & 1.7E-01 \\
\hline \multirow[t]{8}{*}{ ORR } & AR & 9848 & $1.7 E-02$ & 2. $3 \mathrm{E}-02$ & $4.3 E-07$ & $2.2 E-03$ & $5.6 E-02$ \\
\hline & $A Z$ & 9848 & $2.0 \mathrm{E}-02$ & $3.0 \mathrm{E}-02$ & $1.3 \mathrm{E}-07$ & $5.4 E-03$ & 1.1E-01 \\
\hline & NM & 9848 & 2.0E-02 & $3.1 \mathrm{E}-02$ & $1.4 \mathrm{E}-07$ & $2.5 \mathrm{E}-02$ & 1. $4 \mathrm{E}-01$ \\
\hline & NV & 9848 & $6.9 E-03$ & 1.0E-02 & $2.2 E-07$ & $3.0 \mathrm{E}-02$ & 2.1E-02 \\
\hline & OK & 9848 & $1.9 \mathrm{E}-02$ & $2.6 \mathrm{E}-02$ & $1.2 E-06$ & $6.7 E-03$ & 1. $4 \mathrm{E}-01$ \\
\hline & TN & 9848 & $2.4 \mathrm{E}-02$ & 3. $3 E-02$ & $5.9 E-07$ & $3.5 E-02$ & $1.2 \mathrm{E}-01$ \\
\hline & TX & 9848 & $9.5 E-03$ & 1. $4 \mathrm{E}-02$ & $1.2 E-06$ & $8.2 E-03$ & 7. $3 E-02$ \\
\hline & Total & & 1.2E-01 & 1.7E-01 & $3.9 E-06$ & 1. IE-01 & $6.6 E-01$ \\
\hline
\end{tabular}




\begin{tabular}{|c|c|c|c|c|c|c|c|}
\hline \multirow[t]{3}{*}{ Site } & \multirow[t]{3}{*}{ State } & \multirow{3}{*}{$\begin{array}{c}\text { No. } \\
\text { of } \\
\text { Trips } \\
\end{array}$} & \multicolumn{3}{|c|}{ Cargo-Related Risks } & \multirow{2}{*}{\multicolumn{2}{|c|}{$\begin{array}{c}\text { Round-Trip Vehicle- } \\
\text { Related Risks } \\
\end{array}$}} \\
\hline & & & \multicolumn{2}{|c|}{ Incident-Free } & \multirow{2}{*}{$\begin{array}{c}\text { Accident } \\
\text { Public } \\
\end{array}$} & & \\
\hline & & & Crew & Public & & Emission & Accident \\
\hline \multirow[t]{8}{*}{ PGDP } & $A Z$ & 165 & $3.3 E-04$ & $5.0 E-04$ & $2.2 \mathrm{E}-09$ & $9.0 E-05$ & 1.9E-03 \\
\hline & IL & 165 & $1.6 E-06$ & $2.5 E-06$ & $9.7 E-10$ & $0.0 E+00$ & $8.8 \mathrm{E}-06$ \\
\hline & KY & 165 & $2.4 E-05$ & $3.5 \mathrm{E}-05$ & $2.1 E-09$ & $0.0 \mathrm{E}+00$ & $1.8 \mathrm{E}-04$ \\
\hline & MO & 165 & $3.5 E-04$ & $4.8 \mathrm{E}-04$ & $6.4 \mathrm{E}-08$ & 1. $4 E-04$ & $2.3 E-03$ \\
\hline & NM & 165 & $3.4 \mathrm{E}-04$ & 5. $1 E-04$ & 2. $4 \mathrm{E}-09$ & $4.1 E-04$ & $2.3 E-03$ \\
\hline & NV & 165 & $1.2 \mathrm{E}-04$ & $1.7 E-04$ & $3.7 E-09$ & $5.1 E-04$ & $3.4 \mathrm{E}-04$ \\
\hline & OK & 165 & $3.6 \mathrm{E}-04$ & 4.9E-04 & $2.3 E-08$ & $3.1 E-04$ & $2.5 E-03$ \\
\hline & $T X$ & 165 & $1.6 E-04$ & $2.4 E-04$ & 2.0E-08 & 1. $4 \mathrm{E}-04$ & $1.2 E-03$ \\
\hline \multicolumn{2}{|c|}{ Site Total } & & $1.7 E-03$ & $2.4 \mathrm{E}-03$ & 1.2E-07 & 1. $6 \mathrm{E}-03$ & 1. 1E-02 \\
\hline \multicolumn{2}{|c|}{ Pantex AZ } & 53 & 1.1E-04 & $1.6 \mathrm{E}-04$ & 7. $2 \mathrm{E}-10$ & $2.9 E-05$ & $6.1 E-04$ \\
\hline & NM & 53 & $1.1 \mathrm{E}-04$ & 1. $6 \mathrm{E}-04$ & $7.6 E-10$ & $1.3 E-04$ & $7.5 E-04$ \\
\hline & NV & 53 & $3.7 E-05$ & $5.5 E-05$ & 1.2E-09 & $1.6 E-04$ & 1.1E-04 \\
\hline & $T X$ & 53 & $2.8 E-05$ & 4. $1 E-05$ & 4.0E-09 & $4.4 E-05$ & 2.0E-04 \\
\hline \multicolumn{2}{|c|}{ Site Total } & & $2.8 E-04$ & 4.2E-04 & $6.7 E-09$ & $3.7 E-04$ & $1.7 E-03$ \\
\hline \multirow[t]{10}{*}{ Ports } & $A Z$ & 77 & $1.5 \mathrm{E}-04$ & $2.3 E-04$ & 1. $0 \mathrm{E}-09$ & 4. $2 E-05$ & $8.9 E-04$ \\
\hline & IL & 77 & $6.0 E-05$ & $8.7 E-05$ & $2.7 E-08$ & $8.4 E-05$ & 2.7E-04 \\
\hline & IN & 77 & $5.2 E-05$ & 7. $4 \mathrm{E}-05$ & $1.8 \mathrm{E}-08$ & $5.0 E-06$ & 2.0E-04 \\
\hline & $K Y$ & 77 & $6.3 E-05$ & $8.2 E-05$ & $5.8 E-09$ & $1.8 \mathrm{E}-04$ & 3. $3 E-04$ \\
\hline & MO & 77 & $1.5 E-04$ & 2.0E-04 & $2.5 E-08$ & $2.7 E-04$ & $8.9 E-04$ \\
\hline & NM & 77 & $1.6 \mathrm{E}-04$ & $2.4 E-04$ & 1.1E-09 & $1.9 E-04$ & 1.1E-03 \\
\hline & NV & 77 & $5.4 E-05$ & 8.0E-05 & 1.7E-09 & $2.4 E-04$ & $1.6 \mathrm{E}-04$ \\
\hline & $\mathrm{OH}$ & 77 & $4.4 E-05$ & $5.6 E-05$ & 4.7E-09 & $9.9 E-06$ & $8.5 E-05$ \\
\hline & OK & 77 & 1.7E-04 & $2.3 E-04$ & $1.1 E-08$ & $1.5 \mathrm{E}-04$ & 1.2E-03 \\
\hline & TX & 77 & $7.5 E-05$ & $1.1 E-04$ & $9.5 E-09$ & $6.4 E-05$ & $5.7 E-04$ \\
\hline \multicolumn{2}{|c|}{ Site Total } & & $9.7 E-04$ & $1.4 E-03$ & 1.0E-07 & $1.2 \mathrm{E}-03$ & $5.7 E-03$ \\
\hline \multirow[t]{12}{*}{ PPPL } & $A Z$ & 74 & $1.5 E-04$ & 2. $2 E-04$ & 1.0E-09 & 4.1E-05 & $8.5 E-04$ \\
\hline & IL & 74 & 7. $.0 \mathrm{E}-05$ & $9.7 E-05$ & $3.1 E-08$ & 2. $4 \mathrm{E}-05$ & $3.2 E-04$ \\
\hline & IN & 74 & $7.7 E-05$ & 1.0E-04 & 1.9E-08 & 1. $4 E-04$ & $2.5 E-04$ \\
\hline & MO & 74 & 1. $4 E-04$ & 1.9E-04 & $2.4 \mathrm{E}-08$ & $2.6 \mathrm{E}-04$ & $8.6 E-04$ \\
\hline & NJ & 74 & 1.0E-05 & $1.3 E-05$ & $1.5 E-09$ & $4.8 E-05$ & $3.8 E-05$ \\
\hline & NM & 74 & $1.5 E-04$ & 2. $3 E-04$ & $1.1 E-09$ & $1.9 E-04$ & $1.1 \mathrm{E}-03$ \\
\hline & NV & 74 & $5.2 E-05$ & $7.7 E-05$ & $1.7 E-09$ & $2.3 E-04$ & $1.5 E-04$ \\
\hline & $\mathrm{OH}$ & 74 & 1.2E-04 & $1.6 \mathrm{E}-04$ & $1.1 E-08$ & $2.7 E-04$ & 2.1E-04 \\
\hline & OK & 74 & $1.6 \mathrm{E}-04$ & $2.2 E-04$ & 1. $.0 E-08$ & $1.4 E-04$ & 1. 1E-03 \\
\hline & PA & 74 & $2.1 E-04$ & $2.4 \mathrm{E}-04$ & $2.1 E-08$ & $2.7 E-04$ & 1.1E-03 \\
\hline & TX & 74 & $7.2 E-05$ & $1.1 E-04$ & $9.1 E-09$ & $6.2 E-05$ & $5.5 E-04$ \\
\hline & WV & 74 & $9.5 E-06$ & $1.3 E-05$ & $3.3 E-10$ & $5.5 E-05$ & $5.6 E-05$ \\
\hline \multicolumn{2}{|c|}{ Site Total } & & $1.2 E-03$ & $1.7 E-03$ & 1. $3 E=07$ & $1.7 E-03$ & $6.6 \mathrm{E}-03$ \\
\hline
\end{tabular}




\begin{tabular}{|c|c|c|c|c|c|c|c|}
\hline \multirow[t]{3}{*}{ Site } & \multirow[t]{3}{*}{ State } & \multirow{3}{*}{$\begin{array}{c}\text { No. } \\
\text { of } \\
\text { Trips }\end{array}$} & \multicolumn{3}{|c|}{ Cargo-Related Risks } & \multirow{2}{*}{\multicolumn{2}{|c|}{$\begin{array}{c}\text { Round-Trip Vehicle- } \\
\text { Related Risks }\end{array}$}} \\
\hline & & & \multicolumn{2}{|c|}{ Incident-Free } & \multirow{2}{*}{$\begin{array}{l}\text { Accident } \\
\text { Public } \\
\end{array}$} & & \\
\hline & & & Crew & Public & & Emission & Accident \\
\hline \multirow[t]{4}{*}{ RFETS } & $A Z$ & 2441 & $3.5 E-04$ & $5.5 E-04$ & $1.2 \mathrm{E}-09$ & $0.0 E+00$ & $2.2 E-03$ \\
\hline & $\mathrm{CO}$ & 2441 & 4.0E-03 & $5.5 E-03$ & $2.8 \mathrm{E}-07$ & $1.6 \mathrm{E}-03$ & $2.5 \mathrm{E}-02$ \\
\hline & NV & 2441 & $2.1 E-03$ & 3.0E-03 & $4.8 \mathrm{E}-08$ & $2.7 E-03$ & $7.6 \mathrm{E}-03$ \\
\hline & UT & 2441 & 4.7E-03 & 7.0E-03 & $4.8 E-08$ & $1.1 E-03$ & $3.4 \mathrm{E}-02$ \\
\hline Site & Total & & $1.1 \mathrm{E}-02$ & $1.6 \mathrm{E}-02$ & $3.8 E-07$ & $5.3 E-03$ & $6.9 E-02$ \\
\hline \multirow[t]{3}{*}{ SNLA } & $A Z$ & 191 & $3.8 \mathrm{E}-04$ & $5.7 E-04$ & $2.6 \mathrm{E}-09$ & $1.1 E-04$ & $2.2 E-03$ \\
\hline & NM & 191 & $1.9 E-04$ & $2.8 E-04$ & $2.1 E-09$ & $3.3 E-04$ & 1.2E-03 \\
\hline & NV & 191 & $1.4 \mathrm{E}-04$ & 2.0E-04 & 4. $3 E-09$ & $5.9 E-04$ & 4. $0 \mathrm{E}-04$ \\
\hline \multicolumn{2}{|c|}{ Site Total } & & 7.1E-04 & 1.1E-03 & $9.0 E-09$ & 1.0E-03 & $3.8 E-03$ \\
\hline \multirow[t]{12}{*}{ WVOP } & $A Z$ & 424 & $6.1 E-05$ & $9.5 E-05$ & $2.1 E-10$ & $0.0 \mathrm{E}+00$ & $3.7 E-04$ \\
\hline & $\mathrm{CO}$ & 424 & $1.1 E-03$ & $1.5 E-03$ & 7. $4 \mathrm{E}-08$ & $3.6 E-04$ & 7.1E-03 \\
\hline & IA & 424 & $7.4 \mathrm{E}-04$ & 1. $0 \mathrm{E}-03$ & 1.9E-07 & $5.5 E-05$ & $3.9 E-03$ \\
\hline & IL & 424 & 4.7E-04 & $6.3 \mathrm{E}-04$ & $1.7 E-07$ & $7.6 \mathrm{E}-04$ & 1.9E-03 \\
\hline & IN & 424 & $4.6 E-04$ & $5.9 E-04$ & 1.0E-07 & $6.1 E-04$ & 1. $4 \mathrm{E}-03$ \\
\hline & NE & 424 & 8.2E-04 & $1.2 \mathrm{E}-03$ & $2.8 E-07$ & $8.2 E-04$ & $6.6 \mathrm{E}-03$ \\
\hline & NV & 424 & $3.6 E-04$ & $5.3 \mathrm{E}-04$ & $8.4 E-09$ & $4.6 E-04$ & 1. $3 E-03$ \\
\hline & NY & 424 & $2.1 E-04$ & $2.5 E-04$ & 1. $4 \mathrm{E}-08$ & $5.5 E-05$ & $1.5 E-03$ \\
\hline & $\mathrm{OH}$ & 424 & $8.1 E-04$ & 1. $0 \mathrm{E}-03$ & $6.9 E-08$ & $2.1 E-03$ & 1. $3 E-03$ \\
\hline & PA & 424 & $1.5 \mathrm{E}-04$ & $1.7 E-04$ & $9.9 \mathrm{E}-09$ & $0.0 E+00$ & 8. $6 \mathrm{E}-04$ \\
\hline & UT & 424 & $8.1 E-04$ & $1.2 E-03$ & 8.3E-09 & $1.9 E-04$ & 5.9E-03 \\
\hline & Total & & $6.0 \mathrm{E}-03$ & 8. $3 E-03$ & $9.2 E-07$ & $5.4 E-03$ & $3.2 E-02$ \\
\hline
\end{tabular}


Table C.5. Rail Transport From LLW Generators To Barstow - Low Waste Volume Alternative Risks by Site (fatalities)

\begin{tabular}{|c|c|c|c|c|c|c|c|}
\hline \multirow[t]{3}{*}{ Site } & \multirow[t]{3}{*}{ State } & \multirow{3}{*}{$\begin{array}{l}\text { No. } \\
\text { of } \\
\text { Trips }\end{array}$} & \multicolumn{3}{|c|}{ Cargo-Related Risks } & \multirow{2}{*}{\multicolumn{2}{|c|}{$\begin{array}{l}\text { Round-Trip Vehicle- } \\
\text { Related Risks }\end{array}$}} \\
\hline & & & \multicolumn{2}{|c|}{ Incident-Free } & \multirow{2}{*}{$\frac{\text { Accident }}{\text { Public }}$} & & \\
\hline & & & Crew & Public & & Emission & Accident \\
\hline LLNL & CA & 466 & $3.5 E-04$ & 1. $3 \mathrm{E}-03$ & $6.1 E-08$ & $5.4 E-03$ & 2.1E-02 \\
\hline Site & Total & & $3.5 E-04$ & $1.3 E-03$ & $6.1 E-08$ & $5.4 E-03$ & 2.1E-02 \\
\hline LANL & $A Z$ & 1264 & $9.3 E-04$ & $7.7 E-04$ & $8.3 E-09$ & 1.2E-03 & 1.7E-02 \\
\hline & $C A$ & 1264 & 4. $3 E-04$ & $2.5 E-04$ & $2.8 \mathrm{E}-08$ & $5.3 E-05$ & $2.6 \mathrm{E}-02$ \\
\hline & NM & 1264 & $4.6 \mathrm{E}-04$ & $3.1 E-04$ & $2.1 E-09$ & $2.1 E-04$ & $5.5 E-03$ \\
\hline Site & Tota 1 & & $1.8 \mathrm{E}-03$ & $1.3 E-03$ & $3.8 E-08$ & $1.5 E-03$ & $4.8 E-02$ \\
\hline Mound & $A Z$ & 803 & $5.9 E-04$ & $4.9 E-04$ & $5.3 E-09$ & $7.7 E-04$ & 1.1E-02 \\
\hline & CA & 803 & $2.8 E-04$ & $1.6 E-04$ & $1.8 E-08$ & $3.4 E-05$ & $1.7 \mathrm{E}-02$ \\
\hline & IL & 803 & $2.5 E-04$ & $4.4 E-04$ & $4.5 E-07$ & 1.2E-03 & 1. $1 \mathrm{E}-02$ \\
\hline & IN & 803 & $2.4 E-04$ & $9.5 E-04$ & 1.2E-07 & $3.2 E-03$ & 1. $2 \mathrm{E}-02$ \\
\hline & KS & 803 & 4. $3 E-04$ & 6.0E-04 & 1. $3 E-07$ & 1.7E-03 & 7. $2 \mathrm{E}-03$ \\
\hline & MO & 803 & $5.0 E-04$ & $7.5 E-04$ & $7.5 E-08$ & $2.1 \mathrm{E}-03$ & $9.8 E-03$ \\
\hline & NM & 803 & $6.2 E-04$ & $3.9 E-04$ & $2.5 E-09$ & $2.4 E-04$ & 7. $4 \mathrm{E}-03$ \\
\hline & $\mathrm{OH}$ & 803 & $3.0 E-04$ & 1. $2 \mathrm{E}-03$ & $8.6 E-08$ & $4.4 E-03$ & 1. $1 E-02$ \\
\hline & OK & 803 & $1.8 \mathrm{E}-04$ & $9.3 \mathrm{E}-05$ & $1.8 \mathrm{E}-08$ & $0.0 E+00$ & $6.9 \mathrm{E}-03$ \\
\hline & TX & 803 & $3.3 E-04$ & 3. $3 E-04$ & $3.4 E-08$ & $2.7 E-04$ & 1. $4 \mathrm{E}-02$ \\
\hline Site & Total & & $3.7 E-03$ & $5.4 \mathrm{E}-03$ & $9.4 E-07$ & $1.4 \mathrm{E}-02$ & 1.1E-01 \\
\hline RFETS & $A Z$ & 814 & 6. $0 \mathrm{E}-04$ & 4.9E-04 & $5.4 E-09$ & $7.8 E-04$ & $1.1 E-02$ \\
\hline & CA & 814 & $2.8 \mathrm{E}-04$ & $1.6 \mathrm{E}-04$ & $1.8 \mathrm{E}-08$ & $3.4 E-05$ & 1.7E-02 \\
\hline & $\mathrm{CO}$ & 814 & $4.0 E-04$ & 1. $4 \mathrm{E}-03$ & $5.3 E-08$ & $5.4 E-03$ & 7. $0 \mathrm{E}-03$ \\
\hline & NM & 814 & $6.7 E-04$ & $4.5 E-04$ & $2.8 E-09$ & $4.1 E-04$ & $7.9 E-03$ \\
\hline Site & Total & & 1. $9 \mathrm{E}-03$ & 2. $5 E-03$ & 7. $9 \mathrm{E}-08$ & $6.6 E-03$ & 4. $3 \mathrm{E}-02$ \\
\hline
\end{tabular}


Table C.6. Rail Transport From LLW Generators To Caliente - Low Waste Volume Alternative Risks by Site (fatalities)

\begin{tabular}{|c|c|c|c|c|c|c|c|}
\hline \multirow[t]{3}{*}{ Site } & \multirow{3}{*}{ State } & \multirow{3}{*}{$\begin{array}{c}\text { No. } \\
\text { of } \\
\text { Trips }\end{array}$} & \multicolumn{3}{|c|}{ Cargo-Related Risks } & \multirow{2}{*}{\multicolumn{2}{|c|}{$\begin{array}{l}\text { Round-Trip Vehicle- } \\
\text { Related Risks }\end{array}$}} \\
\hline & & & \multicolumn{2}{|c|}{ Incident-Free } & \multirow{2}{*}{$\begin{array}{l}\text { Accident } \\
\text { Public } \\
\end{array}$} & & \\
\hline & & & Crew & Public & & Emission & Accident \\
\hline \multirow[t]{3}{*}{ LLNL } & $C A$ & 466 & $1.8 E-04$ & $1.2 E-03$ & $4.9 E-08$ & $5.4 E-03$ & $1.1 E-02$ \\
\hline & NV & 466 & 4. $4 \mathrm{E}-04$ & $4.6 E-04$ & 1.2E-09 & $1.1 E-03$ & 2.0E-03 \\
\hline & UT & 466 & $3.3 E-04$ & 2.0E-04 & $2.5 E-09$ & $0.0 E+00$ & $1.4 \mathrm{E}-02$ \\
\hline \multicolumn{2}{|c|}{ Site Total } & & $9.5 E-04$ & $1.9 \mathrm{E}-03$ & 5.3E-08 & $6.5 E-03$ & $2.7 E-02$ \\
\hline \multirow[t]{4}{*}{ LANL } & $\mathrm{CO}$ & 1264 & $1.3 \mathrm{E}-03$ & $2.5 E-03$ & $1.1 \mathrm{E}-07$ & $7.3 E-03$ & $2.2 \mathrm{E}-02$ \\
\hline & NM & 1264 & $5.8 E-04$ & $4.2 E-04$ & 2. $3 E-09$ & $3.7 E-04$ & 4. $5 E-04$ \\
\hline & NV & 1264 & $9.8 \mathrm{E}-05$ & $5.5 E-05$ & 2.3E-11 & $0.0 E+00$ & $6.9 \mathrm{E}-03$ \\
\hline & UT & 1264 & $1.1 E-03$ & $8.6 E-04$ & $2.2 E-08$ & $6.9 \mathrm{E}-04$ & $4.8 \mathrm{E}-02$ \\
\hline \multicolumn{2}{|c|}{ Site Total. } & & $3.1 E-03$ & $3.8 E-03$ & $1.3 \mathrm{E}-07$ & $8.4 E-03$ & $7.7 \mathrm{E}-02$ \\
\hline \multirow[t]{9}{*}{ Mound } & $\mathrm{CO}$ & 803 & $1.5 E-05$ & $1.3 E-05$ & $7.8 \mathrm{E}-10$ & $0.0 E+00$ & $2.6 E-04$ \\
\hline & IA & 803 & $5.1 E-04$ & 1.2E-03 & $6.6 E-07$ & $3.6 \mathrm{E}-03$ & 1.0E-02 \\
\hline & $I L$ & 803 & $2.3 E-04$ & $2.7 E-03$ & 4.1E-07 & 1.2E-02 & $1.1 E-02$ \\
\hline & IN & 803 & 2.2E-04 & $9.9 E-04$ & $1.3 \mathrm{E}-07$ & $3.5 E-03$ & 1.1E-02 \\
\hline & NE & 803 & $6.8 E-04$ & $6.9 \mathrm{E}-04$ & $3.0 E-07$ & 1. $0 \mathrm{E}-03$ & $8.6 E-03$ \\
\hline & NV & 803 & $6.2 E-05$ & $3.5 E-05$ & 1. $4 \mathrm{E}-11$ & $0.0 \mathrm{E}+00$ & $2.8 E-04$ \\
\hline & $\mathrm{OH}$ & 803 & $4.2 E-04$ & 1.7E-03 & 1.2E-07 & $5.9 E-03$ & 1. $5 \mathrm{E}-02$ \\
\hline & UT & 803 & $5.9 E-04$ & $9.4 \mathrm{E}-04$ & $3.6 E-08$ & $2.9 \mathrm{E}-03$ & $2.6 E-02$ \\
\hline & WY & 803 & $6.6 E-04$ & $4.9 E-04$ & 7. $3 E-09$ & $5.4 \mathrm{E}-04$ & 2.7E-03 \\
\hline \multicolumn{2}{|c|}{ Site Total } & & $3.4 \mathrm{E}-03$ & $8.8 \mathrm{E}-03$ & $1.6 E-06$ & $2.9 E-02$ & $8.4 E-02$ \\
\hline \multirow[t]{3}{*}{ RFETS } & $\mathrm{CO}$ & 814 & 4.2E-04 & $3.5 E-04$ & $2.1 E-08$ & $2.4 E-04$ & 7. $3 E-03$ \\
\hline & NV & 814 & $6.3 E-05$ & $3.5 E-05$ & $1.5 E-11$ & $0.0 \mathrm{E}+00$ & $2.9 \mathrm{E}-04$ \\
\hline & UT & 814 & $7.1 E-04$ & $5.5 E-04$ & 1. $4 \mathrm{E}-08$ & $4.4 E=04$ & $3.1 E-02$ \\
\hline \multicolumn{2}{|c|}{ Site Total } & & $1.2 E-03$ & $9.3 E-04$ & $3.6 E-08$ & $6.8 \mathrm{E}-04$ & $3.8 \mathrm{E}-02$ \\
\hline
\end{tabular}


Table C.7. Truck Transport From LLW Generators To NTS - Low Waste Volume Avoid Las Vegas

Alternative Risks by Site (fatalities)

\begin{tabular}{|c|c|c|c|c|c|c|c|}
\hline \multirow[t]{3}{*}{ Site } & \multirow[t]{3}{*}{ State } & \multirow{3}{*}{$\begin{array}{c}\text { No. } \\
\text { of } \\
\text { Trips }\end{array}$} & \multicolumn{3}{|c|}{ Cargo-Related Risks } & \multirow{2}{*}{\multicolumn{2}{|c|}{$\begin{array}{c}\text { Round-Trip Vehicle- } \\
\text { Related Risks }\end{array}$}} \\
\hline & & & \multicolumn{2}{|c|}{ Incident-Free } & \multirow{2}{*}{$\frac{\text { Accident }}{\text { Public }}$} & & \\
\hline & & & Crew & Public & & Emission & Accident \\
\hline \multirow[t]{2}{*}{ ETEC } & $C A$ & 104 & $2.4 E-04$ & $3.8 E-04$ & $7.4 \mathrm{E}-09$ & $1.7 E-03$ & $6.9 E-04$ \\
\hline & NV & 104 & $2.4 \mathrm{E}-05$ & $3.7 E-05$ & 3. $0 \mathrm{E}-11$ & $0.0 E+00$ & $2.6 E-04$ \\
\hline Site & Total & & $2.6 E-04$ & 4.2E-04 & $7.5 E-09$ & $1.7 \mathrm{E}-03$ & $9.5 E-04$ \\
\hline \multirow[t]{4}{*}{ ITRI } & $A Z$ & 87 & $1.7 E-04$ & $2.5 E-04$ & $1.2 E-09$ & $4.8 E-05$ & $9.7 E-04$ \\
\hline & $\mathrm{CA}$ & 87 & 1. $4 \mathrm{E}-04$ & $2.1 E-04$ & $3.5 E-09$ & $2.8 \mathrm{E}-05$ & $6.0 \mathrm{E}-04$ \\
\hline & NM & 87 & $8.7 E-05$ & 1.3E-04 & $9.7 \mathrm{E}-10$ & 1. $5 E-04$ & $5.6 E-04$ \\
\hline & NV & 87 & $2.0 E-05$ & $3.1 E-05$ & $2.5 \mathrm{E}-11$ & $0.0 \mathrm{E}+00$ & $2.2 E-04$ \\
\hline Site & Total & & $4.1 E-04$ & $6.2 \mathrm{E}-04$ & $5.6 E-09$ & 2. $3 E-04$ & $2.3 \mathrm{E}-03$ \\
\hline \multirow[t]{2}{*}{ LLNL } & CA & 1397 & $3.8 E-03$ & $5.8 E-03$ & $9.6 E-08$ & $2.1 E-03$ & 1.7E-02 \\
\hline & NV & 1397 & $3.2 E-04$ & $4.9 E-04$ & 4. $0 E-10$ & $0.0 \mathrm{E}+00$ & $3.5 E-03$ \\
\hline Site & Total & & 4.1E-03 & $6.3 E-03$ & $9.7 \mathrm{E}-08$ & 2.1E-03 & $2.0 \mathrm{E}-02$ \\
\hline \multirow[t]{4}{*}{ LANL } & $A Z$ & 3791 & $7.3 E-03$ & $1.1 \mathrm{E}-02$ & 5. $0 E-08$ & $2.1 E-03$ & $4.2 E-02$ \\
\hline & $C A$ & 3791 & $6.0 E-03$ & $9.1 E-03$ & 1.5E-07 & 1.2E-03 & $2.6 \mathrm{E}-02$ \\
\hline & NM & 3791 & $5.5 E-03$ & $7.9 E-03$ & $5.5 E-08$ & $3.2 E-03$ & $3.7 E-02$ \\
\hline & NV & 3791 & $8.6 E-04$ & 1. $3 E-03$ & $1.1 E-09$ & $0.0 \mathrm{E}+00$ & $9.4 E-03$ \\
\hline \multicolumn{2}{|c|}{ Site Total } & & 2. $0 \mathrm{E}-02$ & $2.9 \mathrm{E}-02$ & $2.6 E-07$ & $6.5 E-03$ & 1.1E-01 \\
\hline \multirow[t]{10}{*}{ Mound } & $A Z$ & 2409 & $4.7 E-03$ & $7.0 \mathrm{E}-03$ & 3. $2 E-08$ & 1. $3 E-03$ & $2.7 E-02$ \\
\hline & CA & 2409 & $3.8 E-03$ & $5.8 E-03$ & $9.6 \mathrm{E}-08$ & $7.8 \mathrm{E}-04$ & 1.7E-02 \\
\hline & IL & 2409 & 2. $3 E-03$ & $3.2 E-03$ & 1. $.0 E-06$ & $7.8 E-04$ & 1. $0 \mathrm{E}-02$ \\
\hline & IN & 2409 & $2.5 E-03$ & $3.4 \mathrm{E}-03$ & $6.3 E-07$ & 4. $4 E-03$ & $8.1 E-03$ \\
\hline & MO & 2409 & $4.6 E-03$ & $6.3 \mathrm{E}-03$ & $7.7 E-07$ & $8.3 \mathrm{E}-03$ & 2. $8 E-02$ \\
\hline & NM & 2409 & $4.9 E-03$ & $7.5 E-03$ & $3.4 \mathrm{E}-08$ & $6.1 E-03$ & $3.4 E-02$ \\
\hline & NV & 2409 & $5.5 E-04$ & $8.5 E-04$ & $6.9 \mathrm{E}-10$ & $0.0 \mathrm{E}+00$ & $6.0 E-03$ \\
\hline & $\mathrm{OH}$ & 2409 & $9.5 E-04$ & 1. $2 E-03$ & 7. $4 \mathrm{E}-08$ & $2.8 \mathrm{E}-03$ & 1. $4 \mathrm{E}-03$ \\
\hline & OK & 2409 & $5.2 \mathrm{E}-03$ & $7.2 \mathrm{E}-03$ & $3,4 \mathrm{E}-07$ & 4. $6 E-03$ & $3.7 E-02$ \\
\hline & TX & 2409 & $2.3 \mathrm{E}-03$ & $3.5 E-03$ & $3.0 \mathrm{E}-07$ & $2.0 E-03$ & $1.8 \mathrm{E}-02$ \\
\hline \multicolumn{2}{|c|}{ Site Total } & & $3.2 E-02$ & 4. $6 E-02$ & $3.3 E-06$ & $3.1 E-02$ & $1.9 E-01$ \\
\hline \multirow[t]{7}{*}{ PGDP } & $A Z$ & 165 & $3.2 E-04$ & $4.8 E-04$ & $2.2 E-09$ & $9.0 \mathrm{E}-05$ & $1.8 E-03$ \\
\hline & CA & 165 & $2.6 \mathrm{E}-04$ & 4. $0 E-04$ & $6.6 E-09$ & $5.3 E-05$ & 1.1E-03 \\
\hline & IL & 165 & $1.6 E-06$ & $2.5 E-06$ & $9.7 E-10$ & $0.0 \mathrm{E}+00$ & $8.8 E-06$ \\
\hline & KY & 165 & $2.4 \mathrm{E}-05$ & $3.5 E-05$ & 2.1E-09 & $0.0 \mathrm{E}+00$ & $1.8 E-04$ \\
\hline & MO & 165 & $3.5 E-04$ & $4.8 E-04$ & $6.4 \mathrm{E}-08$ & 1. $4 \mathrm{E}-04$ & 2. $3 E-03$ \\
\hline & NM & 165 & $3.4 E-04$ & $5.1 E-04$ & $2.4 \mathrm{E}-09$ & $4.1 E-04$ & 2. $3 E-03$ \\
\hline & NV & 165 & $3.8 E-05$ & $5.8 E-05$ & 4.7E-11 & $0.0 E+00$ & 4. $1 E-04$ \\
\hline
\end{tabular}




\begin{tabular}{|c|c|c|c|c|c|c|c|}
\hline \multirow[t]{3}{*}{ Site } & \multirow[t]{3}{*}{ State } & \multirow{3}{*}{$\begin{array}{c}\text { No. } \\
\text { of } \\
\text { Trips }\end{array}$} & \multicolumn{3}{|c|}{ Cargo-Related Risks } & \multirow{2}{*}{\multicolumn{2}{|c|}{$\begin{array}{c}\text { Round-Trip Vehicle- } \\
\text { Related Risks }\end{array}$}} \\
\hline & & & \multicolumn{2}{|c|}{ Incident-Free } & \multirow{2}{*}{$\begin{array}{c}\text { Accident } \\
\text { Public } \\
\end{array}$} & & \\
\hline & & & Crew & Public & & Emission & Accident \\
\hline & OK & 165 & $3.6 \mathrm{E}-04$ & 4.9E-04 & $2.3 \mathrm{E}-08$ & $3.1 E-04$ & $2.5 \mathrm{E}-03$ \\
\hline & $T X$ & 165 & $1.6 \mathrm{E}-04$ & $2.4 E-04$ & 2.0E-08 & $1.4 \mathrm{E}-04$ & 1.2E-03 \\
\hline Site $T$ & Total & & $1.8 \mathrm{E}-03$ & $2.7 E-03$ & 1.? E-07 & $1.2 \mathrm{E}-03$ & $1.2 E-02$ \\
\hline Pantex & $X A Z$ & 53 & 1. $0 \mathrm{E}-04$ & $1.5 E-04$ & $7.0 \mathrm{E}-10$ & $2.9 \mathrm{E}-05$ & $5.9 E-04$ \\
\hline & CA & 53 & $8.4 E-05$ & 1. $3 E-04$ & $2.1 E-09$ & $1.7 \mathrm{E}-05$ & $3.7 E-04$ \\
\hline & NM & 53 & 1. $1 E-04$ & $1.6 \mathrm{E}-04$ & $7.6 \mathrm{E}-10$ & $1.3 \mathrm{E}-04$ & $7.5 \mathrm{E}-04$ \\
\hline & NV & 53 & $1.2 E-05$ & $1.9 E-05$ & $1.5 E-11$ & $0.0 \mathrm{E}+00$ & $1.3 E-04$ \\
\hline & TX & 53 & $2.8 \mathrm{E}-05$ & 4.1E-05 & 4. $0 E-09$ & 4. $4 E-05$ & 2.0E-04 \\
\hline Site T & Total & & $3.4 E-04$ & $5.0 \mathrm{E}-04$ & $7.6 \mathrm{E}-09$ & $2.2 E-04$ & 2. $0 E-03$ \\
\hline Ports & $A Z$ & 77 & $1.5 E-04$ & $2.2 E-04$ & 1.0E-09 & 4. $2 E-05$ & $8: 6 E-04$ \\
\hline & $C A$ & 77 & $1.2 E-04$ & 1.9E-04 & $3.1 E-09$ & $2.5 E-05$ & 5. $3 E-04$ \\
\hline & IL & 77 & $6.0 \mathrm{E}-05$ & $8.7 E-05$ & 2.7E-08 & $8.4 E-05$ & $2.7 E-04$ \\
\hline & IN & 77 & $5.2 E-05$ & $7.4 E-05$ & 1. $8 \mathrm{E}-08$ & 5.0E-06 & 2.0E-04 \\
\hline & KY & 77 & $6.3 E-05$ & $8.2 E-05$ & $5.8 E-09$ & $1.8 \mathrm{E}-04$ & 3. 3E-04 \\
\hline & MO & 77 & $1.5 E-04$ & 2.0E-04 & $2.5 E-08$ & $2.7 E-04$ & $8.9 E-04$ \\
\hline & NM & 77 & $1.6 \mathrm{E}-04$ & $2.4 \mathrm{E}-04$ & 1.1E-09 & 1.9E-04 & 1.1E-03 \\
\hline & NV & 77 & $1.8 \mathrm{E}-05$ & $2.7 E-05$ & 2. $2 \mathrm{E}-11$ & $0.0 \mathrm{E}+00$ & 1. $9 \mathrm{E}-04$ \\
\hline & $\mathrm{OH}$ & 77 & 4. $4 E-05$ & $5.6 E-05$ & 4.7E-09 & $9.9 E-06$ & $8.5 E-05$ \\
\hline & OK & 77 & $1.7 E-04$ & $2.3 E-04$ & 1. $1 E-08$ & $1.5 E-04$ & 1.2E-03 \\
\hline & $T X$ & 77 & $7.5 E-05$ & $1.1 \mathrm{E}-04$ & $9.5 E-09$ & $6.4 E-05$ & $5.7 E-04$ \\
\hline Site $T$ & Total & & $1.1 E-03$ & $1.5 E-03$ & 1. $.0 E-07$ & 1.0E-03 & $6.2 \mathrm{E}-03$ \\
\hline RFETS & $A Z$ & 2441 & $3.5 E-04$ & $5.5 E-04$ & 1.2E-09 & $0.0 E+00$ & 2. $2 E-03$ \\
\hline & $\mathrm{CO}$ & 2441 & 4.0E-03 & $5.5 E-03$ & $2.8 \mathrm{E}-07$ & $1.6 \mathrm{E}-03$ & $2.5 E-02$ \\
\hline & NV & 2441 & $5.4 E-03$ & $8.4 E-03$ & 8.0E-09 & $0.0 \mathrm{E}+00$ & $5.8 \mathrm{E}-02$ \\
\hline & UT & 2441 & 4.7E-03 & 7. $.0 E-03$ & $4.8 E-08$ & 1. $1 \mathrm{E}-03$ & 3. $4 \mathrm{E}-02$ \\
\hline Site $T$ & Total & & $1.4 \mathrm{E}-02$ & 2. $1 E-02$ & $3.4 E-07$ & $2.7 \mathrm{E}-03$ & 1. $2 E-01$ \\
\hline SNLA & $A Z$ & 191 & $3.7 E-04$ & $5.5 E-04$ & 2.5E-09 & $1.1 E-04$ & 2.1E-03 \\
\hline & CA & 191 & $3.0 E-04$ & $4.6 E-04$ & 7.6E-09 & $6.2 E-05$ & 1. $3 E-03$ \\
\hline & $N M$ & 191 & 1.9E-04 & $2.8 \mathrm{E}-04$ & 2.1E-09 & 3. $3 E-04$ & 1. $2 \mathrm{E}-03$ \\
\hline & NV & 191 & 4. $4 \mathrm{E}-05$ & $6.8 \mathrm{E}-05$ & $5.5 E-11$ & $0.0 E+00$ & 4.7E-04 \\
\hline Site $T$ & Total & & $9.0 \mathrm{E}-04$ & 1. $4 \mathrm{E}-03$ & 1.2E-08 & $5.0 E-04$ & $5.1 \mathrm{E}-03$ \\
\hline
\end{tabular}


Table C.8. Truck Transport From LLW Generators To NTS - Low Waste Volume Travel Through Las Vegas

Alternative Risks by Site (fatalities)

\begin{tabular}{|c|c|c|c|c|c|c|c|}
\hline \multirow[t]{3}{*}{ Site } & \multirow[t]{3}{*}{ State } & \multirow{3}{*}{$\begin{array}{c}\text { No. } \\
\text { of } \\
\text { Trips }\end{array}$} & \multicolumn{3}{|c|}{ Cargo-Related Risks } & \multirow{2}{*}{\multicolumn{2}{|c|}{$\begin{array}{c}\text { Round-Trip Vehicle- } \\
\text { Related Risks }\end{array}$}} \\
\hline & & & \multicolumn{2}{|c|}{ Incident-Free } & \multirow{2}{*}{$\begin{array}{l}\text { Accident } \\
\text { Public } \\
\end{array}$} & & \\
\hline & & & Crew & Public & & Emission & Accident \\
\hline \multirow[t]{2}{*}{ ETEC } & CA & 104 & $2.2 E-04$ & $3.5 E-04$ & $6.9 E-09$ & 1.7E-03 & $6.0 E-04$ \\
\hline & NV & 104 & $6.5 E-05$ & $9.3 E-05$ & $1.3 E-09$ & $6.4 \mathrm{E}-05$ & $2.4 E-04$ \\
\hline Site & Total & & $2.8 E-04$ & $4.5 E-04$ & 8.2E-09 & $1.7 E-03$ & $8.3 E-04$ \\
\hline \multirow[t]{3}{*}{ ITRI } & $A Z$ & 87 & $1.7 E-04$ & $2.6 E-04$ & $1.2 E-09$ & 4.8E-05 & 1. $0 \mathrm{E}-03$ \\
\hline & NM & 87 & $8.7 E-05$ & $1.3 E-04$ & $9.7 E-10$ & $1.5 E-04$ & $5.6 E-04$ \\
\hline & NV & 87 & $6.1 E-05$ & $9.0 E-05$ & $1.9 E-09$ & $2.7 E-04$ & $1.8 E-04$ \\
\hline Site & Total & & $3.2 E-04$ & 4.8E-04 & 4.1E-09 & $4.7 E-04$ & $1.7 E-03$ \\
\hline \multirow[t]{2}{*}{ LLNL } & $\mathrm{CA}$ & 1397 & $3.6 E-03$ & $5.4 E-03$ & $9.0 E-08$ & $2.1 E-03$ & $1.5 E-02$ \\
\hline & NV & 1397 & $8.8 E-04$ & 1. $3 E-03$ & 1.7E-08 & 8.5E-04 & $3.2 E-03$ \\
\hline Site & Total & & $4.4 E-03$ & $6.6 \mathrm{E}-03$ & $1.1 \mathrm{E}-07$ & $2.9 \mathrm{E}-03$ & $1.8 \mathrm{E}-02$ \\
\hline \multirow[t]{3}{*}{ LANL } & $A Z$ & 3791 & $7.6 E-03$ & $1.1 E-02$ & $5.1 E-08$ & 2.1E-03 & 4. $4 \mathrm{E}-02$ \\
\hline & NM & 3791 & $5.5 E-03$ & $7.9 \mathrm{E}-03$ & $5.5 E-08$ & $3.2 E-03$ & $3.7 E-02$ \\
\hline & NV & 3791 & $2.7 E-03$ & $3.9 E-03$ & $8.5 E-08$ & 1.2E-02 & $7.9 E-03$ \\
\hline \multicolumn{2}{|c|}{ Site Total } & & $1.6 \mathrm{E}-02$ & $2.3 \mathrm{E}-02$ & 1. $9 E-07$ & 1.7E-02 & $8.8 E-02$ \\
\hline \multirow[t]{9}{*}{ Mound } & $A Z$ & 2409 & $4.8 E-03$ & 7.2E-03 & $3.3 E-08$ & 1. $3 E-03$ & $2.8 \mathrm{E}-02$ \\
\hline & IL & 2409 & $2.3 E-03$ & $3.2 E-03$ & $1.0 E-06$ & $7.8 E-04$ & 1. $0 E-02$ \\
\hline & IN & 2409 & $2.5 E-03$ & $3.4 E-03$ & $6.3 E-07$ & 4. $4 E-03$ & $8.1 E-03$ \\
\hline & MO & 2409 & $4.6 E-03$ & $6.3 E-03$ & $7.7 \mathrm{E}-07$ & $8.3 E-03$ & $2.8 \mathrm{E}-02$ \\
\hline & NM & 2409 & 4.9E-03 & $7.5 E-03$ & $3.4 E-08$ & $6.1 E-03$ & $3.4 E-02$ \\
\hline & NV & 2409 & $1.7 \mathrm{E}-03$ & $2.5 E-03$ & $5.4 E-08$ & $7.4 E-03$ & $5.0 \mathrm{E}-03$ \\
\hline & $\mathrm{OH}$ & 2409 & $9.5 E-04$ & 1.2E-03 & $7.4 \mathrm{E}-08$ & $2.8 E-03$ & 1. $4 \mathrm{E}-03$ \\
\hline & OK & 2409 & $5.2 \mathrm{E}-03$ & $7.2 E-03$ & $3.4 \mathrm{E}-07$ & $4.6 E-03$ & $3.7 E-02$ \\
\hline & TX & 2409 & $2.3 E-03$ & $3.5 E-03$ & $3.0 E-07$ & $2.0 \mathrm{E}-03$ & $1.8 \mathrm{E}-02$ \\
\hline Site & Total & & $2.9 E-02$ & 4. $2 E-02$ & $3.2 E-06$ & $3.8 E-02$ & $1.7 \mathrm{E}-01$ \\
\hline \multirow[t]{8}{*}{ PGDP } & $A Z$ & 165 & $3.3 E-04$ & 5. $0 E-04$ & $2.2 E-09$ & $9.0 \mathrm{E}-05$ & $1.9 E-03$ \\
\hline & IL & 165 & 1. $6 \mathrm{E}-06$ & $2.5 E-06$ & $9.7 \mathrm{E}-10$ & $0.0 \mathrm{E}+00$ & $8.8 E-06$ \\
\hline & KY & 165 & $2.4 E-05$ & $3.5 E-05$ & 2.1E-09 & $0.0 \mathrm{E}+00$ & $1.8 \mathrm{E}-04$ \\
\hline & MO & 165 & $3.5 E-04$ & $4.8 E-04$ & $6.4 \mathrm{E}-08$ & 1. $4 \mathrm{E}-04$ & 2. $3 E-03$ \\
\hline & NM & 165 & $3.4 E-04$ & $5.1 E-04$ & $2.4 \mathrm{E}-09$ & 4. $1 E-04$ & $2.3 E-03$ \\
\hline & NV & 165 & $1.2 E-04$ & 1.7E-04 & $3.7 E-09$ & $5.1 E-04$ & $3.4 E-04$ \\
\hline & OK & 165 & $3.6 E-04$ & $4.9 E-04$ & $2.3 E-08$ & $3.1 E-04$ & $2.5 E-03$ \\
\hline & TX & 165 & 1. $6 \mathrm{E}-04$ & $2.4 \mathrm{E}-04$ & 2.0E-08 & $1.4 \mathrm{E}-04$ & 1.2E-03 \\
\hline \multicolumn{3}{|c|}{ Site Total } & 1.7E-03 & $2.4 \mathrm{E}-03$ & $1.2 \mathrm{E}-07$ & $1.6 \mathrm{E}-03$ & 1. $1 \mathrm{E}-02$ \\
\hline
\end{tabular}




\begin{tabular}{|c|c|c|c|c|c|c|c|}
\hline \multirow[t]{3}{*}{ Site } & \multirow[t]{3}{*}{ State } & \multirow{3}{*}{$\begin{array}{l}\text { No. } \\
\text { of } \\
\text { Trips }\end{array}$} & \multicolumn{3}{|c|}{ Cargo-Related Risks } & \multirow{2}{*}{\multicolumn{2}{|c|}{$\begin{array}{c}\text { Round-Trip Vehicle- } \\
\text { Related Risks }\end{array}$}} \\
\hline & & & \multicolumn{2}{|c|}{ Incident-Free } & \multirow{2}{*}{$\begin{array}{c}\text { Accident } \\
\text { Public } \\
\end{array}$} & & \\
\hline & & & Crew & Public & & Emission & Accident \\
\hline \multicolumn{2}{|c|}{ Pantex AZ } & 53 & $1.1 E-04$ & $1.6 E-04$ & 7.2E-10 & $2.9 E-05$ & $6.1 E-04$ \\
\hline & NM & 53 & $1.1 E-04$ & $1.6 \mathrm{E}-04$ & 7. $6 \mathrm{E}-10$ & $1.3 E-04$ & 7.5E-04 \\
\hline & NV & 53 & $3.7 E-05$ & $5.5 E-05$ & $1.2 E-09$ & $1.6 \mathrm{E}-04$ & 1.1E-04 \\
\hline & $T X$ & 53 & $2.8 E-05$ & 4. $1 E-05$ & 4.0E-09 & 4. $4 \mathrm{E}-05$ & 2. $0 E-04$ \\
\hline \multicolumn{2}{|c|}{ Site Total } & & $2.8 \mathrm{E}-04$ & 4.2E-04 & $6.7 E-09$ & $3.7 E-04$ & $1.7 \mathrm{E}-03$ \\
\hline \multirow[t]{10}{*}{ Port } & $A Z$ & 77 & $1.5 E-04$ & $2.3 \mathrm{E}-04$ & 1. $.0 \mathrm{E}-09$ & 4.2E-05 & $8.9 E-04$ \\
\hline & IL & 77 & $6.0 \mathrm{E}-05$ & $8.7 E-05$ & $2.7 \mathrm{E}-08$ & $8.4 \mathrm{E}-05$ & $2.7 \mathrm{E}-04$ \\
\hline & IN & 77 & $5.2 E-05$ & $7.4 \mathrm{E}-05$ & $1.8 \mathrm{E}-08$ & 5.0E-06 & 2.0E-04 \\
\hline & KY & 77 & $6.3 E-05$ & $8.2 E-05$ & $5.8 \mathrm{E}-09$ & $1.8 \mathrm{E}-04$ & 3. $3 E-04$ \\
\hline & MO & 77 & $1.5 E-04$ & 2.0E-04. & $2.5 E-08$ & $2.7 E-04$ & 8.9E-04 \\
\hline & NM & 77 & $1.6 \mathrm{E}-04$ & $2.4 \mathrm{E}-04^{\circ}$ & 1.1E-09 & $1.9 \mathrm{E}-04$ & 1.1E-03 \\
\hline & NV & 77 & $5.4 \mathrm{E}-05$ & 8.0E-05 & $1.7 \mathrm{E}-09$ & $2.4 \mathrm{E}-04$ & 1. $6 \mathrm{E}-04$ \\
\hline & $\mathrm{OH}$ & 77 & 4. $4 \mathrm{E}-05$ & $5.6 E-05$ & 4.7E-09 & $9.9 E-06$ & $8.5 E-05$ \\
\hline & OK & 77 & 1.7E-04 & $2.3 E-04$ & $1.1 E-08$ & $1.5 \mathrm{E}-04$ & 1.2E-03 \\
\hline & $T X$ & 77 & $7.5 E-05$ & 1. IE-04 & $9.5 E-09$ & $6.4 \mathrm{E}-05$ & 5.7E-04 \\
\hline \multicolumn{2}{|c|}{ Site Total } & & $9.7 \mathrm{E}-04$ & 1. $4 \mathrm{E}-03$ & 1.0E-07 & 1.2E-03 & $5.7 E-03$ \\
\hline \multirow[t]{4}{*}{ RFETS } & $A Z$ & 2441 & $3.5 E-04$ & $5.5 E-04$ & 1.2E-09 & $0.0 \mathrm{E}+00$ & $2.2 E-03$ \\
\hline & $\mathrm{CO}$ & 2441 & $4.0 E-03$ & $5.5 E-03$ & $2.8 E-07$ & $1.6 E-03$ & $2.5 E-02$ \\
\hline & NV & 2441 & 2. $1 \mathrm{E}-03$ & 3. $0 E-03$ & $4.8 E-08$ & 2.7E-03 & $7.6 \mathrm{E}-03$ \\
\hline & UT & 2441 & 4.7E-03 & 7.0E-03 & $4.8 \mathrm{E}-08$ & $1.1 \mathrm{E}-03$ & $3.4 \mathrm{E}-02$ \\
\hline \multicolumn{2}{|c|}{ Site Total } & & 1.1E-02 & 1. $6 \mathrm{E}-02$ & $3.8 \mathrm{E}-07$ & $5.3 \mathrm{E}-03$ & $6.9 E-02$ \\
\hline \multirow[t]{3}{*}{ SNLA } & $A Z$ & 191 & $3.8 \mathrm{E}-04$ & $5.7 E-04$ & $2.6 E-09$ & 1.1E-04 & $2.2 E-03$ \\
\hline & NM & 191 & 1.9E-04 & $2.8 E-04$ & $2.1 E-09$ & $3.3 E-04$ & 1. $2 \mathrm{E}-03$ \\
\hline & NV & 191 & 1. $4 \mathrm{E}-04$ & 2.0E-04 & 4. $3 E-09$ & $5.9 E-04$ & 4. $0 E-04$ \\
\hline Site & otal & & $7.1 E-04$ & $1.1 E-03$ & $9.0 \mathrm{E}-09$ & 1.0E-03 & $3.8 E-03$ \\
\hline
\end{tabular}


This Page Intentionally Left Blank 


\section{DISTRIBUTION}

No. of

Copies

\section{OFFSITE}

20

P. Siebach

US Department of Energy (EPG)

Chicago Operations Office

9800 South Cass Ave.

Argonne, IL 60439

5

S. Hamp
U.S. Department of Energy

Albuquerque Operations Office

Pennsylvania and $\mathrm{H}$ Street

Kirtland Air Force Base

Albuquerque, NM 87116

G. Duggan

U.S. Department of Energy

Idaho Operations Office

850 Energy Drive

Idaho Falls, ID 83401-1563

W. Dixon

U.S. Department of Energy

Yucca Mountain Project Office

PO Box 30307

North Las Vegas, NV 89036-0307

E.F. Di Sanza

U.S. Department of Energy

Nevada Operations Office

232 Energy Way

North Las Vegas, NV 89030-4199

K. Grassmeier

U.S. Department of Energy

Nevada Operations Office

232 Energy Way

North Las Vegas, NV 89030-4199

M. Giblin

U.S. Department of Energy

Nevada Operations Office

232 Energy Way

North Las Vegas, NV 89030-4199
No. of

Copies

C. Crawford

Federal Energy Technology Center

PO Box 880

Morgantown, WV 26507-0880

M. Letourneau, EM-20

U.S. Department of Energy

GERMANTOWN

19901 Germantown Road

Germantown, MD 20874-1290

T. Mustin, EM-20

U.S. Department of Energy

FORRESTAL

1000 Independence Ave., SW

Washington D.C. 20585

J. Rhoderick, EM-20

U.S. Department of Energy

GERMANTOWN

19901 Germantown Road

Germantown, MD 20874-1290

N. Akgunduz

U.S. Department of Energy

Fernald Field Office

7400 Willey Road

Cincinnati, $\mathrm{OH} 45030$

Ruth Weiner

Sandia National Laboratory

1515 Eubank

Albuquerque, NM 87123

Fred Dilger

Nuclear Waste Division

Clark County, Department of

Comprehensive Planning

500 S. Grand Central Parkway

Las Vegas, NV 89155-175 
No. of

Copies

Dennis Bechtel, Director

Nuclear Waste Division

Clark County, Department of

Comprehensive Planning

500 S. Grand Central Parkway

Las Vegas, NV 89155-175

Ginger Swartz

State of Nevada

Agency for Nuclear Projects

1547 Irene Drive

Boulder City, Nevada 89005

Earl Dixon

NTS Community Advisory Board

University of Nevada Las Vegas

4505 Maryland Parkway

Box 454009

Las Vegas, Nevada 89154-4009

Jim Williams

838 Milwaukee St.

Denver, CO 80206-3904

Les W. Bradshaw

Nye County Department of Natural

Resources and Federal Facilities

1210 East Basin Road, Suite 6

Pahrump, NV 89048

Bruce Church

Desert Research Institute

P.O. Box 158

1795 Whipple Ave.

Logandale, NV 89021

Mr. Jock Sharp

15 North Church Street

Carbondale, PA 18407

2 B.M. Biwer

Argonne National Laboratory

9700 South Cass Ave.

Argonne, IL 60439
No. of

Copies

S. B. Ross

c/o Raytheon

5555 Greenwood Plaza Blvd.

Englewood, Colorado 80111

\section{ONSITE}

DOE, Richland Operations Office

R. F. Guercia

S7-55

Fluor-Daniel Hanford

J.G. Granger

Waste Management Northwest

J.G. McFadden

H1-11

14 Pacific Northwest National Laboratory

P.M. Daling (5)

K8-03

A.L. Franklin

$\mathrm{K} 8-03$

S.W. Gajewski

$\mathrm{K} 8-03$

M.D. McKinney

K8-03

N. Mahasenan

K8-03

Information Release (5) 